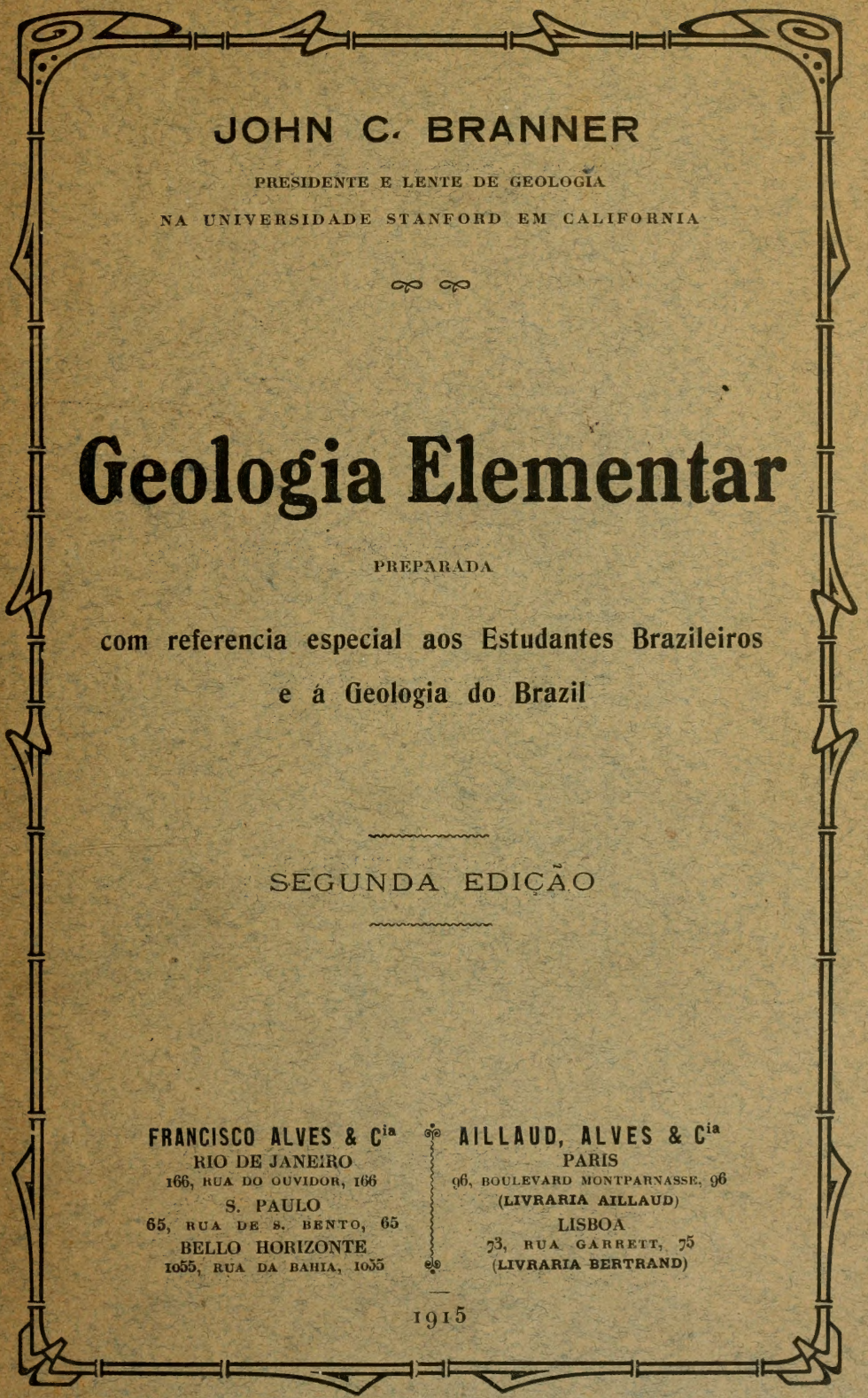




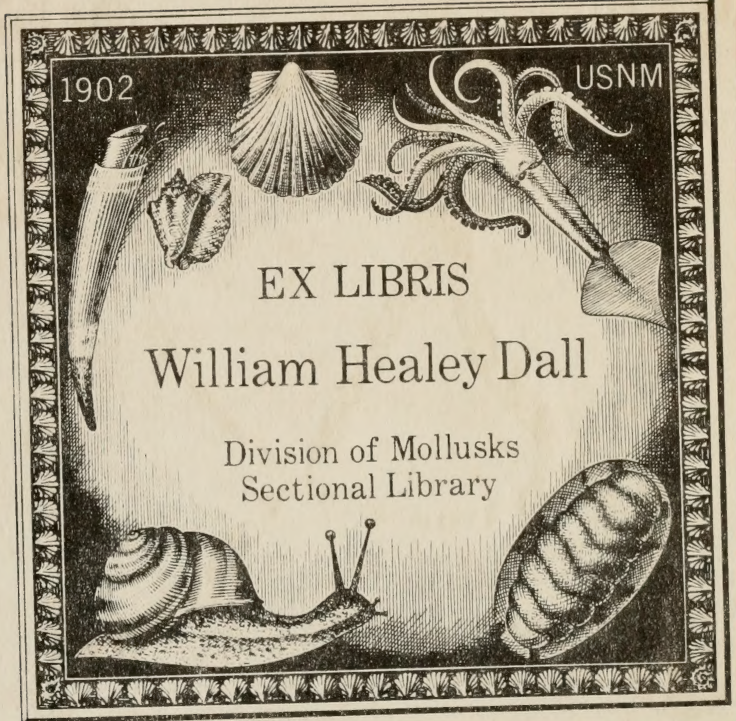


Division of MOllusks LIDRaTY E BEANNER

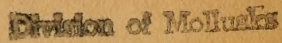

Gectioneal Librocry 

GEOLOGIA ELEMENTAR 



\section{Geologia Elementar}

resenamom

com referencia especial aos Estudantes Brasileiros

e á Geologia do Brazil

POR

JOHN C. BRANNER

PRESIDENTE E LENTE DE GEOLOGIA

NA

UNIVERSIDADE STANFORD EM CALIFORNIA

SEGUNDA EDIÇÃO

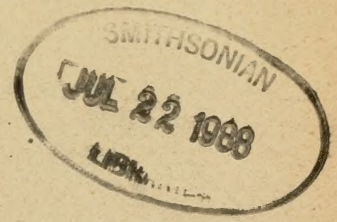

FRANCISCO ALVES \& $C^{\text {ia }}$ RIO DE JANEIRO I66, RUA DO OUVIDOR, 166

S. PAULO

65, RUA DE S. BENTo, 65 BELLO HORIZONTE I055, RUA DA BAHIA, I055
ต่อ AILLAUD, ALVES \& C PARIS 96 , BOUleVARD montPaRnasse, 96 (LIVRARIA AILLAUD) LISBOA 23, RUA GA R IETT, 75 (LIVRARIA BERTRAND) 



\section{PREFACIO}

Sem falar das publicações feitas em Porlugal, os principaes livros sobre geologia até hoje escriptos, na lingua vernacula, são: a "Geologia Elementar », de N. Boubée, traduzida da lingua franceza e publicada no Rio de Janeiro em 1846, e o "Resumo da Geologia » por A. de Lapparent, tambem vertido da lingua franceza pelo Dr. B. F. Ramiz Galvão, e publicada, no Rio de Janeiro, em 1898. Ambas são excellentes para os fins que tinham em vista, isto é, para os estudantes europeus e, si os estudantes brasileiros quizessem ser servidos por traducções, esses trabalhos seriam provavelmente tão bons em especie como poderiam ser.

Mas si a geologia deve ser estudada com vantagem, o seu estudo terá de ser feito no campo e sobre o terreno e o seu assumpto deverá tornar-se real e tangivel ao estudante.

Só se póde conseguir isso, satisfatoriamente, interessando o estudante brasileiro na geologia ao seu alcance, isto é, na geologia do Brasil.

O presente trabalho elementar foi, por isso, expressamente preparado para o uso dos estudantes brasileiros. Os exemplos cilados são, tanto quanto possivel, brasileiros, e as illustrações, da mesma fórma, sempre que fòrem valiosas.

Isto posto, espera-se que a geologia nã̉o conlinue a parecer ao estudante brasileiro um assumpto que só pertença, só diga respeito a outros povos, a outros paizes, a outros continentes.

Com relação aos fosseis mencionados, o autor pede venia para fazer uma suggestão áquelles que queiram usar 
este trabalho no ensino: a menos que os proprios discipulos possuam fosseis, não se deve exigir delles que guardem, de memoria, os nomes de outros.

As lições sobre os fosseis são da mais alta importancia e, quando os discipulos encontram os fosseis nas rochas, este facto lhes causa uma grande impressão, porém os seus nomes não tèem importancia especial, até que se faça um estudo systematico a respeito.

Quando os estudantes se interessarem pela collecçâo e identificação dos fosseis, encontrarâo algumas figuras nos bons compendios, porém as monographias de Derby; Rathbun, White e Clarke, das quaes as figuras que estanpamos foram copiadas, serão muito mais uteis.

Os estudantes não devem imaginar que a geologia do Brasil seja menos interessante ou menos importante do que a geologia de qualquer outro paiz. Aqui ha por toda a parte, excellentes exemplares das operações das leis da geologia, e como se vê na columna geologica, aqui ha representantes de quasi todas as formações das outras partes do mundo.

No preparo deste livro colheram-se informações de todas as fontes accessiveis. Muitos dos artigos originaes que fornecem as informações utilizadas nesta obra, geralmente, mas nem sempre, vêm citados nas notas infrapaginais. Quem quizer informar-se da literatura geologica do Brasil, porém, deve consultar nóssa bibliographia da geologia, mineralogia e paleontologia do Brasil, publicada no Bulletin of the Geological Society of America, volume XX, pp. I-132, Feb. 1909. Os artigos publicados posteriormente foram registrados pelo Dr. Arrojado Lisboa nos Annaes da Escola de Minas.

Devo especiaes reconhecimentos ao Professor Orville A. Derby, chefe do Serviço Geologico do Brasil, a quem o paiz e a mundo geologico tanto devem. 
A primeira edição desta obra foi escripta na lingua ingleza e traduzida para a portugueza pelo Dr. Antonio de Barros Barreto, collaborando como Dr. Derby. As addições á segunda edição foram escriptas em portuguez, e revistas pelo Dr. Barreto e pelo Dr. Miguel Arrojado Lisboa. A estes dois amigos devo meus sinceros agradecimentos pelo auxilio que me deram lanto na lingua como na geologia propria.

J. G. Branner. 



\section{INDICE DAS MATERIAS}

Introducção $\ldots \ldots \ldots \ldots \ldots \ldots \ldots \ldots \ldots \ldots \ldots \ldots$

\section{PARTE PRIMEIRA}

\section{Geologia dynamica.}

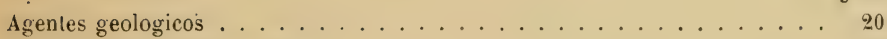

Ação directa da atmosphera. . . . . . . . . . . . . . . . . 20

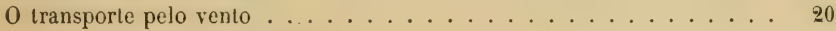

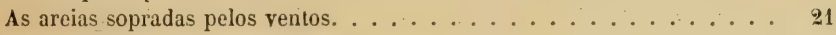

Distribuição de plantas e animaes . . . . . . . . . . . . . 24

Distribuição de cinzas volcanicas pelo vento. . . . . . . . . . . 23

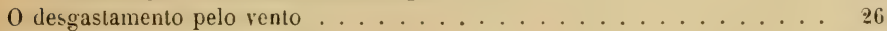

Deposito dos materiaes carregados pelos ventos. . . . . . . . . . . 26

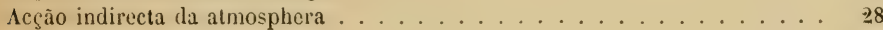

Mudancas de temperatura. . . . . . . . . . . . . . . . . $z 9$

$\Lambda$ formaçào do solo. . . . . . . . . . . . . . . . . . . . . . . . . . . . .

Solos alluviaes. . . . . . . . . . . . . . . . . . . . . . . . . . . . . . . . . . . .

Solos residuarios. . . . . . . . . . . . . . . . . . $5: 5$

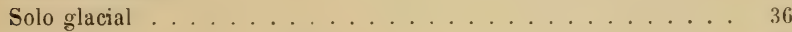

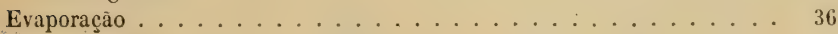

Vagas sobre grandes massas de agua. . . . . . . . . . . . 40

0 effeito do vento em relação ao nivel das aguas . . . . . . . . . . 40

Effeito do vento sobre as correntes oceanicas . . . . . . . . . . . . 41

$\Lambda$ atmosphera como carregador d'agua . . . . . . . . . . . . 42

$\Lambda$ gentes geologicos mechanicos aquosos. . . . . . . . . . . . 4 4

$\Lambda$ chuva na sua acção directa. . . . . . . . . . . . . . . 45

Acção mechanica dos cursos de agua . . . . . . . . . . . . . . 48

Erosão. . . . . . . . . . . . . . . . . . . . 48

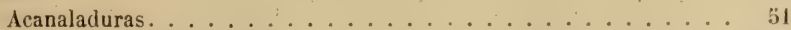

Transporte por cursos d'agua. . . . . . . . . . . . . . 53

A quantidade do material transportado por um curso d'agua. . . . . 
Origem das caxoeiras . . . . . . . . . . . . . . . . . . . . . . . . .

Erosão em relaçĩo á agricultura . . . . . . . . . . . . . . . 59

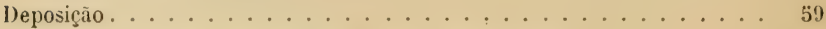

Casos especiaes de deposição pelos cursos d'agua. . . . . . . . 60

Deposição sobre varzeas. . . . . . . . . . . . . . . 60

Origem de aterrados naturaes . . . . . . . . . . . 60

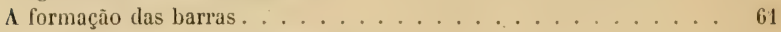

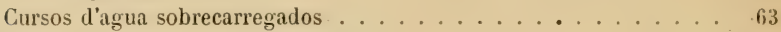

Os agentes aquosos mechanicos nos lagos ............ 63

Dellas . . . . . . . . . . . . . . . . . . . . 6 . 6 . .

$\Lambda$ gentes aquosos mechanicos nos mares e oceanos . . . . . . . . . . . . . . . . .

Correntezas do oceano ......................... 66

Effeitos das correntes. . . . . . . . . . . . . 67

As marés . . . . . . . . . . . . . . . . . . . . . . 67

Acção das marés . . . . . . . . . . . . . . . . . . . . 68

Aç̧ão mechanica dos mares e oceanos . . . . . . . . . . . . 68

Acçào destructira. . . . . . . . . . . . . . . . . . . . 68

Acção destructiva de vagas communs . . . . . . . . . . . . . 68

Acçào no nivel da marí . . . . . . . . . . . . . . . . . 69

Resultados da accão destructiva . . . . . . . . . . 70

O trabalho das ondas das marés . . . . . . . . . . . 71

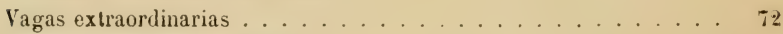

0 poder destructivo das vagas . . . . . . . . . . . . 72

Formas das costas produzidas pelas vagas. . . . . . . . . 76

Trabalho mechanico constructivo dos mares ou transporte e deposiçào

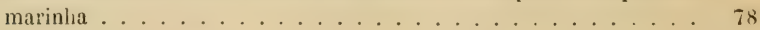

As correntes das marés . . . . . . . . . . . . . . . 78

Agentes marinhos constructivos . . . . . . . . . . . . . . . . . . . . . . . . . .

0 trabąlho constructivo das vagas ................ 78

A resaca . . . . . . . . . . . . . . . . . . . . 80

As correntes oceanicas . . . . . . . . . . . . . . . . 80

Formas e origens dos sedimentos mechanicos . . . . . . . . 81

Praias. . . . . . . . . . . . . . . . . . . 81

Praias de tempestades .......................... 81

Pontaes........................ 82

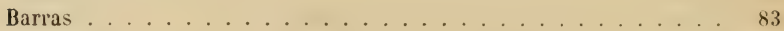

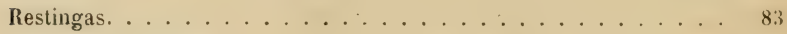

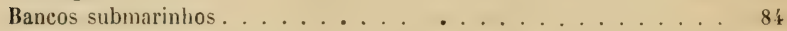

Deltas ........................... 84

Effeito d'agua salgada sobre os sedimentos ............ 86

Crescimento de deltas. . . . . . . . . . . . . . . . . 87

\ posição dos sedimentos marinhos . . . . . . . . . . . . 87

Conclusões referentes aos sedimenlos mechanicos. ... . . . . . . 88

0 gelo como agente geologico. . . . . . . . . . . . . . . . . . . . . . . . . . . .

Congelaçào . . . . . . . . . . . . . . . . . . 90 


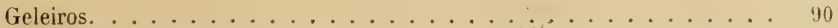

Movimento dos geleiros ....................... 91

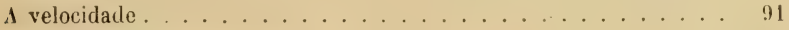

Determinação da velocidade. . . . . . . . . . . . 91

Theorias do movimento do gelo . . . . . . . . . . . . . . 92

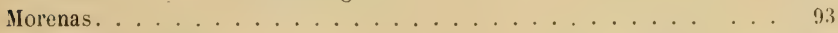

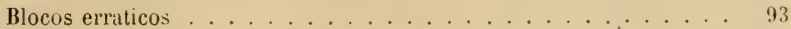

Sulcos glaciaes . . . . . . . . . . . . . . . . . . . . . 94

Trabalho geologico dos geleiros. . . . . . . . . . . . . . . . . . . .

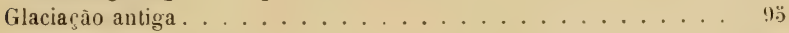

America do Sul ...................... . . 99

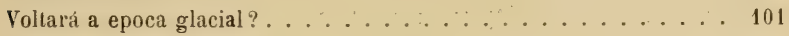

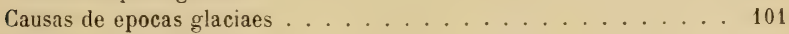

Icebergs. . . . . . . . . . . . . . . . . . 102

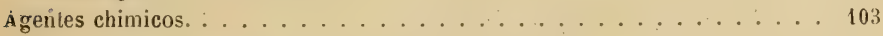

Bioxido de carbono. ...................... 104

Churas cahidas em diversos lugares no Brasil. . . . . . . . . . 104

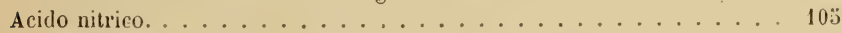

Acido nitrice calculado para a chuva cahida no Brasil. . . . . . . 105

Acidos organicos ......................... 106

Augmento de pressâo . . . . . . . . . . . . . . . . . 106

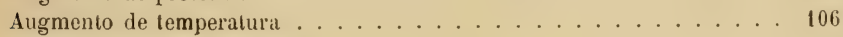

Diminuição de temperatura . . . . . . . . . . . . . . . 107

Material dissolvido nos cursos de agua. . . . . . . . . . . . 107

Os effeitos da erosão chimica. . . . . . . . . . . . . . 108

Resultados mechanicos de solução . . . . . . . . . . . . . 111

A origem das grutas ou cavernas ............... . . . . . 112

Solução subterranea das rochas . . . . . . . . . . . . . . 112

Cavernas em lava com crosta esfriada. . . . . . . . . . . . 115

Pela acçâo mechanica das ondas. . . . . . . . . . . . . . . . . . 110

Peli ação chimica da atmosphera. . . . . . . . . . . . . . 11:

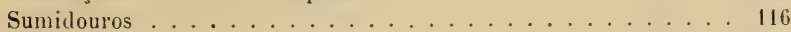

Drenagem subterranea............................ 116

Arcos naturaes ...................................... 116

Deposiçào chimica . . . . . . . . . . . . . . . 116

Quando escapa o solvente............................ 116

Origem de travertino. . . . . . . . . . . . . . . . 117

Quando abaixa a temperatura ......................... 118

Quando a temperatura eleva-se ...................... 118

Quando a pressão diminue. . . . . . . . . . . . . . 119

Quando se effectuam reacçòes chimicas' . . . . . . . . . . . 119

Quando as soluções ficam por muito tempo em repouso. . . . . . 120

Concentraçâo de soluções por evaporação. . . . . . . . . . . 120

A acção chimica nos lagos salgados . . . . . . . . . . . . 121

Desmembramento de um braço do mar .............. 121 
Paginas

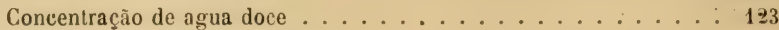

A origem de depositos de sal . . . . . . . . . . . . . . 123

Lagos alcalinos. . . . . . . . . . . . . . . . . 128

Lagos de borax. . . . . . . . . . . . . . . . . . 125

Lagos amargos. . . . . . . . . . . . . . . . . . . . . 125

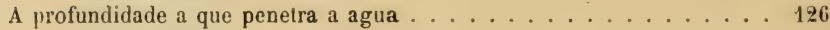

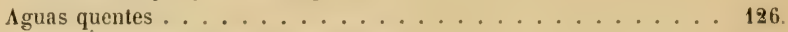

Resumo das operaçoes dos agentes chimicos . . . . . . . . . . . 128

Agentes igneos ou altas temperaturas. . . . . . . . . . . . . . . 128

0 interior da terra . . . . . . . . . . . . . . . . . . . . . . . 128

Theorias relativas ao interior da terra . . . . . . . . . . 129

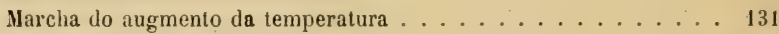

Resultados .......................... 132

Temperaturas das aguas das minas de $\Lambda$ gua Quente . . . . . . 133

Fusão devida a allivio de pressão. . . . . . . . . . . . 131

Os vulcôes e o seu trabalho geologico . . . . . . . . . . . . . . 133

Vulcōes activos. . . . . . . . . . . . . . . . . 13ä

Erupções. . . . . . . . . . . . . . . . . . . . 13̈̈

Lavas . . . . . . . . . . . . . . . . . . . 137

Os ejectamentos fragmentarios. . . . . . . . . . . . . . 138

Inclusôes . . . . . . . . . . . . . . . . . . . . . . . . . . . 138

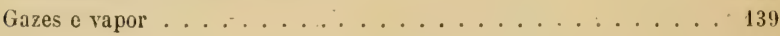

Picos vulcanicos ......................... 139

Rochas vulcanicas ....................... 140

Vulcôes submarinhos. ................... . . 141

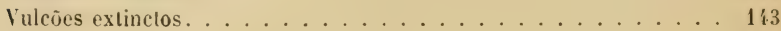

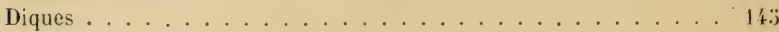

Laccolitos. . . . . . . . . . . . . . . . . . 147

A idade de um vulcão . . . . . . . . . . . . . 147

Geysers. . . . . . . . . . . . . . . . . . . . 147

Fontes quentes . . . . . . . . . . . . . . . . . 149

Poços de Caldas . . . . . . . . . . . . . . . . . . 149

Brejo das Freiras .................... 149

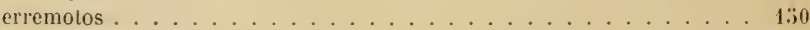

Escala Rossi-Forel. . . . . . . . . . . . . . . . 153

Iludanças de nivel . . . . . . . . . . . . . . . . . . . . . . . . . . . . . . . . .

Tremores de terra no Brazil . . . . . . . . . . . . . 1 . . . . . . . .

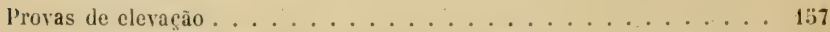

Os organismos marinhos mortos sobre a terra ........ 157

o trabalho dos organismos marinhos na terra. . . . . . . . . 159

0 trabalho das ondas além do seu alcance actual . . . . . . . 160

Os registros humanos . . . . . . . . . . . . . . . . 161

As superficies erodidas de sedimentos marinhos . . . . . . . . 161

Evidencias de depressão . . . . . . . . . . . . . . . . . . . 162

As plantas terrestres cobertas por depositos marinhos. $\therefore \therefore \therefore \therefore 162$ 
Os coraes abaixo do nivel em que elles podem viver.

Os valles submergidos.

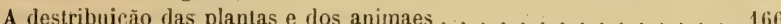

Registros humanos.................... 167

A espessura das rochas sedimentarias . . . . . . . . . . . . 167

As falhas com grandes deslocamentos verticaes. . . . . . . . . 168

A larga distribuição de conglomerados graúdos . . . . . . . . . . . . 168

Distribuição de mudanças do nivel . . . . . . . . . . . . . . 168

A marcha das mudanças do nivel. . . . . . . . . . . . . . . . 169

As causas de elevacão e depressão . . . . . . . . . . . . . . 169

Agentes organicos, ou trabalhos dos organismos na geologia. . . . . . . . . 171

Os agentes organicos destructivos . . . . . . . . . . . . 171

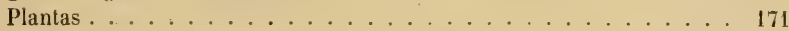

Animaes ........................ 173

Agentes organicos protectivos ou preservativos . . . . . . . . . . 176

Proleccão das praias por animaes . . . . . . . . . . . 176

Proteção pclas plantas. . . . . . . . . . . . . . . . 177

$\Lambda$ gentes organicos constructivos. . . . . . . . . . . . . 179

As plantas como agentes constructivos. . . . . . . . . . . 179

Turfa. . . . . . . . . . . . . . . . 180

Extensão . . . . . . . . . . . . . . . . . . . 181

Lignito . . . . . . . . . . . . . . . . . 181

Carvão bituminoso. . . . . . . . . . . . . 182

Carvão anthracite . . . . . . . . . . . . . . . 183

Varias theorias da origem do carvão de pedra. . . . . . . . . . 183

Depositos sulfurosos feitos pelas plantas . . . . . . . . . . 185

Dejositos ferruginosos feitos pelas plantas . . . . . . . . . 185

Depositos nitrogenosos. . . . . . . . . . . . . . . . 186

Depositos silicosos feitos pelas plantas. . . . . . . . . . . 186

Depositos calcareos provenientes de plantas. . . . . . . . . . . 187

Os animaes como agentes constructivos .............. 187

Depositos calcareos feitos pelos animaes. . . . . . . . . . . 187

Recifes de coral . . . . . . . . . . . . . . . . . . 188

Polypos coraliferos. . . . . . . . . . . . . . 188

Fórmas de coral . . . . . . . . . . . . . . . . . . . . . 189

Condiçôes do crescimento do coral . . . . . . . . . . . . 191

Formas de reciles de coral. . . . . . . . . . . . . . . . . . . 193

Dimensões dos recifes de coral. . . . . . . . . . . . . . 195

Theorias da formação de recifes de coral . . . . . . . . . . . . 196

Theoria de subsidencia . . . . . . . . . . . . . . . . . 196

Theoria de picos submarinhos ................ 197

A marcha do crescimento . . . . . . . . . . . . . . . . 198

Conclusões a respeito dos recifes de coral do Brasil. . . . . . . . . 198

Serpulas . . . . . . . . . . . . . . . . 200

Animaes marinhos microscopicos............. 200 
Paginas

Outros animaes que têm esqueletos calcareos .......... 201

Depositos silicosos formados por animaes. . . . . . . . . 202

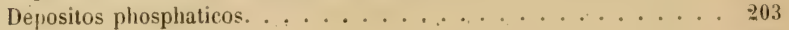

Resumo. . . . . . . . . . . . . . . . . . . . . . 203

0 homem como agente geologico ........................ 204

A influencia do homem sobre as plantas. ............... 204

Plantando . . . . . . . . . . . . . . . . . 204

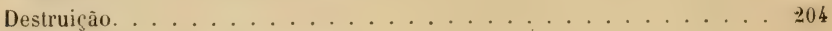

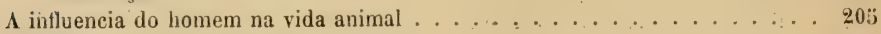

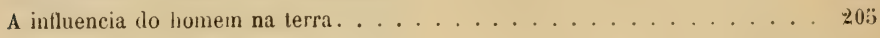

\section{PARTE SEGUNDA}

\section{Geologia Estructural.}

Qualidades, estructuras, e modificaçôes das rochas. . . . . . . . . . 207

Rochas sedimentarias . . . . . . . . . . . . . . . . . 207

Laminação ou estratificação . . . . . . . . . . . . . . . . . . 209

Conformidade ...................... 210

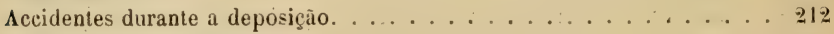

Alternação das camadas. . . . . . . . . . . . . . . . . 214

Persistencia dos estratos ........................... 214

$\Lambda$ deposição lenta de sedimentos . . . . . . . . . ....... 213̈

0 endurecimento das rochas . . . . . . . . . . . . . . 216

Rochas eruptivas ou não estratificadas . . . . . . . . . . . . . . . . . . . . . . . . .

Agrupamento das rochas igneas. . . . . . . . . . . . 221

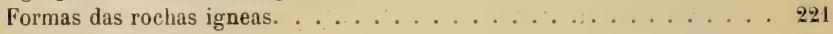

Lenções de lava . . . . . . . . . . . . . . . . . . . . . . . . . . . . . . . . . . . .

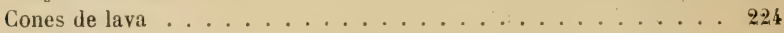

Laccolitos. . . . . . . . . . . . . . . . . . . $2 z^{4}$

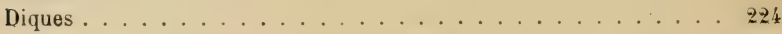

Tufos. . . . . . . . . . . . . . . . . . 22:

Feições estructuraes communs nas rochas . . . . . . . . . . 226

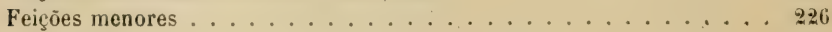

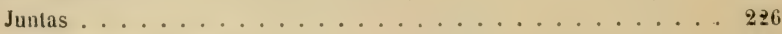

Columnas basalțicas . . . . . . . . . . . . . . . . . . . . . . . . . . . 27

Theoria das juntas. . . . . . . . . . . . . . . . . . . . . . . . . . . . .

Diques de arenito . . . . . . . . . . . . . . . . . 233

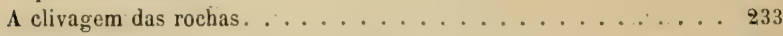

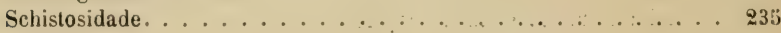




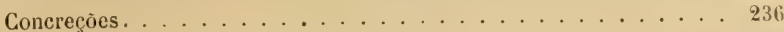

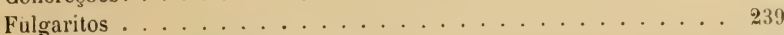

Fèições maiores . . . . . . . . . . . . . . . . . . . . . . 239

A deslocação das rochas . . . . . . . . . . . . . . . . . . 23!

Dobramento das rochas ................ . . . . . . . . . . . . . . .

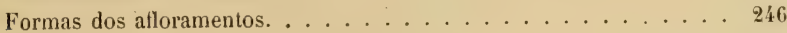

Effeitos das dobras sobre a topographia. . . . . . . . . . 247

Falhas . . . . . . . . . . . . . . . . . . . . . . . . . . . . . . . . . . . . . . .

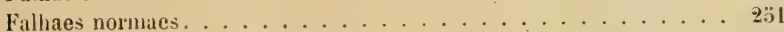

Falhas revertidas ou de empurrão . . . . . . . . . . . . . . . . . . . . . . . . . . . .

Complicaçoes produzidas por falhas . . . . . . . . . . . . . . . . . . . 3

Descobrimento de falhas na superficie da terra . . . . . . . . . 2506

Mineralizacão a longo de linhas de falhas . . . . . . . . . . . 2037

A emergencia de fontes . . . . . . . . . . . . . . . . . . 257

Mudancas na topographia. . . . . . . . . . . . . . . . . . . . . . . . . . . . . . .

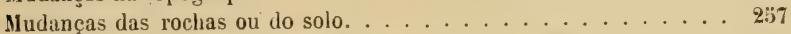

Importancia economica de falhas . . . . . . . . . . . . . . . 237

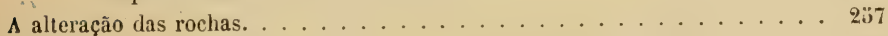

As causas do metamorphismo. . . . . . . . . . . . . . . 258

0 metamorphismo local. . . . . . . . . . . . . . . . . . 259

Metamorphismo geral ou regional . . . . . . . . . . . . . 260

As rochas metamoruhicas. . . . . . . . . . . . . . . . 2. 261

Conclusōes geraes relativas ao metamorphismo. . . . . . . . . . 261

Filões, vieiros, ou bêtas mineraes. . . . . . . . . . . . . . . 262

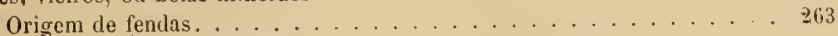

Alarganento de fendas. ................. 264

Profundidade das fendas . . . . . . . . . . . . . . . . . . . 263

0 enchimento de vieiros ....................... 266

Enchimento de vieiros de baixo. . . . . . . . . . . . . . 266

Enchimento de vieiros de cima . . . . . . . . . . . . . . . . 267

Enchimento lateral de vieiros ............... . . . . . . . . . . . . . 67

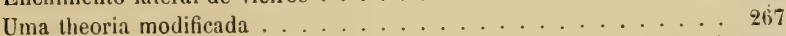

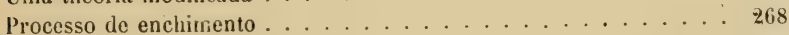

Riscos na ınineração . . . . . . . . . . . . . . . . 269

Relição de vieiros e depositos de alluvião . . . . . . . . . . 270

Fontes e poças em relação á estructura geologica . . . . . . . . . 271

Porosidade devida a espaços entre os fragmentos de materiaes graúdos. . 271

Porosidade devida a juntas ou fendas nas rochas ........... 272

Vias para agua feitas por cavernas. . . . . . . . . . . . . 272

Porosidade devida á dolomitação. . . . . . . . . . . . . . . . . . . 272

Relação á estructura .. . . . . . . . . . . . . . . . . . . 272

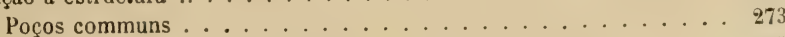

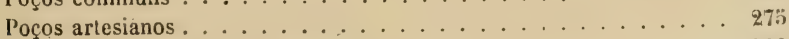

Importancia de altitudes relativás . . . . . . . . . . . . . 276

Aguas mineraes. . . . . . . . . . . . . . . . . 276 


\section{PARTE TERCEIRA}

\section{Geologia Historica.}

Introductorio . . . . . . . . . . . . . . . . . . . . 279

Os fosseis e us seus usos. ........................ 280

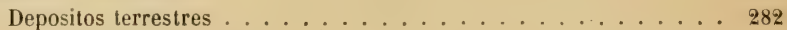

Valores relativos de fosseis ............... 282

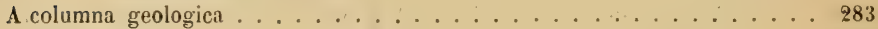

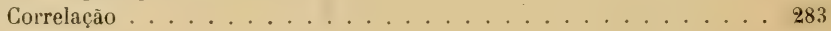

А còr . . . . . . . . . . . . . . . . . . . 283

Conteúdo mineral. . . . . . . . . . . . . . . . . 284

A ordem das camadas. . . . . . . . . . . . . . . . . 284

Emprego de fosseis para correlação . . . . . . . . . . . . 284

0 valor de fosseis. . . . . . . . . . . . . . . . . . . . 28

A columna geologica. . . . . . . . . . . . . . . . . . . . . . . . . . . . . . . . . . . . . . . . .

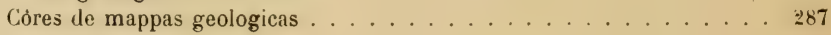

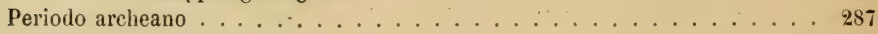

Distribuição do archeano . . . . . . . . . . . . . . . . 289

Depositos economicos do archeano . . . . . . . . . . . . 293

Periodo paleozoic . . . . . . . . . . . . . . . . . . . . . . . . . . . . . . .

Cambriano. . . . . . . . . . . . . . . . . . 29k

Ordoviciano on siluriano inferior. . . . . . . . . . . . . 294.

Siluriano ou siluriano superior. . . . . . . . . . . . . . . . $29 \ddot{3}$

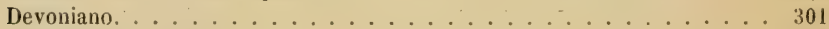

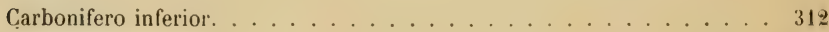

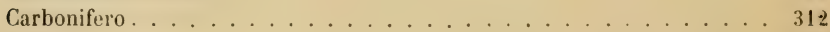

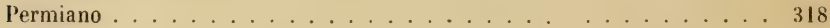

Periodo mesozoico. . . . . . . . . . . . . . . . . . . 331

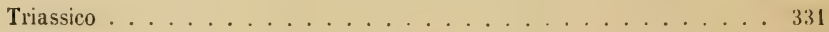

Jurassico . . . . . . . . . . . . . . . . . . . . . . . . . . . . . . . . . . . . . . . . . . . . . . . . .

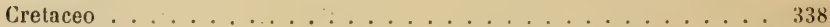

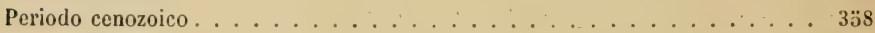

Terciario . . . . . . . . . . . . . . . . . . . . . . . . . . . . . . . . . . . . . . . . . . .

Periodo psychozoico. . . . . . . . . . . . . . . . . . . . . . . . . .

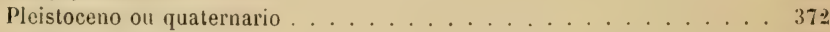

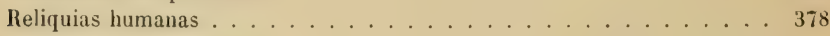

A exlensão do tempo geologico . . . . . . . . . . . . . . . . 379 


\section{GEOLOGIA ELEMENTAR}

\section{Introducção}

A geologia é a sciencia que trata da estructura e da historia da terra.

De ordinario, não é evidente para o principiante que a terra tenha uma estructura definida. I sua superficie, á primeira vista, parece completamente constituida de um solo sem estructura o qual em geral, se nus apresenta cobcrto de vegetação. Aqui e ali, as rochas nuas que ella contém estão expostas em morros e montanhas que, usualmente, mostram muito pouco do que se devêra entender por estructura da terra. Entretanto, si as superficies das rochas forem examinadas com cuidado, verificar-se-á que, emquanto uma exposição ou affloramento differe da outra, muitas dellas tèm certas feições communs e que cada uma patenteia um pouco da estructura do terreno que esclarece alguma cousa de areas maiores, e de todo o globo.

As rochas expostas nas pedreiras, nos canaes dos cursos d'agua, au longo das estradas e nos córtes dos caminhos de ferro, deverão ser examinadas de accôrdo com o que já expendemos. Mas convém notar que a historia da terra, assim como a sua estructura, são tanto quanto ellas se nos revelam visiveis e legiveis, fragmentarias.

Os archivos das rochas não são em toda a parte accessiveis. Alem disso, muitos delles foram escurecidos ou obliterados totalmente, e é sú pela reunião dos seus fragmentos que podemos decifrar a estructura e a historia da terra. E mesmo assim essa historia é sempre mais ou menos fragmentaria.

Das varias divisões da sciencia que ordinariamente figuram nos tratados sómente se tratará na presente obra elementar das denominalas geologia dynamica, estructural e historica. I consideração das divisôes de geologia cosmica, physiographica, petrographica, ete., nos levaria demasiado longe nos dominios da astronomia, geographia physica, mineralogia e outras sciencias relacionadas. 



\section{PARTE PRIMEIRA}

\section{Geologia Dynamica}

A geologia dynamica occupa-se com os agentes formativos e destructivos das rochas. Denominam-se agentes formativos de rochas as forças que as fazem, e agentes destructivos aquelles que as destroem. Estes agentes são os mesmos em todo o mundo; mas, devido ás differenças climatericas e locaes, elles variam grandemente em sua intensidade de uma região á outra, e até, num mesmo logar, de uma estação do anno para outra.

No sentido geral, são semelhantes as rochas em todas as partes do mundo, isto é, as rochas da America são muito semelhantes ás da Europa, Asia e Africa, e as rochas do Brasil assemelham-se ás dos outros paizes. Por esta razão, as leis da geologia applicam-se universalmente.

As rochas podem ser classificadas consoante aos agentes pelos quaes ellas são formadas.

I. - Sedimentos mechanicos, ou aquellas cujos materiaes, derivados de rochas preexistentes, foram mechanicamente depositados pelo ar ou pela agua. Em geral, taes rochas são denominadas sedimentarias, termo em que, estrictamente falando, se incluem tambem algumas de cada uma das classes abaixo mencionadas.

II. - Depositos chimicos, ou rochas precipitadas da solução em agua ou em gazes.

III. - Rochas igneas, ou as que se esfriaram e endureceram, pro- 
vindo d'um estado anterior de fusão. Algumas desıas são tambem deñominadas rochas vulcanicas.

IV. - Rochas de origem organica, ou as constituidas pela accumulação de materia organica.

Mas cada uma destas qualidades de rocha tem certas singularidades caracteristicas pelas quaes podem distinguir-se. Por isso é preciso conherer os agentes nu processos pelos quaes as rochas se formam.

\section{TABELLA DOS AGENTES GEOLOGICOS}

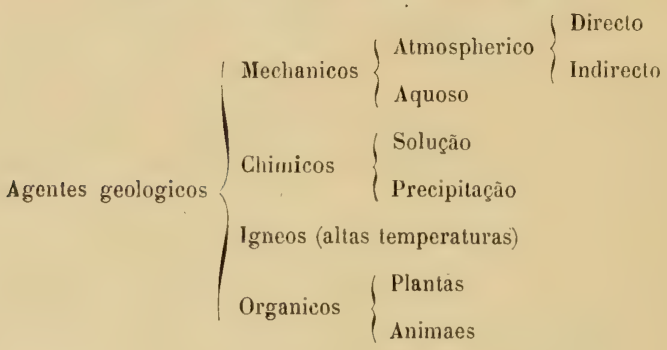

\section{A acção directa da Atmosphera.}

0 trabalho directo da atmosphera, chamado eoleo, é effectuado principalmente nas regioes aridas e nas praias arenosas. Elle consiste no transporte, desgastamento e deposição pelos ventos dos materiaes que formam as rochas. 0 assumpto será estudado nesta ordem.

\section{0 transporte pelo vento.}

Nas regiōes aridas sĩo frequentes as tempestades de areia e pó. Taes tempestades são pronduzidas pelo vento que levanta e conduz para longe e para cima as areias seccas e miudas espalhadas na superficie, em taes quantidades que produzem verdadeiras nuvens de pó. Ha 
poucos logares no Brasil onde o paiz scja de tal modo arido que permitta as tempestades de areia; mas, na Republica Argentina ellas se desencadeam frequentemente nas planicies seccas entre os Andes e o Oceano Atlantico, e entre os Andes e o rio Paraguay. Durante estas tempestades, a poeira éalgumas vezes tão espessa que produz escuridão quasi egual á da noite e, eventualmente, cahe em taes quantidades que obliteram marcos e estradas. Quando estas tempestades são aconpanhadas de aguaceiro, a poeira é carregada com a agua e tem a apparencia de uma chuva de lama (1).

Calcula-se que, durante taes tempestades, o material transportado no ar attinge, pelo menos, a duas mil (2.000) toneladas para uma milha cubica de ar (2).

Para ter-se uma idéa da distancia a que a poeira é assim transportada, basta dizer-se que navios, ao largo da costa da Africa e á distancia de mil quatrocentos e quarenta c oito (1.148) kilometros, tèm recebido essa poeira.

$\mathrm{Na}$ China os ventos do interior trazem quantidades enormes de poeira e espalham-na pelas costas sobre uma area de 2.071 .950 kilometros quadrados.

Na costa oeste como na do sul de Portugal as dunas prejudicam a agricultura em escala grande.

As areias sopradas pelos ventos. - A maior parte do material mineral impellido pelo vento acha-se na fórma de areia commum, tal qual se encontra em todas as costas brasileiras, ou de poeira fina. Quando a areia se acha molhada, não póde ser movida pelo vento; mas quando secca e frouxa, é facilmente carregada. Quando as marés estão baixas, as areias enxugam depressa e, quando o vento sopra em direção á terra, porecões de grãos de areia são transportadas além do alcance das marés e, uma vez que se encontrem na parte permanentemente secca da praia, podem ser impellidas a ongas distan-

(1) Buenos Aires and the provinces of the Rio de la Plata. By Woodbine Parish, pp. 127-128, second edition. London, 1852.

(2) Popular Science Monthly, Sept., 1896, p. 655. 
cias pelo vento. Amontoam-se, então, em lombadas movediças, conhecidas sob a denominação de " dunaș ». (Vède a fig. 1.)

As areias que formam as dunas são, a miude, sopradas para a terra, á distancia de muitos kilometros. Ao longo da costa dos estados do Rio Grande do Norte e do Ceará, as areias das dunas têm sido levadas para o interior onde formam lombadas, em algums logares, de mais de trinta metros de altura e de muitos kilometros de extensão.

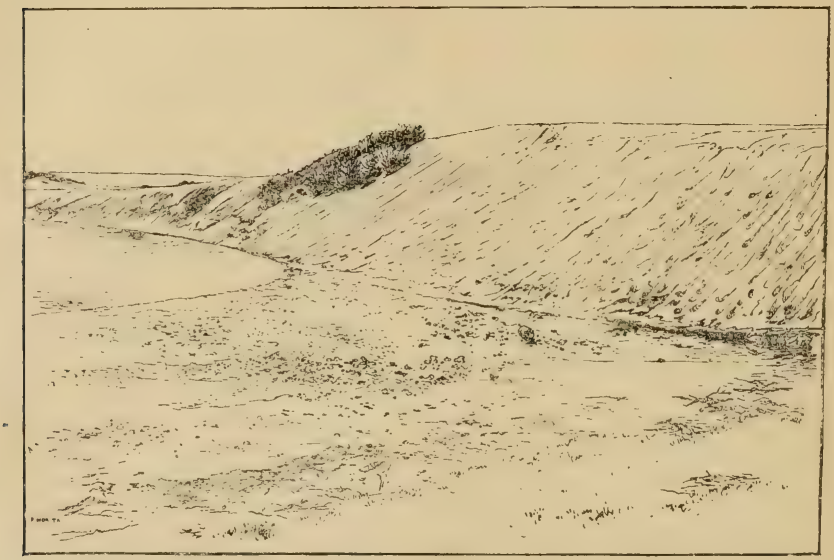

Fig. 1. - O lado de levante de uma duna de areia na costa de Sergipe.

Quando os ventos sopram parallelamente á linha da costa, as areias das dunas são transportadas ao longo da costa, até encontrarem algum obstaculo embaraçando a sua marcha e ali fazem accumulações.

Na costa do Ceará, onde os ventos reinantes são de sueste, as dunas frequentemente se accumulam no lado do sul das boccas dos cursos de agua, os obrigando a seguir para o norte a fim de rodear a areia que obstrue os seus canaes. Muitos cursus d'agua, ao longo da costa do Brasil a oeste do Natal, estado do Rio Grande do Norte, tambem têm dunas de areia ao lado sul das suas boccas. 
As figs. 1-2 mostram as dunas de areia na costa de Sergipe entre a bocca dos rios Cotinguiba e Real.

Nas regiōes dessas areias volantes verificam-se soterramentos pela invasão lenta das areias. No estado do Maranhão a areia se tem accumulado de tal modo na fortaleza da "Ponta da Areia " que, a se não

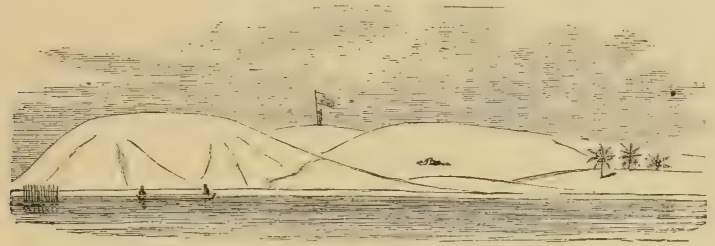

Fig. 2. - Dunas de areia, á bocea do rio Real, no estado de Sergipe (Hartt).

tomarem providencias contra a sua invasão, a alludida fortaleza virá fatalmente a desapparecer (1).

No porto de Natal, estado do Rio Grande do Norte, as areias encostam-se constantemente no rio causando sério prejuizo à sua navegabilidade, não obstante os cuidados a que o governo se applica para evitar damno tão grave. Foi por esse mesmo processo que a esphinge do Egypto, e muitas cidades e monumentos da Africa septentrional ficaram parcial ou completamente sepultados e perdidos.

Em diversos lugares na parte sul da costa do estado do Rio Grande do Norte, depois das areias das dunas terem sido sopradas para dentro da linha da costa, esta tem sido solapada de maneira a ver-se as velhas dunas expostas nos pincaros dos barrancos a trinta e cinco metros acima do nivel da maré. (Vêde fig. 3.)

A partir de ponta do Calcanhar, perto de Cabo de S. Roque, a costa do norte do Brasil segue em rumo de oeste mais ou menos até á punta de Tapagé no estado do Ceará noventa kilometros leste de Camocim. Todo aquelle littoral é baixo, e em geral constituido por areia fina

(1) Refere o Sr. John Hawkshaw que, naquelle local, os soldados do forte escaparam com difficuldade de ficar soterrados. (Melhoramentos dos portos do Brazil, pags. $7 \varepsilon-80$, Rio, $1 \varepsilon-5$.) 
que percorre essas costas em marcha incessante para oeste. As vezes a areia segue por terra, formando dunas que tudo avassalam, attingindo alturas superiores a trinta metros e estendendo-se muitos kilometros para o interior; outras vezes segue por mar, obrigando as embocaduras dos rios a tomar a direcȩão de noroeste e formando barras atravez dos mesmos, ou fechando-os pela acção combinada das vagas e das areias das dunas em periodos de seccas.

Na ponta de Mocuripe no Ceará as areias sopradas pelos ventus do

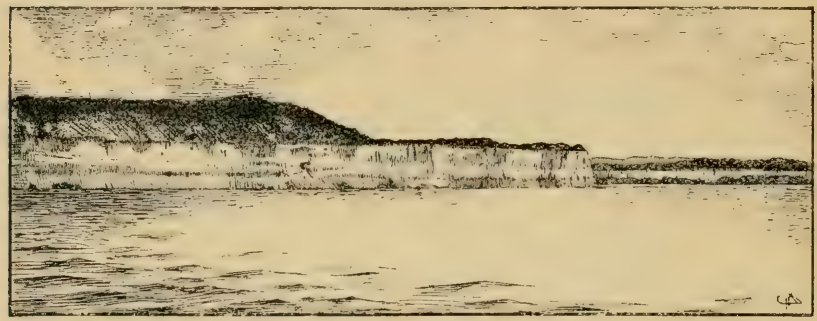

Fig. 3. - Duna antiga por cima do barranco em Pipa, estado do Rio Grande do Norte. O barranco neste ponto tem cerca de 35 metros de altura e a dusi que o colbre cerca de 30 metros.

sueste formam dunas extensas. Para impedir o movimento destas areias e das proximidades da cidade de Fortaleza, o governo mandou plantar capim e outras plantas para evitar o movimento d'ellas. As dunas da ponta do Mocuripe alcançam a altura de 50 metros e uma extensão de mais de tres kilometros. "Essas areias tèm uma direcção quasi constante, e marcham para oeste-noroeste. Parte dellas vai invadindo todo o taboleiro que se estende entre o rio Cocó e a cidade de Fortaleza, parte lança-se na enseada do Mocuripe e atravessa, seguindo depois a praia para oeste " (1).

Distribuição de plantas e animaes. - As sementes de muitas plantas têm azas ou outros appendices que lhes facilitam o

(1) Add., pag. 11, de Manuel Carneiro de Souza Bandeira, Sub.-com. do Ĺstudos dos portos de Fortaleza e Camocim. Rio de Janeiro, 1910. 
transporte pelo vento a largas distancias. Taes dispositivos ajudam a distribuição das sementes no globo e deixam os seus traços na historia da terra.

Certos animaes são levados pelo vento a longa distancia. Passaros que não poderiam voar para tão longe, são impellidos para o mar e assim alcançam ilhas e continentes a que nunca poderiam aportar por seu proprio vôo, si não fôra o auxilio que lhes prestam as correntes atmosphericas. Os insectos, especialmente os gafanhotos, aranhas e borboletas são, amiudadas vezes, levadas a longa distancia por esta maneira.

Os marinheiros raramente se approximam da terra firme do Brasil, sem que divisem borboletas e passaros terrestres perto do navio antes de terem terra á vista, sendo que o apparecimento daquelles animaes é para elles indicio certo de terra proxima.

Distribuição de cinzas vulcanicas pelo vento. - Na vizinhança de vulcũes acontece que as cinzas ou rochas divididas em pedeços miudinhos são expellidas pelas foręas explosivas e arremessadas á grandes alturas. Os ventos carregam essas cinzas ás vezes a distancias enormes. É por isso que na vizinhança de um vulcão activo as cinzas apparecem como um lençol extendido por todos os lados, mas geralmente mais largo na direção em que o vento sopra.

Por occasião da erupção de Krakatoa no estreito de Sunda no anno 1883, cinzas em quantidade foram levadas á distancia de mil e seiscentos kilometros. Em Venezuela verificou-se que as cinzas daquella explosìo attingiram a altitude de $\mathbf{2 6 . 0 0 0}$ metros, e na ilha de S. Hellena de 32.300 metros.

Nas regiões vulcanicas dos Andes, as cinzas arremessadas pelos vulcões espalham-se muito longe, devido ao vento, constituindo camadas que cobrem milhares de kilometros quadrados (1).

(1) Edward Whymper. Travels amongst the great Andes of the Equator, pags. 125, 141, 326, 328. New-York, 1892.

Nature, Apl, 24, 1884, 595; Dez. 6, 1883, 130-133. 


\section{0 desgastamento pelo vento.}

0 vento por si só é incapaz de desgastar as rochas, mas os grãos de areia transportados sĩo capazes de cortar e polir as rochas de encontro ás quaes são soprados. No estado do Cearí, quando o vento sopra fortemente da praia, os grãos de areia são levados de encontro ao rosto de quem passa com tal impetuosidade que causa dòr. A mesma cuusa se verifica passeando contra o vento em qualquer região de dunas. Quando os grãos de areia são soprados de encontro a uma rocha cada grão bate com uma forte pancada de maneira a desprender um pouco da superficie. Por este meio, as rochas e os seixos expostos ás areias volantes são cortados e polidos. Quando a areia é soprada de encontro á vegetação as suas folhas são cortadas, dilaceradas e reduzidas no seu desenvolvimento. Por isso acontece que as plantas ao longo das encostas perto da costa são frequentemente enfesadas.

0 poder cortante da areia soprada tem sido utilisado na invenção conlecida por sand-blast, artificio usado para embotar, cortar e ornamentar vidros e mesmo para cortar e esculpir pedras para e edificação e para fins ornamentaes.

\section{Deposito dos materiaes carregados pelos ventos.}

Quando as areias sopradas pelos ventos cahem na agua formam depositos sedimentares. Quando o mesmo acontece com a poeira ou cinzas vulcanicas os depositos denominam-se tufos. Sobre a terra firme os materiaes soprados pelos ventos formam aquillo que é conlecido pur medos, comoros ou dunas. Quando as areias são sopradas por cima de terreno plano e despido de arvores e outras obstruccoes, as dunas ou monticulos de areia avaneam em linha um tanto irregular, perpendicular á direcrão do vento. si, entretanto, existem arbustos, ou vegetarão de qualquer natureza, formando obstruecões, a areia é varrida para traz delles e as dunas amontoam-se em longas linhas, a partir da obstrucção e na direcção em que o vento sopra.

As areias se accumulam até alturas que variam com as condiçoes 
locaes. Na costa da Ilollanda, attingem muitas vezes a setenta e nove (79) metros de altura; no orcidente na Palestina attingem a sessenta (60) ; em Cat Island, uma das Bahamas, ellas chegam a cento e vinte e duis (122) metros de altura; emquanto, na costa occidental da Afriera, dizem alcanęarem cento e cincoenta (150) metros e mais (1).

I' nordeste da IIespanha, em Toroella de Montegri, as areias tèm sido supradas quinze kilometros do logar de origem e tèm invadido os campos cultivados, transformando-os em desertos (2).

0 movimento das dunas é produzido pelo transporte dos grãos de

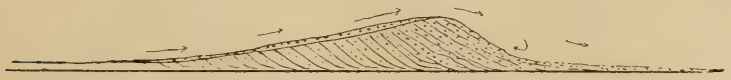

Fig. 4. - Secçāo mostrando uma duna de areia e o arranjamento das suas camadas. As flechas indicam a direcção do vento.

areia por cima do monticulo de birlavento para sotavento unle ficam depositados. 0 resultado é que ha um movimento gradual de todo o corpo da duna. 0 amontoamento da areia, no lado de sotavento, dá ao material uma estructura peculiar e earacteristica. As camadas, quando depositadas, se inclinam sempre na direcção do movimento das dunas, de maneira que umạ seccão cortada atravez de um tal monte de areia, mostraria ter a estructura da figura 4 .

Estas dunas endurecem algumas vezes, devido á deposição de carbonato de cal entre os gràos de areia. As rochas formadas por esta maneira, com os materiaes soprados pelo vento, são chamadas eolias.

Os materiaes de que se formam as dunas e as rochas eolias variam muito. Na costa do Rio Grande do Norte, as areias sopradas são na maior parte, grãos de quartzo, porém ellas contèm algumas particulas de ferro e alguns fragmentos de materia calcarea, quer sejam conchas de molluscos, ou pedaços de coral.

Na ilha de Fernando de Noronha, existem rochas eolias feitas

(1) A reconnaissance of the Bahamas. By Alex. Agassiz. Bul. Mus. Com. Zool. XXVI, pag. 34, Cambridge, Mass. 1884.

(2) Arenas voladoras del n. e. de España. Por Don Rafael Puig y Valls. Bol. Y Memorias de la Real Acad. de Ciencias y Artes, Barcelona, 1900. 
quasi inteiramente de fragmentos de conchas, de modo que estas rochas são queimadas para fazer cal (1). (Vède fig. ว33.)

0 endurecimento do arenito eolio le Fernando de Noronha foi produzido pelas chuvas que sobre as dunas cahiram, dissolveram a cal da parte superior das dunas de areia calcarea e depositaram essa mesma

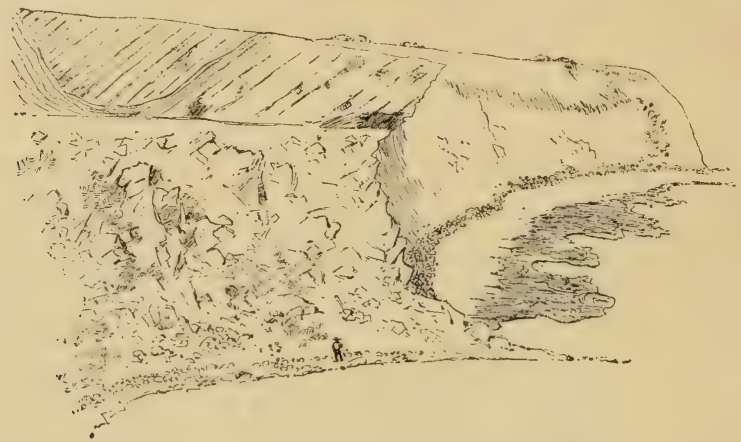

Fig. 5. - Uma antiga duna de areia endurecida

e ora exposta num barranco de rocha ignea. llha Rata, Fernando de Noronha.

cal entre os grãos formadores da parte interna e inferior do monte. A maioria das dunas de Fernando têm sido endurecidas e solapadas pelo mar. As dunas antigas estio, por isso, actualmente expostas como rochas duras ao longo dos barrancos.

Na China os depositos de loess tèm a espessura de 750 metros. Naquelle paiz lazem nos arroios de loess excavaçues que servem para habitạcões do povo. 0 loess, antigamente attribuido á acção dos geleiros, hoje geralmente attribue-se á acção de vento.

\section{Acção indirecta da atmosphera.}

A acęão indirecta dat atmosphera é muito mais importante na geologia do que a directa. Estudal-a-emos sob os seguintes titulos.

(1) J. C. Branner. Os gres eolios de Fernando de Noronha. Revista do Instituto Archeologico e Geographico Pernambucano. N॰44, pags. 161-171. Pernambuco. 1893 . 

I. - Mudanças de temperatura.
II. - Evaporação.
III. -- Producção de vagas nas extensas massas de agua.
IV. - Effeitos sobre o nivel da agua.
V. - Effeitos sobre as correntes oceanicas.
VI. -- Sua açęão como carregadora da agua.

\section{I. - Mudanças de temperatura.}

Sabem todos que as mudanças de temperatura produzem a expansão e contracção dos metaes. Produzem-se effeitos semelhantes sobre os mineraes e sobre as rochas.

Nas rochas crystalinas massiças os crystaes se expandem e se contrahem desigualmente ao longo dos seus differentes eixos e alguns delles, até, se contrahem ao longo de um eixo emquanto se expandem ao longo do outro (1).

Visto que as rochas crystalinas são ordinariamente, compostas de varias especies de mineraes, interlaçados entre si, todas as mudanças de temperatura tendem a lazer com que os mineraes escorreguem uns sobre os outros, affrouxando e desintegrando toda a massa.

Todas as rochas expostas estão sujeitas ás mudanças de temperatura; isto se verifica especialmente nas camadas superficiaes. Mesmo nas. regiões do Brasil onde a temperatura não vai abaixo de zero, as rochas expostas soffrem uma mudança de temperatura na superficie de cerca de $57^{\circ} \mathrm{C}$., isto é, a temperatura, ao sol, durante as horas mais calidas é cerca de $65^{\circ} \mathrm{C}$., eniquanto, á noite, a temperatura póde cahir até cerca de $8^{\circ} \mathrm{C}$. 0 efeito ultimo de taes mudanças consiste na desin-

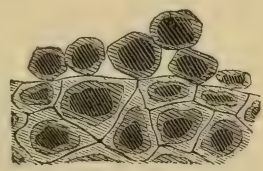

Fig. 6. - Diagramma illustrando a origem dos blocos de decomposição. (Hartt). tegraçãu das rochas e no esfolhamento dellas, formando matacões (enormes pedras soltas) de decomposição e até arredondando os proprios moros e montanhas. (Vède fig. 6.)

(1) F. W. Clarke. Tables of expansion by heat for solids and liguids. Smithsonian Miscellaneous Collection, XIV, n. 289, Washington, 1876. 
Quando extensas superficies de granito estio expostas aos raios solares, a expansão faz com que grandes laminas ou cascas de muitos

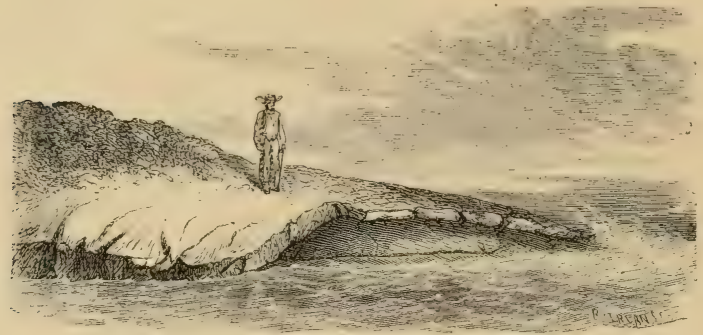

Fig. 7. - Folheamento de granito, Ilha do Boi, estado do Espirito Santo (Hartt).

centimetros de espessura se levantem e se desprendam da massa inferior mais fria. (Vède fig. 7.)

Quando as estradas passam por cima destas grandes cascas, ellas

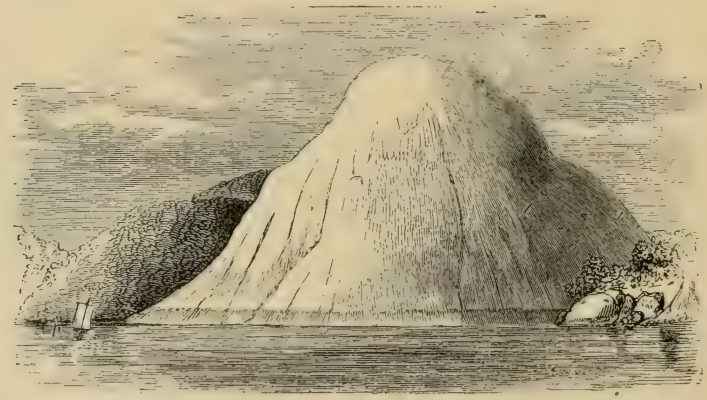

Fig. 8. - O morro $10^{\circ}$ de Março. Um pico de granito exfoliado na Victoria, capital do estado do Espirito Santo (Hartt).

repercutem num som jeo sob os cascos dus cavallos. Os bellos cones de granito que se acham perto e na cidade do Rio de Janeiro e Victoria (vêde tig. 8) devem as suas lindas firmas arredondadas a esse: processo de descascamento ou exfoliação. Nas encostas de quasi todos 
esses picos vêm-se as arestas livres das grandes cascas separadas d'elles por esse processo de contracęão e expansão. Nas pedreiras do Rio de Janeiro os cavouqueiros se utilisam dessas fendas para extrahir blocos de espessura conveniente.

As laminas ou cascas variam em espessura desde poucos centimetros até muitos metros. As laminas grossas porem são susceptiveis de

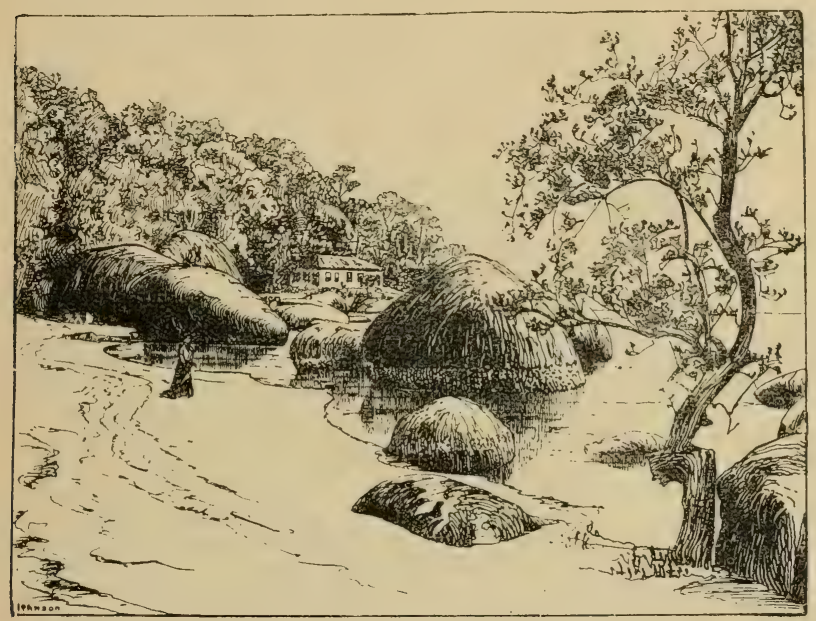

(Fig. 9. - Matacões ou blocos de decomposição de granito, Paquetá, bahia do Rio de Janeiro.

divisão mais fina, mas separam sempre com as faces paralleles á laminação grossa.

0 effeito das mudanças de temperatura sobre blocos de todos os tamanhos é produzir massas proximamente arredondadas.

Estes matacões ou blocos se encontram em todas as regiōes do Brasil onde as rochas são massiças, quer sejam granitos, gneiss, ou outras rochas crytallinas e homogeneas. Existem muitos exemplares excellentes perto do Rio de Janeiro, onde elles surgem á tona d'agua da respectiva bahia, especialmente na Ilha da Agua e na Ilha de Paquetá. 


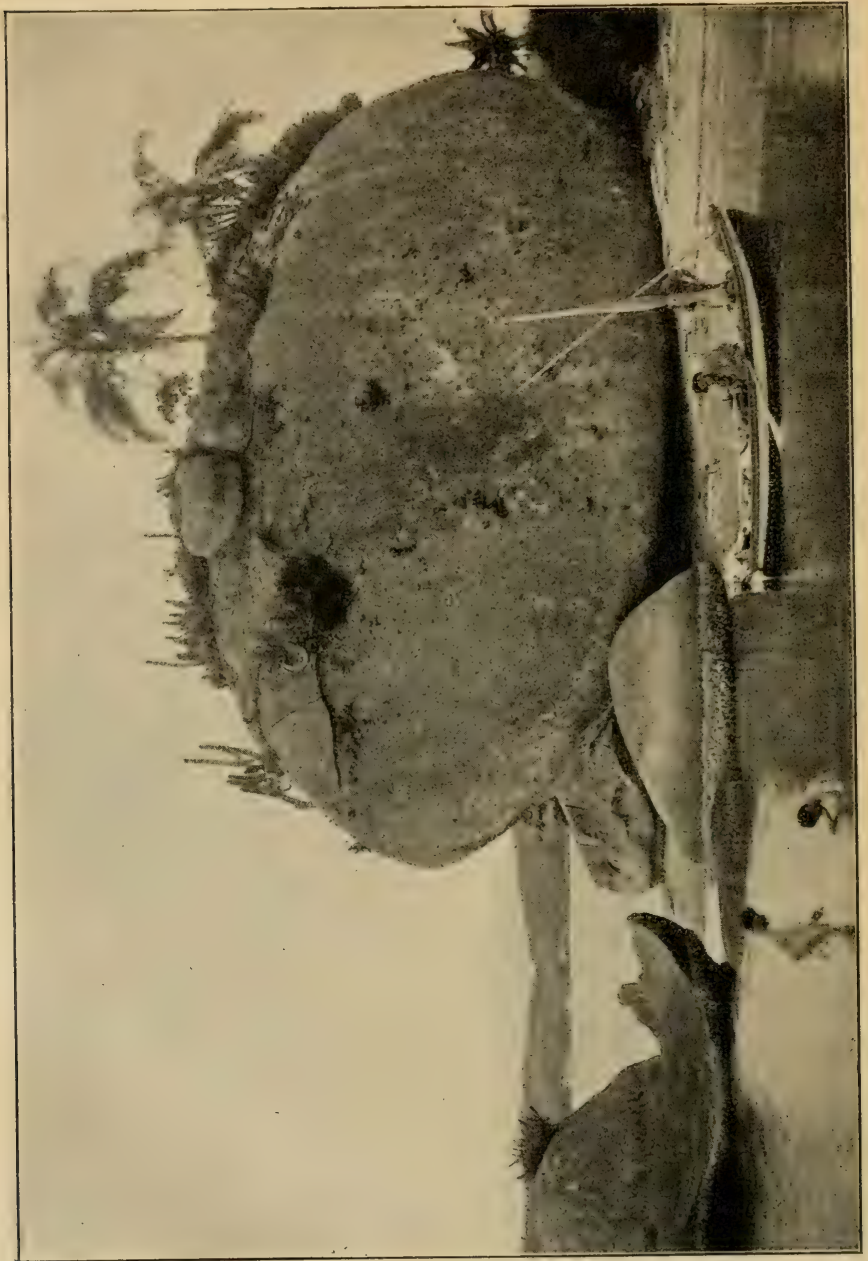

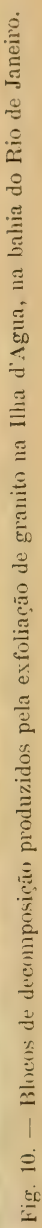


IIa tempos se levantou a hypothese que estes blocos haviam sido espalhados no Brasil pelos geleiros durante a época glacial - um periodo frio que se sabe ter existido nas regiões mais proximas dos polos. Entretanto, estudos posteriores mostraram que esses blocos se originaram, proximo ou mesmo no proprio logar onde ora se encontram, pelos processos de exfuliação e decomposição (1). Na estampa junta vè-se uma grande casca de forma conchoidal já destacada e uma outra ainda assentada sobre o nucleo.

As «furnas do Agassiz » em Tijuca na vizinhança da cidade do Rio de Janeiro são accumulações de blocos de decomposição tendo a sua origem nas serras circumvizinhas.

Afim de entender-se melhor 0 processo pelo qual os blocos angulares se arredondam, imaginemos um cubo de granito com as suas faces divididas por linhas, em quadradus de tamanhos iguaes; supponhamos um centimetro quadrado (Fig. 11).

Ora, si um cubo tal fồ exposto a um augmento igual de tem-

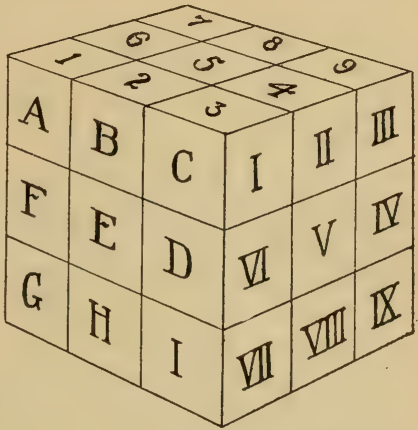

Fig. 11. - Diagramma que illustra a exfoliação. peratura, cada um dos quadrados, em que estão divididas as suas faces, receberia a mesma somma de calor. Si suppuzermos que é de um grau esse augmento de temperatura, então cada quadrado, sobre cada face do cubo, será aquecido na mesma proporção. Aconteceria que os quadrados A, B, C, D, E, etc., seriam aquecidos na importancia de um grau, e os quadrados, na superficie superior, $\mathbf{1}, \mathbf{2}, 3, \mathbf{4}, \mathbf{5}$, etc., seriam semelhantemente aque-

(1) J. C. Branner. The supposed glaciation of Brazil. Journal of Geology, vol. 1, pgs. 753, 7\%2, Chicago, 1893.

A supposta glaciação do Brazil; Reoista Brrasileira, VI, 106-113, Rio' de Janeiro, 1896. 
cidos, emquanto os marcados I, II, III, IV, I, etc., receberiam identico augmento de temperatura. Mas, emquanto alguns dos cubos, que formam o bloco inteiro, têm apenas umä face exposta, outros, ao lorigo das arestas do bloco, apresentam duas faces, e os dus cantos tres faces, e por consequente os cubos marcados 2 B, 4 II, receberão o dobro do calor que recebe os marcados E, V, ou こ̌, a passo que o marcado $3 \mathrm{C}$ I receberá o triplo. 0 effeito desta distribuição de calor será aquecer mais as arestas e os cantos do bloco do que as suas partes centraes. Por outras palavras, o calor penetraria o bloco mais profundamente nos cantos. Na natureza, todas as mudancas de temperatura affectam as rochas mais profundamente nos angulos silientes e a rocha parte-se em laminas, que cahem, deixando por baixo, na parte interna, uma superficie mais ou menos arredondada.

Convêm notar-se, ainda mais, que quando superficies largas de rochas massiças, semelhantes aos granitos e gneiss do Rio de Janeiro, são sujeitas a mudanças consideraveis de temperatura, a expansão e contracção da rocha produzem fendas nas mesmas.

Já se disse que as rochas expostas ao ar, no Brasil, soffrem uma mudança de temperatura de cerca de 57 gráus centigrados.

Os granitose gn iss expandem-se e contrahem-se uma parte em cerca de cento e onze mil $(\mathbf{1 1}, 000)$, ou nove decimos $(0,9)$ de nillimetro para cada cem metros, para cada mudança de um gráo centigrado. Sobre uma superficie de granito de cem metros de comprimento, essa variação de temperatura produziria uma expansão ou uma contracção linear de cerca de cincoenta e um (̋̊) millimetros. Uma tal mudança de temperatura deve necessariamente produzir fendas na rocha.

Devemos notar que por mais resistente que seja uma rocha aus agentes de decomposição, desde que ella se fenda, ficará sujeita an ataque das aguas meteoricas e dos acidos e agentes organicos de varias naturezas que, eventualmente, completarão a sua destruiço. Deve-se tambem notar que, como succede com o calor, esses diversos agentes actuam mais energicamente sobre as arestas e angulos dos blocos angulares e então tendem tambem a produzir matacões arredondados de decomposição.

Em qualquer parte onde se encontrem grandes penedos lisos on 
Brasil, vêm-se linhas de vegetação sustentando-se, ali e alèm, nas fendas produzidas por essas mudanças de temperaturas. As plantas (excepto as epiphytas, que não carecem de solo) não medrariam em taes lugares, si não houvesse solo, e ahi não pode haver solo senâo o produzido pela decomposição da propria rocha.

Nas regiões onde a temperatur a desce abaixo de zero a agua de dentro e em torno das rochas fica gelada, e isto produz um phenomeno poucu conhecido no Brasil, A agua quando gela se expande, e quando enche as fendas das rochas, essa expansão dilata estas fendas separando mais os fragmentos de rucha. Nos climas frios as montanhas ingremes e escarpadas, cujas rochas mais ou menos se fracturam, tèm as suas encostas rapidamente rebaixadas, devido á expansão da agua no acto de gelar-se nos climas frios. Os calçamentos das ruas são frequentemente levantados dos seus respectivos lugares pela congelario das aguas debaixo delles; os tubos d'agua rebentam-se; os tijolos e pedras dos muros deslocam-se e cahem; as encostas das montanhas são rebaixadas formando taludes ao longo de sua base, - tudo por causa dessa mesma força expansiva.

Estes phenomenos, entretanto, limitam-se ás regiōes onde a temperatura desce abaixo de zero, e por isso esse facto tem pouca importancia para quem estuda a geologia do Brasil.

\section{I. - A formação do solo.}

Solos alluviaes. - - Os solos alluviaes são transportados pelos cur'sos d'agua até ao logar em que hoje se encontram e lá se espalham nas varzeas, ou plancies de inundação, durante as cheias. Os solos alluviaes são assim sempre de origem extranha e são limitados aos terrenos baixos que acompanham os cursos d'agua e ás suas varzeas.

Solos residuarios. - Os solos residuarios fornam-se no logar, em que se acham e derivam-se directamente dis rochas pela acção chimica, e parcialmente tambem pelos effeitos de mudança de temperatura subre aquellas rochas. As differenças que se notam entre os solos 
residuarios são, por isso, devidas principalmente ás dissemelhanı̧as das rochas das quaes elles resultam.

A " terra rôxa " do estado de S. Paulo e outros estados das bacias do Paraná e Uruguay formaram-se pela decomposição in situ das rochas eruptivas (diabase) que se encontram embaixo.

É de notar porem, que nem sempre o diabase fica decomposto ao ponto de formar solo. Dr. Lisboa referindo-se ás suas explorações do estado de Matto Grosso notou que: " nem sempre essa rocha decompondo-se transforma-se na typica terra roxa ou noutra que se lhe aproxime. A terra roxa typica com exuberante mata pluvial interior, forma apenas uma orla de legua ou pouco mais de largura, margeando o Tieté, de Avanhandava ao Paraná, abrangendo portanto unicamente a parte mais baixa dos seus valles secundarios $n(1)$.

0 " massapé » ou solo negro do estado de Sergipe e do Reconcavo da Bahia é o resultado da decomposição dos calcareos cretaceos daquellas regiões. Os granitos de grão grosso de muitas partes do Brasil apresentam um solo de pedregulho, conhecido sobe o nome de salmourão, quando uma parte do feldspatho resiste á decomposição e permanece, como o quartzo, em areia grossa ou no meio da terra derivada por decomposição das partes mais decomponiveis compostas de felilspatho e de mica. Estes ultimos são solos residuarios.

Solo glacial. - Nas regiões do mundo onde houve glaciação ha uma especie de solọ feito ou modificado pela acção dos geleiros. Esses solos podem originar-se, ou dos solos residuarios, ou dos alluviaes, ou de qualquer combinaçio dos dois. Como não houve glaciação no Brasil durante o pericdo em que os solos existentes se formaram, esse assumpto não entra no estudo da geologia do Brasil.

\section{II. - Evaporação.}

O trabalho geulogico da evaporação consiste na concentração e deposição da materia mineral contida n'agua. I deposição chimica dus

(1) M. A. R. Lisbon. Oeste de S. Paulo; Sul de Matto Grosso, pg. 10. Rio de Janeiro, 1910. 
mineraes será tratada mais detidamente sob o titulo de " agentes chimicos ».

Aqui apenas estudaremos a formação da efflorescencia.

Nas regiões aridas, encontra-se commummente a superficie da terra coberta por uma crosta delgada de mineraes esbranquiçados, conhecidos sol a denominação de « alcali ๖. Estes mineraes são trazidos em solução do sulo e das rochas inferiores e se crystalisam na superficie quando a agua se evapora.

As aguas que entram e passam atravez das rochas e do solo dissolvem parţe da sua materia mineral. E' essa a rasão porque as aguas de todas as fontes, poços e cursos contêm mais ou menos materia mineral em solução. Nas regiões aridas a atmosphera secca produz a rapida evaporação de todas as aguas a ella expostas. A agua na superficie do solo evapora-se; a materia mineral em solução não se evapora, mas se crystalisa, ficando na superficie do solo. 0 processo é continuado pela agua que vem de baixo, devido á acęão da capillaridade, para substituir a que foi removida pela evaporação.

A materia mineral deixada na superficie do solo não é ordinariamente de uma só substancia; ao contrario, varia consideravelmente. Ella póde ser chlorureto de sodio, ou sal commum, ou póde ser uma outra fórma de soda, ou algumas das fórmas mais soluveis da potassa, cal, magnesia ou alumina. Os mineraes que constituem essa efflorescencia são, em todos os casos, os que se dissolvem facilmente n'agua.

As seguinte são analyses do sal fabricado do alcali do valle do Salitre no estado de Bahia.

\begin{tabular}{|c|c|c|}
\hline Agua e materia organica. & 0.50 & 1.60 \\
\hline Areia . . . . . . . & 1.32 & 0.63 \\
\hline Sulfato de magnesio $\left(\mathrm{Ig} \mathrm{SO}_{4}\right) \ldots \ldots$ & 0.36 & 0.86 \\
\hline Sulfato de calcio $\left(\mathrm{Ca} \mathrm{SO}_{4}\right) \ldots \ldots \ldots$ & 2.68 & 1.78 \\
\hline Chlorureto de ealcio $(\mathrm{Ca} \mathrm{CI}) \ldots \ldots$, . & $n$ & 0.63 \\
\hline \multirow[t]{2}{*}{ Chlorureto de sodio $(\mathrm{Na} \mathrm{Cl}) \ldots \ldots$} & 95.20 & 94.68 \\
\hline & 100.06 & 100.18 \\
\hline
\end{tabular}

A formação dessa efflorescencia não occorre nas regiões onde a queda das chuvas é abundante ou bem distribuida durante o anno, pela 
razão que, sendo muitu soluvel, o material está dissolvido e levado pelas aguas. Por essa razão taes phenomenos não são tão communs no Brasil como nas regiões desertas da Patagonia, Argentina e Chile.

Não tenho conhecimento de analyses chimicas das efllorescencias do Brazil senão as do sal da Bahia; mas as de Lruguay e da Republica Argentina mostram as seguintes composições (1).

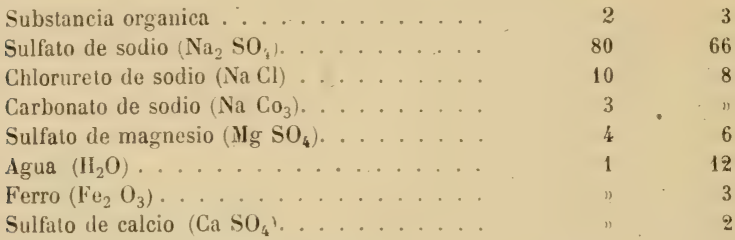

No interior do estado de Pernambuco, perto de Buique, certos arenitos contèm consideraveis quantidades de salitre, que é um mineral muito soluvel. Quando as camadas que o contêm estão expostas ao ar, as aguas se evaporam e o salitre fúrma uma cfflorescencia de crystaes, de côr amarellada. na superficie das rochas. Em crystalisando-se o salitre afrouxa uma camada delgada da rocha de modo que estas rochas salitriferas estão sendo constantemente desintegradas pela formação da efflorescencia deste sal. Este é, então, raspado e utilisado pelo povo dos arredores para fabrico de polvora (2).

Este processo de evaporação frequentemente produz covas na superficie das rochas. Essas covas são usualmente de alguns centimetros de profundidade apenas, mas, algumas vezes, transformam-se em verdadeiras cavernas.

No estado da Bahia logo ao sul da Estrada de Ferro Central e perto da estação Tanquinho existem cavernas enormes nos morros de granito.

(1) Dr. J. Schroder. La composición de dos a eflorescencias salitrosas observadas en el Uruguay y la Argentina. Revista del Instituto de Agronomia de Monteoideo, XII, 15-10. Montevideo, 1913.

(2) L. Lombard. Relatorio sobre a exploração mineralogica de Garanhuns u Buique e da sona salitrosa de Buique. Recife, 1895. 
A fig. junta (n. 12) mostra uma superficic cavernosa tal.

Em uma grande parte do valle do S. Francisco encontram-se rochas saliferas. Dellas são extrahidas grandes quantidades de sal com-

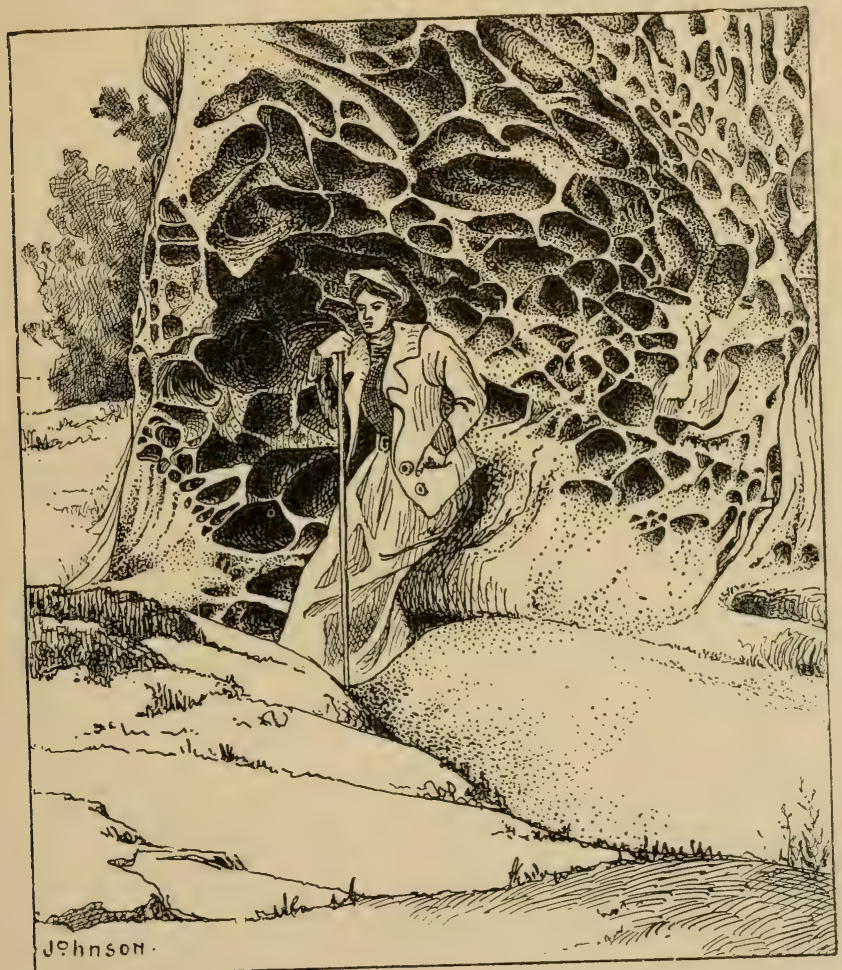

Fig. 12. - Superficie cavernosa de arenito produzida

pela formação da efflorescencia. (De uma photographia.

mum, conhecido por sal da terra, o qual é obtido para o uso local de maneira semelhante á acima descripta. Affloramentos de rochas nas quaes apparecem taes efflorescencias salinas, são muito frequentes 
no interior do Brasil. Denomina-se barreiros, e sào muito apreciadas pelos caçadores e creadores de gado por causa da attracção que offerecem tanto aos animaes domesticos como aos silvestres.

A formaçào de efllorescencia é caracteristica de regives aridas ou semi-aridas, aonde a estação chuvosa fornece a agua que durante a estaçào secca produz a efllorescencia. A efllorescencia não pode apparecer numa região onde chove todo o anno, porque as aguas das chuvas removeriào os mineraes soluveis sem dar-lhes tempo de crystalizarem-se.

\section{III. - Vagas sobre grandes massas de agua.}

Is vagas são um agente geologico de grande importancia. Pela maior parte as vagas são produzidas pelo vento que se move sobre a agua. 0 trabalho geologico das vagas é feito quasi exclusivamente na linha da costa, ou perto della, onde a agua se encosta na terra.

Ao mesmo tempo a acção destruidora das vagas é muito aug̣men tada pela maré nessas occasiões, porque naturalmente assim alcançam maior altura. Esse trabalho consiste no solapamento da costa e no transporte ao longo della dos materiaes excavados e na sua accumulação na forma de pontaes e corôas. Estes assumptos serão estudados circumstanciadamente sob o titulo de "agentes aquosos".

\section{IV. - O effeito do vento em relação ao nivel das aguas.}

Quando o vento sopra sobre uma massa d'agua, por longo tempo, em uma só direção, a agua tende a accumular-se naquella direç̧ão. Este effeito é mais notavel sobre massas alongadas de aguas, taes como os lagos compridos e estreitos.

Em Outubro de 1886, o vento de oeste soprou firme por alguns dias sobre o lago Erie, na America do Norte, obrigando a agua a elevar-se 2.4 metros, em Buffalo, na sua extremidade oriental e a abaixar'-se na mesma proporção, em Toledo, na extremidade occidental do mesmo lago. Em Setembro de 1900, a cidade de Galveston, na costa 
do Golpho do Mexico, foi destruida pelas vagas causadas pelos ventos fortes que sopraram durante muitas horas no alludido golpho. Essas vigas cresceram até cerca de tres metros acima do nivel usual e, como a cidade era construida sobre uma ilha tendo apenas metro e meio a tres metros de elevação acima do nivel ordinario da maré, ella ficou submergida e cerca de cinco mil pessoas pereceram.

Na costa da Asia Menor, os ventos algumas vezes sopram firme em uma só direç̧ão por muitas semanas e, quando são violentos, abaixam a agua em alguns logares, accumulando-a em outros.

Taes phenomenos são frequentemente attribuidos a causas sobrenaturaes. Não é descabida a hypothese de que o abaixamento das aguas no Mar Vermelho, ao tempo da passagem dos Israelitas, fosse devido a esse agente.

\section{V. - Effeito do vento sobre as correntes oceanicas.}

Sabe-se que as aguas oceanicas se movem em grandes correntes mais ou menos constantes em direcçio e marcha. Essas correntes sìo produzidas, em parte, por convecçào ou movimentos internos devidos ás differenças da temperatura; em parte, pelo retardamento das aguas sobre a superficie do globo a girar este ao redor do seu eixo, e, ainda, em parte pelo sopro dos veritos na superficie dos oceanos.

No giro da terra ao redor do seu eixo, a atmosphera gira com ella, porém, devido ao movimento produzido pela differença de temperatura, tende a atrazar-se e, sendo aquecida na região equatorial, eleva-se e derrama-se na direcẹão dos polcs frios. Esse retardamento produz as correntes aereas que, em contacto com o globo (cuja superficie pela maior parte é coberta de aguas) se movem para oeste. Essas correntes aereas contribuem para o movimento das correntes oceanicas, especialmente nos tropicos.

As principaes correntes que seguem ao longo da costa du Brasil sào fornecidas pela corrente equatorial que corre da costa da Africa na direcrão do Cabo de São Roque. Neste ponto fica dividida pela fórma do continente, dirigindo-se para noroeste ao longo das costas do Cearà, 
Maranhão e Pará, e para sudoeste ao longo da costa de sueste do continente.

Essas grandes correntes oceanicas têm uma influencia profunda sobre os climas de certas partes da terra.

Um caso que merece especial attençió é o das aguas que correm do Golpho do IIexico para o Oceano Atlantico septentrional. A corrente quente que corre para noroeste, ao longo da costa do Brasil, entra no Golpho do Mexico e, depois de ter estado muito tempo debaixo dus tropicos aquecidos, estas aguas derramam-se pelo Estreito de Florida, e dirigindo-se para nordeste, atravessam o Oceano Atlantico, abrandando o clima de todo o noroeste da Europa, especialmente o das Ilhas Britannicas (1).

\section{VI. - A atmosphera como carregador d'agua.}

0 trabalho geologico mais importante da atmosphera é o que ella faz como carregador d'agua, conduzindo-a dos mares e oceanos para a terra. Ver-se-á, mais adiante, que a agua é um agente geolngico de primeira ordem; mas não deverá ser esquecido que a maior parte do trabalho geologico feito pela agua é, indir ectamente, obra da atmosphera.

0 ar nunca está em repouso, mas sim em constante movimento por toda a parte do globo.

As grandes correntes aereas movem-se sobre a terra em direcções mais ou menos definidas; mas, devida a mudanças de temperatura, essas correntes são muito influenciadas pelas estaçōes do anno, isto é, pela relação do sol com a superficie da terra. Ellas são tambem provivelmente influenciadas de alguma maneira pelas formas topographicas.

Os factos principaes de importancia geologica rom relação ao ar Sào :

I. - $\Lambda$ absorpção d'agua pelo ar quente.

II. - A elevação do ar quente.

(1) J. E. Pillsbury. The Gulf Stream. National Geographic Magazine, XXII, Aug. 1912, 767-778. 
III. -- A queda d'agua do ar, pelo resfriamento, alem de um certo ponto.

E' facto muito conhecido que o ar quente absorve a humidade. A roupa molhada é collocada ao sol para seccar, porque a experiencia tem mostrado que o sol, aquecendo o ar em contacto com ella, faz a absorpçào da agua. A roupa molhada é posta nuitas vezes junta ao fogão para conseguir-se o mesmo resultado: o fogo aquece o ar e este, sendo aquecido, é capaz de absorver a agua da roupa, deixando-a secca.

0 ar quente eleva-se devido ao facto de ser mais leve do que uma massa egual de ar mais frio.

Nas regiões montanhosas observa-se um phenomeno peculiar que consiste na formação de um pendão de nuvens, devido ao ar quente que se eleva dos valles carregado de humidade que se condensa em fòrma de nuveın, perto dos cumes das montanhas. No Rio de Janeiro, vè-se frequentemente esses pendões de nuvens no cume do Corcovado, e mesmo no Pão de Assucar, emquanto o resto do céu se conserva limpo. 0 povo do Rio de Janeiro, observando aquelles picos, costuma dizer que o Corcovado e o Pão de Assucar coroados prenunciam chuva.

Em geral o ar quente dos tropicos carrega-se de grandes quantidades d'agua e eleva-se com ellas. Passando para latitudes mais altas, esse ar saturado de humidade entra em contacto com o ar mais frio e a temperatura mais baixa faz com que a humidade se condense em nuvens e transforma-se em chuva.

As condições topographicas locaes sĩo, alģumas vezes, a causa quasi constante das correntes ascendentes de ar quente carregadas de agua e, em taes lugares, a chuva costuma ser muito abundante.

0 grande parèdão da Serra do Mar, voltado para o mar, ao longo das costas do Rio de Janeiro, S. Paulo, Paraná e Santa Catharina, é causa de chuvas extraordinariamente abundantes na região desta cordilheira.

0 registro do Alto da Serra do Cubatão, na crista da alludida serra em S. Paulo, mostra que a chuva annual ahi é de tres mil quinhentos e setenta e seis $(3,576)$ millimetros, emquanto a chuva annual na cidade de $\mathrm{S}$. Paulo, a 40 kilometros de distancia, é apenas de mil quatrocentos e noventa e quatro $(1,494)$. A differença é devida á in- 
fluencia topographica e ao mais rapido resfriamento, no tôpo da serra, do ar que vem do mar carregado de humidade.

Nas regiões mais frias da terra, quando a atmosphera, carregada de humidade, resfria-se abaixo de zero, a humidade gela, ou se crystalisa, e cahe em fórma de neve ou de saraiva. Nos paizes tropicaes o phenomeno de neve apresenta-se sómente nas montanhas bastante altas, como os picos dos Andes.

A exposição á atmosphera é fatal às rochas. -- E' este o corollario geral mais importante quanto ás influencias atmosphericas na geologia. 0 resultado não fica logo patente, porque é necessario muito tempo para desaggregar e destruir as rochas. Ellas podem durar por tempo indefinido, mas sómente quandu são protegidas da atmosphera, das mudanças de temperatura e de outras mudanęas a que a atmosphera está sujeita. 0 gastamento das rochas é, pela maior parte um processo subereano.

A profundidade da alteração e decomposiçào das rochas do Brasil é muito notavel. Os cortes das estradas de ferro por toda a parte discobrem as rochas decompostas e alteradas, e nas minas e nos poęos profundos esse facto é ainda mais evidente.

A rocha brasileira chamada itacolumito, que tem a singularidade de ser flexivel, é um arenito metamorphoseado, e depois parcialmente decomposto. Itacolumito quando perfeitamente inalterado não é flexivel (1).

\section{Agentes geologicos mechanicos aquosos.}

A acção geologica d’agua é chimica e mechanica. 0 trabalho mechanico da agua é feito sob as formas abaixo mencionadas:

I. - A chuva na sua acção directa.

(1) Sobre a flexibilidade de itacolumito, vêde American Naturalist, vol. Xivill, pag. 927. Sept. 1884 . 
II. - Os cursos d'agua.

III. - Lagos.

IV. - Mares e oceanos.

V. -- Gelo, nas formas de geleiros e gelos fluctuantes.

\section{I. - A chuva na sua acção directa.}

0 trabalho mechanico da chuva faz-se pela maior parte depois que as aguas se reunem em cursos. Entretanto certas fórmas especiaes do mesmo trabalho são produzidas pelo embate da chuva. Taes são as columnas terrosas encapadas de pedra do Tyrol.

Essas columnas podem formar-se em qualquer parte do mundo onde as condições as facilitem. Um kilometro ao norte da estação de Aramary no estado da Bahia, existem muitas dessas formas ao longo da linha da estrada de ferro.

Quando cahc chuva sobre a terra, ou escorre sobre a superficie, em fórma de correntes, ou penetra no solo para emergir, mais cedo ou mais tarde, como fontes.

E' o effeito mechanico da agua que penetra no solo, que ora consideramos.

Quando solos ou rochas de certas naturezas ficam inteiramente saturados d'agua, escorregam ou resvalam, especialmente se estão nas encostas ingremes dos morros ou montanhas. Estes desmoronamentos são de occorrencia frequente durante a estação chuvosa ao longo de algumas estradas de ferro no Brasil especialmente naquellas que atravessam regiões montanhosas. Produzem-se mais frequentemente ao longo das estradas de ferro porque, em fazendo os córtes para ellas, os arrimos naturaes e originaes do solo sobre a encosta montanhosa foram removidos. Os desmoronamentos não se limitam, porém, ás linhas ferreas; podem occorrer tambem em qualquer declive ingreme.

As rochas da Serra do Mar e de outras regiões de granito e de gneiss do Brasil são constituidas em grande parte do mineral feldspatho. Pela decomposição, o feldspatho se transforma em kaolin. Esta 
substancia estando secca fica bastante firme, mas saturando-se d'agua se torna extremamente escorregadia e não pode mais supportar grande jeso. O resultado é que, depois de um periodo de chuva, os desmoronamentos são de occorrencia frequente nessas regiōes da Serra do Mar, porque o kaulin da rocha decomposta se molha e torna-se muito escorregadio.

Em certas localidades nas regiōes montanhosas, onde as encostas são ingremes e o solo é favoravel, os desmoronamentos são tào frequentes que certos terrenos antigamente plantados de café foram abandonados por esta causa.

Os desmoronamentos são, tambem, favorecidos por certas estructuras geologicas. Quando as camadas das rochas são horizontaes, ou quasi assim, e livres de juntas, ha pouca probabilidade das camadas resvalarem umas sobre as outras, qualquer que seja a sua composiçà mineralogica ou a agua que nellas hajam de cahir. Se, porém, ellas estão inclinadas e sem arrimo do lado para o qual se inclinam, pode produzir-se o desinoronamento sempre que uma camada argilosa se ache saturada d'agua.

A composicio mineralogica da rocha tambem um factor importante. Certas substancias mineraes, taes como kaolin, argilla, serpentina, talco, mica, graphite e pedra-sabão, são materiaes essencialmente escorregadios que favorcem o desmoronamento nas rochas em que abundam.

Em todos os casos a agua é um factor importante dos desmoronamentos e ordinariamente é o que determina-os. Os desmoronamentos occorrem algumas vezes durante os terremotos, porém, estes são de tão rara occorrencia no Brasil, que não precisamos considerar aqui este agente.

Lin resumo as condiçōes favoraveis aos desmoronamentos são:

1. As formas topographicas.

2. ${ }^{\mathrm{a}}$ A estructura geologica.

$3 .^{\mathrm{a}}$ A composição mineralogica.

4. ${ }^{2}$ A presença d'agua.

Se bem que os desmoronamentos sejam agentes geologicos de bastante importancia por deslocarem e removerem para niveis inferiores 
enormes quantidades de terra e de pedras, elles raras vezes nos impressionam no Brasil.

Durante os primeiros annos depois da construcção da estrada de ferro central do Brasil, atravez da Serra do Mar, houve muiıs desmoronamentos em certos lugares onde a inclinação das rochas na direção da linha, a condição decomposta das rochas e as chuvas os facilitaram. Posteriormente os lugarés instaveis foram revestidos com alvenaria,

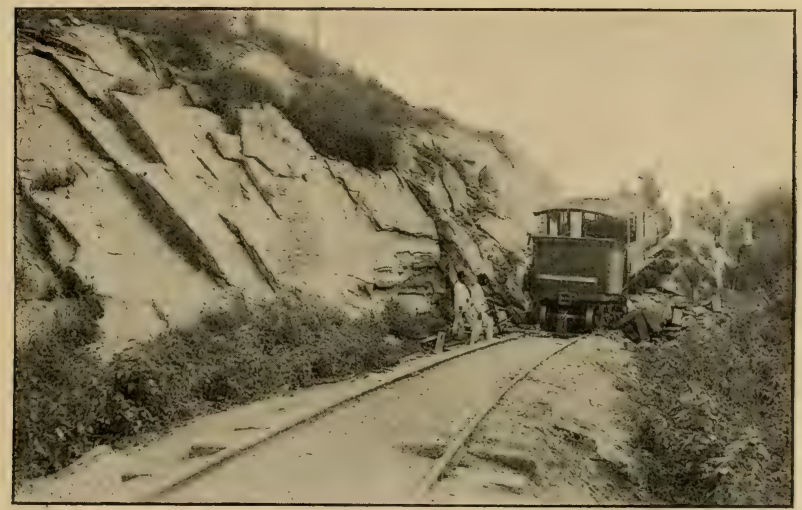

Fig. 13. - Estrada de ferro perto de Senador Pompeo no Ceará onde um desmoronamento e a perda de uma locomotiva foi devido á estruc. tura geologica.

as aguas superficiaes foram captadas em regos, e hoje em dia é raro haver um desmoronamento naquella estrada.

Em alguns paizes elles têm soterrado cidades e villas, causando grandes perdas de vidas e propriedades (1). As vezes represam completamente os cursos d'agua formando lagos temporarios ou permanentes (2).

Falaremos brevemente dos meios que devem ser empregados para

(1) Guide des excursions $d u$ VII ${ }^{\circ}$ Congrès géologique international, $\mathrm{XX}$. St. Petersburg, 1897. Bul. Soc. Géol. de France, 2• série, VII, 188. Paris, 1850.

(2) Nature. Oct. 13, 1898, p. 586; Dec. 7, 1897, p. 127. 
evitar os desmoronamentos. Como elles sĩo produzidos por um excresso d'agua no solo, o primeiro passo para evital-os consiste em desviar a igua da area susceptivel de escorregar. Regos cavados nas encostas que dominam uma area desmoronavel, podem de ordinario serem feitos para transportar a agua para um lado ou outro, afastando-a do trecho, do terreno arriscado a desmoronar. As arvores que ahi se plantem darão raizes para baixo que sustentam desta maneira o terreno.

Em toda a parte onde seja possivel os arrimos naturaes da terra devem ser conservados. Tem havido diversos desmoronamentos desistrosos na cidade do Rio de Janeiro provenientes de remoção da rocha decomposta da base dos morros de maneira a retirar o arrimo natural do solo da parte mais elevada dos mesmos.

Ni construcção das estradas de ferro, represas e outras obras de engenharia, deve-se sempre levar em consideração a estructura greologica do terreno. Actualmente empreza alguma que tenha de lidar com o solo, póde dispensar os serviços de um geologo competente para evitar erros custosos e perigosos.

\section{II. - Acção mechanica dos cursos de agua.}

o trabalho mechanico dos cursos de agua consiste em tres processos :

I. - Erosĩo.

II. - Transporte.

III. - Deposiẹão.

Erosão. - Tudo processo de remoçio de terra, de rocha, solo e materias mineraes de qualquer natureza denomina-se, geralmente, erosão ou denudação.

A erosio ou descastamento feito pelos cursos d'agua é o resultado do embate da agua, ou do esfregamento ou abrasũo dos materiacs que por ellas foram transportados.

Deve-se notar que a correnteza de qualquer curso d'agua nào é a mesma por toda a parte. Por causa da fricęio da agua com o solo, at 
correnteza é menor no fundo e nos lados, e maior no meio, á flòr d'agua. Alem disto, passando uma curva, a força é maior no lado de fora da curva. Assim, no mesmo curso, a força da correnteza é muito variavel, e por conseguinte a acção d'agua sobre o fundo e sobre as margens é muito differente.

Se os materiaes que formam os barrancos e o fundo do canal de um curso de agua forem molles e incoherentes, basta a força das correntes para deslocal-os. No chamado " processo hydraulico " de mineração, a agua é levada para as minas em tubos de aço e debaixo de grande pressão, e arrojada de encontro á terra a minerar com tal força que 1) cascalho e as areias são desmoronados e transportados. Nos cursos d'agua a força da corrente frequentemente solapa os barrancos especialmente no lado externo das curvas onde a força centriluga é maior. Tal erosão é ordinariamente activa na parte inferior do curso dos rios onde ajuda a produzir o voltear ou balanço da corrente de um lado fara outro. Flla tambem leva a corrente a mudar o respectivo canal de um lado do seu valle para outro. Neste processo de erosão lateral as curvas fortes são muitas vezes cortadas e deixadas em lagoas de forma le crescente proximas ao curso original. Mompox, cidade hespanhola que ha cincoenta annos estava na margem do Rio Magdalena, na Colombia, acha-se agora distante trinta e dois kilometros daquelle riu devido á mudança do seu canal (1).

As "terras cahidas " da região amazonica são desmoronamentos causados durante a enchente pelus rios que solapam as suas ribanceiras argillosas as quaes, estando molhadas, molles e sem arrimo, escorregam para dentro dos rios arrastando as florestas que os margeam (2).

0 segundo methodo de erosão, ou esfregamento pelos cursos d’agua é produzido sobre os seus canaes pelos materiaes transportados.

Os materiaes rochosos transportados mechanicamente pelos cursos

(1) W. L. Scruggs, Colombian and Venezuelan Republirs, pag. 44. Boston, 1900.

(2) J. C. Branner. The pororoca or bore of the Amazon. Science, Nov. 75, 1884. 488-192. 
d'agua são blocos, seixos, areias e barro. A agua limpa não pode por si só erodir mechanicamente rochas duras. 0 desgastamento mechanico das rochas duras só pode ser feito quando a corrente transporta materiaes abrasivos, ou lixadores, em uma ou outra destas formas.

Quando um curso de açua transporta pedras, ellas roçam os canaes da corrente, e batem entre si, moendo desta maneira o material transportado. 0 methodo de desgastar o leito rochoso de um curso d'agua consiste simplesmente em mover ou empurrar os fragmentos soltos de rocha sobre o canal rochoso. 0 desgastamento tem logar exactamente como acontece com um machado ou outra qualquer ferramenta quando amolada no rebolo com agua. As pedras soltas escavacam pequenos fragmentos e a agua carrega essas pequenas particulas destacadas das pedras de modo que novas superficies ficam assim constantemente expostas e constantemente escavacadas e desgastadas.

Acontece frequentemente que existem redomoinhos nas correntes onde as pedras sòltas sảo revolvidas em um circulo de pequeno diametro. Em taes casos o desgastamento é localizado, e uma cova lisa e redonda semelhante a um caldeirão se forma no leito do curso. Taes redomoinhos se apresentam frequentemente abaixo das cascatas e cataractas onde formam caldeirões de varias dimensões.

Debaixo da grande cataracta de Paulo Affonso existem muitos caldeirões taes. Na vasante do rio São Francisco alguns destes caldeirões ficam descobertos contendo geralmente algumas pedras desgastadas e arredondadas por terem sido roçadas uma de encontro a outra e de encontro aos lados dos caldeirões.

Estes caldeirões entretanto não são senão effeitos locaes da erosão do curso e são de somenos importancia. Um desgastamento semelhante é feito ao longo de todo o comprimento de cada curso rapido que corre subre fundo rochoso e que carrega pedras, seixus ou areia.

Em certos lugares do interior do norte do Brasil, notavelmente na vizinhança de Quixadá no estado do Ceará, existem caldeirões nos morros de granito de origem differente daquelles acima descriptos. Esses ultimos provem da ação chimica da agua em buracos da rocha, devida a qual os mineraes da rocha se desmancham; depois as 
chuvas entrando nestes buracos mexem as aguas, e os fragmentos pequenos são removidos pela agua na forma de lodo (1).

Certos caldeirões nas regiões de granitos do interior do Brasil, especialmente ao norte, nos estados da Bahia, Sergipe, Alagoas, Pernambuco, Parahyba, Rio Grande do Norte, e Ceará, explicam-se pelo facto de que essas rochas se desmancham localmente sob a acçà) chimica de agua, e depois os buracos são limpos pela mão do homem para servir de poros ou reservatorios que guardem agua no tempo de seccas.

Acanaladuras. - Em conjunç̧õo com os caldeirões nos granitos, existem certas formas singulares chamadas acanuladurus. Estas são regos pequenos caracteristicos de certos morros ingremes de granito, de syenito, ou de outra rocha crystallina e homogenea. Estes regos tèm os fundos arredondados e correm dos morros abaixo em linhas quasi direitas. Is formas parecem ser devidas ao desgastamento, mas como as aguas que elles recebem vèm de uma area muito restricti, o desgastamento pelos perlaços movidos pela agua é quasi nullo. Exemplares notaveis são aquelles da Serra Riscada perto de Quixadá no Ceará, e nas Agulhas Negras no picu de Itatiaya.

Uma parte importante da acção mechanica de uma corrente consiste na moagem dos materiaes transportados. Se o material for barro ou areia muito fina, as particulas são tão pequenas que pouco ou quasi nada affectam entre si. Pode-se verificar isso, examinando com um microscopio as particulas muito finas de areia encontradas em qualquer corrente. Taes particulas são quasi invariavelmente angulares mostrando que ellas não são desgastadas em sendo transportadas pela agua.

Isto não se verifica entretanto com os seixos ou mesmo com os grãos de areia mais grossos ou de tamanho ordinario. Nestes fragmentos maiores verifica-se pelo exame serem os seus angulos arredondados e desgastados pela fricção de encontro ao leito da corrente e d'um contra outro.

(1) J. C. Branner. Fluted and pitted granites in tropical countries. Proc. AmPhil. Soc. Philadelphia, 1913. 
Este arredondamento dos fragmentos das rochas é uma das partes mais caracteristicas do trabalho geulogico feito pelas correntes (e pelas ondas).

Todas as pedras tiradas d'uma corrente rapida se acham mais ou menos gastas pela agua, e vai sem dizer que quanto mais tempo um bloco ou seixo é carregado por uma corrente tanto mais será desgastado e reduzido em tamanho. E' tambem evidente que quando as aguas carregam conjunctamente desta maneira fragmentos de rochas molles - dura as primeiras serão desgastarlas mais rapidamente, e serão as primeiras a serem destruidas, emquanto que as mais duras serão as ultimas a serem desgastadas.

Este processo è bem illustrado nas regiões diamantiferas do Brasil onde os diamantes são encontrados nos canaes dos cursos de agua actuaes ou antigos. Os diamantes derivaram-se originariamante das rochas duras da região na qual elles se encontram, porem devido ao desgastamento pelo tempo e pela decomposição destas rochas, os diamantes ficaram livres e foram transportados pelas aguas do mesmo modo que um seixo qualquer. Devido a sua maior dureza os diamantes resistiram ao desgastamento emquanto a maioria das outras pedras foram desgastadas, sendo carregadas pela agua as particulas finas destruidas. Encontram-se usualmente com os diamantes pequenos seixos arredondados muito duros e lisos, commumment: conhecidos cntre os mineiros por a furmaçào » "feijāo », "favas », etc. Estes seixos occorrem com os diamantes porque elles sào bastante duros para resistir ao desgastamento dos rapidos cursos dos districtos diamantinos.

A existencia de muitas formas singulares entre os seixos desgastados pela ag̣ua dá logar frequentemente a duvidas em relaçào á sua origem. Estı́s formas peculiares sàu geralmente devidas as formas originaes dos fragmentos rochosos dos quaes os seixos originaram-sı. Algumas vezes acontece que se encontra juntos muitos seixos achatados ou compridos e delgados. Isso acontece porque os fragmentos das rochas das quaes elles loram originariamente feitos ram chatos, ou os seixos são delgados porque eram delgados os fragmentos originaes. 
Julgou-se, ha tempos, que a producção de seixus chatos era devida á acção das ondas brandas dos lagos. Esta theoria la sua ori„̌em é insustentavel, pois que verıfica-se pela experiencia que um bloco de pedra redondo ou cubico collucalo ao alcance das undas brandas de um lago não é resvalado para cima e para baixo sobre a praia e dessa maneira desgastado até tornar-se chato ; mas, que ou não é movido, ou é revolvido de modo a ficar arredondado e não chato.

Formas peculiares de seixos sãı ás vezes produzidas tambem pelo desgastamento de fragmentos de rochas de durezas deseguaes. Um bloco cubico rolado em uma corrente será desgastado até torıar-se um seixo chato se acontecer conter uma camada ou banda de rocha mais dura encerrada $€$ utre outras mais molles, mas bloco cubico de rocha homogenea tornar-se-hia seixo redondo.

Já foi provado que os pequenos grãos de areia não são arredondados e desgastados, porém sim angulares. Porèm em qualıuer parte onde os grãos de areia são bastante pesados para serem rolados ao longo do fundo de uma corrente em lugar de estarem suspensos nellu são arredondados como os outros seixos.

Transportes por cursos d'agua. - As aguas da. maioriit de nossos maiores cursos não são claras, mas visivelmente lodosas, especialmente durante a estação chuvosa. Esta côr lodosa é dada á agua pelas particulas miudamente divididas de materia mineral transportada em suspensão mechanica. Isto póde ser promptamente demonstrado enchendo-se um copo com agua e deixando a materia mineral assentar no fundo. No caso de não clarear depois de algumas horas de repouso, o processo póde ser apressado ajuntando um pouco de acido. alcali, sal commum ou pedra hume á agua, ou pela ebullição.

A priori é evidente que se os fragmentos rochosos são transportados pelas correntes, as correntes mais fortes devem ser capazes de mover fragmentos mais pesados do que as fracas; em outras palavras deve haver relações definidas entre a corrente e o que ella póde transportar. A lei desta variação no poder de transporte de uma corrente é expressa pela formula mathematica $F . \alpha V^{6}$; ou o poder de transporte 
Varia com a sexta potencia da velocidade. Augmentindo a velucidade dez vezes augmenta o poder de transporte um milhito de vezes.

Isto é, dobrando a velocidade do curso, o curso pode mover um bloco de 64 vezes o tamanho original. A velocidade dobrada, dobra a foręa, e dobra tambem a quantidade de agua que bate uma certa área; isto é, a foręa é sufficiente para empurrar quatro blocos com a força que se applica a uma face.

Observaçôes directas têm mostrado que as correntes seguintes são requeridas para mover fragmentos rochosos dos tamanhos aqui mencionados. Deve lembrar-se ao mesmo tempo que essas observacôes só se referem aos cursos grandes d'agua.

Para mover

Barro. . . . . . . . . .

Areia miuda .

Seixos do tamanho de uma ervilha. .

Seixos de 25 millimetros em diametro.

Blocos pesando cinco toneladas ....

Blocos de 320 toneladas. . . . . . .
Marcha requerida para a corrente

8 centimetros por segundo.

15

30

68

4,.5 metros por segundo.

9,10̈ metros por segundo.

Se pois imaginarmos pedras de todos estes differentes tamanhos arremessadas n'uma corrente, é evidente que ella separará os materiaes carregando para frente os pequenos fragmentos e deixando atraz os que são demasiado pesados para serem por ella movidos.

Ora, se, como geralmente acontece na natureza, temos uma corrente que é veloz em algumas partes do seu curso e menos rapida em outras partes, deve acintecer que os fragmentos rochosos são facilmente movidos ao longo de algumas partes dos seus canaes, porém pouco movidos em outras, e deixados ir para o fundo sem transporte algum em ainda outros liggares. Dahi resulta o sortimento dos materiaes transportados em cada corrente, e a disposiçio dos materiaes mais gráudo em um lugar, do mais miudo em um outro, e de ainda mais miudo em ainda outro. Segue-se tambem que as correntes que variam em volume, varian no seu poder de mover os materiaes no longo dos seus canaes. Este aspecto da ação da corrente é de especial interesse e importancia no Brasil onde as chuvas são muito mais fre- 
quentes durante certos mezes do anno, o "tempo de chuva ", ou ainda o " tempo das aguas "; e quasi inteiramente ausentes durante outros mezes, " tempo de sol », ou ainda o " tempo da secca. "Isto produz a concentração das chuvas e a alternação de enchentes e vasantes dos rios n'aquellas regiões onde as estações do anno estão em grande contraste.

No interior dos estados do norte, Bahia, Pernambuco, Parahyba, Rio Grande do Norte, Ceará e Piauhy as correntes que são bastante grandes e capazes de ser navegadas por um navio do oceano durante parte do anno são frequentemente reduzidas a uma serie de poços, ou desapparecem completamente nos fins da estação secca (1).

Esta concentraçao da chuva e as consequentes enchentes torna possivel a uma dada quantidade de agua effectuar enormemente mais desgastamento e transporte do que faria se fosse mais egualmente distribuida por todo o anno.

A quantidade do material transportado por um curso d'ayua. A proporção em que as superficies terrestres são removidas e transportadas para o mar pode ser determinada achando-se a porẹão de material mineral transportado pelos cursos de agua. Isto se faz medindo a descarga ou fluxo da corrente de uma bacia hydrographica dada.

Todo o material transportado atravez da sahida de uma bacia deve necessariamente ser derivado da bacia, ainda que naturalmente a maioria d'elle venha de certas partes da sua area e muito pouco de certas outras partes.

As observações sobre uma corrente feitas para determinar a proporção da erosão consistem em medir a descarga ou fluxo d'agua diaria u mesmo mais frequentemente por um longo periodo - diga-se um anno ou mais. São tomadas amostras da agua por occasião das medições : estas amostras devem vir de muitos pontos; sobre a superficie da corrente, perto das margens, no meio, etc. Deven tambem ser tomadas em differentes profundidades. Estas amostras devem ser cuidadosamente medidas e a quantidade da materia

(1) J. C. Branner. Decomposition of rocks in Brasil. Bulletin Geologieal Society America, VII, pags. 309-312. 
mineral nellas deve ser determinada, filtrando-se a agua até ficar perfeitamente clara e pesando-se o papel do filtro usado, tanto antes como depois da filtração. Os dados assim obtidos fornecem os meios de deterninar a quantidade da agua e a da materia mineral mechanicamente retirada da bacia hydrographica pelo curso.

Muitas observaçoes são necessarias porque a quantidade da materia transportada varia em differentes partes da corrente, em differentes profundidades e em differentes estados da agua.

Deve-se notar que nenhuma menção é aqui feita da materii mineral removida em solução nas correntes. Esta parte do assumplu será depois tratada, pois que o material removido em solução é tîo importante como o transportado em suspensão.

A quantidade de materia mineral transportada por uma corrente lodosa é tão grande que se torna quasi incrivel. Observações feitas sobre o rio Arkansas durante o anno de 1887-1888 mostraram que na forȩa da enchente a porção de materia mechanicamente transportada foi 122,06 milligrammas por litro d'agua. A descarga total do lodo durante um mez de vasante foi de $14.922 .000 \mathrm{kilos}$; na enchente foi de \$.634.000.000 kilos; o total para o anno foi 19.433.000.000 kilos.

A razão em que a erosão mechanica das correntes é effectuadi depende de diversos factores, como se segue :

I. Do volume da agua. - Pequenas correntes não podem transportar muito.

2. Do declive do terreno. - E' o declive do terreno que determina a velocidade das correntes, e dessa velocidade depende em grande parte o poder de transporte da corrente.

3. Do caracter das rochas. - As rochas duras resistem melhor a accão erosiva dos cursos d'agua; emquanto as molles sào desgastidas mais rapidamente.

4. ${ }^{\circ}$ Qualidade e quantidade de delritos. - Deve-se notar que se as rochas se desfazem mais rapidamente do que as correntes podem

(1) J. C. Branner. Erosion in the hydrographic basin of the Ar/iansas rioer above Little Rock. Ann. Rep Geol. Sur. Ark. for 1891, vol. II, 153-166, Little Rock, 1894. 
remover os materiaes desbastados, as correntes ficam sobrecarregadas - não podem transportar a carga nellas lançadas. Assim os canaes ficam entulhados com os fragmentos das rochas.

5. Das condições climatericas. - A concentração das chuvas em alguns mezes do anno faz as correntes largas e poderosas por algum tempo e assim as torna capazes de cortar mais rapidımente do que se as chuvas fossem egualmente distribuidas por todo o anno.

Os resultados da erosĩo podem ser considerados como locaes e gercies.

Vè-se os resultados locaes na excavação de desbarrancados ou vosoricas, barrocas e valles. 0 corte de seus canaes pelos pequenos regatos prosegue sob as nossas vistas; e as barrocas das montanhas e os cañons dos rios não são senão canaes maiores, sendo o processo da sua excavação exactamente o mesmo como no caso dos pequenus regatos. 0 cañon do Rio Colorado na America do Norte é o maior canal em forma de calha no mundo tendo algumas centenas de kilometros de largura e de seiscentos a mil e oitocentos metros de profundidade.

0 canal do rio S. Francisco immediatamente abaixo das cachoeiras de Paulo Affonso í tão estreito e de ribanceiras tão ingremes que forma um verdadeiro cañon e nãoé navegavel. Abaixo de Piranhas o canal cortado pela corrente é muito mais largo e é navegavel, porém tem ainda ribanceiras ingremes, como se vè nas figuras, ns. 14 e $1 \%$.

Quasi todos os valles são em grande parte, resulıados da acçâo crosiva da agua. Porem embora sejam modificados pelas correntes, os valles podem originar-se de (1) falhas ou deslocamentos; (2) synclinos ou dobramentos das camadas; (3) ha tumben valles entre montanhas de origem eruptiva. Esses serão tratados mais adiante.

Origem das caxoeiras. - Caxoeiras sào geralmente resulıdos lucaes de erosão, e necessariamente acham-se nos cursos d'agua. São causadas :

I. - Por uma camada de rocha mais resistente em cima de camadas de menos resistencia. Neste caso a camada resistente dá origem a ella ou ao alto do qual a agua se precipita. A caxoeira de Niagara $\dot{c}$ deste typo. Ali uma camada de pedra calcarea apresenta uma mesa 
angular donde a agua cahe. As camadas em baixo se desfazem mais rapidamente du que a de pedra calcarea superior, e como as camadas são todas horizontaes, a forma da caxoeira não varia muito, embora mova-se rio acima numa marcha de um metro e meio por anno.

II. - Formadas por um escarpado relativamente recente em cursos d'agua. Taes escarpados ou quebrados podem ter diversas origens.

1. No littoral onde a acẹao das vagas é mais rapida do que a acẹão de desgástamento pelos cursos d'agua. Por esta razão os rius cahem directamente no mar passando por cima de caxoeiras.

2. De um ou de outro lado de cursos d'agua, onde o curso principal corta mais rapidamente do que os cursos lateraes. Por esta razão as caxoeiras apparecem dos lados do valle principal apresentando a forma de valles suspensos.

3. ${ }^{\circ}$ No lado superior de falhas que atravessam cursos d'aģua.

o resultado geral da erosão e denudaçio é rebaixar a superficie

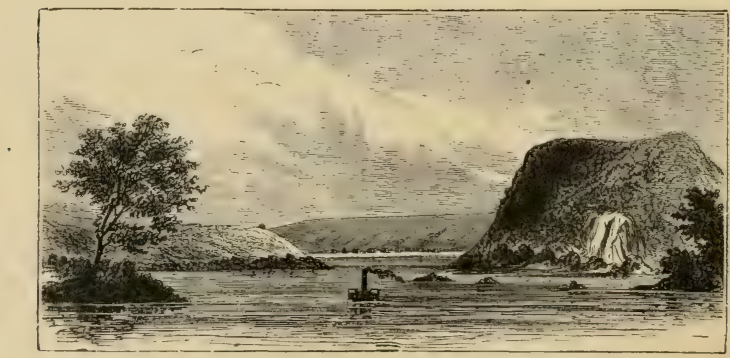

Fig. 14. - O canal de margens ingremes do rio S. Francisco, olhando do Pão de Assucar, rio acima. (Hartt.)

da terra. Este processo prosegue sobre a terra inteira, porém mais rapidamente em alguns lugares do que em outros. Cada pedacinho da terra yue se ergue acima do nivel do mar está sendo. atacado pelos agentes de decompusiẹa e erosão e está sendo transportado pelas correntes para os mares e os oceanos. A topographia actual da terra pouco 
ou quasi nada revela de sua forma original; e sómente aqui e acolá ella suggestiona alguma cousa de sua forma antiga.

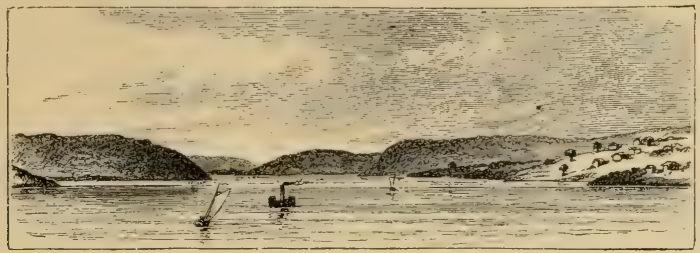

Fig. 15. - O rio S. Francisco, olhando do Pão de Assucar, rio abaixo (Hartt.)

Erosão em relação á agricultura. - Em lugares montanhosos e terrenos ingremes, a erosão está sempre carregando o solo, de maneira que a agricultura fica muita prejudicada por este processo natural. Tal perda pode evitar-se muitas vezes por meio de plantações, ou de regos para levar as aguas superficiaes aos cursos convenientes.

Deposição. - A deposição do material carregado pelos cursos de agua tem lugar de accordo com as leis de transporte. Se os cursos

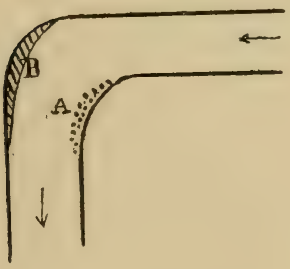

Fig. 16. - Plano da volta de uma corrente mostrando os pontos de corte (B) e de deposição (A). livessem em toda parte uma velocidade uniformenão haveria deposição dos materiaes transportados.

Porém quando un curso earregado tem a sua carreira estorvada, o seu poder de transporte é di-

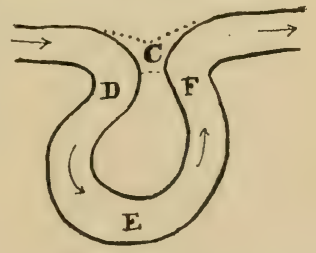

Fig. 17. - Plano da volta de uma corrente mostrando como ella pode abrir caminho atravez de $\mathrm{C}$, e abandonar o caminlio em $\mathbf{E}$.

minuido, sendo depositado o excesso de sua carga. Em todos os cursos tortuosos os sedimentos são depositados na forma de bancos de areia no lado interno das curvas. Isto é devido ao facto que é sempré do 
lado interno das curvas que a correnteza fica reduzida e diminuidu o poder de transporte do curso.

Eu um curso tendo uma volta semelhante i representada nit fig. 16, é evidente que em fazendo a volta a correnteza será mais rapida $\mathrm{cm}$ B e que será reduzida $\mathrm{em} \Lambda$. Como resultado a corrente coriservará o seu canal aberto em B emquanto um banco de areia formitrse-ha em A. Em cursos muito tortuosos o sulapamento das ribanceiras faz frequentemente com que a agua as rompa no ponto C (Fig. 17). Isto faz com que o canal antigo D, E e F seja abındoṇado e a deposiçio de sedimentos em D e F, pela reducção da currenteza naquelles pontus, eventualmente separe o canal abandonado drixando ao lado do rio um lago em forma de crescente

Taes mudanças dos leitos dos rios e as lagoas de forma de crescente, ou ferradura, são caracteristicas de rios tortuosos e vagarosıs, como acontece em çertas partes do rio Paraguay.

\section{Casos especiaes de deposição pelos cursos d'agua}

Nãu obstante toda deposição ter logar de accurdu com a simples lei de iransporte, existem muitos casos interessantes, alguns dos quaes serão mencionados neste logar.

Deposiçuo sobre varseus. - I varzea, on planicie de inundassio. de um curso d'agui é aquella parte do sen valle que se cobre com agua lurante as suas enchentes. Estas varzeas são geralmente mais ou menus planas. Quando " rio transborda, as aguas rarregadas de lodo enrohrem a varzea, e a corrente sendo diminuida deivil affundar-se o material suspenso. Desta maneira o solo da varzra inteira fica augmentado e melhorado.

Origem de atterralos naturaes. - Quando a aguạ de um rio transborda, logo que sahe do canal, ha uma reducção na correnteza de modo que a parte que escapa, licando sobre-carregada, deixi grande parte da sua carga de sedimento proxima a canal principil. Acontecendo que a varzea inteira fique inundada, continuando o rio a voltear pelo seu curso antigo, a corrente em muitos lugares esbarra com as aguas mortas da varzea inundada fazendo uma reducçãn ni 
correnteza que produz o deposio de uma parte da sua carga de sedimentos. A sua corrente é obstruida, e uma parte de sua carga de areia elama é depositada, fazendo assim barrancos mais altos do que a varzea distante da corrente. Estas ribanceiras são chamadas diques naturaes, aterrados ou levées naturaes. Quando as aguas lodosas de uma enchente estendem-se sobre uma varzea larga não ha senão

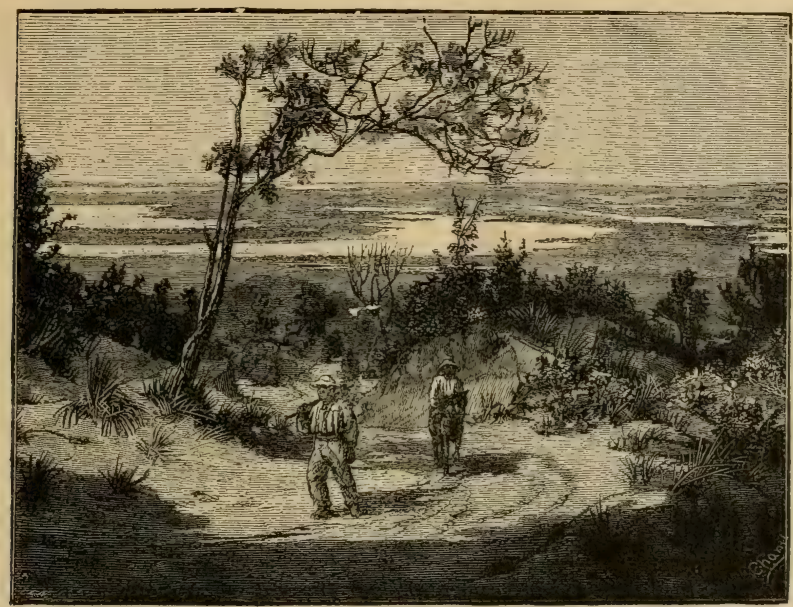

Fig. 1S. - Vista da varzea ou planicie de inundação do Amazonas, de Monte Alegre, Estado do Pará (Champney).

pouca correnteza nas aguas da enchente e como um 'resultado disso os sedimentos são depositados em toda parte onde as aguas descançam por algum tempo. 0 lodo assim depositado forma os solos alluviaes ferteis que se apresentam na maioria dos valles.

A formação das barras. - As barras são bancos ou coròas de areia ou de outros sedimentos trazidos pelos cursos d'agua e depositados rias suas boccas e nas boccas dos estuarios. Quando um curso desagua no oceann formam-se geralmente duas especies de harras. Uma é formada onde as aguas do curso se encontram com as aguas do 
oceano, e a outra se forma, rio acima, onde as aguas da corrente tèm () seu primeiro encontro com as aguas paradas da maré alta.

E' uma particularidade de muitas barras o facto de não serem fixas, antes mudam-se de lugar dentro de certos limites. Isto é devilo a incoherencia dos materiaes de que ellas se formam e á variação das forças que actuam sobre elles, taes como a lôrça da correnteza do rio,

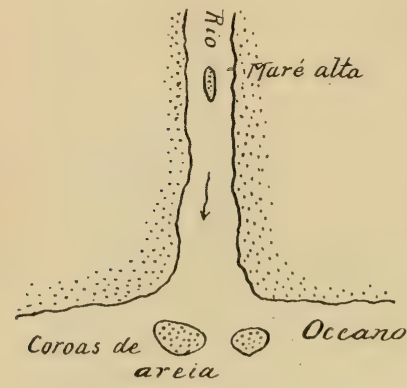

Fig. 19. - Barras na bocea de um estuario, e rio acima.

fórça das ondas do oceano, mudanças nas correntezas do mar.

0 rio $\mathbf{S}$. Francisco tem um semi-circulo de bancos ou corôas de areia na sua bocca formando a sua barra. Esses bancos se formam dos sedimentos trazidos pelo rio e deixados no Oceano Atlantico em frente da foz do rio. Quando o $\mathrm{S}$. Francisco está cheio o volume d'agua doce, descommunalmente grande, arrasta as areias dos bancos mar a fóra; porém na vasante do rio, e especialmente quando os ventos sopram do oceano para a terra, as ondas fazem retroceder as aguas do rio de maneira que o sedimento é depositado junto da costa e a barra é assim empurrada jara a terra. Quando as correntes oceanicas movem-se fortemente costa abaixo os bancos são mudados daquella direcção.

Os bancos na bocca do rio Cotinguiba perto de Aracajú são sujeitos a mudanças constantes.

Tem aconterido que navios entrando do alto mar naquelle perto ficaram presos ahi por mezes por causa da mudança das areias da barra que não os deixaram sahir. Posteriormente ás mudanças dos ventos as barras mudaram-se e os navios puderam sahir.

" 0 isthmo de Olinda é o resultado da accumulação das areias (1)

(1) M. de Barros Barreto. Memoria sobre o melhorramento do porto de Pernambuco, pag. 8. Recife, 1865. 
que as ondas arremessam sobre a costa, formando assim um dique natural $\gg$.

0 porto do Rio Grande do Sul tem sido por longo tempo uma fonte de grande despeza para o governo brasileiro por causa dos bancos movediços de areia na entrada da Lagòa dos Patos, que constituem a sua barra.

En resumo : - a mudança das barras póde ser devida a uma ou mais das seguintes causas :

I. - A desearga variavel do curso en cuja bucca ellas săo formadas.

II. - As tempestades e as ondas no mar do lado de fóra.

III. - Qualquer variação nas correntes marinhas proximas ís barras.

Cursos d'agua sobrecarregados. - Quando um curso d'agua recebe mais sedimento do que elle póde transportar e por isso fica incapaz de conservar o seu canal aberto diz-se estar sobrecarregudo. As partes de qualquer curso que estão fazendo depositos podem ser consideradas sobrecarregadas. Os cursos sobrecarregados não cortam canaes, porém enchem quaesquer canaes que houverem tido. Estão constantemente represando os seus proprios cursos e procurando novos; isto fiz com que elles espalhem o material transportado em largas camadas planas. Quando os cursos sobrecarregados emergem dos morros ou montanhas sobre planicies abertas, elles depositam a sua carga na fórma de um leque ou cone alluvial.

Taes leques são especialmente abundantes ao longo dos flancos orientaes dos Andes onde os cursos sohrecarregados emergem dos canaes ingremes dos valles montanhosos subre o plano mais suave das planicies da Patagunia e da Republica Argentina.

\section{III. - Os agentes aquosos mechanicos nos lagos.}

Os agentes mechanicos portam-se essencialmente da mesma maneira quer nos lagos quer em outras massas d'agua. Ia entretanto uma differença importante : quando o sedimento é transportado para os 
lagos de agua doce os materiaes graudos afundam-se mais rapidamente, e as particulas miudas menos rapidamente do que lariam n'agua salgada. (Vède a parte sob o titulo Floculação.)

Deltas. - Os lagos usualmente offerecem condições altamente favoraveis para a formação de deltas. $\mathbf{E}$ isto acontece porque actuam como poços de descanço ou reservatorios para os cur'sos que nelles desaguam.

No canal do velho aqueducto construido ao longo das encostas do Corcovado no Rio de Janciro existem aqui e aculá caixas ou covas mais profundas e mais largas do que o resto do canal. A agua entra de um

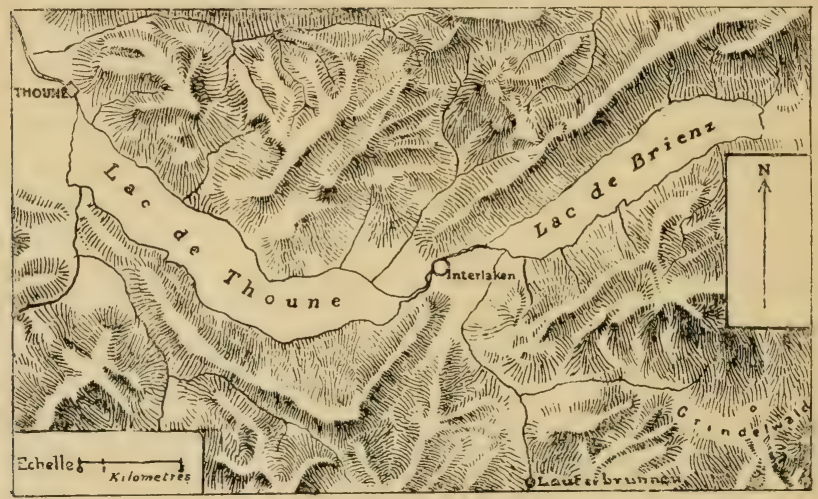

Fig. 20. - Mappa mostrando o lago Thoune e o lago Brienz, separados em dois por um delta em Interlaken.

lado, enche a cova e transborda no lado opposto para o canal de tamanho usual. Quando um seixo ou pedra cahe em qualquer ponto do canal, a corrente o transporta até alcançar uma destas covas, onde por falta de corrente ella vai para o fundo e ali fica. Com este simples artificio a agua conserva-se limpa, e todos os fragmentos de rochas são impedidus de chegarem ao reservatorio principal. Os lagos naturaes servem para reservatorios de repouso de uma maneira semelhante. Cintenas de cursos lodosos correm para os grandes lagos na America 
do Norte, porém o lodo e areia (os fragmentos de rochas) assenta no fundo dos lagos e a agua transborda clara no rio S. Lourenço. As aguas do rio Rhodano quando entram no lago de Genebra são excessivamente lodosas, porém o lodo vai para o fundo na extremidade supe rior do lago, formando um delta, emquanto o Rhodano sahe em Genebra limpido. No tempo dos Romanus o Rhodano desaguava no lago de Genebra em Port Valais; mas pela formação do delta, Port Valais acha-se actualmente a mais que tres kilometros distante do lago. A cidade de Interlaken na Suissa está construida sobre um delta alli feito pelas aguas lodosas do Lauterbrunnen. 0 lago Thoune e o lago Brienz de ambos os lados da cidade de Interlaken formavam primitivamente um unico lago, porém foi separado em dois pelo delta sobre o qual fica Interlaken.

Em geral os deltas formados nos lagos mais cedo ou mais tarde aterra-os e os destroe. 0 delta do Rhodano no lago de Cienebra deve necessariamente estender-se gradualmente lago abaixo. O lago Brienz en tempo ficará cheio pelo lodo trazido pelas aguas do Aar superior () qual será então descarregado directamente no lago Thoune c o ultimo principiará então a encher-se.

Em todos os casos, é notavel que o lago principie a aterrar-se na farte superior onde entram os rios, porque é ali que a correnteza das aguas fica impedida e por isso os sedimentos se depositam.

\section{IV. - Agentes aquosos mechanicos nos mares e oceanos.}

Os oceanos são mais profundos do que as montanhas são altas. 0 uceano Atlantico apresenla profundidades de tres a seis mil metros o oceano Pacifico tem uma profundidade maxima de oito mil trezentos e setenta metros.

Por outro lado sabemos que as alturas dos altos picos da grande cordilheira que borda a costa occidental di America são as seguintes :

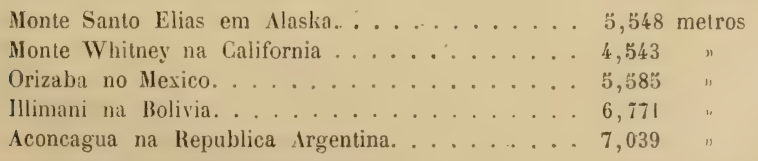


Em geral as aguas do oceano diminuem em temperatura com o augmento de profundidade.

As seguintes sào as temperaturas do Atlantico registradas ao largo da costa do Brasil a $3^{\circ} 30^{\prime}$ ao sul do Equador.

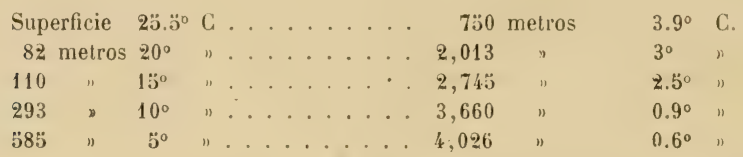

Como a temperatura de $0^{\circ}$ é a do gelo deve-se notar que mesmo debaixo dos tropicos a agua no oceano profundo está tão fria que lica perto do ponto de gelo. Em muitos logares a temperatura está realmente abaixo do ponto de gelo e a congelação deixa de ter lugar tão sómente em virtude da grande pressão da camada d'agua superior e da natureza dos mineraes dissolvidos n'agua.

Correntezas do oceano. - Is aguas do oceano estão por toda parte em movimento, porém movem-se em cursos ou correntes que são mais ou menos fixas. Algumas destas correntes movem-se com uma marcha de 6. A kilometros por hora, porém a maioria dellas movem-se menos rapidamente.

As correntes oceanicas são causadas em parte pela rotação da terra sobre seu eixo combinada com a inercia das aguas oceanicas; em parte pelo retardamento da atmosphera devido semelhantemente á rotação e á inercia, e ainda em parte por causa da convecçio ou movimento interno das aguas, movimento este devido as differentes temperaturas dəntro das proprias aguas.

Alguns imaginam que a salinidade ou densidade das aguas do oreano influe nas correntes; porem embora a evaporaçio augmente a salinidade das agruas, e por conseguinte a densidade, isto acontece pola maior parte nas regiões quentes, e a temperatura elevada deve, ac mesmo tompo, influir em sentido opposto. Tambem o augmento notavel da salinidade só acontere dentro de uns poucos de lugares fechados como no mar Mediterranico e no mar Vermelho. 
Effeitos das correntes. - $\Lambda$ s correntes oceanicas produzem effeitos notaveis e importantes sobre os climas do globo e sobre it distribuição da vida na terra. As aguas quentes que correm para o norte, vindas do Golfo do Mexico, transportam o calor dos tropicos para o Atlantico Norte. Por esta causa as condiẹões sob as quaes a vida do mar quente pode existir são transportadas para a zona temperada do norte tornando possivel o crescimento dos recifes de coral e a deposição de outros restos de organismos tropicaes muito mais longe ao norte do que podiam existir sem a intervenção desta causa.

Por exemplo as ilhas de Bermuda são de coral, e a vida oceanica naquella vizinhanęa é caracteristica antes da zona tropical do que da temperada em que actualmente fica o lugar $\left(32^{\circ}\right.$ norte $)$.

\section{AS MARÉS.}

As marés são fluctuações periodicas do nivel d'agua nos mares e oceanos, e são causadas pela attracção do sol e da lua que actua sobre a agua que cobre o globo. Quando o sol e a lua actuam em commum causam as grandes marés conhecidas pelo nome de "aguas vivas "; quando actuam em sentido opposto, contrariando-se mutuamente, as fluctuações do nivel d'agua sào muito pequenas e são chamadas " aguas mortas. •

Em pleno oceano as marés tèm um jogo vertical de cerca de um metro; nas costas a altura das marés depende grandemente da configuração da costa. Existem marés excepcionalmente altas em Chepstow perto de Bristol na Inglaterra (16. I metros) e na Bahia de Fundy, Nova Escossia (21.3 metros).

A importancia geologica das marés é devida ao maior alcance que ellas dão á acção cortante das ondas. Na costa do Brasil as marés variam em altura de alguns centimetros até mais de dois metros. Nas Rocas, ellas variam de um e meio até tres metros; em Fernando de Noronha ellas são de cerca de 1.8 metros; no Cabo de S. Roque de 2 a 2.3 metros; no Rio Grande do Norte de 1.8 a 2.7 metros; em Pernambuco de 1.20 a 2.33 metros; em Naceió cerca de 1.7 metros; na Bahia de 1 a 2.2 metros; nos Abrolhos de 1 a 2.80 metros; no Rio de Janeiro de 0.4 a 2 metros. 
Devido á dimensão e á direç̧ão do Rio Amazonas, sente-se as marés ao longo daquella corrente a uma distancia de oitocentos até novecentos e sessenta kilometros do oceano. São quasi imperceptiveis neste rio durante os periodos de enchente e mais notaveis nos mezes de 1 gosto e Setembro abaixo de Obidos e no baixo Tapajós.

Acção das marés. - As marés não tèm poder de erosão excepto nas aguas rizas; nas passagens estreitas, entretanto, ellas tendem a conservar os canaes abertos pelo varrimento para fóra (ou para dentro) dos sedimentos que d'outra sorte por fim os encheriam. Nas costas onde as vagas atacam a terra, tambem deixam expostas i acção das aguas uma zona mais larga.

Acção mechanica dos mares e oceanos. Acção destructiva. - Acção geologica mechanica dos mares e oceanos é ou constructiva ou destructiva.

$\Lambda$ accio destructiva consiste na erosão das rochas das costas feita pelas vagas an longo dellas. As vagas para o presente estudo podem ser classificadas como se segue :

I. - Vagas ordinarias inclusive as vagas de tempestades.

II. - Vagas extraordinarias.

Acção destructiva de vagas communs. - Solıre qualquer costa póde se ter a prova do poder destructivo das vagas. Nãi se salie certamente até que ponto abaixo da superficie d'agua as ragas são destructivas, e poucas observações parecem ter sido leitas sobre este assumpto. Entre as mais valiosas estào as feitas em Cabo Frio, sobre a costa do Brasil em 1830, pelo official incumbido das operações de mergulhamento para a recuperação de prata e ouro perdido no naufragio de uma corveta ingleza.

Aquille navio sahiu de Rio de Janeiro com uma carga de prata e ouro cun bitrats, r por conseguinte de alto valôr. Naufragou cm Cados Frio, e a companhia especialmente interessada na carga mandon um official incumbido de recuperar o ouru. As operaçes de mergulho lorito muito interrompidas pelas vagas e tempestades; depois dessas 
interrupęões achou-se que a força das vagas, até á profundidarde de vinte e dois metros, fora bastante para quebrar as partes mais fortes da embarcação e jogar de um lado para outro caixĩes de um pesu enorme, e pedras de peso de muitas toneladas (1).

Delesse disse que no Mediterraneo as ondas operam até a profundidade de cincoenta metros, na Mancha de quarenta metros, e no Oceano de duzentos metros (2).

Estas observações mostram que as vagas do oceano são violentamente destructivas em uma profundidade de vinte e dois metrus abaixo da superficie da agua.

Acção no nivel da maré. - 0 poder das vagas no nivel dı maré baixa e acima delle é mais apparente. 0 embate d'agua por si $\therefore o ́$, é frequentemente enorme, e quando as vagas sĩo arremessadas "ontra um banco de materiaes comparativamente molles, a costa è rapidamente solapada e destruida.

Uma grande parte do poder das vagas para cortar e desgastar it terra é fornecida pelas pedras soltas das praias. Estas pedras sĩo roladas para diante em cada vaga que avança, e para traz em cadi uma que retrocede. Este movimento de vac-vem das pedras sobre a praia rola umas sobre outras, bate umas de encontro com as outras e assim desgasta os seus angulos e produz seixos redondos, exactamente semelhantes aos desgastados pelo rolamento ao longo do fundo de um rio.

Quando as ondas são violentas, estes fragmentos de rochas são arremessados com força de encontro á costa. Is vagas são frequentemente bastante poderosas para arremessar sobre e de encontro ás costas, blocos de rocha pesando até cinco toneladas. Estas vagas violentas actuam com grande vigor não sómente sobre a parte da costa de encontro a qual a força principal da agua é dirigida, porém arremessam borrifos até grandes alturas, atacando as rochas chimicamente,

(1) Narrative of the... recovery of the... treasure sunk in H. M. S. "Thetis" at Cape Frio, Brasil. By Captain Thomas Dickinson, pags. 38, 17, 48, 58, 139, 149, 150. London, 1836.

(2) M. Dellesse. Lithologie du fond des mers, 110-111, Paris, 1871. 
desprendendo o solo e fragmentos de rocha soltos e assim conservando as rochas das costas bem expostas ás influencias da decomposição. Una idéa da distancia na qual é algumas vezes arremessada a agua póde ser tida do facto que ao norte da Escossia a janella de um pharol foi quebrada por ondas jogadas 91.3 metros acima do nivel da maré. No Rio de Janeiro quando os ventos sopram violentamente de sueste, as ondas algumas vezes entram na barra com tal foręa que são arremessadas completamente por cima da fortaleza da Ilha da Lage, e veen quebrar-se com foręa nas praias de Flemengo e Botafogo.

Na Ilha Rasa, do grupo de Fernando de Noronha, a arrebentarào frequentemente é de tal força, que os borrifos são levados atravez da ilha e as rochas superficiaes são tão corroidas pela agua do mar que são deixadas com pontas adentadas de alguns centimetros a um metro de altura e sobre as quaes é quasi impossivel caminhar.

Resultados da acção destructiva. - 0 resultado total do trabalho destructivo ordinario das vagas subre uma costa é solapal-a e assim permanecer em um ataque constante contra a terra. Por esta razão as nossas costas sĩo sempre abruptas naquelles pontos onde as ondas estão fazendo o trabalho destructivo.

Devidu a rapidez com que ellas estão sendo cortadas as ilhas de Fernando de Noronha e Trindade, tèm quasi $\mathrm{cm}$ todo o derredor dellas encostas altas e ingremes ou costões de desembarque muito difficil.

Por outro lado uma face abrupta nas costas testemunha a invasão do mar, terra a dentro, n'aquelle ponto, Fernando de Noronha e Trindade foram anteriormente muito mais extensas do que são agora, porém as suas margens tèm sido desmoronadas pelas ondas e o seu material carregado pelas correntes, e depositado no fundo do oceano na vizinhança destas ilhas.

Quando as ondas batem num só lado de uma ilha este lado fici mais ingreme que os outros. As ilhas dos Abrolhos, por exemplo, são collocadas de tal maneira que as ondas são mais fortes no lado sul, e que por conseguinte são abruptas naquelle lado. Quer dizer que as ondas mais forles vèm do sul, e atacam as ilhas principalmente daquelle lado (pag. 225). 
Deve-se notar que o solapamento na praia propria é capaz de produzir effeitos em toda a altitude dos barrancos superiores.

O trabalho das ondas das marés. - As ondas produzidas pelas marés são, como os outros phenomenos das marés, de occurrencia periodica. Um dos phenomenos mais notaveis das marés é a pororóca ou a onda da maré que se fórma dentro ou perto da bocca do rio Araguary na foz septentrional do rio Amazonas. Estas ondas são especialmente violentas no tempo das aguas vivas. Elevam-se á altura de 3 a 6 metros, e arrebentam-se sobre as costas desde perto do Cabo do Norte até perto de Macapá, na distancia de cerca de cento e sessenta kilometros (1).

Não existem rochas duras ao longo das costas sobre as quaes a pororóca do Amazonas arrebenta, porém estas gigantescas ondas arrancam as florestas pelas raizes e carregam as arvores como se fossem palha, escavam a terra até grandes profundidades e transportam us materiaes para longe formando novas ilhas e entulhando os velhos canaes.

Ondas də marés semelhantes, porém menos violentas, occorrem no Rio Guamá, Capim e Mojú perto do Pará e no rio Mearim, no Maranhão. Fm diversos outros lugares do mundo phenomenos semeIhantes occorrem notavelmente sobre o Ganges, na India, sobre " Garonne em França, sobre o Wve, Severn e Trent, na Inglaterra, e na bocea do rio Colorado, no Golpho da California

$\Lambda$ explicação da pororóca do rio Amazonas é que quando as aguas vivas ou marés de sizygia, movendo-se do Oceano Atlantico profundu e vasto, approximam-se das aguas razas da bocea norte do Amazonas, o movimento livre da onda da maré fica abruptamente perturbado e a onda tropeça sobre os baixos e é forçada a arrebentar justamente como todas as ondas fazem quando chegam nas aguas razas perto da costa.

(1) J. C. Branner. The pororóca or bore of the Amazon. Science. Nov. 28, 1884. Vol. IV, pags. 488-492. 
Vagas extraordinarias. - Vagas de natureza differente sào occasionalmente produzidas pelos terremotos un outros movimentos submarinhos ou terrestres. Estas grandes ondas chamam-se frequentemente tidal waves (ondas da maré) porém de maneira alguma são dit maré, mas antes são ondas catastrophicas ou extraordinarias. As ondas catastrophicas são frequentemente muito perigosas para a vida e propriedade e tambem destruidoras das costas sobre as quaes ellas arrebentam. Por occasião do terremoto de Lisboa em 173 y houve uma grande perda de vidas $(\mathbf{4 0 , 0 0 0}$ almas $)$ não causada pelo terremoto propriamente dito, ou pela queda de edificios derribados por este, porém devido a uma enorme vaga que entrou pelo rio Tejo a dentro, inundando e derrocando os cáes sobre os quaes grande parte do povo da cidade refugiou-se.

A 15 de Junho de 1896 a costa oriental du Japão foi batida pror uma grande vaga catastrophica de 3 a 7 metros de altura e de 280 kilometros de extensão. Em menos de dous minutos, vastas quantidades de solo e rochas foram arrancadas das costas, cujo contorno foi muito alterado, 26,97\% pessoas foram mortas, "̋,390 outras foram feridas, 9,313 casas foram derrubadas e propriedades destruidas no valor de $3,000,000$ dollars.

Nào é bem sabido como se produzem estas vagas extraordinarias. Uma suggestão é offerecida pelo facto que por occasião da erupçio do Krakatôa em 1883, uma massa de rocha igual a cinco mil seiscentos e sessenta e tres milhões $(\$, 663,000,000)$ de metros cubicos cahiu no mar, causando ondas gigantescas.

Quando estas vagas alcançaram as custas de Java, cincoenta e tres kilometros distantes, ellas eram desde quinze até quarenta e um metros de altura, emquanto os mareographos eram affectados em todit a parte do mundo.

Concebe-se facilmente que qualquer elevaçào ou a depressão repentina de uma extensa area do fundo do oceano seja perfeitamente capaz de produzir estas vagas extraordinarias.

O poder destructivo das vagas. - 0 poder destructivo das vagas depende dus factores seguintes: 
I. - Da direcrão dos ventos, especialmente durante ventos rijos c tempestades. As ondas feitas pelos ventos que sopram da terra para ( oceano não atacam violentamente a terra de onde o vento supra. A arrebentação é mais alıa na costa fóra da barra do Rio de Janeiro quando

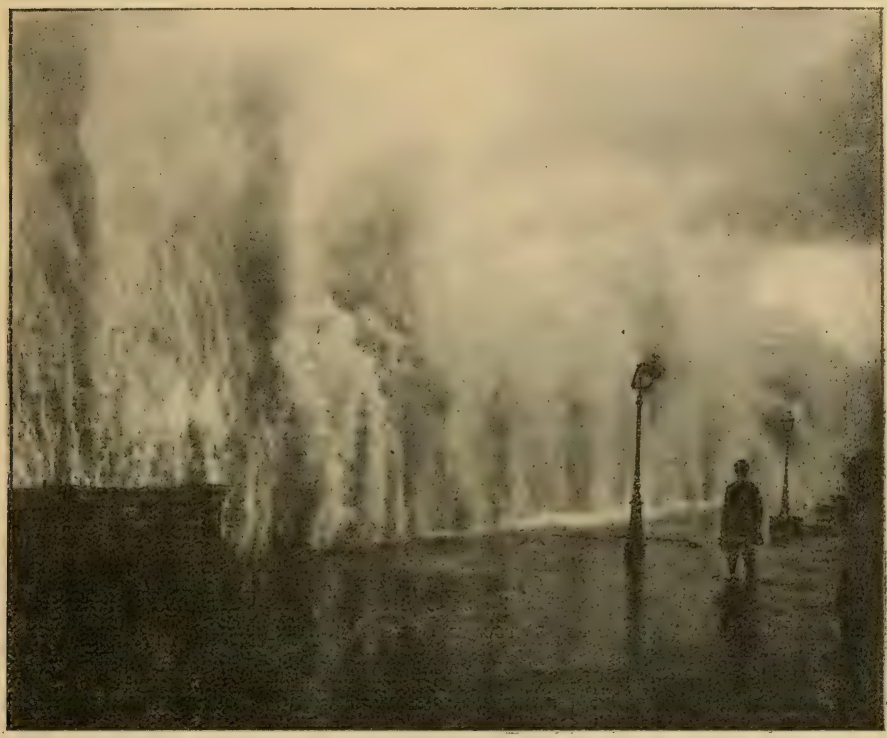

Fig. 21. - Vagalhões arrebentando contra as muralhas da avenida Beiramar 110 Rio de Janeiro no dia 7 de Março de 1913, Dr. H. Morize.

ventos fortes sopram durante alguns dias do quadrante de sueste, isto é, do mar para a terra.

No Rio de Janeiro a 7 e 8 de Marȩo do anno 1913, depois de dois ou tres dias de ventos frescos de sueste e justamente na occasião quando as marés foram as maiores do anıo, os vagalhões provenientes do máo tempo havido em alto mar, penetravam pela barra dentro e vinham arrebentar contra as muralbas da Avenida Beiramar com tanta foręa que foram quebradas em diversos pontos na distancia de mais de um 
kilometro (1). As ruas adjacentes da cidade ficaram inundadas, e muitos residentes foram impedidos de sahir de suas residencias pelo espaço de um dia inteiro.

II. - Da exposição ou direccão da costa com referencia aos ventos reinantes das tempesdades. Isto é um rorolario do que for dito no paragrapho precedente.

III. - Da estructura da costa. A posição dos planos de estratifi-

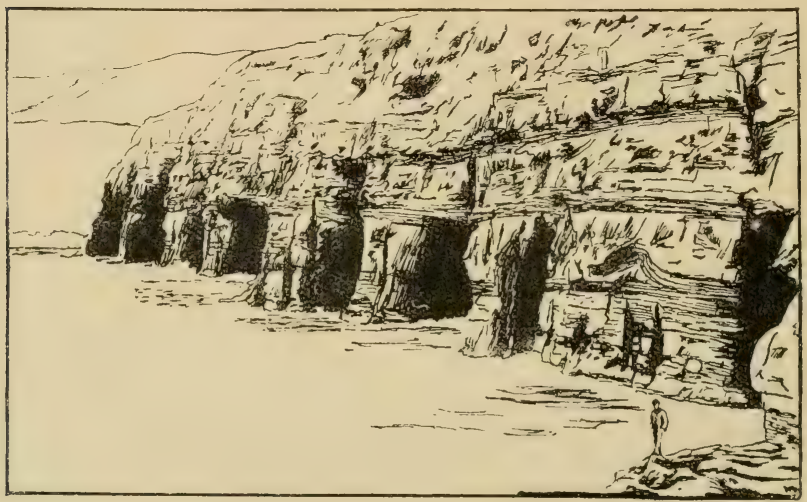

Fig. 22. - Cavernas perto de San Diego, California, cortadas pelas vagas em uma camada molle de arenito.

caçà) das rochas frequentemente determina se são ou não especialmente destructivas as vagas. Algumas vezes as camadas das rochas inclinamse suavemente para o mar, caso em que as vagas que batem de encontro a ellas escorregam para cima e para baixo da rampa sem ser capaz de atacar efficazmente a costa. Este facto é utilizado pelos engenheiros hydraulicos que dão a certos quebra-mares uma boa inclinação na direç̧ão das vaģas afim de que a forıa da agua não possa atacar " IIII'0.

IV. - Do caracter das rochas da costu, a qual concorre materialNacional.

(1) Dados gentilmente fornecidos por Dr. H. Morize, director do Observatorio 
mente para determinar o poder destructivo das vagas. Acontece muitas vezes que camadas de rochas duras e molles se apresentam alternadamente sobre a costa do mar. Em taes casos as camadas molles ,são desgastadas pelas vagas mais rapidamente do que as duras que são deixadas em uma serie de recifes. Algumas vezes as camadas molles sào desgastadas de maneira a deixar cavernas razas e arcos sobre a rosta. A figura junta (n. 22) mostra as cavernas corladas perto de San

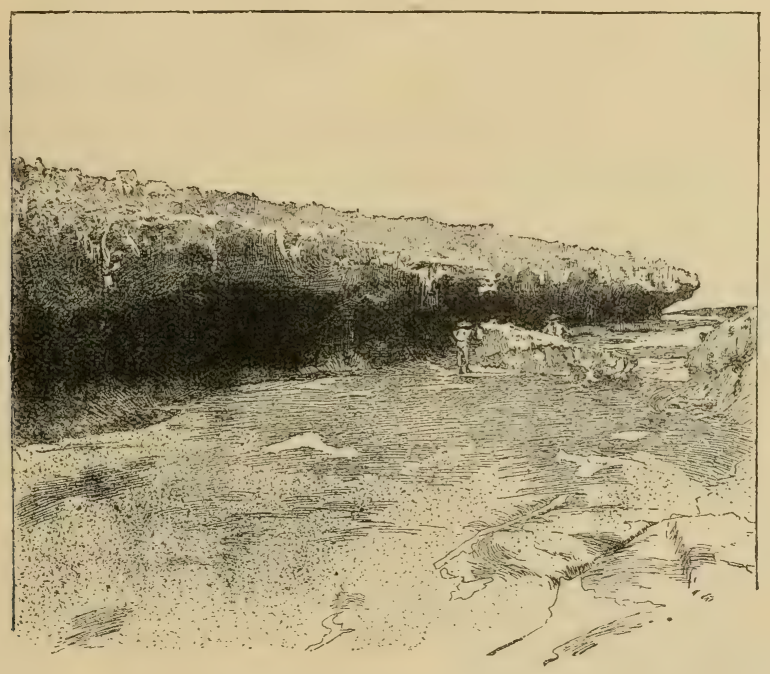

Fig. 23. - A extremidade da Ilha Raza, cortada pelas vagas, Fernando de Noronla. Vista tirada com maré baixa.

Diego, California, em uma camada molle subjacente a outra mais dura.

V. - Da profundidade d'agiıa, mar a fóra, a qual influe muito sobre o poder destructivo das vagas. Quando a agua é profunda juntı á costa as grandes vagas quebram-se sobre ella com grande violencia. Se a agua é raza, mar a fóra, as vagas quebram-se em arrebentações antes de chegarem á costa e perdem assim uma grande parte de seu poder de cortar e de desgastar. 


\section{Formas das costas produzidas pelas vagas.}

As fömas das costas produzidas pelas vagas dependem do mrsmm modo em grande parte da direçào e da força das vagas e da "naturezit cestructura das rochas la costa. Ha frequentemente um sulco cortado pelas vagas na linha da maior actividade, emquanto abaixo do sulco se

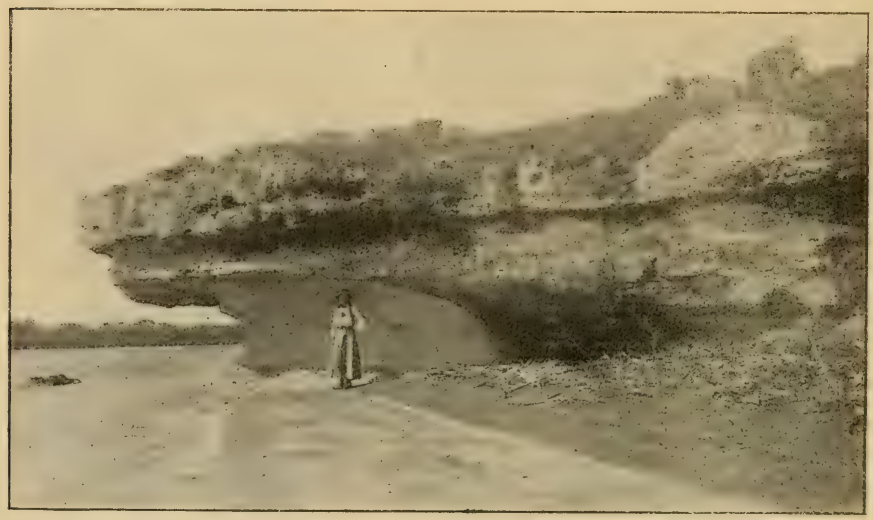

Fig. 24. - " O chapeo". Camadas horizontaes solapadas pelas vagas, Fortinho, porto de Aracaty, estado de Ceará. WVaring.

apresenta um lagcado de maior ou menor largura conforme a natureza das rochas.

A figura junta (n. 23) mostra um tal sulco cortado pelas ondas na Ilha Raza, uma das ilhas do grupo de Fernando de Noronha. 0 primeiro plano da figura mostra o largo lageado emquanto no meio se ri cahido um grande bloco que foi quebrado em virtude de seu proprio peso destacando-se por esta maneira da encosta saliente.

Algumas vezes dois sulcos são cortados na costa - um no nivel da maré alta e um outro no nivel da maré baixa. Cavernas e arcos naturaes são cortados quando a variação das rochas e as condicues locaes são favoraveis. I figura na pagina 77 (n. 23i) mostra o grande 
portão na extremidade nordeste da ilha de Fernando de Noronha.

Neste ponto a excavação do mar formou um isthmo que tem sidı solapado pelas vagas escavando as rochas mais molles de baixo o deixando um arco bem firme de rochas duras.

As fórmas das rochas das costas são ás vezes determinadas por

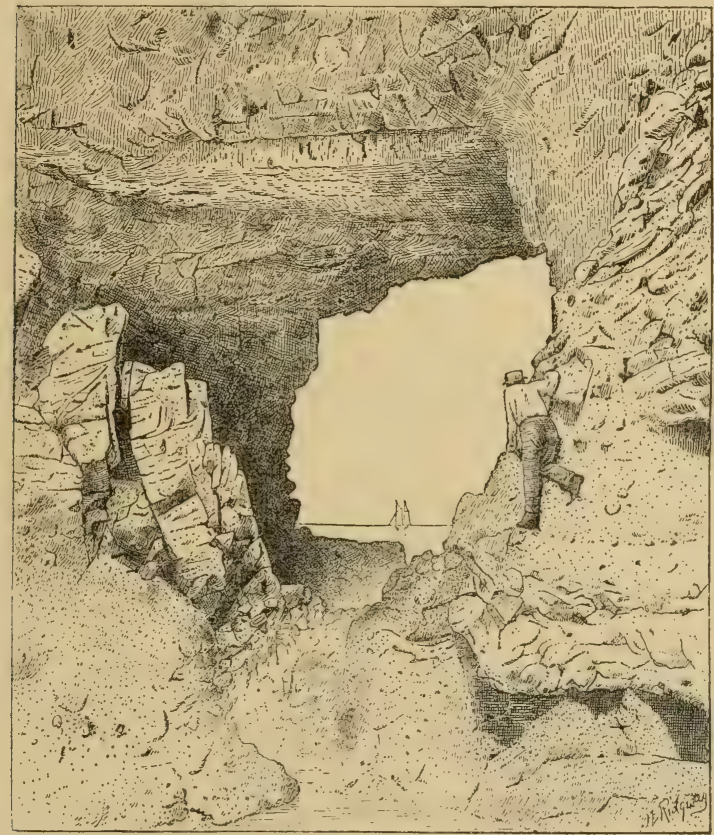

Fig. 25. - O 1'ortão, uma abertura cortada pelas vagas por baixo da extremidade sudoeste da ilha de Fernando de Noronha. Largura doze metros.

certos agentes protectivos. As rochas podem estar cobertas por una 'amada de algas, cracas, coraes, tubos de serpulas e outros organismus que impedem a força das vagas de desgastar as rochas.

Os recifes de arenito em Pernambuco, Bio Grande do Norte, Porto 
Seguro, Santa Cruz e em muitos outros lugares ao longo da costa de nordeste do Brasil teriam sido já destruidos pela acção das vagas s: nio fossem protegidos por taes organismos sobre os seus lados externos ou nas faces viradas para o mar.

\section{Trabalho mechanico constructivo dos mares e oceanos ou transporte e deposição marinha.}

0 transporte nos mares e oceanos é feito por:

I. - Correntes das marés.

II. - Vagas.

III. - Resaca (undertow).

IV. - Correntes oceanicas.

As correntes das marés fazem o seu trabalho de transporte nos estuarios e entre as ilhas ao longo ou perto das costas.

Este trabalho consiste na acção de esfregamento da agua em passando pelos canaes durante a enchente e a vasante das marés. E' a acção destas correntes da maré que conserva as barras dos portus impedindo de se tornarem obstruidos cum os sedimentos. Nunca é necessario fazer qualquer dragagem na barra da bahia do kio de Janeiru porque as marés passando pelo estreito canal entre as fortaleza: de São Joào e Santa Cruz a conserva varrida de todos os sedimentos.

Agentes marinhos constructivos. - U truballo constructivo das vagas consiste no transporte e deposição das materias soltas que lhes ficam ao alcance.

Quando as vagas approximam-se de uma costa no normal á linha da praia, ou de maneira que os eixos das vagas sejam parallelos a ella, os materiaes soltos da costa são simplesmente rolados para cima e para baixo da rampa da praia. Em taes casos os materiaes nâo sîu movidos au longo di costa porém permanecem junto á sua posiçio original. Quando, porém uma vaga bate obliquamente na praia o scixo movido por ella é arremessado para diante na direção do movimento da onda e entào rola, ou é levado novamente pela vaga, para dentro ou perto da beira d'agua. A vaga secruinte arremessato no mesmu 
caminho e novamente elle rola para baixo. Cada vaga assim transporta-o um pouco mais longe ao longo da praia.

0 processo é mostrado na figura 26. Se um seixo sobre a praia em A é arremessado por uma vaga $0_{1}$ movendo-se na direcęào indicad: Iela flecha, elle será movido para diante na direcção do movimentu da vaga e então curvando para a direita rolarí para baixo da praia para em B. A vaga $0_{2}$ o arremessará e depois de um caminho semelhante elle ha-de parar em C. Este processo continuará tanto tempo quanto as vagas façam um angulo com a praia. Quando porém ella

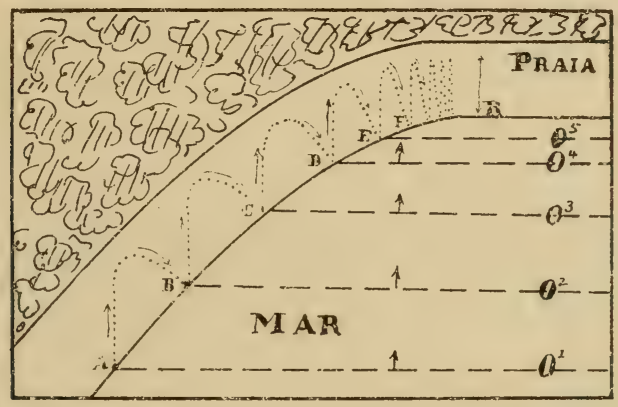

Fig. 26. - Diagramma illustrando o transporte -de materiaes ao longo da praia pelas vagas.

chega ao ponto $\mathbf{R}$ onde as vagas sãu parallelas á linha da praia, elie será rolado para cima e para baixo naquelle ponto sem fazer qualquer caminho ao longo da praia.

Esta acção das vagas necissariamente tem como resultado o transporte do material solto ao longo da praia numa só direção. 0 transporte cessa sómente quando as vagas não batem mais obliquamente ua praia. Uma volta para a parte da terra da linha da costa faz com que o material transpurtado seja depositado formando um pontal como é explicado na pag. 82.

É notavel que a direçầ dus ventos determine a direcção das vagas e o angulo d'ellas nas praias. 
Por isso acontece que em muitos lugares occorre um movimento de vae-e-vem dos materiaes das praias.

Nos lugares onde o vento sopra sempre na mesma direcȩão é claru que o transporte tambem é numa direcção unica, e as accumulações formam pontaes e bancos submarinhos.

A resaca. - A resaca é a volta na direç̧ão do mar das aguas que são arremessadas sobre a costa na forma de vagas. A vaga entretanto arremessa-se sobre a praia acima do nivel medio d'agua, emquanto a resaca corre na direção do mar debaixo do nivel médio. Estes dois movimentos dăo logar a uma circulação - movimentu constante para a terra da agua da superficie e um movimento igualmente constante para o mar da mesma agua abaixo da superficie.

A tendencia deste movimento é arrastar com violencia os materiaes miudamente moidos da praia.

As correntes oceanicas. - Is correntes oceanicas estão geralmente tão longe da costa que nào transportam senào pouco sedimento mechanico.

No caso do rio Amazonas, entretanto, um volume tão enorme de agua carregada de lodo corre para o oceano $\mathrm{cm}$ sua bocca, que it currente oceanica arrasta seus sedimentos até grandes distancias para o noroeste e as distribue sobre o fundo do mar longe da terra.

Quasi toda a deposiçào mechanica tem logar em obediencia á lei do transporte já dada, isto é, que o poder mechanico da agua para mover rochas varia com a sexta potencia da velocidade. Existem duas excepções importantes a esta regra.

Primeiro, a agua salgada, sendo mais densa do que a doce, é capaz de mover materiaes um tanto mais pesados, com uma corrente dada, Io que a agua doce. A segunda excepção é devilo ao facto que a agua salgada tem um effeito singular sobre o lodo transportado para us vceanos pela agua doce. Este cffeito é chamado floculação e consiste no agrupamento, ou liga, do lodo tino de maneira que elle affunda-se mais rapidamente do que fariam n'agua doce. (Vède pag. 86). Is aguas dos rios carregados de lodo depois de seren misturadas com a 
agua salgada tem os seus sedimentos finos precipitados em um quinze avos de tempo requerido para o mesmo lodo affundar-se n'agua doce.

\section{Formas e origens dos sedimentos mechanicos.}

Os depositos mechanicos nos mares e oceanos sĩo feitos em uma das formas seguintes :
I. - Praias.
II. - Pontaes.
III. - Barras.
IV. - Restingas.
V. - Bancos submarinhos.
VI. - Deltas.

1. Praias. - As praias são de duas naturezas: as priaias ordinarias e as praias das tempestades.

Praias ordinarias. - Por praias ordinarias se entende a cinta de areia ou outros miteriaes soltos que ficam entre a maré baixa e 0 alcance superior das vagas ordinarias. Estes materiaes que formam as praias são na maior parte derivados da terra, porém elles recebem contribuição dos restos organicos e dos materiaes mechanicos retirados pelas aguas dos mares razos e arremessados pelas vagas.

Já foi mencionado como taes materiaes são transportados ao longo das praias pelas vagas: este processo resulta no aterro, pelas areias transportadas, das angras e bahias augmentando assim a terra. As praias arenosas frequentemente dão origem a dunas. Quando as ireias das praias se tornam seccas os ventos sopram parte dellas para a terra onde eventualmente formam extensas accumularĩes, vulgrarmente medos.

Praias de tempestades. - Praias de tempestades são aquellas cujos materiaes são arremessados pelas ondas das tempestades alem do alcance das vagas ordinarias. Taes praias são muitas vezes arremessadas pelas vagas atravez das boccas dos cursus de aguas furmando assim lagos d'agua doce ou d'agua salobra atraz de si, ou compellindo as correntes a fazerem longas voltas afim de alcancrarem o mar. Ao longo da costa brasileira existem muitas praias desta natureza. Quando um rio tem a sua bocca completamente fechada por praias de tempes- 
tades elle é popularmente conhecido pelo nome apropriado de * rio tapado ».

Nas costas de Alagôas, Pernambuco e Rio Grande do Norte ha diversos rios tapados. Alguns delles são fechados somente quando a maré está baixa, porque a maré alta passa por cima e cobre o banco dr areia que atrevessa as boccas dos rios.

As areias das praias são muitas vezes, arremessadas em monticulos peculiares em forma de cuspides. Estes são formados pela interferencia de dois jogos de ondas. A interferencia das ondas é muilis vezes produzida dentro de uma bahia por uma ilha na entrada d'ella : em taes casos us cuspides de areia são formados sobre a praia da bahia (1).

As figuras 68 e 69 mostram a apparencia dos cuspides da praia e explicam o processo da formação delles.

II. Pontaes. - Pontaes são praias de construcção ou extensias linguas de terra construidas, extendendo-se da costa por dentro da agua. Quando o material movediço da praia - areia, seixus, etc. é varrido ao longo pelas vagas, como loi explicado na pagina precrdente, até alcançar uma curva da costa na direçiò da terra, o material movediço dir praia é depositado na agua morta na curva da costa. A accumulação destes materiaes formam uma extensĩo delgada da fraia que é conhecida pelo nome de pontal.

Quando um pontal é construido em agua funda elle é geralmente recurvado para a terra em sua extremidade exterior ou de crescimento. O cabo Cod na costa oriental da America do Norte é um extenso pontial de areia recurvado, construido na maneira aqui indicada. Sandy Hook é um notivel pontal recurvado á entrada da bahia do porto de NirYork.

Os pontaes são tambem algumas vezes formados ao lonģo da linha de contacto entre uma corrente terrestre e as vagas do mar, espercialmente onde a corrente corre na mesma direcò̃o que a corrente

(1) J. C. Branner. The origin of beach cusps. Journ. Geol. Sept.-Oct. 1909. VIII, pags. 481-484. 
maritima. Taes pontaes sào ainda augmentados em altura pela acção das vagas das tempestades. 0 grande pontal na bocea do rio Vistula no mar Baltico foi formado desta maneira.

Quando a agua entre duas ilhas contiguas é raza os pontaes são frequentemente formados de maneira a juntar as ilhas.

A mesma cousa acontece quando uma ilha fica perto da terra e as correntes não carregam para longe os sedimentos locaes.

A rocha ou peninsula do Gibraltar na Hespanha ja foi ilha, mas agora está reunida á terra pelí acção das ondas que depositaram as areias das praias entre a ilha e a terra firme.

III. Barras. - As barras já se disse ser o resultado da aç̧ão combinada dos cursos de agua e das vagas e correntes do mar. Ellas sìo formadas junto ás boceas da maioria dos cursos terrestres e dos estuarios que dão no mar.

Em frente á bocca do rio Sào Francisco existe uma barra, ou coròa de areia, feita assim, da trazida pelo rio e depositada onde sua corrente fica interrompida.

IV. Restingas. - Restinga ou praia luarreira é o nome dado a uma ilha ou peninsula comprida e delgada semelhante em forma a um pontal, formado por sedimentos ao longo e parallelo ás linhas da costa.

As restingas são produzidas pelas vagas provenientes do mar fundo arrojando para traz sobre o fundo do mar mais razo os sedimentus transportados da terra pela resaca. Estas formas principiam como baixios, depois pela accumulação de sedimentos tornam-se bancos de areia e ainda depois ilhas ou peninsulas. Existem exemplos nutaveis de praias originando-se desta maneira ao longo das costas da C'arolina do Yorte, Texas e Yucatan na America do Norte. Frequentemente acontece que lagruas sio formadas atraz das restingas e estas no correr (1) tempo são aterradis com o ludo trazido pelos cursos de agua e eventualmente formam terra firme. A Lagìa dos Patos, Lagôa Mirim e Lagóa Mangueira, e muitos pequenos lagos ao longo da costa do Rio Grande do Sul e tambem os lagos das planicies da costa de Santa Ca- 
tharina, São Paulo (Ilha Comprida entre Iguape e Cananéa) Rio de Janeiro e Alagòas tem sido circumdadas pela formação de barras e restingas. Interiormente haviam muito mais lagos desta natureza do que existem presentemente, porque muitos delles já tem sido aterrados completamente e formam agora terra firme. Na costa da Parahyba do Norte, na Traição, havia antigamente um lago - Lagòa de Sinimbú que foi gradualmente aterrada completamente pelos sedimentos levados para ella e pelo crescimento da vegetação. Isto não é senão uma illustração do que está acontecendo com todos os lagos de nossas costar. Com o correr dos tempos elles todos devem estar completamente aterrados da mesma maneira.

V. Bancos submarinhos. - Os bancos submarinhos são formados em qualquer parte do fundo do oceano onde os sedimentos se depositam por um longo periodo de tempo. Logo que taes bancos alcançam ou approximam a superficie da agua as vagas amontoam os materiaes acima desse nivel e a terra principia na forma de restinga.

Desta maneira a terra extende-se na direcęão do mar, especialmente nas fozes dos rios onde as correntes deixam cahir os sedimentos trazidos da terra pelos rios.

VI. Deltas. - Os deltas são formados nos mares da maneira porque se formam nos lagos (vède p. 6 1 ). Os cursos de agua carregam sedimentos da terra, e quando as condições são d'outra sorte favoraveis, estes sedimentos sào depositados loggo que alcançam o mar e o delta é formado na bocca da corrente. E' um facto notavel entretanto quo os deltas são formados nas boccas de alguns cursos d'agua e não de outras.

Porque dellas se formam nas boccas de alguns rios e nũo de outros. Essa differença pode ser divida a caracter das aguas do rio, ou ás correntes do oceano em frente á foz do rio.

o S. Lourenço, grande e importante rio da America do Norte, não tem delta; emquanto que o Mississipi, um outro rio da America do 
Norte, tem um extenso delta (fig. 27). A differenęa nestes casos é devida ao facto ser o rio Mississippi muito lodoso transportando enormes quantidades de lama para o Golfo do Mexico no qual se forma o delta, emquanto o S. Lourenço é um rio de aguas limpidas, o seu lodo havendo sido depositado nos grandes lagos atravez dos quaes elle corre.

A Africa era antigamente separada da Asia, porém o Nilo formou o seu grande delta até os dois continentes ficarem por elle unidos. 0 rio Colorado antigamente corria para o lado oriental do golfo da Cali-

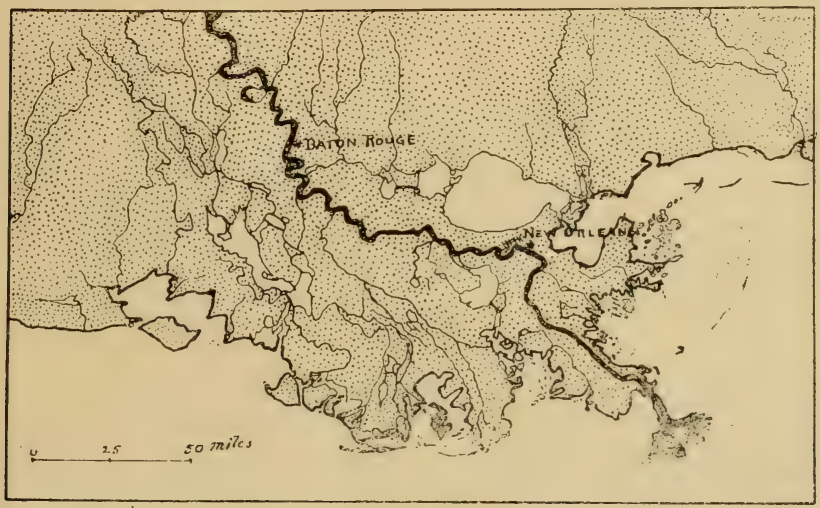

Fig. 27. - As boccas do Rio Mississippi.

fornia, porém a lama transportada pelo rio formou um delta que eventualmente cortou o golfo em dois e como a parte septentrional desta massa de agua se acha em uma regiảo arida, a agua se evaporou, e agora somente resta um pequeno lago de salmoura muito forte e este mesmo reduzido em nivel oitenta metros inferior ao do oceano.

Em outros casos os cursos de agua que transportam grandes quantidades de lodo não tem deltas porque as correntes marinhas transportam o lodo para o oceano tão rapidamente como os rios o trazem. 0 Rio da Prata parece ser um caso desta natureza. As areias que formariam de outra sorte um delta no bocca daquelle rio são trans- 
portadas ao longo das costas pelas correntes e espalhadas sobre o fundo do mar não longe da terra.

Os deltas são usualmente formados, não de uma unica, porém de muitas ilhas e as aguas dos rios entram no mar por diversas boccas. Estes canaes tendem a augmentar em numero e o numero de ilhas tambem augmenta.

Estas ilhas são formadas pelo aterro do mar fúra da bexcea dos rios até se formar uma barra e depois os lodos se depositam no lado exterm desta barra, formando assim um banco alongado dirigido para o mar. Este longo banco gradualmente toma a forma de $\mathrm{V}$ com a extremidad. aguda dirigida rio acima.

Effeito d'agua salgada sobre os sedimentos. - $\Lambda$ floculação é o nome dado ao processo pelo qual as mais miudas particulas de lodo de aguas turvas reunem-se em flocos, molhos ou cachos. Este effeito pode ser produzido de muitas manciras. Certas substincias postas em aguas lamacentas causam a lloculação: entre ellas estão o sal commum, pedra-hume, acidos " alcalis. A pedra-hume ou sulfate de aluminio é agora extensivamente usada para provocar a floculacia do lodo nas aguas antes dellas serem filtradas para o abasteciment d'agua ás cidades. Sie as aguas lamacentas sào fervidas ou geladas produz-se o mesmo effeito sobre o lodo - este flocula-se e vai para o fundo. A cal tem um effeito semelhante, e é em parte por esta razio que as aguas fortemente calcareas são, geralmente, inteiramente limpidas.

0 facto que o sal causa floculação é um factor de grande iniportancia no comportamento do lodo transportado pelos rios para o mar, porque a floculação produzida pelo sal na agua do mar faz com que a carga mechanica das correntes terrestres vá para o fundo em $u m$ quinze avos do tempo que seria necessario para afundar-se n'agua doce. De facto esta affirmargão é antes aquem do que além dia verdade. Is experiencias feitas com aguas de certos rios tem mostrado que nas circumstancias orduarias as particulas de barro muito miudas permanecem em suspensĩo indefinidamente em aguas doces lamacentas. A floculario do lodo das correntes lamacentas pelo sal do 
mar deve por isso ser considerado como um processo geologico importante.

Crescimento de deltas. - A marcha do crescimento de deltas necessariamente varia muito com as condições. O delta do Mississippi cresce para o mar na marcha de um kilometro em dez annos. 0 delta do Pó tem crescido mais do que trinta e dois kilometros desde o tempo do Imperador Augusto.

No tempo de Christo, Mileto era um porto fundo na foz do rio Menderes, na Asia Menor, e fronteiras havia diversas ilhas no mar. Hoje o porto de Mileto não existe mais, e as antigas ilhas apparecem agora como pontos rocheos na planicie de sedimentos depositados pelo rio. A costa fronteira ao rio está crescendo na media doze metros por anno.

A posição dos sedímentos marinhos. - Os depositos das praias geralmente inclinam-se para o mar. A maioria dos sedimentos depositados quer n'agua doce quer na salgada são tão proximamente horizontaes quanto permittem as circumstancias. Se o terreno sobre 0 qual elles são depositados é desigual, os sedimentos tendem a encher e encobrir inteiramente estas desigualdades, sendo as depressões enchidas mais rapidamente do que as partes elevadas.

Os sedimentos da terra, quer provenientes do corte das costas pelo mar quer trazidos pelas correntes do interior do continente, cobrem extensas areas ou fachas approximadamente parallelas ás costas. 0 arranjamento e a distribuição deste material são determinados pelas correntes oceanicas e pelo tamanho das particulas de lodo. As particulas mais graudas são depositadas mais perto das costas emquanto as mais miudas sào transportadas para mais longe da costa e mais longe de suas origens. Segue-se que, no geral, os sedimentos da terra são distribuidos em fachas approximadamente parallelas á costa; que as fachas de materiaes maiores ou mais pesados são mais estreitas e mais proximas á costa ; que as dos mais miudos estão mais afastados, e que os extremamente miudos são depositados ainda mais longe e que elles cobrem areas mais extensas. 
Assim é possivel muitas vezes determinar a natureza e direcção das correntezas e a origem dos sedimentos que formam as camadas de rochas sedimentarias.

A's vezes acontece que barragens, diques, e taes construcęoes artificiaes feitas para proteger um porto de mar, ou para formar $11 \mathrm{~m}$ porto, causa accumulaçũes de areias em pontos inesperados. No Ceará um quebramar causou accumulacões de areias de tal modo que umis parte do porto ficou entupido e abandonado.

Conclusões referentes aos sedimentos mechanicos. Săn as seguintes as conclusões geraes referentes aos sedimentos mechanicos :

I. - Is sedimentos transportados pelos cursos de agua são exclusivamente rochas fragmentadas e decompostas e materiaes da terra.

II. - 0 fundo do oceano é o destino de toda a terra.

III. - A marcha da remoção da terra depende :

1. Da topographia: tanto mais ingreme a inclinação geral, quanto mais rapida a marcha da erosão. Isto acontece tanto na erosão pelos cursos d'agua como na erosão pelas ondas. Nos cur'sos a erusào é mais rapida porque tanto mais ingreme a inclinação quanto mais rapidas as correntes.

Nas costas ingremes, havendo ao largo aguas fundas, as vagas alcançam a costa com maior força e o solapamento é mais efficiente tanto por causa da maior força das vagas como por causa da maior massa miriada na costa.

2. Do clima. A congelação e o degelo apressam a decomposição e a denudaça. A concentração da chuva do anno em alguns mezes ou semanas augmenta a denudação total para o anno.

3. Da estructura e caracter das rochas. As rochas mais friaveis são desgastadas mais rapidamente, emquanto as mais resistentes ficam salientes.

IV. - A maior parte da remogão de terra ou rocha é feita durante o tempo da enchente dos cursos d'agua, devido ao maior volume d'agua, á maior velocidade da correnteza, e ás contribuições teitas pelos cursos entrando nos dois lados. 
V. - A denudução ataca toda a superficie da terra e affecta as rochas tão profundamente quanto penetram as aguas da superficie, não alcançando porém muito abaixo do nivel do oceano.

VI. - Uma superficie erodida indica a condição de terra firme, ou de agua raza.

VII. - 0 endurecimento da rocha é de certo modo um accidente.

VIII. - A disposição dos sedimentos transportados por qualquer corrente é determinada pelas leis do transporte.

IX. - Assim os sedimentos graudos só podem ser removidos por fortes correntes, e os miudos só podem ser depositados em correntes fracas.

X. - 0 caracter dos sedimentos, desta maneira, indica a natureza das correntes em que elles são depositados.

XI. - Em uma area ao largo da costa :

1. Os sedimentos graudos são úepositados perto da costa.

2. Os sedimentos mais miados são depositados mais distantes da costa.

$3 .^{\circ}$ Os sedimentos graudos são depositados em uma zona parallela a costa.

$4 .^{\circ}$ Os sedimentos mais miudos são depositados sobre uma area mais larga que os graudos.

XII. - 0 desgatamento feito pela agua e o acamamento feito na agua são caracteristicos e indicam condições aquosas.

\section{V. - 0 gelo como agente geologico.}

0 gelo como agente geologico é de grande importancia nas regiões polares e nas zonas temperadas da terra, mas de pouco interesse ou importancia directa nos paizes tropicaes. 0 gelo tem, porém, representado um papel importante na historia da terra e por este motivo serí brevemente considerado aqui.

0 trabalho geologico do gelo se effectua por tres modos :

I. - Pela txpansão mechanica da agua no acto de congelar-se 
pela qual as ruchas sioo desintegradas o us declives da terra e rocha são alterados.

II. -- Pelos geleiros ou correntes de gelo.

III. - Pelos gelos fluctuantes (icebergs e floe-ice).

Congelação. - I expansão d'agua no acto da congulação, a desintegração de rochas e o derrocamento de paredões e encostas rochnsas por este processo tem sido já considerados debaixo do titulo de mudanças de temperatura na pagina 29 a qual o estudante deve reportar-se.

\section{Geleiros.}

Quando a agua é precipitada das nuvens com a temperatura abaixo do ponto de congelação, cahe, não na forma de agua, mas na de neve, ou particulas de gelo, isto é, de agua na sua forma crystallina. Quando a neve cahe em grandes quantidades, com a correr do tempo, conglutina-se, assim formando gelo solido. Este gelo, quando uitu ampirado for um lado, eventualmente corre devagar de um modo muito semelhante ao do breu ou melado grosso ou de outra qualquer substancia viscosa. Nas regióes montanhosas onde cahe muita neve, a neve recem-caida vai augmentando successivamente as accumularoms de gelo formadas de neve; an passo que as partes inferiores destas accumularoes se movem vagarosamente pelas encostas dos valles na firma de geleiros ou correntes de gelo, derratendo-se na sua extremidade inferior. Em outrus termos: - nas regióes onde a humidade cahe na forma de neve a drenagem se effectua na forma de geleiros ou cursos de gelo. O movimento destes geleiros é muito vagaroso, mas, geralmente obedecem ás leis do fluxo dos cursos d'agua.

Por conseguinte as condięões necessarias á formação de geleiros sâo :

I. - Uma região que se estende acima da altitude da neve perpetua.

II. - Uma precipitação abundante de neve.

III. - Differenças de temperatura durante o anno. 
Os geleiros se formam em qualquer regiào na qual cahe mais neve na estação fria do que derrete-se na estação quente. Portanto elles se formam sómente acima do limite da neve perpetua. Na Suissa a altitude de neve perpetua é de 2330 a a 2700 metros para cima. Este limite é baixo nas regiões polares, mas se eleva á medida que se approxima ao equador onde se acha a quatro mil oitocentos e oitenta metros acima do nivel do mar. Na America do Sul só ha geleiros ao nivel do mar na região do Estreito de Nagalhães, ao passo que mais ao norte só se acham nos picos elevados dos Andes. Ainda mesmo debaixo do equador elles se apresentam naquella alta cordilheira de montanhas.

\section{Movimento dos geleiros.}

A velocidade. - A velocidade do movimento dos geleiros varia muito nas suas diversas partes exactamente como a d'um rio 01 outro curso d'agua. A velocidade do movimento do geleiro varia tamben conforme as diversas estações do anno. Os das montanhas da Suissa se movem na razão de quarenta e cinco até cento e vinte metros por anno; o grande geleiro Muir de Mlaska na occasião da mediçio em 1891 estava se movendo na razào de setecentos e setenta nove metros por anno. Os geleiros da Groelandia se movem desde dois metros : quatro decimetros até treze kilonetros por anno. Estas grandes dillerenças nas razũes de movimento são causadas :

1. - Pelo declive do leito do geleiro sendo que yuanto mais inclinado o leito mais rapido é o fluxo.

11. - Pelo calor do verio sendo que quanto mais quente o verào mais rapido é o fluxo.

III. - Pela precipitação da neve, ou em outras palavras pela massa do geleiro, sendo que quanto maior o volume mais rapido é o fluxo.

Determinação da velocidade. - Determina-se a velocidade, fincindo estacas atravez dos geleiros em linha rigorosamente recta e. determinando a distancia que estas estacas se deslocam desta linha 
depois de alguns dias ou horas. Observações feitas por este modo tem demonstrado :

I. - Que os geleiros se movem mais rapidamente na parte superior do que na inferior (em virtude da frição do gelo sobre o leito rochoso).

II. - Que se movem mais rapidamente na parte mediana do que nas partes lateraes (em virtude da fricęão do gelo sobre os lados do canal).

III. - Que no dobrar as curvas a corrente é mais rapida na parte externa da curva.

IV. - Que o movimento é mais rapido onde o declive do leito é mais forte porque nos declives fortes a frição fica reduzida.

Theorias do movimento do gelo. - Tem-se proposto muitas theorias para explicar o fluxo dos geleiros, mas a gerilmente acceira pelos geologos é a conhecida pelo nome de theoria da regelarão proposta pelo physico inglez Tyndall. Conforme esta theoria o gelo se move em virtude do fraccionamento e recongelação em toda a massa. o processo póde ser illustrado do modo seguinte. Collocando atravez. de um bloco de gelo um pequeno arame com pesos fixos a cada extremidade de modo que estes puxem para baixo, nota-se que o arame passa vagorosamente por todo o bloco, mas que este fica tão solido como antes da passagem do arame, porque 0 gelo se reforma por traz d'elle. Se o gelo fơr sujeito a forte pressão elle púde amoldarse a qualquer fórma. E' esta facilidade em ceder á pressão que faz. com que os geleiros corram semelhante a uma corrente de material molle plastico ou viscoso. A pressão nos geleiros é produzida pela gravidade do proprio gelo.

Por esta razão os grandes geleiros movem-se mais rapidamente que os pequenos, os declives sendo os mesmos.

A' medida que os geleiros se movem pelos seus valles abaixo cahem sobre elles pedras soltas, terra e areia, ou estes materiaes são depositados em cima delles pelos cursos de agua. Estes materiaes se accumulam ao longo dos lados do gelo, e á medida que o geleiro se move para diante são carregados e finalmente depositados onde o 
geleiro se derrete. No correr do tempo estes materiaes se accumulam formando montes e lombadas que se chamam morenas.

\section{Morenas.}

Fragmentos de rochas, areia, ou lama, e materiaes de diversas qualidades cahem nos lados dos geleiros e ali fazem accumulações que são transportadas, á medida que o curso de gelo move-se para diante. Essas accumulações chamam-se morenas.

Ha tres typos geraes de morenas : - morenas lateraes, morenas mudianas, e morenas terminaes.

Morenas lateraes são os montes de pedias, terra, etc., carregados ao longo dos lados dos geleiros.

Quando as correntes de gelo se unem umas das morenas lateraes de cada uma se juntam no meio do geleiro maior formando assim o que se chama uma morena mediana.

E quando todos os detrictos carregados por um greleiro ficam depositados pelo derretimento do gelo na extremidade inferior delle accumulam-se em um monte o qual, com o correr do tempo, fórma uma morena terminal.

Morenas terminaes geralmente tèm uma forma mais ou menos semi-circular ou crescente.

No material das morenas geralmente vem muito misturado o fino com o mais grosso.

Blocos erraticos. - 0 tamanho dos blocos de pedra que um geleiro púde carregar é quasi illimitado. Os materiaes das morenas podem provir de qualquer parte do valle no qual corre o geleiro e podem ser levados até o fim do geleiro, seja qual för o seu comprimento. Esses blocos chamam-se erraticos pela razão de achar-se longe das suas origens. Os fragmentos da rocha que cahen sobre a superficie de um geleiro as vezes se afundam gradualmente até o leito, e as vezes elles chegam ao leito cahindo nas crevasses ou fendas que se formam, aqui e acolá, no gelo em movimento. 
Sulcos glaciaes. - Ao chegar no fundo do geleiro estas pedras sĩu arrastadas de modo a arranhar e sulcar o leito rochoso sobreo

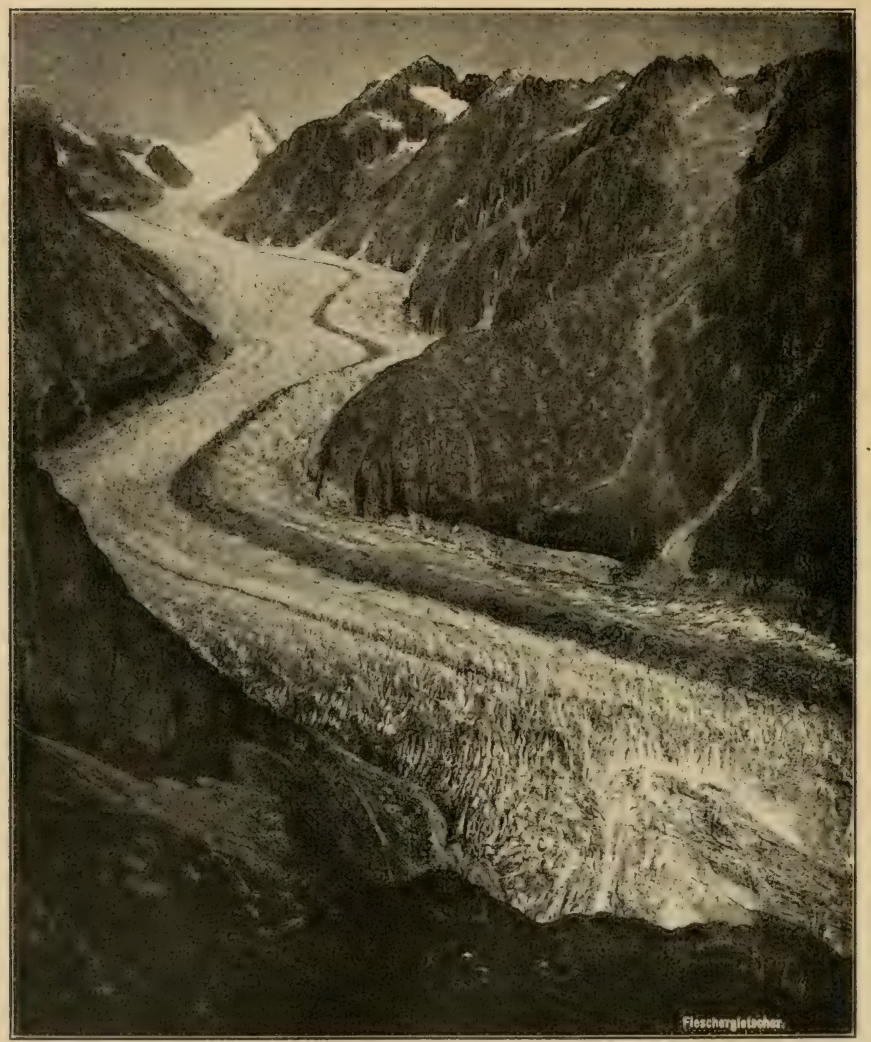

Fig. 2s. - 0 geleiro Fiescher nos Alpes Bemeses, na Suissa.

qual o grelo se move. De outro lado estes blucos soltos são tambem moidos e estriados, mas estando livres para se virarem, acuntece que se formam sobre celles diversas facetas e que as estrias nas suas fitces 
correm em muitas direcẹoes. Não são facetados, porém, todas as massas de pedra carregadas por um geleiro, porque muitas dellas nunca chegam ao fundo do gelo onde seriam moidas contra o leito rochoso.

Os sulcos feitos nas rochas sobre as quaes o gelo se move são proximamente parallelos e arrumados na direcção do seu movimento. Estes sulcos constituem uma das provas mais caracteristicas e indubitaveis do trabalho do gelo, ainda mesmo depois que este tem desapparecido.

\section{Trabalho geologico dos geleiros.}

O trabalho geologico dos geleiros, como o dos cursos d'agua, consiste no desgastamento, transporte e deposiẹão. 0 desgastamento se effectua por meio dos fragmentos rochosos que esfregam o leito dos geleiros. Alguma idéa da somma de trabalho effectuado por este modo é dada pelo caracter da agua lodosa que corre da extremidade dos geleiros, e tambem pelas encostas arredondadas das superficies sobre as quaes o gelo se moveu. Mais adiante far-se-á referencia vutra vez a estas superficies. A maior parte do trabalho effectuado pelos geleiros é, porém, o de transportar os materiaes soltos, quer na fórma de solo ou na de fragmentos rochosos que cobriram a superficie quando primeiro se formou o geleiro; quer na dos materiaes que depois cahiram sobre o gelo. Isto quer dizer que o poder transportante de um geleiro parece ser mais importante, geologicamente fallando, do que o seu poder erosivo.

Os materiaes carregados por gelciros são depositados na extrenidade inferior do gelo na forma de morenas terminaes ou lateraes, vu na de blocos isolados, ou os materiaes mais miudos são carregados ainda mais longe pelos cursos d'agua que sempre corre dos geleiros.

\section{Glaciação antiga.}

0 interesse principal dos geleiros reside no facto que durante a época que se conhece pelo nome de "época glacial " - pouco remota geologicamente fallando - geleiros de dimensões enormes cobriram 
grandes areas da Europa septentrional e da America do Norte e do Sul. Que houve uma tal época glacial é claramente indicado pelo estriamento das rechas in situ sobre as areas antigamente cobertas pelo gelo, pelos blocos erraticos carregados de uma parte de uma região glaciada para outra, pelo estriamento de muitos dos materiaes transportados, pelas formas caracteristicas das morenas deixadas por estes antigos geleiros, e pela evidencia biologica da passadi distribuição do gelo.

Na Suissa os geleiros alpinos actuaes são apenas os restos resumidos dos geleiros da época glacial. E' manifesta a prova que o gelo cnchia antigamente todos os valles d'aquelle paiz e que correu pelo valle do Rhodano desde S. Gothardo até Lyon na França pelo lado do

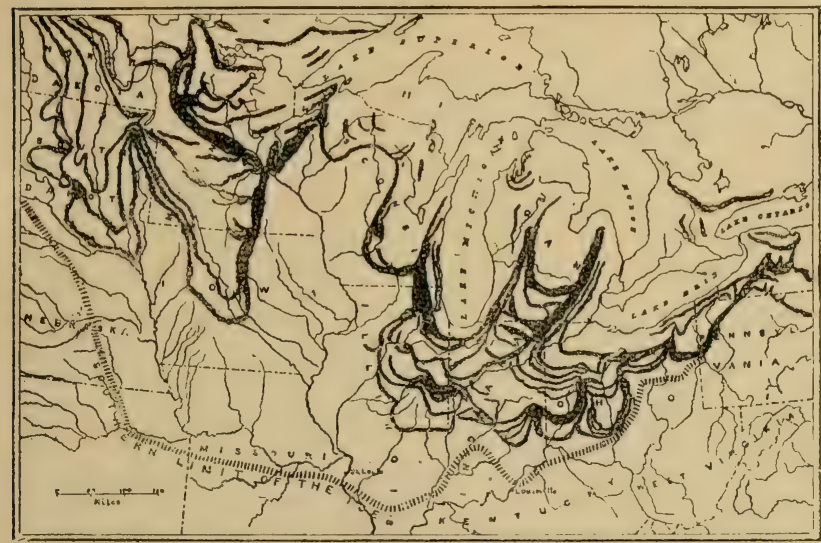

Fig. 30. - Mappa mostrando as principaes morenas da região dos Grandes Lagos na America do Norte.

sudoeste, e pelo lado do nordeste no valle do Rheno, att adiante de Neuchatel e Zurich.

Durante aquella época o gelo cobriu tambem uma grande area na Austria-Hungria occidental e houve pequenas areas cobertas de gelo nas altas montanhas da Hespanha e [de Portugal. Os maiores geleiros, 
porém, eram os da Europa septentrional que das montanhas de Noruega e Suecia correram[solore estes dois paizes e sobre toda a Laponia, Finlandia, Dinamarca e Hollanda, e sobre grande parte da Allemanha

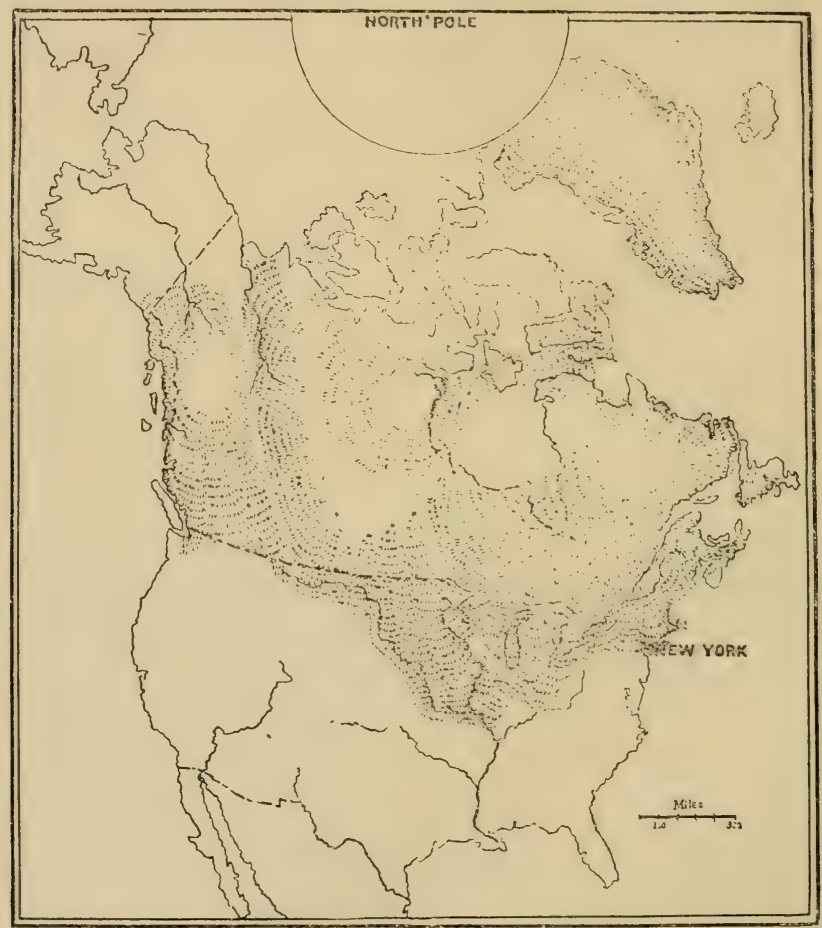

Fig. 31. - Mappa mostrando a distribuição no gelo sobre o continente norte-americano durante a epoca glacial e os tres centros principaes de onde o gelo correu.

septentrional, e a parte noroeste da Russia, além da area actualmente coberta pelo Mar do Norte e pelo Baltico. Durante o mesmo periodo esteve tambem debaixo do gelo tuda a Irlanda . Escossia e quasi toda a Inglaterra. Na America do Norte o gelo cobria toda a parte septen- 
tricnal do continente, isto é, toda a Canadá e a parte septentrional dos Estados Unidos, estendendo-se para o sul até as cidades de Nova York, Cincinnati, Louisville e S. Luiz.

Este lençol norte-americano de gelo tinha a espessura de mais de. mil e oitocentos metros. Isto se evidencia. pelo facto que picos e montanhas desta altura foram completamente sobrepujadas pelo gelo. Na costa do Pacifico o gelo cobria a regiào em redor da Sonda de Puget c de lá se estendeu para o norte até Alaska. E’ porém singular que este ultimo paiz estivesse apenas em parte coberto pelo gelo. Nas mon-. tanhas Sierra Nevada e nas Montanhas Rochosas os geleiros cobriram: grandes areas, mas foram locaes e correram destas mesmas montanhas em lugar de correrem das altas latitudes septentrionaes como. fez o corpo principal do lençol de gelo. De algumas partes da area glaciadla o gelo removeu quasi todo o solo deixando as rochas desnudadas, accumulando em outros lugares estes materiaes na forma de morenas terminaes e lateraes que pelas suas formas indicam as dos lobulos de gelo.

Deve ser especialmente notado que o gelo que cobriu as áreas glaciadas do hemispherio norte não correu, como as vezes se imagina, do polo norte, mas veio de certos centros elevados situados ao sul das regiúes polares. 0 gelo que cobriu a parte septentrional da America do Norte veio principalmente de tres centros, a saber: um em Labrador, um logo ao oeste da bahia de Hudson e do terceiro proximo ao Oceano Pacifico e ao sul do Alaska. Na Europa ns geleiros da Austra-Hungria, Suissa, IIespanha, Portugal e do Caucaso foram de origem local; os da Irlanda, Escossia e uma parte da Inglaterra foram locaes, mas o grande centro da distribuição era nas montanhas da Noruega e Suecia e o gelo desta região se unia com o das Ilhas. Britannicas e até corria atravez de uma parte da Inglaterra.

America do Sul. - Na America do Sul os geleiros cobriram antigamente a Terra do Fogo e quasi toda a Patagonia. Para o norte as provas da existencia destes geleiros se apresentam ao nivel do mar até Concepcion no Chili. Deste ponto para o sul toda a extremidade do continente foi coberta com gelo. Ao norte de Concepcion as evidencias 
da glaciação se elevam cada vez mais nos valles a medida que se approxima do Equador, faltando nas elevaejōes mais baixas. Nas altas regiões andinas existem provas da glaciação atravez do Chili, Bolivia, Perú, Equador e Colombia.

Acreditou se, ha tempos, que o Brasil tambem tinha sido glaciado, mas estudos posteriores tèm demonstrado que não ha provas concludentes da acção glacial em parte alguma deste paiz (1). Julģouse que os morros arredondados da vizinhança do Rio de Janeiro, e bem conhecidos ao longo da costa, tanto no norte como no sul, apresentavam superficies glaciadas : estas formas porém foram produzidas pela esfuliação. Os grandes blocos ou matacões nas praias de Paquetá foram considerados como blocos erraticos, mas são blocos de decomposição tal qual os que hoje se formam em muitas partes do Brasil. (Vède as figuras das pags. 29 e 31). Os grandes blocos no valle abaixo da Tijuca, conhecidos como as furnas do Agassiz, foram considerados como sendo blocos erraticos razidos de alguma outra parte do continente, mas são derivados do grande dique da encosta desta mesma montanha. As argillas vermelhas que por toda a parte formam o subsolo da Serra do Jar eram consideradas como till, ou argilla glacial; estas porém são apenas os productos da decomposição in situ das rochas crystallinas da região. Em parte alguma do Brasil tem-se encontrado uma rocha estriada in situ ou um bloco estriado, ou qualquer outra prova evidente e indubitavel da acião glacial durante o periodo pleistoceno.

As serras do Ceará, que foram consideradas por Agassiz como sujeitas á glaciação, são tambeı serras de granito que por toda a parte mostram a exfoliarão caracteristica dessas rochas. Is fraldas das serras de Aratánha e de Pacatuba não exibem tão pouco morena alguma.

(1) J. C. Branner. A supposta glaciøşũo do Blasil. Levista Brazileira. Vol. VI, pags. -49-55, 106-113. Rio de Janeiro, 1896. 


\section{Voltarả a época glacial ?}

Se a época glacial voltará ou não depende da sua causa. Se a causa for uma que seja recorrente deve-se esperar que a época tambem reapparecerá. Isto nos leva a indagar se a terra tem passado por mais de uma das taes épocas.

Os geologos que tèm dedicado attenção especial ao assumpto da glaciação encontram evidencias concludentes de diversas épocas durante os tempos pleistocenos. Além disto, tem-se encontrado provas satisfactorias da glaciação durante periodos geologicos muito mais remotos em diversas partes do mundo.

Em Canadá, na America do Norte, houve glaciação no archeano (1).

Na China (2) e na Australia (3) durante o cambriano.

Na India e na Africa do Sul durante o carbonifero (4).

Nos estados do sul do Brasil (5), Australia, e Tasmania no permiano.

Na India durante o periodo mesozoico; na Australia do Siıl, durante o terciario.

Por conseguinte pode-se dizer que é muito provavel que a época glacial haja de voltar.

\section{Causas das épocas glaciaes.}

Para explicar periodos glaciaes tem-se suggerido duas classes de causas, - geographicas e astronomicas. As causas geographicas suggeridas como capazes de produzir uma tal época são :

1. A mudança das correntes oceanicas.

2. A mudança dos ventos alizios.

(1) Journal of Geology, XVIII, 459-467, 1910.

(2) Carnegie Institution, Yearbooli, n. 3, pag. 118. Washington; 1904.

(3) Journal of Geology, XX, 193, 1912.

(4) Nature, LXXI, 55-57, 1904.

(5) J. B. Woodworth. Bulletin, Museum, Comparative, Zoology. 
$3 .^{\circ} \mathrm{A}$ elevação da terra para cima da linha do neve.

4. ${ }^{\circ}$ A mudança na distribuição da terra e da agua.

As causas astronomicas que se julgam capazes de produzir uma época glacial são :

5. 0 augmento da obliquidade da ecliptica.

6. ${ }^{\circ}$ effeito combinado da precessão dos equinoxios e da excentricidade da orbita da terra.

7. As mudanças na posição do eixo da terra.

8. 0 giro de uma crosta externa da terra sobre um centro fixo.

9. A variação do calor emittido pelo sol.

10 A variação da temperatura do espaço.

11 A diminuição do calor original da propria terra.

Estas theorias não serão aqui discutidas, principalmente porque só indirectamente podem ser consideradas como assumptos geologicos. E' evidente que épocas glaciaes são produzidas por um abaixamento da temperatura annual em um longo periodo de tempo, seja este abaixamento produzido por que modo fòr (1).

\section{Icebergs.}

Os icebergs são agentes geologicos de importancia. São formados de geleiros que desembocam no mar. 0 gelo sendo empurrado por debaixo da superficie da agua é levantado por esta em virtude da sua tendencia de boiar e assim grandes blocos se destacam e fluctuam para longe. Estes blocos se chamam icelerys, ou morros de gelo. Boiando, de $6 / 7$ a $7 / 8$ partes desses morros de gelo ficam submersos, e somente o resto está expostó acima d'agua

Este gelo contém muitas vezes pedras e outros detritos e á medida que o gelo viaja e derrete-se estas pedras cahem e espalham-se sobre o fundo do mar. Visto que os icebergs frequentemente viajam centenas

(1) Estas theorias acham-se discutidas nas seguintes obras: Discussions on climate and cosmology, by James Croll, Edinburgh, 1855. Island Life, by Alfred R. Wallace, pags. 121-16?, London, 1880. 
de kilometros antes de se derreterem completamente, são agentes importantes de transporte de rochas, areia e terra, até grandes distancias.

\section{Agentes chimicos.}

São pela maior parte invisiveis os processos e as operaçũes geologicas dos agentes chimicos, e sómente com o correr do tempo são apparentes os resultados do seu trabalho. Por exemplo, todas as aguas de fontes, poços ou correntes, por mais limpidas que sejam, contém materias mineraes em solução, e visto que estas materias tém sido dissolvidas das rochas da terra, é evidente que taes aguas estão carregando as rochas em soluęão, da mesma maneira que as carregam em suspensão as aguas turvas.

0 facto que todas as aguas de poços, fontes e correntes contém materia mineral em soluẹão póde ser demonstrado evaporando a secco um pouco dellas. Uma delgada pellicula do mineral dissolvido será deixada cobrindo a superficie interna do vaso $\mathrm{em}$ que se effectuar a evaporação.

Aguas tomadas de tres rios e de dezoito poços ao longo da Estrada de Ferro Baturité no estado do Ceará foram examinadas chimicamente, e verificou-se que essas aguas contem desde 118 , a 4915 grammas de materia mineral em soluẹão por litro, e que, termo medio, ellas contem 1058 grammas por litro (1).

Quando cahe chuva sobre a terra um pouco da agua se evapora e assim fica devolvida directamente á atmosphera, mas a sua grande massa corre sobre a superlicie, ou se infiltra no chão. Aquella que corre effectua trabalho mecanico cortando canaes e carregando material mecanico, ao passo que a parte que penetra no chão effectua trabalho chimico dissolvendo certos mineraes e os carregando em soluẹão. Estas aguas subterraneas podem emergir na fórma de fontes sobre a terra, ou podem surgir debaixo de lagos ou do mar como fontes submarinas. Em

J. A. Lorimer, carta particular, Oct. 2, 1911. J. C., B. 
qualquer dos casos as aguas subterraneas acham-se carregadas de material mineral tirado das rochas que atravessam. 0 poder da agua de tomar material mineral em solução é devido em grande parte ao facto que ella não é agua simples e pura, mas contém alguma substancia que augmenta o poder dissolvente, ou accelera a sua actividade chimica. Esta actividade accelerada póde ser devida :

1. - Ao acido carbonico.

II. - Ao acido nitrico.

III. - Ao acido humico ou outros acidos organicos.

IV. - Ao augmento de pressão.

V. - Ao augmento de temperatura.

VI. - A' diminuição de temperatura.

Bioxido de carbono $\left(\mathbf{C O}^{2}\right)$. - Existe na atmosphera uma certa porção de acido carbonico gazoso, ou bioxido de carbono, e a chuva quando cahe toma para si parte deste gaz. A decomposição de materia animal e vegetal dentro do solo ou sobre elle produz o bioxido de carbono, que é tambem produzido pela respiração dos animaes. Nas regiões vulcanicas o mesmo gaz é emittido pelas ventas ou fendas nas rochas. Seja qual for o seu modo de formação, este bioxido de carbono, sendo ajuntado á agua, augmenta enormemente o poder desta de dissolver certos mineraes. A quantidade de acido carbonico effectivamente carregada pela chuva tem sido determinada em muitos lugares, e na presupposięão que is resultados obtidos em outras localidades tropicaes sejam applicaveis as Brasil, temos que o acido carbonico total contido na chuva de um anno nes lugares abaixos menionados será dado na tabella que segue.

\section{Chuvas cahidas em diversos lugares no Brasil.}

Rio de Janeiro.

Millimetros
de $\mathrm{CO}_{2}$ na chura
3.21
8.26
11.80
4.93
5.15
5.40

Santos, São Paulo. . . . . . . . . 8.26

Alto da Serra do Cubatão, S. Paulo. . . . . 11.80

São Pàulo, (cidade) .......... 4.93

Uberaba, Minas . . . . . . . . . . 5.15

Morro Velho, Minas. . . . . . . . . 5.40 


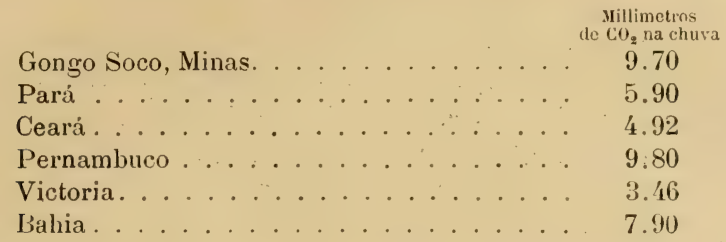

Deve-se lembrar que estas quantidades só vèm das chuvas, e não incluem o bioxido de carbono produzido de outras maneiras.

Acido nitrico (HNO). - As descargas electricas no ar produzem acido nitrico, e este acido é arrastado pela chuva, do ar para o chão. Visto serem mais frequentes nas regiões tropicaes do que nas temperadas os relampagos, deve-se esperar que nos tropicos haja maior quantidade produzida de acido nitrico. Esta theoria parece ser confirmada pelas observações. Em Caracas, Venezuela, o termo medio de acido nitrico na agua de chuva é de $\mathbf{2 . 2 3}$ milligrammas para um litro de agua. Em st. Denis, Ilha de Bourbon, (quasi na mesma latitude do Rio de Janeiro) o acido nitrico é de $\mathbf{2 . 6 7} \mathrm{mm}$. por litro. Na hypothese que a quantidade de acido nitrico num litro de agua da chuva cahida no Brasil seja egual á de Caracas, temos para os lugares abaixo mencionados as seguintes quantidades annuaes para o acido, nitrico, quel livre, quer em forma de ammoniaco.

\section{Acido nitrico calculado para a chuva cahida no Brasil.}

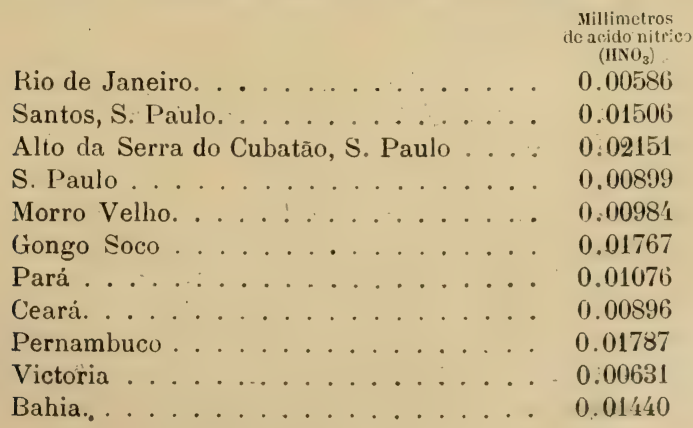


Posto que muitas rochas não sejam f́acilmente atacadas pelo acido nitrico, o tempo e os processos complexos da acção atmospherica eventualmente as sujeitam ao effeito de influencias que no principio pouco actuaram sobre ellas.

Acidos organicos. - Além do acido carbonico, diver'sos acidos humicos sĩo derivados da decomposição da materia organica no solo. Este é especialmente o caso nos paizes como o Brasil onde o calor e a humidade do ar fornecem as condições lavoraveis para o crescimento rapido da vegetação e para a sua decomposięão egualmente rapida. $\Lambda$ agua cahindo sobre a materia em decomposição é retida pela vegetação, carregando-se com acidos organicos, penetra finalmente no chão e effectua o seu trabalho destructivo sobre as rochas. A natureza pesada, esponjosa e aquosa, caracteristica de grande numero das plantas tropicaes, e especialmente da vegetaço rasteira, accelera materialmente a rapidez da decomposição e portanto a da produção de acidos organicos.

Augmento de pressão. - Visto que as aguas da chura penetram até grandes profundidades na terra, o seu peso produz uma pressão directamente proporcional, em alguns casos, á altura da columna aquosa. Tem-se demonstrado experimentalmente que o poder dissolvente da agua, fica augmentado pela pressão, e tem-se demonstrado em minas profundas, que a agua penetra centenas de metros na crosta da terra. Grande parte da materia mineral que a ag̣ua toma em soluçio sú se conserva dissolvida emquanto a agua se acha debaixo de pressão. Logo que a agua sóbe ficando por isso diminuida a pressĩo, deve haver deposiçĩo, porque o poder dissolvente da agua não é mais capaz de conservar os mineraes em solução.

Augmento de temperatura. - E' facto familiar que sendo aquecida a agra, fica grandemente angmentado o seu poder de dissolver certas substancias. 0 effeito do aquecimento de aguas contendo carbonatos em solução é bem illustrado pela deposição de carbonato de cal nas caldeiras e chaleiras quando se emprega aguas contendo muita cıl en! soluęão. 
E: de muita importancia geologica este facto porque a agua que - penetia profundamente na crosta da terra tem muitas vezes grandemente augmentada a sua temperatura, e por conseguinte o seu poder dissolvente. Mesmo um augmento pequeno de temperatura é capaz de produzir mudanças muito importantes nas rochas atravessadas pelas aguas.

Diminuição de temperatura. - Certos mineraes (os carbonatos) são mais facilmente dissolvidos em agua fria do que em quente. Portanto uma diminuiȩão de temperatura da agua favorece a solução de taes mineraes pelas aguas que os atravessám.

Material dissolvido nos cursos de agua. - $\Lambda$ quantidade de material mineral carregado em solução por um curso d'agua dado é determinado pela medição da descarga do curso e da quantidade de material mineral em solução em um litro da agua descarregada. São, porém, necessarias muitas observações em vista da variação no volume do curso é no caracter da agua. E’ tambem necessario filtrar todas as amostras afim de separar a materia em suspensão da materia em soluçào. Determina-se então a quantidade em solução evaporando a secco a agua limpida e pesando a materia que fica. Não se tem feito taes obser. vaçũes sobre muitos cursos, e entre os da America do Sul parece que sómente as aguas do Amazonas e do Rio da Prata tém sido assim examinadas (1).

Estas ohservacões mostram que o Rio da Prata carrega para o mar em solução cerca de noventa e um milhōes $(91,000,000)$ de toneladas cada anno, ao passo que o Amazonas carrega em solução cento e sessenta milhũes, oitocentas e trinta tres mil e seiscentas $(160,833,600)$ toncladas por anno (2). Estas quantias não incluem as materias carregadas como sedimentos mechanicos que devem ser ajuntadas para obter a somma total de material mineral carregado por estes dois rios.

(1) J.J. Kyle. - La composición quimica de las arjuas de la Republica Argentina. Anales de la Soc. Cientifica Argentina XLIII, 19-25. Buenos Aires, 1897.

(2) The denudition of the two Americas. By T. Mellard Reade. American Journal of Science. 1855, XXIX, pags.290-300. 
Os mineraes que carregam em solurão acham-se principalmente na forma de carbonato de cal, sulphato de magnesia, silica, ferro, alumina e sal commum.

Os rios variam muito entre si tanto no caracter como na quantilade da materia carregada em solucão. Até o mesmo rio carrega mais n'uma estação do anno do que em outras. A differença entre dois rins quaesquer na quantidade de materia mineral contida num litro de sua agua é devida a differenças na composição das rochas que formam a sua bacia hydrographica, e nas quantidades de acidos contidas nas suas aguas.

Is variações na agua de $\mathrm{um}$ unico rio são devidas ao facto que a maior parte da sua agua possa vir, em uma occasião, de uma parte da sua bacia hydrngraphica, e em outra occasiãu, de uma outra parte differente da mesma bacia, onde as rochas apresentem differencas entre si : ou porlem tambem ser devidas á concentração da agua pela evaporação. Frequentemente acontece que um rio carrega a maior quantidade de material mineral em solução no seu estado de vasante, devido ao facto que é então alimentado principalmente por fontes cujas aguas tem passado pelas rochas e são portanto mais carregadas com mineraes, ao passo que no estado de enchente as suas aguas vêm principalmente da superficie sem passar pelas rochas.

\section{Os effeitos da erosão chimica.}

As rochas sĩo compostas de mineraes. Destes mineraes alguns dissolvem-se com facilidade, outros mais difficilmente, porem com o tempo todos os mineraes tornam-se soluveis. 0 material dissolvido pelas aguas é todo mineral, e de especies diversas conforme as rochas. Tem-se demonstrado que a agua passando pelo solo e pelas rochas dissolve parte dos mineraes n'ellas contidos. Isto é, a erosão, ou denudação chimica. Em alguns casos a rocha inteira é carregada em solução chimica, a solução actuando unicamente na superficie. Em outros casos a agua penetra na rocha e por um processo de seleção carrega apenas algumas partes deixando atraz outras. Este ultimo processo de 
Soluẹão, decomposięão ou alteração das rochas produz um ou mais dos seguintes resultados :

I. - A formação de solos residuarios.

II. - A formação de kaolin e argillas ou de outros mineraes de decomposição.

III. - A concentração dos mineraes não dissolvidos.

Os solos residuarios são os que se formam directamente das rochas dizendo-se que estào in situ, isto é na posição na qual originaram-se. Nas áreas em que os solos são assim formados in situ elles variam mais ou menos conforme a natureza das rochas das quaes são derivados. Os arenitos por exemplo, produzem pela decomposição solos arenosos; os schistos ou rochas argillosas produzem solos argillosos, etc. A terra roxa do estado de S. Paulo se encontra onde certas qualidades de rochas eruptivas tem soffrido decomposição, ou onde, depois de decompostas, tèm sido levadas e depositadas em outros lugares.

0 kaolin é um mineral definido formado por um processo de decomposição e recomposição chimica do mineral feldspatho. As seguintes analyses mostram a composição theorica de diversos feldspathos e do kaolin. Por ellas fica evidente que no processo de formação do kaolin o feldspatho perde parte da sua silica e toda a potassa, soda ou cal, e que ha uma tomada de agua.

\section{Analyses mostrando as mudanças do feldspatho em kaolin.}

COMPOSICÃO THEORICA DO FELDSPATHO

\begin{tabular}{|c|c|c|c|c|c|c|c|c|}
\hline & & Orthoclase & & Ilbite & & Inorthite & & Kaolin \\
\hline & & 6 k. 7 & & 68.7 & & 13.2 & & \\
\hline & & 18.4 & & 19 & & 36.7 & & 39 \\
\hline sa. & & 16.9 & Soda & 11.8 & Cal. . & 20.1 & Agua . & 14.0 \\
\hline
\end{tabular}

Is seguintes analyses chimicas de gneiss fresco e alterado, ou decomposto, mostram bem este processo na natureza ( 1 ).

(1) G, P. Merrill. A treatise on rocks, rock-ueathering chod soils, p. 215. NewYork, 1897. 


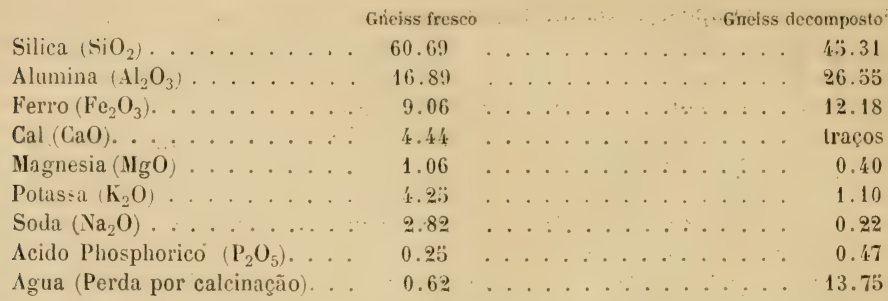

O mineral feldspatho é o ingrediente principal dos granitos e gneisses no Brasil e é frequente encontrar-se nestas rochas lugares (segregaęões) onde só existe foldspatho. Quando estas rochas soffrem decomposiçio forma-se kaolin da maior pureza ao longo destas linhas de segregaçio. A profundidade até onde se estende a decomposição das rochas varia muito; em alguns lugares pouco ou nenhuma ha, e as rochas duras se apresentam na superficie ; em outros lugares a decomposiçĩo tom penetrado até grandes profundidades. Em muitos pontos da cidade do Rio de Janeiro e na sua visinhanȩa, como tambem nos estados do Rio de Janeiro, S. Paulo, Minas, Espirito Santo e outros, as rochas graniticas acham-se decompostas até á profundidade de trinta metros ou mais, e conhece-se muitos casos em que a decomposição estonde-se até além de cem metros (1). Convém dirigrir aqui attençào especial a este assumpto da profundidade da decomposięão e tambem ás irregularidades que ella apresenta, afim de indicar as condições necessarias para poder esperar encuntrar jazidas de kaolin. Pelo que já ficou dito é evidente que só devem ser procuradas em regiōes de rochas feldspathicas decompostas. A profundidade em que hão-de ser encontradas dependerá da profundidade da decomposiçio das rochas, e a fórma dos depositos será determinada pelas fórmas das massas originaes de feldspatho.

Formam-se ás vezes depositos de kanlin pelo transporte e redepo-

(1) J. C. Bramer. Decomposition of roclis in Braxil. Bulletin of the Geological Society of Ameriea, 1896. Vol. VII, p. 266.

O. A. Derby. DeEmposition of rockis in Brazil. Journal of Geology 1896. Vol. IV. pags. $5: 9-510$. 
sição, em fórma de sedimentos, do material destas jazidas originaes. A maior parte das argillas ordinarias, argillas dos oleiros, e dos fabricantes de tijolos é composta principalmente de kaolin misturado com alguma silica, ferro e varias outras impurezas.

A concentraşão é um outro resultado da retirada chimica de alguns constituintes das rochas. Se de uma massa dada de rocha forem retirados os mineraes mais soluveis, segue-se que os menos soluveis tornamse mais abundantes na massa que resta. Este processo de solução e concentração tem tido o effeito de enriquecer e tornar mais valiosos muitos depositos mineraes que de outro modo seriam inaproveitaveis. Alguns dos depositos de manganez do Brasil tem sido enriquecidos pela perda por lixiviarão dos elementos associados com o manganez deixando o minerio em fórma mais concentrada e por conseguinte mais valiosa. Os alluvióes auriferos são ricos em proporȩão com a remoȩăo da rocha sem valor na qual o ouro estava originalmente de permeio, porque de tal remoção resulta a concentração das particulas de ouro. Convém porém notar que neste caso entra tambem a concentração mechanica depois da desagregarão, por processos chimicos, do minerio original. Os depositos diamantileros do Brasil são enriquecidos pelos mesmos processos de alteração chimica e concentração mechanica dos diamantes.

\section{Resultados mechanicos da solução.}

Alem dos resultados chimicos ha outros que são pela maior parte mechanicos.

1. Solução chimica ja foi tratada á pagina 36 .

2. Acanaladuras tambem á pag. כ̌ı .

3. ${ }^{\circ}$ Estructura cavernosa.

4. ${ }^{\circ}$ Engrandecimento dos valles. 


\section{A origem das grutas ou cavernas.}

Cavernas ou grutas são de origens diversas, mas é conveniente tratar do assumpto de uma só vez.

Is cavernas ou grutas podem originar-se de quatro maneiras :

I: - Pela solução subterranea de rochas.

II. - Por um curso de lava sahindo debaixo de uma crosta de lava esfriada.

III. - Pela acção mechanica das ondas nas costas altas.

IV. - Pela acção da atmosphera sobre escarpadas.

I. Solução subterranea das rochas. - Um dos effeitos locaes da erosão chimica é a formação de certas cavernas e sumidouros. As rochas calcareas são facilmente dissolvidas $\mathrm{cm}$ agua contendo acido carbonico. Nas regiōes calcareas a agua frequentemente

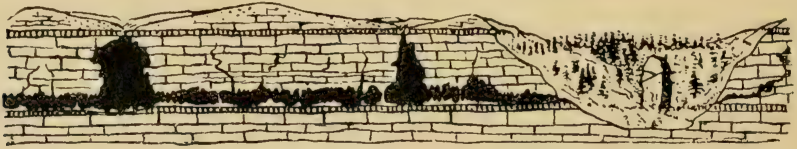

Fig: 32. - - Seceño atravez de uma região de rochas calcareas mostrando eavernas. Do lado direito existe um arco natural deixado pelo desgas. tamento de parte das rochas de uma caverna. (Shaler.)

penetra nas rochas pelas juntas e planos de estratificaçio e, dissolvendo uma parte da rocha, alarga estas aberturas até formar cavernas ou grutas de diversas dimensões. As taes cavernas são frequentemente de muitos kilometros de comprimento e tem cursos de aqua correndo for ellas. Ima das cavernas mais notaveis do mundo é o Ilammoth Cave no estado de Kientucky na America do Norte, que tem cerca de sessenta e cinco kilometros de galerias em que uma pessoa pode andar, além de muitos kilometros de galerias menores. Em alguns pontos esta caverna apresenta a altura de sessenta metros. Cavernas semelhantes, porém menores, se apresentam em diversos dos estados visinhos, sendo todas em regiões de rochas calcareas.

Nas cavernas das rochas calcareas o tecto frequentemente desaba, 
ou fica penetrado por aberturas que ligam a caverna com a superficie do solo. Por estas aberturas a agua entra nas cavernas e muitas vezes acontece que a drenagem de uma regiào calcarea é feita principalmente por cursos subterraneos. Acontece ás vezes que estes sumidouros ficam cheios de terra e assim se formam pequenas lagoas nas suas bacias. Is farnosas cavrrnas da Lagoa Santa, da Lapa Nova de Iaquiné e

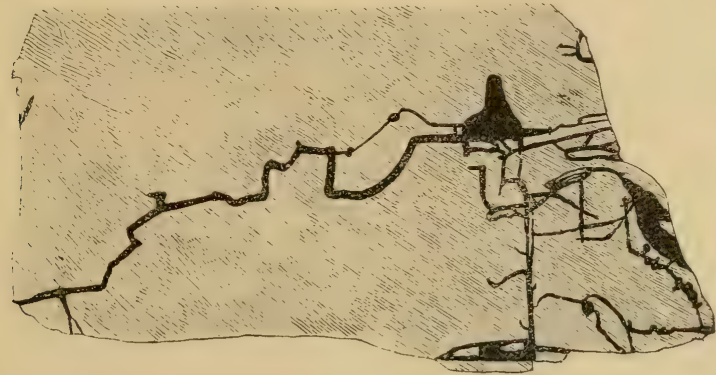

Fig. 33. - Plano das cavernas da Lapa Vermelha, Lagoa Santa, estado de Minas Geraes. (Reinhardt.)

Lapa Vermelha e de S. José d'El-Rei no estado de Minas Geraes acham-se em rocha calcarea, como tambem as cavernas salitrosas de Minas septentrional (1).

Yo sul do estado de S. Paulo existem cavernas notaveis na bacia do riu de Ribeira de Iguape, esperialmente na do rio Bethary ao norte de rio Iporanga. É uma região montanhosa e muito elevada que laz parte da grande Serra do Mar. Is rochas da região são calcareas paleozoicas, crystallinas, lobradas e falhadas, e muitos dos cursus d'agua sào subterraneos. Entre umas quaranta e tantas cavernas conhecillas estão as do Monjolinho que é serca, e de Santo Antonio da qual sahe o ribeirão do Sumidouro (2).

(1) Sobre as cavernas de Minas Geraes, véde Nelson de Sena no Annuario de Minas, II, 395-399, $190 \%$.

2) Ricardo Krone. As grutas calcareas do Iporanga. Reoista do . Museu Paulista, III, 477-500. S. Paulo, 1898; e Archioos do Aluseu Nacional, XV, Rio de Janeiro, 1909. 
0 maior numero destas grutas de Iporanga tem agua, especialmente durante o tempo das chuvas. Essas cavernas são quasi todas forradas de estalacritos e estalagmitos de uma belleza extraordinaria. Talves não haja no mundo cavernas mais bonitas de que as desta região do Brasil.

O famuso sanctuario do Bom Jesus da Lapa na margem direitil do rio S. Francisco no estado da Bahia acha-se numa caverna, num barranco de cerca de cincoenta merros de altura, aberta no calcareo siluriano superior daquella região (Vède figura 129, p. 297).

A " caverna do Abreı " fira no valle do rio Salitre numa regiào de

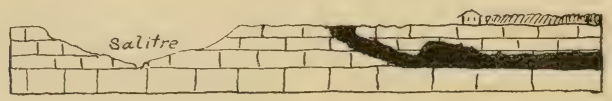

Fig. 34. - Caverna de Abreu, Estado da Bahia. (Crandall.)

ruchas calcareas no estado da Bahia, na fazenda Baixa Grande, uns cem kilometros a oeste de Villat Nova. Tem um comprimento de duze kilometrus, com salas de diversas alturas e larguras, e as paredes sãn cobertas de estalactitos de formas esquisitas. A entrada é pela planicie do valle do rio Salitre, e o fundo da raverna fica uns trinta metros abaixo do châo e mais u menos no nivel do rio Salitre. Logo na entrada é « o convento », com uma sala de trinta metros de diametro e altura de quinze metros. Ha um curso de agua ao longo de quasi todo o comprimento da raverna durante as rhuvas, que desapparece nos tempos seccos.

As cavernas que dizem existir em Jacobina no estado da Bahia não são em Jacobina, mas sim numa fazenda chamada "Catinga do Moura „ uns cincoenta kilometros a oeste de Jacobina, e mesmo n" valle do rio Salitre, numa região de rochas calcareas.

No Ceará ha uma gruta chamada de Ubajárṛa na povoação de Jacaré, proxima a S. Benedicto, no serrote ao pé da Serra Grande.

Dizem que tem u comprimento de tres kilometros explorado, que tem um curso dir agua, e que fica numa rocha calcarea. ") 
tecto e as paredes são encrustadas de estalactitos de formas caprichosas (1).

Existem notaveis exemplares de cavernas formadas pelo processo de alteração atmospherica nos granitos da Bahia perto da estracla de ferro central na estação Tanquinho, e nos rochedos graniticos da vizinhança de Quixadá no Cearí. Yestes casos, e nos outros deste genero, a rocha é sempre homogenea, e por conseguinte taes cavernas se acham as vezes nas rochus arenitiras. Exemplares se encontram nas camadas terciareas ao sul de Natal no estado do Rio Grande lo Norte no morro dos Morcegos.

Nestes casos as mudanęas de temperatura e a açăo chimica atacam as rochas em certos pontos mais susceptiveis ; o mais resiste it tal acção. Geralmente a rocha decomposta, areia, etc., são levalas pelo vento (2).

II. Cavernas em lava com crosta esfriada. - Nas regiões vulcanicas quando acontece que a lava enche um valle estreito e endurece na superficie, a parte inferior é sujeita a correr por debaixu da crosta dura deixando uma caverna. Taes cavernas são communs nos Andes mas não são conhecidas no Brasil.

III. Pela acção mechanica das ondas. - Nas costas rochosas do mar a açiin destructiva das ondas ás vezes ataca as manchas mais fracas das rochas, excavando assim cavernas que em regra geral apresentam pouca profundidade. (Vède figs. 22 e 23).

Por muitos kilometros ao longo da costa norte da ilha Trindade no norte de America do Sul as ondes do oreano cortarão nas pirarras ao pé da serra uma linha de cavernas no nivel d'agua. Na custa de Cabo Frio, Brasil, existem cavernas formadas desta mesma maneira.

IV. Pela acção chimica da atmosphera. - Em certos lugares, espocialmente em regiòss aridas a semi-arilas ravernas se formam em certas camadas horizontaes ds sedimentus pela açio atmospherica em combinação com o vento.

(1) Pompeo de Souza Brasil. Ensaio Estatistico, pag. 55.

(2) Pompeo de Souza. Cenráa no começo do Sec. XX, pag. 93. 
A differença da resistencia ao tempo faz, ás vezes, com que se formem cavernas razas nos rochedos marinhos, e isto tem lugar quando as rochas variam notavelmente na sua resistencia á acção đo tempo.

Sumidouros. - Sumidouros formam-se, especialmente em regiões das rochas calcareas, pela solução subterranea e remoção da materia pelas aguas subterraneas. A's vezes os sumidouros são formados pelo desmoronamento dos tectos das cavernas, mas pela maior parte são as partes exteriores dos buracos ou tocas compridas pelas quaes as aguas escapam. Quando alargadas, as partes exteriores destes cursos apresentam uma forma mais ou menos semelhante á de um funil pelo qual a agua pode entrar. Iuitas rezes estes sumidouros tornam-se lagos pequenos.

Drenagem subterranea. - Em regiões de rochas calcareas muitas vezes os cursos de ag̨ua são quasi todos subterraneos.

Arcos naturaes. - Arcos naturaes são formas singulares que ás vezes se acham em regiões de rochas calcareas.

\section{Deposição chimica.}

Já se tem mencionado que a solução é devida a uma ou mais tas causas seguintes ; acidos na agua, pressão, temperatura alta, temperatura baixa, reacries chimicas e solubilidade debaixo das condicoes mdinarias dos mineraes que formam as rochas. Segue-se dahi que se forem removidas essas causas o material mineral não póde mais continuar em soluẹa e deve ser depositado. A deposicão chimica portinto tem logar :

1. Quando escapa o solvente. - Se o poder dissulvente de 
uma certa agua fór devido principalmente á presença nella de bioxido de carbono, vai sem dizer que no caso de se remover o bioxido de carbono, ficará correspondentemente reduzido o poder dissolvente da agua. Acontece frequentemente que aguas subterraneas e das fontes contem muito carbonato de cal em soluẹão. Quando estas aguas são burrifadas, onde, por exemplo, cahem sobre obstaculos ou em saltos, o bioxido de carbono escapa na atmosphera e, sendo assim diminuido o poder dissolvente da agua, uma parte da cal se deposita. Isto causa a formação de depositos de travertino nas cascatas.

Nas regiões calcareas onde existem cavernas acontece l'requentemente que aguas carbonatadas, carregadas com cal, enfiltrem-se pelas rochas e pinguem dos tectos das cavernas. Quando essa agua fica exposta em pequenas gottas nas cavernas abertas, uma parte do seu bioxido de carbono escapa e dahi resulta a deposição de uma parte do carbonato dissolvido sobre o tecto da caverna. No correr do tempo este deposito no tecto cresce para baixo, podendo afinal alcançar o fundo da caverna. Chama-se estalactito um tal deposito. Quando essas aguas carbonatadas cahem sobre o chão, o borrifamento da agua causa uma outra deposição da rocha calcarea, e sobre o chão da caverna onde cahe a agua se formam depositos semelhantes. Estes se chamam stalagmitos. Quando os estalactitos crescendo para baixo encontramse com os stalagmitos crescendo para cima, elles se unem para formar pilares ou columnas de pedra calcarea.

Quando as aguas carbonatadas correm pelas paredes das cavernas os depositos ás vezes encrostam estas paredes formando grandes lençōes de travertino que se chamam, as vezes, " cascatas de rocha. " A Lapa Nova de Maquiné no estado de Minas foi descripta por Lund como sendo forrada por depositos bellamente translucidos de estalactitos (1). A mesma acontece em quasi todas as cavernas notadas a paginas 113 e 114.

Origem de travertino. - E de notar que, em fontes naturaes em regiões de rochas calcareas, muitas vezes existem em roda do lugar

(1) Pedro W. Lund. Cavernas existentes do calcareo do interior do Brasil, Annaes da Escola de Minas. N. 3, pags. 61-91. Rio de Janeiro, 1884. 
onde a agua escapar, depositos dre um mineral estranquicardo e molle. Com a tempon o mineral condurece e a monte vai crescendo. a deposito

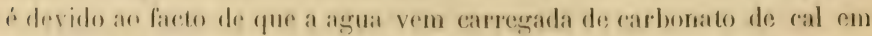
solucio. Loge que a agua sahe do chio e encontra a atunosphera, o liovido dre carbono escapa, a agua nio pode mais conter o mineral em

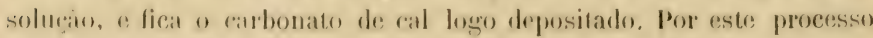
essas acromularous van crescendo, trazendo o material do interior para superlicir da rerra. Este á o tronerlino ou tufo dos antigos. $\Lambda$ 's vezes setes depositos attingem tamambo quasi incrivel. Um caso motavel ${ }^{\circ} 0$ de Bagni e Tivoli na vizinhanea da cidade de Roma na Italia anomes us depositos de travertiono adquirem uma espessura e extension que Ihes dio grame importameia na architerema de Roma e das outras

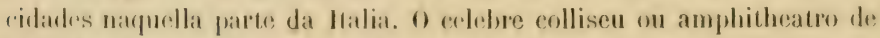
Vespasiano de liomat, a a cidade de: Roma mesma, foram edificades de predras vindas das pedreiras dos depositos travertinos de Bagni. Aquellas pedreiras anda sion aproveitadas para edificios, pontes, e outras obras de alvenaria.

11. Quando abaixa a temperatura. - As aguas quentes (sio geralmente mais chimiramente arlivas, do que as frias. Quando a agnat rntra no solo a sua temperatura i geralmente baixa, mas á medida que desce na terra encontra as rochas tepidas ou quentes do interior dis terra e recebe 110 angmento d: temperatura. O poder dissolvente dit acua augmenta an mesmo tempor, e esta agua profunda fica conseyuentemente capaz de dissolver muita materia mincral das rochas pulas quares passia. No correr do tempo, porém, esta mesma agua approxima-se outra ve\% da superficie, e abaisando-se a sua temperatura, os mineraes so redeposilados devido a diminuiço do poder dissolvente da aguat resfriada. E" em parte em virtude deste abaixamento da temperatura que se formam, geralmente, montes de materia mineral rm redor das ventas de fontes quentes. Quando forr alealina a agua aquerida, clla dissolve a silica das rorbas e os depositos formatos onde a agua escapa são compostos principalmente de silica.

III. Quando a temperatura eleva-se. - Quando as aguas 
contendo carbonato de cal sio aquecidas este mineral i depositude logen que o hioxido de eartiono tem moma npportunidade de eseapartese.

Nas regioes onde as aguas usadis para lins domesticos contem muita cal cm soluega enentra-se a cal precipitada nas paredes interiores das chaleiras a vasos enonstantemente usados parta anpueere agua.

As caldeiras que usam aguas tates, siut timbem frequentemente lato concostadas com os depositos calcareos de maneira a seriamente. allectar a efficiencia d'elles.

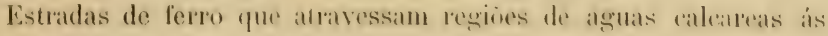
razes tem muita diffieuldade em supprit as maldeiras das lexmontivas for causa das inserustacies drpusiladas pelas aguas dopuis de angeciclas.

Na regite de rochas caleareats do interior do estade da Bahial, ean muitos lugares as aguas dos rios san solmeearregadas de ral por tal mancina, que quande expenstas ao sol e anpuecidas, "b hoxido de carbonu escapar a a ral liea deposilada no fundo. Yos leitos dos rius estes depositos formam represils ou arodes naturaes, " muitas vezes romem rompletamente os canaes dos rios. Naquella regitu als aguas dats chuvas estio sempre atacando as rochts calcareas. e depositamdo a cal $\mathrm{mm}$ pence mais adiante. Devido it dimimuegon das chuvas datqualla regico nos ultimos periodos geologions, os rios nio prodem nem rortar us seus canaes nem mesmo conserval-os abertos. Fi num processo de

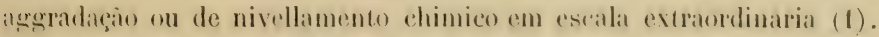

IV. Quando a pressão diminue. $-\Lambda$ igna que desce profundamente na terra por uma cavidade que esta sempre cheia fiea sujeita, á medida que desee, a uma pression que augmenta constantementr. Como já foi mencionado, esta pressio augmenta grandemente at actividade chimica da agua. Quando, em temper, a agua volta em direcrio á superficie, o allivio da pressio hydrostatica diminue o forder dissolvente da agua e os mineraes am soluggio sio redepositados.

\section{Quando se effectuam reacções chimicas. - $A$ depu-}

(1) J. C. Branner. Aggraded limestune plains of the interior of Buthir. Bulletin Geologienl Societ!y America, XXII, 187, 206, 1911. 


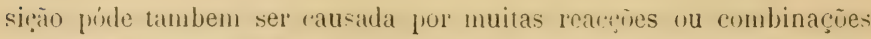
chimicas diversas. E' facto bem conhecido que certas soluęies, quand» misturadas, reagem entre si de modo a causar uma precipitaçio. Quando a agua que contem ferro dissolvidu do solo ou das rochas fir exposta por algum tempo ao ar, o ferro combina-se com o uxygeno do ar formando oxido de ferro que, sendo um mineral pesado, afunda-so na agua. Esta é uma especie de reacệu chimica produzida pelo oxyengen, e ainda ha muitas outras.

Calsos notaveis no Brasil sito os recifes de pedra que seguem a costa do norte sobre uma distancia de 1.600 kilometros. Aquelles recifes são praias consolidadas. As areias estão misturadas com fragmentos de conchas, coraes, e outros restos calcareos..

Os rios naquellas partes da costit muitas vezes sảo tapados pelas vagas do oceano regeitando as areits. Is aguas dos rios e das lagvits formadas por elles atraz destes diques nituraes contêm muito acido organico formado pela decomposięio de plantas e outro material orgatnico. Escapando na direcrio do mar por meio das areias essas aguas atacam c dissolvem os fragmentos de conchas e pedra calcarea, e depois, sendo já carregadas de cal, encontrando as aguas densas e salgadas do mar depositam a cal nos intervallos entre os grãos dr areia, assim formando rocha dura (1).

VI. Quando as soluções ficam por muito tempo em repouso. - Em alguns casos é evidente que os mineraes tèm sidu drpositados de soluęũes que têm ficado por muito tempo em repouso. Encontram-se frequentemente nas cavidades das rochas, taes como geodes, forradas com crostas de quartzo, cilcedoniit e agata. Parecr provitvel que as soluçies que depositaram estas crostas ficaram por muito tempo sem serem perturbadas.

VII. Concentração de soluções por evaporação. - A eviporaçìo é um phenomeno limitado quasi exclusivamente ao exterior di superficie da terra, e é especialmente activa nas regiōes aridas. Quando

(1) J. C. Branner. The stone reef's of the coast of Brasil. Bulletin of the Geological Society of America, vol. XVI, 1-1:, 1905. 
a agua que contem em soluçio materia mineral for exposta a ar secco, ella se evapora: se a evaporação fir continuada por bastante tempo, a solução ficará tão concentrada que não póde mais reter a substancia dissolvida e esta se deposita, usualmente em forma de crystaes. 0 processo é bem illustrado com a agua do mar que contem muito sal em solução.

Afim de obter o sal na sua forma crystalisitdit bastit expor a agua do mar ao ar secco até ficar concentrada pela evaporação até o ponto em que o sal não fỏr mais soluvel, quando elle se depositará em forma de crystaes. Deste modo se forman certos depositos de valor economico; taes como os depositos de borax, e as camadas de nitro do Chili. Do mesmo modo se originaram tambem as grandes camadas de sal e muito do gesso do mundo.

\section{A acção chimica nos lagos salgados.}

0s lagos salgados podem ter a sua origem : $1^{\circ}$ - pelo desmembramentu de um braço do mar : '2' - pela concentraçào da agua doce ; $3^{\circ}$ - por alguma combinação dos dous processos.

I. Desmembramento de um braço do mar. - 0 sal existente nas aguas dos nossos mares actuaes deve ter sido contido originalmente nas rochas da terra. Destas rochas tem sido lixiviado pelis aguas e tem sido concentrado nos mares. A concentração póde ser levada ainda mais longe pela eraporação artificial da agua marinha; de facto, como já mencionado, se a evaporação proseguir o sal se separi em forma crystalina. Nào é raro encontrar nas ruchas das costas do Brasil depressões cheias de agua salgada carregada em borrifos pelo vento além da linha d'agua. Durante a estação secca a agua nestes porgos se evapora deixando as bacias forradas com crystaes de sal commum. 
A evaporarajo é necessariamente mais rapida nas regiões aridas. Por este motivo as aguas dos mares em taes regives que se ligam com o weano itravés de canaes estreitos que impelem a circulaşão livre, sio muito mais densas, isto é, contèm miior quantidade de mineraes dissolvidos, do que a do alto mar. As aguas do Mar Vermelho, por exemplo, saio mais salgadas do que as do Oceans Indico. A agua do Mediterranco está constantemente diluida pela agua doce de muitos rios que nelle desaguam, mas mesmo assim, por se achar n'um clima quente e um tanto arido e por ser ligado com o Atlantico pelo estreito delgado de Gibraltar, as aguas deste mar são muito mais salgadas do que as do Oceano Atlantico. Mesmo no alto mar existem em certas areas aguas mais salgadas do que em outras. Uma destas areas de alta densidide acha-se junta da costa do Brasil desde um ponto logo ao sul da foz do Amazones até um outro ponto no. sul do estado da Bahia. I maior densidade da agua au longo desta costa é devida ao facto da corrente oceanica que lavit a regiaio nos arredores do Cabo de Sĩo Roque vir da costa da Africa atravessando toda a largura do Ocentu Atlantico por debaixo da zona equatorial onde a evaporação ¿ muito grande. 0 resultado desta longa viagem debaixo do equador é que com o tempo gasto em alcanear a costa brasileira as aguas da corrente ficam muito concentradas.

IIa, portanto, duas razies fortes para a existencia da industria do fabricu de sal na costa do estado do Rio Grande do Norte : a primeira é que a agua ahi é mais densa do que em outras secȩões da costa do Brasil, é a segunda é que o clima desta parte do Brasil é muito secco durante uma parte do anno.

Pelas consideraroues acima licat evidente que no caso de ficar separado do oceano qualquer corpo menor de agua salgada, especialmente se fòr n’um clima arido, at evaporação rapida causará uma concentrarào igualmente rapida da agua, e por ultimo a crystalisação e deposição da materia dissolvida. Se n'um tal brargo de mar desaguam cursos de agua doce, estes tenderão a diluir a agua salgada e retardar a deposição do sal.

Se o inlluxu da agua doce fór mais rapido do que a evaporaçio, o laşo salgado ficará no correr do tempo convertido em um de agua doce. 
II. Concentração da agua doce. - Já se tem mencionado yue toda a agua das fontes e cursos contèm mais ou menos sal en solurão; encontram-se tambem commummente $\mathrm{cm}$ taes aguas diversos sutros sies, especialmente sulphato de magnesia e carbonato de cal. Se taes cursos de agua formam lagos e estes lagos soffrem evaporação, seguc-se que no correr do tempo, a agua ficará mais fortemente carregitda com estes mineraes, e teremos deste modo lagos salgados formados directamente de agua doce. Se, porém, a bacia do lago tem um escoadouro a agua retem o seu caracter de doce porque não fica bastante tempo na bacia para se concentrar a ponto de se tornar salina.

Encontram-sc na Terra Santa hons exemplos das duas especies de lagos: o Mar de Gallileo é um lago de agua doce com a sua bacia transbordando através do rio Jordão; estas mesmas aguas entram no Iar Morto, lá se evaporam e formam uma agua salgada muito concentrada.

Ya Imerica do Sul a influencia das condições climatologicas subre os cursos d'agua é bem illustrada nos tributarios do Rio Paraguay. Os cursos que entram naquelle rio provenientes das regiões chuvosas do Brasil são todos de agua doce, ao passo que os que alravessam as regiñes aridas da Argentina septentrional são todos mais ou menos salobres:

Lm dos exemplos mais notaveis da influencia de evaporação sobre a agua doce é o do Grande Lago Salgado de Utah na America do Norte. Antigamente era um lago d'agua doce, enormemente maior do que actualmente, e desaguava por intermedio do Rio Snake no Rio Columbia e no Oceano Pacifico. Agora está reduzido pelas evaporações a uma vigesima quinta parte do seu tamanho original. A sua area primitiva era de cento e vinte e cinco mil kilometros quadrados, ao passo que actualmente è de cinco mil apenas, e a sua ağua, que era doce, é agora muito mais salgada do que a do oceano.

A origem de depositos de sal. - Visto que a agua do mar afim de depositar o sal tem de perder por evaporação mais do que oitenta por cento de seu volume, e que o sal se dissolve facilmente na agua do mar, é evidente que os depositos de sal não podem se formar no alto 
mar. Sú se podem formar onde a ağua salgada fór isolada do vceino e evaporada ate uma densidade muito maior do que a da agua do mar. Existem em muitas partes do mundo depositos de sal nativo de notavel espessurit. No estado de Nova-York na America do Norte ha camadas de sal de vinte até noventa e sete metros de espessura; na Louisiana as camadas de sal apresentam espessura de quinhentos e sessenta e nove metros: na Hespanha perto de Barcelona são de noventa e um e meio até cento e vinte e duis metros em espessura e em Stassfurt nit Allemanha apresentam a enorme espessura do mil c quatrocentos e sessenta e dois metros. Estas enormes camadis de sal não podiam ser formadas pela evaporação de uma unica bacia cheia de agua ordinaria do mar. Para produzir uma camada de sal da espessura de um metro seria necessaria a espessura de oitocentos e vinte e dois metros e um decimo $\left(822.1^{\mathrm{m}}\right)$ de agua do mar, As camadas de Barcelona exigirian uma espessura de agua de duzentos e quarenta e seis mil seiscentos trinta metros $(\mathbf{2 4 6 . 6 3 0}$ m) que í muito maior que a profundidade do oceano mais fundo. (A parte mais funda do Oceano Pacifico tem oiti mil quinhentos e dezoito metros $\left., 8,518^{\mathrm{m}}\right)$.

0 processo pelo qual se formaram estas camadas grossas devia ter sido continuo, mais ou menos semelhante ao que se observa, pelo menos em parte, na Lagoa Rodrigo de Freitas perto do Rio de Janeiro. Nas condiẹ̃es ordinarias esta lagoa não se acha ligada ao oceano, porém por occasião de marés muito grandes a agua do mar transbordit a restinga de areia que a separa do oceano, entra na lagoa e suppre : agua perdida pela evaporação. Se este laço fosse muito grande e se o clima fosse arido, a agua ficaria logo concentrada no ponto de deposição do sal, e o processo continuaria empuanto a agua continuasse a entrar e evaporar-se. Visto que o sal sú se fórma naturalmente em regiōes aridas, a existencia de camadas grossas desta substancia em diversas partes do mundo geralmente indica a aridez antiga das regices em que se encontram as camadas de sal.

Existem tambem outros depositus de sal que parecem provir de aguas quentes e salgadas subindo de grande profundidade e deixando crystallizar o mineral ao passo que se approximam á superficie (t) solo. 
Estas formações, uma especie de concreçà em escala grande, occorrem no estado de Louisiana na America do Norte (1).

Fabricam o sal em muitos lugares aridus no interior da Bahia onde a agua, passando por cima das rochas sedimentarias contendo um pouco de sal, forma lagoas pequenas. Evaporada a agua naquella região aridi, fica o sal concentrado e depositado na terra no fundo das lagoas. Esta terra salgada é apanhada e lixiviada com agua, e depois de evaporada, deposita o sal. Estas terras salgadlas abundam na bacia do rio Salitre e por tuda a zona arida ao longo do rio São Francisco, onde o fabrico do sal já foi uma industria importante.

Parece porem que o sal só se acha na vizinhanȩa das rochias calcareas.

Lagos alcalinos. - Nào é súmente o sal commum que as aguas subterraneas tiram por lixiviaçio das rochas, mas tambem qualquer outro mineral que se dissolve com facilidade. As aguas da drenagem de uma região sedimentaria geralmente produzem sal commum quando são concentradas, mas as que drenam regives de rocha eruptivas nas quaes predominam os carbonatos alcalinos tornam-se alcalinas quando evaporadas.

Lagos de borax. - Quando as aguas correm ou escoam pelas rochas que contèm mineraes de borax (biratos) produzem, pela evaporação, aguas fortemente boratadas e mineraes le borax. 0 borax do commercio era antigamente retirado dos sedimentos cncontrados no fundo de certos lagos desseccarlos das regives aridas. Actualmente é Iroduzido pela perfuração de poẹos nos valles de certas regicies arilis e pela evaporação da agua obtida.

Laygos amargos se forman dos lagos salgados por uma concentraçio mais a diantada, depois da precipitaçào do sal commum. Contém diversos mineraes mais soluveis do que o sal commum, taes como " sal de Glauber (sulphato de soda) e sal de Epsom (sulphato de magne-

(1) G. D. Harris. Immense salt concretions. Popular Science Monthly, February, 1913, pags. 187-191. 
sia). Na excarapás do canal de Suez fordm cortados dis ssos lazos amargos. O Mar Morto da Terra Santa is um exemplo de amargo.

0 ponts principal de interesse relativo a todos os lagos de aguas mineraes é que o scru cunteúdu mineral foi derivado das rochas subre e através das quaes as suas aguas tinham corrido, e que a natureza dest: conteúdo mineral varia conforme a variação das rochas.

A profundidade a que penetra a agua. - A profundidade a que penetram na terra as aguits superficiaes fica suggerida, de algum modo; (1) pela temperatura das fontes quentes, e (II) pela profundidade da alteração das rochas pelo tempo.

Aguas quentes. - Nos pros fundos e nas minas se observa que a temperatura da terra augmenta com a profundidade em uma marcha que varia localmente, mas que em termo médio, regula ser cerca de. um grau centigrado para cada 27.4 i metros abaixo do niv el da tempr ratura constante. As aguas das fontes quentes, especialmente as qu1. nào se acham nas visinhanȩas de actividades vulcanicas, são consideradas como subindo do interior aquecido da terra depois de terem descido da superficie.

A temperatura das aguas thermaes de Pogos de cialdas no sul de Minas é de 46 graus. Tomand $20^{\circ}$ como temperatura normal na superficie do chão temos uma differenęa de 26 graus acima do normal e $26 \times 27.43$ metros egual 713 metros, a profundidade em que a temperatura de 46 graus deve encontrar-se. É preciso lembrar, porém, que a marcha da temperatura de cima para baixo é muito variavel de um lugar para outro.

A profundidade da alteracio das rochas suggere que as aguas superficiaes penetram pelı menos até i profundidade na qual as rochas se acham assim affectadas. No Brasil os côrtes e tunneis na Estradi dr. Ferro Central mostraram que em muitus lugares as rochas são alteradas até a profundidade de trinta inetros. Sondagens feitas nas regives carboniferas do Rio Grande do sul mostraram decomposiçäo na profundidade de cento e vinte (120) metros, e em algumas das minas de Minas Geraes as rochas foram encontradas amollecidas até i profun- 
didade de cento e vinte e dois (122) metros. Em outras partes do mundo tem-se referido alterações das rochas em profundidades ainda maiores, indo até quatrocentos e sessenta (400) metros. Estas mudanças sãu produzidas pela penetração até essas profundidaes das aguas superficiaes.

A actividade chimica das aguas superticiaes produzem os seguintes resultados geraes :

1. As rochas sio dissolvidas em um lugar e depositadas em outro.

2. Os materiaes mais soluveis são removidos em primeiro e os menos soluveis em ultimo lugar.

3. 0 processo de soluęão produz cavernas, sumidouros, e canaes subterraneos.

4. Os mineraes dissolvidos siou depositados posteriormente nas fendas e vieiros e na fórma de accumulações superficiaes.

๖. Levam materia em solução para o ożeano onde

a) fica em solução,

b) está absorvida por animaes e plantas,

c) está precipitada de outro modo. 


\section{Resumo das operações dos agentes chimicos.}

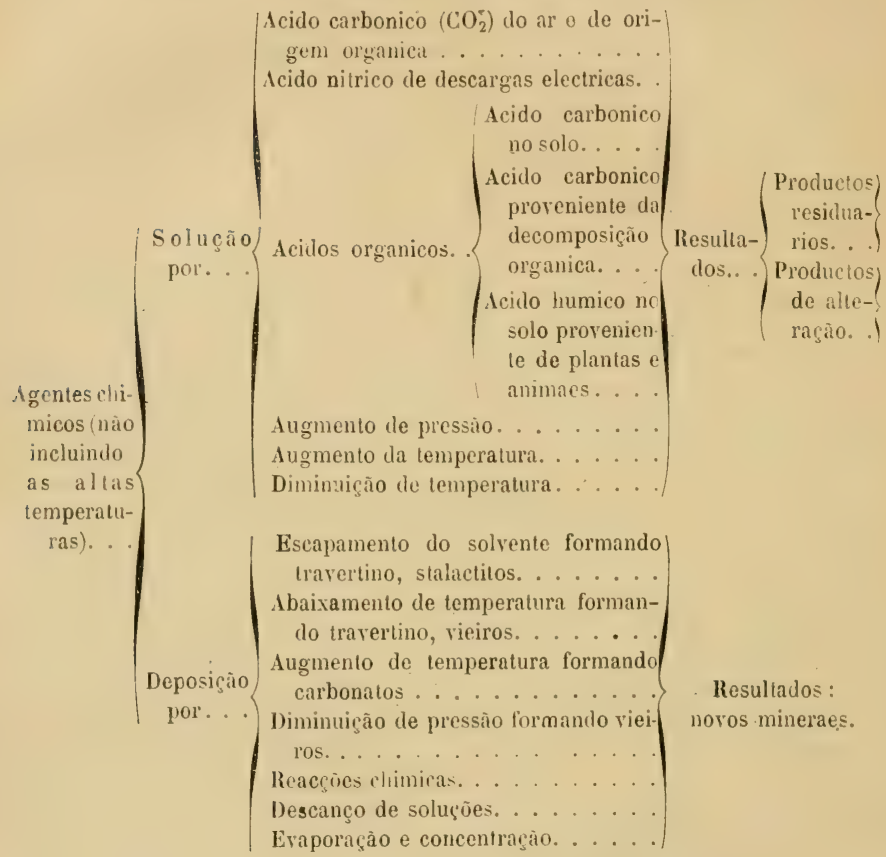

\section{Agentes igneos ou altas temperaturas.}

\section{0 interior da Terra.}

Que o interior da terra é muito quente é mostrado pelos seguintes factos :

1. - Felo augmento da temperatura com o da profundidade.

II. - Pelos vulcões e os phenomenos que os acompanham, a saber : vapor, gazes quentes, e rochas fundidas. 
III. - Pelos geysers e outras fontes quentes que trazem para a superficie aguas de alta temperatura.

IV. - Pelas posiçñes e caracteres de certas rochas, taes como as dos diques e dus lençóes de lava, que tém evidentemente estado em condição de fusão e ligadas com massas que penetram profundamente na crosta da terra.

Julga-se, que o interior aquecido da terra tivesse tido grande influencia sobre os climas do globo. Pode ser que esta influencia fosse grande nas épocas primitivas da historia da terra, porém actualmente não tem mais importancia.

\section{Theorias relativas ao interior da terra.}

Entre as muitas theorias que de vez em quando se avançam relativas ao interior da terra, quatro merecem menção.

I. - A theoria de um interior fluido e de uma crosta rigida recebcu o seu apoio principal do caracter das lavas que surgiram em forma de rocha fundida, e apparentemente provenientes do interior profundo da terra,

As altas temperaturas encontradas em grandes profundidades e as aguas quentes que surgem da terra parecem prestar apoio a esta theoria. A terra, porém, não se comporta como um globo fluido porque se fôsse, seria affectada, dentro da sua massa plastica, pelas marés; isto é, as influencias astronomicas que produzem as marés do oceano fariam o papel de um freio por causa da fração interna, e o globo deixaria de revolver. Portanto não se considera mais sustentavel a theoria do interior fluido do globo.

II. - A segunda theoria é que o globo seja tão solido quanto u'n globo de vidro ou de aşo. Tira-se esta conclusão da sua exempção aos effeitos das marés e do seu comportamento como um planeta tendo um movimento de revolução. Julga-se que se fosse fluido o interior da 
terra, as rochas fundidas retardariam o movimento ao redor do seu eixo pondo afinal termo a revolução. Pode-se formar uma idéa da efficiencia desta lei pela seguinte experiencia simples. Se um ovo for cozido até ficar duro, e então posto em rotacio sobre uma placa lisa ou um pedaço de vidro, elle continuará por algum tempo a revolver livremente. Se, porém, tentamos revolver da mesma maneira um ovo crú, verificamos que é impossivel fazel-o revolver por tanto tempo como faz o ovo cozido. A razão deste comportamento é que sendo fluido o material do ovo crú, se produz frição interna quando fôr revolvido rapidamente, ao passo que sendo solido o ovo cozido, não ha friç̧ão interna para retardar a sua revolução.

Deste ponto de vista a thcoria do globo solido parece satisfazer as exigencias do caso. Oppunha-se, porém, a esta theoria do globo rigido a consideração que existe evidencia concludente que o globo não é perfeitamente rigido. Em todas as partes da terra encontram-se evidencias incontrovertiveis de elevaęões e depressões da superficie. Estes movimentos tem sido sufficientes para levantar camadas que foram originalmente depositadas no oceano até elevações de mais de tres mil metros acima do nivel do mar, sendo bastante provavel que os deslocamentos da crosta da terra tenham-se estendido a uma distancia egual por debaixo do nivel do oceano.

Os movimentos da crosta da terra mostram, portanto, que o globo não é perfeitamente rigido: que elle seja tão rigido como seria um globo de vidro ou aço do mesmo tamanho pode-se admittir, se um tal globo for capaz de permittir as elevarões e depressões acima referidas e das quaes existem provas satisfactorias.

III. - Uma outra theoria é que a crosta e o centro da terra são solidos tendo uma camada fundida entre si. A esta hypothese se oppunha a consideração que un tal globo não acabaria com as difficuldades de retardamento por frição interna de um corpo rotatorio, visto que deixa a crosta da terra livre para mover-se ao redor do seu centro.

IV. - A quarta theoria é que a alta temperatura deve-se á presenȩa de ridio (radium). Sobre este ponto é preciso esperar mais 
experiencias e melhor conhecimento da natureza c acção do radion na 'rosta da terra. Porém já temos muitos estudus sobre este assumpto (1).

V. - Que as duas quintas partes do rádio do globo no centro é de materia differente da parte exterior. Esta conclusão está hoje bem estabelecida pelo estudo da marcha de tremores da terra. De um tremor partindo de um certo ponto e passando para o lado opposto do globo por diversos caminhos, alguns chegam atrazados, de maneira a demonstrar que tém passado pelo meio de materia differente daquella pela qual os outros passaram (2).

VI. - A theoria de um globo solido com bolsas locaes de rocha fundida parece satisfazer melhor do que outra qualquer as exigencias do caso; pois por ella se elimina as difficuldades da fricção interna. E' tambem provavel que a maior parte destas bolęas estejam apenas t.mporariamente na condiçào fundida, como está explicada na pagina seguinte.

Marcha do augmento da temperatura. - Existe uma camada externa, porém muito delgada, da crosta da terra que se acha sujeita ás mudanças diarias de temperatura. Debaixo desta camada não penetra o aquecimento diario pelo sol e o resfriamento que usualmente tem lugar á noite. A espessura desta camada de mudança diaria é apenas de poucos centimetros. Nas regiões temperadas da terra, porem, o anno se divide em seis mezes de tempo mais quente e seis mezes de tempo mais frio. As mudanças annuaes de temperatura penetram na crosta da terra até á profundidade de quinze metros na latitude de Nova York; mais ao norte a penetração da mudança annual é ainda maior, ao passo que nos tropicos é de cerca de um metro apenas. Estas mudanças superficiaes sào exclusivamente devidas a influencias externas ou solares.

Abaixo do limite de mudança annual, ou abaixo do nivel de ne-

(1) J. Joly. Radioactivity and geology. London, 1909.

O. Fisher. Nature, vol. 76,1907 , pags. 8, 55, 102.

T. C. Chamberlin. Journal of Geology, XIX, 673-695. 1911.

(2) R. D. Oldham. Quarterly Journal Geological Society, London, LXII, 456-175. 1906. 
nhuma mudança de temperatura, a das rochas augmenta e continua a augmentar a medida que se penetra nellas. A marcha do augmento da temperatura, porém, varía em diversos lugares e em diversas profundidades no mesmo logar. As seguintes são as profundidades para um augmento de um grau centigrado dos lugares mencionados: Norte de Inglaterra, 26.9 metros; Novo Galles do Sul, 44 metros; Schladebach perto de Leipzig, Allemanha 30.7 metros; minas de cobre de Michigan, America do Norte, 123 metros; em muitos poros artesianos cerca de 27 metros; na mina de Morro Velho no estado de Minas Geraes, Brasil, na profundidade de 1.200 para 1.500 metros é 70.9 metros.

Estas grandes differenças podem ser devidas ou à conductibilidade variavel das rochas, ou ás condições variaveis que produzem as altas temperaturas, sejam quaes forem estas condições.

No Brasil temos sobre este ponto umas observações feitas na serra do Caraça do estado de Minas Geraes no anno de 1849. 0 auctor. destas notas mandou fazer tres sondagens perto das minas de Agua Quente com as respectivas profundidades de $0.91,1.83$, e 2.74 metros, e nestas observou as temperaturas desde 22 de Maio até 13 de Julho de 1849 (1).

\section{RESULTADOS}

\begin{tabular}{|c|c|c|}
\hline PROFUNDIDADE EM METROS & $\begin{array}{c}\text { EXTRENOS } \\
\text { de } \\
\text { TEMPERATURA CENTIG. }\end{array}$ & $\begin{array}{c}\text { V.RILÇĀO } \\
\text { de } \\
\text { TEMPERATURA CENTIG. }\end{array}$ \\
\hline 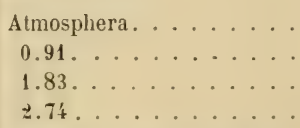 & $\begin{aligned} 6.11 & \text { a } 23 \\
21.72 & \text { a } 23.16 \\
21.44 & \text { a } 22.0 \\
21.66 & \text { a } 22.11\end{aligned}$ & $\begin{array}{r}16.89 \\
1.44 \\
0.56 \\
0.45\end{array}$ \\
\hline
\end{tabular}

Embora estas observaçies sejam poucas, é claro que a mudanȩa de temperatura devida ao clima vai diminuindo da superficie para

(1) W. J. Henwood. Transactions of the Royal Geological Society of Cornwall, VIII, Pt, II, 767-780. Penzance, 1871. 
haixu rapilamente, e que na profundidade de uns tres metros a mudança deve ser nulla. É de notar porém que a natureza das rochas e o tempo do anno devem influir nestes resultados.

0 mesmo auctor notou as seguintes temperaturas das aguas tiradas das minas de $\mathbf{A g u a}$ Quente perto destas mesmas sondagens (1).

\section{TEMPERATURAS DAS AGUAS DAS MINAS DE AGUA QUENTE}

\begin{tabular}{|c|c|c|}
\hline PROFUNDIDADE EM METROS & $\begin{array}{c}\text { TEMPERATURA C. } \\
\text { D'AGUA }\end{array}$ & $\begin{array}{l}\text { TEMPERATUR. } \\
\text { Do } A \mathrm{R}\end{array}$ \\
\hline $\begin{array}{l}12.6 \ldots \ldots \\
18.0 \ldots \ldots \\
27.0 \ldots \ldots \\
32.4 \ldots \\
43.2 \ldots \\
46.8 \ldots \ldots\end{array}$ & $\begin{array}{c}33.3 \\
30.0 \\
31.1 \text { a } 3 \ddot{3} .5 \\
32.7 \\
29.4 \\
32.5 \\
33.3\end{array}$ & 15.7 \\
\hline
\end{tabular}

Nis minas de Morro Velho no estado de Minas Geraes, que são as mais profundas no Brasil (1.500 metros no anno 1913), a temperatura das rochas vai crescendo com a profundidade. Na profundidade de 1227 metros a temperatura, na occasião de abrir a mina naquelle nivel, foi de 36.63 graus centigrados; na profundidade de 1.300 metros foi de 40. graus. Depois de aberta a entrada do ar para a ventilação, vão esfriando as rochas uns seis ou sete graus (2).

A maior parte das nossas rochas podem ser fundidas na temperatura de $1,648^{\circ}$ centigrado. Na hypothese de ser o augmento de temperatura, com a profundidade na razão de um grau para $\mathbf{2 7 . 4 3}$ metros, a temperatura de $1,648^{\circ}$ - sufficiente para fundir rochas - seria encontrada na profundidade de $1,648 \times 27.43=43,204$ metros. Podia-se suppor portanto, que na profundidade de $\nmid \breve{3,204}$ metros as rochas esta-

(1) IV. J. Henwood. Op. cit., p. 725-732.

(2) Estes dados interessantes foram fornecidos por Dr. George Chalmers, gerente da companhia. 
riam n’uma condição fundida. Como, porém, as rochas se expandem no acto de fusão, os 48,204 metros de rocha acima deste plano deve elevar o pronto de fusão pela sua grande pressão. Fica, portanto, exigido uma profundidade maior para alcançar uma temperatura sufficiente para fundir as rochas. Esta maior profundidade porém, augmenta a pressão das camadas sobrepostas, e o ponto de fusão avanẹa, portanto, até uma profundidade ainda maior.

Devido á impossibilidade da reproducção no laboratorio das condiçoes complexas das partes profundas do interior da terra é difficil raciocinar em relação a ella com muita confiança.

Fusão devida ao allivio de pressão. - Parece rasoavel suppor, to que acima ficou dito, que podemos ter rochas infusiveis na temperatura de $2,000^{\circ}$ quando sujeitas a uma pressão dada, mas fusiveis quando a metade daquella pressão fôr removida. P’ode ser que seja isto a explicaçĩo da natureza local dos phenomenos vulcanicus sobre o globo. Em cada paiz encontramos provas da pressão lateral á qual as rochas tem sido sujeitas : em alguns lugares as camadas tèm sido levantadas em dobras bruscas e elevadas milhares de metros acima dos oceanos debaixo dos quaes estavam originalmente depositadas; em outros lugares as camadas estão quebradas por este empuxo e empurradas umas adiante das outras. Estes empuxos lateraes nas rochas devem, aqui e acolá, alliviar a pressão sobre as camadas subjacentes, e se estas camadas forem impedidas de se fundirem por causa di pressão sobre si, tal allivio permittiria a passagem das rochas quentes para o estado de fusão.

Em apoio desta theoria rem o facto que a actividade vulcanica sobre o globo acha-se principalmente limitada ás regioes de quebramento, dobramento e escorregamento. Em todo caso os phenomenos igneos, ou os devidos a alta temperatura, provèm, pela maior parte, de um nivel profundo, não obstante elles se manifestarem frequentemente na superficie. 


\section{Os vulcões e o seu trabalho geologico.}

Os vulcões não são agentes tão activos como geralmente se julga na formação das rochas e das montanhas. Em alguns paizes elles são abundantes e por causa de suas actividades elles impressionam sobremaneira o espirito e a imaginação do homem.

Com relação á formação das montanhas do Brasil elles sào de ponca importancia. Em toda a região dos Andes porem sĩo de primeira importancia.

Vulcões podem ser classificados como :

I. - Activos.

II. - Extinctos ou dormentes.

Vulcões activos. - Um vulcão é usualmente um morro ou uma montanha conica com um ou mais orificios pelos quaes rochas fundidas, gazes e cinzas escapam do interior aquecido para a superficie.

A montanha ou morro é o resultado, e não a causa, ou mesmo uma parte essencial, do vulcão.

Erupções. - Os vulcões são mais ou menos espasmodicos em suas actividades. Em alguns vulcões se tem observado uma tal ou qual periodicidade, porém estes periodos variam muito. Por exemplo, o Stromboli na Italia faz erupções uma vez no intervallo de quatro a dez mezes, emquanto o Kilauea das Ilhas Hawianas faz erupečo uma rez em cada oito ou nove annos. A sequencia dos eventos por occasicio de uma erupção é usualmente como se segue : (1) estrondos, (2) choques de tremores de terra, (3) a emissão de vapores pelo vulcão, (4) explosões com ejecções de fragmentos de rochas, (วั) a elevaçĩo de lavas, (6) transbordamento de lava, (7) descahimento da erupção. Quando uma erupesão för quieta a lava pode escorrer sobre o bordo da cratera, ou labio do vulcão, e póde esfriar-se como um lençol de lava sobre os declives do cone, ou ella póde escorrer para baixo nos valles da vizinhança. Algumas vezes a lava escorre de fendas nos lados da montanha. A pressão hydrostatica da lava no interior de um alıo vulcão é enorme. Muitos dos picos ingremes dos Andes são vulcões e uma 


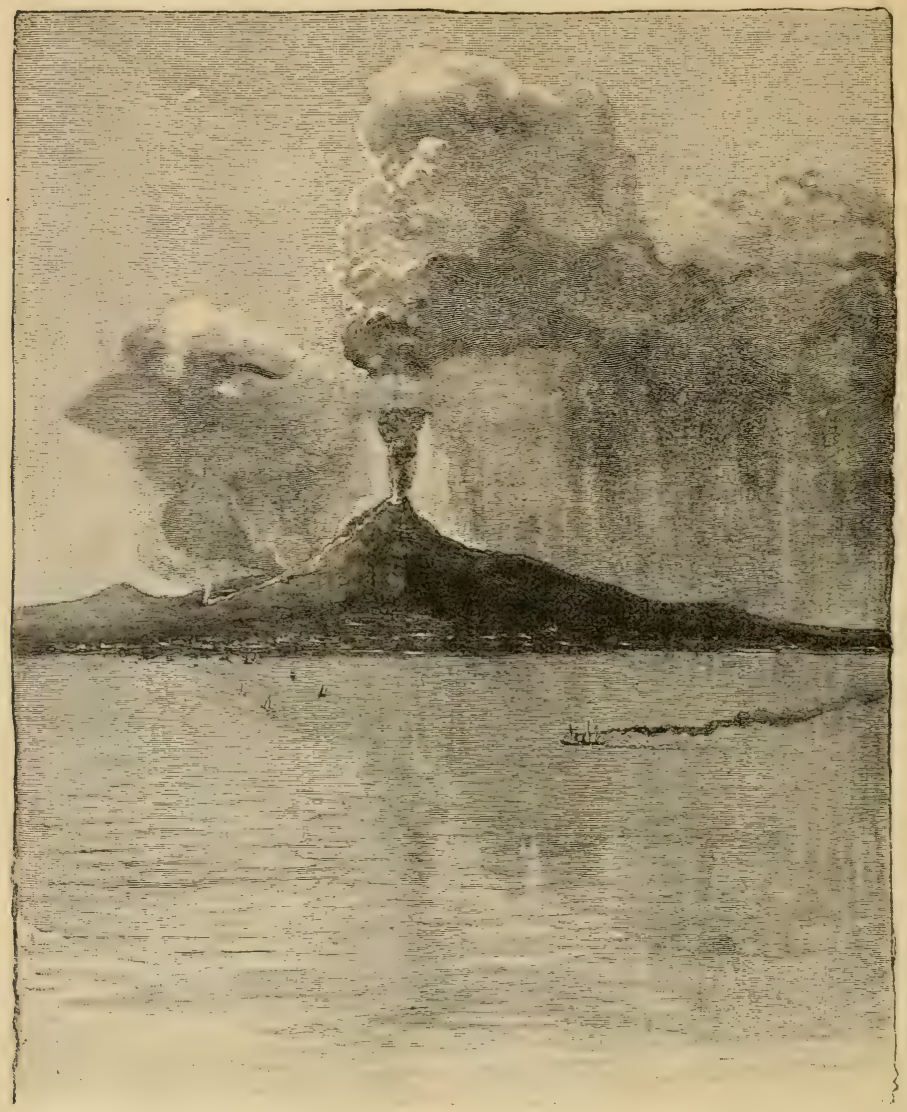

Fig. 35. - O Monte Vesurio em erupš̃o. De uma photographia tirada em Napoles a 26 de Abril de 1872. 
idéa da pressão da lava dentro delles póde ser tirada de sua elevação. o Cotopaxi tem 5,978 metros de altura; o Chimborazo 6,243 metros; o Antisana $\check{5}, 893$ metros; e o Cayambe, $\dddot{3}, 847$ metros. A grande for necessaria para erguer a lava até o topo de uma cratera com essas elevações frequentemente arrebenta os lados das montanhas e a lava escapa pelas fendas assim formadas.

Os materiaes das erupşões vulcanicas sũo (1) lavas, (2) ejectamentos fragmentarios, (3) inclusões, (4) gazes, vapor, etc.

(1) Lavas. - Quasi todas as rochas podem ser fundidas em fogo bastante quente e as lavas são simplesmente ruchas que foram fundidas pur uma temperatura muito alta. 0 caracter e comportamento da lava depende em grande parte da porção d'agua que contem. Quando contem muita agua, é perfeitamente liquida e grande parte della é arremessada como pedra pomes e poeira; emquanto a lava que nio contem senão pouca agua requer uma temperatura muita alta para fundil-a e é antes viscosa do que muito fluida. Quando as lavas vasam dos vulcões obedecem, de uma maneira geral, ás leis da hydrostatica, e escorrem pelos declives abaixo para os valles e outras depressões. A frente de um curso de lava entretanto nào é achatada como a de um curso de agua, porém vertical e dependurada sobre as arestas com uma altura que ás vezes attinge de tres até sete metros ou mais. Tambem acontece que a superficie se resfria rapidamente emquanto a grande massa de baixo está ainda se movendo, resultando dahi o quebramento da crosta da superficie em massas angulares e denticuladas de todos os tamanhos e formas.

Quando as erupęões são grandes e a lava lluida, a rocha fundida se espalha sobre areas extensas da circumvizinhança enchendo os valles e forcando os cursos d'agua a procurarem novos canaes. Algumas vezes as lavas escorrem atravez dos valles fazendo represas atraz des quaes são gradualmente formadas lagos.

Dois dos maiores lençoes de lava no mundo são os da India e da America do Norte. 0 primeiro cobre uma area de quinhentos e dezesete mil e novecentos kilometros quadrados com uma profundidade, que varia de trinta até mil oitocentos e vinte oito metros. 0 grande lençol de lava da parte noroeste do occidente da America do Norte 
cobre uma area de trezentos e oitenta e oito mil e quatrocentos kilometros quadrados.

(2) Os ejectamentos fraymenturios dos vulcòes consistem de pedacos de rochas de varias limensũes e formas e conhecidos por outros tantos nomes differentes, taes como lapilli, bombas, cinsas, etc. 0 que se chama "fumara " e " cinza ", sìo pela maior parte súmente us fragmentos muito miudos de rochas fundidas que foram arremessados ao ar pelas explosies debaixo da massa fundida dentro da cratera.

Estes fragmentus siin is rezes arremessados a uma elevação de 6,000 metros acima da cratera (1).

Quindo esses materiites miudos cahem sobre a terra são algumas vezes suprados em dunas pelo vento. Quando cahem na agua fazem depositos estratificalos que se assemelham em estructura com as camadas sedimentarias. Elles sĩo então chamados tufos estratificados. Luando cahe chuva atrave\% das nuvens de cinza miudas, ella vem semelhante a lama.

As chuvas de cinza que cahem na vizinhanęa de alguns vulcões contribuem muito para o damno feito pelas erupecoes. E' de todos conhecida a destruiẹão for cinzas vulcanicas das cidades romanas Pompea e Herculano. Em Herculano os depositos de cinzas apresentam a espessura de vinte a trinta e quatró metros.

Quando a preira é muito miuda ella frequentemente se eleva até grandes alturas e se expalha sohre areas enormes. Entre as erupgões desta natureza registradas uma das mais notareis foi a do Krakitoa (Agosto de 1883) na qual a poeira ergueu-se a uma altura tal que coloriu o céo por subre todo a mundo durante tres mezes. Conforme a estimativa, esta fina poeira ergueu-se a uma altura de mais do que trintit e dois mil metros, emquanto a materia pesada na rizinhanea inmediata foi arremessada a uma altura de cerca de cincounta mil metros.

(3) Inlusões. - As inclusies, como o nome indica, são pedaços

(1) E. Whymper. Travels amongst the great Andes, pags. 125, 141, 326, 328, 330. New York, 1592. 
de rocha de natureza differente da lava, trazidos para cima dentro da massa desta. Estas inclusões são simplesmente fragmentos quebrados dos lados da abertura na crosta da terra atravez da qual a lava sahe. Ellas podem ser de qualquer especie de rocha - quer eruptiva, quer sedimentaria. Nào é pouco frequente ellas conterem restos de animaes e plantas. A's vezes se encontram conchas nas inclusões em redor d" Monte Vesuvio. Julgou-se primeiramente que estas conchas provinham do mar e que entraram no vulcào por algum canal subterraneo. Ellas são derivadas das rochas atravez das quaes a lava passa no seu caminho para a superficie.

(4) Ga:es e vapor. - Quando as rochas quentes chegam em contacto com a agua dos lagos, dos cursos terrestres ou do mar, forma-se vapor. A chuva cahindo sobre os materiaes soltos que cobren rochas aquecidas penetra-os, formando vapor quando alcanıa as lavas quentes.

As explusĩes são frequentemente causadas pela formação subita do vapor sob pressão.

Os gazes produzidos pelos vulcões sào de diversas naturezas. Alguns delles são altamente explosivos. A devastação e enorme destruição de vidas nas Ilhas da Martinica e S. Vicente nas Indias Occidentaes em Maio de 1902, parece ter sido causada por gazes explosivos. A cidade de St. Pierre na Martinica foi completamente destruida e os seus 30,000 habitantes foram mortos em menos de tres minu$\operatorname{tos}(1)$.

Picos vulcanicos. - Os picos vulcanicos sào feitcs pelos ejectamentos que frovèm de aberturas, ou ventas na terra. As lavits escorrem para fóra e esfriam-se; as cinzas e os blocos soltos são arremessadis prara fóra pelas explosões, e emquanto os materiaes mais miudos podem cahir longe da bucca, a parte maior e mais pesada cahe perto da bocca ao redor da qual gradualmente forma-se um cone. Novas lavas escorrem e juntam-se a este cone e novas erupecóes empilham mais cinzas. Os picos vuleanicos mais altos sĩo os dos Indes

(1) National Geographic Magazine. July, 1902, XIII, N. 7. 
que attingem alturas de $\ddot{Ð}, 181$ até 5,791 metros. O Orizaba no Hexic é um vulcio que tem uma altura de $\check{5}, 0082$ metros acima do mar.

E' bem conhecido o facto que os cones formados em grande parte do cinzas são muito mais ingremes do que os leitos principalmente de lava. A figura 36 mostra um pequeno cone vulcanico do norte dia

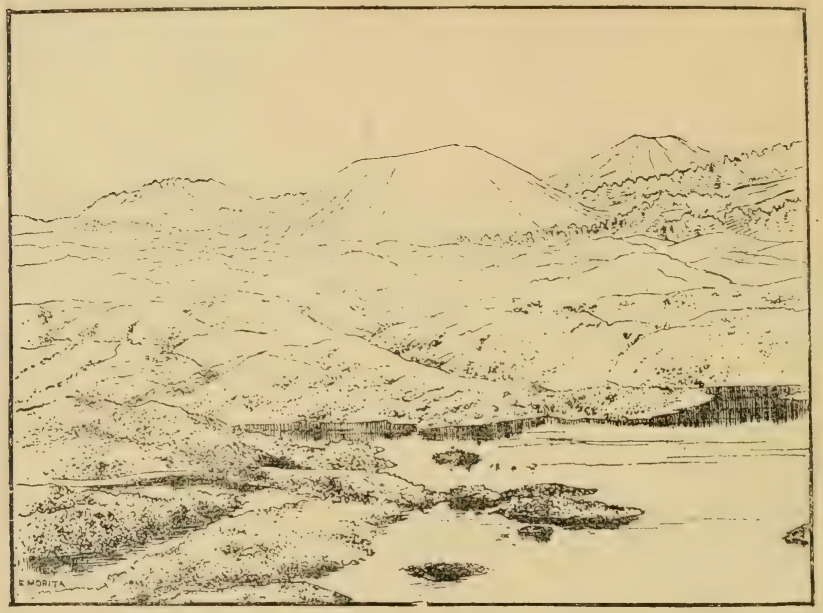

Fig. 36. - Um pequeno cone vulcanico de cinzas ao norte da California. (Diller.)

California feito inteiramente de materiaes fragmentarios arremessados de um vulcão de edade recente, porém, actualmente extincto.

Rochas vulcanicas. - As lavas sio na maioria rochas de coloraçào escura, porém quando decompoem-se ou depois de terem sido expostas á atmosphera frequentemente se tornam pardas, amarellas ou vermelhas. Algumas dellas são vitreas e se quebram con uma fractura lisa semelhante ao vidro; muitas d'ellas tèm a apparencia empolada, isto é, são cheias de pequenas cavidades reclondas formadas pelos gazes ou vapores emquanto as rochas estiveram quentes. Com o esfriamento as lavas algumas vezes racham formando 
o que são chamadas columnas basalticas. Estas columnas formam-se perpendicularmente á superficie da lava em resfriando-se de maneira que quando a lava forma uma camada horizontal as columnas se apresentam frequentemente, mas nem sempre, em sentido vertical. Quando a lava sobe atravez de uma grande fenda em outras rochas as columnas são muitas vezes approximadamente horizontaes. Fig. 81 mostra a estructura columnar das lavas na ilha de Fernando de Noronha.

Vulcões submarinhos. - Os vulcões algumas vezes irrompem debaixo do mar. As formas de muitos picos submarinhos leva-nos a concluir que são cones vulcanicos.

is lavas dos vulcões submarinhos são as mesmas que as terrestres. Acontece occasionalmente que uma ilha rulcanica ergue-se do mar, porém, se não fôr bastante grande, será immediatamente arrazada pelas vagas.

Em 1628 uma das ilhas dos Açores perto da ilha de S. Miguel ergueu-se em quinze dias do fundo do mar onde havia anteriormente uma profundidade de 292.6 metros, até uma altura de 109.7 metros acima do nivel do mar. Tiuha legua e meia de largura e tres de comprimento. Em 1831 uma ilha vulcanica ergueu-se ao largo da costa dis Sicilia até uma altura de sessenta e um metros acima do mar. Esta ilha tinha cinco kilometros de circumferencia e esteve em activa erupçào durante tres semanas. Dentro de dois annos foi completamente demolida pelas vagas.

As ilhas de Fernando de Noronha e Trindade ao largo da costa do Brasil são ambas quasi exclusivamente feitas de rochas vulcanicas, e provavelmente foram em primeiro lugar vulcões submarinbos. Ambas estão profundamente cortadas pelas vagas usurpadoras e apresentam encostas ingremes, dando raros e difficeis pontos de bom desembarque, sendo este principalmente o caso com a Trindade.

A distribuiç̃o dos vulcões sobre o globo, especialmente sobre o continente americano, é digna de nota. Aqui elles seguem o eixo da grande cordilheira que estende-se desde a Terra do Fogo ao longo de toda a costa occidental do continente atravez da America do Sul, America Central e America do Norte até á mais occidental das ilhas Aleu- 


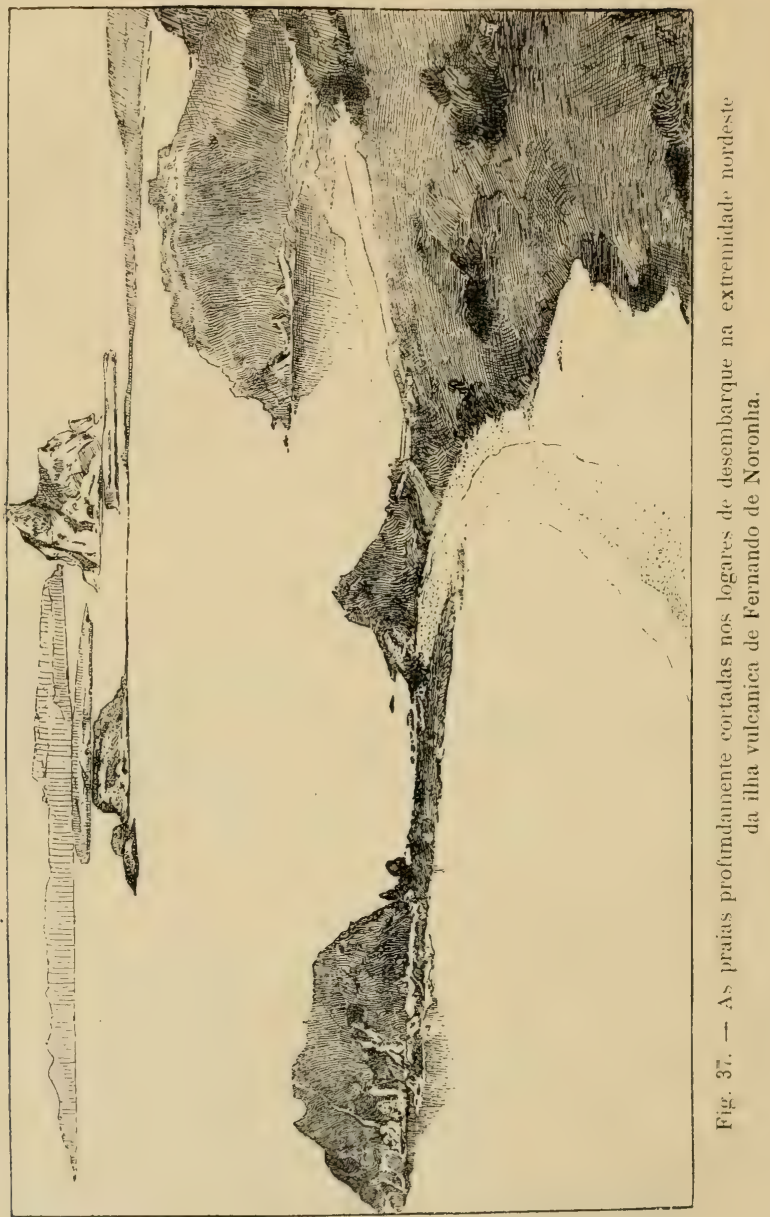

cianas no Mar de Behring que separa a America do Norte da Asia. Uma outra, ou talvez a mesma linha de vulcões continua de sudoeste 
de Kamtschatka atravez das ilhas de Jesso, Japão e das Philippinas para Nova Guiné. Existem afóra destes, diversos grupos de ilhas vulcanicas no Oceano Pacifico.

Muitas das ilhas das Intilhas são de rochas igneas; taes sĩo S. Lucia, Martinica, Dominica, Guadalupe (em parte) ete.

Tambem são vulcanicas as ilhas Açôres, Madeira, Santa Helena, Cabo-Verde, e as Canarias.

Vulcões extinctos. - Alguns vulcies estii) sempre activos, alguns estão quietos durante annos, e alguns parcrem estar completamente extinctos. E' difficil senão impossivel trarar qualquer linha de distincęão entre os activos e os extinctos; en parte, porque um vulcão póde ficar em repouso por muitos annos, "u inesmo por seculos, e depois começar um periodo de grande actividade. As ilhas de Fernando de Noronha e Trindade (1) já foram citadas como vulcies brasileiros e as suas rochas são basaltus, phonolites e trachytes nas formas de lavas, tufas, e agglomeradas.

Ambos estes vulcões estão em apparencia completamente extinctos. Existem muitos restos de lençóes de lava no Brasil entre as rochas antigas. Ao norte do cabo de Santo Agostinho existe um cabeço conhecido por Pedras Pretas onde um antigo lençol de lava trachytica está exposto ao longo da costa. A ilha de Santo Aleixo ao largo da costa de Pernambuco em frente á Barra de Serinhaem é formada tambem de rochas eruptivas. A principal ilha do grupo dos Abrolhos é na maior parte completamente feita de uma rocha eruptiva sendo ella um diabase com olivine, ou um gabbro.

No interior do estado de S. Paulo existem extensas areas cobertas por lençóes de rochas eruptivas. Estas rochas estão expostas nos municipios de Piracicaba, Santa Barbara, Rio Claro, Limeira, Botucatí, S. Simão e outros. No estado do Paraná este mesmo lençol eruptivo forma as summidades da Serra de Ipucarana e da Serra da Esperança e se estende na direç̧ão oeste daquellas linhas de mon-

(1) Horace E. Williams. Notas sobre a geologia da Ilha Trindade. Pub. do Serviço Geologico do Brazil, 1913. 
tanhas com certas interrupçies até o Rio Paraná. No estado de Santa Catharina a Serra do Espigão e a Serra Geral são cobertas com uma rocha eruptiva que semelhantemente estende-se na parte occidental daquelle estado. No Rio Grande do Sul os grandes campos que estendem-se da Serra do Mar á nordeste de Porto Alegre até a fronteira Argentina são cobertas com a mesma rocha trapiana que é encontrada em S. Paulo, Paraná e Santa Catharina.

Ainda não se sabe com certeza si as rochas eruptivas do sul do Brasil fazem parte de um grande lençol de lava, ou são erupçoes mais ou menos separadas, ainda que estreitamente connexas.

E possivel que exista ahi um grande lençol de lava que se extende pelos estados de Matto Grosso, S. Paulo, Paraná, Santa Catharina, e Rio Grande do Sul, e pela parte oriental de Paraguay e pelo norte de Uruguay, cobrindo assim uma area de 750,000 kilometros quadrados mais ou menos, e por conseguinte maior que os notaveis derramamentos da India e d'America do Norte.

Certos factos, porem, parecem provar que o lençol de lava consta de muitos derramamentos que são approximadamente da mesma idade geologica.

Em muitos lugares o arenito de Baurú está em cima das eruptivas, mas em outros este arenito assenta directamente sobre o arenito de Botucatú que geralmente fica em baixo da lava. Dr. Lisboa notou (1) que, entre Macuco e Avanhandava no rio Tieté, o arenito de Baurú repousa directamente nos lençóes de trap, emquanto Dr. Florence achou o Baurú logo em cima do arenito de Botucatú, acima de Avanhandava.

Uma outra e provavelmente mais antiga serie de rochas com ventas limitadas e com ejectamentos fragmentados, que lhe dão um caracter vulcanico mais typico, foi reconhecida por Derby na ilha de Cabo Frio, Serras de Tinguá e Mendanha perto do Rio de Janeiro; nas serras de Itatiaya, Picú e Caldas, na região da Mantiqueira, e nas serras de Ipanema e Jacupiranga na região da Serra do Mar do Sul de

(1) M. A. R. Lisboa. Oeste de S. Paulo; Sul de Matto Grosso, pag. 7. Rio de Janeiro, 1910. 
s. Paulo (1). Rochas semelhantes ás caracteristicas destes pontos occorrem no Pão de Assucar nas margens do Rio Paraguay e é provavel que ahi tambem houvesse uma antiga venta vulcanica.

Diques. - Quando a lava enche uma fenda nas rochas e ahi endurece ella é chamada dique. Quasi se pode dizer que estes diques podem ser de qualquer comprimento e largura. Deve-se observar, entretanto, que os diques muito delgados não podem ser introduzidos

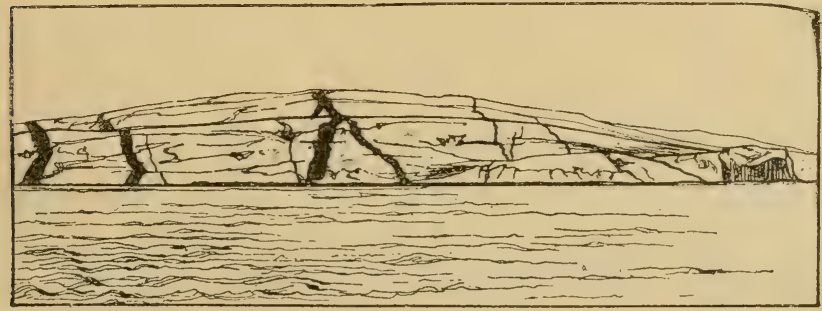

Fig. 38. - Diques de trap de differentes dimensões em granito, num morro de 30 metros de altura na costa do Labrador.

dentro de rochas frias. Nem a rocha fundida nem mesmo o metal fundido pode ser derramado em pequenas fendas senão quando a rocha fendida esteja tão quente que não resfrie rapidamente a materia fundida. Os diques se apresentam em qualquer posição desde a vertical até a horizontal, e podem estar isolarlos ou em grupos, ou pidem dividir-se em diversos diques; podem ser rectos ou tortuosos (vède a fig. 38). Não é raro acontecer que as rochas dos diques sejam mais duras ou mais resistentes do que as que os contem, e nestes casos as rochas conterminas são destruidas pelos agentes desnudadores mais rapidamente do que as do dique e este fica posto em relevo semelhante

(1) Orville A. Derby. On the nepheline rocks of Brazil. Quart. Jour. Geol. Soc., XLIII, pags., 457-473 : XLVII, pags., 251-265. London, 1887, 1891.

O. A. Derby. Sobre as rochas nephelinas do Brasil. Reoista de Engenharia. Rio de Janeiro, 1888. 
a um muro. A figura 39 representa um tal muro nas Montanhas Rochosas.

Quando a rocha do dique é mais promptamente decomposta do que as rochas conterminas ella ás vezes deixa na paisagem uma depressão semelhante a um rego.

Os diques cortam rochas de qualquer qualidade, ou eruptivas ou

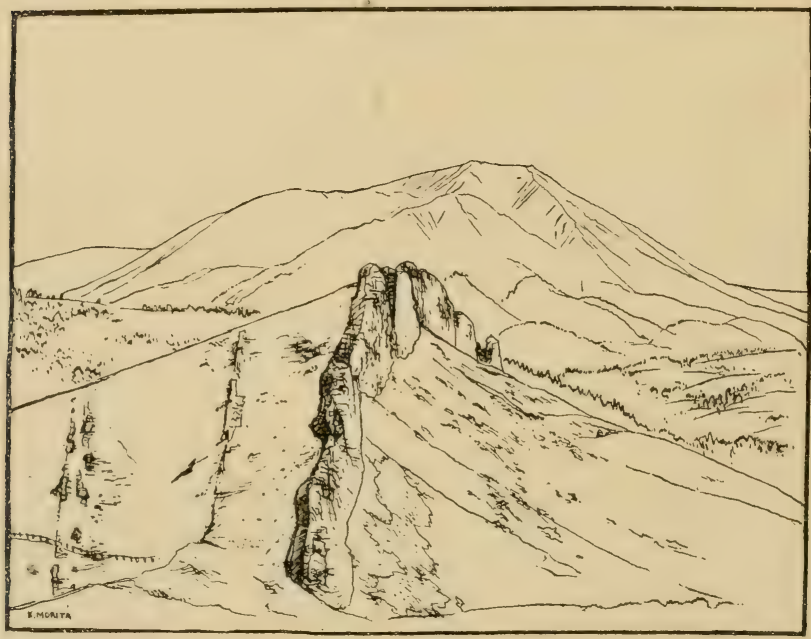

Fig. 39. - Diques verticaes a pino postos á vista pela erosão.

Montanhas Rochosas, Ameriea do Norte.

sedimentarias, e de qualquer idade geologica. Na Ilha de Fernando de Voronha que é de rocha vulcanica, ha muitos diques, tanto grandes como pequenos.

Yo Brasil ha diques em qualquer parte onde existem rochas eruptivas, quer sejam modernas quer sejam antigas. No norte do Brasil, pelo interior dos estados do Ceari, Rio Grande do Norte, Parahyba, Pernambuco, Alagòas, Sergipe e Bahia, diques abundam onde cortam granitos ou rochas sedimentarias antigas. Ao longo da estrada de ferro na vizinhanģa de Baixa-Verde no estado de Rio Grande do 
Nort., na distancia de muitos kilometros existem diques cortando schistos e granitos.

Diques são frequentes em toda a regiào de idade permiana nu veste de S. Paulo e no sul do Brasil. Nas minas de carrão de S. Jeronimo no Rio Grande do Sul ha diques de andesito que cortam as camadas de carvão (1).

To estado de Santa Catharina diques foram notados por I. C. White nus seguintes lugares: Bonito, rio Passa-Dois, fúz do rio do Rasto; dois kilometros abaixo de Orleans; cinco kilometros abaixo de Vinas (pags. 224-220̈).

Laccolitos. - Quanda a lava é introduzida na parte superior da crosta da terra de modo que as rochas de cima nào quebrem-se, as camadas superiores sĩo levantadas pela lava injertadia que esfria-se entre as camadas inferiores formando massas lenticulares. Essas intrusues são chamadas laccolitos. Com o correr do tempo os laccolitos podem ser descobertos pelos processos de erosão.

A idade de um vulcão. - 1 idade de um vulcão prehistorico extincto, ou de lavas, diques e deriamamentos de rochas igneas de tudas as qualidades, só gude ser determinada verifirando a relarão de sults lochas com as camadas fossiliferas de sua vizinhança. Por evenplo, si as eruptivas tèm sedimentos depositados sobre ellas a idade das eruptivas pode ser reconhecida como mais antiga que os sedimentos. Se os sedimentos de uma idade conhecida são cortados pelas eruptivas, estas derem ser mais novas que os sedimentos.

Geysers. - Geyser é o nome dado na Islandia a fontes querites que periodicamente fazem erupęoes. As aguas dos geysers são necessariamente quentes porque as crupçoes são devidas á formação de rapur em baixo da superficie d'agua. Os gerser's mais notaveis siu os da Islandia, da Yora Zelandia e do Yellowstone Park na America 1) Norte. Na America do Sul existem geysers proximo de Carthagena

(1) 1. C. White. Relatorio, pags., 116, 218, :224. 
no rio Magdalena, Colombia. Todos os geysers estio em requies de actividades vulcanicas actuaes ou extinctas.

Os phenomenos das erupeões succedem-se em uma ordem regular : (1) um ruido nas proximidades do geyser é seguido fror (y) um transbordamentu d'aggua pela abertura; vem então (3) um escuiche d'ascua, que é seguido pelo (') escapamento ruidoso do rapor.

A theoria da causa e sequencia desses phenomenos é a seguinte. As rochas abaixo da superficie estão tudas quentes, algumas dellas bastante quentes para fazer a agua ferver. As aguas da superficie alcan bando aquellas rochas quentes são aquecidas até o ponto de ebulliçón, porém como a ahertura para a superficie está cheia d'agna a pressãu desta imperle que a aguit quente em grande profundidade forme vapor'. Os cantes subterraneos, comtudo, são muto ramificados, e de $v \%$ em quando a agua é levada an ponto de ebulliegão em alşum ponto n'arquelles cantus. Guando o vapor forma-se em qualquer ponto a agua que ses acha por cima é levantada pela expansio do rapor e derrama-se na superficie. Estr derramamento allivia a pressào sobre o resto da columna d'agrua, carquellas poresoes que estavam já provimo ao ponto de ebulliecion de subito transforman-se $\mathrm{em}$ vapor e este nown vapor, assim formado arremessa o resto d'agua para o ar e entà escapal-se. Depois de uma dessis eruperes a agua accumula-se outra vez nas cavidades subterraneas e $\operatorname{logo}$ que de novo é aquecida o mesmo processo repete-se.

As comlicões necessarias para os geysers são evidentement? as seguintes :

1. - Rochas igneas que em certas profundidades estejam ainda hastantr quentes para ferver a agua sendo porém menos quentes proximo à superficie do terreno.

iI. - Iguas meteoricas tendo accesso até ás rochas quentes.

III. - Um tubo ou abertura para o escapamento da agua e do vapor.

Em todas as regioes de geysers é notorio que a frequencia das. Mrupçoes está gradualmente diminuindo. Na Islandia as erupçoes saio muito menos frequentes do que eram quando os geysers foram deseriptos por Mackenzie em 1810. 
o Yellorvstone National Park na America do Norte contem o mais notavel conjuncto de geyser's ora existentes. Existem mais de tres mil aberturas naquelle parque. A temperatura do maior é de 63. :" C. ; quando em erupção elle lança agua a uma altura des sessenta e um metros e vapor a uma altura de trezentos e quatro metros. Alguns dos geysers menores lanȩam agua a setenta e seis metros de altura.

O trabalho geologico dos geyser's consiste na construcção ao redor das suas aberturas, de cones formados pela precipitação da materia mineral em soluçĩo nas aguas quentes do geyser. Alguns desses depositos são silicosus e outros são calcareos.

Fontes quentes. - A alta temperatura das fontes quentes é causada pelo contacto das aguas provenientes da superficie com rochas quentes antes de emergirem.

Debaixo das condições acima mencionadas, formam-se os geysers, porém de outro modo sómente as fontes quentes. $\mathrm{A}$ origem da alta temperatura das fontes d'agua quente é algumas vezes attriluida a agentes mysteriosos. $\Lambda$ s altas temperaturas conhecilas das rochas profundas da terra é sufficiente para explicar as aguas quentes. E' notavel, comtudo, que as fontes quentes rariam muito pouco em seu fluxo _ um facto que é attribuido a arbarem-se nas profundidades da terra canaes pelos quaes as aguas éscoam-se.

Poços de Caldas. - Is aguas celebres de Poços de Caldas no sul de Minas tèm uma temperatura de $41^{\circ}$ a $46^{\circ}$ graus Cent., e sahem de rochas igneas (1) de idade paleozoica.

Brejo das Freiras. - Uns dez kilometrus a oeste ou noroeste da villa de S. João do rio do Peixe no estado de Parahyba existe uma fonte de agua quente. Está situada ao pé de uns morros baixos de rochas crystallinas. As aguas surgem de arenitos perto dis rochas crystallinas, e a estructura parece mostrar uma pequena falha normal. IIa tres fontes principaes, e a temperatura d'agua é de $36^{\circ}$ Cent. A

(1) Pedro Sanches de Lemos. As aguas thermaes de Pocos de Caldas, Minas Gerces. Bello Horizonte, 1904, pag. 164. 
descarga visivel é só de tres para quatro litros por minuto mas o brejo vizinho parece demonstrar que ha mais agua neste lugar (1).

As fontes thermaes ou caldas do Sipó no estado da Bahia estão situadas a margem direita do rio Itapicurú. Ha cinco ou seis fontes neste lugar e outras meia legua rio abaixo. As fontes sahem numa

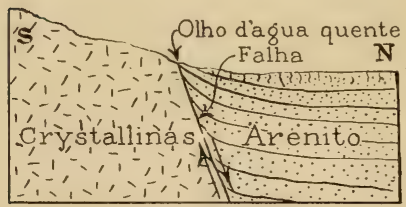

Fig. 40. - Seçăo mostrando a estruc. tura geologica no Brejo das Freiras, estado de Paralıyba. (Wering.) altitude de cinco metros acima do nivel da agua du rio Itapicurú. A temperatura da agua é de 3 t para $3 \Xi$ graus C. (Temperatura ambiente $22^{\circ}$ a. $1 \mathrm{~m} ., 27^{\circ} \mathrm{m} ., 233^{\prime \prime}$ a $24^{\circ}$ á tarde). Is camallas expostas na vizinhança são todas de rochas sedimentarias e talvez da idade terciaria.

E possivel que essas åguas vảo-se esfriando perceptivelmente. Durval Vieira de Iguiar no livro intitulado "Descripeões praticas da Provincia da Bahia », publicado na Bahia no anno 1888, á pagina 86, fallando das aguas do Sipí, diz que a temperatura das mais quentes é de 40 graus centigrados.

\section{Terremotos.}

Terremotos são choques, concussões, ou abalos propagados como undas atravez das rochas da crosta da terra. Essas concussões podem ser produzidas por' qualquer dos modos seguintes:

I. - Pela fractura de rochas sob esforço.

II. - Pelo escorregamento ou reajustamento das rochas umas sobre as outras.

III. - Por explosões dentro dit crosta da terra nas vizinhaveas de vulcões, provavelmente por formação e collapso de vapor.

Para se entender os terremutos e seu comportamento é necessario estudar a propagarão das ondas atravez das rochas sob as condicoues

(1) Carta particular de G. A. Waring; 29 de Julho de 1911. 
complexas derivadas da variabilidade das estructuras geologicas, composições, esforços e fracturas.

Onde as rochas forem muito dobradas ou falhadas parece muitissimo provavel que deve ter havido terremotos, quando as falhas se deram. Onde na crosta da terra se apresentarem linhas de frarueza e reajustamento ha probabilidade de terremotos. A linha de actividade vulcanica que segue a borda occidental dos dois continentes americanos da Terra do Fogo até a Alaska é uma linha de fraqueza e de consiante reajustamento, e consequentemente é uma linha de terremotos. Onde esta linha de actividade vulcanica passa na direcrão sudoeste pelu Japão, Philipinas, Sumatra e Java, existe tambem uma linha de frarqueza da crosta, de reajustamento e de terremotos. Embora os terremotus sejam simplesmente ondas ou abalos transmittidos atravez das rochas, deve-se suppor que essas ondas movem-se com differentes velucidades de accordo com a natureza e posição das camadas das rochas. E isto pelas observações feitas tem sido verificado. Is differentes rochas tim conductibilidades differentes; a areia solta conduz ondas ou abalus na razão de 299.8 metros por segundo, os arenitos na razão de 2,253.50 metros por segundo, e o granito na razão de 2,804 metros por segundo.

$O$ fóco ou centro d'onde um abalo de terremoto irradia-se está commummente bastante abaixo da superficie.

0 ponto na superficie da terra, onde primeiramente chega a onda de um abalo e do qual parece irradiarem-se os abalos successivos, designa-se pelo nome de epicentro.

Do epicentro as ondas espalham-se sobre e ao longo da superficie da terra. Observando em diversos lugares o tempo exacto em que $u$ m abalo de terre é sentido, tem sido possivel determinar a furma e a marcha do movimento de taes ondas.

0 deslocamento de uma particula ou ponto na superficie do solı na occasiīo de um abalo de terre não é tão grande como geralmente se imagina. Raras vezes monta a mais de tres a quatro millimetros; algumas vezes é apenas uma fraçio de millimetro. Nìn nos referimos aqui á vibração de objectos suspensos, ou ao deslocamento de urn ponto onde as rochas são quebradas e falhadas. 0 maior deslo- 
camento registrado no ())servatorio Astronomico de Lick na Calilornia

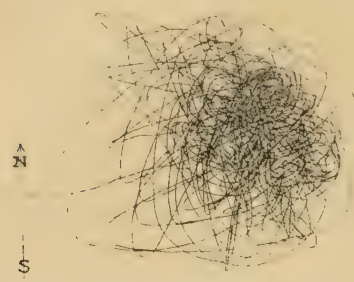

Fig. 41. - Registro de um seismographo mostrando os movimentos lateraes de um ponto sobre a superficie da terra durante um terremoto no Japão.

foi apenas de um pouco mais que cinco millimetros. E' evidente portanto que a destruição causada pelos lerremotos não é devida tanto ao deslocamento como á duração do tempo que leva no movimento de um ponto para outro.

A figura junta (figura 11) mostra o registro de $\mathrm{mm}$ sismographo feito durante um terremoto no Japão.

A figura 42 mostra uma fenda e uma pequena falha produzidas na occasião de um terremoto em Arizona, America do Norte. Os terrores dos terre-

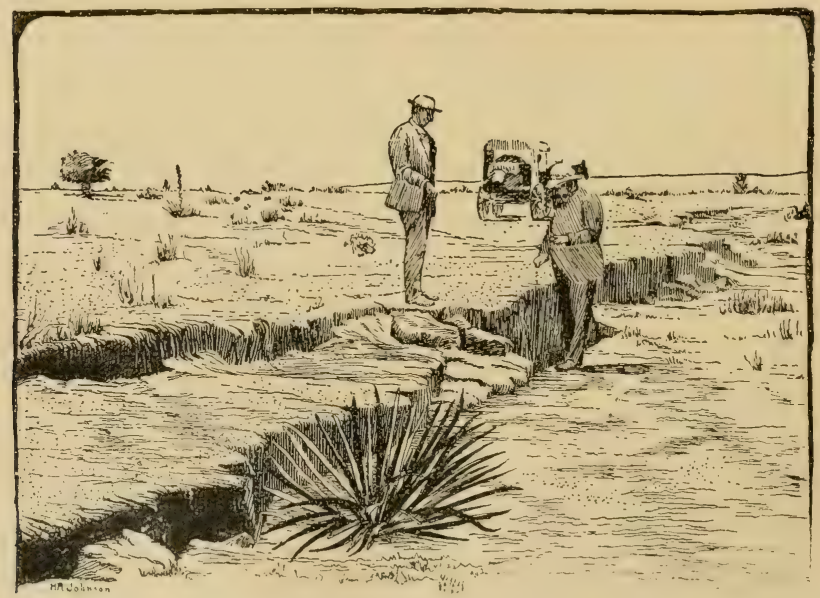

Fig. 42. - Uma fenda e falha produzidas durante um terremoto em Arizona, na America do Norte.

motos, para a lumanidade são devidos em parte ao lacto que nio ha meios de predizer a occasião ou natureza dos seus abalos e 
parcialmente á instabilidade temporaria da terra que é sempre considerada a mais estavel das cousas, e em grande parte á nossa ignorancia das causas e origens dos abalos. 0 abalo produzido pela passagem de um carro pesato, por uma locomotiva, e o trepidar de um vapor em marchia, nio espantam a ninguem, embora estes abalos sıjam muito parecilos com us terremotos. Comtudo nenhuma coragem ou pericia pode evitar os terremotos. A destruiçio causada por occasiào diss terremotos, todavia, nào é sempre o resultado directo do choque ou mesuro do desabamento dos edificios. Por occasião do grande terremoto de Lisbóa que teve lugar a 1 de Novembro de $173 \ddot{3}, 40,000$ pessoas, conforme dizem, pereceram. Esta grande perda de vida foi causadas por uma grande onda ou vaga de translação doze metros mais alta que " nivel das maiores marés, que varreu o rio Tejo e submergiu as pessoas que tinham-se accumulado sobre os caes por segurança.

Para dar uma idea mais ou menos exacta das intensidades ou violencias de terremotos, os geologos inventaram diversas escalas de intensidade. A mais usadit é a chamada Rossi-Forel que aqui segue.

\section{Escala Rossi=Forel de intensidades de terremotos.}

I. - Tremor microsismico : registrado por um unico sismographo, ou por sismographos do mesmo modelo, mas nào por diversos sismographos de differentes modelos; o tremor notado por observadores peritos.

II. - Tremor extremamente fraco: registrado por sismographos de diversos modelos; notado por um pequeno numero de pessóas em repouso.

III. - Tremor muito fraco: notado por diversas pessôas em repouso; de força sufficiente para poder determinar a duração do tremor.

IV. - Tremor fraco: sentido por pessoas em movimento; deslucação de objectos muvediços, portas, janellas; as vigas das casas estalĩo.

V. - Tremor de intensidade moderada: sentido por todo o mundo) deslocaçio de mobilia, tocando as campainhas suspensas. 
VI. - Tremor algum tanto forle: accordando pessoas que dormem ; as campainhas tocam, oscillação de lampadarios suspensos ; os relogios param; as arvores tremem; algumas pessoas assustadas fogem das casas.

VII. - Tremor forte : transtôrno de objectos movediços; quada de estuque; is sinos tocam; panicn geral sem estragos de casas.

VIII. - Tremor muito forte: queda de chaminés; fendas nas paredes das casas.

IX. - Tremor extremamente forte : destruicào parcial ou completa de alguns edificios.

X. - Tremor da intensidade extrema: grande desastre; ruinas; deslocarão das camadas das rochas; abrem-se fendas no chão: as rochas cahem das montanhas.

Embora nenhuma parte da terra esteja inteiramente livre de terremotos o Brasil é talvez menos perturbado que qualquer ourar poreão do gloho de igual tamanho. A occurrencia de falhas e de super ficies polidas pelo attrito (slickensides) nas rochas mostram que nas eras geologicas passadas houve terremotos no Brasil, porém elles são agora de rara occurrencia e de pouca importancia.

0 numero de todos os terremotos registrados no Brasil até o anno 1912 rĩ̃o passa de uns 60, e estes de uma intensidade tiio baixa que nunca chegaram a ser catastrophes ou de fazer estragos.

Os tremores que talvez causaram maior commorio no Brasil nestes ultimos annos foram os do anno 1901 na vizinhanega de Bom successo no estado de Minas Geraes. Mas além de assustar o povo năi fizeram damno algum (1).

Na costa do Pacifico na America do Sul ao contrario existem muitos lugares onde raramente passam-se tres dias sem que hajam abalos.

(1) Alvaro A. de Silveira. Os tremores de terro em Bom Successo, Mincts Gerrles. Bello Horizonte, 1906.

J. C. Bramner. Terremotos no Brosil. Bulletin of the Seirmological Society of America, II, 105.117. Stanford University, 191:. 
Segue a lista dos tremores notados no Brasil com as intensidades conforme á escala de Rossi-Forel (vede pag. 1506).

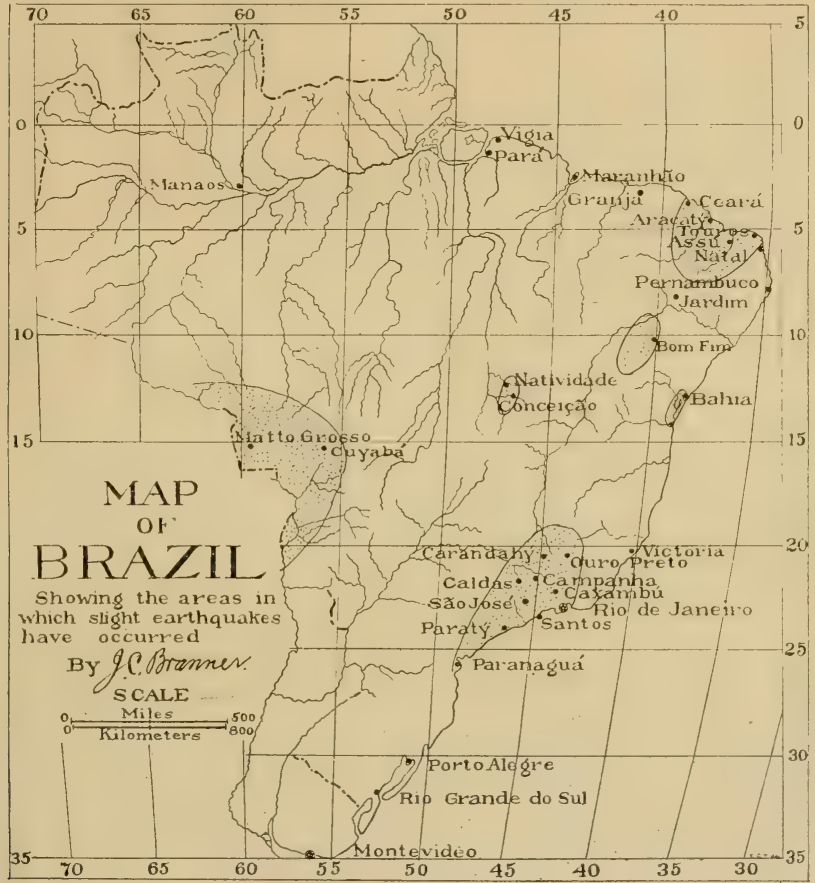

Fig. 43. - Esboço do Brasil mostrando as areas de tremores pequenos.

\section{Mudanças de nivel.}

As mudanças de nivel são devidas, pelo menos em parte, a causas ligadas con a condição interna da terra. Ellas são algumas vezus bruscas e algumas vezes muito lentas e uniformes. Essas mudanças são comnummente julgadas pelas relações da terra com " nivel médiv do oceano. Ellas podem dar-se ou como elevaçies ou como depressũes. 
TREMORES DE TERRA NO BRASIL

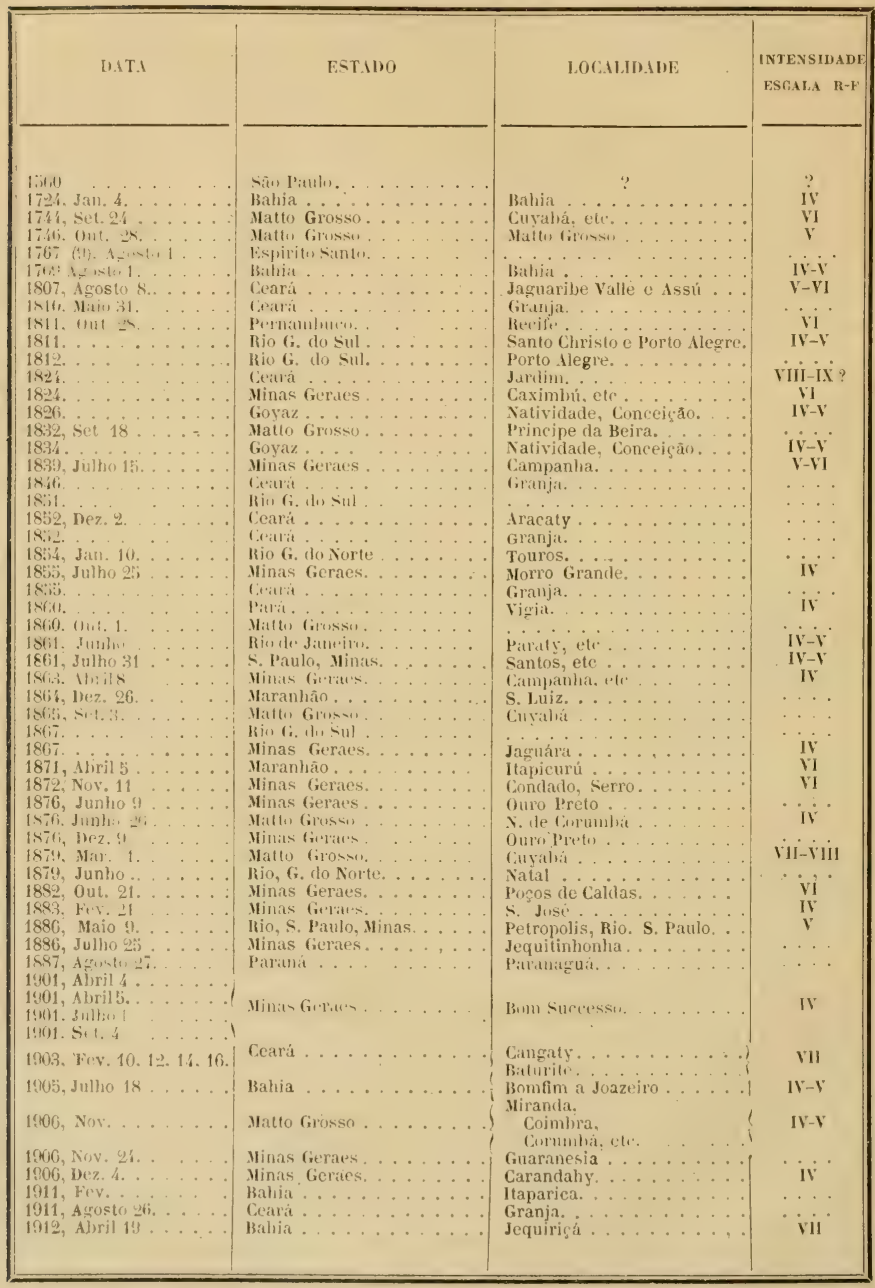




\section{Provas de elevação.}

As provas de elevação são de cinco naturezas.

I. - Os organismos marinhos mortos, ou os seus. réstos, em terra secca.

II. - 0 trabalho dos organismos marinhos em terra secea.

III. - 0 vestigio do trabalho das ondas nas costas acima do alcance actual dellas.

IV. - Os registros humanos.

V. - As superficies erodidas de depositos sedimentares marinhos.

I. Os organismos marinhos mortos sobre a terra. - 0 s polypos coraligenos são organismos que só porlem viver n'agnui salgada clara de mares quentes. Esses pulypos, quando vivus, secretam e depositam esqueletos de carbonato de cal. Vivem muitas vezes en colonias enormes que, em circumstancias favoraveis, formam extensos recifes de coral.

Algumas vezes acontece que reciles de coral morto siil achados füra d'agua. A sul e a leste de Iombara na costa oriental dia Africa existem barrancos e um planalto de taes coraes que tem sido levantado do fundo dos mares. Na ilha de Cuba os recifes de coral tém emalguns casos sido levantados tresentos e trinta e cinco metros acima do nivel do oceano. Na costa do Perú o professor Alexandre Agassiz encontruu recifes de coral na encosta das montanhas na altura de vitocentus e oitenta metros acima do mar (1).

Somos obrigados a considerar esses recifes de coral morto como provas inquestionaveis da mudança das relarões da terra e d'agua nos logares onde elles se apresentam. Elles devem ter-se originadu debaixu do oceano e ter sido levantados acima do seu nivel.

Dr. Williams notou na ilha Trindade um recife de coral que está

(1) Alexander Agassiz. Letters and recollections, pag. 140. Boston, 1913. 
cerca de meio metro fóra d'agua na occasicio da baixa-maré que indica uma pequena elevação daquella ilha (1).

Em roda da Bahia em muitos lugares existem extensos depositos le conchas marinhas que as marés altas nunca mais alcanęam. Estas

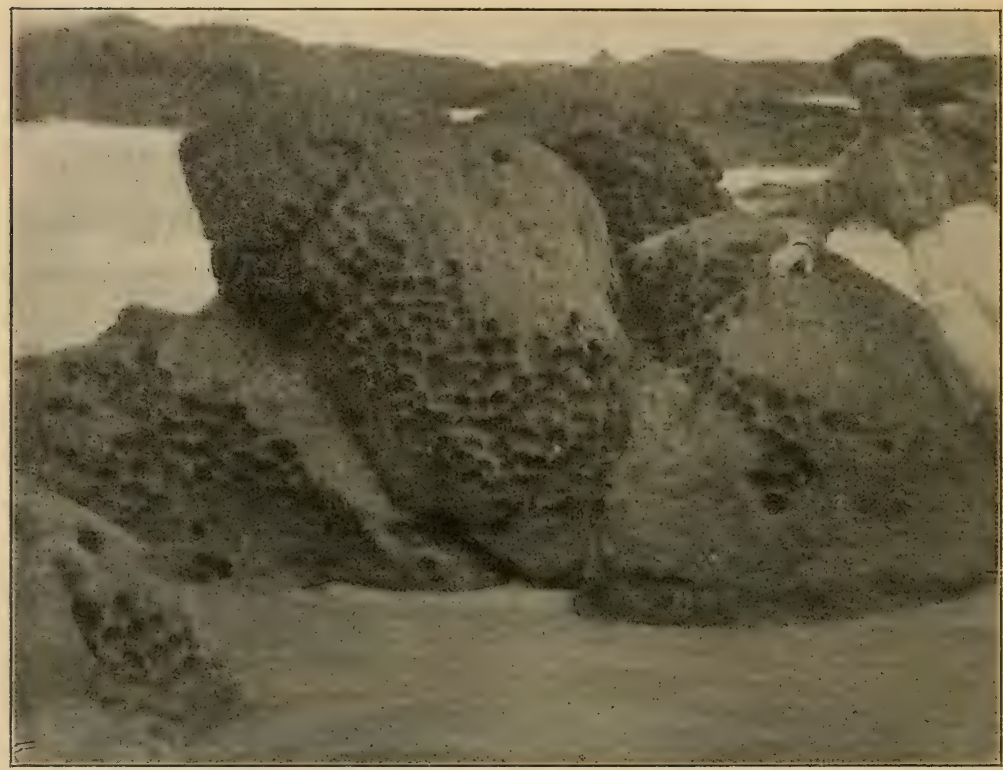

Fig. 44. - Blocos de trachyte cavados por ouriços do mar na costa de Pernambuco, num lugar chamado Pedras Pretas, ao norte de Cabo Santo Agostinho.

camadas foram depositadas abaixo do mar, e a elevaçio da regiào transformou-as em terra firme. No rio Itapicurú no estado da Bahia, entre Missio e Sipo, e de cinco a oito metros acima daqualle rio, ha uma camada de ronchas marinhas da espiessura de un metro. Aquelle

(1) H. E. Williams. Notas sobre a geologici da itha da Trindade. Serviço Geologico do Brasil, inedito. 
deposito fica pelo menos sessenta metros acima do nivel da maré. É claro que aquellas camadas foram depositadas ali quando o mar cobria aquelle lugar'; é tambem claro que aquella regiào foi elevada sessenta metros, pelo menos, depois do tempo em que o mar a cobria.

II. O trabalho dos organismos marinhos na terra. - A poucas milhas ao norte do cabo de Santo Agostinho em Pedras Pretas as rochas proximas á praia são esburacadas pelos ourięos do mar. Esses buracos estão $\mathrm{cm}$ tal altura acima da maré média, que é agora impossivel aos ouriços do mar viverem nelles. Embora a elevação aqui indicada seja somente um ou dous metros, nào é menos uma elevação sensivel.

A figura 44 reproduzida de uma photographia tirada em 1899 mostra alguns daquelles buracos. Dizem que em alguns lugares na bahia do Rio de Janeiro existem buracos semelhantes feitos nas rochas de granito pelos ouriȩos do mar.

Em Marahú uns 115 kilometros ao sul da Bahia, Gonzaga de Campos tem notado blocos de rochas calcareas com as marcas do antigo nivel da prèa-mar e com ostras, que ficam de dois a tres metros mais altas do que a linha a que actualmente attinge a maior maré (1).

Na Victoria, estado do Espirito Santo, uma linha horisontal proxima á base do pico de granito "Morro Primeiro de Março, dous metros acima do nivel d'agua mostra uma elevaçào da costa. Este sulco é provavelmente causado pelo primitivo crescimento naquella linha de algas e outros organismos. A figura junta (fig. 4\%), foi reproduzida de uma photographia daquella linha.

Um exemplo notavel da mesma natureza é o velho templo de Jupiter Serapis ao norte de Puzzuoli perto de Napoles na Italia. Naquelle lugar existem tres columnas do pedra, partes das ruinas de um antigo templo romano. Essas columnas são perfuradas até a altura de seis metros com furos feitos por uma especie de Lithodomus, um mollusco furador, que vive no mar Mediterraneo. E' evidente que o terreno onde

(1) Gonzaga de Campos. Reconhecimento geologico na bacia do Rio Marchi. pag. 3. S. Paulo, 1902. 
este templo agora existe ahateu-se depois de construido o templo e que conscrvou-se debaixo d'agua bastante tempo para os molluscos fiazerem seus luros, sendo subsequentemente elevado í sua posição actual.

Ao longo da costa da California na America do Norte cncontra-ses uma concha furadora semelhante, uma especic de Pholas, em buracos cavados nas rochas das praias em uma elevação de proximamente seiscentos metros acima do nivel actual do oceano. E' evidente que as

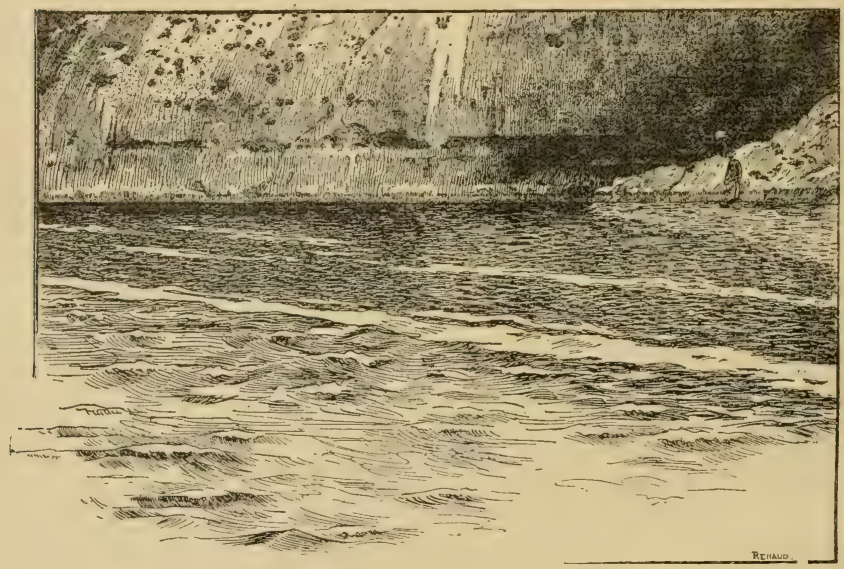

Fig. 45. - Um sulco horizontal na base do morro Primeiro de Narço na Victoria, estado do Lispirito Santo. O sulco acha-se a cerca de dois metros acima do nivel da maré. De uma photographia pelo autor.

rochas onde esses buracos e conchas agora se encontram estavam em algum tempo, no passado, debaixo d'agua do Oceano Pacifico. Muitos exemplos de natureza semelhante podiam ser citados.

\section{O trabalho das ondas além de seu alcance actual.}

— lá se referiu que os curtes feitos pelas ondas ao longo das linhas da costa apresentam certos caracteristicos topographicos pelos quaes porlem ser identificados mesmo depois do desapparecimento das agua: que os formaram. Emquanto as ondas escavam a terra os detritos var- 
ridos das praias formam depositos submarinhos, taes como deltas, que são igualmente reconheciveis.

Na costa do Brasil existem em diversos lugares terraços formados d'esta maneira. Um destes é no lugar chamado Opaba, um kilometro ao norte de Ilheos; outro é na Vellosa uns tres kilometros ao norte de Ilheos no estado da Bahia; outro se vé ao norte de ponta de Pedras no estado de Pernambuco. Sem duvida muitos outros existem ao longi) da costa nordeste do Brasil, mas sendi) geralmente cobertos de mata, não se reconhecem facilmente (1).

Uns trinta kilometros ao nordeste da cidade de Santos na vizinhança de Bertioga, ha uma praia elevada na Ponta da Enseada (2). Esta praia ou terraço é de arenito, e fica uns quatro ou cinco metros acima das marés mais altas. As camadas contem conchas semelhantes ás das praias actuaes.

Alguns dos fiordes da Noruega apresentam terracos semelhantes mostrando que arquella costa tem tambem subido aos saltos.

IV. Os registros humanos. - Dentro do periodo humano haviam elevações da terra de que existem registros dignos de confiança. Na Scandinavia tem sido estabelecido pontos de referencia, e em periodos determinados linhas de niveis from corridas para determinar as mudanças de nivel. Achou-se que a parte do norte da Scandinavia eleva-se em uma marcha maxima, de 1.32 a 1.82 metros por seculo.

V. As superficies erodidas de sedimentos marinhos. E' evidente que as camadas sedimentarias que contém abundancia de restos fosseis de organismos marinhos só se podiam formar no fundo do mar. Em muitos casos encontram-se taes camadas marinhas que mostram ter soffrido erosão na superficie. Essas superficies erodidas são consideradas como prova concludente de uma condição terrestre, e devem ter sido produzidas depois que as camadas marinhas foram elevadas do fundo das aguas em que foram depositadas.

(1) J. C. Branner. The stone reefs of Bravil, pags. 153-160. Cambridge, 1901.

(2) Fé, H. E. Williams. 


\section{Evidencias de depressão.}

As provas de depressão da terra são mais difficeis de observar-se porque a superficie da terra vai para baixo d'agua e fica assim occulta. Nào obstante ella é algumas vezes reerguida, como no caso do templo de Jupiter Serapis já mencionado onde a prova de uma depressão anterior é visivel e concludente. As provas da depressão da crosta da terra são as seguintes :

1. - As plantas terrestres em lugares cobertos por depositos marinhos.

II. - Os coraes abaixo do nivel em que os polypos coraligenos podem viver.

III. - Os valles submergidos.

IV. - A distribuição de plantas e animaes.

V. - Os registros humanos.

VI. - A espessura dos sedimentos.

VII. - As falhas com os lados levantados bem erodidos.

VIII. - A larga distribuição de conglomerados graúdos.

Essas classes de prova serão consideradas na ordem mencionada.

\section{1. - As plantas terrestres cobertas por depositos} marinhos. - E' bem sabido que a turfá é le origem vegetal e que cresce solore a terra - nunca abaixo do nivel da maré. Na Bahia de Fundy em Nova Escossia existe, agora, turfa abaixo do nivel da maré. Ella deve ter sido formada subre a superficie da terra neste lugar quando achava-se em um nivel superior ao actual e dere ter sido levada para baixo pelo rebaixamento da terra.

Em Nova Jersey na America do Norte tocos de pinheiros subre a terra são agora alcançados pela agua do mar, porém o pinheiru nào póde viver ao alcance d'agua salgada; no mesmo estado são encontradus, agora, tocos abaixo do nivel do mar. Evidentemente a terra nesses lugares afundou-se depois que as arvores cresceram.

Na Pensylvania encontram-se fosseis de origem marinha em rochas que cobrem camadas de carvão. Porém, como o carvão é de origem vegetal, a terra deve ter descido abaixo do mar depois que as 
camadas de carvão roram formadas de modo a permittir a deposição acima dellas de camadas contendo fosseis marinhos.
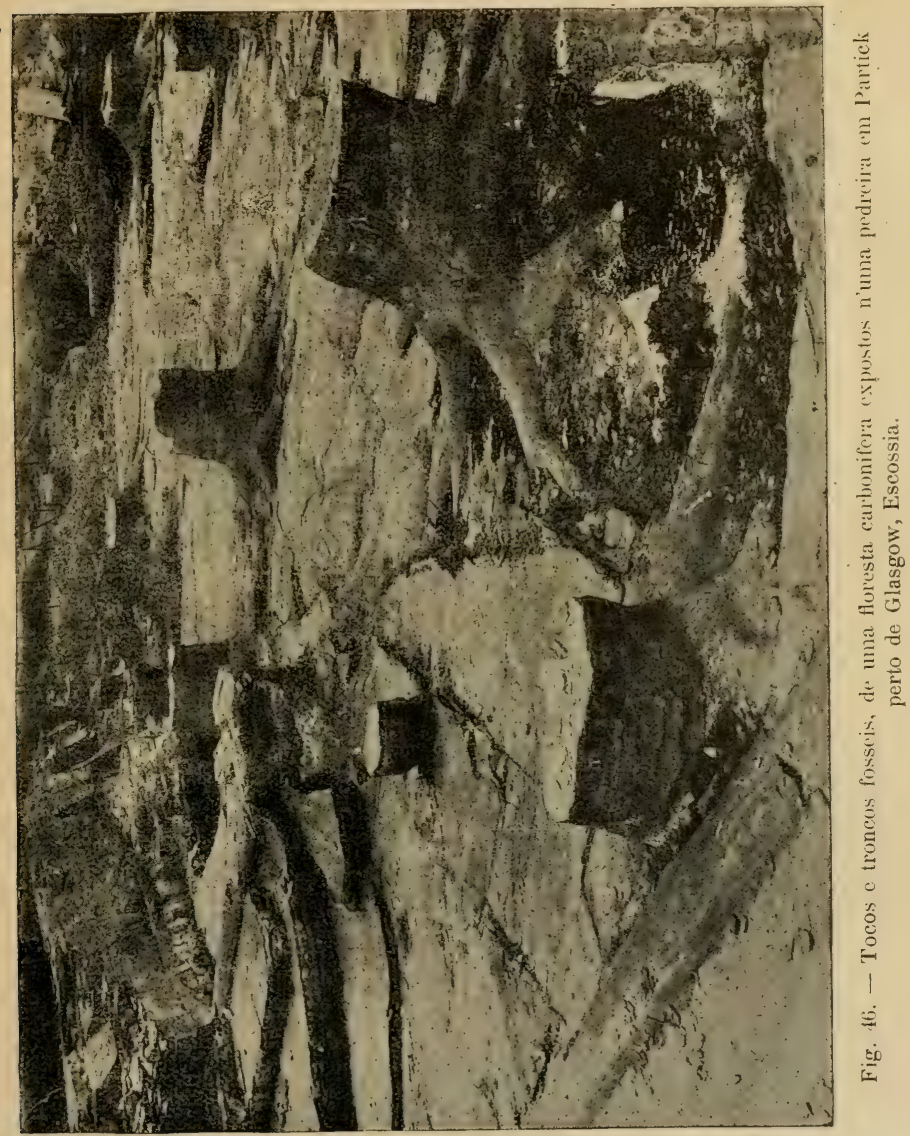

Nas costas do Perú o carvão tem sido minerado abaixo do mar; este carvão deve tambem ter-se originado sobre a terra, e sub- 
sequentemente por uma depressão d'ella foi levado abaixis do nivel do mar.

\section{Os coraes abaixo do nivel em que elles podem} viver. - Os coraes formadores de recifes não podem desenvolver-se n'agua mais profunda do que quarenta e seis metros. Os poços abertos sobre os recifes de coral ao nordeste da Australia em 1897 penetram em coral até uma profundidade de duzentos e treze metros. Esta profundidade só teria sido possivel pelo crescimento dos coraes dentro do limite de quarenta e seis metros e pelo abaixamento subsequente na importancia de cento e sessenta e sete metros pelo menos. Neste caso a depressão da superficie da terra tem sido cento e sessenta e sete metros ou mais.

III. Os valles submergidos. - Certas formas de valles são produzidas pela erosão da terra. Se esses valles estivessem proximos do oceano e a terra se afundasse, os fundos dos valles passariam abaixo d'agua onde elles se transformariam em bahias ou estuarios. Ao longo de muitas costas taes depressões tèm produzido um litoral recortado com muitos portos. Os compridos e delgados fiordes na Noruega são apenas as extremidades inferiores de valles que foram levados abaixo do oceano por um abaixamento da terra. As bahias do Rio de Janeiro, Bahia, e Santos foram produzidas pela depressão abaixo do oceano de valles proximos á costa. Em Santos as extremidades superiores de muitos dos braços originaes daquella bahia foram aterrados pelos sedimentos provenientes da terra lançados nelles. Os lagos do estado do Alagòas, Lagòa Manguaba, Lagòa do Norte, Poxim e Iiquiá, são as extremidades inferiores de valles compridos que afundaram-se abaixo do nivel do mar de modo a formar bahias, e essas bahias tèm tido suas boccas quasi fechatas pelas areias arremessadas sobre ellas pelas ondas.

Pouco depois do abaixamento da costa do Brasil havia muito mais portos do que existem agora; porém no correr do tempo «ses valles rebaixados ou submergidos tèm sido parcial ou completament? aterrados com sedimentos. Nuitos, talvez a maior parte, dos mangues das costas do Brasil se formaram sobre lodos que aterraram comple- 
tamente valles submergidos. Na Parahyba do Norte um desses valles submergidos foi sondaclo no ponto onde elle foi cruzado pela estrada de ferro entre a cidade e Cabedello. Nesse logar elle tem 11.7 metros de profundidade mostrando uma depressão de pelo menos aquella quantidade (1) (Figura 47). E' muito provavel que naquella mesma vizinhança existem outros e mais profundos valles submergidos.

Nuitas vezes acontece que as sondagens no mar têm descoberto alguns desses valles, ou gargantas submergidas, que estendem-se por muitos kilometros fóra da costa. Em Nova York, por exemplo, verifi-

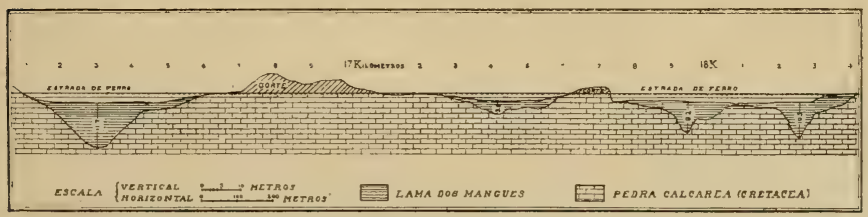

Fig. 47. - Perfil ao longo da Estrada de Ferro Conde d'Eu, na Parahyba do Norte. A lama dos mangues encheu os canaes que eram cortados na pedra calcarea cretacea quando a terra estava num nivel mais alto.

cou-se que o canal do Rio Hudson estende-se muitos kilometros além da bocea actual daquelle rio (2). Na costa do Pacifico na America do Norte as sondagens tèm mostrado a existencia de muitos valles profundos submergidos que se ligam com o antigo systema de drenagem da. terra vizinha (3).

A parte sul da America do Sul desde Terra do Fögo até Ancud na costa occidental, e incluindo o estreito de Magalhães, é uma região de depressão onde us valles perto da costa tornaram-se canaes e estreitos (fiords). Sondagens no Atlantico ao largo dos Abrolhos mos-

(1) J. C. Branner. The stone reefs of Brawil, pags. 129-132. Cambridge, 1904.

J. C. Branner. Geology of northeast Brawil. Bultetin of the Geological Society of America, vol. Vill, pags. 51-52. Rochester, 1902.

(2) Lindenkohl. American Journal of Science, 1885, CXXIX, 475-480.

(3) George Davidson. The submerged oalleys of the coctst of Californid. Proceedings California Academy of Sciences, 3rd. series, Geology, I, pags. 73-101. San Francisco, 1897. 
tram que a costa desta parte do Brasil antigamente ficava fóra d'agua, e que foi cortada profundamente por rios.

IV. A distribuição das plantas e dos animaes. - I pequena ilha de Santa Rosa na costa sul da California está a quarenta e cinco kilometros do continente do qual se acha separado por 110 canal de duzentos e quatorze metros de profundidade em sua parte mais raza. Restos de elephantes que abundam ém condição fossilisada na terra firme tèm sido encontrados tambem naquella pequena ilha. E' evidente que os elephantes nunca teriam atravessado do continente para a ilha desde que esta tornou-se ilha; elles devem ter vivido alli quando a ilha fazia parte da terra firme, e a separação foi causada pelat depressão de toda a area, que levou abaixo d'agua as terras baixas intermediarias, deixando emerso o topo da montanha que hoje fórma a ilha de Santa Rosa.

Da mesma maneira a presença de elephantes fosseis na ilha de Sicilia prova que aquella ilha antigamente estava unida ao continente africano.

A distribuição dos animaes nas ilhas do Oceano Pacifico é de grande interesse sob este ponto de vista (1).

Os animaes encontrados como fosseis nas ilhas da Gran Bretunhi e os achados no continente da Europa mostram que aquellas ilhas formaram anteriormente uma parte do continente. A sua separaça actua foi causada por uma depressão que submergiu as terras baixas intermediarias.

Certos animaes encontrados na America do Sul, não só viventes como fosseis, mostram que aquelle continente tinha antigamente ligação terrestre com a Nova Zelandia, Australia e Africa. A separaçio foi causada por uma depressão que cobriu com agua as terras entre os actuaes continentes (2).

Tem-se verificado que certos rios separados que desaguam nu

(1) A. R. Wallace. Island life. London, 1880.

A. R. Wallace. Malay archipelago. London, 1894.

(2) A. E. Ortmann. Reports of the Princeton University expedition to Patrgonia, rol. IV. Part. II, Plate 39. Prinecton 190\%. 
Oceano Pacifico ao longo da costa da California tèm faunas eguaes de peixes, emquanto outros tèm seus peixes inteiramente differentes. Estas particularidades são devidas ao facto que a costa anteriormente era mais alta e que naquelle tempo alguns daquelles rios que são ágora separados uniam-se antes de chegar ao mar. Por uma depressão da terra a juncção dos rios foi levada abaixo do mar, e os peixes que anteriormente misturavam-se livremente foram assim separados, porque elles são de especies que não pódem entrar no mar para passar de un curso d'agua para outro.

V. Registros humanos. - Na Scania, uma cidade ao sul da Suecia, a depressão tem sido tão grande que certas ruas estão agora debaixo d'agua.

Perto da bocea do rio Mississippi existe um edificio construido no anno de 1690, mais ou menos. Em 1877 a terra nos arredores tinha abatido de modo que a soleira da porta do edificio estava trez metros abaixo do nivel d'agua. Em 1896 foi verificado que o abaixamento continuava na mesma marcha, isto é, 1.52 centimetros por anno. Grandes extensões de terra nas proximidades da bocca do Mississippi têm sido abandonadas por causa da invasão d'agua do mar, devida ao abaixamento da terra (1).

VI. A espessura das rochas sedimentarias. - Já foi mostrado que as camadas sedimentarias são depositadas proximo ás linhas da costa e em aguas comparativamente razas. A espessura dos sedimentos que é possivel depositar em qualquer mar é necessariamente limitada pela sua profundidade. No estado de Arkansas na America do Norte os sedimentos carboniferos por si só tèm uma espessura de sete mil duzentos e quarenta e oito metros; e essas camadas pela maior parte apresentam os caracteristicos de depositos em pantanos ou lagos de agua doce com certa uniformidade de caracter por toda a parte, se bem que incidentemente se encontrem depositos marinhos intercallados entre elles. Estes factos suggerem a hypothese que a região sobre

(1) E. L. Corthell, o delta do rio Mississippi. National, Geographic Magazine, VIII, pags, 352-353. Washington, 1897. 
a qual essas camadas se apresentam afundou-se proximamente com a mesma marcha que os sedimentos accumularam-se, e que de vez $\mathrm{cm}$ quando esteve abaixo do nivel do mar. Estas camadas foram subsequentemente elevadas até á sua posição actual.

\section{As falhas com grandes deslocamentos verticaes. -} No estado de Alabama, na America do Norte, uma falha passa atravez de camadas de carvão, e estas tèm sido abaixadas até ficarem contrapostas a rochas que estiveram originariamente a 3,000 metros ou mais abaixo das camadas de carvão. E' evidente que, n'um tal caso, ou o lado com o carvão se afundou pelo menos tres mil metros, ou que 0 lado opposto se elevou daquella quantidade. Como, porém, o carvão fíi levado abaixo do nivel do inar, não ha duvida que grande parte desta falha foi causada por uma depressão.

\section{A larga distribuição de conglomerados graúdos.} - Os sedimentos marinhos pesados são sempre depositados nas praias ou proximo dellas onde as correntes sào fortes. Porém encontramos em alguns casos sedimentos pesados, taes como conglomerados, espalhados sobre enormes areas. Tal distribuiçâo só poderia ser produziłla por um rebaixamento gradual da terra fazendo com que grandes areas passem por uma condiçãn de praia. Sob estas condięões os sedimentos pesados seriam depositados ao longo de uma linha parallela á praia; porém á medida que a depressão continuava os materiaes conglomeraticos seguiram a linha invasora da costa sobre uma extensa area. $\Lambda$ existencia de conglomerados sobre grandes areas é portanto ronsiderada como uma prova de depressão.

Distribuição de mudanças do nivel. - Os casos de elevavaçio e depressão da superficie da terra que tèm sido mencionatos são apenas exemplos do que acontece, em um tempo ou em outro, sobre toda a superficie da terra. Acontece que essas mudanȩas proseguem mais rapidamente em um lugar que em outro, e que muitas rezes pode haver elevição em um ponto em quanto ha depressão cm outro. Parece comtudo que nenhuma parte da crosla da terra estí perfeitamente estacionaria por muito tempo. En todos os continentes achamos 
grandes areas cobertas com sedimentos espessos que foram dopositados abaixo do nivel do mar.

A marcha das mudanças do nivel. - Como já ficou dito a marha das mudan ras de nivel varia enormemente. No anno de 1871 recifes de coraes foram elevados tão subitamente na ilha de São Thomaz, Antilhas, que os polypos morreram sobre a praia posta em seceo. Darwin diz que um baixio rochoso proximo á Ilha de Santa Mlaria nit costa do Chile, perto de Concepcion, foi levantado tão subitamente em 1834 que os mexilhòes morreram onde estavam presos á rocha (1).

Por observaçũes dirertas verificon-se que a costa da Noruega aı norte de Stockholm está subindo com uma marcha de 1.52 a 1.82 metrus por seculo. A costa da New Jersey na America do Norte está afundando na marcha de sessenta e um centimetros por seculo. Recentes linhas de nivelamento de precisão corridas nas vizinhanças dos grandes lagos da America do Norte demonstram que a superficie da terra naquella regirio está sendo pendida para o lado de oéste na razão de 0.128 metros por seculo em uma distancia de cento e sessenta kilometrus. Na bocea (1o rio Mississippi está tendo lugar um abaixamento na marcha de 1.52 metros por seculo,

\section{As causas de elevação e depressão.}

P'ara explicar as mudanças de nivel na superficie da terra, ou os movimentos de elevaçio e depressão, tem-se recorrido a quatro classes de phenomenos.

0 aquecimento e restriamento das rochas causam contraç̧ão e expansão, e acredita-se que isto por si só é capaz de causar muitas das mudanças de elevação e de deprressão quando grandes areas e grandes profundidades de rochas sio envolvidas nestas mudanças de temperatura.

A theoria da isostasia (2), ou o ajustamento da crosta da terra para

(1) Charles Darwin, Geological observations, 2d. ed., pag. 216.

(2) J.F. Hayford. The geodetic evidence of isostacy. Washington, Acad. Sc., VIII, 25-40. Washington, 1906; Journal of Geology, XX, 526-578. Sept.-Oct: 1912. 
a carga de rocha que soffre deslocação sobre ella, tem sido apresentada por alguns geologos como a causa destes movimentos. A idèa é q̨ue se enormes massas de rochas são deslucadas de uma parte da terra para outra, o lugar do qual a carga é tirada deve subir e arquelle para o qual é transferida deve-se afundar. 0 afundamento da regiào nas proximidades da bocca do rio Mississipi é explicado conforme esta theoria pelo facto que o lodo transportado para aquelle rio sit-se accumulando em enormes quantidades no fundo do golpho do Mexicu nas vizinhanças immediatas da bocca do rio.

As mudanças da condição do interior da terra tèm sido apresentadas como um contribuinte da mudança de nivel. E' sabido que certas rochas contrahem-se pela crystalisação. Se taes rochas formavam uma parte consideravel da crosta da terra, nós podemos razoavelmente esperar mudanças de nivel causadas pela crystalisação de taes camadas.

A mudanga de volume pela perda d'agua, ar ou gazes é tambem. capaz de produzir mudança de nivel, especialmente depressões.

$\Lambda$ absorpção de agua ou gaz pelos mineraes ou pelas rochas, e o aquecimento ou esfriamento causando incremento ou diminuição de volume são foręas capazes de produzir elevação ou depressão da superficie da terra.

Nos casos que acabamos de considerar, apenas empuxos para cima e para baixo foram tomados em conta. As mudanças de nive podem-se effectuar, e effectivamente se effectuam, pela acção de quaesquer empuxos ou esforços, seja qual fôr a sua origem, que produzam dobras ou falhas nas rochas. E um esfore que dobra as camadas é capaz de produzir ambas as mudanças de nivel; isto é, tanto elevaçio como depressão, até no mesmo tempo. 0 mesmo se verifica para as falhas, podendo o empuxo que as produz elevar as rochas de um lado emquanto descem no lado opposto. Não se deve suppôr portantu que todas as elevações são devidas a empuxos directos de dentro e em angulo recto á crosta da terra. 


\section{Agentes organicos, ou trabalhos dos organismos na geologia.}

Os agentes organicos em suas relações com a geologia podem ser destructivos, protectivos ou constructivos.

1. Agentes organicos $e$ destructiuos são aquelles que produzem ou apressam a decomposição das rochas e mineraes.

2. Agentes protectivos são aquelles que protegem as rochas, taes como algas, vermes, e mexilhões que protegem as rochas das praias contra a força das ondas ;

3. Agentes constructivos são aquelles que formam rochas novas, 'omo a turfa que se forma de plantas, e calcareos que se formam dos restos de animaes de esqueletos calcareos.

\section{I. - 0 s agentes organicos destructivos.}

\section{PLANTAS}

A decomposição de plantas e de animaes produz acidos humicos.

Nos processos de deterioração todas as plantas e animaes vénr debaixo deste titulo, porque mais cedo ou mais tarde todos os organismos morrem e decompõem-se, e na decomposição elles produzem acido humico e outros acidos que atacam os mineraes das rochas. Nas regiōes tropicaes o crescimento e a deterioração das plantas são extremamente rapidos, sendo correspondentemente grande a quantidade daquelles acidos em taes regiões.

Na parte do sul da Florida os cursos d'agua são tão carregados com acidos organicos produzidos pela decomposição da vegetação que suas margens calcareas são notavelmente solapadas pelo poder dissolvente da agua (1).

(1) N.-S. Shaler. The topography of Florida. Bulletin of the Museum of Comparatice Zoology, XVI, n. 7, pags. 144-145. 
As rui:es das plantus atacam as rochas tanto chimicamente, cumo mechanicamente. Em uma experiencia feita para determinar o efleito

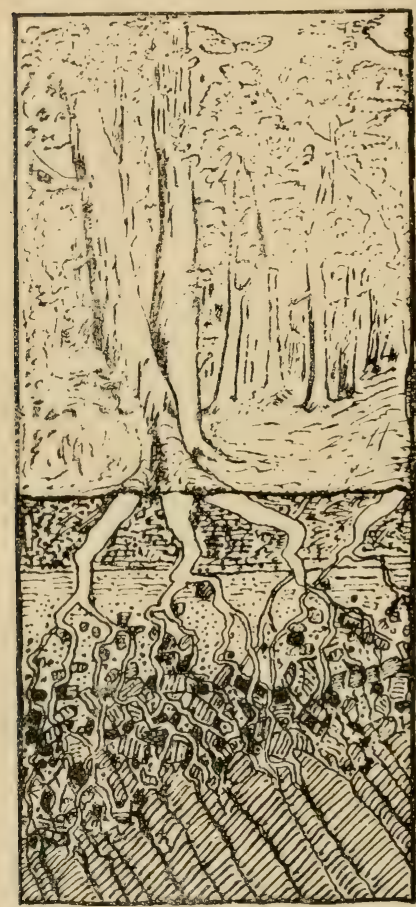
de plantas penetrando o solo e contribuindo para a fragmentaçāo de rochas duras.
Fig. 48. - Secção mostrando as raizes

chimico das raizes das plantas sobre certos mineraes, alguns annos atraz, um botanico pôz plantas novas n'um vaso tendo no fundo uma placa de marmore polida. Depois das raizes das plantas terem alcançado o fundo do vaso, a placa de marmore foi retirada e viu-se que estava coberta com linhas embaçadas de corrosão em todos os pontos onde as radiculas em crescimento tocavam-n'a (1). Evidentemente, pois onde as pontas das raizes em crescimento ficam em contacto com rochas e mineraes, alguma parte da materia mineral é decomposta e absorvida pela planta.

A acęão mechanica das raizes das plantas é familiar a todos. Plantas novas que nascem nas fendas das rochas separam-n'as á medida que crescem. Nas regiões do solo pouco espesso as raizes frequentemente penetram abaixo das camadas de rocha e á proporção que crescem, essäs camadas são erguidas das camadas inferiores. Quando as rochas apresentam camadas ou juntas verticaes as raizes penetram nas fendas e com o crescimento separam e fragmentam as rochas (Fig. 48).

(1) A. D. Hall. The soleent action of roots. Science Progress, London 1906, I, $51-57$. 
Nas regiōes semi-aridas as raizes das plantas penetram a uma profundidade muito maior. Em todos estes casos a tendencia das raizes das plantas é quebrar as rochas e os mineraes e absorvel-os.

A profundidade alcançada pelas raizes das plantas é maior do que provavelmente se suppòe, se bem que essa profundidade varia muito com as especies. Raizes de cerca de meia pollegada de diametro tèm sido verificado penetrarem no solo e nas rochas até á profundidade de vinte metros.

Além dessa influencia mechanica as raizes fornecem caminhos pelos quaes as aguas da superficie penetram mais promptamente na terra. Quando os engenheiros constroem reprezas permanentes solre fundarões de solo elles têm o cuidado de tirar todas as raizes das arvores de modo a evitar que a agua, seguindo-as atravez das funda¿ões, as ponha em perigo por causa de taes canaes subterraneos. Além disso todas as raizes, deteriorando-se, contribuem com os acidos organicos que atacam as rochas.

\section{ANIMAES}

Os animaes cavadores são agentes geologicos de importancia em todas as regiñes. Darwin escreveu um trabalho muito interessante dando os resultados dos seus estudus sobre o trabalho das minhocas, ou vermes da terra. Elle mostrou que estes humildes animaes são agentes geologicos importantes e muito activos. Nas regiòes tropicaes as formigas são excessivamente abundantes e penetram no solo sobre extensas areas e em profundidade de mais de tres metros. No Brasil todos são familiares com a destruição causada pelocupim e formigaem varias especies de plantações.

A vegetação é levada para dentro dos tunneis feitos pelasformigas, onde deteriora-se e contribue com acidos organicos para atacarem as ruchas e mineraes do solo, emquanto os proprios tunneis expōem a terra a uma circulação mais rapida, tanto do ar como d'agua. As liguras 49 e 20 mostram alguns dos grandes montes feitos pelas formigas no interior do Brasil.

Os montes feitos pelas formigas ás vezes attingem a altura de 4.5 metros com diametro de 130 metros na base, e contendo 263 me- 
metros cubicus de terra. Em certos lugares esses insectos tornam-se verdadeiras pragas pela destruição das plantações. Talvez não haja lugar no mundo onde as formigas e os termitas ou cupim tenham tanta importancia geologica como no Brasil (1).

Existem tambem alguns animaes vertebrados, taes como preás e tatús, que vivem em buracos que penetram na terra a profundidades consideraveis. Essas aberturas tanto abrem a terra á circulação do ar

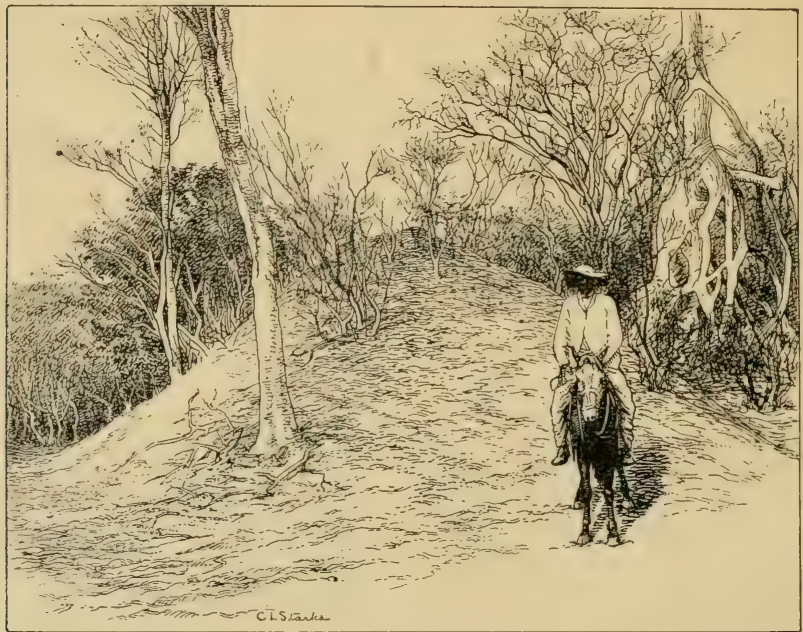

Fig. 49. - Monte feito pelas formigas, perto de Mundo Novo, estado de Bahia. (Crandall.)

d'agua, como tambem os materiaes removidos, quando trazidos á superficie, ficam mais expostos do que quando estavam debaixo da terra.

Nas costas e sobre o fundo rochoso e razo do mar certos mollusros, taes como Pliolas e Lithodomus, fazem buracos nas rochas. Os

(1) J.-C. Branner. The geologic toork of ants in tropical America. Bulletin Geological Society America, XXI, 449-496, 1910. 
ouriços do mar tambem excavam buracos razos, mesmo nas rochas as mais duras. A figura 51 mostra como as rochas são ás vezes completamente esburacadas de covas razas. Taes ouriços são abundantes ao

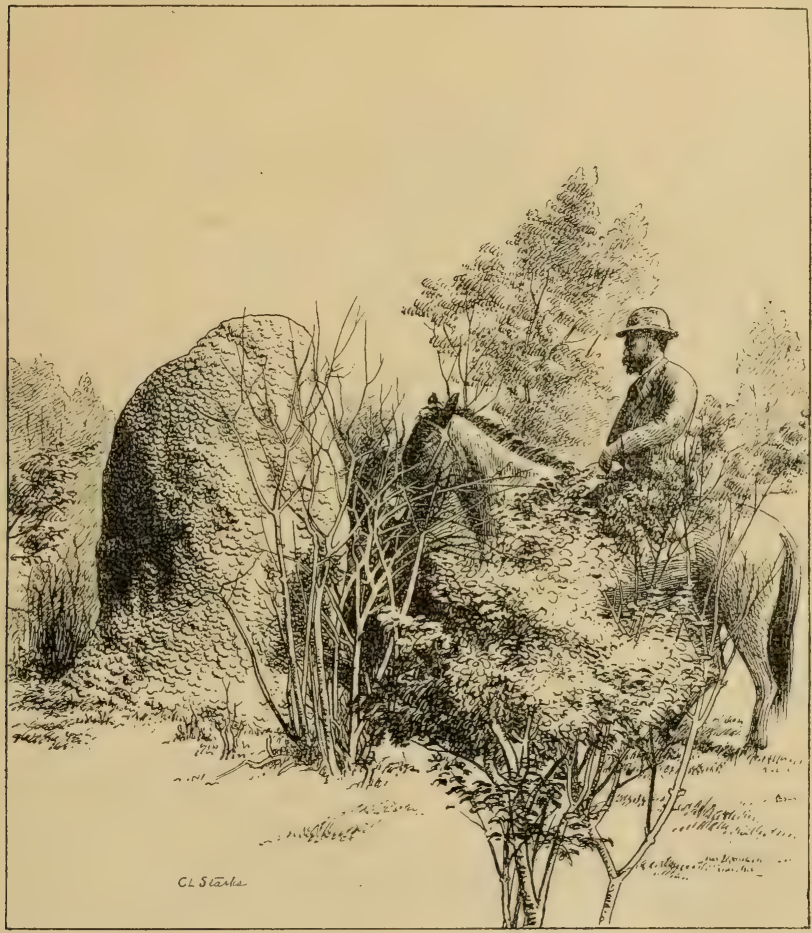

Fig. 50. - Monte feito pelo cupim. De uma photographia tirada perto de Queluz; no estado de Minas Geraes. (Branner.)

Iongo da costa do Brasil. 0 recife de Pernambuco e outros semelhantes do norte do Brasil são ás vezes cavados desta maneira pelos ourięos do mar.

Os caranguejos e certas especies de camarões esburacam os leitos 
dos cursos d'agua e as terras molles e pantanosas ao longo das suas margens. Estas aberturas tamben auxiliam de algum modo a circulação das aguas do subsolo.

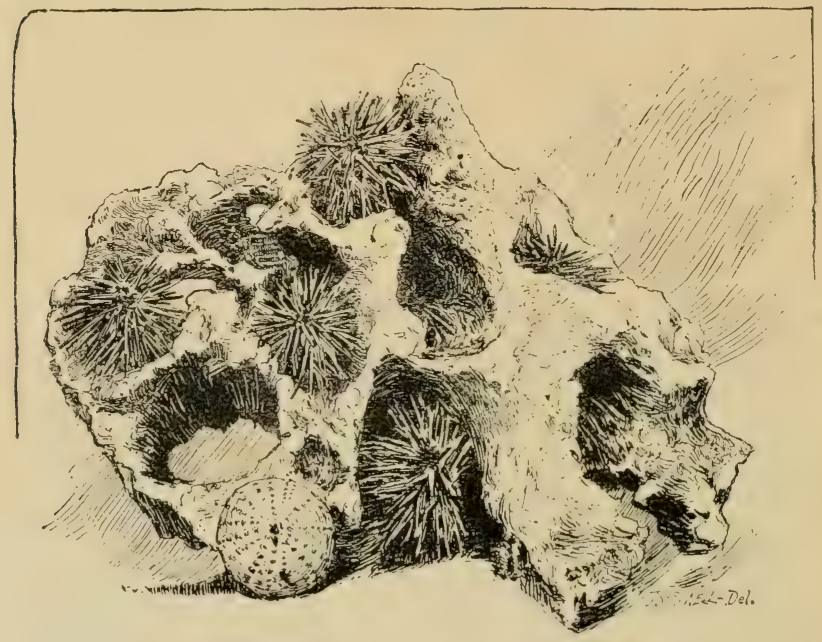

Fig. 51. - Una rocha dura (rhyolite compacto) cavada por ouriços do mar. Ilha de Santo Aleixo, na costa de Pernambuco.

\section{II. - Agentes organicos protectivos ou preservativos.}

Protecção das praias por animaes. - Nos mares a proteção das rochas e praias é muitas vezes effectuada pelos vermes (serpulas), mexilhões e coraes critre os animates, e pelas algas e as coritlinas (algas calcareas) entre as plantas. os roraes tamben furmam recifes de muitos kilometros de extensão e largura que elevam-se do fundo do mar até á superficie das aguas (en maré baixa). Esses recilés cujo crescimento é sempre limitado ás aguas razas, quebram a for'a das ondas que de outro modo cortariam mais rapidamente as praias.

Onde os pontos rochosos hajam soffride por muito tempo it forra 
das ondas vê-se que as rochas estão cobertas com algas e tubos de vermes e algumas vezes com mexilhões e cracas, todos dos quaes fazem com que a rocha melhor resista á acção triturante das ondas. Parece muito provavel que estes agentes protestivos tenham tornado os recifes de pedra do Rio Grande do Norte, Traição, Pernambuco, Rio Formoso, Porto Seguro, Santa Cruz, ete., capazes de resistir por tanto tempo ás ondas do oceano. Ao longo de algumas costas onde as rochas são um tanto molles existe algumas vezes uma aresta saliente coberta por algas e mexilhòes, sendo esta protecção devida á protecção fornecida ás rochas por esses organismos crescentes sobre suas superficies. $\mathrm{Na}$ costa do Japão existem pilares de cabeça grande cujos topos são assim protegidos por mexilhões (1).

Protecção pelas plantas. - Os extensos manyues da costa do Brasil não só protegem a terra contra as esfregações das correntes das marés, como tambem, reprimindo aquellas correntes, causam a deposição rapida de lodos e consequentemente acceleram a formação de terra firme nas partes razas dos estuarios.

N'agua doce existem outras naturezas de plantas que protegem a terra contra os agentes destructivos. Ao longo do rio Amazonas e do rio Paraguay bambús e muitas outras plantas das ribanceiras inclinam-se para a agua e assim enfraquecem mais ou menos a correnteza, difficultando o córte rapido de suas margens pelos rios. En muitos de nosios cursos de agua doce existem enormes quantidades de "Baroneza » ou a Dama do lago », uma planta fluctuante que enfraquece as correntes e a erosão, e tambem quando morrem e vão ao fundo contribuem com grandes quantidades de materias organicas para o lodo depositado onde ellas se desenvolvem.

Quando acontece que certas plantas que medram em terrenos arenosos se estabelecem sobre dunas ellas fazem parar o assopramento daquellas areias. Ao longo da costa do Rio Grande do Norte havia antigamente enormes dunas de areia que agora estão cobertas de florestas porque 0 assopramento das areias foi primeiramente impedido

(1) Agassiz. Bul. Mus. Comp. Zoology, XXVI, 53. Cambridge, 1894. 


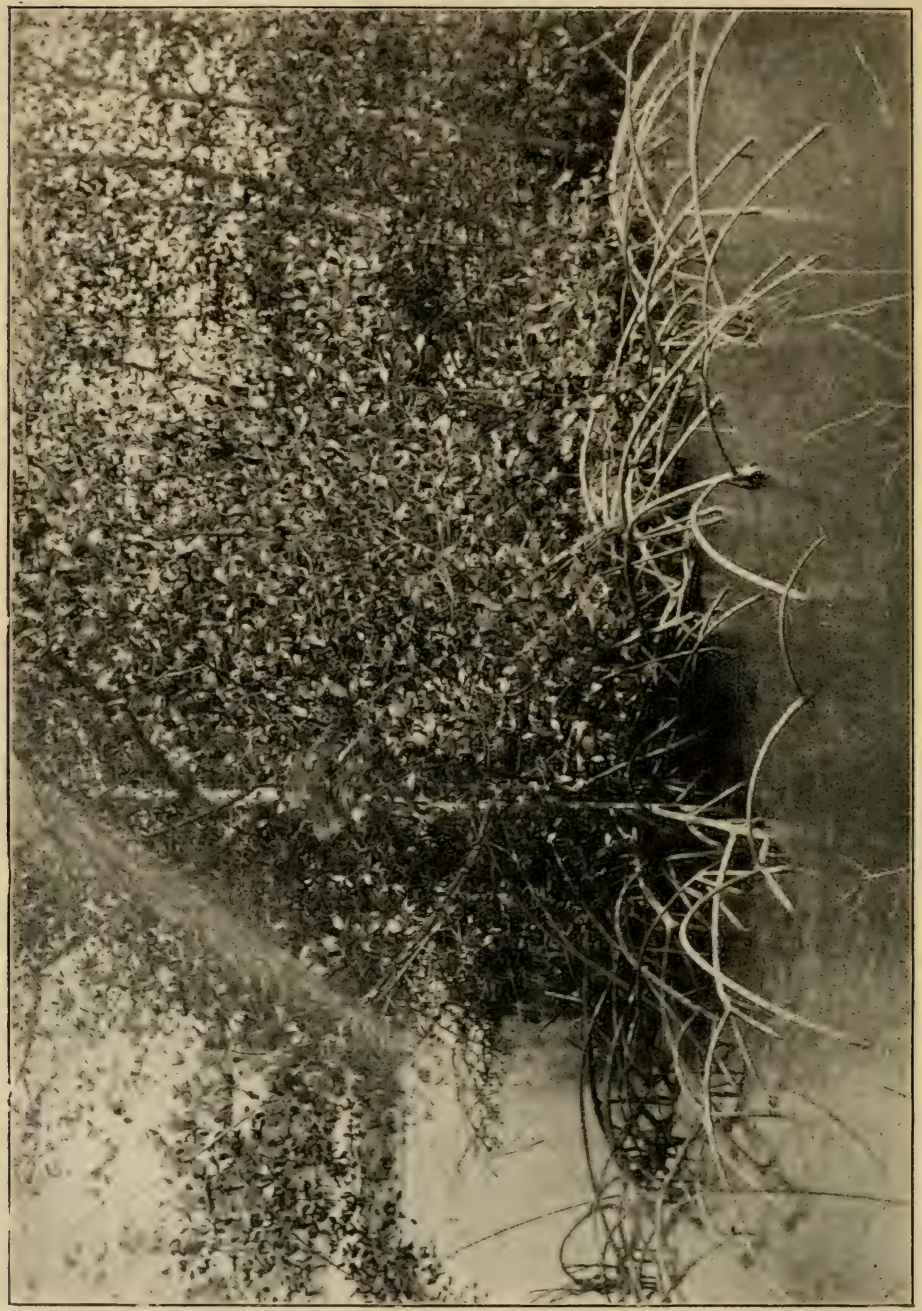

年 
pelas plantas rasteiras amantes de areia até que as arvores tiveram tempo de se enraizar. Em alguns paizes se trata de fixar as dunas pelo plantio de taes plantas.

Na Ponta Mucuripe ao sul de Fortaleza e á foz do Rio Grande do Norte tem-se feito taes plantações a fim de fixar as areias volantes.

En todas as regiões cobertas de floresta as aguas das chuvits são impedidas pela vegetação de escoarem-se immediatamente. As folhas mortas e os detritos das arvores formam uma camada espessa, molle e esponjosa que detem a agua e assim reduz a erosão que de outra sorte seria mais rapida quando os cursos d'aguas se acham augmentados pelas chuvas.

\section{III. - Agentes organicos constructivos.}

Os organismos contribuem grandemente para a formação das rochas e mineraes da terra.

Os depositos de origem organica, porém, variam muito entre si em caracter, [en composição e nos methodns de accumulação. Is plantas formam maior numero de depositos differentes do que os animaes como se vêda lista seguinte:

$$
\begin{aligned}
\text { As plantas formam depositos. . } & \begin{array}{l}
\text { Carbonaceos. } \\
\text { Sulfurosos. } \\
\text { Ferruginosos. } \\
\text { Nitrogenosos. } \\
\text { Silicosos. } \\
\text { Calcareos. }
\end{array} \\
\text { Os animaes formam depositos... } & \left\{\begin{array}{l}
\text { Calcareos.! } \\
\text { Silicosos. } \\
\text { Phosphaticos. }
\end{array}\right.
\end{aligned}
$$

Estes depositos não incluem os formados pelas substituições. Elles serão considerados na ordem dada.

As plantas como agentes constructivos. - Depositis: 11:BoxACEOs. - As accumulações mais importantes de materiaes carbonaceos que temos de tratar em geologia são os depositos de carrĩu de 
pedra, lignite, turfa e os depositos correlativos de hydro-carbonos, isto e, - petroleo, gaz natural, asphalto e os varios compostos de petroleo. As partes carbonaceas das rochas são derivadas principalmente das plantas. A gradação de alguns desses mineraes entre si é instructiva.

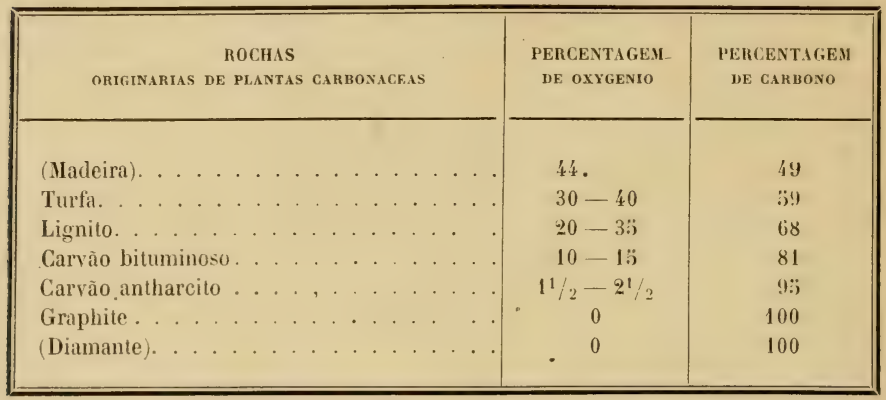

Nesta taboa nota-se que nessas substancias parece haver uma certa graduação de uma para outra e que a percentagem de carbono augmenta da madeira para a graphite á proporção quo o oxygenio decresce. Isto fornece uma suggestão valiosa em relação ás mudanças soffridas pela madeira e turla na sua transformação em lignito e carvão.

\section{TURFA}

A turfa (1) é materia lenhosa que perdeu parte do seu oxygenio e está assim parcialmente transformada em carvão. Forma-se em terreno pantanoso e humido chamado turfeiras (" peat-bogs " ou " peatmosses »), pelo crescimento do Sphagnum, uma especie de musgo. Este musgo frequentemente cresce nas margens dos lagos razos e estes lagos ficam eventualmente cheios pelas massas sempre invasoras de plantas. Essas plantas morrem nas raizes emquanto as partes

(1) Hampus von Post. The formation of peat-mosses, Bulletin Geological Institute of the Unioersity of Upsala, 1892-3, vol. I., p. 281; II, 345. 
superiores ficam vivas e crescendo para cima. Com o correr do tempu o musgo no fundo de um desses charcos (bogs) torna-se pardo escurn ou negro; a estructura vegetal desapparece gradualmente e a substancia toma uma consistencia semelhante a queijo. A turfa é tambem formada por outras plantas além do Sphagnum.

A marcha de crescimento da turfa varía conforme as condicões desde alguns centimetros até um metro ou mais por seculo.

Extensão. - A extensão das turfeiras na Irlanda é tão grande que chegam a cobrir uma setima parte de toda a ilha. 0 " moss » de Shannon, um dos maiores da Irlanda tem de tres a cinco kilometros de largura e oitenta kilometros de extensão. Na America do Norte o Dismal Sivamp da Virginia cobre uma area de setecentos e setenta e cinco kilometros quadrados. Em Norfolk, Inglaterra, existem mil duzentos e noventa e cinco kilometros quadrados de turfa. Depositos semelhantes são encontrados no norte da Europa. No Brasil dizem existir depositos extensos de turfa entre Macahé $\epsilon$ Campos no estado do Rio de Janeiro (1), e tambem na região do Amazonas.

Devido á natureza molle da turfa algumas vezes acontece depois de grandes chuvas que os charcos transbordan e a turfa desce os valles como avalanches ou desmoronamentos de lama. Em algumas regiões onde o combustivel é dispendioso a turfa é cortada em parallelepipedos que são empilhados e deixados seccar, para serem empregados como combustivel para usos domesticos. Ellit é muito usada na Irlanda e no norte da Europa. 0 lignito ou carvão pardo parece derivar-se da turfa por uma perda de oxygenio e um augmento correspondente de seu conteúdo em carbono.

\section{LIGNITO}

O lignito é achado não em pantanos como a turfa, porém enterrado sob camadas de rochas como o carvão, e frequentemente cobrindo muitos kilometros quadrados. As mudanȩas pelas quaes a turfa é transformada em lignito são tão demoradas que não podem ser observadas;

(1) O Novo Mundo, Out. 23, 1875, vI, 19. 
entretanto é concludente a evidencia da derivaçao do lignito da turfa. Essa prova consiste nos seguintes factos :

1. - Espóros de plantas semelhantes aos da turfa são arhados no lignito.

II. - Impressões de plantas taes como as que se acham nos charcos de turfa são encontradas no lignito.

III. - A turfa e o lignito são ís vezes achados passando gradativamente uma a outra.

IV. - As camadas de argilla que muitas vezes se encontram em baixo das camadas de lignito contèm as impressões das raizes quo nellas penetraram exactamente como as raizes penetram as argillas debaixo dos depositos de turfa.

V. - Tem sido até demonstrado experimentalmente que a turfi pode ser transformada de maneira a parecer-se nas suas propriedades physicas com o carvão (1).

A interstratificaçà de lignito com camadas sedimentarias contendo fosseis marinhos mostra indubitavelmente que os charcos de turfa em que os lignitos se originaram foram occasionalmentr abaixados de modo a ficarem cobertos pelo mar (2).

\section{CARVÃO BITUMINOSO}

O ćlvũo bituminoso, como já foi suggerido, é uma alteraçĩo mais adiantada do lignito. Nio se deve suppor contudo que essas mudanças de turfa para lignito, e de lignito para carvão tèm legar com perceptivel rapidez. A mudança é tào vagarosa que é duvidoso que ella possi ser percebida em um scculo ou mesmo em varios seculos. Is camadis de carvão bituminoso geralmente tèm camadas de argilla por baixo dellas justamente como o lignito e a turfa, e essas camalas de argilla sii) muitas vezes abundantemente penetradas pelas raizes das plantas. Frequentemente tocos de grandes arvores são encontrados a pino nats

(1) Darid White. Economie Geology, 1908, III, 292-318.

(2) Science. Jan. 21, 1898. new ser. Vol. VII, p. 83.

W. H. Twenhofel! Am. Jour. Sci, 191'), CLXXX, 65-71.

J.J. Stevenson. Proc. Amer. Phil. Soe., 1911, L. 1-116. 
partes inferiores das camadas de carvão com suas raizes enterradas nos sedimentos subjacentes (1). (Vède fig. 46, pag. 163).!

\section{CARVÃO ANTHRACITE}

O carvão anthracite representa uma mudança mais adiantada do carvão bituminoso produzida por mais uma perda de oxygenio e um augmento correspondente da percentagem do carbono. Em alguns calsos esta mudança tem ido tão longe que o carvão perde alguınas de suas propriedades valiosas. 0 anthracite de Rhode Island na America do Norte tem soffrido uma transformação tão grande que não tem tanto valor para combustivel como o encontrado na Pennsylvania.

\section{Varias theorias da origem do carvão de pedra. - A} theoria de ser o carvão originario da turfa é hoje a geralmente acceite pelos geologos.

0 carbono do carvão vem da atmosphera, e é assimilado pelas respectivas plantas; o carbono do ar provém do mar e das rochas crystallinas, de maneira que assion a atmosphera pode ficar approximadamente sempre com a mesma composição.

Os fosseis achados no carvão tambem indican a origem da turfa.

Outras theorias tèm sido suggeridas e tèm de ser de vez em quando consideradas e respondidas.

I. - A origem marinha para o carvão tem frequentemente sido suggerida ; isto é, que o carvão foi formado por uma accumulação de algas. Esta theoria tem sido proposta em parte por causa da larga distribuição de carvão em algumas regiões, e em parte por causa dos depositos marinhos occasionaes encontrados intercallados com as camadas sedimentares em que o carvão apparece. Uma objecção valiosa a esta theoria é que as algas são compostas exclusivamente de tecidos cellulares e não contèm verdadeiro lenho. Uma outrạ objecção é que os

(1) W. S. Gresley. Coal plants... Geological Magazine, Dec., 1900, VII, pags. 538-514. 
esporos encontrados tão abundantemente no carvão são os de plantas terrestres e d'agua doce - não os de plantas marinhas.

II. - Tambem tem-se proposto a hypothese de que os materiaes que formam o carvão foram soprados pelo vento da terra para os lagos. Muitos factos em relação ao carvão admittem uma explicação tal; porém as areas cobertas por alguns terrenos carboniferos são tão grandes que esta theoria deve ser considerada como completamente inadequada. Os estratos, contendo carvão, na America do Norte, cobrem uma area de cerca de quinhentos e vinte mil lilometros quadrados.

III. - Os madeiros transportados pelas correntes tèm sido indicados como uma fonte possivel de camadas de carvão. Nas regiões de grandes mattas o material dessa especie que é carregado durante as enchentes é muito grande. Em algumas regiões os rios na parte infcrior de seu curso ficam completamente obstruidos pelos madeiros fluctuantes e a agua é obrigada a procurar novos canaes. Taes depositos, porém, são de distribuição e espessura desiguaes, e estão misturados com a lama depositada pelas mesmas correntes. Pelo contrario as camadas de carvão são pela maior parte de notavel egualdade de espessura por milhares de kilometros quadrados sem mistura de lama. Parece pouco provavel que os madeiros fluctuantes tenham produzido as grandes camadas de carvão do mundo.

IV. - Os madeiros carregados para o mar por cursos d'agua têm tambem sido citados; porém o facto que troncos a pino são frequentemente encontrados na parte inferior das camadas de çarrão com suas raizes penetrando nas camadas que lhe ficam por baixo, mostra que as arvores devem ter crescido no proprio lugar do carvão e como as arvores não podiam ter crescido no mar as camadas de carvão não podem ter sido formadas nelle.

A graphite é uma fórma pura de carbono que se julga ter sido derivada de plantas pela perda de oxygenio. $\Lambda$ graphite é encontrado em algumas das rochas mais antigas onde se suppõe ter sido formaro pelo effeito do calor sobre o carvão ou sobre as plantas que produzem carvão. Como, porén, a graphite se apresenta tambem em meteoritos e em certas rochas eruptivas, esta hypothese nào é applicavel a todas as suas jazidas. 
Os diamantes são egualmente carbono puro. Diversas theorias tèm sido emittidas para explicar a origem dos diamantes, e não é impossivel ou mesmo inverosimil que elles tenham-se originado por mais de uma maneira. No Brasil o facto da graphite ter sido encontrada nas camadas do itacolomite - a rocha da qual a maioria dos diamantes brasileiros parecem ter sido derivados -- é considerado como uma suggestão que os diamantes podem ter sido formados por uma maior alteração o crystalização da graphite embora a prova neste ponto esteja longe de ser concludente (1).

Na Árica do Sul os diamantes se acham associados aos folhelos carbonaceos e rochas eruptivas, e suppũe-se que este material forneceu o carbono para os diamantes. Os diamantes e carbonados da Bahia parécem ser formados nos "Quartzitos de Lavras 》 còr de rosa, onde se-acham in situ (2).

Perto de Diamantina, no estado de Minas Geraes, nas minas de Sopa, lıa diamantes em conglomerados, e alguns geologos são da opinião que os diamantes deste lugar são derivados de outras rochas mais antigas.

Depositos sulfunosos feitos pelas plantas. - Certas bacterias extraem o enxofre d'agua sulfuretada dos esgottos e o accumulam em globulos. As bacterias que formam enxofre são tambem achadas nas fontes quentes no Japão onde a temperatura varia de $68^{\circ}$ á $69^{\circ}$ centigrados. Essas formas, porém, só podem viver em agua contendo sulfureto de hydrogenio, e os depositos feitos por ellas não são grandes ou especialmente importantes.

Depositos ferruginosos feitos pelas plantas. - As aguas que procedem da terra muitas vezes contêm ferro em solução na fórma de um carbonato. Certas bacterias tiram dessas aguas o bioxydo de carbono e o oxydo de ferro é precipitado. Desta maneira por intermedio de plantas inferiores se formam depositos de minerios de ferro.

(1) J. C. Branner. Minerals] associated with diamonds and carbonados in the state of Bahia, Brazil. American Journal of Science, June 1911, 480-190.

(2) O. A. Derby. Brazilian eoidence on the genesis of the diamond. Journal of Geology, VI, pags. 121-146. Chicago, 1898. 
Depositos nitrogexosos. - O nitro ou salitre é tambem formado por intermedio de fórmas inferiores de plantas conhecidas como bacterias nitrificantes.

Depositos silicosos feitos pelas plantas. - As diatrmaceas são formas inferiores de plantas (algas) que vivem n'agua salgada ou na agua doce. Essas diatomaceas tèm esqueletos muito delicados de silica extrahida da agua em que vivem. Seus esqueletos são tão extremamente pequenos que só podem ser vistos com um microscopio composto de grande augmento. As diatomaceas vivem proximo a superficie de certos mares, e quando morrem seus esqueletos afundam e accumulam-se em quantidade tal que formam depositos muitas vezes de grande espessura. No estado da California esses depositos de diatomaceas têm uma espessura de quasi dois mil metros.

Logo que as camadas se formam os materiaes são molles e pulverulentos; porém com o correr do tempo elles tornam-se semelhantes a griz, e mesmo por um processo de mudança interna elles se transformam em pederneira. Quando estes depositos de diatomaceas sĩo molles e puros, ou sem mistura de outros materiaes, o seu material é muitas vezes empregado como pó para polir (tripoli) e para varios fins de abrazão.

Pelo facto que os esqueletos das diatomaceas são localmente mudados em pederneira acredita-se que muitas das camadas desta redra tenham sido formadas pela alteraçio de camadas formadas por csqueletos de diatomaceas.

Nas aguas doces, especialmente nas aguas razas e mortas de charcos e pantanos, as diatomaceas muitas vezes medram e os esqueletos silicosos accumulam-se nos fundos de taes massos d'agua. Em certas fontes thermaes fórmas baixas de plantas que secretam silica muitas vezes medram e formam sinter silicoso.

A madeira silicificala não é propriamente fallando um deposito silicosu frito por plantas, porém sim uma substituição da fibra lenhosa pela siliea da soluęĩo. Em algumas partes do mundo, inclusive partes do Brasil, abunda madeira silicificada encontrando-se enormes troncos de arvores prostrados e tócos a pino inteiramente compostos de silica. 
No Rio Grande do Sul acham-se pedaços grandes de troncos silicificados. Estas amostras geralmente se acham enterradas nos cascalhos e areias.

\section{DEPOSITOS CALCAREOS PROVENIENTES DE PLANTAS}

Os Depositos calcureos provenientes de plantas sào formados pelas 'oralinas, ou algas calcareas. As plantas desta natureza são abundantes nas proximidades dos recifes de coral ao longo da costa do Brasil, e cllas contribuem muito para os materiaes que compõem os proprios recifes e para os depositos submarinhos nas vizinhanças de taes recifes. Essas coralinas são geralmente mais ou menos quebradas pelas ondas e as accumulaçies são frequentemente feitas deste material fragmentado. Além da formação directa dos depositos calcareos por esta maneira algumas vezes acontece que os depositos calcareos sìo pruduzidos indirectamente pelas algas. Citan-se casos, por exemplo, em que aguas contendo muito carbonato de eal cm solução sĩo desprovidas do bioxydo de carbono pelas algas causando a preripitação da cal na forma de nodulos.

\section{OS ANIMAES COMO AGENTES CONSTRUCTIVOS}

As accumulações geologicas formadas directamente pelos animaes são calcareas, silicosas ou phosphalicas.

A. Depositos calcareos fettos pelos animaes. - As accumulações calcareas formadas pelos animaes são de tres categorias :

I. - Coraes e serpulas cujos esqueletos estão presos ás rochas ou ao fundo do mar.

II. - Conchas de organismos marinhos microscopicos que vivem na superficie ou proximo á superficie d'agua.

III. - Restos de outros animaes tendo esqueletos calcareos taes como molluscos, radiados, crustaceos e vertebrados. 


\section{RECIFES DE CORAL (I)}

Sol) o titulo de recifes de coral vem as mais importantes de nossas camadas calcareas, não só antigas como modernas. Entre as formaçòes antigas das rochas do mundo existem muitas camadas que se originaram como recifes de coral, e esses calcareos especialmente os calcareos dolomiticos cobrem extensas areas da actual superficie terrestre do globn. Actualmente os recifes de coral occlipam enormes areas en quasi todos os mares tropicaes. Na costa da Australia, por exemplo, os recifes tèm uma extensão de dous mil kilometros e uma largura de dezeseis a cento e quarenta e cinco kilometros. Na costa do Irasil os recifes de coral estendem-se com algumas interrupçôes desde a extremidade sul dos Abrolhos até o Cabo de Sào Roque e a ilha das Rocas, uma distancia de mil e oitocentos kilometros.

Polypos coraliferos. - Embura os recifes de coral sejam rochas duras, os seus materiaes rochosos são os restos de esqueletos de polypos carnosos e molles que medram nas aguas quentes do mar. Estes animaes tèm uma estructura radiada - uma bocca cercada por tentaculos radiantes - e pertencem á divisão do reino animal que se chama Radiados ou Coclenterados. São animaes pequenos inconspicuos não tendo nenhum dos polypos que constroem os recifes encontrados nas costas do Brasil mais que tres centimetros de largura quando fechados (2).

As partes carnosas desses polypos são molles, gelatinosas e muitas vezes transparentes embora ellas variem muito em côr. Porém emquanto as partes superiores dos polypos são gelatinosas e capazes

(1) Charles Darwin. The structure and distribution of coral reefs. $3 \mathrm{~d}$. ed. London, 1889.

J. D. Dana. Corals and coral islands. 3d. ed. New York, 1890.

John Murray. On the structure and origin of coral reefs and islands. Proceedings of the Royal Society of Edinburgh., 1880, X, p. 505.

W. Saville-Kent. The great barrier reef of Australia, London.

(2) Deve-se fazer distinção entre o tamanho dos polypos individuaes e o tamanho das massas rochosas de coral feitas pelas colonias desses poly pos crescendo conjunctamente. Os poly pos são pequenos, emquanto as massas de rocha são frequentemente de un metro ou mais em diametro. 
de moverem-se de alguma maneira, os animaes secretam por baixo dos seus estomagos esqueletos de carbonato de cal que estão firnemente presos ás rochas e recifes do fundo do mar.

A proporȩão que as partes carnosas dos polypos crescem por cima, us esqueletos internos ficam presos em baixo na forma de substancia rochosa e dura. A formação da rocha coralifera é assim uma funcção vital dos polypos que produzem coral; e os recifes são formados pelos polypos que vivem juntos em colonias ou communidades que muitas vezes estendem-se sobre centenas e mesmo milhares de kilometros quadrados. 0 carbonato de cal e de magnesia do qual esses esqueletos são formados é derivado d'agua do mar (1).

Deve-se prestar especial attenção a essas condições, porque ellas lançam muita luz sobre a historia de muitas de nossas pedras calcareas e sobre a historia da terra onde quer que taes rochas sejam encontradas.

Por exemplo, existem recifes de coral fosseis nas ilhas britanicas - uma regiāu na qual as aguas do mar são agora tão frias que os coraes que fazem recifes não tèm possibilidade de viver nellas. E' a necessidade desta temperatura que torna recifes de coral impossiveis fóra de mares quentes.

A existencia de recifes fosseis na Gran-Bretanha fornece uma suggestão interessante em relação ás mudanças de clima que aquelle paiz tem soffrido depois da formação daquellas rochas.

Formas de coral. - Os coraes que constroem recifes crescem em tres fórmas geraes. Elles podem ser ramosos, esphericos ou tabulados. Estas fórmas são abundantes nas costas do Brasil. Um dos mais abundantes dos coraes ramosos do Brasil é a Millepora alcicomis (fig. 53). Esse coral é achado em todns os recifes do Brasil.

Um dos coraes solidos ou hemisphericos encontrados nos recifes brasileiros é o Porites solida. Essa massa de coral é abundante sobre todos os recifes; elle varía em tamanho de alguns centimetros até um metro de diametro.

(1) Nature, June 12, 1890, pgs. 162, 166. 


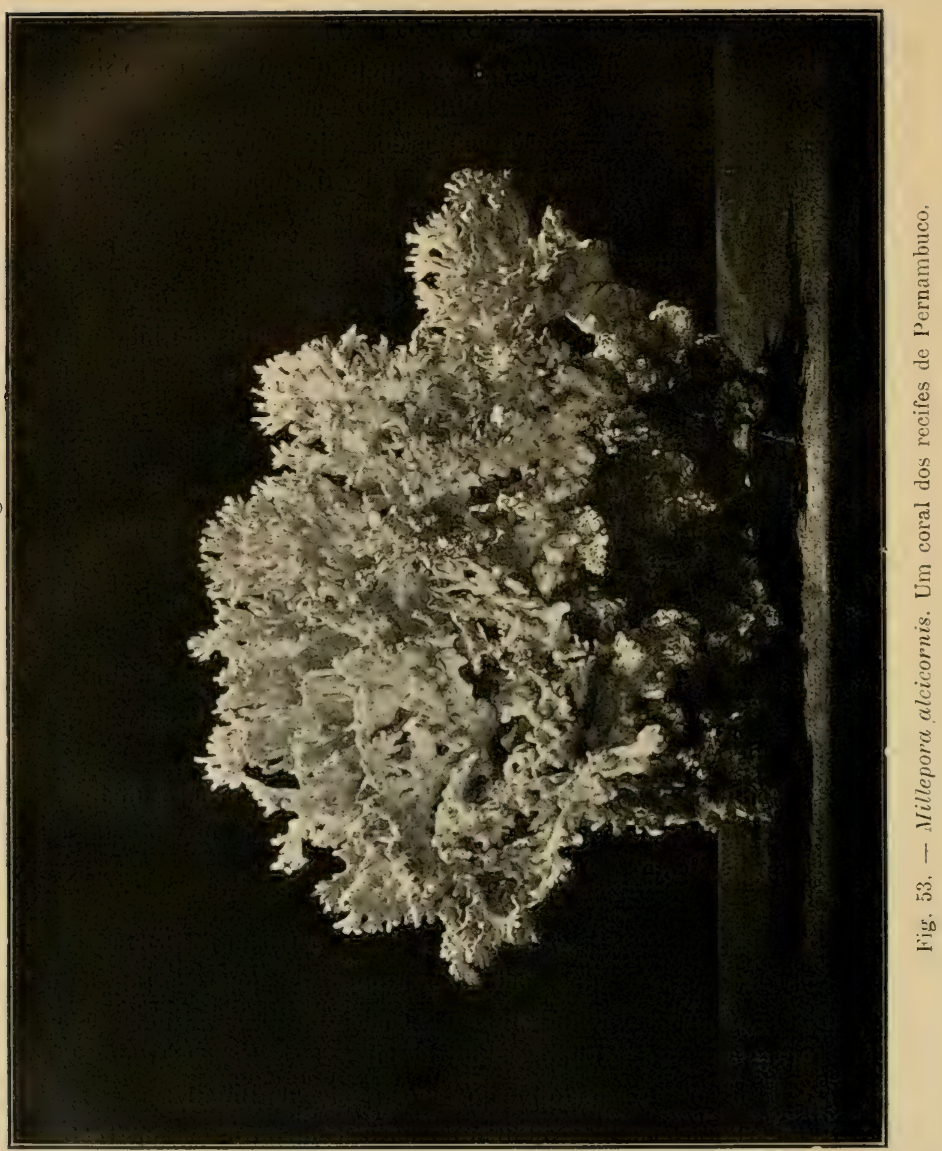

Us coraes tibulados não são tĩo abundantes como os outros e eonsequentemente nio sio tio impurtantes nus recifes brasileiros.

Ila boas ariostras dos coraes do Brasil no Ilusen Nacional do Rio de Janciro. 
Para lista completa dos coraes do Brasil vède " The stone reefs of Brazil » by J. C. Branner, paginas 266-268.

Condições do crescimento do coral. - 0.s polypos reproduzem-se de duas maneiras:

1. ${ }^{\circ}$ Por meio de ovos, que tèm poder lucomotivo na agua, e assim boiando movem-se livremente até que afinal collocam-se nas rochas no fundo do mar.

2. Por meio de galhos ou ramas que se dividem à medida que as colonias crescem.

Embora os polypos que formam coral vivam sob enormes areas nos mares existentes, elles são extremamente sensiveis e medram sómento sob certas condições de profundidade, temperatura e caracter d'agua.

As condições são :

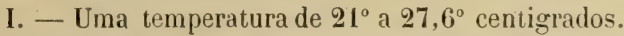

Assim é claro que recifes de coral só podem medrar, nos oceanos tropicaes.

II. - Uma profundidade de 46 metru; ou menos; a profundidade mais favoravel é de 15 metros e menos.

Alguns coraes são achados em grandes profundidades no oceano porém sào individuos isolados e não das especies que formam recifes. Embora os construidores de recifes possam viver em uma profundidade de quarenta e seis metros, elles medram melhor em uma profundidade de quinze metros ou menos. Este facto é tambem de importancia no estudo da historia dos movimentos verticaes da crosta da terra. Evidentemente é impossivel para um recife de coral ter uma espessura maior do que quarenta e seis metros, a menos que os recifes se afundassem emquanto os coraes crescem para cima. Existem contudo muitas camadas calcareas formadas de coral com uma espessura muito maior, e este facto justifica a conclusão que houve uma depressão naquelle lugar em progressão emquanto o recife estava sendo construido.

A poucos annos passados praticou-se uma sondagem em Funafuti ao nordeste da Australia com o fim de determinar a espessura dos recifes de coral ali existentes. Em Setembro de 1898 aquella sondagem tinha alcançado 300.8 metros de profundidade estando sempre em ro- 


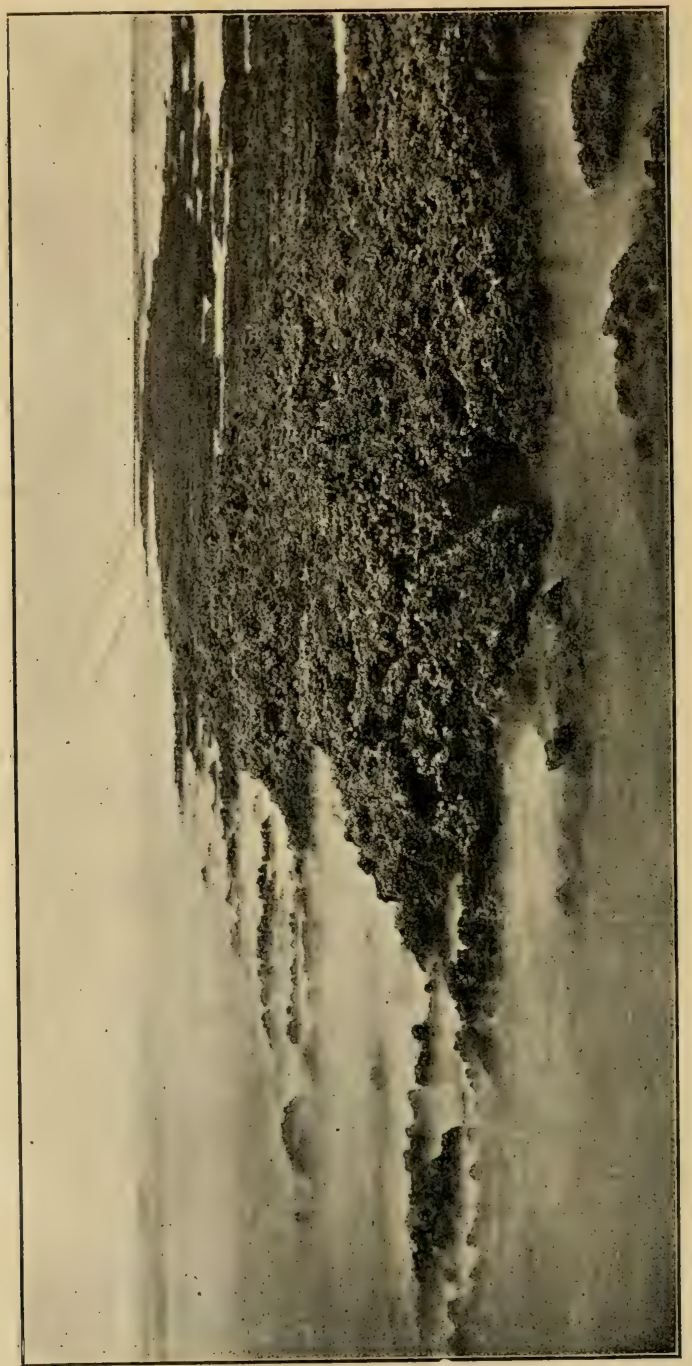

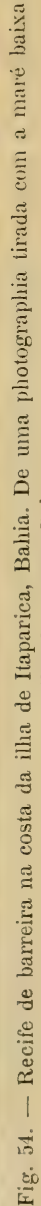


cha de coral. Desprezando qualquer espessura addicional do coral que possa ainda existir abaixo daquella profundidade, é claro que aquelle lugar deve ter abatido pelo menos duzentos e cincoenta e cinco metros desde que os coraes começaram a crescer.

III. - Agua salgada clara.

o terceiro requiisito para recifes de coral, o d'agua salgada clara, explica a ausencia de recifes em alguns mares razos e quentes onde as outras condições são aliás favoraveis. 0 grande volume d'agua doce derramado no oceano pelo rio São Francisco e a agua doce lamacenta despejada pelo rio Amazonas explicam a ausencia de recifes de coral ao longo da costa nas proximidades das boccas daquelles rios.

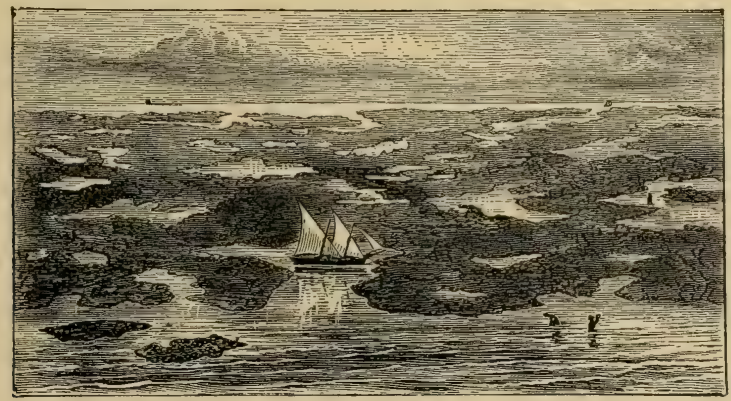

Fig. 55. - Esboço do recife da Lixa em frente da costa de Caravellas, estado da Bahia. As rochas de coral só se acham expostas na occasião da maré baixa.

IV. - Uma mudança constante d'agua, pela necessidade de cal e oxygeneo.

Fórmas de recifes de coral. - Embora as varias fórmas de recifes de coral confundam-se, ellas são commummente divididas em tres fórmas: em franja, de barreira e circular.

Recifes em tranja são aquelles que prendem-se á terra por um lado emquanto o outro lado cresce mar a fóra.

Os recifes de barreira formam barreiras entre a terra e o mar, isto é, existe agua entre a terra e o recife. Os recifes de coral do Brasil 


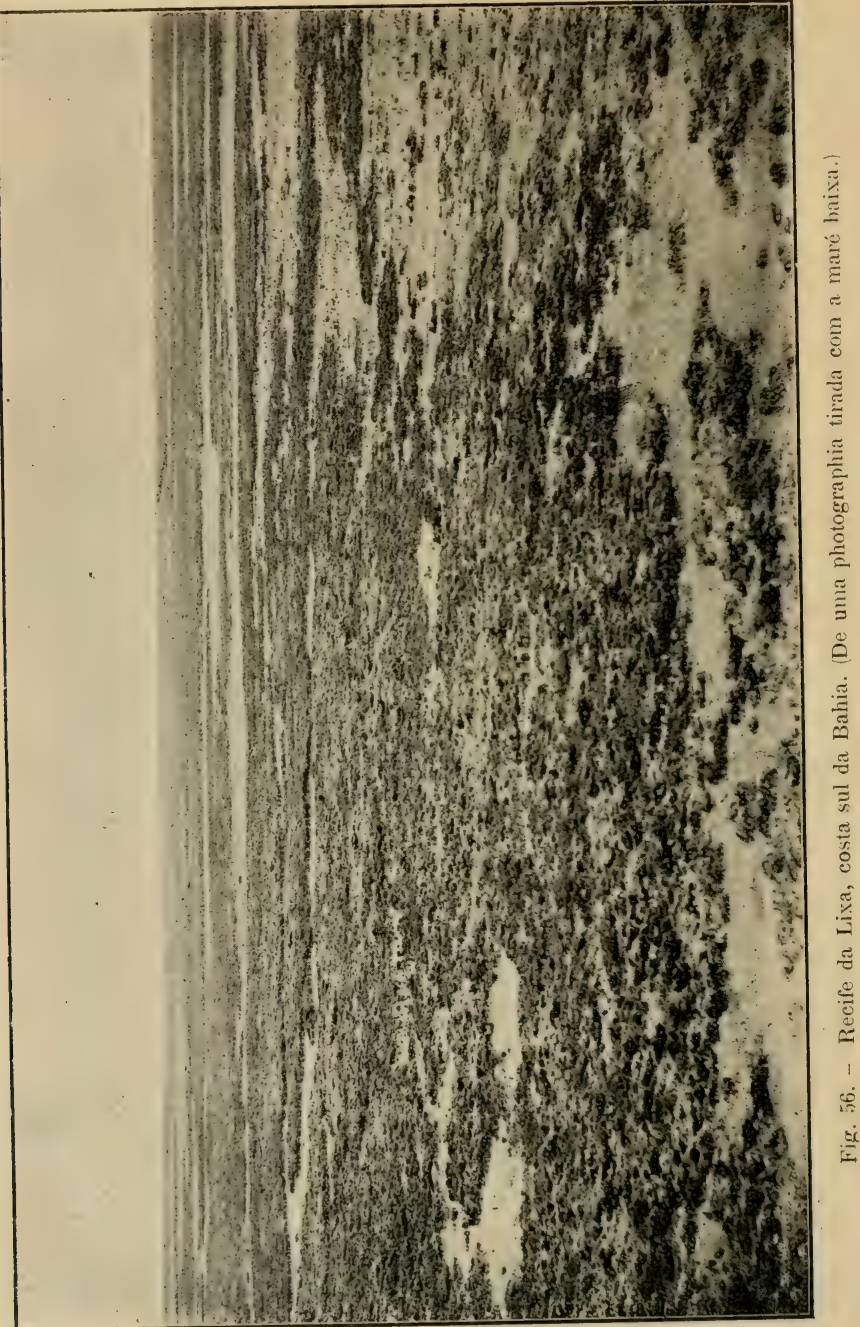


são de ambas as naturezas: isto é, alguns delles prendem-se á terra emquanto outros ficam a alguma distancia da praia com portos por detraz delles.

Alguns dos maiores recifes, contudo, são manchas irregulares nos mares razos e parecem não ter relações definidas com as costas circumvizinhas. Assim é o grande recife da Lixa ao largo da costa sul

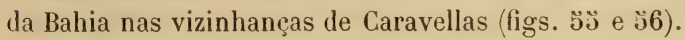

As figuras juntas mostram em seções as relações dos recifes de

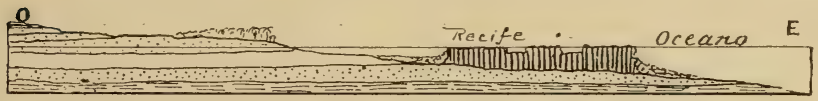

Fig. 57. - Secção mostrando as relayões com a terra do recife de coral de Caravellas, estado da Bahia.

coral brasileiros com a terra em dois lugares typicos - Caravellas e Iacció. Em suas feições geraes aquelles recifes são portanto muito semelhantes. Em muitos lugares ao norte de Maceió os recifes de coral ligam-se á terra, isto é, elles são recifes em franja. Na maior parte, contudo, elles podem ser considerados como recifes de barreira ficando em alguns casos bastante distantes da praia.

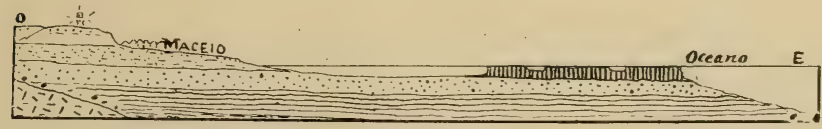

Fig. 58. - Secçăo mostrando as relações com a terra do recife de coral de Maceió, estado das Alagôas.

Os recifes circulares ou atolls são só approximadamente circulares em fórma. Elles muitas vezes circundam uma massa d'agua; porém essas bahias ou lagunas algumas vezes enchem-se de lodo e toda a area fica transformada em uma unica ilha.

Dimensões dos recifes de coral. - Em tamanho os recifes de coral variam enormemente entre pontos de coral de poucos decimetros de diametro até areas de centenas de kilometros quadrados. O grande 
recife de coral de Australia, o maior do mundo, tem o comprimento de dois mil kilometros, e a largura de quinze a $\mathbf{1 4 5}$ kilometros.

Os recifes de coral do Brasil, embora não muito grandes, são bastante importantes para a formação de portos e a proteção que offerecem á costa contra a aç̧ão das vagas. As portas de Mlaceió e de Tamandaré são feitas por recifes de coral.

Theorias da formação de recifes de coral. - A maior area de recifes de coral do mundo é actualmente a da parte tropical do Oceano Pacifico desde cerca de $128^{\circ}$ oéste até á costa oriental da Africa. Os recifes daquella região, mais especialmente aquelles entre $128^{\circ}$ oéste e $130^{\circ}$ leste, foram os primeiros que despertaram a attınção dos geologos pelos estudos de Darwin, naturalista inglez, e depois pelos trabalhos de Dana, geologo norte-americano.

Theoria de subsidencia. - Darwin, depois de seus estudos, propoz a theoria de subsidencia para explicação das fórmas peculiares e caracteristicas dos recifes de coral. De accordo com esta theoria a maioria dos recifes de coral originaram-se como recifes em franja nas ilhas da costa, e pela depressão lenta da região e pelu crescimento dos coraes elles tornaram-se recifes de barreira e ainda depois circulares. Este processo será entendido pela referencia ás figuras juntas na qual o $\mathrm{n}$. I representa o primeiro estado no qual o recife apparece corno um recife em franja proximo á praia de uma ilha. No n. 2 houve uma vagarosa depressão e o crescimento para cima dos coraes formou um recife de barreira; no n. 3 uma depressão maior ainda levou a ilha central abaixo do nivel do mar, emquanto o crescimento dos coraes formou o recife circular, formando uma ilha de fórma especial a que se dá o nome de « atoll ».

Esta theoria recebe seu apoio das quatro classes de factos seguintes :

1. A intergraduação das fórmas de recife; isto é, uma graduação completa entre o recife em franja e o circular póde ser encontrada.

2. A subsidencia effectiva de algumas ilhas de coral existentes. Citam-se exemplos nos quaes a subsidencia tem sido verificada pela 
observação effectuar-se em uma marcha que não teria morto os coraes viventes.

3. A profundidade em que as rochas de coral tém sido encontradas. As sondagens feitas em Funafuti atravessaram trezentos metros de coral. Uma tal espèssura só teria sido possivel por uma

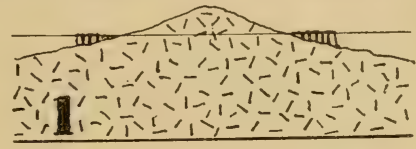
depressão lenta da região. A lentidão do movimento é essencial, porque um afundamento subito de mais de quarenta e seis metros levaria os polypos a uma profun-

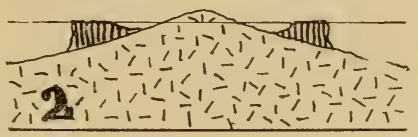
didade na qual elles não poderiam viver, e o recife cessaria de crescer.

4. A elevação de certos recifes os tem collocado a algumas centenas de metros fóra d'agua. Isto tem uma relação possivel com o assumpto em vista da inferencia apparentemente bem sustentada que as elevaçôes e depressões são mais ou menos eguaes sobre a superficie da terra.

Theoria de picos submarinhos. - A outra theoria que desperta a attençào é a theoria de Murray dos picos submarinhos. 0 fundo do oceano é desigual, e em muitos lugares os picos submarinhos elevam-se muito acima do fundo do mar nos arredores. A theoria de Murray é, que quando um desses picos alcança a superficie, ou a distancia conveniente da superficie do mar, elle é apossado pelos polypos de coral e os recifes começam a crescer ali. Quando a profundidade sobre um pico tal é muito grande suppõe-se que as accumulações dos restos organicos submarinhos elevam-no eventualmente até elle chegar ao alcance ios coraes que então tomam posse delle.

Não parece inverosimil que ambas essas theorias - a theoria da 
subsidencia, e a theoria dos picos submarinhos - possam ser correctas.

Isto é, os recifes podem formar-se de uma e de outra maneira. No Brasil os recifes assentam subre as rochas da costa, ou sobre os fundos baixos, e crescem até chegarem á flor d'agua onde deixam de crescer por necessidade. Nas margens porém os recifes vĩo crescendo, especialmente no lado do mar. Sem duvida si a costa fusse elevada os recifes ficariam expostos ao ar e deixariam de crescer. Si a costa fosse abaixada cincoenta metros os menos os coraes cresceriam até chegar á flor d'agua. Mas, como está explicado mais adiante, a costa do Brasil tem tido uma historia complicada com muitas elevações e muitas depressões.

A marcha do crescimento. - A marcha do crescimento dos recifes de coral pode ser determinada por observação directa, a despeito do facto que esta marcha é necessariamente muito lenta. Em muitos lugares ao longo da costa do Brasil onde existem recifes de coral os pescadores constroem curraes para apanhar peixes. Os polypos de coral têm frequentemente se prendido aos postes enterrados no fundo do mar razo para aguentar aquelles curraes. Quando a data do assentamento dos postes é conhecida pode-se obter uma idéa approximada da marcha do crescimento dos coraes que estão presos a elles.

Em diversos casos a marcha do crescimento tem sido medida. As avaliaçũes da marcha do crescimento do coral varia entre tres e seis decimetros por seculo. Tomando a marcha mais alta estimamos o tempo necessario para a construcção do grande recife australiano até á espessura penetrada - trezentos metros - em cincoenta mil annos; ou se tomarmos a marcha mais baixa, seria necessario cem mil annos.

Conclusões a respeito dos recifes de coral do Brasil. liecifes de coral extendem-se ao longo da costa do Brasil desde as ilhas dos Abrollos na latitude $18^{\prime \prime}$ sul, quasi até a fóz do Amazonas. Estes recifes porém não são continuos mas são mais ou menos interrompidos por muitos e grandes intervallos.

Os unicos muito afastados da terra são os recifes das liocas, latitude sul $3^{\circ} 51^{\prime}$, longitude $33^{\circ} 48^{\prime}$, e 223 kilometrus do continente. 
Geralmente os recifes da costa săo estreitos, tendo a largura de dez a cincoenta metros. Os mais largos são os recifes de barreira e destes alguns tèm a largura de trinta kilometros.

Os recifes em franja ou das praias têm pouca profundidade e geralmente não excedem dez metros de espessura; os mais afastados são mais profundos, mas os recifes dos Abrolhos, que talvez sejam os mais profundos do Brasil, não passam a profundidade de quarenta metros.

Muitos dos recifes do Brasil quer recifes de barreira quer em franja já são mortos por ter chegado á flor d'agua.

A rocha calcarea dos recifes brasileiros já está se mudando para dolomia pela substituięão pelo calcareo original de magnesia tirada d'agua salgada.

Os recifes de coral do Brasil protegem a costa em muitas lugares contra a acção mechanica das ondas, e alguns dos portos pequenos da costa, como por exemplo Tamandaré e Maceió, são formados pelos recifes de coral.

A lista completa dos coraes conhecidos do Brasil inclue umas trinta especies que são relacionadas (1) com os coraes das $\Lambda$ ntilhas.

Os recifes de coral dão-nos as seguintes importantes lições geologicas :

I. - Os calcareos derivados de coral são formados pelo crescimento de animaes, auxiliados pela acção das vagas e pela consolidação subsequente dos materiaes calcareos fragmentarios que accumulam-se nas poças da superficie dos recifes.

II. - Os calcareos derivados de coral são de origem marinha e foram formados em aguas tepidas e razas.

III. - Estas camadas podem attingir e effectivamente attingem grandes espessuras pela subsidencia do fundo do mar e pelo crescimento ascendente dos coraes.

IV. - Calcareos derivados de coral, ainda que sejam da idade paleozoica, foram formados sob as mesmas condições, e quando se

(1) J. C. Branner. The stone reefs of Brazil... with a chapter on the coral reefs. Bul. Mus. Comp. Zoology. XLIV. Cambridge, 1904. 
acham em regiões afastadas das tropicaes, indicam as condięões diı agua, temperatura, e profundidade em que foram formados.

\section{SERPULAS}

Além dos coraes que vivem presos ás rochas ou aos recifes por elles mesmos formados, certas serpulas ou vermes marinhos secretam conchas calcareas duras e vivem presas ás rochas abaixo da superficie do mar. Os depositos de conchas ou cascas das serpulas tèm frequentemente espessura consideravel, porém não formam camadas tão extensas como as dos coraes. Ellas são frequentemente encontradas enchendo as poças nos recifes e contribuindo muito material calcareo ás rochas do recife. Em alguns lugares na costa do Brasil, notadamente na costa de Alagôas, as serpulas formam pequenas ilhas que assemelham-se a chapéos pretos gigantescos na superficie do mar por occasião da maré baixa (1).

\section{ANIMAES MARINHOS MICROSCOPICOS}

Depois dos coraes pela sua importancia como construidores de depositos calcareos estão os foraminiferos. Estes são organismos microscopicos tendo esqueletos calcareos e vivem no mar proximo á superficie. Quando morrem, seus esqueletos vào ao fundo onde accumulam-se formando vasa (ooze dos navegantes inglezes). Estes esqueletos são encontrados até à profundidade de quatro mil e duzentos metros; porém é interessante notar-se que não apparecem em profındidade maior. A razão é que quando os foraminiferos afundam em aguas mais profundas, a pressão é tão grande que os esqueletos dissolvem-se na agua. Tem sido suggerido que a solução dos foraminiferos em grandes profundidades era devida não á pressão, porém ao lapso de tempo requerido para que tão pequenas conchas se afundem tanto. Si isto fosse a razão poderiamos esperar observar estarem dissolvidos tambem aquelles esqueletos que tèm permanecido por muito tempo em aguas razas. Entretanto isto não acontece.

(1) Agassiz. Bul. Mus. Comp. Zoology, XXVI, pgs. 253-272. 
Os foraminiferos formam extensas camadas calcareas no fundo do mar. 0 giz ou greda origina-se deste modo como um deposito marinho. Muitas das rochas calcareas do estado de Sergipe contem grandes quantidades de esqueletos de foraminiferos mostrando que os lugares onde aquellas rochas são agora encontradas estiveram outr'ora no fundo do oceano.

\section{OUTROS ANIMAES QUE TÊM ESQUELETOS CALCAREOS}

Sob este titulo vêm muitas especies differentes de animaes, incluindo os molluscos, radiados, crustaceos e vertebrados e todos os

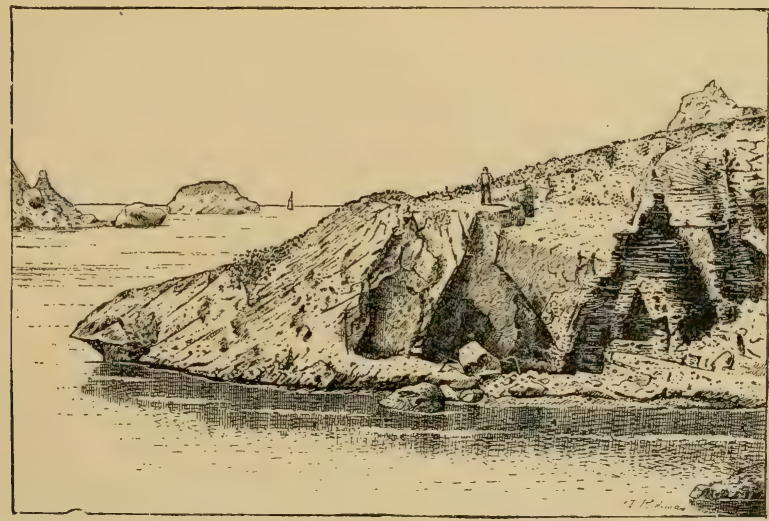

Fig: 60. - Calcareo eolio composto de fragmentos de conchas e plantas, Bahia de Suéste, Fernando de Noronha.

outros animaes que secretam cal, afóra os coraes e os foraminiferos já considerados. As condições ao redor dos recifes de coral são usualmente favoraveis para muitas naturezas de vida além das dos polypos .que os formam. Como resultado sempre achamos muitas especies de animaes marinhos vivendo sobre os recifes e nas suas proximidades, e quando esses animaes morrem os restos das suas partes duras accumulam-se no fundo d'agua e auxiliam o processo da formação do recife e afinal 
das rochas calcareas. Em alguns lugares, contudo, mesmo onde não existem recifes, certos molluscos são tão abundantes que as praias são formadas quasi inteiramente de suas conchas quebradas. Na costa da Florida existe uma accumulação de taes conchas que solidificou-se a tal ponto que o material póde ser usado para a construcção de muros e casas.

Os crinoides, ou lirios do mar (animaes marinhos radiados) antigamente cresciam em taes quantidades que quando morriam suas hastes quebradas em pequenos pedaços formavam accumulações de enorme extensão nos mares razos. Os crinoides vivem agora nos recifes de coral do Brasil, porém elles não são agora tỉo abundantes como eram durante a formação das rochas chamadas " calcareos de encrinites » da idade carbonifera.

No lado suéste da ilha de Fernando de Noronha existem camadas de calcareo composto de fragmentos de muitas especies de animaes e plantas marinhas. A rocha foi originalmente areia eolia calcarea, porém está agora endurecida.

\section{DEPOSITOS SILICOSOS FORMADOS POR ANIMAES}

Embora as esponjas sejam molles, algumas dellas secretam pequenas particulas microscopicas de silica chamadas spiculos. Essas particulas de silica tèm-se accumulado tanto em muitos lugares no fundo (i) mar que formam depositos de consideravel importancia geologica. E' geralmente acceito que as pederneiras sào quasi inteiramente feitas destas accumulações dos spiculos de esponjas. Existem pederneiras negras em muitos lugares no estado de Sergipe no Brasil que suppõe-se terem-se originado desta maneira. E' possivel comtudo que essas cimadas de pederneiras, ou partes dellas pelo menos, fossem formadas pela accumulação dos esqueletos silicosos das diatomaceas (algas) antes do que dos spiculos de esponjas. As pederneiras são tumbem communs em partes dos estados de S. Paulo, Paraná e Rio Grande do Sul. 


\section{DEPOSITOS PHOSPHATICOS (1)}

Os excrementos dos passaros e de outros animaes algumas vezes accumulam-se em quantidades taes que formam depositos de importancia geologica. De tal origem são os depositos phosphaticos na ilhi Rapta em Fernando de Noronha e os celebres depositos de guano na costa do Perú. Em muitas outras partes do mundo existem depositos phosphaticos que podem-se ter originado de modo semelhante.

São mais abundantes em regiões aridas onde não ha muita chuva.

Em geral os organismos marinhos são mais abundantes nas aguas razas perto das costas, especialmente nas regiões tropicaes. Nas regiões polares a fauna é mais abundante á profundidade de noventa a duzentos e setecentos metros.

\section{Resumo.}

Temos agora tratado resumidamente de todos os differentes processos pelos quaes os materiaes que formam rochas são accumulados. Verificou-se que todas as rochas originaram-se em uma das quatro maneiras differentes.

1. Sedimentos mecanicos depositados pela agua ou pelo vento.

2. Depositos chimicos provenientes de solução.

3. Rochas igneas resfriadas de um estado de fusão.

4. Rochas organicas feitas por plantas ou animaes.

Todos èsses materiaes são sujeitos a varias mudanças depois de terem sido depositados. Esta parte do assumpto será tratada sob o titulo de geologia estructural.

(1) J. Murray. Nature, 1897, LV. 500-501. 


\section{0 homem como agente geologico (1).}

Embora o homem não tenha contribuido directamente com cousa alguma de importancia para os depositos geologicos, elle veio a ser um agente modificador importante que com o correr do tempo deve profundamente affectar a superficie da terra. A razão principal pela qual o honıem tem até agora tão pouco feito geologicamente é que elle está sobre a terra um tempo muito pequeno comparado com o tempo durante o qual as plantas e outros organismos que formam rochas tèm permanecido n'ella. Até aqui a influencia do homem tem effectuado mudanças nas plantas e florestas, tambem nos animaes e na propria terra.

\section{A INFLUENCIA Do HOMEM SOBRE AS PLANTAS}

Plantando. - As plantas que agora são cultivadas foram outr'ora selvagens. As consideradas uteis foram dos seus lugares originaes distribuidas propositadamente sobre todas as partes da terra onde as condições do clima favorecem sua cultura. Taes plantas, como o trigo, o centeio, a aveia, o arroz, o milho, os feijões e as batatas fornecem a grande massa do alimento da raça humana. Outras medram súmente em regiōes tropicaes; taes como cocos, tamaras, bananas, laranjas, café, cacau e canna de assucar. Até mesmo arvores florestaes sĩo agora mudadas de um continente para outro. 0 Eucalyptus, por exemplo, cujo lugar nativo é a Australia acha-se agora plantado na America do Sul e nas partes mais quentes da America do Norte. Em alguma partes da Suissa são plantadas florestas para evitar os desmoronamentos. Na costa occidental da França florestas extensivas de pinheiros tèm sido plantadas por causa da resina que elles produzem e para impedir o movimento das areias das dunas.

Destruição. - Em alguns lugares as florestas têm sido destruidas pelo homem na exploração de alguma industria como seja a fabricaçào do carvão, a extracȩão das cascas para cortume e o córte de

(1) G. P. Marsh. The earth as modified by human action. New-York, 1885. 
madeira e lenha, e a extracção da borracha. Tem havido tambem muita destruição de florestas causadas pelo fogo acceso por homem.

A remoção das florestas augmenta a acção erosiva dos cursos d'agua, e encobre o solo á acção do sol.

Ao longo da costa brasileira em muitos lugares os mangues têm sido cortados parı lenha e isto tem demorado o aterro dos estuarios que prosegueu mais rapidamente com o auxilio dos mangues.

En geral porém as mattas derrubadas restabelecem-se rapidamente nas regiões tropicaes.

\section{A INFLUENCIA DO HOMEM NA VIDA ANIMAL}

0 humem tem tratado e domesticado certos animaes que podem servil-o; emquanto outros têm sido exterminados. Cavallos, carneiros, vaccas, porcos, gallinhas, abelhas, patos, ganミos, etc., tém sido levados pelo homem de suas moradas originaes para todas as partes da terra. IIesmo raças de homens tèm sido escravisadas e espalhadas sobre a terra. Os africanos foram desta maneira levados como escravos para a Europa e para as duas Americas onde elles tèm-se misturado com as raças aborigenes, americanas e européas.

Alẻm destas distribuições propositaes muitos animaes foram transportados casualmente pelo homem. Das setenta e tres especies dos principaes insectos nocivos encontrados nos Estados Unidos da America do Norte, trinta e seis foram introduzidos accidentalmente pelo homem.

Certos animaes bravios uteis tèm sido involuntariamente quasi exterminados pelo homem: taes são os castores, os bufalos e as phocas.

Em alguns casos a destruição dos animaes tem sido sómente feita pelo gosto de destruir como no caso dos passaros das ilhas de guano e dos buffalos na America do Norte.

\section{A INFLUENCIA do HOMEM NA TERRA}

E' sob sua influencia na terra e nas costas do mar que o homem parece prometter sua influencia geologica mais importante.

Reclamações de terrenos. - Na Hollanda grandes diques 
artificiaes foram construidos, os quaes fecham o mar e fazem terras araveis daquillo que de outra sorte seria o fundo razo do mar. Em muitos casos, alagados e pantanos extensos tèm sido drenados e submettidos á cultura. Em algumas partes da Suissa os canaes dos cursos d'agua tèm sido rectificados e forrados de pedras, assim reduzindo muito as escavações feitas por aquellas correntes e augmentando ao mesmo passo o terreno aproveitavel. 0 rio Pó na Italia tem suas margens levantadas para evitar as inundações, de modo que os lodos que antigamente cram espalhados pelas varzeas ao nivel do rio siu agora lançados no mar Adriatico e o delta está augmentado em uma marcha crescente. Diques semelhantes são construidos ao longo da parte inferior do rio Mississippi com um effeito semelhante sobre seu delta. Em alguns lugares onde os rios sinuosos atacam e escavam suas margens ellas são protegidas por meios artificiaes.

As aguas do rio Niagara estão sendo agora utilisadas até um certu ponto para fornecerem electricidade e para mover machinismos. Lm tal uso d'um curso d'agua reduz a marcha do córte por elle effectuado. Nas regiões onde se encontram alluviões auriferos ou diamantes os rursos d'agua são desviados de seus leitos naturaes e empregados para desbastar os terrenos auriferos ou diamantiferos emquanto os valles abaixo são muitas vezes obstruidos com a lama arrastada neste processo. Em algumas partes do estado da California as lamas das minas de ouro tèm completamente aterrado muitas fazendas a uma profundidade variando de um a seis metros.

As dragagens que se effectuam e os quelora-marés que se constroem nos portos interferem com a operação natural das marés, ondas e correntes.

Os despejos das cidades que são muitas vezes lançados nos mares proximos eventualmente formam depositos caracteristicos emquanto as cidades e outros trabalhos humanos sĩo de vez em quando enterrados e conservados nas rochas como, por exemplo, os monumentos do Egypto cobcrtos pelas areias sopradas do deserto; ou como Herculano e Pompéa enteradas e conservadas debaixo das cinzas e lavas do Vesuvio. 


\section{PARTE SEGUNDA}

\section{Geologia estructural.}

\section{Qualidades, estructuras e modificações das rochas.}

Na primeira parte desta obra mostrou-se como e por intermedio de que agentes as rochas se originaram. As rochas, porém, estão sujeitas a certos rearranjamentos de seus elementos constituintes bem como a mudanças ou accidentes que serão considerados sob o titulo de geologia estructural.

Em referencia á sua origem, todas as rochas podem ser classificadas do modo seguinte :

1. ${ }^{\circ}$ Sedimentarias, acamadas ou estratificadas.

2. ${ }^{\circ}$ Iguteas, massiças ou não estratificadas.

3. Depositos filonarios.

Serão consideradas na ordem supra.

\section{Rochas sedimentarias ou estratificadas.}

Póde-se formar uma idéa da importancia das rochas sedimentarias ou estratificadas se lembrarmo-nos que ellas cobrem nove decimas partes da terra firme e todo ou quasi todo do fundo do mar. As suas 
camadas podem ter a espessura de muitos kilometros, calculando-se na média cerca de trinta e dois kilometros.

As rochas sedimentarias podem ser duras ou molles.

Não se podendo traçar uma linha de separação entre materiaes ronsolidados e não consolidados, por haver transição de um estado a outro, os molles ou incoherentes são tambem considerados rochas, como os duros (ou pedras) o são. A seguinte tabella indica a origem, caracter e nome de todas as rochas estratificadas, sejam ou não ellas consolidadas.

$$
\begin{aligned}
& \begin{array}{cccc}
\text { Origem } & \text { Caracter } & \begin{array}{c}
\text { Nome quando } \\
\text { nâo consolidadas }
\end{array} & \begin{array}{c}
\text { Nome quando } \\
\text { consolidadas }
\end{array} \\
\text { Agglomerado. }
\end{array}
\end{aligned}
$$

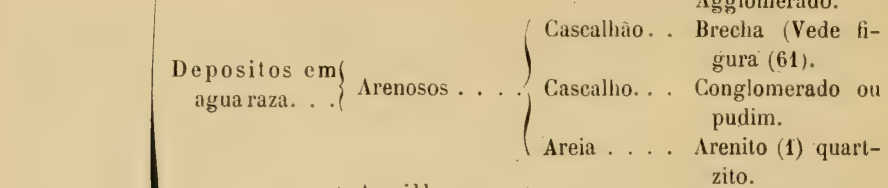

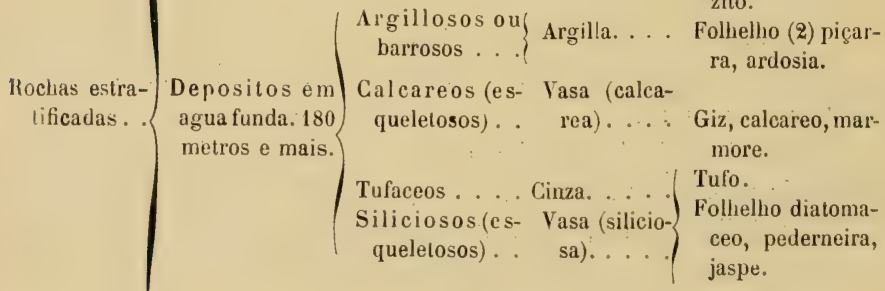

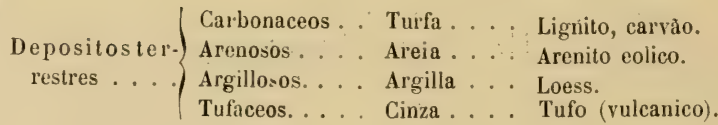

(1) Na primeira edição desta obra Dr. Barreto propoz o termo arenito para o equivalente do inglez sandstone e o francez grez, derivando-o do latim arena con a terminação grega ite. Exprime exactamente a "pedra de areia " do portuguez. Este rucabulo já tinha sido empregado pelo Professor A. J. Gonçalves Guimarães, p. 130, de seus Elementos de Geologia, Coimbra, 1895. Tendo sido assim proposto por dois geologos independentemente, é claro que é um termo bem escolhido.

(i) O termo a folhelho " foi proposto por Dr. Barreto na primeira edição. Exprime bem o caracteristico essencial da rocha (folhada, cousa de muitas folhas) e deixa o termo "schisto " para ser empregado no sentido restricto em que está geralmente cmpregado pelos geologos estrangeiros. Piçarra é o antigo nome portuguez muito usado no Brazil. Guimarães, p: 116. 
Das rochas sedimentarias, as argillas e os folhelhos formam vitenta por cento, os arenitos furmam onze por cento e as pedras calcatreas nove por cento (1). Esta regra porém sí se refere an mundu inteiro, e não á qualquer região limitada.

\section{Laminação ou estratificação.}

I forma assumida por qualquer deposito deve necessariamente lepender em stande parte do modo da sua formarão. As rochas estra-

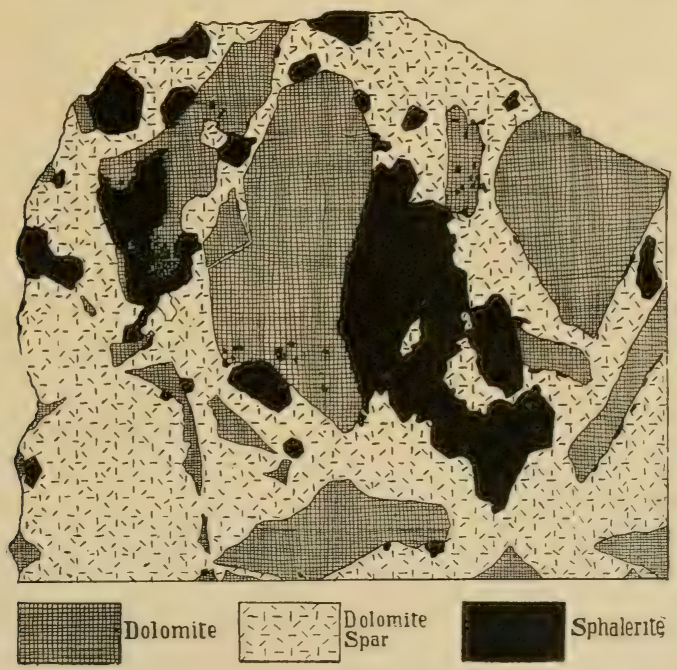

Fig. 61. - Breccia de dolomite e splualerite cimentada com spatho dolomitico. Tamanho natural.

tificadas são assim chamadas porque são depusitadas em camadas ou leitos estratificados. I'm unico leito ou camada chama-se um estruto. Quando o estrato i muito delgado, é ás vezes rhamado lamella. (1:-

(1) W.-J. Mead. Journal of Geology, X V, 238-256, 1907. 
trumos leito, camada, estrato e lamella sào, porém, empregadlos de uma maneira pouco restricta.

Is camadas ou leitos formados pelos materiaes depositados mechaniuamente são ás vezes achatados e de espessura uniforme, outras vezes são lenticulares.

Dit-se o nome de estratificucio falsa is lamellas curtas e bastante

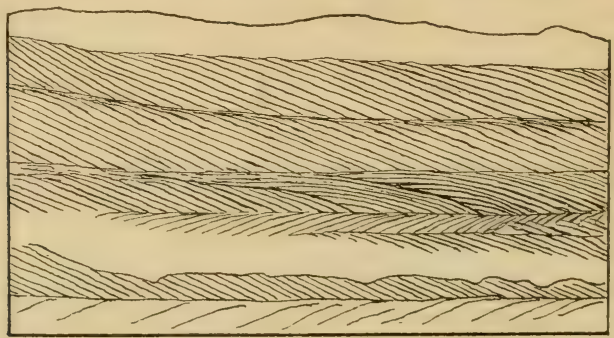

Fig. 6\%. - Secção mostrando estratificação falsa.

De uma photographia. Metade do tamanho natural.

inclinadas formadas por correntes que transportam e aceumulam miteriaes na extremidade de uma camada em crescimento. Estat estrat-
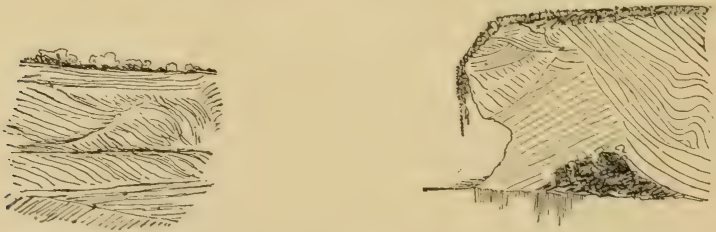

Fig. 63 e 64. - Estratificaşão falsa no arenito da Ilha Raza, Fernando de Noronha.

tificatcio fialsa é mais ou menos caractaristica de quasi todos os sedimentos pratulos depositados pela ağua. A areia carregada pelo vento e depositadla em dunas toma um arranjo interno semelhante.

Conformidade. - Quando os materiaes que formam as rochas sio depositados em ramadas successivas parallelas diz-se que sĩo 
ronformuveis. Se as camadas primeiramente depositadas foram desnudadas, e então camadas posteriores depositadas sobre a superficie erodida, diz-se que as duas series são discordantes ou inconformaveis. A inconformabilidade póde apparecer quando as camadas inferiores formam um angulo com as superiores ou jazem parallelas a ellas. Estas duas condi-

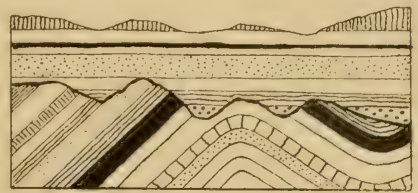

[Fig. 65. - Descordancia ou incmulin:mabilidade entre as camadas dobradas de baixo e as horizontaes de cima.

rões sào illustradas nas figuras $6 \ddot{0}, 66$ e 67 . È de notar que a discordancia ou inconformabilidade pode existir entre uma camada nova

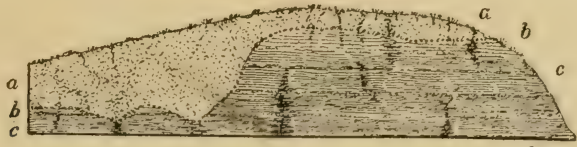

Fig. 66. - Descordancia ou inconformabilidade segundo a linha $b$. $b$. As camadas $\bar{c}$ depois de depositadas foram erodidas até a linha $b$, sendo depois as camadas $\alpha$ depositadas em cima della.

e uma camada mais antiga, porém a differença entre as duas idades pode ser pouca ou muita. Dr. Guilherme Florence notou nas explora-

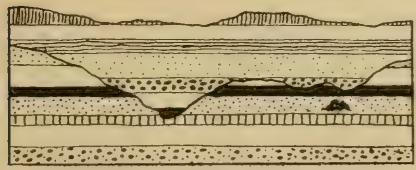

Fig. 67. - Descordancia ou inconformabilidade entre duas series de camadas horizontaes.

Para appreciar a differença nas idades das duas formaçĩes vède a columna geologica à pagina 286 deste.

(1) G. Florence. Exploração do Rio Grande. Commissāo Geographica e Geo. olgica do estado de S. Paulo, p. 31. S. Paulo, 1913. 
Accidentes durante a deposição. - No processo de deposirão de sedimentos acontece ás vezes que as aguas são ligeiramente perturluadas. Em virtude desta perturbaçio os materiaes não são depositados com perfeita regularidade, mas são arrumados $\mathrm{cm}$ pequenas rugas chamadas marcas ondulares (ripple-marks). As marcas ondulares encontram-se em aguas até á profundidade de cento e cincuenta metros (1). As perturbações são geralmente produzidas pelas ondis na superficie das aguas.

No Lago de Genebra, Suissa, as rodas dos vapores produzem vilira-

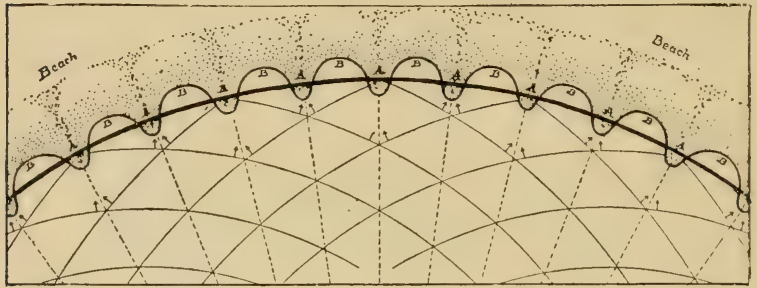

Fig. 68. - Diagramma mostrando a origem de cuspides das praias e as ondulações parallelas em mares razos.

çies na agua que deixam muito ondulada a areia sobre as partes razas do fundo do lago.

A interferencia de duas series de ondas nas aguas razas proximas á praia dispòe os materiaes soltos em rugas ou marcas ondulares gigantescas. Quando ellas terminam sobre a praia são denominadas cuspides (2).

Os cursos d'agua, ou as marés, correndo sobre areia solta tambem produzem marcas ondulares. A figura junta é reproduzida de uma photographia tirada atraz do recife de Cunhahú, na costa do Rio Grande do Norte, na maré baixa. A maré vasante correndo da esquerda prara a direita deixou as rugas perpendiculares á direç̧ão da corrente.

(1) A. de Lapparant. Traité de géologie, 4. ed. p. 254. Paris, 1900.

(2) J. C. Branner. The origin of beach cusps. Journal of Geology, vol. VIII, pags. 481-184, 1900 . 
Na figura 68 a linha grossa representa a linha da praia e as curvas concentricas representam duas series de ondas. As ondas se movem nas duas direçóes mostradas pelas flechas, e se cncontram ao longo

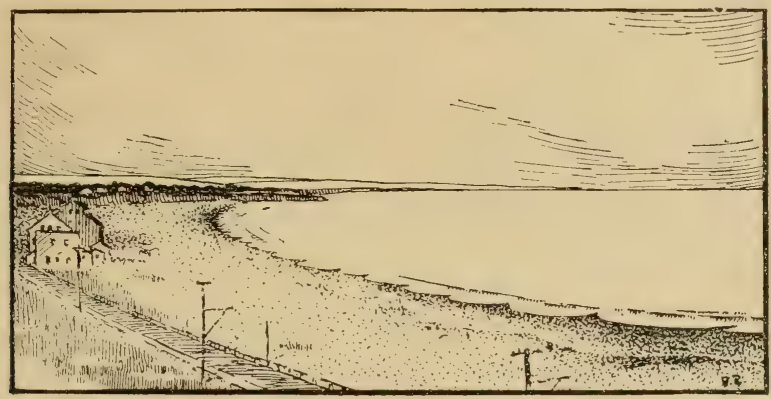

Fig. 69. - Cuspides da praia feitas de areia solta. As pontas são as extremidades que se extendem debaixo do mar em angulo recto com a costa, na praia de grandes ondulações.

das linhas pontuadas. As ondas que se movem para a direita ao encontrar a praia jogam as areias á direita, ao passo que as que se movem para a esquerda as jogam naquella direção. Ao longo das linhas de

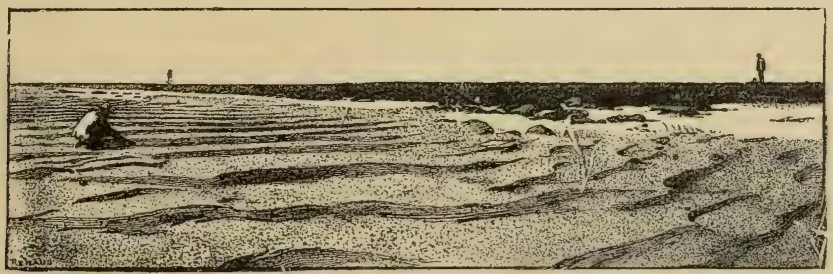

Fig. 70. - Marcas ondulares atraz do recife de Cunhlahú, costa do Rio Grande do Norte. (De uma photographia tirada com maré baixa.)

interferencia a areia se accumula numa ruga, ou ondulação grande, sobre o fundo do mar, e sobre a praia estas rugas formam cuspides nos pontos marcados A.

Impressões da chuva são formadas por gottas de chuva cahindo 
sobre lama bastante molle para ficar marcada por ellas. As taes impressões são ás vezes conservadas nas rochas pela deposição de outras camadas sobre a lama logo depois de se fazer a impressão.

Fendas do sol são produzidas em lama, quando esta fica exposta a seccar no sol. Estas fendas tambem ficam conservadas pela deposição de camadas em cima da superficie fendilhada e enchendo as fendas.

Rastos de animaes que andaram sobre materiaes molles acham-se conservados da mesma maneira. Em algumas camadas de rochas achanse conservados em grande numero rastos de aves e outros animaes.

No oeste de S. Paula Dr. Pacheco achou rastos de vermes nos arenitos de Botucátú (1).

Fosseis são as partes duras ou as impressũes de animaes ou plantas que viveram ou que foram levados pelas aguas, nos mares, lagos ou outras massas d'agua, onde, depois de mortos, desceram para o fundo e foram enterrados nas accumulaçèes que alli se formaram. E' evidente que os animaes que viveram no mar n'uma época dada tiveram os seus restos depositados com as outras accumulações do periodo cm que viveram e não nas de um periodo anterior ou posterior. E' este facto que dá aos fosseis a sua importancia e valor no estudo da historia das rochas.

Alternação das camadas. - No exame de uma espessura consideravel de camadas sedimentarias nota-se que ha uma tendencia nas rochas de mudar de sedimentos mais graúdos para mais miudos ou vice-versa; em outras palavras, é raro haver perfeita uniformidade de material atravez de uma grande espessura de camadas sedimentarias. Esta alternação das camadas pode ser produzida :

1. Pelas condições variaveis do supprimento dos materiaes.

2. ${ }^{\circ}$ Por mudanças nas correntes nas quaes os materiaes foram depositados.

Persistencia dos estratos. - Lu passo que alguns estratos sĩo de distribuição limitada, outros cobrem areas enormes. Comı os

(1) J. A. Pacheco. Geologia do valle do Rio Grande. Commissão Geographica e Geologica de S. Paulo, p. 35. S. Paulo, 1913. 
sedimentos provenientes da terra são, pela maior parte, depositados proximos á praia, a distribuiçăo destes sedimentos é, em geral, parallela ás linhas da costa.

\section{A deposição lenta de sedimentos.}

Parece razoavel suppor que os sedimentos de que se formaram as rochas mais antigas foram depositados em condiçòes semelhantes ás em que hoje se accumulam sedimentos semelhantes. E' evidente que em todos os tempos os sedimentos miudos foram depositados em agua quieta e os graúdos em correntes mais rapidas. Estes factos não são, porém, por si só sufficientes para provar a marcha enı que os sedimentos foram accumulados. Ha, porem, alguma prova interna mostrando que a marcha tem sido, no todo, muito lenta. I laminaśão dos folhelhos é considerada como uma prova disso.

Em muitas camadas sedimentarias encontram-se fosseis, taes como ostras e outras conchas, que apresentam tubos de serpula adherentes á superficie interna, bem como ossos de animaes vertebrados cobertos por esses tubos. E' evidente que taes fosseis devem ter ficado descobertos sobre o fundo do mar depois da morte dos animaes, durante bastante tempo para permittir ás serpulas crescerem sobre elles. A accumulação destes sedimentos deve ter sido lenta ou espasmodica.

Uma das melhores provas da accumulação lenta de certas camadas sedimentarias encontra-se na natureza e na origem dos materiaes. Os folhelhos diatomaceos e as pederneiras derivadas destes não podiam accumular-se rapidamente; porque, pela propria natureza das cousas, seria impossivel que organismos tão diminutos se ajuntassem com rapidez.

Os seixos arredondados que formam os nossos conglomerados exigem muito tempo no gastar. A grande espessura de alguns conglomerados exigiria um lapso consideravel de tempo para o simples attrito dos seixos de que são compostos gastal-os como se mostram na rocha.

Algumas das nossas grandes camadas conglomericas tèm uma 
distribuição tĩo larga que parece que a receberam em virtude de uma lepressão da terra que a fez passar pela condição de praia. Mas para que uma area larga passe pelas condiçoes de praia e para que os seixos sejam arredondados e alizados seria necessario que a depressão da terra fosse lenta: de outro modo os materiaes não seriam bem gastos, nem os depositos teriam grande espessura.

Demais a marcha da desnudação que suppre os sedimentos para formar as camadas sedimentarias determina a da sedimentação. Esta desnudação só pode proseguir numa certa marcha sem que os cursus l'agua fiquem sobrecarregados e portanto incapazes de cortar os seus canaes ou de carregar para o mar os materiaes que recebem da terra. Finalmente a marcha de deposięão tem sido observada em muitos caso: nas boceas dos grandes rios, taes como o Pó, o Mississippi, o Rheno e o Rhodano. Em todos os casos, mesmo quando as condições são as mais favoraveis para a deposição rapida, a marcha é lenta.

Em geral, pois, a espessura das rochas sedimentarias suggere que exigiram longos periodos de tempo para a sua deposição.

\section{0 endurecimento das rochas.}

1) endurecimento das rochas pode ser produzido chimica ou mechanicamente, ou por uma combinação dos dois processos.

0) endurecimento chimico pode ser produzido (I) pela deposiço de solução, nos instersticios das rochas, de algum mineral que a consolide, tal como carbonato de cal, silica, oxido de ferro, ou outro mineral: (II) por mudanças produzidas pela elevação de temperatura na presença de agua dentro da rocha.

o endurecimento mechanico é produzido por pressio. Os folhelhos " as ardosias, por exemplo, são argillas endurecidas mechanicamente.

o endurecimento tem logar actualmente em muitas rochas, havendo no Brasil excellentes exemplos deste processo. A crosta ferruginosa tão rommum em muitos lugares no estado de Vinas Geraes onde é conhecida pelo nome de cangu é produzida pela oxidagio dos mineraes de ferro expostus na superficie. Estes mineraes eram originalmente molles ou incohrentes, mas pela combinaçio com oxygenio 
e agrua se forma a crosta de canga subre a superficie du chào e com a expessura de um ou mais metros, achando-se incluidos muitos fragmenlos de rocha. Na vizinhança de Ouro Preto e entre os arraiaes de Inficionado e Aguu Quente em Minas existe uma planicie coberta com um soalho desta canga ou mineral de ferro oxidado encerrando cascalho e outros lragmentos de rocha. Em alguns lugares a canga apresenta a espessura de déz metros, sendo devida a ella a protecção da planicie de elosão.

Na ilha de Fernando de Noronha ha dunas de areia contendo mui-

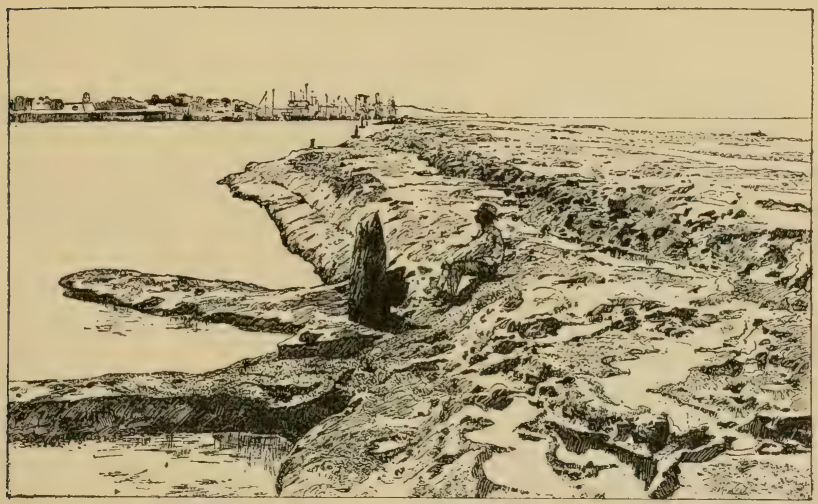

Fig. 71. - O recife de arenito em Pernambuco visto da extremidade de sul. A rocha é de areia endurecida pelo carbonato de cal.

us fragmentus de coraes e conchas. Quando a chuva cahe sobre esta areia a agua dissolve parte do carbonato de cal na parte superior, tornandes a deposital-o outra vez mais no fundo da duna e por este modo a areia se transforma em rocha dura (vêde fig. 60 na pagina 201). Por este mesmo processo foram consolidadas areias calcareas accumuladas pelo vento na ilha de Bermuda. Os recifes de arenito que na costa do Brasil, abundam Jesde Ceará até Santa Cruz no estado da Bahia siu compostos principalmente de arcia quartzosa commum endurecida pela deposição de carbonato de cal entre os seus grãos. 
Estes recifes são os mais notaveis do mundo deste genero. Muitas pessoas imaginam que são de coral, mas estr é um erro facil de verificar. Já no anno de 1387 Gabriel Soares de Souza escreveu que as rochas destes recifes erão de areia, e que contèm conchas e pedaços de coral ; em 1832 Olfers emittiu a mesma opinião; cm 18侎
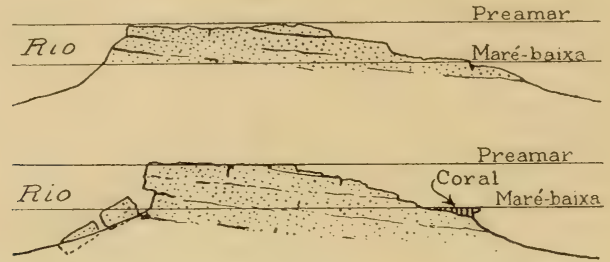

Fig. 72. - Secção mostrando a estructura dos recifes de pedra de Rio Formoso, Pernambuco, Natal, Santa Cruz, etc.

Charles Darwin publicou um artigo no mesmo sentido, e no anno, de 1863 M. de Barros Barreto, num relatorio sobre o porto de Pernambucu diz, com toda a razão, que " os recifes são de pedra, formados de un grez-quartzoso e fragmentos de conchas, ligados por um cinento silico-calcareo (1) ). De vez em quando essa pedra inclue pedacinhos de coral, e estes talvez dão origem á idéa que os recifes sejam de coral, mas os fragmentos são muito poucus e vim dos pequenos recifes de coral que margeam as costas no lado de fora dos recifes de pecira.

Collocando um pedaço desta rocha num acido bastante forte para dissolver a cal, os grãos de areia ficam soltos logo que fór dissolvidoo cimento calcareo.

0 endurecimento de rochas por pressão mechanica tem sidu demonstrado experimentalmente. A greda molle collocada debaixo de uma forte pressão no laboratorio e assim conservada pelo espare d.

(1) M. de Barros Barreto. Memoria sobre o melhoramento do l'orto de P'ernambuco, p. 3, Recife, 1865.

Vêde bibliographia deste assumpto no Stone reefs of Brazil, por J. C. Bramner, p. 201. 


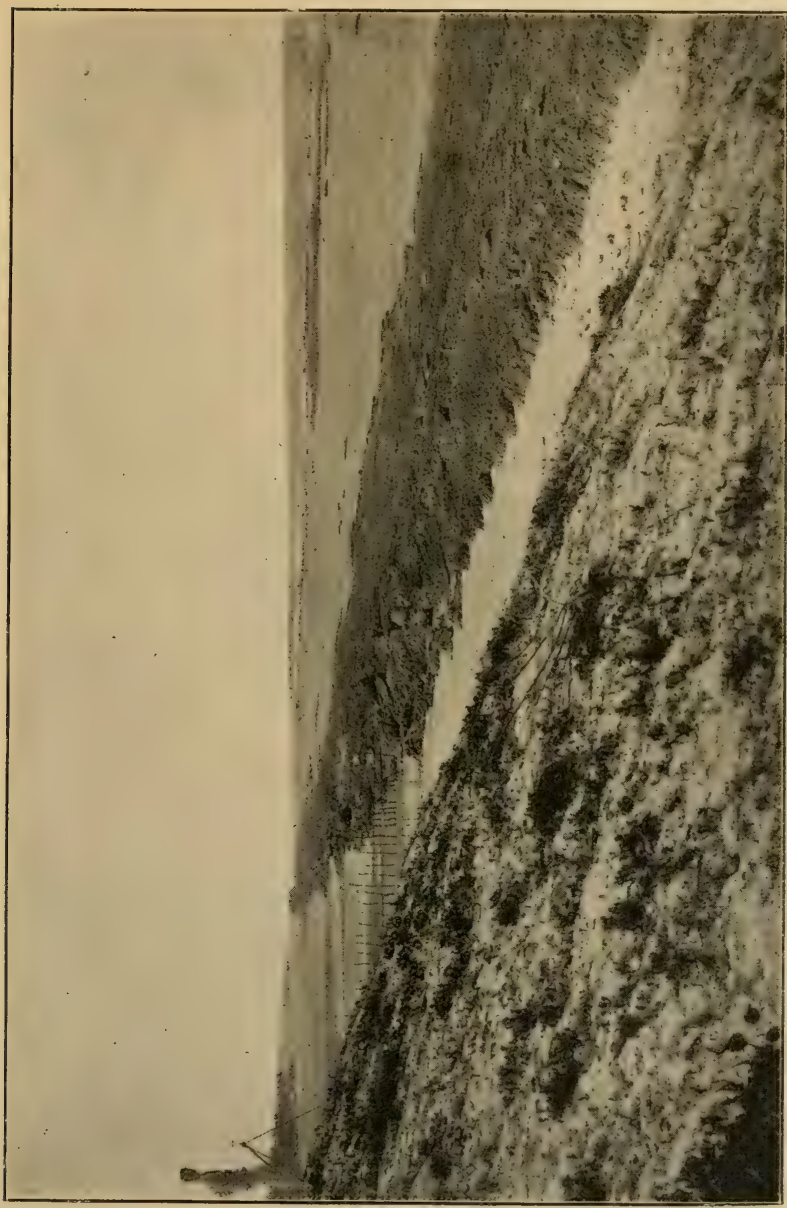

वे

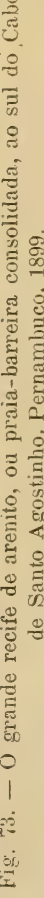
$\underset{\sim}{\infty}$ S त्ञ త్ 2 ว. $\frac{2}{3}$ o क 
tres annos foi encontrada convertida em marmore compacto quando removida (1).

E claro que estes processos de endurecimento das rochas estãı agora activos.

Is leis da materia justificam as seguintes conclusões com relação aos depositos sedimentarios:

I. - As rochas estratificadas devem ter sido accumuladas por meio dus mesmos agentes e debaixo das mesmas condięões que as que governam a deposição de materiaes semelhantes no tempo presente.

II. - As camadas mais antigas derem ter sido depositadas em primeiro lugar e as mais novas por cima destas, e assim por diante.

III. - As rochas estratificadas foram originalmente depositadas em camadas proximamente horizontaes, e todas as modificaçues que tèm nellas havido, quer seja consolidação, quebramento, dobramento, ou falhas, tiveram lugar subsequentemente e são de alguma maneira accidentaes.

\section{Rochas eruptivas ou não estratificadas.}

Rochas igneas ou eruptivas são as que tèm estado em condição de fusão. Geralmente pouco ou nenhuma difficuldade ha em distinguir entre as rochas sedimentarias e as igneas, se bem que occasionalmente as suas feiçoes caracteristicas não estejam hem definidas. As differenças entre os dous grupos de rochas são bem salientes comparando-as pelo modo indicado nas columnas seguintes.

(1) Géologie experimentale, par A. Daubrée, p. 132. Adams and Nicholson. science, 1898, II, VII, 82-83. 
ROCHAS SEDIMENTIRIAS

ROCIILS IGNEAS

Clasticas, ou compostas de fragmentos .... $\begin{gathered}\text { Crystallinas, ou compostas de } \\ \text { crystaes. }\end{gathered}$ En camadas ......................

Massicas: (a apparencia de camadas póde ser produzida por corrimentos differentes de lava).

Contendo fosseis

( Seni fosseis, salvo em inclusões e em alguns tufos.

Sem estructura fluxional

Com estructura tluxional (em parte).

Sem cavidades contendo gaz. ....... Com cavidades conlendo gaz (em parte).

Com textura variavel, conforme as correntes de ( Con textura variavel, conforme agua de deposição............ as condições de resfriamento.

\section{Agrupamento das rochas igneas.}

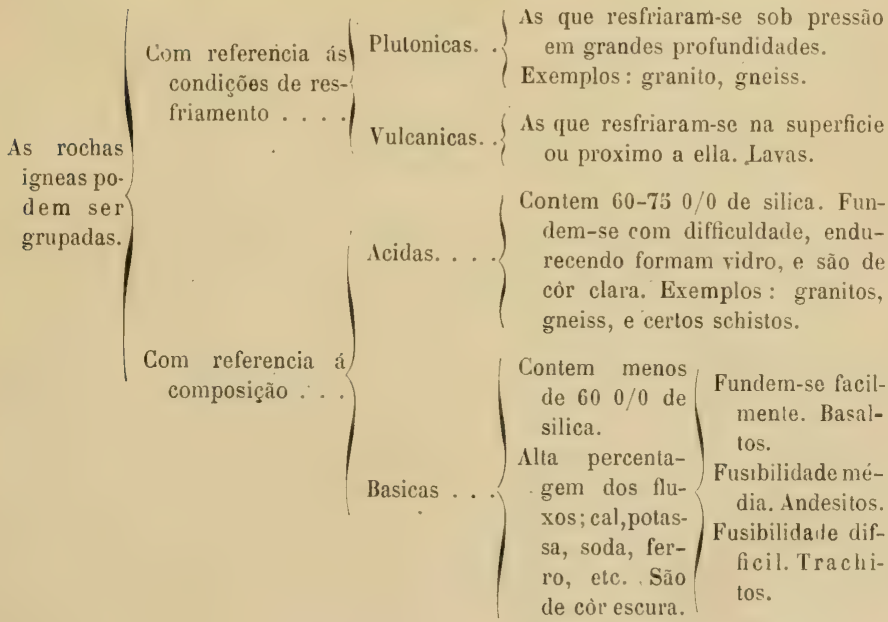

\section{Formas das rochas igneas.}

As rochas igneas ou eruptivas podem sahir de aberturas na crosta da terra mansamente, ou podem ser lançadas por erup̧ões violentas. 
Issim as formas tomadas variam com as circumstancias. Podem assim formar :

I. - Lençóes de lava.

II. - Cones de lava com angulo de deposição de $35^{\circ}$ á $40^{\circ}$.

III. - Intrusões na fórma de laccolitos.

IV. - Intrusões na fórma de diques.

V. - Depositos fragmentarios, como tufos.

Lençóes de lava. - Quando as rochas eruptivas são muito liquidas, podem se estender subre grandes areas, abatendo e aterrando completamente a topographia com inundações. Tres dos grandes corrimentos de lava do mundo, um destes no Brasil, são mencionados na pagina 137 e na 332 .

Acontece ás vezes que successivos corrimentos são empilhados um rin cima de outro, de modo que vistos de certa distancia assemelhamse, em apparencia, ás rochas sedimentarias. $\Lambda$ disposição em taes casos para formar terraços em forma de escada dá origem ao emprego do termo trap que vem da palavra sueca trappa, significando escada.

Ité no mesmo lençol ou camada de lava vè-se a similhança de camadas delgadas, produzida pelo movimento da lava ainda fluida. Dr. Lisboa fez a seguinte nota sobre as lavas na cachoeira do Avanhandava, no rio Tieté: - "Tambem ahi se observa um caracter muito conmum no trap : effeitos de phenomenos dynamicos que se traduzem por uma apparente stratificação. Na parte central do salto esse caracter está muito accentuado, estando a rocha dividada em finas laminas que dio ao conjuncto a absoluta semelhança de uma rocha sedimentaria de stratos horizontaes » (1).

En algumas partes do mundo lençóes de lava de espessura unifor'me tèm sido espalhados sobre uma região dada, e subsequentemente a erosào tem cortado as rochas deixando o lencol encimando os morros da região de modo a formar taboleiros como o mostrado na figura junta. Um caso mais ou menos semelhante se apresenta no grande

(1) M. A. R. Lisboa. Oeste de S. Paulo; Sul de Matto Grosso, p. 6. Rio de Janeiro, 1910. 
lencol de lava que cobre parte do interior dos estados de S. Paulo, Paraná, Santa Catharina, Rio Grande do Sul, e Matto Grosso, e pela diabase sobrejacente ás rochas sedimentarias das ilhas dos Abrolhos.

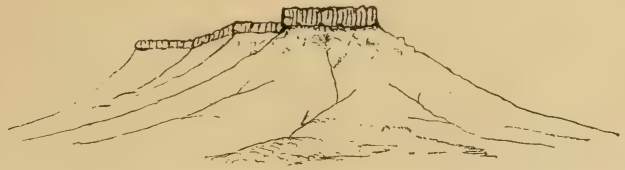

Fig. it. - Trypo de murros capeados por um lençol de lava.

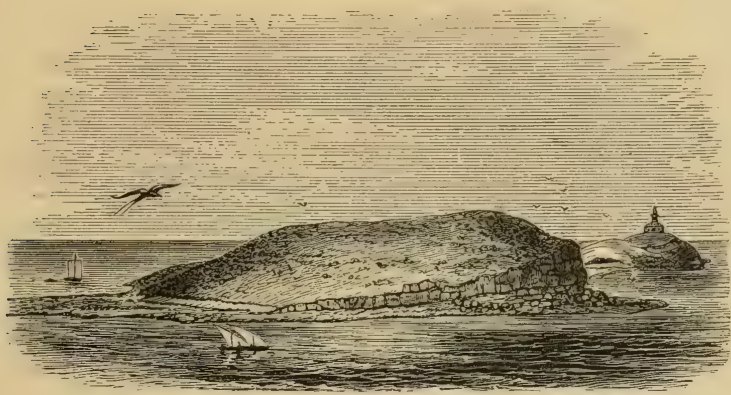

Fig. 75. - A Ilha de Santa Barbara dos Abrolhos. As camadas sedimentarias inferiores mergulham para o noroéste e sảo cobertas por um lençol de lava. (Hartt.)

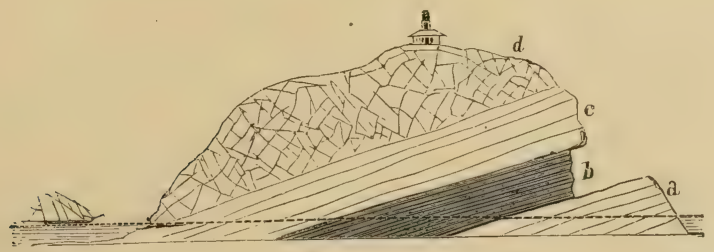

Fig. 76. - Secẹão atravez da Ilha de Santa Barbara dos Abro. lhos mostrando a estructura geologica. A camada $b$ é folhelho, $\alpha$ e $c$ são arenito e $d$ é um lençol de lava (diabase). (Hartt.) 
Como ja foi dito a pagina $\mathbf{1 4 3}$ parece provavel que o lençol de lava do sul do Brasil estende-se ao Matto Grosso, Paraguay e Irugua!, formando assim um dos maiores do mundo.

Cones de lava. - Quando a lava é viscosa ou yuandu resfriasu rapidamente, ella não póde percorrer longo trajecto antes de endurecer formando rocha solida. Corrimentos suceessivos de uma litva semelhante sithindo da mesma passagem produzem a formaęio de um cone em redor da passagem. 0 angulo de inclinação de um cone semeIhante deve variar necessariamente com a lluidez da lava, mas em regra geral os cones de lava apresentam angulos um tanto baixis de $\breve{\circ}^{\circ}$ a $25^{\circ}$ - conforme a fluidez.

Laccolitos. - Quando rochas eruptivals surgem atravez da crosta da terra, acontece ás vezes que atravessam as camadas inferiores, mas

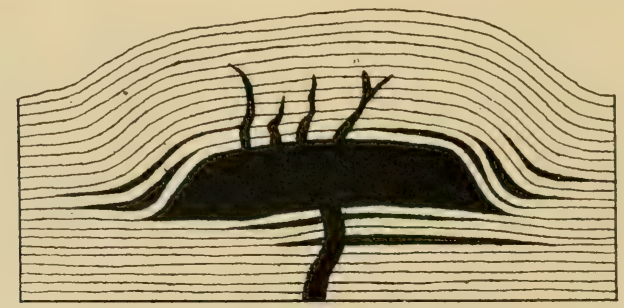

Fig. 7\%. - Um laccolito, ou massa lenticular de rocha eruptiva injectada entre outras camadas de rocha. (Gilbert.)

que devido á difficuldade de achar sahida atravez das camadas superpostas, a lava corre entre os estratos e alli resfria-se sem chegar á superficie. Essas massas são chamadas laccolithos ou liceolitus (cisternas de pedra). Apparecem occasionalmente expostos em virtude da erosão das camadas que ficaram por cima delles (Fig. 77).

Diques. - Acontece frequentemente, com reprecialidade nas regives vulcanicas, que as rochas eruptivas entram e resfriam-se nas fendas abertas em outras rochas. Estas massas sio chamadas diques. 
Tomam a fórma das fendas que enchem, sendo ás vezes tortuosas, ás vezes rectas. Variam tambem em tamanho e grossura até centenas de metros em largura. Formam-se ás vezes entre os planos de estratificação das outras rochas, porém podem tambem atravessar as camadas em qualquer angulo.

No Brasil ha muitos diques na ilha de Fernando de Noronha onde cortam outras rochas eruptivas. Na area das rochas vulcanicas ao sul do Brasil os diques são communs, e até atrevessam as camadas de carvão de pedra no Rio Grande do Sul. Em Ereré no estado do Pará os diques de diabase cortam camadas devonianas de arenito. Nas regiões de rochas crystallinas tambem ha muitos diques que atrevessam os granitos, os gneiss, e as outras rochas crystallinas. Em umutos lugares estão bem expustas nas cortes ao longo das estradas de ferro.

Tufos. - Os materiaes fragmentarius injectados pelos vulcũes silu de varios graus de grandeza. As cinzas mais miudas são frequen-

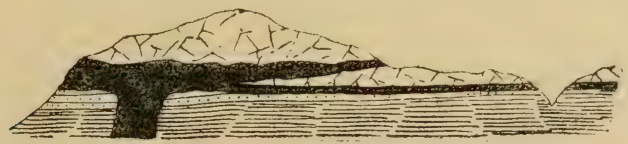

Fig. 78. - Seç̧ão mostrando um dique $\mathrm{em}$ baixo que forma lençóes de lava em cima. (Geikie.)

temente espalhadas pelos ventos sobre grandes a!reas, ao passo que os fragmentos mais graúdos cahem ao redor do orificio construindo um cone de cinzas tendo uma cratera, ou abertura, em fórma de copo, no cume. (Vede fig. 36 na pagina 140.)

Quando as cinzas cahem na agua, tomam as feiçoes estructuraes de rochas sedimentarias e são consideradas como tufos depositados na agua. Os tufos assiın depositados contèm ás vezes fosseis, restos de animais, que existirem nas aguas antes de cahirem as cinzas. Quandu eahem sobre a terra são ás vezes carregadas pelo vento como as areias soltas das dunas. 


\section{Feições estructuraes communs nas rochas e produzidas depois da deposição.}

\section{FEIÇÕES MENORES}

Juntas. - Chamam-se juntas as faces nitidamente cortadas que atravessam as rochas independentemente dos planos de estratilicação. Estas juntas se apresentam em rochas de todas as naturezas quer se-

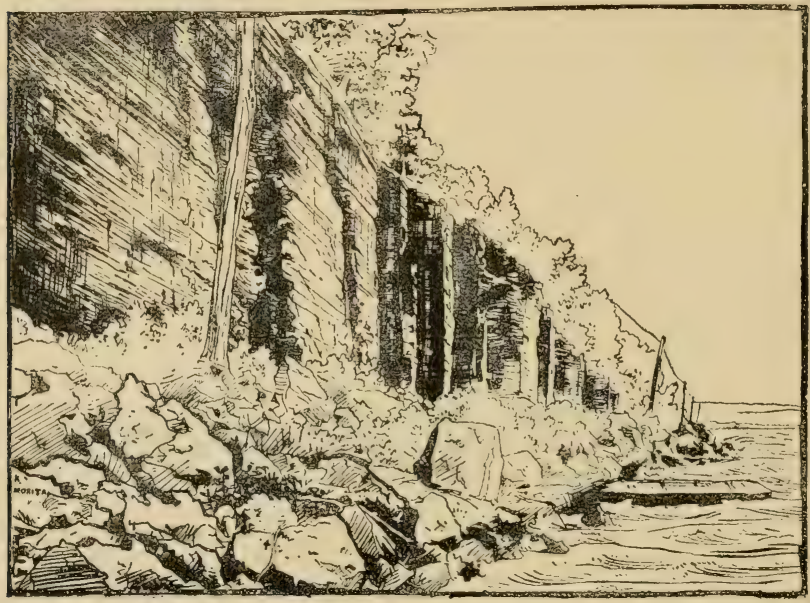

Fig. 79. - Juntas verticaes em camadas horizontaes de folhelho, margens do lago Cayuga, estado de New York.

dimentarias, quer eruptivas, e muitas vezes cortam os scixos e outros pequenos frąmentos que formam as camadas. São communs nas rochas mais duras, mas apresentam-se tambem em maleriaes molles e mesmo em camadis de areia. As juntas frequentemente se apresentam em diversas series nas mesmas camadas, e estas series sio sujettas a se? cruzarem em angulos mais ou menos definidos. As juntas são em algumas regiões tào importantes que influem de modo notavel sobre: topographia e sobre os cursos de agua. 
A fịura mostra os paredões do Logo Cayuga cujas faces lizas são devidas a juntas verticaes em camadas horizontaes do folhelho. Alguns dos tufos da vizinhanea de Antonio Olyntho, no Estado de Pernam-

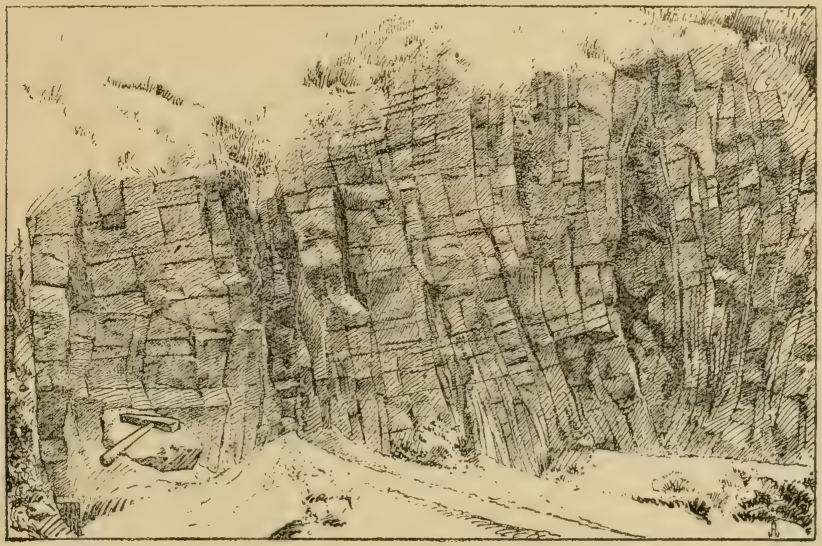

Fig. s0. - Juntas verticaes em camadas horizontacs de tufo rhyolitico perto de Antonio Olyntho, estado de Pernambuco.

buco, apresentam camadas quasi horizontaes cortadas por juntas verticaes (fig. 80).

Columnas basalticas. - Algumas rochas eruptivas, a resfriar, divid.m-se em columuas hexagonaes geralmente chamadas columnas basalticas. Estas se formam perpendicularmente á superficie de resfriamentu, e portanto um lençol de lava basaltica acha-se sujeita a ter as suas columnas formadas em posição vertical.

Em diversos pontos no sul do Brasil os grandes derramamentos de rochas eruptivas formam lindas columnas basaluicas. Um lugar notavel é no Rio du Rissto, onde a estrada atravessa a serra no estado do Rio Grande du Sul (1).

Acontece îrequ zntemente, porém, que estas columnas, sầ cur-

(1) Francisco de Paula Oliveira, p. 22. 
vadas. Apresentam-se tambem, ás vezes, em posiçau horizontal. A figura junta mostra as columnas proximamente horizontaes que se encontram na ilha de Fernando de Noronha. Em alguns casos a horizontalidade das columnas é devida ao facto de ter resfriado o material dentro de fendas verticaes.

Pela maior parte as columnas basalticas apresentam a forma

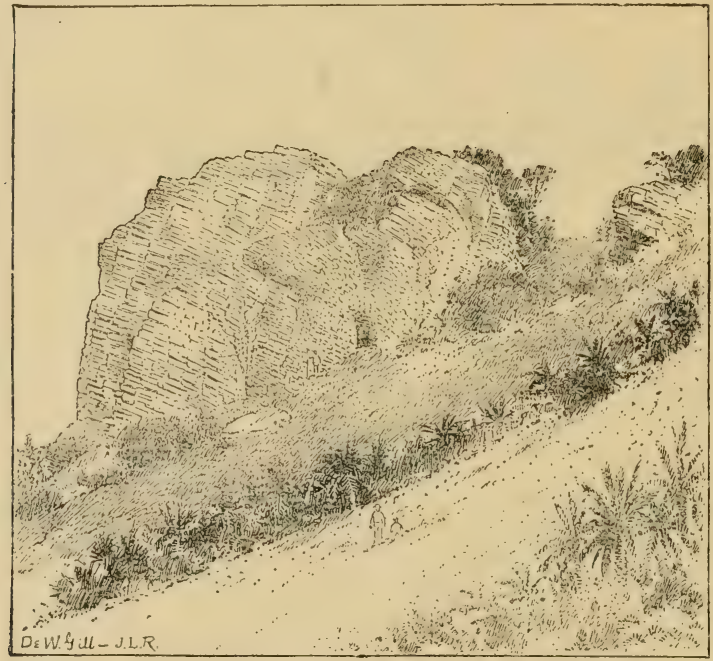

Fig. 81. - Columnas basalticas quasi horizontaes na ilna de Fernando de Noronha.

hexagonal. A razão desta forma hexagonal é a seguinte. Durante o restriamento a contracrăo obriga as rochas a se racharem. Uma superticie plana só pode ser dividida em tres typos de figuras regulares : " quadrado, o triangulo equilateral e o hexagono. 0 allivio da contraçào deve, portanto, dar lugar á producegio de uma dessas figuras, se as figuras forem tudas semelhantes. Partindo de um ponto dado, o fendimento em quadrados exige uma separaça ao longo de quatro linhas formando angulos de 90 gráus entre si (lig. 82); para produzir trian- 
gulos o quebramento deve ser ao longo de seis linhas (fig. 83) formando angulos de $60^{\circ}$, ao passo que o rachamento $\mathrm{em}$ hexagonus exige 1) fenulimento ao longo de tres linhas formando angulos de 120
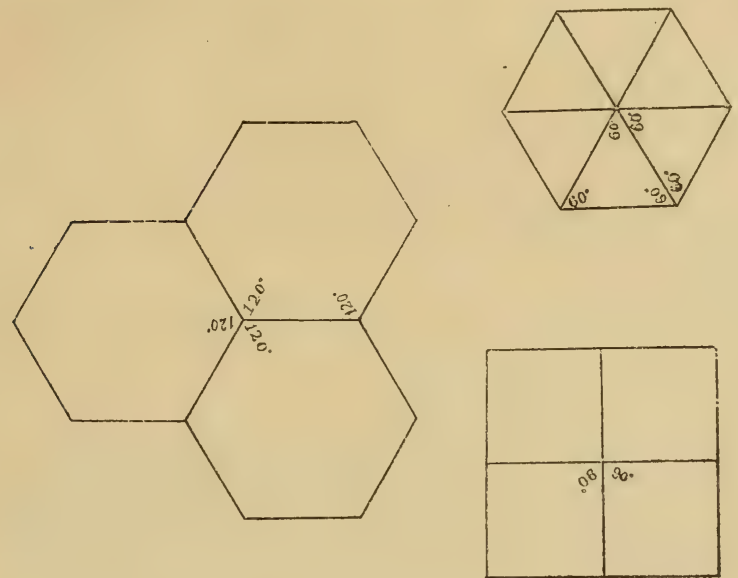

Fig. 82,83 e 84 . - Diagrammas para demostrar a origem da forma hexagonal das columnas de basalto.

(lig. 81). Para dar allivio, esta ultima é portanto a forma mais facilmente produzida em virtude da maior simplicidade do fendimento.

Theoria das juntas. - Exceptuando-se as das columnas basalticas). Tem-se proposto quatro theorias para explicar a formação das juntas nas ruchas, a não ser as das columnas basalticas, a saher : contracção, torȩão, terremotos e pressão.

A theoria da contraçióo ensina que as juntas das rochas sào produzidas como as fendas que se produzem em lama no acto de seccar, isto é, pela perda de volume devida ao escapamento de agua. Pouca duvida pode haver que fendas produzidas pelo calor são occasionalmente formadas e conservadas visto que são encontrudas ás vezes nas rochas duras; mas estas fendas se distinguem facilmente das juntas 
urdinarias. As fendas solares não são geralmente rectas e nitidas como as juntas das rochas.

1 torgão, ou enroscamento, é capaz de produzir series de fracturas cruzando umas as outras. Isto tem sido demonstrado experimentalmente (1). As figuras juntas são copiadas de photographias, por Daubrée, de laminas de vidro que foram submettidas a uma torẽ̃o
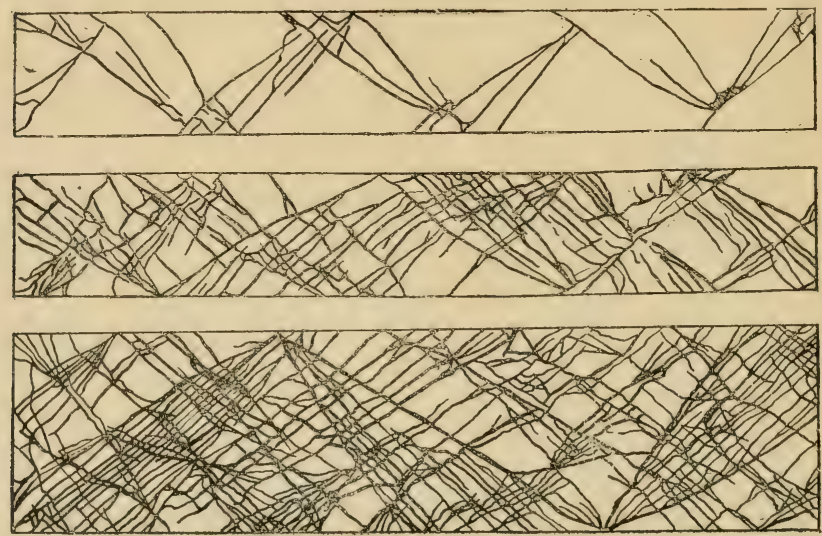

Fig. 85. - Fracturas produzidas pela torção em laminas de vidro. (Daubrée.)

subita. Nota-se que ha duas series de fracturas que se cruzam quasi em angulo recto e tambem que as fracturas dì uma só serie são provimamente parallelas entre si.

Já se notou que os terremotos sãu tremores ou choques propagados como ondas pelas rochas da crosta di terra. Parece provavel que estas ondas possam ser bastante fortes para produzir series de fendas nas rochas, especialmente se estas estiveram sob tensão na occasião do choque.

A pressio por si só é capaz de produzir duas series de fracturas pelo menos, e é possivel que algumas das juntas das rochas resultem

(1) A. Daubrée. Geologie experimentale, pags. 300-314. Paris, 1879. 
de empuxo lateral, ou mesmo da pressão da grande carga de camadas sobrejacentes de rochas.

Daubrée tem notado que quando se sujeita blocos de cera a esmagamento, estes quebram com angulos definidos de cerca de $45^{\circ}$ da normal e perpendiculares entre si (1).

As provas de esmagamento sobre materiaes de constıucção mostram, porém, que as diversas qualidades de rochas quebram segundo
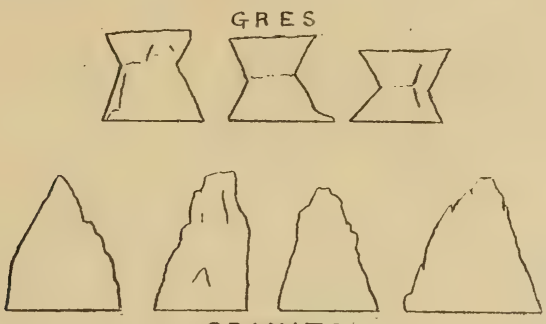

GRANITO
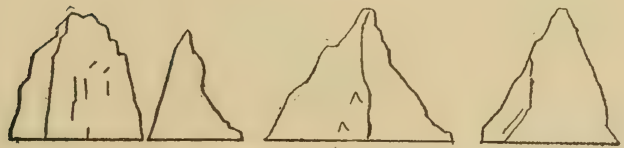

PEDRA. CALCAREA.

Fig. 86. - Perfis de cubos de pedra quebrados por grande pressão. Metade da altura natural. (Buckley.)

planos que fazem entre si angulos que variam um tanto conforme a natureza da rocha, porém tendo ainda uma notavel semelhança. Este facto é bem illustrado na figura 86 (2). As figuras mostram os contornos de cubos de granito, calcareo e arenito, que foram esmagados em machinas feitas para provarem a resistencia de pedras de construcç̃o.

Existe tambem uma semelhança notavel entre os angulos de fra-

(1) Géologie expérimentale, pags. 317-320.

(2) Buckley. Journal of Geology, VIII, pags. 526-567. 


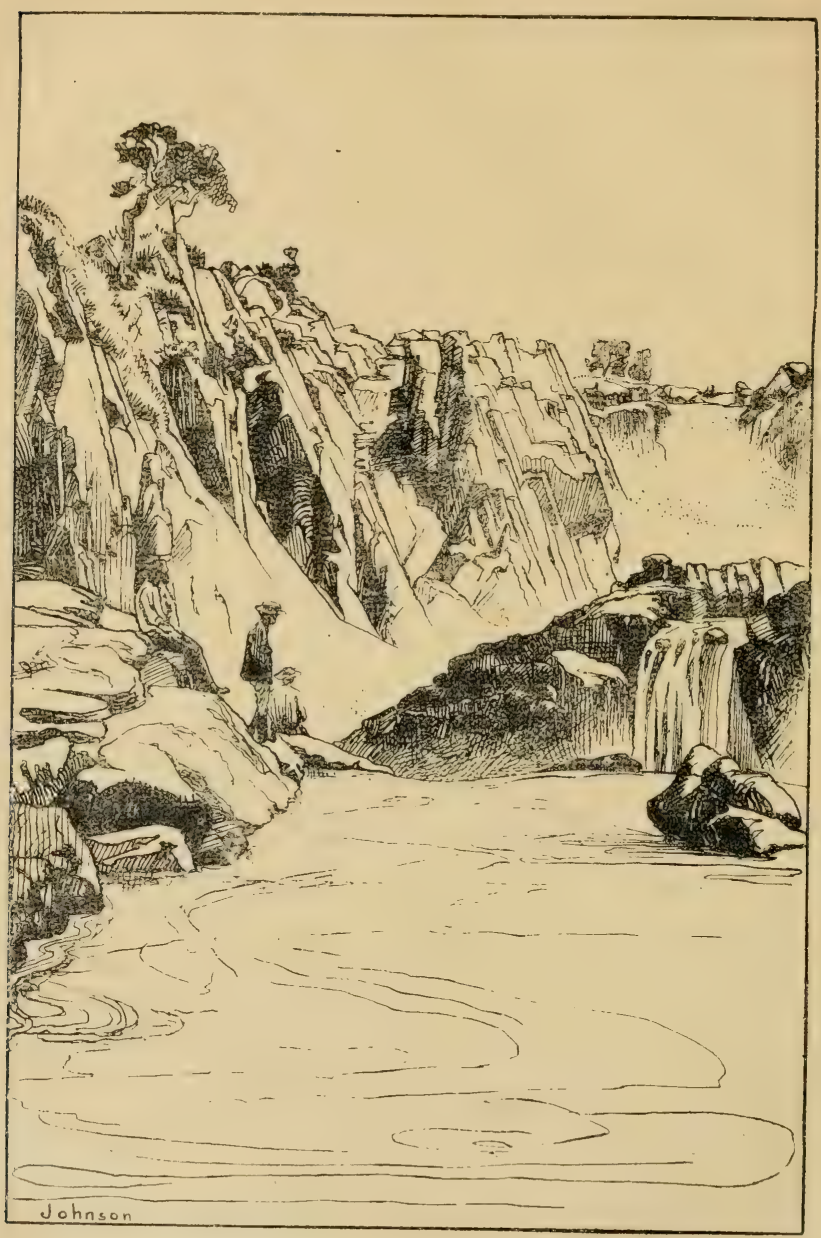

Fig. 87. - Juntas nas rochas graniticas do cañon do rio S. Francisco abaixo do salto de Paulo Affonso. 
ctura nestes cubos esmagados e os que se encontram nas rochas em muitas localidades. Na cachoeira de Paulo Affonso, por exemplo, us paredões no cañon abaixo do salto principal (Fig. 87) apresentam juntas que se assemelham aos planos de fractura dos cubos de prova de fig. 86 .

Diques de arenito. - De vez em quando acontece que as iuntas das rochas recebem, ou de cima, ou debaixo, materia clastica que, depois de consolidada, forma rocha dura. Estas rochas se chamam diques de arenito ou diques clasticos. As fórmas e as dimensões destes diques dependem das fórmas e dimensões das juntas, mas geralmente não são muito grandes. Variam de uns quantos millimetros a um ou dois metros em espessura.

Parece que o material do maior numero destes diques de arenim rem debaixo, transportado por agui ou petróleo subindo para a superficie (1).

Nas rochas eruptivas da cachoeira do Avanhandava do rio Tieté, Dr. Lisboa notou veios ou diques pequenos de arenito (2).

\section{A clivagem das rochas.}

Por clivagem dè rochas entende-se a sua tendencia para se rachar com maior facilidade an longo de certas planos parallelus. Notam-sie nas rochas tres especies de clivagem, a saber :

I. Clivagem crystallina que é peculiar ás formas mineraes crys1allinas. E' bem illustrada no fendimento da mica e du gypse em placas delgadas parallelas. Esta natureza de clivagem é sempre em plano: parallelos definidos, isto é, atravessa o mineral unicamente em direc¿ões definidas. E' devida ao arranjo mollecular dos constituintes do mineral.

(1) J. F. Newsom. Clastic dikes. Bulletin Geological Society of America, XIV, 227-268. 1903.

(2) II. A. R. Lisboa. Oeste de S. Paulo; Sul de Matto Grosso, pag. 6. Ris de Janeiro, 1910. 
II. Clivagem em layes é o fendimento das rochas ao longo dos planos de acamamento. Estes planos são devidos ao arranjamento mechanico dos materiaes na nccasião da sua deposição. E' mais ou menos saliente em todos os sedimentos, mas é esprecialm'nte bem definido nos mais miudos, taes como arenitos de grãu fino e piẹarras.

No estado de Sergipe existem pedreiras em rochas calcareas que formam lages. Utilizam essas lages para o calcamento das ruas na cidade de Aracajú.

III. Clivayem ardosiaca é devida a um rearranjamento superinduzido aos materiaes que formam a rocha, fazendo com que ellas se fendam ao longo de planos parallelos que, em regra geral, são intei-

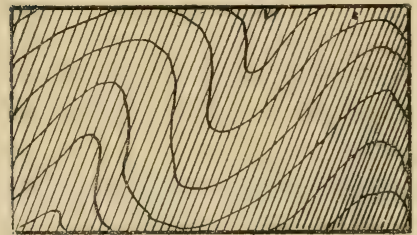

Fig. 88. - Secção mostrando clivagem ardosiaca en linhas quasi verticaes atravessando os planos de acamąmento da rocha em varios angulos.

ramente independentes do acamamento. E' uma particularidade da clivagem ardosiaca o vir sempre associada com camadas dobradas ou contorcidas, nunca com as camadas que não são perturbadas. Ella as atravessa em qualquer direçãa : isto é, os planos de clivagem se conservam parallelos seja qual fôr o grau do dobramento das camadas.

Outra particularidade é que a clivagem ardosiaca acha-se limitada a rochas de granulação miuda, taes como os folhelhos, não se apresentando nas de sedimentos mais graúdos, taes como conglomerados e arenitos grossos.

Nota-se tambem que as particulas e mineraes constituintes das rochas que possuem clivagem ardosiaca acham-se todas arranjadas parallelamente aos planos do clivagem.

No estudo da origem e significação da clivagem ardosiaca é interessante notar o effeito das condições em que se formam certas outras substancias. 0 ferro em fusão por exemplo, se fòr dei xado reslriar sem pressão fica granular : se fòr esticado como arame fica fibroso; mas quando rolado os seus granulos são achatados desenvolvendo uma estructura ou clivagem escamosa. Estes factos suggerem que a com- 
pressão tende a produzir no ferro uma clivagem perpendicular á direcção em que se applica a pressão. Se fragmentos delgalos e achatados de uma substancia qualquer, por exemplo, lamellas de mica, forem misturados com argilla ou massa, e esta argilla fòr submettida a pressão, encontram-se depois as lamellas arranjadas purpendicularmente á direção da pressão. Mesmo qualquer substancia homngenea, como cera, quando sujeita á pressão tende a se separar em folhas ou escamas perpendicularmente á linha de pressão.

Estes factos todos tendem a mostrar que a clivagem ardosiaca é causada por um esforço de pressão applicada em angulo recto aos planos de clivagem ardosiaca. E', naturalınente, possivel que a pressão por si só não seja sufficiente para produzir a clivagem perfeita que se nota em muitas ardosias, e que seja acompanhada tambem por um rearranjamento chimico. Que a pressão, porèm, é o factor importante está provado pelos factos seguintes além dos já mencionados :

I. - As jazidas de ardosia apresentam, ás vezes, camadas delgadas e enrugadas de areia que as atravessam.

II. - As rochas em regiões de ardosia são sempre dobradas.

III. - Os fosseis que se encontram nas ardosias são sempre deformados pela pressão.

IV. - Os mineraes das ardosias apresentam os seus eixos maiures parallelos aos planos de clivagem.

\section{Schistosidade.}

A schistosidade é o fendimento de rochas em lamellas delgadas; porém, differindo neste respeito da clivagem ardosiaca, as lamellas sãı mais ou menos enrugadas. As rochas apresentam muitas vezes um aspecto semelhante a feltro. Suppunha-se ser a schistosidade devida á expres̃são ou escorregamento (shearing) nas rochas quando comprimidas em profundidades consideraveis abaixo da superficie. As camadas proximas á superficie, quando sujeitas á pressão lateral, são dobradas: ao passo que as mais profundas e sob maior pressão se tornain schistosas. Tambem é produzida por crystalização. Schistosidade é muitu commum nas rochas crystallinas do Brasil. 


\section{Concreções.}

Concreçôes são geralmente massas arredondadas ou lenticulares desde o diametro de um millimetro até metro ou mais, cuja dureza differe da das rochas em que estão engastadas, e geralmente tambem differem um tanto em outros caracteres. Algumas concreções são tho arredondadas e lisas que se assemelham a seixos gastos pelas aguas; porém differem destes em não serem perfeitamente lisas na superficie externa. As concreções são produzidas pela precipitação de soluçãc de certas substancias cimentantes dentro de um espaço limitado. A tendencia de certos mineraes de segregar quando crystalizam faz com que se reunam nas formas peculiares que então așsumem.

As concreções podem-se apresentar em rochas igneas ou sedimentarias. Podem ser contemporaneas com as camadas encaixantes, isto ¿, podem (I) ter-se originado e ter sido depositadas como concreries; (II) ou podem ter sido formadas subsequentemente.

En certas fontes thermaes as aguas precipitam carbonato de cal na forma de pequenas concreçôes ou pelotas arredondadas que logo descem para o fundo. Estas são contemporaneas com os outros materiaes formativos de rochas com os quaes são depositados.

Quando as concreçẽes se formam depois da formação das camalas ' 'm que se apresentam sào produzidas pela precipitação de algum mineral cimentante de soluejôes dentro das proprias camadas. Neste ultimo caso os planos de acamimento das rochas podem passar atravez \las concreções, ou antes o endurerimento das concreções não se achıı limitado a uma unica camada. As concrerões que se formam em arenito são frequentemente endurecidas por carbonato de cal; ao passo que as formadas em calcareos são geralmente endurecidas por silica. Ha uma tendencia geral de se formarem concreções em redor de ossos ou fragmentos de conchas, ou alguma outra substancia organica, como ponto de partida.

Na formação glacial conhecida pelo nome de loess a cal frequentemente forma nodulos fantasticos conhecidos pelo nome de loessjuppets (bonecos de loess), como os representados na fig. 89. 
Hi uma disposição entre as concreções para formarem-se ao longo
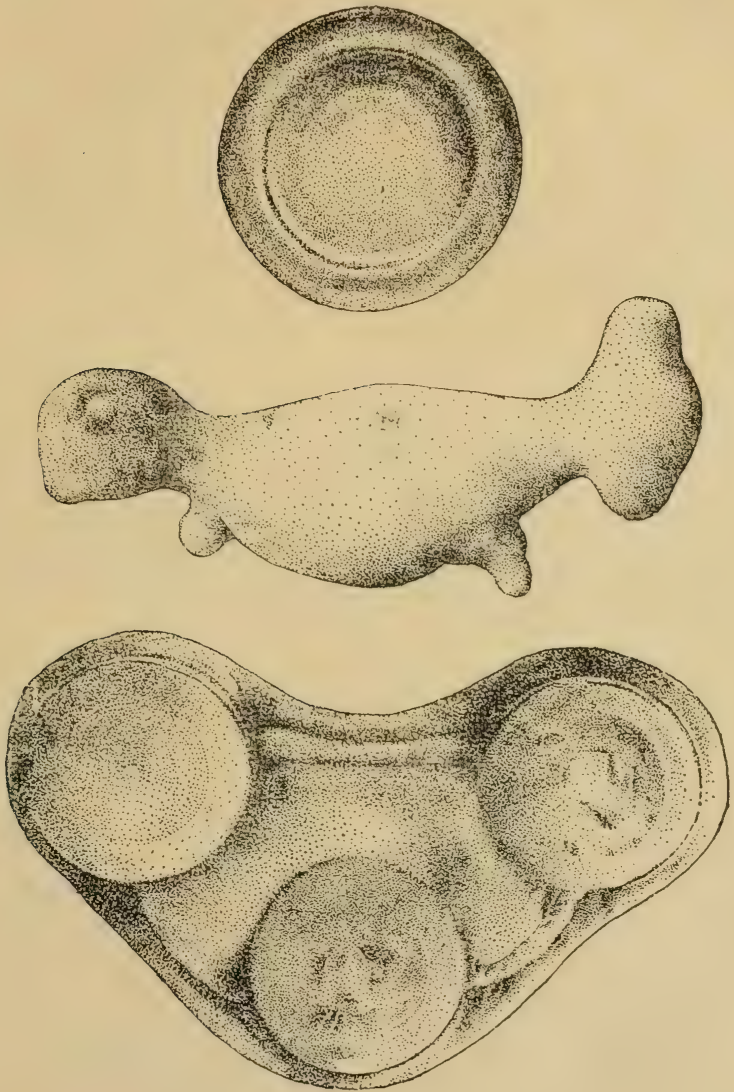

Fig. 89. - Concreções nas argillas pleistocenicas do Valle de Connecticut, Americo do Norte. Tamanho natural.

de certas camadas de preferencia a outras, e em taes casos, se as camadas forem delgadas, as concreções são mais ou menos achatadas. 
Quanclo as concreções são ocas, são frequentemente forradas com calcedonia ou com bellos crystaes de quartzo, ou calcite, e são então chamadas yeodes. Em certas formaçoes geologicas estas geodes são muito abundantes e variam em tamanho desde o diametro de poucos millimetros até meio metro. As bellas agathas que se encontram nos estados do Rio śrande do Sul, Santa Catharina, Paraná e São Paulo são, irequentemente, geodes ocas. Estas agathas foram formadas pela deposição de calcedonia em cavidades nas rochas eruptivas. Subsequentemente foram livradas da massa da rocha encaixante pela decomposição desta.

Nas rorhas eruptivas ao longo do rio Grande no oeste de S. Paulo tem-se notado muitas geodes de quartzo com a fórma de um con tendo a base reentrante, como o fundo de uma garrafa (1).

Dr. Euzebio de Oliveira publicou um artigo sobre concrecões arenosas e de fórmas cylindriras achadas no estado do Paraná. Acham-se na serra das Pedras Brancas 16 kilometros veste da cidade de Tibagy onde são popularmente conlecidas como " palmeiras petrificadas ". 0 autor diz que são concreções de areia (2).

Quando as concrecões sĩo muito prequenas e occorrem em quantidade sĩo chamadas oolitos, ou rogenstein, em virtude de sua semeIhanęa aos ovos de peixe. Quando são do tamanho de ervilhas são chamadas pisolitus. Acontece ás vezes que camadas extensas de rocha são compostas em grande parte destas pequenas concreções.

Na serra da Bodoquena perto de Miranda no estado de Matto Grosso o Dr. Lisboa achou uma rocha branca, còr de leite, cimentando concreçoes de silica leitosa com a forma de bagos de lentilhas ou feijāosinhos. Era um pisolito (3).

As estructuras concrecionarias se apresentam ás vezes em rochas erystallinas sendo em taes casos devidas ao arranjo concentrico dos crystaes na occasião do resfriamento da rocha.

(1) J. \. I'acheco. Geolngia do valle do Rio Grande. Commissão Geographica 1) Geologica de S. Paulo, 191\%. pag. 34.

(2) Patria e Lar. Curitiba, 1912.

(3) M. A. R. Lisboa. Oeste de S. Paulo; Sul de Matto Grosso, pag. 42. Rio de Janeiro, 1910. 
Deve- se prevenir contra o engano de tomar por concreções certas outras formas arredondadas que as rochas apresentam. A coloração concentrica, por exemplo, apresenta certa semelhança, a concreções, ınas é produzida pela penetraçào nas rochas de aguas carregadas com subsiancias mineraes.

A exfuliaçâo esplicroidal produzida pela acçào do tempo tambem dá lórmas arredondadas que se assemelham um tanto a concreções. 0 processo de exloliação já foi explicado na pagina 33.

\section{Fulgaritos.}

Fulgarito é uma especie de tubo de fórma irregular e de diametro de cinco a dez centimerros feito na areia ou solo pela fusão d. ssas substancias quando sahe um raio. Geralmente um fulgarito tem o diametro maior na superficie da terra e vai diminuindo para baixo e formando ramos que desapparecem em pouca distancia. 0 comprimento não passa de dois metros mais ou menos.

\section{Feições maiores.}

\section{A deslocação das rochas.}

Já se mencionou as evidencias das el vações e depressões da crosta da terra á pagina 15 š. Mostrou-se tambem que quando a crosta da terra sc levanı em alguns lugares, ella esı́a sendo deprimida em outros. Estes novim ntos produz m nas rochas de que se forma a crosta da terra inclinação, dobramento e falhas.

Só se póde vèr o que acuntece nas ruchas e quacs as mudanças estructuraes que estes nuvimentos da crosta produzem quando forem 
accessiveis secçòes das rochas, quer sejam em exposições naturaes ou artificiaes.

As seções artificiaes encontram-se em córtes de estridas de ferro, minas e poços. Estas secções, porém, raras vezes penetram mais de mil metros. As minas de cobre do estado de Michigan tèm a profundidade de mil quatrocentos e trinta e tres metros, e um poeso fundo perto de Leipzig, na Allemanha, a de dois mil metros.

A maior profundidade alcançada na crosta da terra no Brasil é

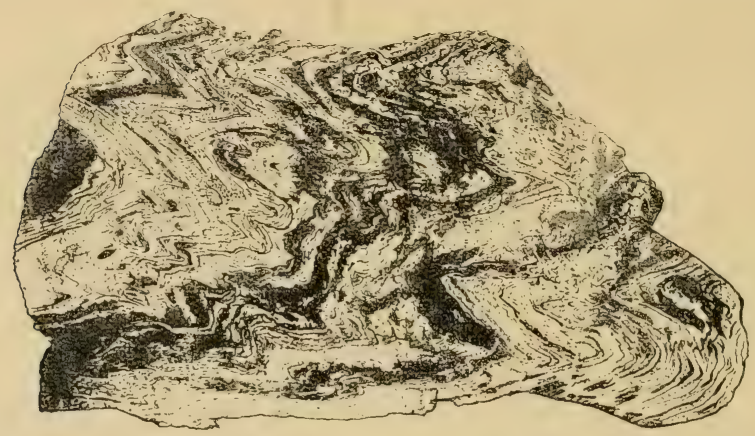

Fig. 90. - Especimen de um syenito amarrotado. (De uma photographia: metade do tamanho natural.)

nas minas de Morro Velho no estado de Minas Geraes. Ali a mina tinha a profundidade de 1567 metros no anno 1913 , isto é 737 metros abaixo do nivel do mar.

As seções nuturaes são expostas nos canaes de rios e em cañons. o Grand Cañon do Rio Colorado na America dı Norte tem a profundilate maxima de dois mil metros. Neste caso a seç̧ão é quasi exclusivamente atravez de camadas horizontaes de rocha.

Em regra geral, porém, as seções naturaes apresentam as maiores espessuras onde as rochas tèm sido dobradis e depois erodidas de modoa expor na superficie as rochas mais fundas. (Vede a fig. 91.)

Por is so os dobramentos, falhas, e outras feicoes estructuraes tornam-se de maxima importancia no estudo da geologia. 


\section{Dobramento das rochas.}

E' um dos postulados da geologia que as rochas sedimentarias füram originalmente depositadas em camadas proximamente horizontaes. Sendo isto verdade, segue-se que as dobras, inclinações e falhas
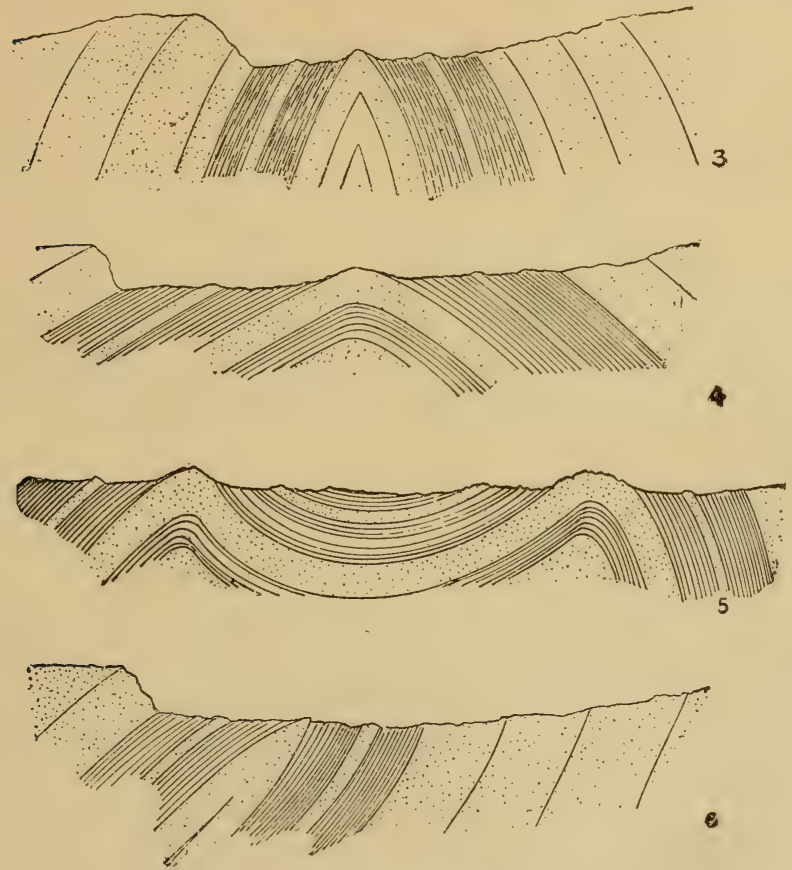

Fig. 91. - Secções de porções dobradas da crosta da terra mostrando anticlinos. N. 6 é um anticlino subvertido. N. 5 tem um synclino entre dois anticlinos.

em camadas sedimentarias fòram feitas subsequentemente á deposiç̃o das camadas. As dobras nas rochas săo rugas de varios tamanhos. Podem ser largas e suaves com os seus eixos muito separados, ou po- 
Iem ser fortemente amarrotadas romo no caso de alguns dos schistos (fig. 90).

As dobras grandes pódem ser tão fortemente comprimidas que subvertem-se rompletamente. As dobras pódem occorrer isoladamente ou em grupos em fórma de leques. As partes de uma dobra tem nomes listinctos. I'm afloramento é qualquer exposięão de rocha in situ na

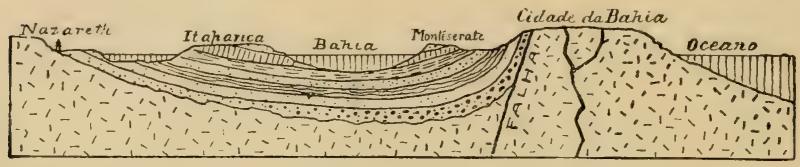

Fig. 9:. - Secção hypothetica mostrando a estructura synclinal entre a cidade da Bahia e Nazareth.

superficie. O eixo de uma dobra é um plano imaginario ao longo do qual a dobra se fórma. Estes eixos são verticaes quando as dobras são uniformes, isto é, semellıantes nos dois lados; são inclinados quando a dobra está subvertida, isto é, quando um lado tem uma inclinaçào, ou declive, mais forte do que o do outro.

Anticlino é o nome dado a uma dobra cujas camadas se inclinam

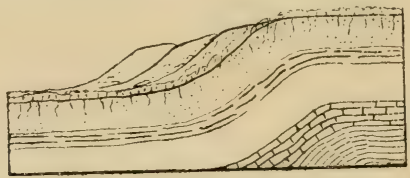

Fig. 93. - Seç̧ão mostrando a estructura de um monoclino.

a partil do eixu para ambos os lados semelhantemente ao tecto de uma casa, ou a um arco.

Synclino éo nome dado a uma dobra cujas camadas se inclinam para o eixo como os lados de um coche. Os anticlinos e os synclinus pódem ser coches estreitos ou largos. O Reconcavo da Bahia é um grande coche synclinal que se estende desde a cidade da Bahia a léste até Nazareth a o'ste numa distancia de sessenta kilometros. 
I'm monoclino è o declive das camadas apenas n'uma direç̧àı sem serem subvertidas.

Os eixos destas dobras siu locados pelo exame dos alloramentos, ou exposições, das rochas e pela determinarão das direções das inclinaçòes e a sua representação sobre o mappa da região que está sendo estudada.

Pendor ou inclinarăo significa o declive das camadas ou o angulo que esta faz com o horizonte. E' a direcrão que uma bala tomaria

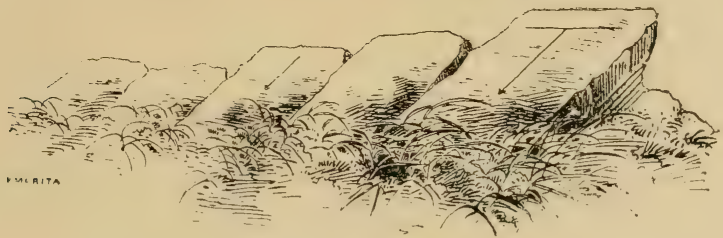

Fig. 94. - As flechas mostram a inclinação ou pendor das camadas.

A linha perpendicular á inclinação é chamada o rumo ou a orientação.

quando posta a rolar pela superficie da camada, ou a em que a agua correria pela supesficie. A inclinação é medida com o clinometro ou outro qualquer instrumento applicavel á medição de angulos verticaes. Nos trabalhos geologicos do campo as inclinaròes devem ser medidas e representadas sobre o mappa. Estes devem registrar tanto o angulo que as rochas fazem com o horizonte como a suit direção com referencia ao meridiano. Por exemplo, $40^{\circ} \mathrm{N} .20^{\circ} \mathrm{E}$, significa que as camadas fazem o angulo de quarenta graus com o horizonte, e que a dir'eção do declive acha-se em vinte graus a léste do norte. Ao ubservar as inclinaçoes das rochas deve-se prevenir contra a estratificaçio falsa que não mostra a direç̧ão verdadeira dos estratos (1).

L's vezes tambem ha possibilidade de se enganar com o "arrastamento (creep) das margens das ramadas. Fste arrastamenti) è o cur-

(1) E' tambem necessario, ao notar sobre o mappa a direç̧ão da inclinação, to mar em conta a deflecȩão da agulha magnetica. Esta deflecção varia muito em diversas localidades. Vêde A oariaşäo secular e a distribuiçâo da declinașĩo magnetica no Brasil, pelo Engenheiro Horace E. Williams. S. Paulo, 1913. 
vimento para baixo das margens de ramadas um tanto friaveis quando expostas no declive dos morros. N'um caso como o illustrado na figura junta, o geologo, vendo sómente as extremidades das camadas na superficie do chão, pode-se enganar tomando a inclinação das camadas como estando na direcęão opposta á verdadeira.

Pode-se enganar tambem a respeito da inclinação das camarlas

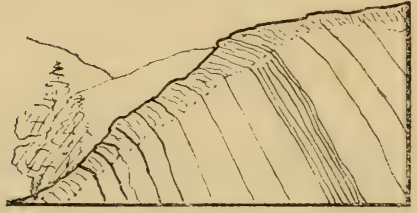

Fig. 95. - Secção mostrando a inclinação ou pendor das rochas e o arrastamento das extremidades decompostas de suas camadas.

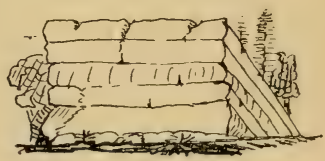

Fig. 96. - As camadas vistas de frente parecem estar horizontaes; vistas de lado tem uma inclinação ingreme.

visando-as de um certo ponto de vista. Na figura junta as camadas parerem ser horizontaes, mas visando-as da extremidade do parcdão vè-se que estāo fortemente inclinadas fig. 96.

Em regiões de rorhas dobradas a inclinacão das camadas é as-

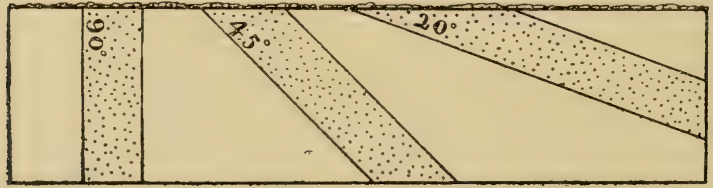

Fig. 97. - Camadas tendo a mesma espessura, porém inclinando-se em angulos differentes. Về-se que a camada com a inclinaçăo de 20 tem um afloramento que excede de duas vezes o da camada vertical da mesnia espessura.

sumpto da maior importancia. A largura de um afloramento varia com o angulo da inclinação. Na fig. 97, por exemplo, as tres camadas sĩo da mesma espessura; porém na superficie a segunda tem exposto cerea do dobro da largura da primeira e da metade da terceira. 
0 conhecimento da inclinaçào é indispensavel na determinação da espessura das rochas, assumpto de maior importancia em todos os estudos da geologia estructural.

Na figura junta vè-se que dos tres blocos de terreno do mesmo tamanho tendo carvão por baixo, A tem o carvão mais proximo á superficie, sendo este mais profundo $\mathrm{em} \mathrm{B}$ \& ainda mais profundo $\mathrm{em} \mathrm{C}$. 0 terreno $\mathrm{C}$ tambem tem nais carvão por hectare do que os outros em virtude do dobramento ou posição das camadas.

1 orientação (strike) de uma camada é o seu rumo na superficic do chão. Faz geralmente angulo recto com a direcção da inclinação. Etili-

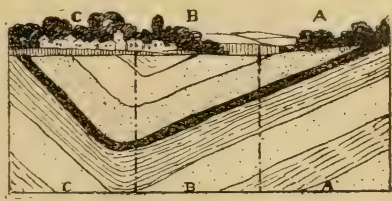

Fig. 9s. - Illustrando a importancia economica da inclinação. za-se da orientação no traçar as camadas e afloramentos na superficie do chào. Na figura 94 na pagina 2 '13 a orientação é a linha traçada na face da rocha em angulo recto com a inclinação.

As dobras das camadas de rocha podem ser traçadas por longas distancias; porém mais cedo ou mais tarde desapparecem. Acontece ás vezes, tambem, que ao traşar uma dobra atravez de uma região até que

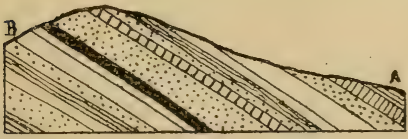

Fig. 99. - Secção mostrando as camadas geologicamente superiores em um nivel hypsometricamente inferior. ella desappareça encontra-se o começo de uma outra ao lado e em escalão.

Is dobras tambem desapparecem em profundidade, isto é, uma dobra na superficie torna-se gradativamente menos saliente á medida que se penetra na terra, até que finalmente desapparece de todu. Em taes casos a compressão que se acha representada pela dobra na superficie foi compensada pelo esmagamento da massa di rocha nas maiores profundidades onde a pressão era maior. Ao fallar das reliłões das camadas entre si é usual referir-se ás depositadas por ultimo como as camadas de cima e as depositadas primeiro como as camadas de baixo. Deve-se notar, porém, 
que as palarras; "mais alto e mais baixu, cima e fundo " empregamse na geologia estructural sem referencia á elevaçào acima do nivel do uceano. Na figura junta as camadas em $\mathbf{A}$ são as mais altas e as em baixo de $\mathbf{B}$ as mais baixas (fig. 99).

Formas dos afloramentos. - I fórma de um afloramento é
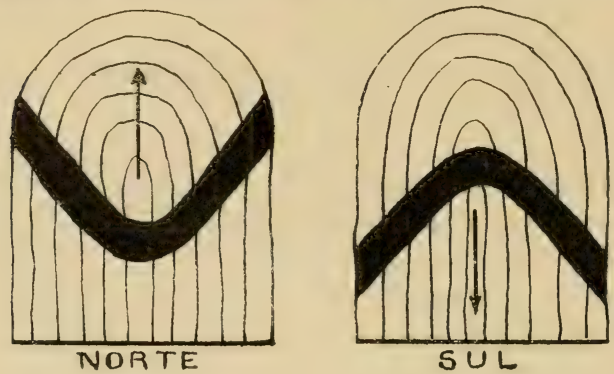

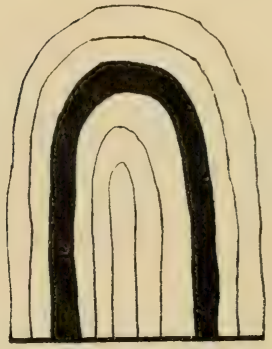

HORIZONTAL

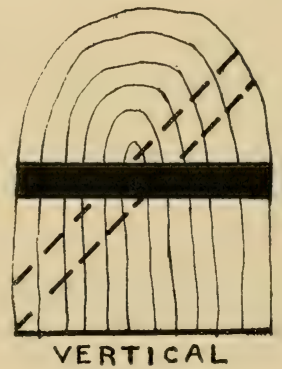

Fig. 100. - Formas de afloramentos variando coma direcção e importancia da inclinação. As flechas mostram a direç̧ão da inclinação das camadas.

determinada pela forma e inclinação das camadas. Num trecho toposraphico dado, como das figuras juntas, a forma dos morros fica a mesma, mas a direccăo do afluramento de uma camada dada varia com a inclinação.

Dobras subvertidas sio simplesmente dobras anticlinaes que tèm 
tèm sido comprimidas até que cahiram de um lado. Estas do bras subvertidas são feiçũes estructuraes bastante communs em algumas partes do mundo, porém absolutamente desconhecidas em outras.

Effeitos das dobras sobre a topographia. - A erosào a que estão sujeitas as rochas expostas sobre a terra frequentemente escurece as feições estructuraes devidas ás dobras. Se não fosse assim, todos os synclinos formariam valles e todos os anticlinos formariam morros.

Na realidade podemos ter, e temos, valles e morrus anticlinaes e synclinaes e tambem lombadas monoclinaes e isoclinaes.

Valles anticlinaes são os que se acham excavados ao longo dos eixos de dobras anticlinaes. A sua estructura geral acha-se representada na figura junta. Neste caso o apice do arco anticlinal tem sido removido por erosão (fig. 104).

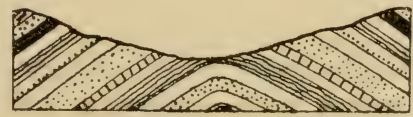

Fig. 101. - Seç̧ão mostrando a estructura de um valle anticlinal.

Valles synclinaes são os que acompanham dobras synclinaes mais ou menos como o que se acha representado na figura 102 .

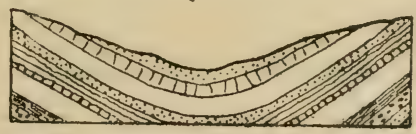

Fig. 102. - Seção mostrando a estructura de um valle synclinal.

Morros synclinaes sào deixados pela erosào das rochas de cada lado de uma dobra synclinal, ficando esta como o cume de un morro ou lombada. 
Morros anticlinaes apresentam uma estructura anticlinal como se mostra na figur 10 \%.

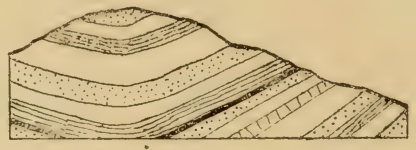

Fig. 103. - Seção mostrando a estructura de um morro synelinal.

Lombudas monoclinaes sào aquellas em que as camadas horizontaes acham-se dobradas para baixo ao longo de um eixo dado, como na figura 88 na pagina $\mathbf{2 4 2 .}$

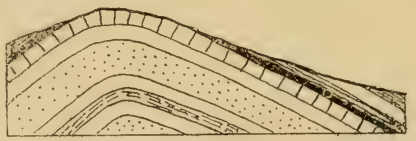

Fig. 101. - Secção mostrando a estructura de $u$ morro anticlinal.

Lombalus isoclinaes sio aquellas em que, por uma serie de dobras subvertidas, foi dada a mesma inclinação a todas as camadas, como se vê na figura 105 .

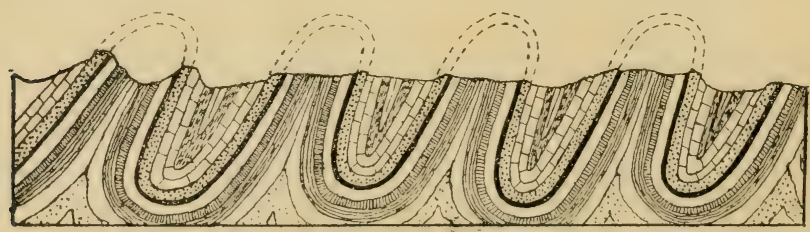

Fig. 105. - Secção mostrando a estructura de dobras e lombadas isoclinaes.

Nas regióes onde parece haver uma espessura descommunal de camadas sedimentarias tendo todas a mesma inclinação, o geologo devese prevenir contra erros induzidos pela estructura isoclinal.

Quando as rochas sĩo dobradas, parece depender principalmente la sua inclinação, ou posição original, serem formados anticlinos ou 
synclinos, e cahirem n'uma direcȩào ou na outra as dobras subvertidas. Dado que na figura junta as linhas verticaes representem paredes inflexiveis contra as quaes se empurra um corpo flexivel : aquelle corpo se dobra para cima ou para baixo conforme a sua posiçâo quando se começa a applicar a pressĩo. No larlo esquerdo a dobra para
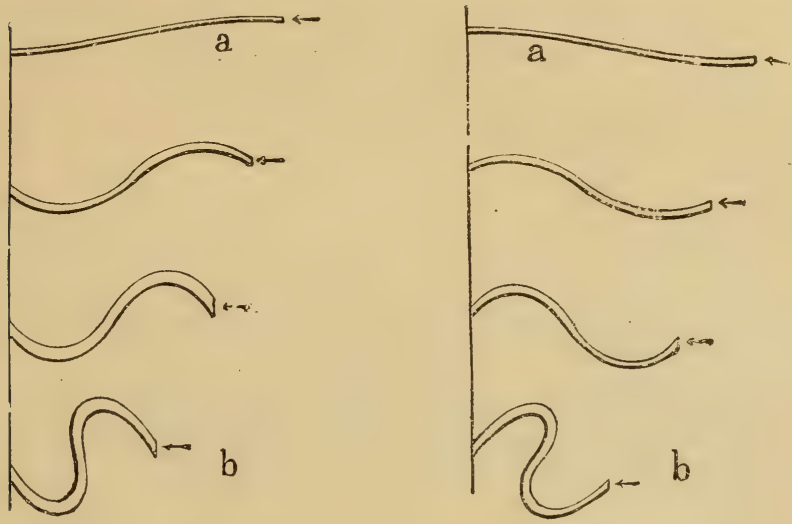

Fig. 106. - Diagramma illustrando a influencia da inclinasão inicial sobre a estructura.

haixo se acha junta a parede ao passo que no lado direito está na extremidade mais distante della: no esquerlo as dobras cahem distante do ponto de pressão, no direito cahem proximas a mesmo ponto.

o dobramento das rochas pode ser moroso an ponto de não quebrar as camadas. Em taes casos ha uma recrystallizario da propria rocha. Este processo está bem illustrado pelo dobramento gradual das lapides de marmore nos tumulos do cemiterio da Cunsolação na cidade de S. Paulo. Ali se rèem lapides deitadas em posição quasi horizontal ha muitos annos apoiadas simente nas extremidades, iuja parte mediana abaixou-se gradualmente, ficando ellas sempre rijas. As seguintes notas foram tomadas naquelle cemiterio no mez de Junho de 1913. 
LAPIDE (WII A OATA DE 188'

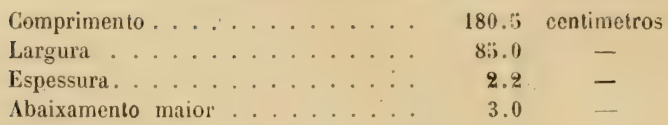

\section{LAPIDE COM A DATA DE 1877}

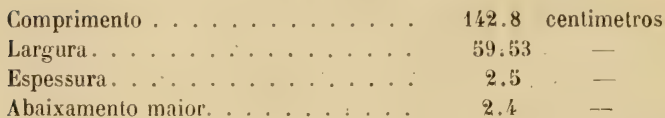

LAPIDE CON A DATA DE 1868

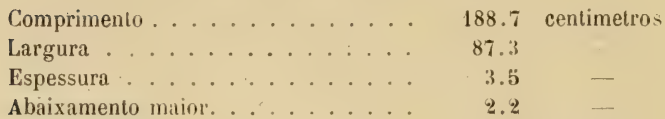

LAPIDE COM A DATA DE $187 \%$ OU DE 1896

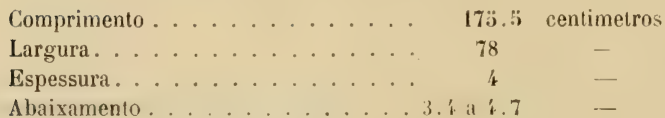

LAPIDE COM A DATA DE 1880

Comprimento ........... 17\%.: centimetros.

Largura . . . . . . . . . . . . . . 77

Espessura . . . . . . . . . . . . .

Abaixamento ........... 0.19

Cumpre notar que parece provavel que o abaixamento ou empeno das lapides nào seja devido inteiramente ao pezo da pedra, mas sim talvez ás temperaturas ou á humidade relativa dos dois lados. Mas em todo caso é facto que as lapides curvam-se, seja qual fir a causa.

Quando uma lapide de marmore de espessura de 3.5 centimetros chega a curvar-se desta maneira em $45^{\circ}$ annos, ou menos, podemos fizer ideia do que pode acontecer em muitos seculos com as rochas da crosta da terra que estão debaixo de pressão enorme. 


\section{Falhas.}

Quando, porem, o debramento se opera de repente, ou quando as rochas não cedem com promptidão á pressão, falhus se formam.

Chama-se falha um deslocamento de uma camada de rocha que interrompre a sua continuidade. As falhas podem cruzar as rochas $\mathrm{em}$ qualquer direç̧ão; podem occorrer isoladamente ou em series, cruzando-se, neste ultimo caso, em varios angulos. Chamam-se as falhas normaes ou invertidas conforme a direcęão dos deslocamentos.

\section{Falhas normaes}

Falhus normaes chamam-se ás vezes falhas de gravidade. Sio produzidas por tensão ou por uma distensão das camadas quebradas.

Nos districtos de mineração, onde as falhas são desta natureza, existe uma bem conhecida regra " que a falha se inclina para o lado

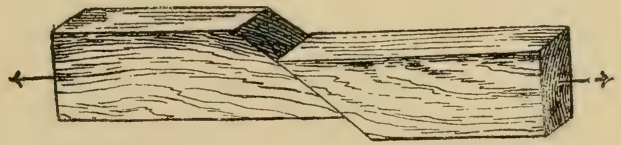

Fig. 107. - Para illustrar o deslocamento produzido por uma falha normal, ou de gravidade. Os blocos são esticados nas direcções indicadas pelas flechas.

cahido. " Comprehende-se isto pelo exame da figura 107. Quando os blocos são separados de modo a deixarem juntas as suas faces, cahe para baixo o lado para o qual se inclina a face da fractura. Falhas normaes, de tensão ou de gravidade, se apresentam nas regiões de tensão superficial ou da pressão para baixo sómente de pesadas massas de rocha.

As falhas podem enganar a respeito da espessura das camadas

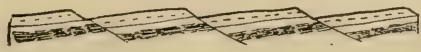

Fig. 108. - Seç̧ão mostrando a repet ção da mesma camada por falhas normaes n'um paiz chato.

envolvidas. Na figura 108, por exemplo, se nĩo fòrem consideradas à f.llhas, podia-se imaginar que a espessura era quatro vezes maior dn que a verdadeira, por serem as camadas repetidas pelas falhas. Esta 
especie de falhas pode-se apresentar em regiōes montanhosas bem como nas achatadas como se vê na figura $\mathbf{1 0 9 .}$

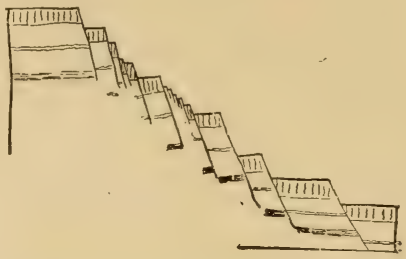

Fig. 109. - Seç̧ão atravez de muitas falhas em degraus em uma região montanhosa mostrando muitas repetições das mesmas camadas.

\section{Falhas revertidas ou de empurrão.}

Com os mesmos blocos mostrados na figura 107 produz-se uma outra especie de deslocamento, se os pedaços fôrem empurrados em

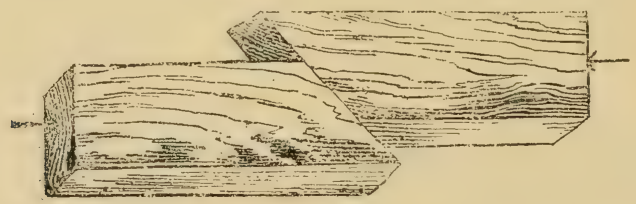

Fig. 110. - Blocos deslocados por um empurrão illustrativo de uma falha revertida.

falha revertida, sendo tambem revertida a regra relativa á inclinaşio lugar de serem esticados. Com as rochas este empurrão produz uma

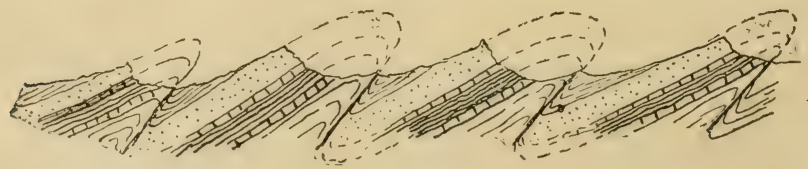

Fig. 111. - Falhas revertidas mostrando diversas repetições das mesmas camadas.

da face da falha n'uma regiào de falhas normaes, isto é, a falha se inclina para o lado levantado. 
As falhas revertidas tamben produzem a repetição das camada: falhadas, como se vê na figura $\mathbf{1 1 1}$.

\section{Complicações produzidas por falhas.}

No estudo de falhas é bastante importante saber se a regizio é umir de compressão, onde se deve esperar fulhas revertidas, ou de contracęão, onde se deve esperar falhas normaes.

Nas regiões de mineração é necessario comprehender as falhas por que estas frequentemente deslocam os corpos de minereo tornando necessario descobril-o novamente no lado opposto da falha. Na figura 112, por exemplo, onde o carvão é cortado por uma fallıa, vè-se que é preciso, ao chegar a esta, saber se o carvão deve ser procurado para cima ou

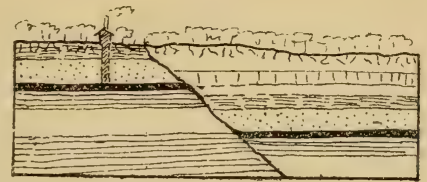

Fiğ. 112. - Sececão mostrande o deslocamento de uma camada de carrão por uma falha normal.

para baixo no lado opposto dil falla. Frequentemente se produzem falhas ao longo dos eixos de dobras, especialmente quando o plano axial desta fồ muito inclinado.

Na figura 113 mostra-se o resultado de uma experiencia feita sobre camadas de cera dobradas e falhadas por pressão lateral applicada com uma carga de chumbo de caça collocada em cima da cera.

0 deslocamento nas falhas varia enormemente. Acontece ás vezes nque falhas passam por pequenos scixos e que estes depois de falhados ficam recimentados. As taes falhas apresentam o deslocamento de poucos millimetros apenas. Frequentemente as falhas são tão pequenas que só se reconhecem com o microscopio composto. Desde estes deslocamentos microscopicus ha falhas que attingem proporções enormes. Nas montanhas Appallachianas da America do Norte ha deslocamentos de seis mil metros; nas montanhas Wasatch de Uiah ha uma falha coin o deslocamento de doze mil e duzentos metros, ao passo que entre 
as lalhas subvertidas (overthrust faults) dit Escossia ha uma de muitos kilometros.

Na sua continuidude as falhats sào igualmente variaveis. E' provavel que a sua profundidade seja limitada em virtude da disposição las rochas a celer quando debaixo de grande pressão, como se fossem plasticas, em lugar de se quebrar e escorregar. Longitudinalmente, falhas pódem ser compridas ou curtas. Alguns exemplos notaveis são

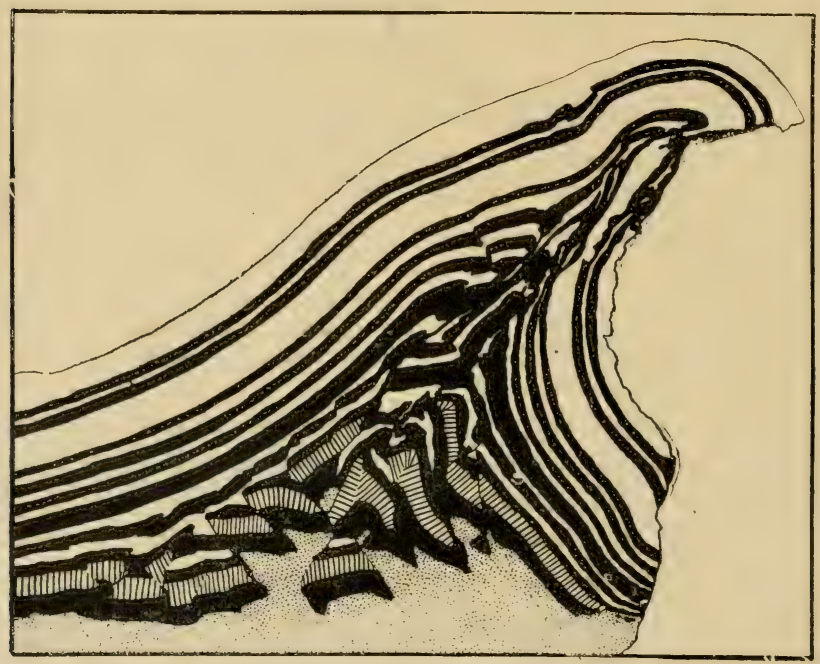

Fig. 113. - Uma dobra artificial em camadas de cera passanclo para uma grande e muitas pequenas falhas. (Willis:)

ciladus na Africa onde dizem que uma tem " comprimento de cento o noventa e cinco e outra e de quatrocentos e trinta e cirico kilometros. Va California ha diversas falhas de cento e noventa e cinco até trezentos e oitenta kilometros de comprimento.

Dr. Gonzaga de Campos é da opinião que os rumos dos grandes rios do oeste do estado de S. Paulo sĩo determinados por um systema 
de falhas parallelas que correm a veste-noroeste (1). A direção das falhas pode variar entre vertical e horizontal, e em lugar de um empurrão simples pode haver uma especie de movimento de enrollamento

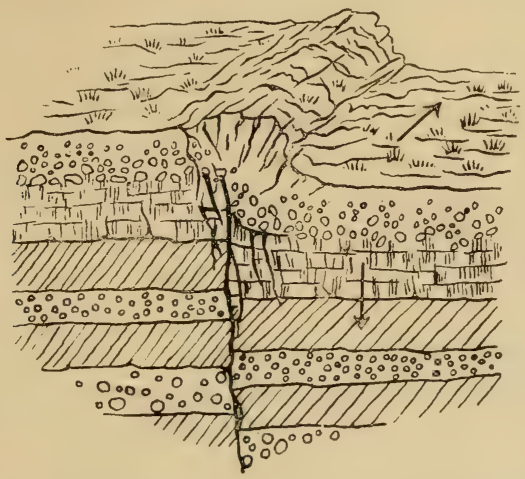

Fig. 114. - Secçio atravez de uma falha mostrando tanto deslocamento rertical como lateral nas direçẽes indicadas pelas flechas.

un torsio. A ligura 11 ' mostra uma falha na qual tem havido deslocamento em duas direcȩões, tendo o lado direito cahido e ao mesmo témpo sido empurrado lateralmente. A direcção dos movimentos achase indicada pelas flechas.

Quando as falhas sĩo produzidas por pressão, os hlocos ou seções

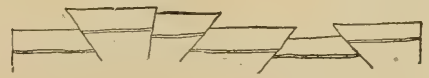

Fig. 115. - Secção mostrando como blocos de terreno falhado podem ser empurrados para cima ou para baixo de conformidade com o angulo de fractura da falha.

pridem ser empurrados para cima ou para baixo. Isto se comprehende pela inspeç̧ão da figura 115 que mostra a relação evidente entre a direcção do movimento e a dos planos das falhas.

(1) Gonzaga de Cannss. Reconheciments da sona comprehendida entre Baurú e Itapura, p. 12. S. Paulo, 1905. 
A idade de uma fallha é muitas vezes assumpto de grande importancia. Esta pode ser determinada com referencia ás camadas falhadas e ás não falhadas. E' evidente que uma falha deve ser mais recent* do que a camada que fór affectada ou deslocada por ella. As falhas sio de todas as idades; mas, visto que as rochas mais antigas tim sido sujeitas a maior numero de movimentos do que as mais modernas, aquellas são mais falhadas do que estas. E’ certo, porém, que mesmo no tempo actual se formam falhas.

As margens das falhas quando se apresentam na superficie do chão são geralmente mais ou menos franjadas, irregulares e tortuosas. Acontece, porém, ás vezes, que uma falha é quasi recta na distancia de alguns kilometros.

Slickensilles são estrias, arranhões, ou arranhaduras sobre as facer deslocadas onde os dois lados de rochas falhadas tèm-se esfregado um contra o outro. São muito parecidas com as estrias feitas por geleiros sobre o seu leito rochoso.

\section{Descobrimento de falhas na superficie da terra.}

Para descobrir falhas não é sempre necessario vêr uma scção vertical mostrando o deslocamento das camadas.

(1) A terminaçio brusca das camadas ao longo da orientaçī (strike) muitas vezes fornece evidencia satisfactoria da existencia de

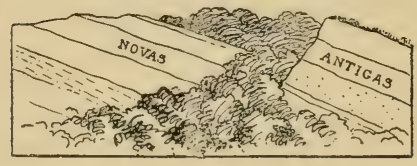

Fig. 116. - Uma falha suggerida por camadas mais novas apparentemente mergulhando debaixo das mais velhas, porém com o contacto encuberto. falhas. Nestes casos o córte por desnud:irão do lado levántado mostra um: falha.

(2) A passagem apparente de camadas mais novas por debaixo de outras mais antigas, conforme indica a figura 116 , constitue evidencia satisfactoria de uma falha. Nesta figura, se fòr sabido que as camadas no lado direito são mais antigas do que as que parecem se inclinar por debaixo della, é certo que deve haver uma falha onde as duas series de camadas se encontram. Isto resulta do facto que nor- 
malmente as camadas mais antigas devem jazer por baixo das mais novas, salvo um tal deslocamento.

Outros phenomenos antes suggerem do que demonstram com certeza a existencia de uma falha. Estes. são :

(3) Mineralização ao longo de linhas de falhas. - 0 leslocamento das camadas muitas rezes fornece vias para agua nas quaes se formam vieiros mineraes.

(4) A emergencia de fontes. - As vias aquosas formadas ao longo de linhis de falha frequentemente dào lugar para a agua rhegar á superficie na forma de fontes.

(5) Mudanças na topographia. - Na passagem de um ladu de uma falha para o outro encontra-se ás vezes uma mudança notavel na topographia devida a differenças no caracter das rochas nos doilados da falha.

(6) Mudanças das rochas ou do solo. - Uma mudança brusca no caracter da rocha ou do solo, que não se póde attribuir a outra estructura conhecida, é muitas vezes devida a uma fallia que tra\% á superficie do chão rochas de duas qualidades nos lados oppostos da fallia.

\section{Importancia economica de falhas.}

As falhas têm frequentemente a maior importancia economica. Esta importancia pode ser positiva, - devida ao facto que valiosos depositos mineraes encontram-se muitas vezes em falhas, ou negativa - devida ao destiscamento de corpos de minerio por falbas. As falhas assim muitas vezes tornam difficil e problematica a mineração.

\section{A alteração das rochas.}

Depois de uma vez formadas, quer sejam sedimentos mechanicos, depositos chimicos ou organicos, ou de origem ignea, as rochas não ficam sempre no mesmo estadú pois que estão sujeitas a muitas modi- 
ficaries, atém dus deslocamentos puramente mechanicos jai menciumados, entre as quaes algumas até alteram a sua composiçào chimica.

Metamorphismo é o nome dado a qualquer mudança, sem ser a (1) deslocamentos mechanicos, que as rochas soffrem depois de sua formação original, quer seja chimira, mineralogira ou outro qualquer rearranjamento. Este metamorphismo muitas rezes escurece nio simente a fúrma original como tambem o modo de formação das ruchas affectadas. Os effeitus do metamorphismo variam conforme a natureza das rochas e a dos agentes metamorphoseantes. 0 metamorphismo pode produzir um ou mais dos effeitos seguintes :

1. - Mudança de còr.

11. - Endurecimento. 0 arenito é frequentemente transformado em quartzito, e as argillas em ardosia.

III. - Expulsão d'agua e outros ingredientes vaporisaveis.

IV. - Assamento e fusão.

V. - Crystallisação acompanhada ou não por mudanȩa nos mineraes constituintes. O marmore, pror exemplo, é um calcareu alterado.

VI. - A producęão de mineraes novos.

VII. - Schistosidade e folheação.

VIII. - obliteraça do contendo fuscil. Os fosseis não são sempre obliterados.

IX. - Obliteraçõo dos planós de acamamento.

As causas do metamorphismo. - 0 calor e a humidale sio us agentes principaes do metamomphismo. O cator porle sir produzido :

1." Pela acção chimica.

2. Pelo escorregamento, esmagamento, ou pressĩo.

3. Pela injeção das rochas quentes.

4. Pela invasão do calor interno do globo.

¿. Pela radio-actividade.

Viin é necessariamente grande a somma de calor exigrida para fmorluzir metamorphismo. In farto as rochas metamorphicas cuntem 
alguns mineraes que nào pódem resistir a uma temperatura muito elevada.

Pouca humidade sómente é exigida para o metamorphismo. A humidade, porém, parece ser indispensavel visto que o calor succo não affecta profundamente as rochas.

Um elemento importante na alteração das rochas é o espaço de tempo durante o qual se acham expostar aos agentes metamorphoseantes. Resulta, purtanto, que as lochas mais antigas são as que, considerado o conjuncto, se acham mais alteralas.

\section{0 metamorphismo local.}

0 metamorphismo púde: ser convenientemente considerado como In'ul ou metamorphismo de cuntacto; ou como amplo ou metamorphismo regiunal ou em massa. O metamorphismo local ou de contacto é produzido pela injeceão de rochas quentes que alteram as camadas com as quaes rem em contacto.

Em muitos lugares as effeito- d: taes intrusies são muito notaveis. To Colorado na Imerica do Nortr, por exemplo, rochas igneas tèm penetrado em camadas de carvin e este loi alterado em coke ou em graphito pulverulentu ou ainda em alguma outra forma de carbono. No norte da Irlanda um dique cortando uma camada de giz tem alterado ssta substancia de modo que se purle distinguir sete cintas dillerentes na coloracão e nos pruductos da alteratrio. Proximo ao dique o wiz $t \in m$ sido convertido em calcareo arystallirio de cor pardacenta uscura; depois vem calcareo sacrharoide de grau miudo e com o aspercto de porcellana, azulado, cinzento e amarellado, passando finalmente o caleareo gradualmente au giz nàn ilterado adjacente. Ya Ifrica tem-se encontrado rochas sedimentarias alteradas por um lenrol de lava para uma « porcellana branca. »

Deve-se notar, porém, em taes casos de metamorphismo por contacto, que a area affectarla é em seral simente uma cinta estreiti adjacente as rochas quentes injectadas. I lirgma da cinta alterada varia considerovelmente; mas, sendo iguaes as ontras condiçoses, apre- 
senta uma certa proporção para com a largura do dique ou da massa intrusiva. Um factor importante é tambem o caracter da rocha fundida injectada.

To sul do Brasil, onde ha grandes lenęues de rochas eruptivas, a acçio metamorphica dos diques sobre os estratos adjacentes não é muito grande. Uma camada de dois metros (1) de espessura que se intercaluu entre camadas de carvĩo e o arenito superposto apenas tornou vermelho o arenito e mudou a apparencia das plantas fusseis. I'm dique vertical que corta o carvãn nas minas de S. Jeronỵmo no Rio Grande do sul transformou o carvão parcialmente em coke, sumentr na extensão de tres ou quatro metros.

Metamorphismo geral ou regional. - Applici-se o nome de metamorphismo regional a areas de rochas alteradas ond: nâo ha relação apparente entre o metamorphismo e os phenomenus igneos locaes. Is mudanças uas rochas pódem, por si, serem as mesmas, mas no presente caso são de extensão muito mais lata. Debaixo deste titulo de metamorphismo regional vem o dos schistos crystallinos e cutras rochas metamorphoseadas que cobrem grande parte do interior do Brasil. No metamorphismo regional é tambem para notar que tanto " caracter cono o grau da alteração varia consideravelmente. As diffelenças sã devidas :

I. - I diflerencas na quantidade da agua contida nas rochas.

II. - A' condicào ou tamanho das particulas constituintes das rochas.

III. - A variações na composição das rochas.

Estas differenças nas rochas originaes dão origem a resultados variados. Acuntece ás vezes que, em regiōes de motamorphismo largamente estendido, algumas camadas sio pouco ou nada affectadas ; ao passo que outras sio completamente alteradas e ainda uuras apenas rm parte. Estis diflerenı́as parecem ser explicaveis sómente pela rele-

(1) I. C. White. Relatorio final da Commissão de Estudos das Minas de earoão de pedra do Brasil, p. 218. Rio de Janeiro, 1903. 
rencia ao caracter ou á condição original das rochas e ao seu conteúdo em humidade.

0 Dr. Francisco de Paula Oliveira pensa que o metamorphismo exhibido pelas grandes lages que se encontram em Illıta, nos arredores d'Itajahy em Santa Catharina, em Pantôjo e pertu de Itú em S. Paulo é devido, diz elle, a "metamorphismo regional ausiliado pela erupção dos granitos roseos, que tambem transformaram os calcareos carbonosos em marmores brancos nos arredores de Camboriú, margem do Itajahy Mirim e Limeira na mesma zona; em Caçapava no Riu Grande do Sul, no salto do Volurantim em Sorocaba, S. Paulo e em outros lugares ».

\section{As rochas metamorphicas.}

Is rochus metamorphicas abrangem os schistos, quartzitos, ardosias, alguns marmores, serpentinas e muitas outras. Deve-se notar que as regiōes montanhosas nuitas vezes tim as suas ruchas metamorphoseadas. Taes regiões são arras de movimento, puxõ's, escorregamentos e dos phenomenos de alta temperatura que sào capazes de produzir taes alterações.

As rochas metamorphicas são frequentemente muito antigas; mas nem sempre e nem necessariamente isso acontece. São mais lrequentemente rochas profundas, e quando encontradas na superficie é isto geralınente-devido ao facto de serem descobertas pela erosãu de camadas que antes as cobriam.

\section{Conclusôes geraes relativas ao metamorphismo.}

1. Metamorphismo é a mudança de fórma uu de estructura interna das rochas quer sejam sedimentarias ou igneas.

2. Em todos os casos o metamorphismo teve lugar depois da formação das camadas.

(1) Subsidios ro estudo da geologia do Brasit, p. 12, 1907. 
3. () metamorphismo é produzido por calor, pressão e mudanüas cnimicas auxiliadas por aguas e alcalis.

^. O metamorphismo pode ser lucal, isto é, produzido por contacto com rochas quentes; ou regional, isto $\dot{e}$, largamente estendido.

๖. O metamorphismo nảo é sempre uniforme atravez de uma serie de rochas e pode mesmo se apresentar em ramadas salteadas de uma serie.

6. O metamorphismo póde affertar as camadas no sentido vertical ou horizontal.

7. 0 metamorphismo uào introduz. nas rochas novos elementos chimicos, mas sómente causa um rearranjamento dos já existentes.

8. A natureza das mudanças numa rocha depende do caracter do) material original e da natureza e intensidade da acção do aģente metamorphoseante.

9. 0 metamorphismo púcle apparecer em rochas de qualquer idade, nio sendo, portanto, prova da idade das rochas em que apparece.

10. 0 metamorphismo é, porém, mais largamente estendido nas rochas mais antigas.

11. 0 metamorphismo é mais commum nas regines que têm uma grande espessura de estratos.

12. Raras vezes o metamorphismo é uniforme numa area grande; geralmente é mais forte num lugar e menos forte em outro.

13. As rochas metamorphicas do Brasil são schistos, ardosias, quartzitos, itacolumitos, marmores, e serpentinas.

14. Em geral o metamorphismo tem lugar numa grande profundidade abaixo da superficie do chão, "as rochas metamorphicas tèm ficado expostas posteriormente pelos processos de erosão e denudação.

\section{Filões, vieiros ou bêtas mineraes.}

Os viciros mineraes sio de pequena extensão, mas são de grande importancia economica devido ao facto que muitos dos mais valiosos de nossos mineraes n'elles se apresentam.

Deve-se lembrar, porém, que os depositos geologicus de villor economico não são todos em forma de vieiros. 
I'm vieiro é um lençol de rocha depositado de solução e enchend»r uma fenda em outra rocha. Na fórma ha muitas vezes uma forte semelhança entre um dique e um vieiro. Comquanto, porém, o dique se fírme n'uma fenda das rochas, como um viciro, elle é formado de rocha fundida, e n'um espaço de tempo curto; ao passo que um vieiro é formado na fenda por aguas circulantes nas rochas sendo o material do vieiro ali depositado lentamente de solução .

Iuitos vieiros se fórmam de morlo differente do enchimento de uma simples fenda; mas os que enchem fendas serão considerados em primeiro lugar.

Para comprehender a fórma dos vieirus é, porém, necessario saber alguma cousa da origem e fórmas das fendas nas quaes são depositados.

\section{Origem de fendas.}

As fendas se fórmam nas rochas:

I. - Por torsão.

II. - Por choques quando as rochas se acham sujeitas a tensào.

III. - Por falhas. Quando existem falhas, as faces da rocha, depois do falhamento, nem sempre se ajustam exactamente de modo que ficam fendas irregulares ao longo das linhas de fractura.

IV. - Por tensão e quebramento, ou por compressão e abertura das camadas ao longo dos cumes de lombadas anticlinaes.

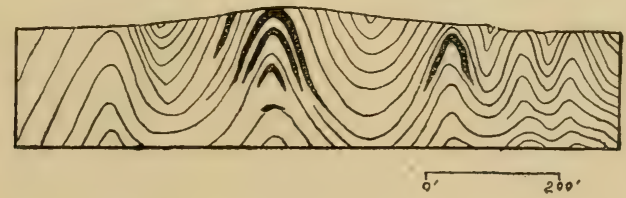

Fig 117. - Secção atravez dos vieiros sellados (saddle reef's) em Hargreaves, Nova Galles do Sul. As areas negras representam mineraes depositados em aberturas nas cristas dos anticlinos:

A figura junta mostri como a compressão apertada dos cumes de dobras anticlinaes tem aberto cavidades nas quaes se fórmam vieiros mineraes. 
As lendas ás vezes se abrem tambem ao longo dos fundos de dobras synclinaes, porém a tendencia geral nas camadas internas de uma ruga synclinal é para a consolidação por compressão.

V. - Por contração devida á dolomitação e perda de agua. Quando uma parte da cal de um calcareo fór substituida pela magnesia o processo, chamado dolomitação, causa uma contracção da camada original na importancia de doze por cento.

\section{Alargamento de fendas.}

Filões podem crescer :

1. - Por expansão devida á crystallisação em fendas incipientes.

II. - Pela sulução das rochas aos ladus dos filões e pelo alargamento das fendas ao passo que os vieiros crescem.

III. - Ha tambem formações que parerem ser depositadas de
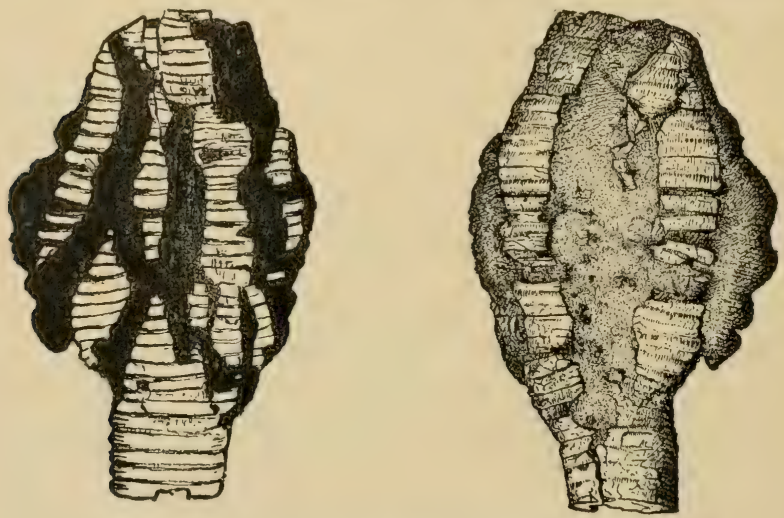

Fig. 118. - Haste de um crinoide expandida pela deposição de quartzo no seu centro oco. Tamanho natural.

soluçio entre fragmentos enchendo cavernas ou galerias abertas. Estes depositos geralmente têm a forma de breccia. $\mathbf{E}$ claro que estes depositos crescem somente ao passo que as cavernas se fórmam e desabam. 
Alguns vieiros parecem estar em fendas que nunca fôram abertas, sendo as suas paredes separadas pelo empuxo dos mineraes depositados nellas. A figura junta mostra os dois lados de uma haste de crinoide quebrada e recimentada por vieiros de quartzo. Parece provavel que neste caso o quartzo fosse depositado gradualmente em aberturas muito delgadas e não em fendas bem definidas.

Profundidade das fendas. - Comquanto as fendas nas rochas variem consideravelmente em profundidade, acha-se limitada a sua extensão vertical. Isto é devido ao facto que passando a pressão de um certo peso as rochas cedem como inassas plasticas, e qualquer ruptura que se fórme n'ellas fecha-se immediatamente.

Esta zona pode-se chamar a zona de fluxão.

Ella principia entre a profundidade de 24 e 32 kilometros abaixo da superficie da terra. Para as rochas mais duras e mais resistentes essa profundidade é ainda maior.

E' esta a hypothese a respeito do comportamento de rochas quando submettidas a grande pressão, e que ellas effectivamente assim se comportam tem sido demonstrado experimentalmente (1). Dahi se segue que vieiros formados em fendas ahertas devem ter sido feitos acima, ou dentro, da zona da estabilidade das rochas.

Podemos, porém, conceber 0 alargamento de fendas pelo processo da crystaliisação de soluções de materia mineral onde a força mechanica da crystallisação fòr bastżnte grande para vencer a pressão das paredes rochosas.

Vieiros variam muito em tamanho; alguns tèm apenas poucos millimetros de espessura ao passo que outros tèm muitos metros. Até o mesmo vieiro varia bastante sendo muito delgado em alguns pontos e grosso em outros. Apresentam-se ás vezes isolados, ás vez's em series, parallelos uns aos outros, e ainda outras vezes em diversas series cruzando-se em varios angulos. Pódem até apresentar anastomoses,

11) Adams and Nicholson. $X I$ Congrès Giéologique International. Compt. Rend. 1910, pag. 911 -. L. V. King. Journal of Geology, 1912, XX, 119.138. Bibliographia. V. Geologische Rundschau, 1911, II, 145-147. 
ou rormerem todas as direceones sem seguir qualquer uma em particular.

Os vicirus se apreschtam em rochas de torlas as idades desde as mais velhas até as mais novis. Sia um lanto mais abundantes nas ruchas mais antigas, mas pur vutro lado estas pódem ser inteiramente livres d'elles. Que viciros se formem ou nio en certas areas ou rochas depende, nion dia idade das rorhas, mas das condieões lucaes.

A ma oria dos viciros são estereis em mineraes de valor econo. mico; sendo muito menos abundantes os que são valiosos. A unicia dilferença essencial entre vieiros estereis e valiosos é que os ultimos rontêm um mineral, ou talrrz mais que não se apresenta no outro. Xinhuma differenęa essencial ha no modo de formaça dos dois.

O enchimento de vieiros. - $\lambda$ origem. dos mineraes quw "uchem os vieiros tem sido assumpto de muito estudo e discussão. As theorias adiantadas pódem ser collocadas em tres grupos conforme os suppostos pontos de derivacio dos mineraes: (I) de baixo: (II) de cima : (III) dos lados.

Enchimento de vieiros de baixo. - I theoria da origem. frofunda de corpos de minereo tem sido e ainda is mantida por muitus dos mais habeis geologos.

Entre os fictos que se apresentam 'm apoio desta theoria merecem mençio os seguintes. As aguas nas grandes profundidades são sujeitas a grande pressĩo e frequentemente possuem temperatura elevada, " portanto o seu poder dissolvente as habiliti a dissolver muitos don mineraes com os quaes rim em contacto. A' medida que estas aguas so approximam á superficie, abaixa at temperatura e ao mesmo tempo diminue a pressão a que estão sujeitas, de modo que não pódem mais r'eter em solução os seus mineraes, e estes sĩo portanto depositados nas fendas pelas quaes passam as aguas (1).

(1) Uma exposição comprehensira desta theoria foi publicada pelo American Institute of Alining Enginer's com o tituh The genesis of ore deposits, pelo P'm fessor Franz Posepny, New York, 1895. 
Enchimento de vieiros de cima. - U firto que as aguals cahindo sobre a superficie da terra penetram para baixo dissolvento mineraes no seu caminho e entrando em quacsquer cavidades que encontrem é apresentado en apoio da theoria da origem da materia dr cima dos vieiros. Muitos corpos do minereo sú se apresentam valiosos em profundidades moderadas, ": este facto parece dar apoio a esta theoria. Em geral, porém, nào se considera com tanto lavor esta theoria como qualquer uma das outras duas.

Enchimento lateral de vieiros. - A feicio principal dir theoria da origem lateral do enchimento de vieiros è que as aguas depusitando os minereos nos vieiros se infiltraram nas findas das paredes rochosas adjacentes, e que os minereos föram tomados em soluçio nestas rochas das paredes e redepositadus nas cavidades das fendas. Attribue-se esta theoria ao geologo allemio Sandlurger, mas em fórma um tanto modificada é agora sustentada por muitos dos melhores geologos economicos.

Uma theoria modificada. - Se fósse possivel seguir uma cotta de agua na sua passagem atrave das rochas desde o momentu 'm que cahe sobre a superficie da terra, achariamos que ella ás vezes se move para baixo, outras vezes para cima e ainda outras vezes frara IIm e outro lado. Estes movimentos seguent-se necessariamente do factu que as vias de passagem que a agua tem de tomar não são simples e rectas, mas tortuosas "romplicadas. Considerando a via como um tubo, é evidente que emquanto a cabeceira, ou a extremidade onde a agua entra, fôr mais elevada do que a sahida, a agua correrá pelo tubu movendo-se em todas as direções tomadas por este por mais tortuosu que seja. As vias das aguas subterraneas devem, portanto, ser consideradas como syphões invertidos e irregulares. Nestas circumstancias a agua póde descer a uma grande prolundidade na terı e depois voltar em direção á superficie com muitas mudanęas intermediarias de lirecção, de temperatura, e de pressão; e no seu curso atravez das rochas dissolverá mineraes em alguns pontos e os depositará em outros, conforme forrem as condições favoraveis para a soluçio ou para i deposição. 


\section{Processo de enchimento.}

O processo de enchimento de viciros não é, porém, sempre o mesmo. Algumas substancias sào volatilisadas, e são precipitadas desta condição pelo resfriamento á medida que se approximam da superficio da terra.

A agua quente carrega certos mineraes em solução e estes sĩo

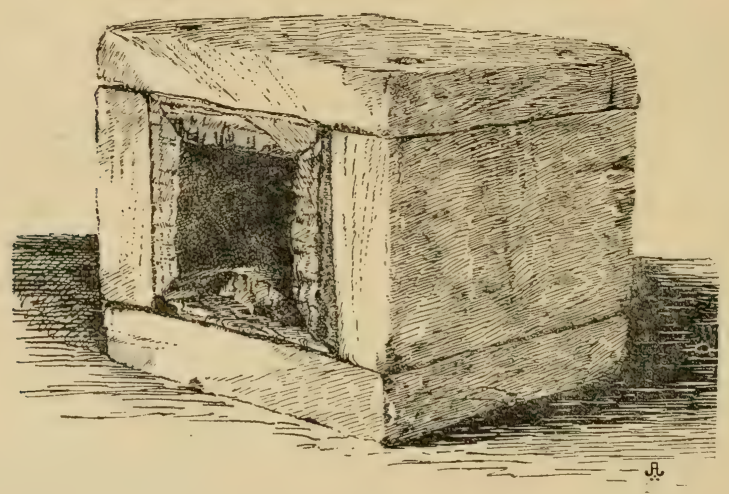

Fig. 119. - Seeçio de uma calha de madeira usada durante 10 annos para tevar agua quente da mina atravez das minas de Comstock, America do Norte. Uma camada de aragonito sulido com a espes-ura de 1.5 millimetros se formou sobre as paredes internas da calla.

precipitados á medida que a agua se resfriat. A figura junta representi uma calha empregada em conduzir agua quente de uma parte de uma mina para outra. Na sua passagem pela callia as aguas forram um tanto resfriadas sendo por causa disso precipitada uma parte da materia mineral que levavam em solução.

Parece razoatvel suppòr que, passando a agua por uma cavidade nas rochas em lugar de uma calha, a precipitação teria lugar onde as paredes da cavidade resfriassem as aguas.

Aguas ordinarias, ou antes aguas com temperaturas ordinarias, frequentemente precipitam materia mineral sobre as paredes de cavi- 
dades nas rochas quando encontram aguas de composiega differente, tambem quando ficam por muito tempo paradas.

Além dos vieiros acima considerados, enchidos por via lıumida (circulação d'agca e vapores suliterraneos), ha ainda outros de natureza de diques cujo material consiste em rochas eruptivas, nas quaes se apresentam, frequentemente, segregações de mineraes aproveitiveis. Em taes casos os diques são geralmente denominados vieiros : muitas vezes ha difficuldade em distinguil-os dos vieiros de enchimento humido.

Riscos na mineração. - Nguns dos riscos na mineraȩão são inteiramente independentes da geologia dos depositus de minereo. Tanto quanto as incertezas dependem da geologia, são devidas a irmgularidades do vieiro, irregularidades das condiçóes de deposiçâ, e a deslocamentos dos vieiros. Do qué já foi dito em relação á origem de vieiros é evidente que as fracturas ao longo das quaes se depositam os minereos raras vezes são regulares, e que, mesmo sendo, nìo se púde contar com esta regularidade indefinidamente ou por una extensão indefinida.

Ainda que haja pouca irregularidarle no tamanho de um. corpo de minereo, o seu valur é sujeito a variar conforme as condiroes variaveis

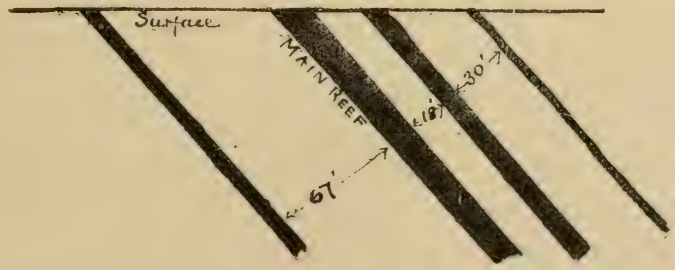

Fig 120. - Seção atravez de quatro "reef's " ou camadas de minereos no districto do Rand, Africa meridional.

em que a maior parte destes corpos se formarem, isto e, o minereo póde ser muito valioso em alguns pontos e imprestavel em outros.

Em algumas das minas da Africa meridional o ouro se encontra em camadas de rochas sedimentarias que são muito mais regulares 
em espessura e posicano do que os vieiros ombinarios. $\Lambda$ ligura junta mestrat a regularidade que estes corpos de minereo ás vezes apresentam. Os algarismos entre as camadas indicam o espaco em pies inglezes entre as camadas mineralisadas.

Os minereos saio muitas vezes deslocarlos ou fragmentados por fallıas de modo a diminuir grandemente "seu valor pelo augmento do custu da extraregão do minereo. Em alguns casos o terreno do lado levantado da falha foi erodido estando inteiramente removida a parte do vieiro daquelle lado. Tars easos, porém, pridem geralmente ser deterninados de antemio por 1 m estudo genhogiro ruidadoso. (Vèle a) fig. 112 na pagina 253 ).

Relação de vieiros e depositos de alluvião. - - . Yi raso (l) depositos auriferos, an passu que us vieiros originaes föram formados em alguns dos modos acima indirados, os que se conhecem

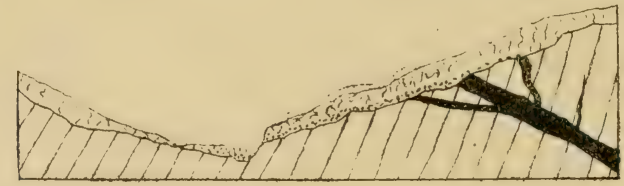

Fiğ. 121. - Secçĩo mostrando a furmação de deposito de placer's pelo quebramento complete de vieiros.

pelo nome de placers tém sido derivados dos vieiros. Em alguns ('asos as rochas envolventes do vieiro se decompoiem, e o propriu vieiro tambem, e o ouro desembaracado da rocha, é carregado p"r cursos de agua até rhegar em lugar onde a força dit corrente nai, haste mais para o mover, e descendo ahi para o fundo conjuntamente com o cascalho e as areias pesadas que o acompanham. Issim se formaram os depositus de alluvioes auriferas do Brasil. Quando 1) ouro se apresenta no stilo das encostas dos morros, cimo ás vezes acontece no estado de Minas Geries, é derido au fieto de haver vieiros auriferos nas rochas subjacentes.

E' lastante commum stippor que us depositos de alluvioes ricas indicam vieipos ricos de umo. Istu porm. nim i neressariamente " 
caso. A riqueza de uma alluviàn aurifera púde sor devida á grande somma de material do vieiro que tem sido concentrado parat a produzir.

No Brasil os diamantes tambem se ajresentam em depositos do alluvião. Yeste caso fòram originalmente espalhados em algumas das rochas estratificadas da regiio diamantifera, semdo desembaraçado pela decomposiçio da matriz encaixante e accumulades nos leitos dos rursos de agua antigos ou recentes junus ron ouro e ontros mineraes pesados.

\section{Fontes e poços em relaçào á estructura geologica.}

As aguas que sahem do sulo ria fórma de lontes sio as mesmas que cahiram sobre a terra em fórmas de chuva, neve, saraiva e serem infiltraram-se no solo e depois de un percurst maior ou menor atravez das rochas, surgiram como fontes. Ë a sravidade, ou mox imentw descendente natural da agua, que a traz plati a superfirie, e nu seu curso atravez das ruchas, é guiada pulas aherturas ou vias de passagem nellas existentes, ou pelas camadas porosas.

A agua só póde-se accumular e circular naquellas rochas que apresentam aberturas, ou porosidade. I porusidarle de una rucha é devida á sua estructura e pride ser pronluzidit pur diveras maneiras.

\section{Porosidade devida a espaços entre os fragmentos} de materiaes graúdos. - Os pequenus lragmentos componentes le uma rocha se ajuntam tao ippertalamente qur. us espareos entre us

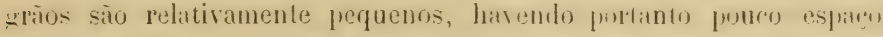
para a agua, sem fallar da grande fricrail) que matem te remeer an passar atrarez de taes materiaes, e assim a limblat tem funca funsidade. I medida que os fragmentos augmentam 1.m tamanho us "sparus ficam maiores e a porosidad augmenta correpondentemente. Ei a razio por que nunca produzem muita agua is ruchas rompmas de materiaes mimlos, ao passo que as areias a almitos grabdus us catcalhos e conglomerados são capazes de guatditi e puduzir muiti așlli.

Deve-se notar, porém, que os espaços entre os fragmentos de

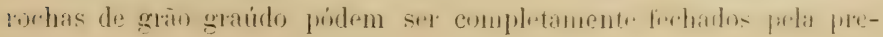


sença de um pouco de material miúdo como a argilla. Por isso ás vezes acontece que os conglomerados se tornam rochas bem fechadas e compactas.

II. Porosidade devida a juntas ou fendas nas rochas. Acontece ás vezes que rochas compactas e de granulação miúda permittem a passagem d'agua ao longo de juntas ou fendas quando estas são abundantes.

Não é sempre porém que as rochas com fendas e juntas pódem fornecer agua, porque a presenȩa da agua depende tambem das condições meteornlogicas locaes. Em regiões onde ha muita chuva, e onde a chuva está hem distribuida pelo anno inteiro, taes rochas púdem fornecer poços perennes. Mas nas regiões de seccas no norte do Brasil rochas deste caracter não produzem agua pela razào de que a chuva ali, não estando bem distribuida, cahe quasi toda de uma ve\%, e corre logo para o mar, sem ter tempo de entrar no chão e nas rochas.

III. Vias para agua feitas por cavernas. - Em regiōes calcareas onde pela solução da rocha se fórmam cavernas, encontram-se frequentemente grandes vias abertas para agua. Em regiões vulcanicas, cursos d'agua tambem correm em cavernas formadas originalmente pelo derramamento de lenȩóes de lava que resfriaram e endureceram na superficie emquanto a rocha embaixo estava ainda fluida. Taes cursos d’agua não são, porém, devidos á porosidade mas á existencia-de grandes aberturas cavernosas.

IV. Porosidade devida a dolomitação. - Quando um calcareo tem uma parte da sua cal substituida pela magnesia a rocha se contrae de modo a perder doze por cento do seu volume. Assim se produz porosidade na dolomia recem-formada.

Relação á estructura. - Em relação aos movimentos subterraneos d’agua, é uma regra geral que a agua vai para onde póde correr com maior facilidade. E' portanto guiada nos seus movimentos pelas feições estructuraes das rochas pelas quaes passa, isto é, por porosidade, fendas, falhas e dobras que por un lado permittem movimento: 
e por outro lado por estractos impermeaveis que impedem a sua passagem.

Numa região de rochas horizontaes vè-se muitas vezes a emergencia de fontes ao longo da margem superior do afloramento de uma camada impermeavel. Num tal caso, a agua penetra nas camadas sobrepostas, mas ao chegar á camada impermeavel é obriganla a mover-se ao longo do seu plano superior até encontrar sahida na superficie.

Na serra do Porto-Alegre no estado do Rio Grande do Norte ha um bello exemplar da relação da estructura geologica com a sahida

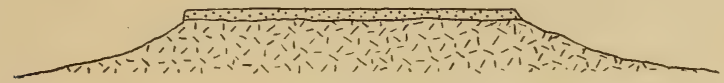

Fig. 122. - Serra do Porto Alegre, estado do Rio Grande do Norte.

A base é de rochas crýstallinas; o cume é de arenito. (Soper.)

natural das aguas. O cume daquella serra é de uma camada grossa de arenito que se sobrepõe ao gneiss que fórma a massa inferior da serra. As aguas das chuvas que cahem ali penetram com facilidade na rocha arenosa, e descendo até chegar ao gneiss debaixo, que não é muito permeavel, vèm sahir nas encostas da serra ao pé do arenito onde fórmam muitas fontes naturaes.

E um facto conhecido que muitas fontes existem ao longo dos escarpamentos da chapada do Araripe no estado do Ceará, chapada esta composta de camadas de rochas sedimentarias (1).

Poços communs. - A maior parte dos poços communs obtèm o seu abastecimento d'agua pela infiltração lenta d'esta atravez das rochas ou materiaes sol tos ou permiaveis penetrados pelo poço. Quando o poço chegar a uma camada aquifera a agua escòa na abertura com bastante rapidez para substituir a que for retirada. Estas condições encontram-se em camadas de sedimentos graúdos e nos terrenos de alluvião, nos quaes as camadas graúdas do fundo acham-se em geral completamente saturadas d'agua.

(1) G. A. Waring. Supprimento d'agua no Nordeste do Brasil. Pub. 23. Inspectoria de Obras contra as Seceas, pag. 8. Rio de Janeiro, 1912. 
Acontece as vezes que poros situados proximo uns dos outros fornecem agua de qualidades differentes, devido isto a differenęas na natureza das camadas donde provèm as aguas.

0 encuntro de agua no alto de morros ou montanhas ás vezes é motivo de surpreza. Ia sempre, porém, alguma razão geologica que
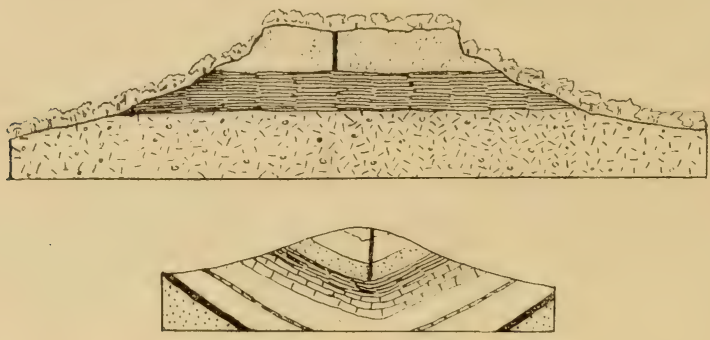

Fig. 123 e 124. - Seções mostrando

como a agua é ás vezes encontrada no alto dos morros. A agua accumula-se numa camada porosa em cima de uma outra impermeavel.

explica taes occorrencias. Nos casos representarlos nas figuras juntas, jor exemplo, a occorrencia de agua que á primeira vista parece

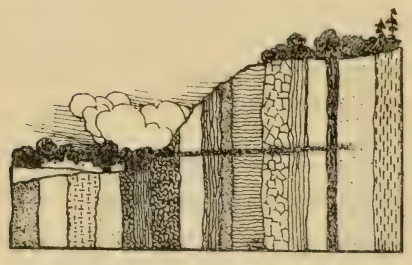

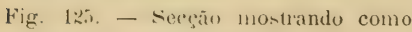
un poso horizontal póde obter agua em rochas em camadas verticaes. anormal, é facilmente explicavel quando se comprehende a estructura geologica.

Em alguns casos encontra-se agua ao furar poços horizontalmente nas encostas de morros em lugar de verticalmente nos valles. Isto acontece em regiões de rochas verticaes.

Quando as rochas são dobradas, a posição das principaes vias d'agua é determinada pela das dobras. Em taes casos é necessario determinar detalhadamente a geologia estructural para saber a locaràn das melhores posiẹies para obter agua. Na figura junta é evidente que as melhores locaçies para porsos só póde ser determinada pelo conhe- 
cimentu da estructura; e tambem (que esta determinarão nào é questano de hypsometria, ou da elevacão relativa das differentes partes da superficie da terra.

Em tcios os casos é claro que a agua subterranea vae para onde púde passar com a maior facilidade. Dada a esperança quasi universal de poder achar agua em qualquer lugar do sertão do nordeste do Brasil, será bom seguir o conselho do hydrologo, Jr. Waring, que disse do granito e outras rochas crystallinas daquella região : "Estas rochas não permittem o accumulo d'agua subterranea em grande quantidade porque são muito compactas e as suas falhas não são em numero sufficiente (1) 》.

Pelo contrario é provavel que em inuitos pontos das rochas sedimentarias da costa nordeste e das serıas do Araripe e Ibiapába seja encontrada agqua subterranea em quantidade importante.

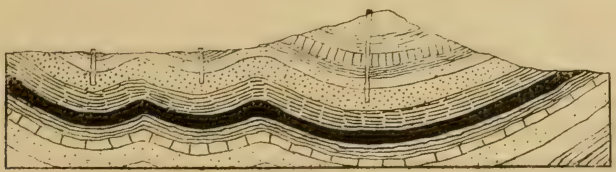

Fig. 126: - Seção mostrando as melhores locações para poços determinadas pela estructura geologica.

Poços artesianos. - Poços artesianos são aquelles em que a agua corre pela sua propria gravidade. Em taes casos a agua se accumula debaixo de condições estructuraes especiaes. Em geral temos que fazer com grandes areas, isto é, a agua se accumula sobre uma grande area de territorio.

As condiç̃es essenciaes para poços artesianos são as seguintes :

I. - Um estrato acquifero para conter a agua. Este é geralmente uma rocha de granulação graúda.

II. - Um estrato sobrejacente e confinante que impede o escapa-

(1) G. A. Waring. Supprimento dagua no Nordeste do Brasil, pag. 54. Rio de Janeiro, 1912. 
mento natural da agua. A camada confinante é geralmente de argilla, picarra, folhelho ou outro material compacto semelhante.

III. - Cabeceira, ou elevação relativa do ponto de origem da agua, sufficiente para a trazer á superficie onde se faz a abertura. Acontece frequentemente que a cabeceira é apenas sufficiente para trazer a agua numa parte do caminho para á superficie.

IV. - Precipitação d'agua, ou chuva no aftloramento.

E. preciso lembrar que as aguas das fontes e dos poços são as mesmas que cahem das nuvens.

Importancia de altitudes relativas. - Acontece ás vezes que mesmo conhecendo a estructura geologica, a questão de obter um fluxo artesiano só púde ser determinada com referencia á altitude exacta da camada aquifera em diversos pontos. I's vezes isto póde ser feito por uma inspeç̧io rapida da geologia e topographia, mas is vezes é necessario correr linhas de nivel para verificar os factos.

Aguas mineraes. - Do que fica dito á pagina 107, é evidente que todas as aguas (que penetram as rochas dissolvem certos mineraes que ali encontram. Assim acontece que as aguas, sahindo da terra, vèm carregadas de mineraes em soluçio, e como estes mineraes variam de um lugar para outro, as aguas variam em composiçâo na mesma marcha e pela mesma razão. Has é costume chamar qualquer agua empregada para o tratamento das molestias " aguas mineraes ".

No Brasil existem muitas fontes de aguas mincraes. As seguintes analyses são typicas das mais conhecidas. 
ANALYSES DE TRES FONTES DE POCOS DE CILDAS SLL DE MINAS GERAES (1)

(Em grammas por litro)

\begin{tabular}{|c|c|c|c|}
\hline & $\begin{array}{c}\text { Pedro } \\
\text { Botelho } \\
-\end{array}$ & Mariquinlias & Macacos \\
\hline cido sulfurico . . . . . . & 0.0903 & 0.0820 & $0.0: 366$ \\
\hline Silica . . . . . . . . & 0.0180 & .0170 & .0200 \\
\hline Acido earbonico............ & 0.2100 & $0.219 \ddot{3}$ & 0.2293 \\
\hline 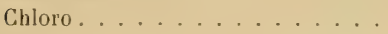 & 0.0037 & 0.0039 & 0.0042 \\
\hline Call. . . . . . . . . . & 0.0120 & 110 & 0.0110 \\
\hline Potassil. . & 0.11110 & 0. & $0.016 . ;$ \\
\hline Soda. . . . . . . . . & 0.2780 & 0.2816 & 0.2973 \\
\hline Organica e perdas......... & 0.0120 & 0.0150 & 0.0191 \\
\hline Total por litro....... & 0.000 & 0.6430 & 0.004 \\
\hline
\end{tabular}

Destas analyses é claro que o ingrediente principal dessas tres aguas é o (arbonato de soda. Mas as aguas de Poegos de Caldas sio thermaes, isto é, ellas tèm uma temperatura de 41 para 46 graus cintegrados, e sem duvida as suas propriedarles therapeuticas dependem em parte a alta temperatura. Parece provavel tambem que essas aguas sejam radio-activas, mas for ora esse ponto ainda nào loi determinado.

(1) Pedro Sanches de Lemos. As aguas thermaes de Poesos de Caldas. Bello Holizonte, 1904. 



\section{PARTE TERCEIRA}

\section{Geologia Historica.}

Quando se examina qualquer grande serie de rochas seclimentarias verifica-se geralmente que as differentes divisões da série contèm fosseis caracteristicos - os restos dos animaes e plantas que existiram no tempo em que as camadas foram depositadas.

E' tambem evidente sem discussão que quaesquer modificações que se encontram no caracter biologico dos fosseis das camadas são indicios de modificações que operaram com os animaes e plantas emquanto se effectuava a deposição das camadas.

As camadas sedimentarias tambem contem no seu caracter, ordem e arranjo, outras evidencias sobre a natureza das aguas e correntes nas quaes foram depositadas. Todos estes factos e quaesquer outros que elucidem a origem, arranjo, fórma e condição das camadas em questão fornecem meios de aprender a sua historia. 0 estudo da historia, ordem e idades relativas das rochas chama-se portanto geologia historica.

A historia das rochas póde ser deduzida das leis conhecidas da materia e do estudo das manif zstações destas leis quando os seus effeitos se acham conservados nas proprias rochas.

Pelas considerações precedentes parecem evidentes ou satisfactoriamente estabelecidos, os seguintes factos :

I. - As rochas estratificadas ou sedimentarias tèm sido depositadas debaixo d'agua (salvo depositos aeolianos e alguns de restos vegetaes) em camadas proximamente horizontaes.

II. - As camadas mais antigas fóram dejositadas primeiro; as mais modernas depois e em cima daquellas. 
III. - I perturbaçĩo da horizontalidade approximada e da continuidade das camadas e quaesquer alteraçòes que ellas tenham soffrido devem ter occorrido depois da sua deposição.

IV. - Se uma localidade esteve fóra d'agua durante um tempo dado, nenhuma camada sedimentaria sub-aquosa poderia ser depositada nella durante aquelle periodo.

V. - Visto ser a crosta da terra susceptivel de elevações e depressôes, a deposição de sedimentos num lugar dado é sujeita a ser interrompida pela elevação della á condição de terra firme, e não podemos portanto esperar encontrar uma deposição continua e nào interrompida de sedimentos em todos os lugares, ou talvez em lugar algum.

V1. - As rochas conservam dentro de si muitos signaes evidentes das condicoes prevalecentes quando e onde forram depositadas.

VII. - Os fosseis encontrados numa camadi dada de sedimentos sĩo os restos de plantas ou animaes que viveram quando as camadas forram sendo depositadas (salvo os casos de fragmentos derivados de camadas mais antigas).

VIII. - Os periodos de apparecimento e de mudanças em faunas e floras são indicados ou suggeridos pelos fosseis.

IX. - Em muitos lugares grandes espessuras de rochas sedimentarias tên sido removidas pela erosão, e assim a historia do lugar originalmente conservada nestas rochas foi obliterada.

X. - 0 registro geologico é portanto imperfeito, ainda quando as condições sejam as melhores.

Assim é claro que a historia da terra, onde não está ainda obliterada pelo metamorphismo ou pela denudação, se acha registrada na natureza e nas condicões das rochas, e nos caracteres dos fosseis inclusos.

\section{0s fosseis e os seus usos.}

Qualquer reliquia, rasto, ou impressão de planta ou de animal nas rochas chama-se fossil. Sĩo muitas vezes chamadas "petrefactas ", se bem que não estejam sempre pretificados. Na geologia se empregam os fosseis para determinar as idades e posicies relativas das rochas nas 
quaes elles se apresentam, e tambem para determinar as condições em que se formaram as camadas que os contém. Por exemplo, os restos do animaes marinhos encontrados nas rochas mostram que forran depositalas no mar : as fórmas cararteristicas da agua salobre são consideradas como indicativas de depositos em agua salobre: e as de agua duce como indicativas de depositos em agua doce ou sobre a terra, se bem que aconteça ás vezes serem carregadas fórmas terrestres e de agua doce para o mar e ahi depositadas. Visto ser differente a vida dos mares profundos da das aguas razas, os fosseis, ás vezes, mostram se as camadas fóram depositadas em agua funda ou raza. Póde-se dizer o mesmo de aguas frias e calidas; climas frios e calidos; plantas terrestres e maritimas, etc.

0 valor dos fosseis vem do facto da vida sobre a terra ter mudado de um a outro periodo, e até ir mudando ainda hoje. Por exemplo, durante os ultimos seculos certos animaes tim desapparecido completamente da terra, taes como o Dodo da Iustralia, o Dinarius casuari de Nova Zelandia. Um exemplo original do esqueleto deste ultimo passaro acha-se actualmente no Yuseu Nacional do hio de Janeiro.

A mesma coisa tem acontecido com muitas plantas e animaes. A's vezes uma planta ou um animal desapparece d'uma parte do mundo, porém continua em outra. Mudanças semelhantes se deram durante os periodos geologicos.

Aquellas plantas ou animaes que tèm partes duras, ou osseas, sãu mais adaptaveis de conservação como fosseis, ao passo que aquellas que não tém partes duras, (como as aguas viras, as lesmas e as alyas molles), raras vezes são assim conservadas. E' tambem necessario que as cundiçes sejam em outros respeitos favoraveis afim de que os fusseis sejam conservados depois de depositados. Arontece ás vezes que, depois de elevadas á condição dé terra firme as camadas que contim fosseis, a infiltração d'agua atravez das rochas dissolve e carrega os organismos soluveis deixando as rochas privadas de fosseis.

Os depositos maritimos estio sujeitos a cunter coraes, ossos, dentes e escamas de peixes e reptis, conchas de molluscos, e as partes duras de crinoides, de crustaceos e de qualquer outro animal que vive no mar. 
Depositos terrestres. - Os animaes e plantas terrestres, salvo o caso de cahirem n'agua ou lama onde pódem ser enterrados e conservados, geralmente apodrecem e desapparecem. $\Lambda$ 's vezes, porém, cahem em lagos onde fican enterrados nos sedimentos : ou crescem em pantanos turfosos onde algumas partes licam conservadas na turfa, ou são carregadas por cursos d'agua e depositadas nos deltas, onde descem para o fundo para ser enterradas nos sedimentos. Taes depositos podem conter impressões de plantas terrestres e de agua doce, folhas, cascas e fructas, rastos de insectos, passaros, amphibios e de outros animaes.

Não é raro encontrar, especialmente em regiões de rochas aalca reas, as aguas tão carregadas de saes calcareos que formam depositos envolvendo folhas, frutas, e qualquer outras cousas que nellas cahem, assim produzindo putrefaccóes calcareas. Este facto se dá nas areas de rochas calcareas do estado da Bahia, e foi notado na vizinhança de Miranda no estado de Matto Grosso por Dr. Lisboa (1).

Entre os depositos terrestres deve-se contar os feitos em cavernas ondese acham ás vezes conservados pela formação acima delles de capas estalactiticas de carbonato de cal; ou enterrados em outras accumulações formadas sobre o chão das cavernas.

Valores relativos de fosseis. - Nem todos us fosseis são egualmente valiosos para a determinaçào das idades das rochas. Isto é devilo ao facto que certos animaes tèm existido descle as primeiras epochas da historia dir terra até a actual, e portanto os seus restos nenhum indicio offerecem da idade das camadis nas quaes se encontram. Alguns dos protozoarios, esponjas e Lingulas (brachiopodes) encontram-se assim em rochas de todas as idades. Alguns organismos são de distribuição tão limitada que rẻlativamente pouco valor offerecem para fins paleontologicos por causa da sua raridade. Isto tambem acontece com certas formis altamente desenvolvidas e especialisadas.

(1) M. A. R. Lisboa. Oeste de S. Paulo; Sul de Matto Grosso, pag. 14. Rio do Janeiro, 1910. 


\section{A columna geologica.}

Se as rochas da crosta da terra tivessem sido depositadas numa serie não interrompida desde os tempos primitivos até os ultimos, teriamos conservada nellas a historia greologica continua e completa e esta serie constituiria a columna geologica. Não se encontra, porém, uma tal serie em nenhuma localidade, se bem que haja lugares onde se apresentem diversas divisôes da serie. Comquanto não exista num só lugar uma seção geologica completa, os geologos reunem theoricamente os representantes das rochas depositadas atravez de toda a historia da terra para formar a columna geologica, isto é, uma collecção completa das rochas da crosta da terra arranjadas na ordem da sua formação ou idade. Se bem que esta columna seja apenas hypothetica, certas camadas são consideradas como typicas.

Correlação, - Nas primeiras tentativas para correlacionar estratos ou para determinar os equivalentes de um grupo de camadas num lugar com outro grupo em outro lugar, procurou-se fazer uso de caracteres lithologicos, côr, composição mineralogica e a ordem das camadas para esta correlação ou identificação. Achou-se, porém, logo que não se podia contar com os caracteres lithologicos porque os calcareos, os arenitos, as argillas, os conglomerados e as rochas eruptivas formaram-se, e ainda se fórmam, contemporaneamente. 0 resultado é que um estrato que em um lıgar é um calcareo passa a ser a alguns kilometros de distancia, arenito ou folhelho, ou passa a ser um tufo : e isto póde acontecer tanto com as rochas mais antigas como com as mais modernas.

A côr. - Do mesmo modo tem-se tentado empregar a côl das rochas para identifical-as, e alguns nomes, baseados na còr, como * velho arenito vermelho " e " novo arenito vermelho ", tèm sido muito empregados, e ainda hoje persiste, em escala limitada, este uso. A côr por si só, porém, é de pouca importancia, salvo localmente, porque a mesma côr é muitas vezes repetida em rochas de idades muito 
differentes, e uma camada píde ter uma cor numa localidade e oulra n'outra.

Conteúdo mineral. - Tem-se recorrido tambem ao conteńde mineral no intuito de correlacionar camadas. Em alguns casos e dentro de areas limitadas súmente, esta, como as outras tentativas acima mencionadas, é bem succedida. O carvão, por exemplo, em certas partes do mundo só se encontra em rochas da idade carbonifera. Porém fóra destes limites determinados isto deixa de ser verdade, porquo o carvão nào se acha linitado exclusivamente ás rochas carboniferas, mas se apresenta nas de todas as idades desde a devoniana até a torciaria. Podia-se citar muitos outros casos semelhantes.

A ordem das camadas. - $\Lambda$ orden en que as camadas se succedem tambem é constante sómente dentro de areas limitadas. Frequentemente acontece que as camadas mais novas, em lugar de jazerem sobre as immediatamente anteriores, jazem sobre outras muito mais antigas, ou mesmo sobre as mais antigas de todas. Em taes casos algumas das camadas faltam na serie, de modo que a seç̧ão num lugar não é sempre semelhante à de um outro lugar.

Além da inipossibilidade de correlacionar camadas pelos meios acima referidos, as difficuldades de correlação acham-se augmentadar por elevação differencial, dobramento, subversào, metamorphismo, falhas, e pela erosão das camadas.

Emprego de fosseis para correlação. - Púde-se ás vezes estabelecer a correlação seguindo as camadas au longo dos seus afluramentos de um lugar para uutro. Isto, porém, nem sempreé conveniente ou possivel. Os fosseis fornecem o unico meio seguro para a correlacio de rochas de differentes areas, regióes, e paizes, e em partes muito afastadas do mundo. Istu é porque os fosseis representam as fórmas animadas dos periodos nos quaes as camadas firam depositadas. Pela maior parte cada periodo tem tido as suas fórmas proprias, mas como as faunas e flóras tèm mudado, ellas tèm-se approximado cada vez mais intimamente da vida presente do globo. 
Isto é especialmente importante quando considerado $\mathrm{cm}$ connexão com o facto que em todos os paizes tem havido a mesma ordem geral de successão no desenvolvimento das fórmas animadas. Portanto a identidade nos fosseis é acceita pelos geologos como indicando proximamente a mesma idade geologica.

O valor dos fosseis. - o valor biologico dos fosseis provém da informaçio que fornecem relativamente as desenvolvimento da vida sobre a terra. E, constituindo os fosseis o criterio pelo qual as rochas Se classificam historicamente, fornecem os meios para determinar as idades das rochas fossiliferas onde se apresentam; mas tão súmente pela sua referencia á columna geologica, - a secęão typica. Acontece frequentemente que, dentro de uma região dada, certos mineraes de vilor economico achani-se limitados a rochas de uma determinada ilade. Neste caso torna-se importante saber se uma determinada camada fica acima ou abaixo do horizonte mineralifero, e saber em que rumo se deve ir para encuntrar os depositos mineraes. Nas regivies de rochas dobradas ou falhadas, especialmente quando se trata de grandes areas desnudadas, os fusseis se tornam ainda mais importantes.

A tabella seguinte dá os nomes acceitos para as divisões e subdivisies das rochas e as fórmas predominantes da vida existente $\mathrm{cm}$ cada periodo. Esla forma a columna geologica.

As grandes divisões e a ordem d'ellas são as mesmas para todo o mundo, mas empregam-se por toda a parte nomes locaes para as subdivisũes. Nesta tabella, por exemplo, nota-se que os nomes empregados no Brasil são nomes brasileiros.

Yota-se tambem que certos periodos, como por exemplo o cambriano, ainda não foram reconhecidos no Brasil. Se as camadas cambrianas existem aqui ๆão se póde dizer com certeza por ora pela razĩo de que é difficil ou impossivel reconhecer ou coordenar depositos que não tèm fosseis. 0 mesmo póde-se dizer a respeito de outras divisües da columna geologica no Brasil. 
A COLUMNA GEOLOGICA

\begin{tabular}{|c|c|c|c|c|}
\hline $\begin{array}{c}\text { VIDA } \\
\text { CARACTERISTICA }\end{array}$ & PERIONO & SYSTEMI & $\begin{array}{l}\text { DIVISÓLS } \\
\text { N. AMERICANAS }\end{array}$ & $\begin{array}{l}\text { EQUIVILENTES } \\
\text { BRASILEIRAS }\end{array}$ \\
\hline \multirow[t]{2}{*}{ Homem. } & \multirow[t]{2}{*}{ Psychozoico. } & Recente. & Mecente. & $\begin{array}{l}\text { liceifes de arenito } \\
\text { e de coral. }\end{array}$ \\
\hline & & Pleistoceno. & $\begin{array}{l}\text { Plioceno ou Qua- } \\
\text { ternario. }\end{array}$ & $\begin{array}{l}\text { Camadias com mas- } \\
\text { todonte; praias } \\
\text { elevadas. }\end{array}$ \\
\hline \multirow[b]{2}{*}{ Mammiferos. } & \multirow[b]{2}{*}{ Cenozoico. } & \multirow[b]{2}{*}{ Terciario. } & Pliocena. & $\begin{array}{l}\text { Bacias de agua tlo- } \\
\text { ce em S., Paulo, } \\
\text { Minas, lin. }\end{array}$ \\
\hline & & & $\begin{array}{l}\text { Hiocena. } \\
\text { Oligocena. } \\
\text { Eocena. }\end{array}$ & $\begin{array}{l}\text { Riacho boce, Ila- } \\
\text { goas; Olinda, Ila- } \\
\text { ria Farinha, Ita- } \\
\text { maraca, Ponto } \\
\text { de Pedra, Per- } \\
\text { nambueo. }\end{array}$ \\
\hline \multirow{7}{*}{ Reptis. } & \multirow{7}{*}{ Mesozoico. } & \multirow[t]{2}{*}{ Ciretaren. } & Superior. & $\begin{array}{l}\text { Parahyba do Nor- } \\
\text { le, Sergipe. } \\
\text { Para? }\end{array}$ \\
\hline & & & Inferior. & $\begin{array}{l}\text { Ceará, Sergipe, } \\
\text { Icre, Bahia. }\end{array}$ \\
\hline & & \multirow{3}{*}{ Jurassiro. } & Superior. & \multirow{3}{*}{$\begin{array}{l}\text { Eruptivos da Serra } \\
\text { Geral, arenito de } \\
\text { Botueati. }\end{array}$} \\
\hline & & & Media. & \\
\hline & & & Inferior. & \\
\hline & & \multirow[b]{2}{*}{ Triassico. } & Superist: & \multirow{2}{*}{$\begin{array}{l}\text { S. Bento em parte, } \\
\text { Bacias do Paraná } \\
\text { e.Uruguay. }\end{array}$} \\
\hline & & & Media. & \\
\hline \multirow[t]{3}{*}{$\begin{array}{l}\text { Acrogeneos. } \\
\text { Imphibios. }\end{array}$} & \multirow{10}{*}{ Paleozoiro. } & \multirow[t]{3}{*}{ Carbonifero. } & Permiana. & $\begin{array}{l}\text { Passa bois c Tuba- } \\
\text { rão, Rio Gr. do } \\
\text { Sul, Santa Catha- } \\
\text { rina, Paraná, s. } \\
\text { Paulo, Estancia } \\
\text { da Bahia c ser- } \\
\text { gripe. } \\
\end{array}$ \\
\hline & & & Coal Mcasures. & Lavras? \\
\hline & & & $\begin{array}{l}\text { Carbonifera. infe- } \\
\text { rior. }\end{array}$ & $\begin{array}{l}\text { Itaituba Pará, Para- } \\
\text { guassu? }\end{array}$ \\
\hline \multirow{3}{*}{ Peixes. } & & \multirow{3}{*}{ Desoniano. } & $\begin{array}{l}\text { Devoniana supe- } \\
\text { rior. }\end{array}$ & \\
\hline & & & $\begin{array}{l}\text { Ouondinga. } \\
\text { Hamilton. }\end{array}$ & $\begin{array}{l}\text { Ererè Pará. } \\
\text { Chapada, } \\
\text { Mitto Grosso. }\end{array}$ \\
\hline & & & $\begin{array}{l}\text { Oriskany. } \\
\text { Cornifera, } \\
\text { Helderberg infe- } \\
\text { riwr. }\end{array}$ & $\begin{array}{l}\text { Maecurú Pará. } \\
\text { Paraná. }\end{array}$ \\
\hline \multirow{4}{*}{ Inverteluratos } & & \multirow{2}{*}{$\begin{array}{l}\text { Siluriano. (Silu- } \\
\text { riano superior). }\end{array}$} & Salina. & \multirow{2}{*}{$\begin{array}{l}\text { Tombador? } \\
\text { Bacia de São Fran- } \\
\text { cisco, Babia. } \\
\text { Trombetas Pará. }\end{array}$} \\
\hline & & & Niagara. & \\
\hline & & $\begin{array}{l}\text { Ordoviciano.(Silu- } \\
\text { riano inferior). }\end{array}$ & $\begin{array}{l}\text { Trenton: } \\
\text { Canadiana. }\end{array}$ & \multirow[b]{2}{*}{ Serie Jacobina? } \\
\hline & & Cambriano. & $\begin{array}{l}\text { Saratogan. } \\
\text { leadian. } \\
\text { Ocree. } \\
\end{array}$ & \\
\hline Nenhum. & $\begin{array}{l}\text { Eozrico. } \\
\text { Izoico. }\end{array}$ & Ircheano. & $\begin{array}{l}\text { Huroniana. } \\
\text { Laurentiano. }\end{array}$ & $\begin{array}{l}\text { Complexo Jrasilei- } \\
\text { ro da Serra do } \\
\text { Mar, Bahia, efe. }\end{array}$ \\
\hline
\end{tabular}


Significação das côres nos mappas geologicos. - As côres empregadas por geologos nos mappas para mostrar a distribuição das diversas camadas ou formações nada tem com as côres das proprias rochas. Cada uma corr geralmente está limiıda á area de uma cérta formação, certa camada, ou serie de camadas. Tambem não ha uniformidade no emprego das corres; um geologo póde servir-se de certas côres para uma serie de rochas quando outro póde empregar còres differentes para a mesma serie. E o mesmo geulogo ás vezes serve-se de uma còr para uma serie, e depois passa a servir-se d'aquella côr para outra formação. Todos os mapjas porèm devem trazer, sem falta, as dividas explicações das còres empregadas e nestas explicaçôes a côr de cada uma formaçào deve estar no seu proprio lugar, isto é, as rochas mais antigas devem ser representadas em baixo e as mais recentes em cima.

0 congresso internacional de creologos formulou certas regras sobre este assumpto, e cm geral os geologos do mundo servem-se daquellas regras (1).

Ao mesmo tempo cada um tem a liberdade de formular as regras que the convierem.

\section{Periodo archeano.}

0 archeano é tambem chamado, is vezes, agnotozoico (vida desconhecida), ou azoico (sem vida), porque não se tem encontrado fosseis nas rochas desta idade. Não se sugue, porem, que a falta de fusseis prove a ausencia de vida no periodo em que se formaram as rochas archeanas. Ha os seguintes motivos para inferir que havia vida solsre a terra nos tempos archeanos.

I. - As rochas immediatamente sobrepostas, - o cambriano, contèm evidencias abundantes de vila, e esta vida é tão altamente or-

(1) The worl: of the International Congress of Geologists and of its committees. Published by the-American Committee, 109 pag., 1886.

Bailey Willis. Index to the stratigraphy of North America. Professional Paper 71. U. S. Genlogical Sureey, pags, 21-30. Washington, 1912. 
ganizada que parece rasoavel suppor que tivesse antepassados num periodo anterior.

II. - Existem ralcareos (marmores) entre as rochas archeanas e sendo os calcareos, pela imaior parte, de origem organica, não é impossivel que estas camadas, sn tivessem originado de modo semeIhante.

III. - Existem minereos de ferro entre as rochas archeanas. Alguns minereos de ferro foram accumulados no solo e nas rochas por intermedio de acidos organicos em lagunas e pantanos. E' possivel qur alguns dos nossos minerens de ferro estratificados do archeano tenhamse originado desta maneira.

IV. - Encontra-se graphite nas rochas archeanas e este mineral, conforme suppõem muitos geologos, é originario de plantas, tendo chegado á condięão graphitica pelo metamorphismo.

V. - A apatite, um mineral phosphatico, ahundante nas rochas archeanas, póde em alguns casos ser uma fórma metamorphoseada de uma rocha phosphatica de origem organica.

VI. - Ha tambem evidencia presumptiva que as plantas precederam os animaes em seu apparecimento sobre a terra, visto que muitos animaes vivem das plantas, e por isso mesmo parece provavel que houvesse plantas de uma idade anterior áquella em que se encontram os primeiros restos de animaes. Demais, se, conforme se presume, as aguas dos primeiros mares eram quentes, a sua temperatura elevada não seria desfavoravel para certas fórmas baixas de plantas.

0 tempo archeano divide-se em tres periodos como se segue:

I. - O periodo de un globo fundido quando a temperatura era demasiado elevada para admittir a existencia de vida.

II. - 0 periodo do resfriamento c'.a crosta. Durante este periodo se suppunha que os vapores $\mathrm{em}$ redor ha terra se resfriaram ao ponto de cobrir a terra com agua. Se qualquer parte da crosta ficou acima da agua devia ter começado nella a acção de erosão.

III. - Durante o terceiro periodo a temperatura abaixou ao ponto de admittir a existencia das fórmas mais haixas de vegetação. Foi este o inicio da vida sobre o globo.

As rochas do periodo archeano sĩo as mais antigas conheridas - 
as mais baixas que nos são accessiveis. Fúrmam, portanto, o nucleo, ou ou base, sobre a qual descançam as rochas dos periodos subsequentes.

Como esta serie de rochas cobre uma area enorme deste continente, especialmente no Brasil, proponho o nome complexo brasileiro para esta serie.

\section{Distribuição do archeano na America do Sul. - Na} America do Sul as rochas archeanas encontram-se ao longo de uma cinta mais ou menos quebrada na costa occidental desde a Terra do Fogo até o Isthmo de Panamá. Fórmam tambem grande parte das terras altas da Goyana e do Brasil septentrional, e uma grande parte do planalto brasileiro ao sul do Amazonas.

As rochas archeanas do Brasil, são geralmente massiças e crystallinas. Na vizinhanȩa do Rio de Janeiro algumas sào granitos massięos, algumas são gneiss, e outras de estructura schistosa. Em muitos lugares são cortadas por diques de pegmatito. Por toda a parte, no Brasil, as rechas archeanas contêm diques, falhas e vieirós. Na região da Serra do Mar, porém, ellas não são tão amarrotadlas como no norte do Brasil.

Parece impossivel fazer uma linha de demarcação entre os granitos, os gneiss, e os schistos do complexo brasileiro. Tal demarcação é especialmente difficil quando as rochas são mais ou menos decompostas. Em geral, a schistosidade apparenta maior desenvolvimento com a progressiva decomposição do gneiss. Assim acontece que um gneiss decomposto quasi sempre parece um schisto molle. Na base occidental do morro da Lrca, na cidade do Rio de Janeiro, perto do $\mathbf{M i}$ nisterio da Agricultura, ha afloramentos de granito, de gneiss e de schistos crystallinos, todos mais ou menos amarrotados, falhados, e cortados por diques de pegmatito, e tudo isso num espaço de poucos metros. São apenas diversos aspectos da mesma rocha (1).

Fallando da geologia do norte do Brasil Dr. G. A. Waring diz que "não é possivel distinguir entre os granitos, os gneiss e os schistos crystallinos (2).

(1) Sobre a geologia do districto federal vêde o estudo de Alberto Paes Leme. Rio de Janeiro $1910,8^{\circ}, 20$ paginas.

(2) Carta particular, 23 de Maio de 1912. 
Crandall crè que os schistos crystallinos do Ceará são mais antigos que os granitos daquelle estado, porem as provas das idades relativas dessas rochas ainda faltam.

Antigamente os geologos norte americanos dividiram o archeano em " laurenciano " em baixo e " huroniano » em cima, e na primeira divisão Dr. J. W. Dawson, distincto geologo canadaense, julgou ter achado fosseis de um animal extincto a que elle chamou $E_{0 \approx 00 n}$ cancdaense. Mais tarde numa rocha de Alagoas perto das caxoeiras de Paulo Affonso, Derby achou uma amostra calcarea de que Dr. Dawson diz: " não tenho duvida de que este calcareo é da epocha laurenciana, e em parte composto de Eozoon, e julgo provavel que pesquizas mais prolongadas poderão descobrir nelle massas inteiras do fossil » (1).

Hoje, porém, o E0:0on não está geralmente acceito como resto de organismo. Na America do Norte os geologos reconhecem uma serie chamada "algonkiana " sobreposta á archeana, mas por falta de estudos, ainda não fui possivel nem fazer divisũes do archeano, nem m ssmo definir claramente o proprio archeano no Brasil.

0 facto de não se ter encontrado fosseis nas rochas antigas que formam os planaltos de Minas Geraes e Goyaz difficulta a determinação dos periodos a que pertencem as rochas mais antigas dessas regiões. Parece provavel serem archeanos os gneiss granitoides da Serra do Mar e Serra da Mantiqueira romo tambem algumas das rochas que os acompanham. Estas rochas do complexo brasileiro se estende m desde a republica do Uruguay atravez do estado do Rio Grande do Sul, ficando reduzidas a uma zona estreita ao longo do littoral nos estados de Santa Catharina, Paraná e S. Paulo, para depois se alargarem ao ponto de occupar em grande parte das do Rio de Janeiro, Espirito Santo, Minas Geraes, Goyaz e Bahia. Apparecem tambem no interior dos estados de Sergipe, Alagoas, Pernambuco, Parahyba, Rio Grande do Norte, Ceará, Piauhy, Maranhão, Pará, Amazonas e Matto Grosso. Na figura 127 se mostra de um modo geral a distribuição destas rochas no Brasil, devendo-se, porém, notar que, devido á impossibilidade de as separar das

(1) Reoista de Engenharia. Rio de Janeiro, 1880, II, 115-116; American Journal of Science, XIX, 324-325, abril 1880 . 


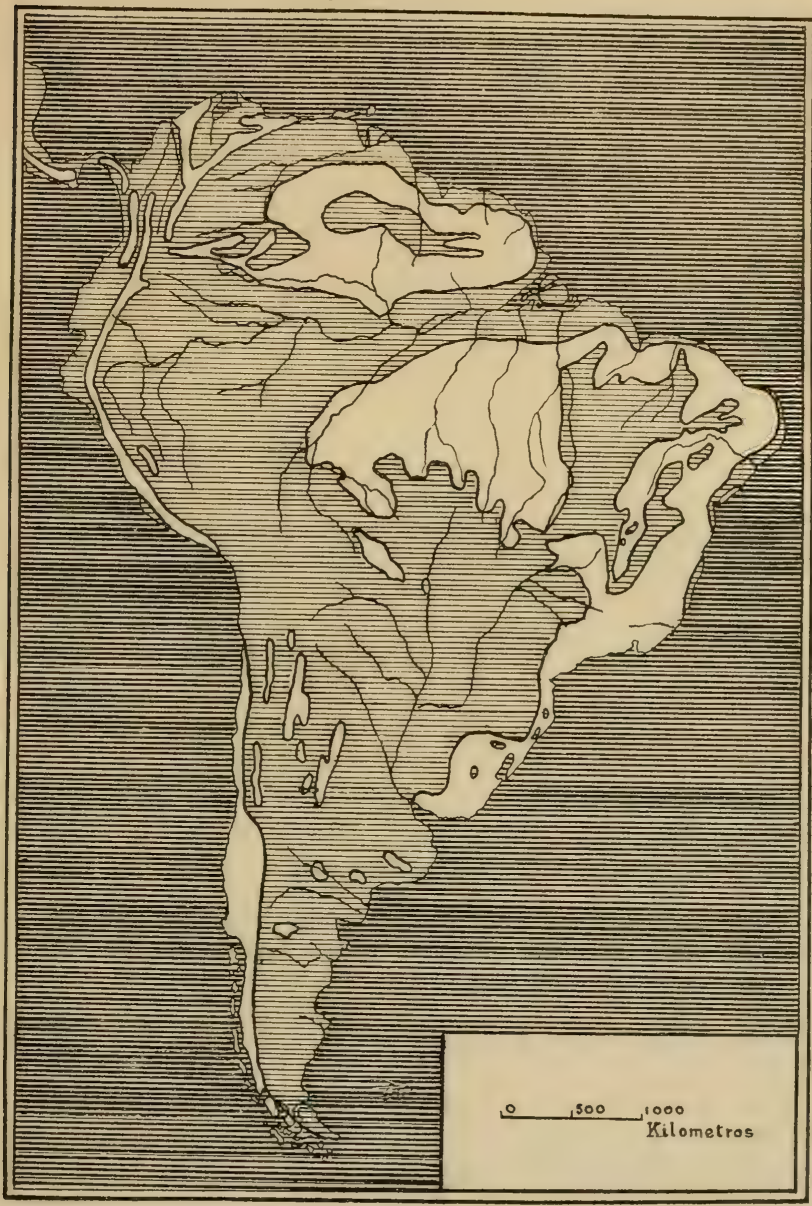

Fi. 127. - Esboço mostrando em branco as áreas principaes de rochas archeanas na America do Sul. 
rochas das duas divisũes subsequentes, as areas são demasiado grandes, e que sobre uma grande parte da area amazonica e central ellas se acham cobertas por depositos mais modernos de modo á só apparecerem nos fundos dos valles.

As feições estructuraes do archeano no Bıasil ainda não forão estu-

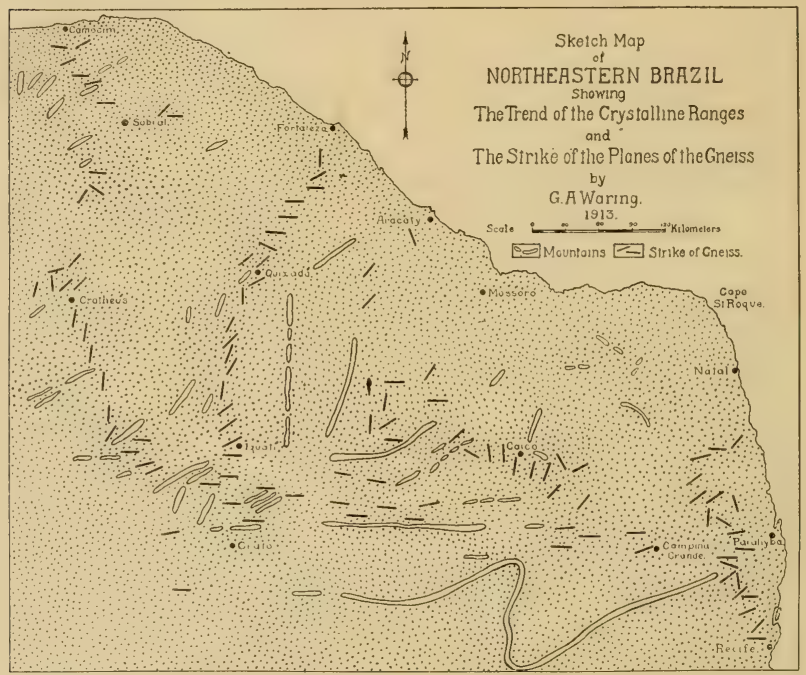

Fig. 128. - Esboço do nordeste do Brasil mostrando a direcção das serras de rochas crystallinas e a da foliação dos gneiss. (Waring.)

dadats, e as poucas notas que existem estão espalhadas pela literatura da geologia do paiz.

As unicas que abrangem uma area consideravel são as do Dr. G. A. Waring tomadas no norte do Brasil e indicadas no esboço junto. Disse Dr. Waring (1) que " o rumo ou direção da foliação dos gneiss notado no nordeste do Brasil é geralmente e. w. na parte sudeste da

(1) Carta particular, 29 de julho de 1911. 
região examinada, mas entre as villas de Saboeiro e Tauá o rumo murlase progressivamente de e. wv. ao norte-sul, e continua com este rumo até á nossa ultima observaçăo para o oeste. Na região do Apody e Jardim de Seridó e de Pau dos Ferros os rumos são mais irregulares. A inclinação ou pendor da foliação do gneiss no maior numero dos lugares é vertical, mas ha lugares onde as rochas são amarrotadas tanto que o pendor é quasi horizontal ».

Depositos economicos do archeano. - Nos outros continentes as rochas archeanas contêm grandes massas de minereos de ferro, graphite, marmore e apatite. E' provavel que alguns dos depositos de ferro e de manganez do Brasil pertençam ao archeano, mas a sua idade não foi ainda satisfactoriamente determinada.

Os depositos de ferro no estado de Minas Geraes são hoje os mais importantes do mundo. São semelhantes a quasi todos os respeitos aos da America do Norte, e talvez da mesma idade geologica, quer dizer precambriana (1). Em alguns lugares esses depositos de ferro tèm uma espessura de seiscentos metros e contêm sessenta e cinco por cento uu mais de ferro metallico.

As rochas da Serra do Mar produzem granadas e mineraes de metamorphismo, alguns de valor commercial (2).

E' possivel que a este pertençam os depositos em que se acham as minas de ouro dos estados de Espirito Santo, Minas Geraes, S. Paulo, Goyaz, e de outras partes do Brasil.

São conhecidos depositos de marmore nos estados do Rio de Janciro, Minas Geraes, S. Paulo, Paraná, Rio Grande do Sul, Pernambuco perto de Aguas Bellas, Bahia perto de Joazeiro, no Rio Grande do Norte, no Ceará perto da estação de Agarap̣e, e em Goỵaz, que são provavelmente da idade archeana.

(1) Leith and Harder. Hemcitite ores of Brazil. Economtc Geolory, VI, 6ro686, nov. 1911.

2) Francisco de Paula Oliveira. Subsidios ao estudo da geologia do Brasil, p. 10. Rio de Janeiro, 1907. 


\section{Periodo paleozoico.}

\section{CAMBRIANO}

U nome cambriano foi dado a certas camadas da Gran-Bretanha, e tem sido applicado ás rochas do mesmo periodo nas outras partes do globo.

Não se conhece com certeza planta alguma do cambriano, mas se infere que deviam ter existido plantas para fornecer alimento para a vida animal abundante daquelle periodo. Os animaes conhecidos são esponjas, hydrozoarios, vermes, echinoides, trilobitas, gasteropodes, lamellibrachios, brachiopodes e cephalopodes.

Rocha alguma brasileira é positivamente verificada como peṛtencendo á idade cambriana porque aqui ainda não se acharão fosseis cambrianos, mas é possivel que sejam deste periodo uma parte das rochas do planalto do Brasil incluindo as que contêm os depositos de ouro, ferro e manganez (em parte) de Minas Geraes, Bahia e Goyaz, bem como os sedimentos metamorphoseados de grande parte do interior da Bahia, Sergipe, Alogôas, Pernambuco e outros dos estados septentrionaes do Brasil. E' possivel que tambem pertençam aqui os calcareos de Corumbá em Matto Grosso e parte dos de S. Paulo e Paraná, bem como aquelles de Acarape no Ceará, de Pernambuco e Alagôas de Rio Grande do Norte e da Bahia.

Parece possivel tambem que aqui devem ser classificados os quartzitos e schistos da serra de Jacobina no estado da Bahia (1) que têm uma espessura de mil metros ou mais.

Ordoviciano ou siluriano inferior. - Os fosseis do ordoviciano mostram um adiantamento notavel na vida deste periodo sobre a do cambriano. Fòram especialmente abundantes os gräptolites e trilobites; abundaram tambem os cephalopodes e coraes; os molluscos e bivalvos e os gasteropodes augmentaram grandemente em tamanho e

(1) Serra de Jacobina. American Journal of Science, dec. 1910, pags. 385-392. 
numero, e as centopeias, os primeiros animaes terrestres conhecidos, se encontram fossilisadas nas rochas ordovicianas. Os mais antigos animaes vertebrados conhecidos — os peixes - são da divisão Trenton do ordoviciano da America do Norte (1).

Na America do Norte o petroleo de Ohio e Indiana provem das rochas ordovicianas: em alguns estados encontra-se nestas rochas minerio de chumbo e em outras abunda o marmore.

No Brasil acontece que, devido á apparente ausencia de fosseis, nenhuma das rochas tem sido identificada com:s ordoviciana, mas é bem provavel que aqui pertençam algumas das camadas metamorphoseadas do interior do paiz. Parece tambem possivel que as camadas do Trombetas mencionadas abaixo terão de ser correlacionadas com a parte superior do ordoviciano e com a inferior do siluriano.

\section{Siluriano ou Siluriano superior.}

As rochas silurianas contêm como fusseis abundantes bryozoarios e brachiopodes: os pteropodes são ahundantemente representados mas sào menores do que os do tempo ordoviciano: os graptolites e os trilubites fôram menos abundantes do que no periodo anterior : os crinoides fòram mais abundantes: e havia tambem algumas plantas, insectos e tubarões.

A natureza dos fosseis suggere mares temperados tepidos, e a occorrencia de extensas camadas de sal nativo no estado de Nova York e no Canadá mostra que o clima devia ter sido arido nestas partes do continente norte americano durante os tempos silurianos - um clima bem differente do actual

Nas rochas silurianas se apresentam as camadas de minerio de ferro da região montanhosa appalachiana, e as grandes camadas de sal, gesso e cimento de Nova York e Canadá.

No Brasil se conhecem rochas silurianas no lado de norte do valle

(1) Bul. Geol. Soc. Amer, III, pags. 153-172. 
do Amazonas (1). Jizem sobre granitos e quartzitos que se suppunha ser de idade archeana deste proximo ao Rio Jary, ao norte de Almeirim, ao longo de uma zona que corre para o oeste cruzando o Rio Uatumá ao nordeste de Manáos.

Subindo o rio Negro de Manáus e subindo depois o rio Branco durante o tempo de aguas baixas, Dr. R. Crandall achou arenitos e schistos quasi até á zona das caxoeiras do rio Branco, e mesmo nas caxneiras achou conglomerados. Elle é da opinião que o canal do rio Branco foi cortado nestas rochas sedimentarias, talvez da idade siluriana, e que só nas caxoeiras o rio chegou a expor os granitos.

Tem-se encontrido fosseis nestas rochas nas cachoeiras dos rios Trombetas, Curuá e Maecurú. As rochas são sedimentos maritimos que se inclinam ligeiramente para o sul e os seus fosseis são os mais antigos até agora conhecidos no Brasil (2). Parecem ser equivalentes aos das camadas Niagara di America do Norte, mas são tambem intimamente relacionadas com a parte superior do ordoviciano e é possivel que devam ser correlacionadas tanto com o Trenton como com o Niagara da America do Norte. No rio Trombetas as rochaz silurianas fórmam uma zona da largura de seis a oito kilometros exposta na primeira e parte da segunda cachoeira. São tambem bem expostas no oiteiro do Cachorro na margem do pequeno rio deste nome logo acima da sua confluencia com o Trombetas. $\Lambda$ parte inferior deste morro consiste de felsito tendo em cima um paredão de camadas silurianas.

Na parte inferior da segunda cachoeira (Vira-Mundo) as camadas silurianas jazem sobre syenito e se inclinam einco graus para o susudoeste. Calcula-se a espessura toial das rochas silurianas neste lugar em cerca de trezentos metros. As rochas são, pela maior parte, arenitos em camadas delgadas. Parecem representar um intervallo entre a parte superior de Trenton e a inferior do Niagara da secçã norte americana. Os fosseis do Trombetas que indicam relacões com a fauna de Trenton รão :

(1) O. A. Derby. Contribuișão para a geologia da regiäo do baixo Amazonas. Archivos do Museu Nacional, II, 77-104. Rio de Janeiro, 1877.

(2) John M. Clarke. A fauna siluriana superior do rio Trombetas. Arehivos do Museu Nacional do Rio de Janeiro, 1897-99, X, pags. 1-18. 
Orthis freitanu, O smithi, Anodontopsis putilla, A austrina, Tellinomya pulchella, T. subrecta, Clidophorus brasiliensis, Primatiu minula. Os que suggerem uma equivalencia com o Niagara ou a parte inferior do Siluriano são: Lingulops derbyj, Orthis callactis, var amusonica, Chonetes sp., Anabaia paraia, Bucaniella trilobata var brusiliensis, Tentaculites sp., Comularia ama:onica, Bollia lata. Ha rochas

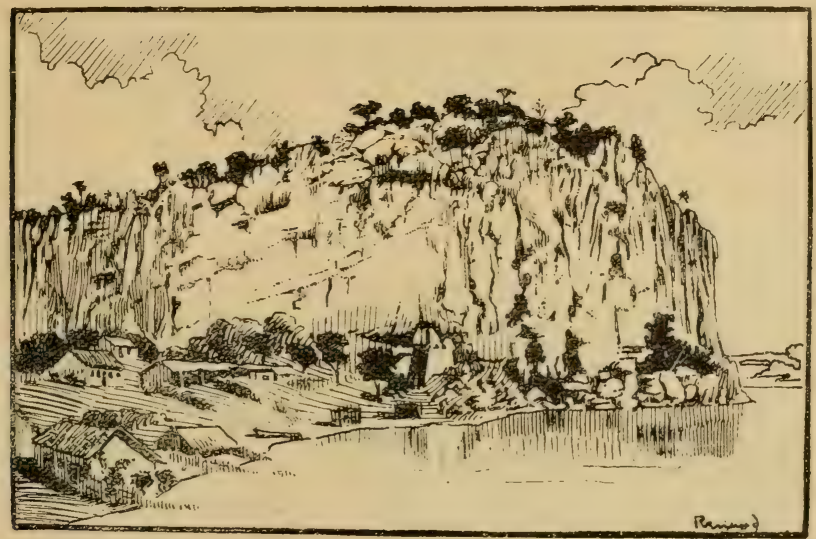

Fig. 129. - Paredão de calcareo siluriano (?) em Bom Jesus da Lapa, Rio S. Francisco. (Wells.)

sedimentarias no rio Lrubú, a nordeste de Manáus (1), mas não se conhece a sua idade que púde ser siluriana ou talvez devoniana ou mesmo mais moderna.

Não se tem reconhecido com certeza rochas silurianas no lado sul do valle do Amazonas nas immediações do rio.

Em Bom Jesus da Lapa sobre o rio S. Francisco, Derby achuu coraes fosseis (Favosites e Chetetes) que clle considera como provivelmente de idade siluriana (2).

(1) João Barbosa Rodrigues. Relatorio sobre os rios Urubu e Jatapú, pags. $\because 9-33$. Rio de Janeiro, 1875.

(2) Archivos do Museu Nacional, IX, p. 7\%. 
No anno $1909 \mathrm{Sr}$. Guilherme Lane tambem achou em Bom Jesus da Lapa coraes fosseis.

Uma serie de arenitos e quartzitos que fórmam o paredão da serra

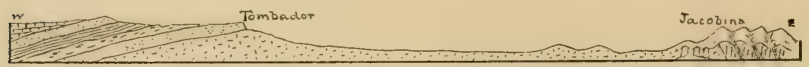

Fig. 130. - Secção mostrando a estructura entre a serra do Tombador e Jacobina, estado da Bahia.

do Tombador trinta kilometros ao oeste de Jacobina e as escarpas das serras do Mulato e do Encaibro ao longo do Rio S. Francisco está tentativamente referida por Branner, á idade siluriana. Até agora porém fosseis não forão descobertos nessas camadas, e por conseguinte a idade não está definitivamente determinada (1). 0 arenito do Tom-

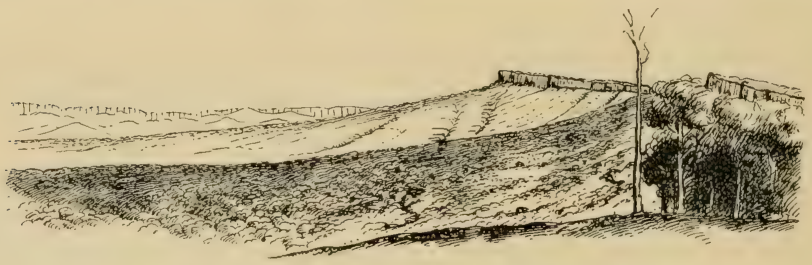

Fig. 131. - Paredão da serra do Tombador numa altitude de 780 metros e trinta kilometros ao oeste de Jacobina. $\mathrm{O}$ arenito do Tombador forma o cume e escarpa da serra.

bador tem a espessura maxima de $\mathbf{1 0 0}$ metros na vizinhança de Jusseape no interior da Bahia.

$\Lambda$ estampa junta apresenta figuras de alguns dos fosscis mais càracteristicos da idade siluriana encontrados até agora no Brasil.

$50 a, 50 b$ e $50 c$. Anabia paraia Clarke. Tres vistas de um molde interno de ambas as valvas mostrando a sua convexidade relativa : augmentadas duas vezes. Rio Trombetas, estado do Pará.

51. Orthis (Dalmanella) freitana Clarke. O processo cardinal e as lamellas crúraes: augmentadas tres vezes. Rio Trombetas, estado do Pará.

(1) J. C. Branner. The Tcmbador escarfment in the state of Bahia. Amer. Journ. Science, november 1910, 335-343. 


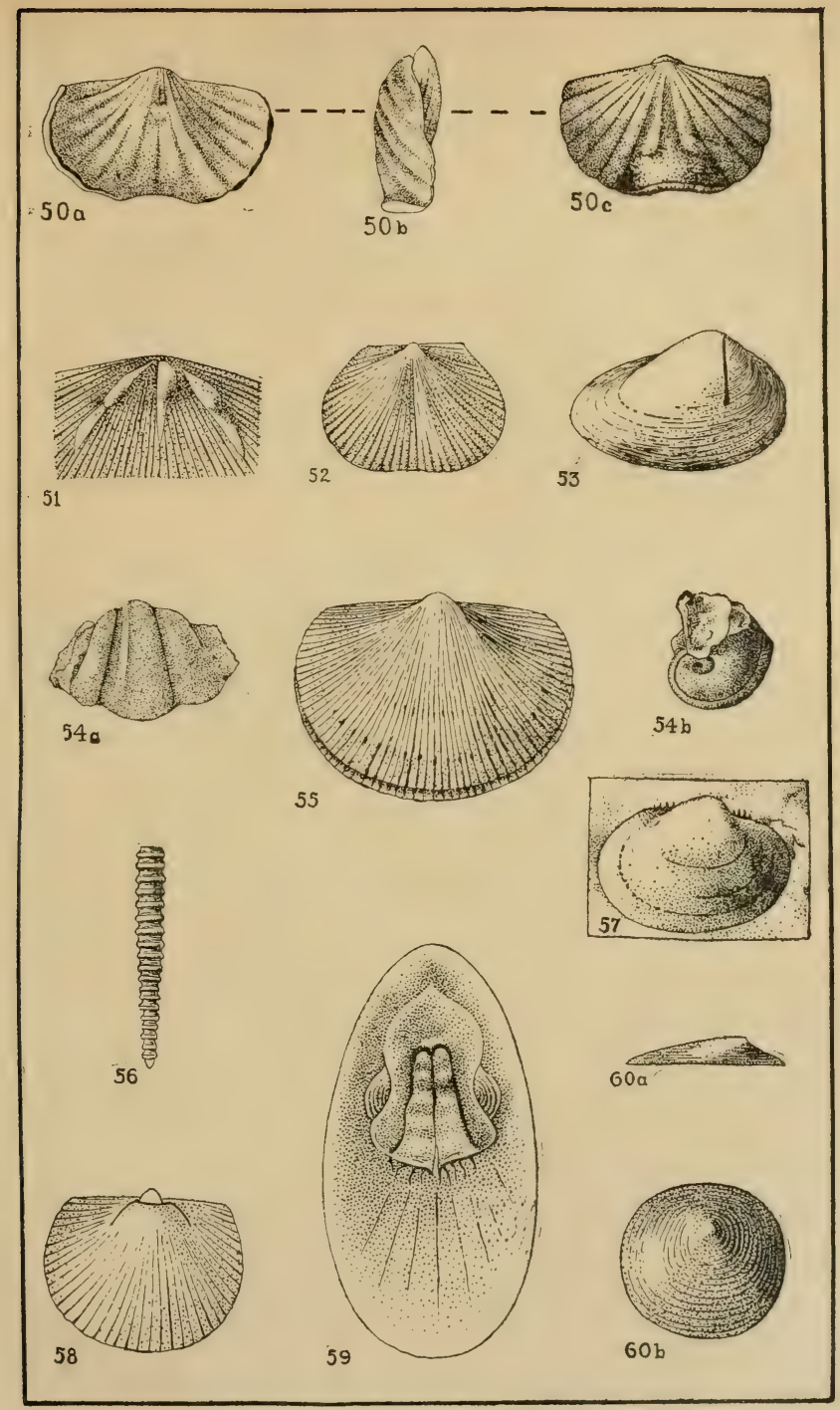

Fig. 132. - Fosseis brasileiros silurio nos caracteristicos. 
;2. Orthis (Dalmanella) smithi Clarke. O exterior de uma valva brachial: augmentada duas vezes. Rio Trombetas, estado do Pará.

:33. Clidophorus brasilianus Clarke. Molde interno de uma valva direita: augmentada tres vezes. Rio Trombetas, estado do Pará.

5' $a$ e 54 b. Bucaniella trilobata, var. vira-mundo Clarke. Duas vistas do individuo maior e mais bem conservado. Rio Trombetas, estado do Pará.

5:3. Orthis (Dalmanella) freitana Clarke. Uma grande valva pedicular. Rio Trombetas, estado do Pará.

56. Tentaculites trombetensis Clarke. 0 exterior: augmentada tres veze s. Rio Trombetas, estado do Pará.

:77. Tellinomya subrecta Clarke. Um molde interno mostrando o contorno da especie e as poucas crenulações da charneira: augmentada tres vezes. Rio Trombetas, estado do Pará.

58. Orthis (Dalmanella) smithi Clarke. Um molde interno da valva pedicular: augmentada tres vezes. Rio Trombetas, estado do Pará.

59. Lingulops derbyi Clarke. O interior da valva mostrando as divisões da platafórma, as impressões musculares e as impressões vasculares. Desenhada de uma impressão de um molde interno e augmentada vinte vezes. Rio Trombetas, estado do Pará.

$60 a$ e 60 b. Orbiculoidea hartlii Clarke. Uma valva brachial vista do apice e em perfil: augmentada tres vezes. Rio Trombetas, estado do Pará.

A seguinte é uma lista completa dos fosseis silurianos identificados no Brasil (1).

\section{PLANTAS}

A'throphycus harlani Conrad.

\section{BRACHIOPODA}

Linyula, sp. (compara-se L. oblata Hall).

Lingulops derbyi Clarke.

Orbiculoidea hartti Clarke.

Pholidops trombetana Clarke.

Orthis callactis Dalman, var. amazonica Clarke.

1) (Dalmanella) freitana Clarke.

" " smithi Clarke.

Choneles sp. (compara-se C nova-scolica Hall.)

Anabaia paraia Clarke.

(1) John M. Clarke. Fauna Siluriana Superior do Rio Trombetas. Arehiros do Museu Nacional, X, 1-18. Rio de Janeiro, 1899. 


\section{PELECYPODA}

Anodontopsis cutilla Clarke. 1) austrina Clarke.

Teltinomya pulchella Clarke. 1) subrecta Clarke.

Clidophorus brasilianus Clarke.

\section{GASTEROPODA}

Bucanella trilobata Conrad, var. vira-mundo Clarke. Murchisonia, sp.

\section{PTEROPODA}

Tentaculites trombetensis Clarke.

Conulariu amazonica Clarke.

\section{CEPHALOPODA}

Orthoceras, sp.

Cyrtoceras? sp.

\section{CRUSTACEA}

Primitia minuta Eichwald.

Bollia lata Vanuxem (Conrad), var. brasiliensis Clarke.

\section{SYSTEMA DEVONIANO}

Os fosseis mais abundantes das rochas devenianas sio os brachiopodes. Os coraes tambem são abundantes e grandes. Os peixes dos tempos devonianos foram notaveis pelo seu tamanho e numero, sendo alguns encontrados na America do Norte de seis metros de comprimento e de dois metros de largura atravez da cabeça. A vida vegetal tambem era muito abundante, tanto que se encontram ás vezes delgadas camadas de carvão nas rochas devonianas. Encontram-se tambem os primeiros amphibios conhecidos nas rochas de idade devoniana.

Na America do Norte as rochas devonianas produzem petroleo e gaz natural em grandes quantidades, e abundam tambem em rochas desta idade valiosos depositos de phosphatos e de calcareo hydraulico. 
No Brasii as rochas de idade devoniana jazem por cima das camadas silurianas ao longo do lado septentrional do valle do Amazonas desde um ponto ao norte de Almeirim para oeste até o Rio Uatumá, pequeno rio entre os rios Trombetas e Negro. Tem-se encontrado fosseis nestas rochas ao redor da povoação de Ereré e nas margens dos rios Maecurú e Curuá. As rochas fussiliferas são de arenito graudo, branco e amarellado tendo no Maecurú e Curuá a espessura de de\% metros e a inclinação de cinco graus para o susudoeste. Acham-se associados com camadas mais possantes de folhelhos argillosos pretos e avermelhados contendo algas fosseis, tendo a formação a espessura total de uns duzentos metros pelo menos. Alguns dos leitos de arenito são duros, outros friaveis e muito fossiliferos. Em Ereré as camadas devonianas tèm a espessura de cerca de sessenta metros e são cortadas por diques de rocha eruptiva (diabase). Não são conhecidas nas terras baixas em redor de Manáus e Borba, mas apresentam-se no lado sul do Amazonas no Rio Mauéassú ao sul de Laranjal, e no Tapajós ao sul de Itaituba. Deste lugar ellas tèm a orientação para o nordeste e provavelmente cruzam o Xingú perto de Nıry. A leste do Xingú a sua extensão não tem sido determinada (1).

Os fosseis reconhecidos nas camadas devonianas da região amazonica são os seguintes (2).

\section{PLANTAS}

Spirophyton typum Hall. ........

Protosalvinia brasiliensis Dawson.....

Protosalvinia bilobata Dawson

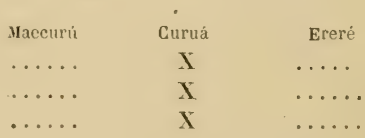

BRYOZOA

Fenestella parallela Hall.

Reptaria stolonifera Rolle

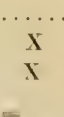

(1) Orville A. Derby. Contribuição para a geologia do baixo Amazonas. Archivos do Museu Nacional do Rio de Janeiro, II, pags. 77-101, 1878: Pruceedings of the American Philosophical Society, XVIII, pags. 155-178, 1879.

(2) John M. Clarke. Molluscos devonianos do estado do Pará, Brasil. Archivos do Museu Nacional, X, pags. 49-139. Rio de Janeiro, 1899.

John M. Clarke. As trilobitas do grez de Ereré e Maecurú. Reoista do Museu Nacional, I, pags. 1-54. Rio de Janeiro, 1896. 


\section{BRACHIOPODA}

Productella maecuruensis Rathbun ....

Chonetes comstocki Hartt .........

Chonetes freitasi Rathbun.

Chonetes curuaesis Rathbun

Orthis nettoana Rathbun. ........

Orthis hartti Rathbun ..........

Sireptorhynchus(Orthethetes) agassizi Hartt

Strophodonta perplana Conrad ......

Spirifer duodenarius Hall. .......

Spirifer derbyi Rathbun..........

Spirifer pedroanus Hartt.

\begin{tabular}{|c|c|c|}
\hline Maceurú & Curuá & Ereri \\
\hline $\mathrm{X}$ & $\ldots \ldots$ & $\ldots$ \\
\hline $\mathrm{X}$ & $\ldots \ldots$ & $\mathrm{X}$ \\
\hline $\mathbf{X}$ & $\mathrm{X}$ & ? \\
\hline$?$ & $\ldots \ldots$ & \\
\hline $\mathrm{X}$ & $\ldots \ldots$ & $?$ \\
\hline $\mathbf{X}$ & $\ldots \ldots$ & \\
\hline $\mathbf{X}$ & $\ldots \ldots$ & $\mathrm{X}$ \\
\hline$X$ & $\mathrm{X}$ & \\
\hline $\mathbf{X}$ & $\ldots \ldots$ & \\
\hline X & $\ldots \ldots$ & $\ldots$ \\
\hline $\mathbf{X}$ & X & $\mathrm{X}$ \\
\hline $\mathbf{X}$ & $\ldots \ldots$ & . \\
\hline $\mathbf{X}$ & $\ldots \ldots$ & $\ldots$ \\
\hline $\mathrm{X}$ & $\ldots \ldots$ & $\mathrm{X}$ \\
\hline $\mathrm{X}$ & $\mathrm{X}$ & $\mathrm{X}$ \\
\hline$?$ & $\ldots \ldots$ & $\mathrm{X}$ \\
\hline$X$ & X & . \\
\hline $\mathrm{X}$ & $\ldots \ldots$ & \\
\hline$\ldots$ & $\mathrm{X}$ & $\mathrm{X}$ \\
\hline $\mathbf{X}$ & $\mathrm{X}$ & $\mathrm{X}$ \\
\hline $\mathbf{X}$ & $\mathrm{X}$ & $\mathrm{X}$ \\
\hline$\ldots \ldots$ & $\ldots \ldots$ & $\mathrm{X}$ \\
\hline$\ldots \ldots$ & $\ldots \ldots$ & $\mathrm{X}$ \\
\hline$\ldots \ldots$ & $\ldots \ldots$ & $\mathbf{X}$ \\
\hline & $\ldots \ldots$ & $\mathrm{X}$ \\
\hline$\ldots \ldots$ & $\ldots \ldots$ & $\mathrm{X}$ \\
\hline
\end{tabular}

Spirifer buarquianus Rathbun. ......

Spirifer hartti Rathbun ..........

Retria jamesiana Hartt ........

Retzia wardiana Hartı.........

Rhynchonella dotis Hall .........

Amphigenia elongata Hall. . . . . . . .

Terebratula derbyana Hartt

$\mathrm{X}$

Terebratula rathbuni Clarke.

Tropidoleptus carinatus Conrad. .....

Vitulina pustulosa Hall ..........

Orbiculoidea lodensis Vanuxem......

Lingula spalulara Vanuxem (?). . . . . .

Lingula stauntoniana Rathbun ......

Lingula graçana Rathbun .........

Lingula rodriguezi Rathbun.

\section{LAMELLIBRANCHIOS}

Actinopteria eschwegei Clarke. . . ....

Actinopteria humboldıi Clarke ......

$\mathrm{X}$
$\mathrm{X}$
$\mathrm{X}$

Liopteria browni Clarke. . . . . . . . .

$\mathbf{X}$

Liopteria sawkinsi Clarke . . . . . . . .

Modiomorpha helmreicheni Clarke. . . . .

Modiomorpha sellowi Clarke. . . . . . .

Modiomorpha pimentana Hartt e Rathbun.

Goniophora woodwardi Clarke. ......

$\cdots$
$\mathbf{X}$

Tochomya freilasi Clarke ........

Taechomya rathbuni Clarke.
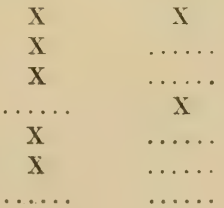

Sphenotus gorceixi Clarke.

Sphenotus bodenbenderi Clarke..... . . X

Cimilaria karsteni Clarke. . . . . . . X X 
Cimilaria sp. . . . . . . . . . Guerangeria, (ou Nyassa) ortoni Clarke . Cypricardella hartti Clarke . . . . . . . Cypricardella pohli Clarke ........ Grammysia pissisi Clarke......... Crammysia burmeisteri Clarke . . . . . Grammysia lundi Clarke . . . . . . . . . Grammysia gardneri Clarke. . . . . . . Girammysia ulrichi Clarke.

Pholadella parallela Hall.

Edmondia sylvana Hartt e Rathbun ... . Nucula bellistriata Conrad, var. parvula

Clarke. .......... . . p. .

Nucula kayseri Clarke. . . . . . . . .

Nuculites smithi Clarke... . . . . .

Nuculites ererensis Hartt e Rathbun ... Nuculites nyssa Hall, var. majora Clarke Nuculites branneri Clarke.

palaeoneilo orbignyi Clarke.

Maecuru
$\mathrm{X}$
$\mathrm{X}$
$\mathrm{X}$
$\mathrm{X}$
$\mathrm{X}$
$\mathrm{X}$
$\mathrm{X}$
$\mathrm{X}$
Paleoneilo sulcata Hartt e Rathbun. .. Paleoneilo pondeana Hartt e Rathbun . . Paleoneilo? simplex Harit e Rathbun . . Leda diversa Hall .

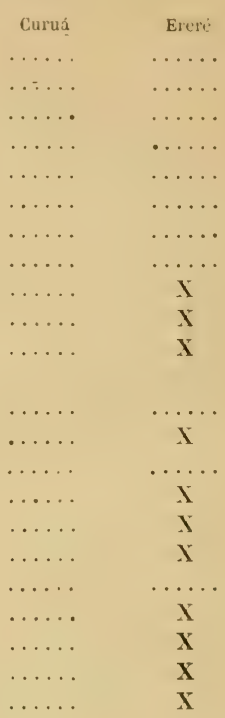

\section{GASTEROPODA}

Platyceras whitii Clarke......... Platyceras whitii, var. curua Clarke. . . Platyceras hussati Clarke. . . . . . . . Platyceras steinmanni Clarke....... Platyceras harti Clarke . . . . . . . . . Platyceras symmetricum Hall (?) . . . . . Platyceras symmetricum Hall, var. maecuruense Clarke. . . . . . . . . . Diaphorostoma dorwini Clarke . . . . . Diaphorostoma ? agassizi Clarke ..... Diaphorostoma furmaniana Hartt e Rathbun Pleurotomaria rochana Hartt e Rathbun. . Bellerophon stelzneri Clarke. . . . . . . Bellerophon morganianus Hartt e Rathbun Bucania freitasi Clarke . . . . . . . . . Bucanella reissi Clarke . . . . . . . . . Bucanella coutinhoana Harit e Rathbun. . Plectonotus derbyi Clarke ........

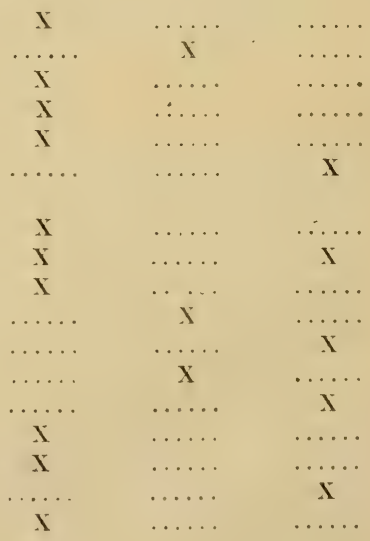


Plectonotus ? salteri Clarke. . . . . . .

$\begin{array}{ccc}\begin{array}{c}\text { Мaecurú } \\ \mathrm{X}\end{array} & \text { Curuả } & \text { Ereré } \\ \ldots \ldots & \cdots \cdots & \ldots \ldots \\ \mathrm{X} & \cdots \cdots & \ldots \ldots\end{array}$

\section{PTEROPODA}

Tentaculites stubeli Clarke. . . . . . . .

Tentaculites oseryi Clarke. . . . . . . .

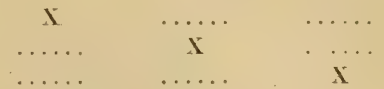

Tentaculiles eldredgianus Hartt e Rathbun

\section{TRILOBITA}

Homalonotus oiara Harts e Rathbun . . . .

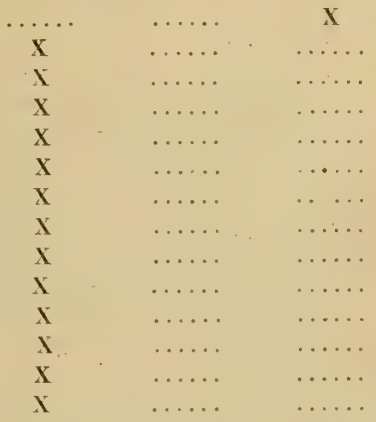

IIomalonotus derbyi Clarke . . . . . . . .

Homalon"lus (Colymene) acanturus Clarke

Phacops brasiliensis Clarke . . . . . . .

Phacops menurus Clarke. . . . . . . . .

Phacops scirpens Clarke.

Phacops (?) pullinus Clarke. . . . . . .

Phacops (I)almanites) macropyge Clarke .

Dalmanites maecurua Clarke. . . . . . . .

Dalmanites australis Clarke.

Dalmanites galea Clarke.

Dalmaniles infractus Clarke. . . . . . . .

Dalmanites tumilobus Clarke

Dalmanites gemellus Clarke.

Dalmanites (Cryphaeus) paituna Hartt e

Rathbun .

Na pag. 306 dá-se figuras de alguns dus mais caracteristicos entre ns fosseis devouianos até agora encontrados na regiảo amaznnica, tiradas das duas memorias acima citadas do professor J. M. Clarke.

61. Dalmanites paituna. Hartt e Rathbun. Uın cephalon imperfeito do tamanho medio, augmentado duas vezes. Rio Maecurú.

62. Phacops brasiliensis Clarke. Molde interno de um cephalon inteiro, mostrando a fórma e as proporçōes geraes. Rio Naecurú.

63. Dalmanites paituna Harlt e Rathbun. Um pygidio ligeiramente restauralo no lato ilireito, tamanho natural. Rio Naecurú.

64. Phax"ps menurus Clarke. Um pygidio imperleito, augmentado duas vezes. Rio Naecurú.

65. Actinopteria eschwegei Clarke. Valva esquerda. Rio Maecurú

66. Spenotus bodenbenderi Clarke. Uma valva direita. Rio Maecurú. 


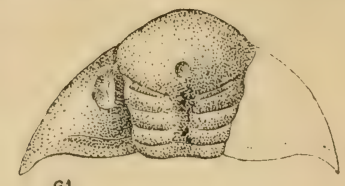

61
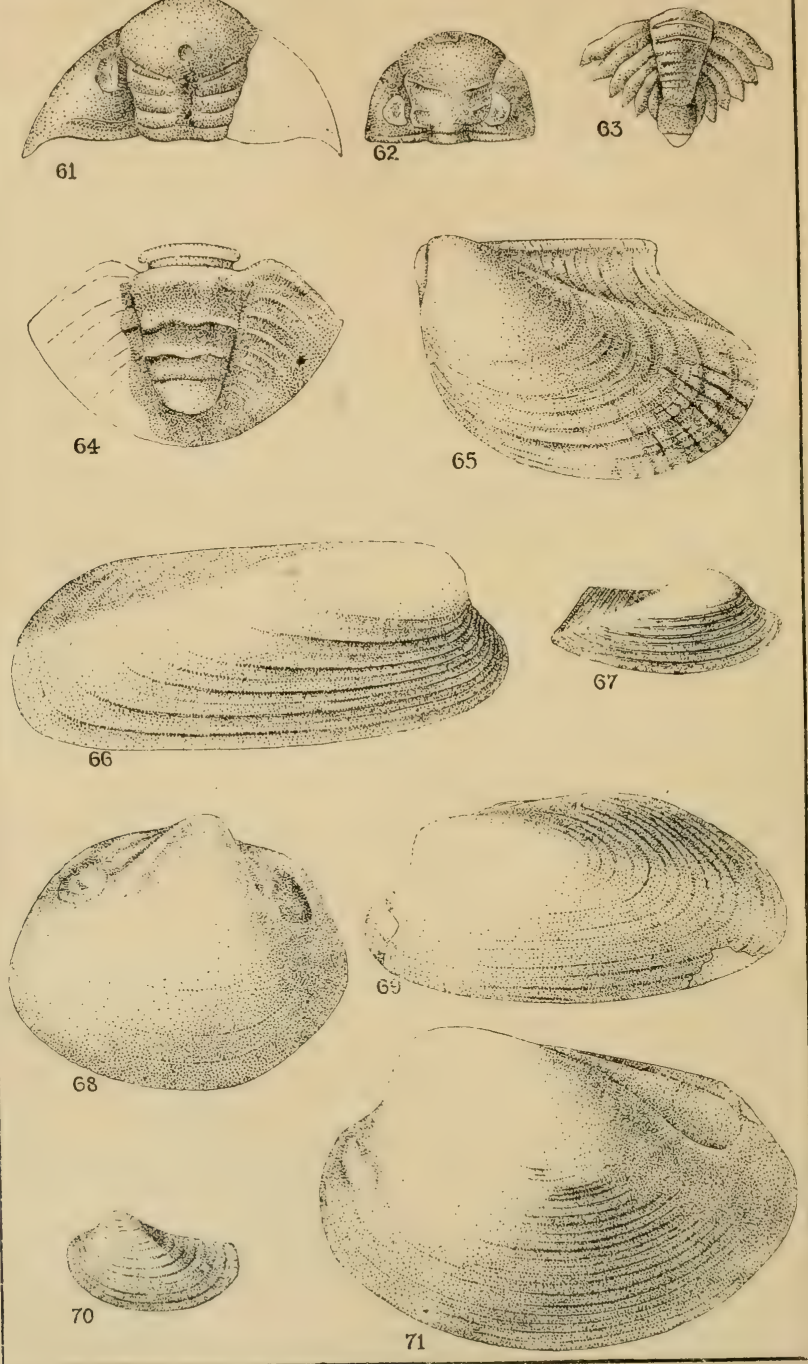

Fig. 133. - Fosseis trasileiros devonianus caracteristicos. 
67. Cimituria karsteni Clarke. Uma valva direita. Rio Maecurú.

68. Toechomya ralhbuni Clarke. Interior de uma valva direita. Rio Maecurú.

69. Modiomorpha pimentana Hartt e Rathbun. Cma valra esquerda grande. Ereré.

70. Cimitaria kersteni Clarke. Uma valva esquerda. Rio Maecurú.

71. Grammysia pissisi Clarke. Uma valva esquerda mostrando as impressões musculares. Rio Maceurú.

Camadas devonianas fórmam o alto da Chapada a leste de Cuỹabá no estado de Matto-Grosso. (1)

I seç̧ão junta mostra a estructura geral da região da Chap̧ada.

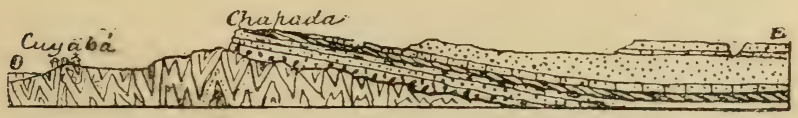

Fig. 134. - Secção atravez da Chapada a leste de Cuyabá mostrando as camadas devonianas da Chapada sobrepostas aos schistos de Cuyabá.

A quatro kilometros ao sul de Lagoinha e sessenta e dois a lesnorleste de Cuyabá, foram achados os seguintes fosseis descriptos por Von Ammon.

Phacops brasiliensis lilarke, Bellerophon chapadensis v. Ammon, Tentaculites bellulus Hall, Discina baini Sharpe, Chonetes falklandia Morris e Sharpe, Spirifer ungeli v. Ammon, Leptocoelia tlahellites Conrarl, Rhynchonella ou Rielsia Jumesima.

Nesta mesma região, num lugar chamado Sant'Anna da Chapada existem rochas fossiliferas, provavelmente calcareus alterados muito ricos em hematitos. Uma colleç̧ão de fusseis feita ali por Dr. Carl Carnier foi descripta por Clarke numa monographia publicada pelı Serviço Geologico do Brasil (1).

A lista dos fosseis identificados desta luralidade por Clarke sào: Tentaculites crotalimus Salter ( $\boldsymbol{T}$. bellulus $v$. Ammon), Diaphrostomu Baini (sharpe). Janeia brasiliensis Clarke, Chonetes falkilandicus

(1) J. M. Clarke. Fosseis Devonianos do Paraná. Monographia do Serviģo Geo. lógico. Vol. I. Rio de Janeiro, 1913. 


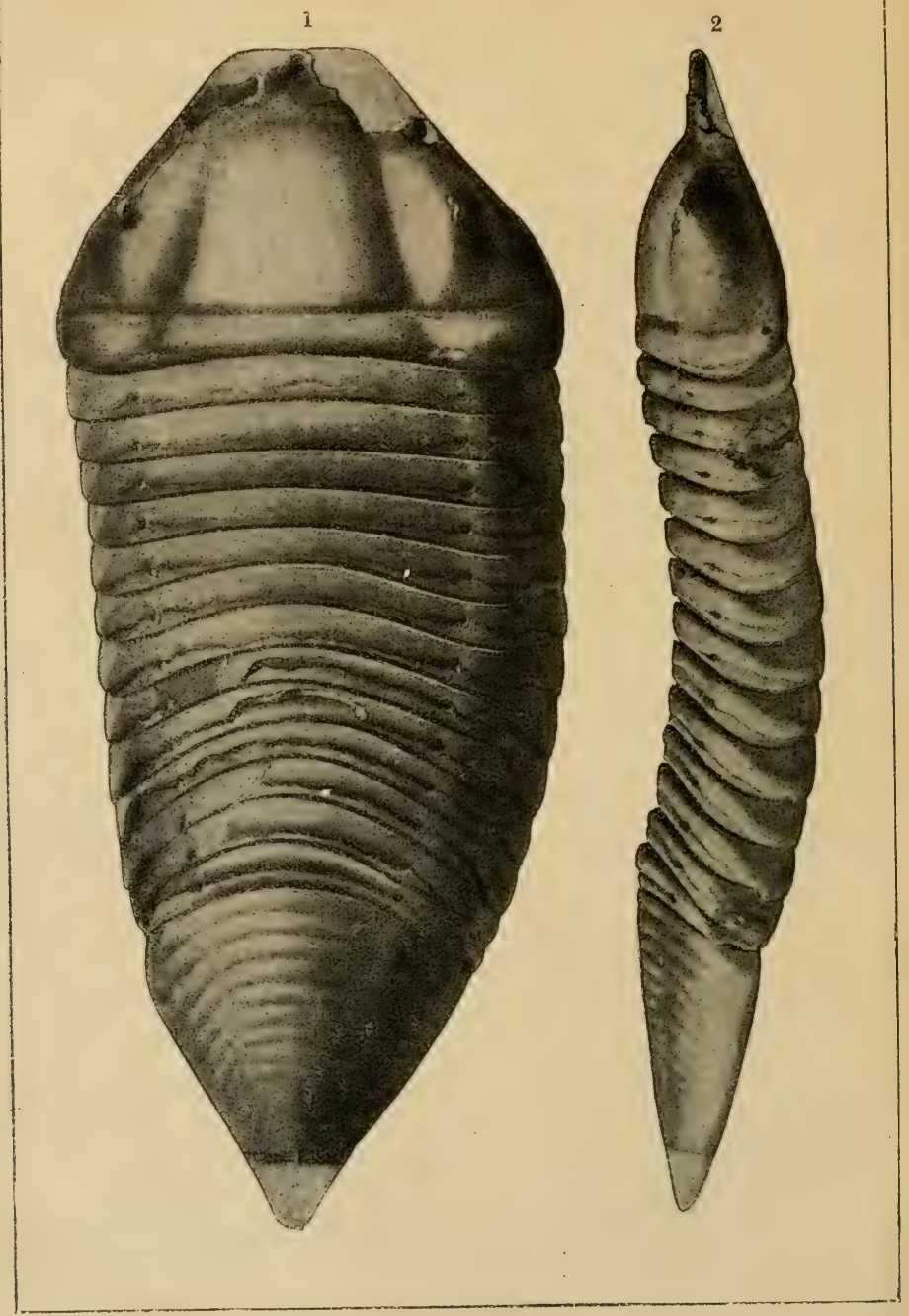

Fig. 135. - Ilomalonotus noticus Clarke. Uma trilobiti: Vista dorsal e de perfil de um individuo completo de dimensöes naturaes. Localidade Ponta Grossa, Paraná. 


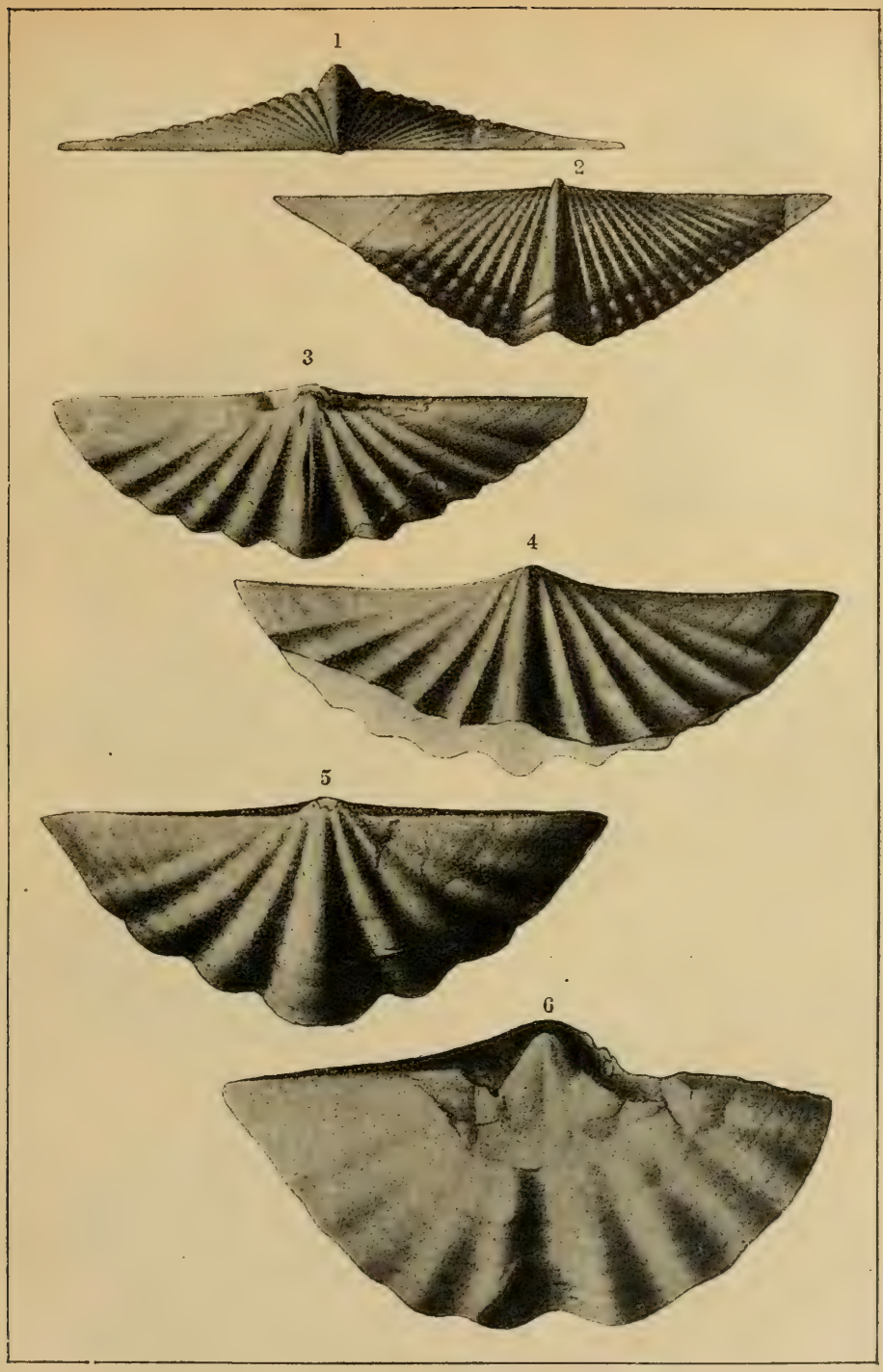

Fig. 136. - Brachiopodes devonianos do Brasil.

1, 2. Spirifer Katzeri Clarke, do Rii Maecuru, Pará.

:, 4. Sptrifer contrarius Clarke, da Punta Grossa, Paraná.

5,6. Spirifer Paraná Clarke, da Ponta Grossa, Paraná. 


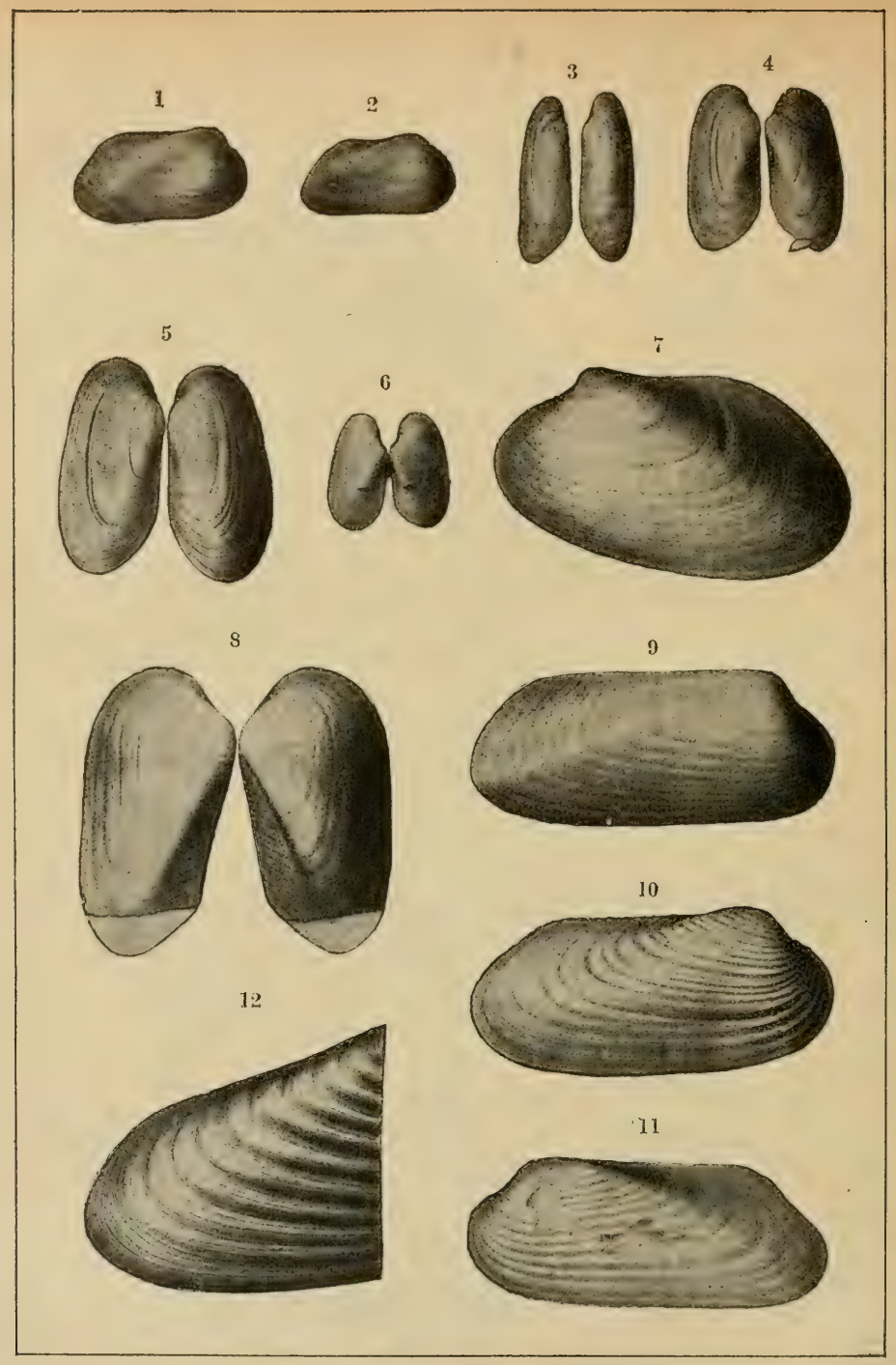

Fig. 13\% - Pelectpodes no estado de Parana.

1, : Goniophora abbreoiata Clarke, de Jaguariahyva.

3, 1, 5. Pulafanatina erebus Clarke, de P'onta Grossa.

6, 7. Cypricardella ? oliveiria Clarke, de Ponta Grossa.

s, 9. Sphenotus lagoensis Clarke, de Lago.

10, 11. Leptodomus capricornus Clarke, de Ponta Grossa. 
Norris e Sharpe, Derbyiana Smithi (Derby), Brasilia Margarida (Derby), Leptocolia flabellites Conrad, Spirifer antarcticus (Morris e Sharpe), Urbiculoidea Baini (Sharpe).

$\Lambda$ descripção dadı por Castelnau da geologia da região faz suppòr que as camadas devonianas da Chapada se estendem para a parte sudoeste do estado de Goyaz e que terminam na margem oriental do planalto de Matto Grosso na Serra de Taquara ao oeste do rio Pitombas Grande (1).

Encontram-se tambem rochas devonianas nos estados de S. Paulo e Paraná e é possivel que as hajam nos de Santa Catharina e Rio

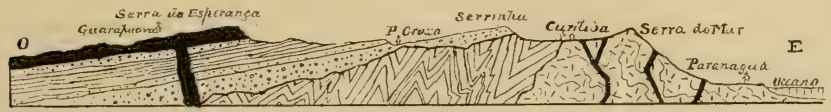

Fig. 138. - Seção atravez da Serra do Mar e Serra da Esperança, estado do Paraná. (eonforme Derby).

Grande do Sul - sendo provavel que todas sejam partes de um grande lençol que se estende para oeste até Matto-Grosso. As duas seçũes juntas - uma no estado do Paraná e a outra no de Matto-Grosso mostram ser muito semelhante a geologia das duas regiões, e suggerem que a regiăo intermediaria é um grande geosynclino.

Fosseis devonianos fóram descolertos em Ponta-Grossa, estado do Paraná, por Luther Wagoner, no anno 1876 (2).

Em Jaguarahyva, Gonzaga de Campos achou o Dalmanites, Chonetes e Orthothetes (Streptorhychus). Depois Keyser descreveu de perto de Tibagy o Sprififer iheringi Kayser, Spirifer borbai Kayser, Spirifer antarticus Morris e Pholadella radiata Hall.

(1) Orville A. Derby. Notr sobre a geologia e paleontologia de Matto-Grosso. Archivos do Museu Nacional, IX, pp. 59-88. Rio de Janeiro, 1896.

(2) Dr. Ludw. v. Ammon. Deoonische Versteinerungen oon Lagoinha in MattoGrosso (Brasilien). Zeit. der Gésellschaft für Erdkunde zu Berlin, XXVIII, pp. 35*366. Berlin, 1893.

A. Derby. A geologia da rerjião diamantifera da prooincia do Paraná. Archivos do Museu Nacional do Rio de Janeiro. III, pp. 89-99, 1878: e Proc. Amer. Phil. Soc., XVIII, pp. 251-258, Philadelphia, 1880. 
Colleçêes mais completas feitas no Paraná pelo serviço Geologico do Brasil, e descriptas por Clarke na monographia citada, incluem treze especies de trilobitas, dois cephalopodes, tres conularias, um pteropode, seis gasteropodes, vinte e tres pelicypodes, vinte e tres brachiopodes, dois echinodermatas e uma espo' ja. Esses fosseis quasi todos vèm dos folhelhos de Ponta-Grossa, camadas estas que tèm uma espessura de oitenta para cento e vinte metros. Abaixo destes folhelhos os arenitos das Furnas com uma espessura de cento e cincoenta metros, jazem sobre as rochas crystallinas da Serra do Mar (1).

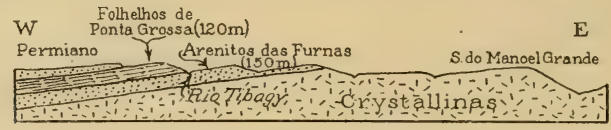

Fig. 139. - Secção geral ao sul de 'Tibagy no estado do Paraná. (Oliveira).

Suppoe-se que a divisão geologica do interior da Bahia designada por Branner pelo nome de "folhelho Caboclo ", embora não tenham ainda dado fosseis nelles, seja devoniana. Naquella região o "Caboclo " está bem exposto no valle de Almas e nas cabeceiras do rio Bassauá onde tem a espessura de quinhentos metros ou mais. 0 nome é derivado da serra do Caboclo que fica no lado oriental do valle de Almas e no lado occidental do valle do Salitre (2).

Carbonifero inferior. - As rochas do carbonifero inferior sàu pela maior parte calcareos e contèm muitos fosseis dos grupos dos crinoides, coraes, brachiopodes, bryozoarios e alguns trilobitas. No Brasil não ha rochas conhecidas pertencentes a esta serie.

\section{CARBONIFERO}

0 carbonifero propriamente dito é geralmente conhecido pelo nome de "coal measures" (Medidas de carvào) por conter entre as suas

(1) John M. Clarke. Fusseis deoonianos do Paraná. Monographias do Servico Geologico do Brasil, vol. I, pp. 62-67. Rio, 1913.

(2) J. C. Branner. The geography of northeastern Bahir. Geographical Journal. London, Aug. 1911 p. 151. 
camadas os grandes depositos de carvão da Europa e da America do Norte. Os sedimentos do carbonifero tèm na Nova Escocia a espessura de quatro mil oitocentos e setenta e sete metros e no estado de Arkansas nos Estados Unidos a de sete mil duzentos e quarenta e oito mitros. As rochas consistem em folhelhos, arenitos, conglomerados e camadas de carvão. A area total coberta pelas rochas carboniferas na America do Norte é de setecentos e vinte seis mil duzentos e vinto e oito kilometros quadrados.

As camadas de carvão e os folhelhos que as acompanham contèm uma abundancia de plantas fosscis mostrando que no tempo de sua deposição a terra estava coberta por grandes pantanos durante longos periodos de tempo. A's vezes encontram-se fosseis maritimos entre estas fórınas terrestres mostrando que de vez em quando houve depressĩes da superficie que levavam a terra de baixo do mar.

Os fosseis mais abundantes do carbonifero são as plantas conservadas em connexão com o carvão : fetos, lycopodiaceas e coniferas. Tămbem abundaram no tempo da deposição do carvão insectos, peixes e amphibios.

Os principaes productos economicos do carbonifero são as extensas camadas de carvão, tanto bituminoso como anthracitico. Na America do Nurte ha tambem camadas importantes de minereo de ferro e de argilla refractaria associadas ao carvão.

No Brasil as rochas conhecidas de idade carbonifera só se encontram no valle do Amazonas. Apresentam-se no Rio Tapajós desde as cachoeiras até perto de Aveiros na distancia de cento e trinta kilometros e sa estendem dahi para oesie e para leste parallelas ao eixo principal do valle do Amazonas (1) A oeste do Tapajós ellas se apresentam no rio Mauéassú em Fructal e Pedra do Barco. A leste é provavel que se apresentem tambem no Xingú e Tocantins, se bem que ainda não se tenha encontrado fosseis nos valles destes rios.

No lado norte do valle amazonico as camadas carboniferas se apri-

(1) O. A. Derby. On the Carbonifernus Brachiopoda of Itaituba, Rio Tapujós. Bulletin of the Cornell University. V. 1, n. 2. pp. 1-63. Ithaca, N. Y., 187.

O. A. Derby. The Amazonian Carboniferous fauna. Journal of Geology, II, pp. 480-500. Chicago, 1894. 
s'ntam na vizinhança de Alemquer e se estendem para o norte ao longo dus rius Curuá, Iaecurú e Trombetas. São conhecidas no oeste até o rio Latumá e a leste até Jauary perto de Prainha. As rochas são folheIhos, arenitos e calcareos, sendo os fosseis fornecidos principalmente por este ultimo. Em Itaituba a camada de calcareo tem a espessura de oito metros e é empregada para o fabrico de cal.

$\Lambda$ s rochas carbonifteras da regiào amazonica, até onde são conhecidas, mostram pelos seus fosseis serem depositos maritimos e não se tem encontrado camadas de carvão associadas a ellas. A espessura das camadas é calculada em cerca de seiscentos metros e como apenas uma pequena parte foi eximinada detalhadamente é possivel que hajam tambem depositos de agua doce, offerecendo assim alguma probabilidade da existencia de carvĩo.

No estido de Sergipe as rochas cretaceas expostas a leste da Serra de Itabaiana siu sobrepostas a camadas sedimentarias da serra, cuja idade não foi determinada, sendo possivel que esta seja carbonifera, ou talvez mais antiga.

Certas rochas dos estados de S. Paulo, Paraná, Santa Catharina e Riv Grande do Sul, que tèm sido consideradas como sendo de idade carbonifera são agora reléridas á permiana.

A seguinte é uma lista completa dos fosseis carboniferos conhecidos do Brasil compilada da lista de Derby já citada.

\section{BRACHYPIODA}

Terebratula itailubense Derby.

Waldheimia coutinhoana Durbs.

Eumetria mormoni Narcou.

Athyris subtilita Hall.

" sublamellosa Hall.

Spirifer camaratus Morton.

Allyyris rockimontanus Marcou.

Spirifer (Martinia) perplexus Me Chesney.

" (Martinia) planoconvexa Schumard.

Spiriferina transversa Hc Chesney.

" spinosa Norwood e Pratten.

Rhynchonella pipira Derby.

Orthis penniana Derby.

1) Morganiana Derby. 
Streptorhynchus hallianus Derby.

n (Derbya) correiamus Derby.

1) (Ortholhetes) tapajolensis Derby.

Chonetes amazonica D.rby.

"' glabra Geinitz.

Strophalosia cornelliana Derby.

Productus semiroticulatus Martin.

" cora d'Orbigny.

1) chandlessi Derby.

1) batesianus Derby.

1) rhomeanus Derby.

" wallacianus Derby.

1) clarkianus Derby.

"nebrascensis Owen.

, punclalus Martin (?).

\section{JAWELLBRANCHOS}

Entolium aviculatum Swallow (?).

Lima rectifera Schumard.

dviculopecten occidentalis Schumard.

" - carboniferus Stevens.

"neglectus Geinitz.

" coxanus Meek e Worthen.

" (Streblopteria?) herlzeri Meek.

Avicula sp (compare-se A. longa Geinitz).

" (compare-se Bakewellia bicarinata King).

". ( " " parva Meek e Worthen).

". ( " " sedgwicliuna King).

Pinna peracuta Schumard.

Myalina kansasensis Schumard.

Macrodon tenulineatus Meek e Worthen (?).

Schizodus wheeleri Swallow (?).

1) rossicus de Verneuil (?).

Pleurophorus tropidophorus Meek (?).

Allorisma subcuneala Ileek e Worthen.

\section{Gasteropoda}

Pleurotomarici speciosa Heek e Worthen. marcouana Geinitz (?)
" conoides Heek e Worthen (?).
") (compare-se P. subdecussata Geinitz).
1)$$
\text { ( } ⿻ P \text {. depressa Cox). }
$$

Naticopsis nana Meek e Worthen. 
Platyceras nelirasensis Meek.

Bellerophon carbonarius Cox. crassus Meek e Worthen.

\section{BnyozoA}

Synocladia biserialis Swallow (?).

Fenestrella shumardi Pront (?).

1) intermedia Prout (?).

Glauconome trilineata Me'k (?).

Polypora submarginata Meek (?).

Plilodicta carbonaria Meek (?).

\section{Coraes}

Lophophyllum sp.

Stenopora sp.

Fistulipora nodulipora Meek. sp.

Rhombipora lepidodendroides Meek

Monticulipora sp.

\section{Echinodermata}

Eocidaris hallianus Geinitz (?)

Archaeocidaris sp.

\section{Trilobitas}

Philipsia sp.

" (Grifflthides) sp.

\section{Foramenifeika}

Finsulina sp.

Na pagini 317 se mostra alguns dos fosseis carbonileros mais caracteristicos descriptos pelo professor Derby na região amazonica.

\section{LXplicacĩo das figuras de fosseis carboniferos}

72. Athyris subtilita Hall. Vista ventral. Bom Jardim, estado do Parí.

72a. Athyris subtilita Hall. Vista dorsal. Bom Jardim, estado do Pará.

73. Orthothetes (Sireptorhynchus) tapajotensis Derby. Interior da valva dorsal. Itaituba, estado do Pará

74. Spirifer camaratus. Morton. Vista ventral. Bom Jardim, estado do Pari. 


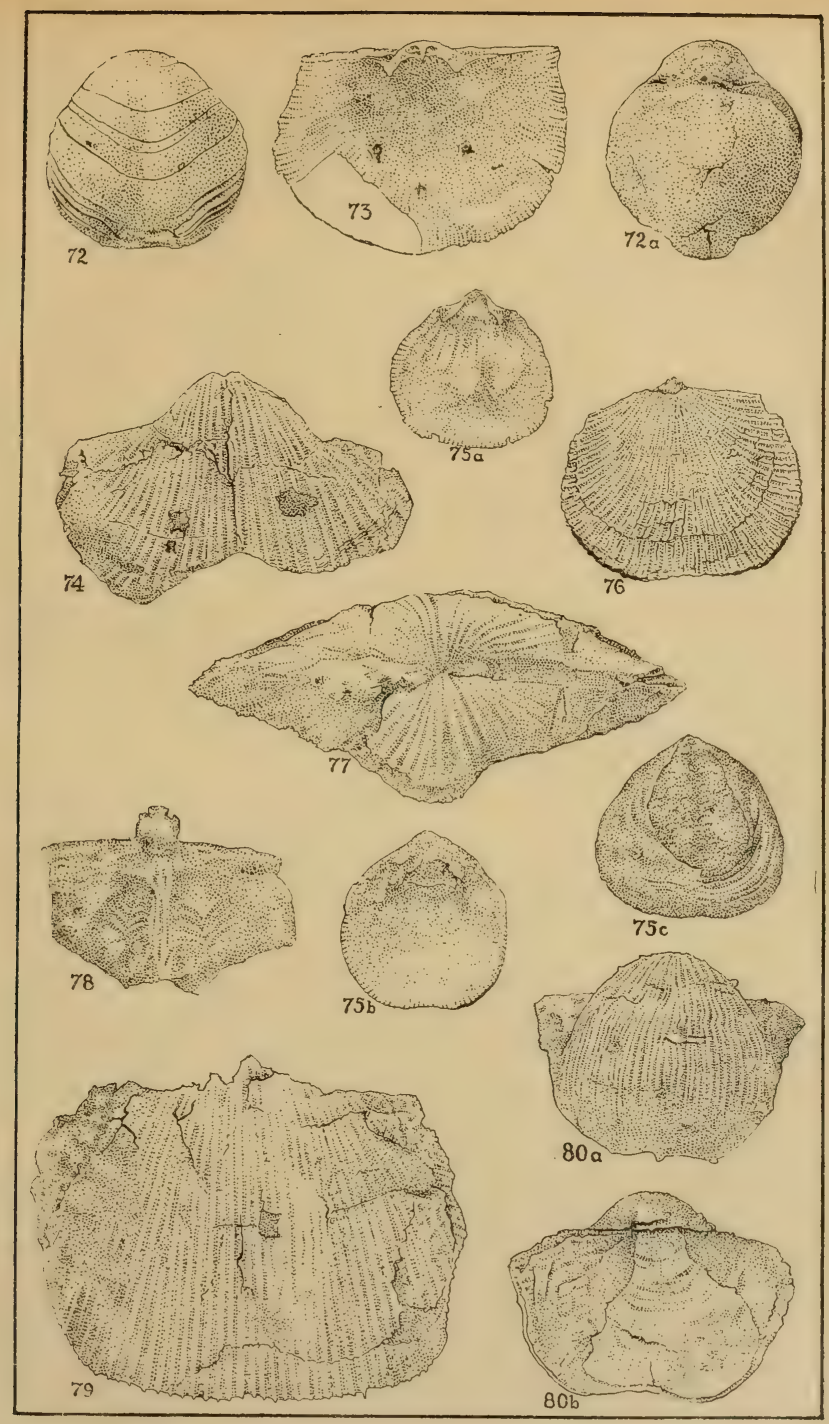

Fig. 140. - Fosseis carbonifero caracteri-tibus d, Brasil. 
75a. Orthis pentana Derby. Interior da valva ventral. Bom Jardim, estado do Pará.

75) b. Orthis penniana Derby. Interior da valva dorsal. Bom Jardim, estado do Pará.

75 c. Orthis penniana Derby. Vista dorsal de un grande exemplar com sinus. Bom Jardim, estado do Pará.

76. Orthothetes (Streptorhynchus) tapajotensis Derby. Vista ventral. Bom Jardim, estado do Pará.

77. Spirifer camaratus Morton. Vista cardinal do um exemplar desusadamente alongado. Bom Jardim, estado do Pará.

78. Productus semireticulatus Martin. Interior de um fragmento de uma valva dorsal. Itaituba, estado do Pará.

79. Productus semireticulatus Martin. Exterior de nma valva ventral mostrando o caracter e arranjo dos espinhos. Bom Jardim, estado do Pará.

80a. Productus chandlessii Derby. Vista ventral. Pedra de Barea. rio Pariuary, estado do Pará.

80b. Productus chandlessii Derby. Vista dorsal. Bom Jardim, estado do Pará.

Na regiăo diamantina do estado da Bahia as formações chamadas for Derby "Lavras » e "Paraguassú » são provavelmente da idade arbonifera, embora ainda não tenham dado fosseis. Essas formações tèm grande importancia economica no Brasil porque è dellas que vèm us diamantes e carbonados. São, pela maior parte, arenitos duros ou quartzitos côr de roza com a laminação falsa bem - marcada. Os diamantes e carbonados estão cravados nas rochas, das quaes são soltus pela decomposição natural (1).

\section{PERMIANO}

Com o permiano as trilobitas desappareceram completamente, us reptis fizeram o seu primeiro apparecimento, e os crinoides se tornaram muito menos abundantes do que no tempo carloniferu. Na America do Norte formaram-se extensas camadas de gessoe de sal gemma, mostrando que partes do valle do Mississippi eram aridas durante os tempos permianos.

No Brasil tem-se reconhecido rochas permianas nos estados de

(1) J. C. Branner. Diamond bearing highlands of Bahia. Engineering and Mining Journal. LXXXVII, 981, 1031, May 15 and 22, 1909. 
S. Paulo, Paraná, Santa Catharina, Rio Grande do Sul, Bahia, Sergipe, Alagõas, Piauhy, Maranhão e Goyaz,

As rochas consistem de folhelhos e arenitos molles com camadas subordinadas de calcareo silicoso. Delgadas camadas de carvão constituem feição muito persistente e nos estados do Rio Grande do Sul e Santa Catharina estas já dão lugar á exploração industrial, como na

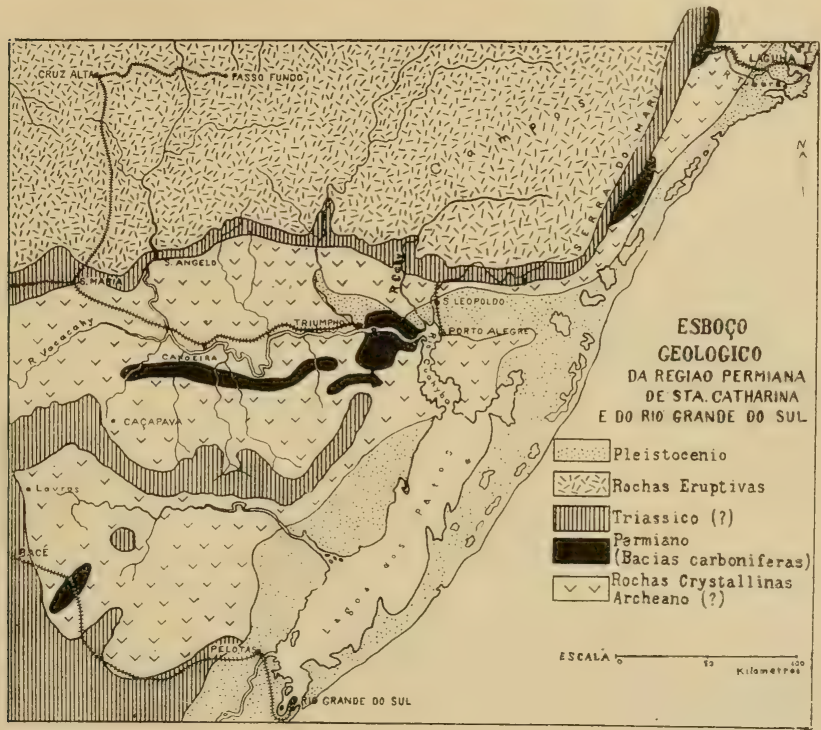

Fig. 141 .

bacia do Arroio dos Ratos no primeiro estadu e na do Rio Tubaràı no segundo. A occorrencia destes depositos de carvão e de troncos de arvores silicificados (coniferas e fetos arborescentes) indicam que as condições predominantes no tempo da deposição destas camadas eram as de terra firme e de lagõas de agua doce.

Por toda a parte no Brasil onde são conhecidas, as rochas permianas sãn de origem terrestre, isto é fluvial e lacustre. Certas camadas 
nu estad, do Paraná tem fosseis que parecem permianos mas por emquanto a area conlsecida é restricta, e parece provavel que neste caso os fosseis fòram depositados num estuario.

E notavel que as formações Gondivana da India e as do Karroo

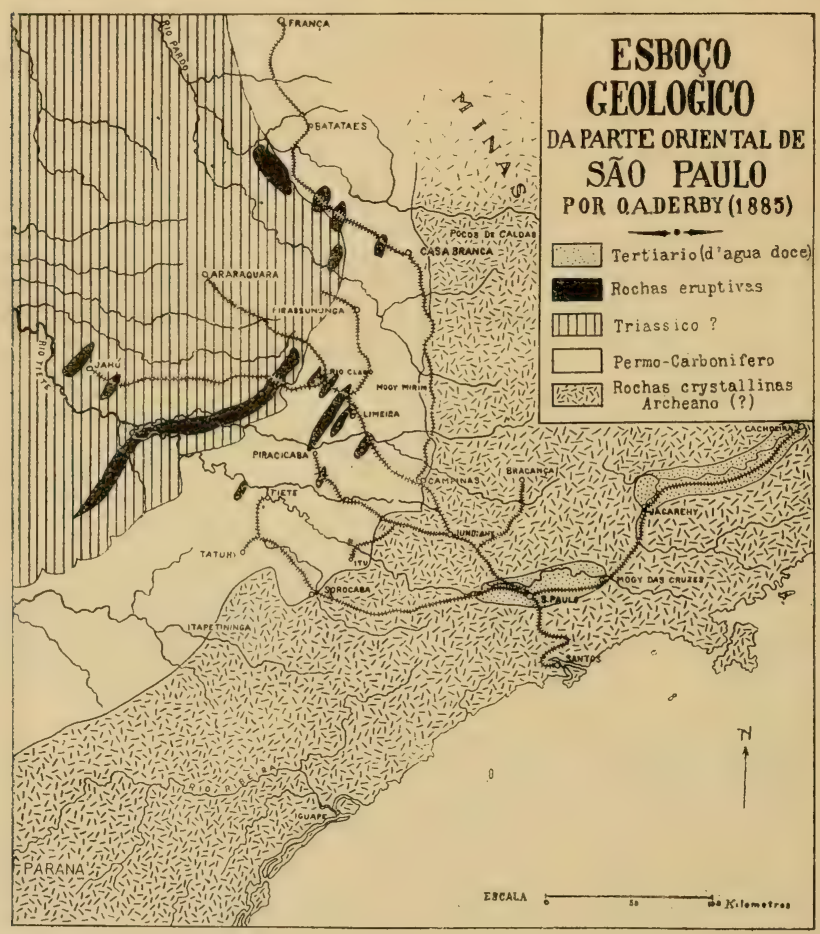

Fig. 142.

da Africa, ques se suppunhan ser da tinesma idade geslogica, tambem são todas de origem terrestre.

Diques e lencre de rochats eruptivas, diabase) wio muito frequentes

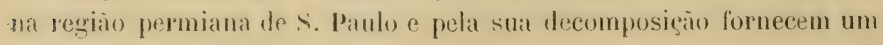


solo muito carregado de oxido de ferro conhecido pelo nome de " terra roxa " e muito apreciado pelos lavradores, especialmente os de café. Os folhelhos desta formação sendo geralmente marnosos tambem fornecem um solo fertil, ao passo que as areas cobertas de arenito são consideradas como relativamente estereis. 0 esboço junto mostra de modo schematico a distribuição dos terrenos permianos e de algumas das mais conhecidas manchas da terra roxa no estado de S. Paulo.

Uma feição muito caracteristica das camadas permianas é a occorrencia abundante nos calcareos e em alguns dos folhelhos de nodulos e leitos silicosos (pederneira) e de madeiras silicificadas que, pela sua resistencia á decomposição, ficam espalhadas na superficie e assim fornecem um meio facil de traçar a formação. Antes da introducção de armas modernas e de phosphoros, estas accumulações fôram aproveitadas em muitos lugares para fornecer pederneiras para armas de fogo $\mathrm{e}$ isqueiros.

Outra feição caracteristica é a occorrencia no meio dos arenitos de grandes depositos de blocos e materiaes estriados indicativos de acção glacial durante o periodo permiano no sul do Brasil. H. Bross achou num corte da estrada de ferro 236 kilometros ao norte de PontaGrossa, no estado de Paraná, deposito glacial com blocos estriados, e achou blocos erraticos e estriados em Villa-Velha a vinte e cinco kilometros a leste de Ponta-Grossa: (1).

Os depositos glaciaes do sul do Brasil sâo conhecidos nos estados de São Paulo, Paraná e Santa Catharina. Os lugares onde foram determinados pelo Professor Woodworth, que os estudou especialmente no anno 1908, são rio Jaguaricatú (Sengens) e Conchas, no norte do Paraná, e rio Negro em Santa Catharina. Parece que o movimento do gelo foi de norte para o sul. A distribuição dos depositos glaciaes não é bem conhecida por ora (2), mas a estriação dos fragmentos é perfeitamente clara. A idade dos depositos glaciaes do Brasil é a mesma que a dos depositos "Talchir » da India, e do conglomerado "Drvyka » da

(1) H. Bross. Centralblatt f. Min..1909, n. 18, 558-561.

(2) J. B. Woodworth. Geological expedition to Brazil. Bulletin Museum Comparatioe Zoology, LVI. Cambridge, 1912. 
Ifrica do Sul e do conglomerado basilar Argentino - todos da idacle permianà (1).

Depositos glaciaes, apparentemente da mesma idade, encontram-se nas ilhas Falkland ao sul da Republica Argentina (2), mostrando que a glaciação permiana na America do Sul não se limitou ao Brasil.

Algumas camadas da formação permiana são muito abundantes eli fosseis representando peixes, reptis e molluscos (lamellibranchios) no reino animal e gymnospermas (coniferas), lycopodiaceas e filices no reino vegetal. As plantas fosseis descriptas das diversas bacias carboniferas do sul do Brasil sảo incluidas na lista á pagina 326,327 .

No anno 189:, Zeiller chamou attenção para o facto que Ganyamopteris é uma das fórmas mais caracteristicas das camadas Glossopteris da India, ao passo que Noeggerathia e Odontoteris suggerem

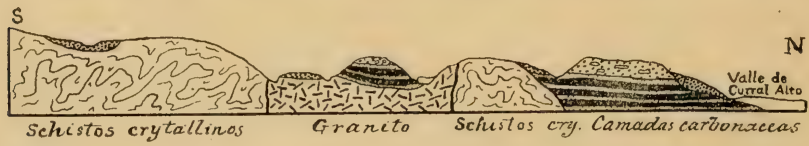

Fig. 143. - Seção atravez da região permiana entre o valle do Curral Alto e a Serra do Boqueirão. Rio Grande do Sul. (Cabral.)

outras fórmas do permiano inferior. Elle julgou que o Lepidodendron derbyi das camadas de S. Paulo fosse identico ao Lepidodendron pedroanum das camadas do Rio Grande do Sul.

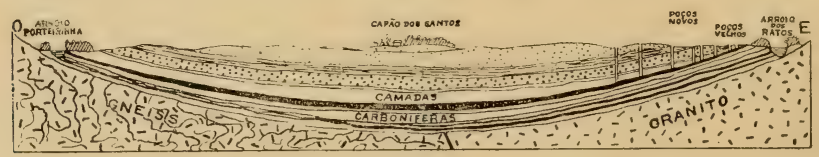

Fig. 141 - Seção atravez da bacia do Arroyo dos Ratos. Rio Grande do Sul. (Dahne).

E' possivel que as rochas permianas contendo carvào do Rio Grande do Sul e de Santa Catharina sejam partes ora desta-

(1) David White. Journal of Geology, XV, 615, $190 \%$.

(*) Zeit. f. Prakt. Géolorie, 1896, 120. 
cadas de um unico lençol que originalmente cobriu uma area muito maior.

Os depositos do Rio Grande se apresentam em quatro bacias que talvez tivessem sido destacadas uma das outras por denudação. As bacias do Rio Tubarão e do Rio Verde no estado de Santa Catharina eram, talvez, semelhantemente ligadas com as que lhes ficam mais ao sul. 0

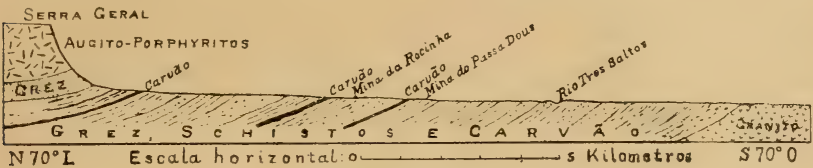

Fig. 145. - Secção atravez de uma parte da bacia permiana de Passa Dois, Santa Catharina. Conforme Gonzaga de Campos.

recente e muito importante estudo detalhado (1) das bacias do Tubarão e Passa Dois suggere a hypothese que o carvão destas areas se afunda debaixo das terras altas que lhes ficam ao oeste. (Vide figura 1/.̈.)

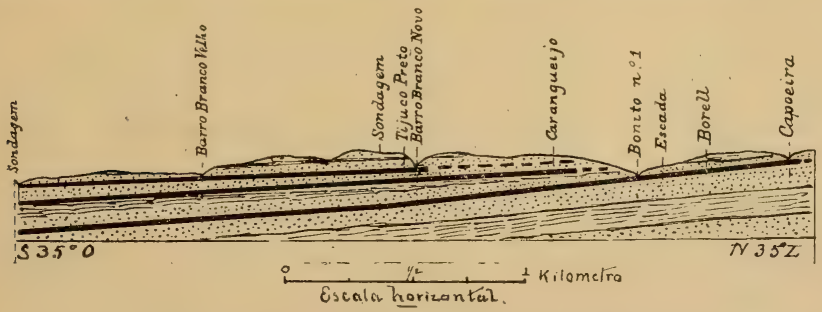

Fig. 146. - Seç̧ão atravez de uma parte da bacia permiana do Tubarão, Santa Catharina. Conforme Gonzaga de Campos.

Na pagina $32:$ : vem reproduzidas da já citada memoria de Carruthers, as figuras de tres das mais caracteristicas plantas das camadas permianas do Rio Grande do Sul.

(1) Minas de caroão do Tubarāo, Santa Catharina. Relatorio, apresentado ao Exm. Sr. General Francisco Glycerio, Ministro da Agricultura, etc., pelos engenheiros F. Hostilio de Moraes Rego, Luiz Gonzaga de Campos e João Caldeira de Alvarenga Messeder. Rio de Janeiro, Imprensa Nacional, 1890. 


\section{EXPLIGACiTOO DAS FIGURAS DE FOSSEIS PERMIANOS}

81. Lepidodendron (Flemingites) pedroanum Carruthers. Extremidade de um galho mostrando o eixo solido e as bases persistentes dos petiolos e folhas.

82 a. Lepidodendron (Flemingites) pedroanum Carruthers. Cicatrizes sobre um fragmento do um galho, augmentadas quatro vezes.

82 b. Lepidodendron (Flemengites) pedroanum Carruthers. Fragmento de um galho.

83 a. Odontopteris plantiana Carruthers. Parte de uma pinna.

83 b. Odontopteris plantiana Carruthers. Pinnula inferior da mesma.

84. Noeggerathia obovata Carruthers. Tamanho natural.

Outros fosseis vegetaes que ainda não tèm sido estudados e descriptos são as madeiras silicificadas que se encontram em grande abundancia e bello estado de conservação em todos os quatro estados do sul do Brasil. Entre estas Derby julga reconhecer representantes do genero Psaronius, Cordaioxylon (madeira fossil de Cordaites) do grupo das Cordaites, e Araucarioxylon (madeira fossil de Araucaria), Cupressoxylon (madeira fossil de Cupressus) e talvez Taxoxylon (madeira

- fossil de Taxus) no grupo das coniferas ordinarias.

Ultimamente o governo brasileiro mandou fazer um estudo mais minucioso do carvão nos estados de Paraná, Santa Catharina e Rio Grande do Sul, e o relatorio do geologo da commissão, Dr. I. C. White, reune os ultimos resultados a respeito da geologia carbonifera e das formações associadas com o carvão no sul do Brasil (1).

Segue a tabella das formações nas posięões relativas umas ás outras, com a espessura de cada uma, e com as equivalencias ás formações nas outras divisões do mundo.

(1) I. C. White. Commissão de estudos das minas ide caroão de pedra do Brasil. Relatorio final. Rio de Janeiro, 1908. 


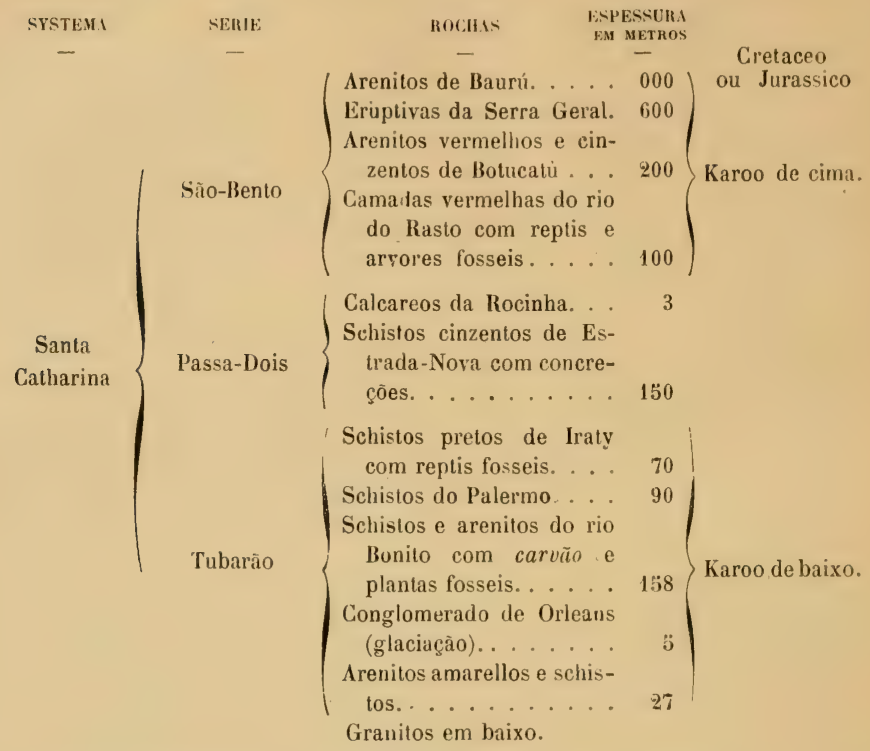

Os seguintes fosseis forão colligidos destas formações :

1. Dos arenitos do rio Rasto: Scaphonyx fischeri.

2. Schistos do Iraty : Mesosaurus brasiliensis e Stereosternum tumidum.

3. Schistos do rio Bonito : flora Gangamopteris que inclue as siguintes planlas determinadas ou descriptas por David White no relatorio citado :

Reinschia australis Bert. and Ben., var brasiliensis.

Rosellinites Gangamopteridis.

Hysterites brasiliensis.

Equisetites calamitinoides.

Schizoneura? -

Phyllotheca Griesbachi Zeill.

Phyllutheca Muelleriana.

Phyllotheca (?) sp.

Lycopodiopsis Derbyi Re.

Lepidodendron Pedroanum (Carr) Zeill.

Lepidophoios laricinus Sternb.

Sigillaria Brardii Brongn.

Sigillaria australis. 


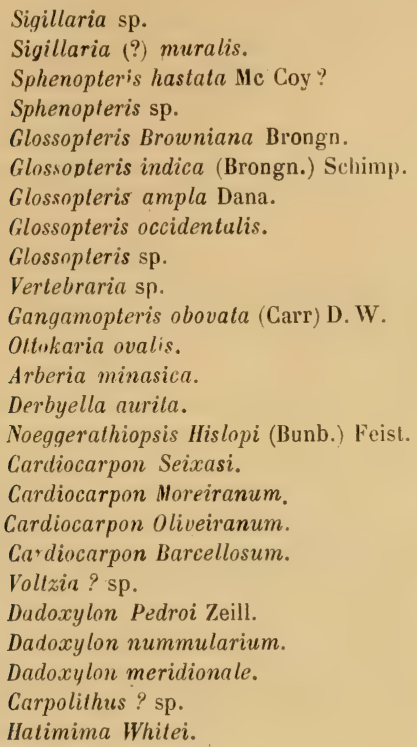

E notavel que a lista abrange certas fórmas representativas da llóra Gondwana da India, que são : Phyllotheca, Glossopteris, Gangamopteris e Noeggerathiopsis.

Os fosseis do systema Santa Catharina parecem justificar a conclusão que o Karroo superior da Africa do Sul corresponde á seric $\mathrm{S}$. Bento do Brasil, e que o Karroo inferior corresponde á serie Tubarão, incluindo nesta ultima os schistos pretos de Iraty, que contèm os restos de Mesosaurus brasiliensis $\mathbf{I}$. Gregor e Stereosternum tumidum Cope.

Perto de Santa Maria da Bocca do Monte no Rio Grande do Sul foi descoberto ultimamente um reptil fossil Scaphionix fischeri que parece completar o parallelismo entre o systema Santa Catharina e o systema Karroo da Africa do Sul.

Nas mesmas camadas com os fosseis vegetaes tem-se encontrado tambem um dente de um batrachio gigantesco, Labyrinthodon, e 
dentes e escamas de peixes ganoides. 0 primeiro destes fosseis é muito semelhante a um descripto com o nome de Mesosaurus tenuidens Gervais, do Karroo da Africa meridional unde foi considerado como pertencente ao periodo seguinte, ou o triassico. No Brasil, porém, estes fosseis se acham associados com fórmas vegetaes caracteristicas do periodo permiano.

Associadas com as camadas contendo os fosseis acima referidos e que são depositos d'agua doce, encontram-se mais raramente nos estados de S. Paulo e Paraná camadas delgadas de pederneira com abundantes fosseis maritimos. São todos lamellibranchios e, associados com os generos Schizodus, Myalina, Conocardium, etc., que se consideram como caracteristicos do permiano; ha outros que se assemelham mais com os do periodo subsequente. Assim na sua fauna como na sua flóra estas camadas brasileiras apresentam uma curiosa mistura de fórmas permianas com outras que geralmente se consideram como caracteristicas do periodo mesozoico, reproduzindo assim, no Brasil, um phenomeno que já se tem notado nas formações correspondentes da Australia, India e Africa meridional.

Além dos estados acima mencionados e que abrangem o lado esquerdo da bacia do Paraná com a bacia do Uruguay e as suas confrontantes do litoral, parece provavel que essas camadas serão encontradas no sul do estado de Matto Grosso e na Republica do Paraguay, na região entre os rios Paraná e Paraguay, e tambem na bacia do Amazonas na região das cabeceiras dos rios Tapajós e Xingú.

Ultimamente fetos fosseis que parecem permianos forram descobertos na fazenda Jacú perto da villa de Aracy no estado da Bahia, uns treze lilometros ao norte da estação de Serrinha. Estes fosseis vèm de uma serie de rochas sedimentarias conhecida no Brasil como a serie de Estancia, por estar bem exposta na cidade deste nome no estado de Sergipe. Estas rochas pela maior parte são arenitos vermelhos, mas a serie tambem inclue argillas, calcareos e folhelhos de còr cinzenta. Os fosseis vêm dos folhelhos. A unica especie até agora reconhecida é Alethopteris branneri (1).

(1) David White. American Journal of Science, XXXV, 633-636, June, 1913. 
1 distribuição destas rochas permianas nos estados de Sergipe, Bahia e Alagóas está indicada approximadamente no mappa que accompanha 0 artigo citado.

Numa excur'são geologica feita pelo geologo Dr. Miguel Arrojado Lisboa no anno 1909 á procura de informações a respeito da planta fossil Psaronius (1) pelo riorte do Brasil, elle descobriu que a formação de que este fossil é caracteristico (quer dizer permiana) tem uma extensão enorme naquella parte do paiz. Ficou assim determinado que a area permiana se extende sobre grande parte dos estados do Maranhão, Piauhy e Goyaz. As lucalidades onde fòram achados fosseis permianos e os estudos stratigraphicos de Dr. Lisboa naquelles estados e no de Matto Grosso bem como os effectuados em S. Paulo patenteam o facto que o permiano abrange uma area de cerca de 282,000 kilometros quadrados nos estados de Maranhão, Piauhy e Goyaz, e que provavehmente essa formação extende-se tambem ao sudeste até reunir-se com o permiano do interior da Bahia e Sergipe, e ao sudoeste até ligar-se com o permiano de S. Paulo e Matto Grosso.

0s resultados destes estudos feitos no campo, tomados em conjuncȩão com os estudos do mesmo autor em Matto Grosso e S. Paulo e com o que já sabemos a respeito do permiano nas outras partes do Brasil, tornou evidente o facto que o permiano é talvez o terreno mais caracteristico do territorio brasileiro. Como disse Dr. Lisboa " está provado que o continente de Gondwana abrangia o Brasil de norte ao sul desde quasi o Atlantico, logo abaixo da bocca do Amazonas, até os confins com o Uruguay (2). »

(1) A. Brongniart. Notice sur le Psarontus brasiliensts. Bul. Soc. Botanique de France, XIX, 3-10. Paris, 1872.

(2) $U$ relatorio de Dr. Lisboa infelizmente ainda não está publicado, embora forme uma das mais importantes contribuições feitas á geologia do Brasil. No American Journal of Science sahiu ultimamente um resumé dos resultados sob o titulo : Permicun geology of northern Brasil. Vol 187, paginas 425-443. May, 1914. 


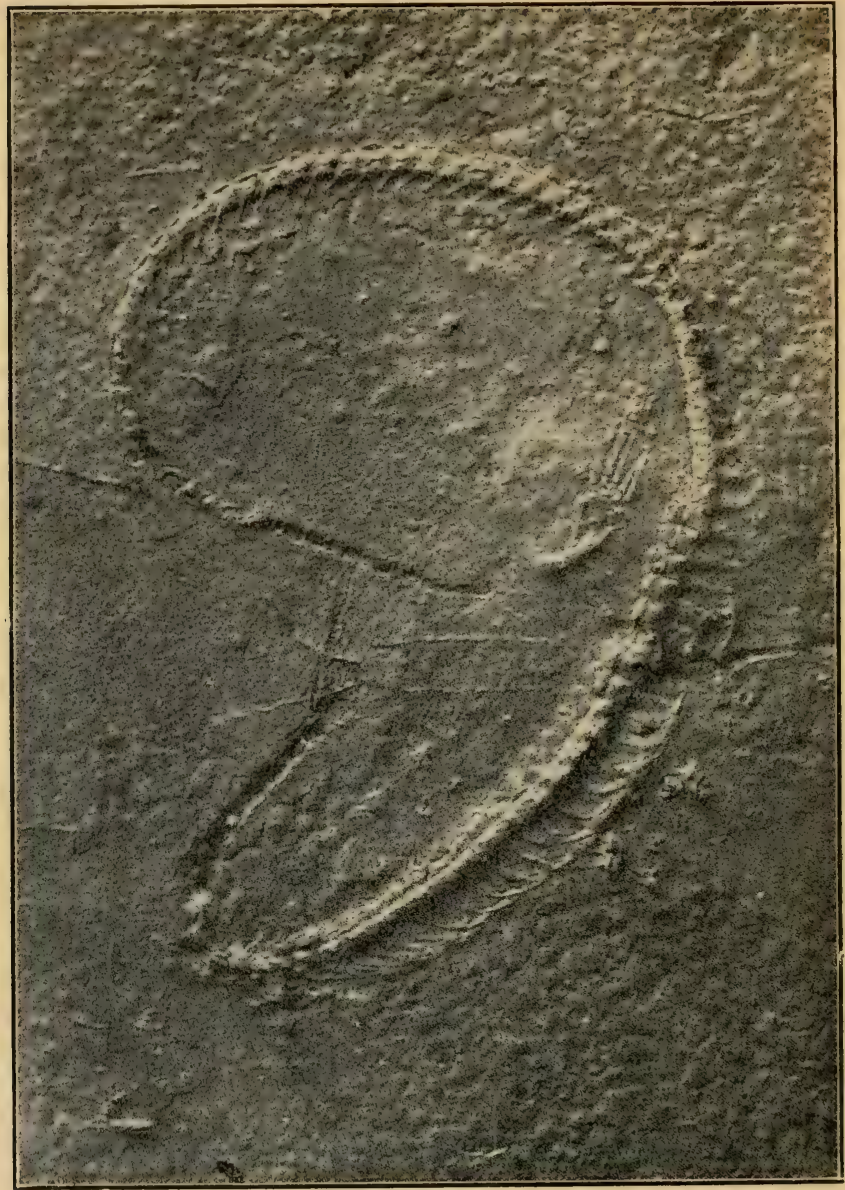

Fig. 148. - Esquelets de Stereosternum tumidum sobre uma lage de calcaren de Limeira. S. Paulo. 


\section{Periodo mesozoico.}

\section{TRIASSICO}

A vida do triassico foi modificada pelo desapparecimento de certos crinoides (cistoides e blastoides) e o declinio dos brachiopodes. Houve um augmento notavel nos lamellibranchios e cephalopodes; os reptis tornaram-se mais abundantes; os amphibios chegaram ao seu maximo grau de desenvolvimento, e os mammiferos fizeram o seu primeiro apparecimento. Na America do Norte as camadas triassicas são caracterisadas localmente por uma coloração parda avermelhada. Nos estados da Virginia e Carolina do Norte existem depositos de carvão, e no estado de Kansas apresentam-se depositos importantes de gesso e sal gemma.

No Brasil as camadas triassicas occupam uma extensa area na parte central e occidental da bacia do Paraná nos estados de Matto Grosso, oeste de S. Paulo, Paraná, Santa Catharina e Rio Grande do Sul, estendendo-se tambem para as republicas visinhas do Lruguay e do Paraguay. A referencia destas rochas ao triassico baseava-se antigamente no facto da sua superposição ás camadas permianas e na semelhança das suas rochas, especialmente as eruptivas, com as triassicas da Europa e da parte oriental da America do Norte.

Porém no anno de 1902 um pequeno numero de ossos de reptis (Scaphiony.x fischeri Smith-Woodward) descobertos proximo de Santa Maria da Bocea do Monte (Serrito) no estado do Rio Grande do Sul, parecem provar que os depositos em que föram encontrados devem ser attriluuidos á epoca triassica. E notavel que o Scaphionyx representa o primeiro reptil terrestre descoberto na America do Sul pertencente á fauna do "Gondwana » da India, e á parte triassica (1). Mais tarde fosseis fòram descobertos em S. José do rio Preto no estado de S. Paulo, 450 kilometros oeste da capital daquelle estado. Estes

(1) A Smith-Woodward. Ossos fosseis de réptis do estado do Rio Grande. do Sul. Reoista do Museu Paulista, 'VII, 46-57. São Paulo 1907. 
fosseis parecem ser de um jacaré e de um Dinosauro caracteristico do triassico e do rhoetico das outras partes do mundo (1).

No sul do Brasil. - As rochas consistem em arenitos molles e avermelhados sobrepostas e quasi sempre associados com rochas eruptivas de typo diabasico que se apresentam em diques e lençóes de notavel extensão e espessura. 0 conjuncto destas camadas attingem em diversos lugares uma espessura de quinhentos ou mais metros, regulando em geral entre cem e tresentos metros. Jazem em posição proximamente horizontal, isto é, são isentas de dobras, mas são muito perturbadas por falhas de notavel extensão e amplitude.

As rochas eruptivas se apresentam ás vezes na fórma massięa e granular de diabase, mas, pela maior parte, são prophyriticas (diabase porphyrite) e frequentemente esponjosas ou amygdaloides, indicando que provavelmente se derramaram na superficie da terra como corridas de lava. Não se tem reconhecido, porém, centros vulcanicos no sentido restricto, e é provavel que as erupções fossem do typo conhecidas por " massiças " sem os phenomenos explosivos que constroem cones vulcanicos. Para este caracter das erupções concorreu indubitavelmente 0 do magma eruptivo que é essencialmente basico e assim proprio para dar lavas dotadas de alto grau de fluidez.

As rochas eruptivas estão bem expostas ao longo da estrada nova em Santa Catharina onde fórmam um escarpado quasi vertical. Começam a 748 metros acima do mar e succedem-se em lençóes, alguns com estructura columnar de vinte a cincoenta metros de espessura, até mil e quatro centos metros no alto da Serra-Geral a kilometro vinte e cinco de Minas.

São estas as rochas eruptivas que formam a subida da Serra.Geral tão difficil em muitos pontos em Santa Catharina e no Rio Grande do Sul.

$\Lambda$ estructura amygdaloide que caracterisa grande parte das rochas

(1) A. Smith-Woodward. On a ltusk of a triassic dinosaur from São Paulo, Brasil. Transactions British Association, 1909, p. 483, London, 1910.

R. von Thering. Fosseis de S. José do Rio Preto. Revista do Museu Paulista, VIII, 141-146. S. Paulo, 1911. 
eruptivas desta formação dá logar á formação abundante de geodes das varias fórmas de silica (chalcedonia, agatha e quartzo)e de varios zeolitos. Os geodes silicosos resistindo á decomposição ficam lastrando o solo resultante da alteração, geraimente bem profunda, da rocha encaixante, e assim servem (como as pederneiras na zona pcrmiana) de meio facil para identificar e seguir a formaŗão nas extensas areas em que difficilmente se encontra a rocha bem conservada.

Nas margens do Rio Uruguay no estado do Rio Grande do Sul, diz Dr. Paula de Oliveira que a o solo é todo de amygdaloides cheios de bellas agatas, opalas, cornalinas, calcedoneas e silex de differentes. colorações, que pódem dar lugar a um commercio vantajoso. » (1)

Em muitas partes da area triassica as agathas são de uma belleza excepcional ao ponto de constituir um objecto de commercio no Estado do Ris Grande do Sul e na Republica de Uruguay. Do ultimo paiz vêm, nas cavidades amygdaloides da rocha eruptiva, as afamadas " pedras d'agua ou geodes de chalcedonia vermicular com uma cavidade central cheia d'agua e com uma bolha movel.

No lado oriental da bacia do Paraná as rochas triassicas occupam uma zona larga que se estende desde a margem septentrional da bacia, na Serra da Canastra fonteira ás cabeceiras do Rio S. Francisco, atravez. dos estados de S. Paulo e Paraná, sendo cortada, na parte média dos. seus cursos, pelos rios Grande, Tieté, Paranápanema e Iguassú, que a atravessam em profundos valles excavados 200 a $̋ 00$ metros abaixo do nivel geral da grande chapada formada por suas camadas proximamente horizontaes. Ao sul do rio Iguassú a margem oriental da zona, dirigindo-se para leste, circumda as cabeceiras do rio Uruguay chegando a apontar no cume da Serra do Mar no sul do estado de Santa Catharina e norte do Rio Grande do Sul.

Esta margem é marcada por uma bem pronunciada escarpa que constitue feição topographica tão saliente que recebe a denominação popular de serra, como Serra de Araraquara, de Botucatú, da Espe-

(1) Francisco de Paula Oliveira. Subsidios ao estudo $d \alpha$ geologia do Brasil. p. 22, Curityba, 1917. 
rança, etc. Esta escarpa conserva a elevaçio geral de cerca de 1000 metros e dá accesso a uma chapada de nivel quasi uniforme, salvo as profundas depressões dos valles que a atravessam. Em frente da escarpa : presentam-se frequentemente massas destacadas da chapada, de fórma caracteristica bem expressa nos nomes populares de " morros de chapeu " e cuscuzeiros ". Esta linha de escarpas e de cuscuzeiros assignala evidentemente uma zona de falhas de notavel extensão e importancia. E' ao longo desta zona que se encontram as mais extensas e espessas massas eruptivas, se bem que estas se apresentem com maior ou menor frequencia por toda a região triassica.

Passando da bacia do Paraná para a do Uruguay, a linha de es. rarpas acompanha proximamente as margens da bacia deste rio de maneira a vir formar o prolongamento da linha orographica da Serra do Mar, até proximo á cidade de Porto Alegre, onde dobra para o oeste e atravessa todo o Estado do Rio Grande do Sul correndo parallelamente ao curso dos rios Jacuhy e Ibicuhy. Ao sul desta linha os depositos triassicos cobren grande parte do estado do Rio Grande do Sul e da Republica do Uruguay, porém em nivel mais baixo e com a superficie mais desfeita pela denudação.

Na parte central da bacia do Paraná as camadas triassicas desapparecem, nas partes mais elevadas da chapada, debaixo de uma formação mais recente, mas continuam nas encostas e nos fundos dus valles onde as numerosas cachoeiras são formadas pelos seus resistentes leneóes de rocha eruptiva. $\Lambda$ oeste do Paraná estas camadas surgem outra vez na superficie geral da chapada, formando grande parte do espigão entre os rios Paraná e Paraguay no sul dos estados de Goyaz et MattoGrosso e na Republica do Páraguay.

As areas da zona triassica em que aflóram as rochas sedimentarias, que são quasi exclusivamente arenitos, apresentam um solo arenoso reves tido geralmente por vegetação campestre. As areas em que allóram as rochas eruptivas apresentam, pelo contrario, um solo reputado extremamente fertil e geralmente revestido por frondosas florestas. Este solo (como o das areas permianas proveniente da decomposição de rochas semelhantes) é fortemente colorido em vermelho por oxido de ferro donde lhe vem a sua denominação popular " terra roxa ». Devido 
em parte ás suas excellentes qualidades chimicas e physicas e em parte ao facto que, em regra geral, occupam posições elevadas que as pũem em abrigo das fortes geadas, as terras roxas são as preferidas pelos lavradores de café do estado de São Paulo onde a prosperidade dos afamados centros cafeeiros de Ribeirão Preto, Jahú, S. Manoel, Botucatú, etc., attestam as suas qualidades superiores.

Fóra das bacias do Paraná e Uruguay não se tem identificado com o mesmo grau de probabilidade rochas triassicas no Brasil. No estado de Sergipe se apresentam ao longo do rio Piauhy na visinhança da cidade de Estancia, arenitos vermelhos que têm sido referidos ao triassico em virtude da sua posiçâo em baixo de camadas fossiliferas da idade cretacea.

Ultimamente, porém, fosseis fôram descobertos no estado da Bahia que parecem provar que esta serie seja da idade permiana. Sobre estas rochas vede pagina 328.

E' bem possivel que na bacia do Amazonas na parte superior ou média dos cursos dos rios Araguaya, Xingú e Tapajós, haja uma zona triassica correspondente à da parte semelhante da bacia do Paraná, mas sobre isto nada se sabe de positivo, salvo o facto referido por Hebert Smith que ao norte da villa da Chapada de Matto-Grosso existe uma chapada donde se tem extrahido ossos fosseis. Pela sua posição em seguida ás camadas devonianas, as camadas que compõem esta escarpa correspondem, de alguma maneira, ás escarpas da bacia do Paraná, nas quaes se encontram rochas permianas e triassicas. Em qualquer uma lestas formações não seria de estranhar a presença de ossos fosseis, mas até conhecel-os melhor não se póde determinar sua idade exacta.

Na parte occidental dos estados de Minas Geraes e de S. Paulo, temse notado ultimamente que na parte superior da serie de camadas referidas até agora á idade triassica faltam as erupçōes diabasicas caracteristicas da parte inferior, sendo porém, substituidas por outras de caracter basaltico. Estas ultimas por emquanto só são conhecidas na fúrma de depositos de cinzas que parecem ter sido expellidas de verdadeiros centros vulcanicos. Ao lado dessa mudança no caracter das eruprôes e dos seus productos nota-se tambem uma tendencia nas rochas sedimentarias para se tornarem mais conglomeraticas, argilosas e calca- 
reas, havendo em alguns pontos verdadeiros calcareos com caracteristicos de depositos em agua doce, que embora impuros se prestam para o fabrico de cal. Julga-se, portanto que, aqui existe uma formação geologica independente da triassica typica, cuja idade deve ser triassica superior, ou mais provelmente post-triassica.

Por emquanto esta formação só tem sido reconhecida na região entre Uberada e Bagagem no estado de Minas Geraes e nas de Jaboticabal, Ribeirãozinho e S. Paulo dos Agudos no de S. Paulo, sendo provavel que cubra uma area extensa na parte central da bacia do Paraná, estendendo-se talvez para os estados vizinhos de Goyaz e Matto-(irosso. Perto de Uberaba esta formação attinge a espessura de cerca de $2: 30 \mathrm{me-}$ tros e fórma uma escarpa semelhante a que margea a zona triassica. Em S. Paulo dos $A$ gudos a espessura é menor mas a margem da zona é egualmente escarpada.

Um dos depositos de cinzas vulcanicas, em Agua Suja, perto do Bagagem no estado de Minas Geraes é diamantifero apresentando assim na sua idade geologica e no caracter das suas rochas, muito maior analogia com a afamada regiào diamantifera da Africa Austral do que com as da parte central dos estados de Minas Geraes e Bahia no Brasil.

Na mesına região tem-se reconhecido uma outra seric eruptiva caracterisada por rochas (syenitos, phonolitos e basaltos) contendo os mineraes nepheline et leucite. Associadas com as rochas massiças ha verdadeiras tufas que mostram que as eruprões eram explosivas, isto é, vulcanicas no sentido restricto. $\Lambda$ idade destas erupsões não póde ser determinada exactamente, mas é certo que as de Ipaniema e Poços de Caldas nos estados de S. Paulo e Minas Geraes eram post-permianas, sendo de presumir que fôram proximamente contemporaneas ás dos outros pontos conhecidos, que são : Jacupiranga e Ilha de S. Sebastião no Estado de S. Paulo; Ilha do Cabo Frio, Serra de Tinguá e Serra da Iendanha no do Rio de Janeiro ; Serra de Itatiaya e Serra do Picú no de Minas Geraes e Pào de Assucar no de Matto-Grosso (1).

(1) Orville A. Derby. On nepheline, rocks in Brazil. Quarterly Journal of the Geological Society. Vol. XLIII, pags. 457-173; vol. XLVII, pags. 261-265. London, 1887 a 1891 . 


\section{JURASSICO}

As rochas jurassicas tomam o seu nome das montanias Jur na Suissa. Durante os tempos jurassicos os cephalopodes culminaram; os reptis fòram muito abundantes, alguns sendo alados, e muitos delles fòram de tamanho enorme. $\Lambda$ s primeiras aves conhecidas no estado fossil provèm das rochas desta idade, e algumas destas aves tinham dentes.

Na America do Norte os viciros auriferns das montanhas de California acham-se principalmente nas rochas de idade jurassica.

No Brasil não se conhece definitivamente rochas da idade jurassica. Entre os fosseis encontrados nas rochas cretaceas do estado de Sergipe existem alguns cujo aspecto é jurassico mas a preponderancia da evidencia mostra que o conjuncto das camadas reunidas pertencem á idade cretacea. E' porém bem possivel que estudos mais detalhados da genlogia do estado de Sergipe revelará a presenȩa de rochas jurassicas nesta parte do Brasil. Tambem alguns dos reptis e peixes da bacia d'agua doce da Bahia, referida á cretacea apresentam um aspecto jurassico.

É mesmo provavel que a maior parte da serie São Bento referida a pagina 326 pertença ao jurassico inferior ; mas por emquanto faltitm fosseis para confirmar esta correlação.

Conforme as determinações e estudos feitos pelos paleontologistas e tratados no relatorio de I. C. White sobre a geologia da região de carvão no sul do Brasil, o grande lençol de rochas eruptivas dos esta- dos do Rio Grande do Sul, Santa Catharina, Paraná, S. Paulo e Matto Grosso é de idade jurassica. Esta opinião, porém, basea-se sobre o facto de os reptis fosseis do rio do Rasto serem clasificados romo triassicos, e que o arenito de Botucatú segue com uma espessura de duzentos metros, e que as lavas são ainda mais novas.

Ao longo do rio Grande no estado de S. Paulo Dr. G. Florence achou " a borda do immenso lençol de trapp (diabase intercalada no 
grez de Botacatú) ", mostrando que uma parte peio menos das lavas desta area, é de idade jurassica (1).

Sendo possivel que ainda se venha a descobrir no Brasil camadas fossiliferas da idade, jurassica damos duas estampas representando alguns dos fosseis mais caracteristicos das camadas desta idade que se apresentam nas partes mais proximas do continente, isto é, na Republica Argentina (2).

\section{BXPLICACÃO DAS FIGURAS DE FOSSEIS JURASSICOS}

85 a e 85 b. Haploceras faculatum Steuer. Vista da frente e do lado. Cieneguita na parte occidental do estado de Mendoza, Republica Argentina.

86 a e 86 b. Odontoceras nodulosuin Steuer. Vista da frente e do lado. Cieneguita na parte occidental do estado de Mendosa, Republica Argentina.

87 a e b. Reineckeia micrucantha Oppel. Vista da frente e do lado. Loncoche e Arroyo la Manga no estado de Mendoza, Republica Argentina.

88 a e b. Hoplites vetusus Steuer. Vista da frente e do lado, Cieneguita, Estado de Mendoza, Republica Argentina.

89 a e 89 b. Phyloceras torulosum Tornquist. Vista da frente e do lado. Dos Andes na parte occidental do estado de San Juan, Republica Argentiua.

90 a e 90 b. Sonninia subdeltafalcata Tornquist. Vista da frente e do lado. Espinazito-Pass, estado de San Juan, Republica Argentina.

91 a e 91 b. Sphaeroceras extremuin Tornquist. Uma amostra pequena, vista da fr nte e do lado. Fspinazito-Pass, estado de San Juan, Republica Ar»entina.

92 a e 92 b. Slephanoceras sphaeroceroides Tornquist. Vista do lado e uma secçâo transversal vista da frente. Espinazito-Pass, estado de San Juan, Republica Argentina.

\section{CRETACEO}

O nome cretaceo (do Latim crela) foi dado ás camarlas desta illade por causa da greda, ou giz, da Inglaterra, que pertence a esta

(1) G. Florence. Exploraçöes do Rio Grande, pag. 32. S. Paulo, 1913.

(2) A. Steuer. Argentinische Jura-Ablagerungen. Palaeontologische Abhandlungen N. F. Bd. III, Jena, 1897, Ileft 3 .

A. Tornquist: Der Dogger am Espinazito-Pass. Pal. Abhand. N. F. Bd. VII, Heft 2. Jena, 1898. 


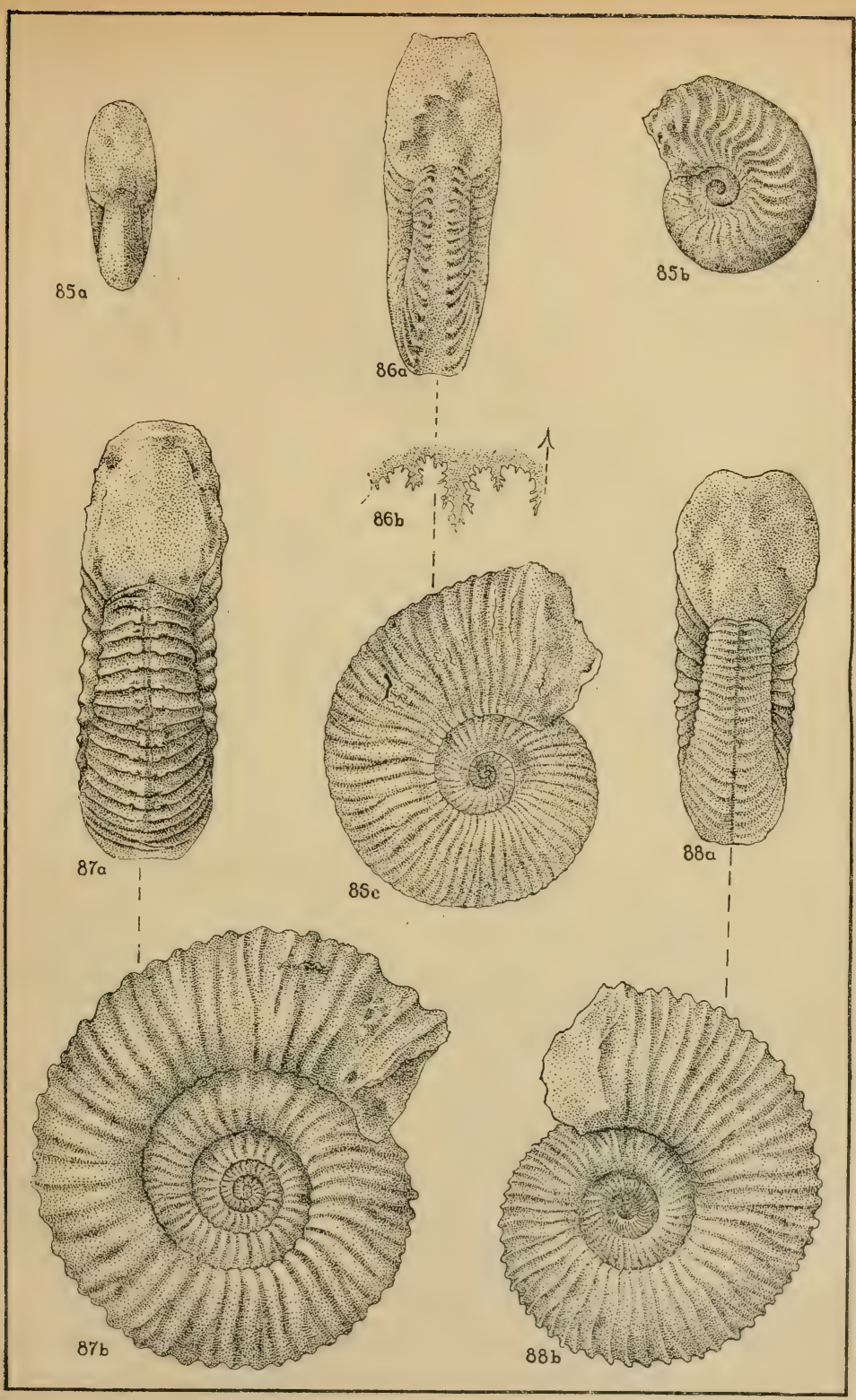

Fig. 149. - Fosseis jurassicos caracteristicos. 


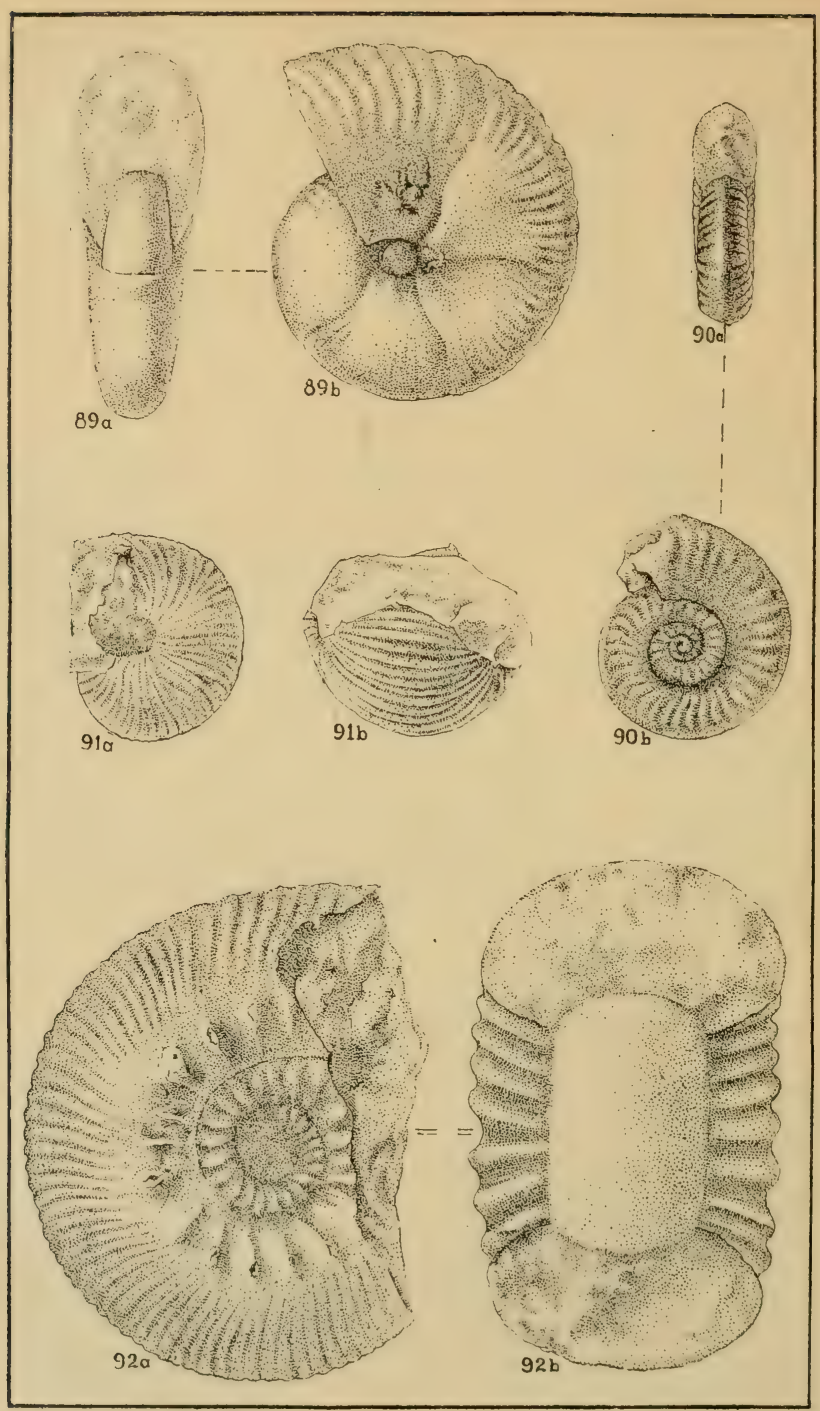

Fig. 150, - Fosseis jurassicos earacteristicos. 
serie. Os fosseis mostram mudanȩas notaveis na vida vegetal do periodo sendo assignalado pelo primeiro apparecimento de palmeiras e de plantas dicotyledonias. Abundaram os peixes com esqueletns osseos, bem como crocodilos e outros reptis dos quaes alguns eram de tamanho enorme e de fórmas cxtravagantes como se vê na figura junta.

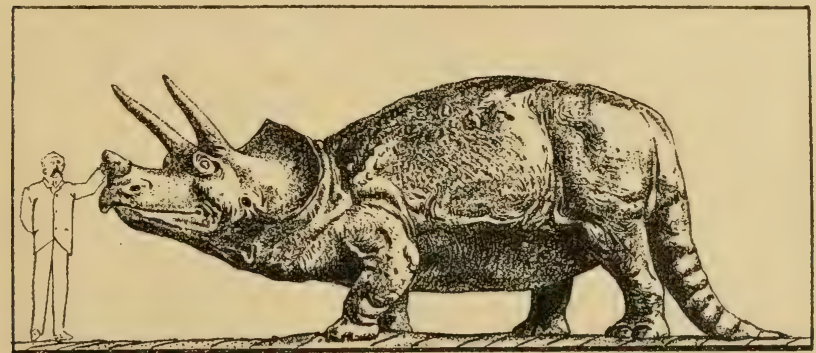

Fig. 151. - Triceratops prorsus, Marsh, um reptil gigantesco tendo chifres e bico como o da tartaruga. Das camadas cretaceas da America do Norte.

Como nos tempos jurassicos algumas das aves tinham dentes.

Na Europa as camadas cretaceas consistem frequentemente de greda, mas na parte occilental da America do Norte extensas camadas de carvão apresentam-se entre as rochas desta idade. Em alguns pontos du estado de Colorado o carvão cretaceo tem sido alterido em anthracito.

No Brasil as rochas cretaceas acham-se distribuidas ao longo da costa desde os Abrolhos até o Amazonas : na bacia amazonica até perto do sopé dos Andes, e sobre uma grande area do planalto central abrangendo grande parte das bacias dos rios S. Francisco, Parnahyba, Tocantins (?) e outros adjacentes além de uma area extensa no valle do Paranả. Apresentam-se nestas diversas regiões differenças nos seus caracteres e fosseis de modo que não se póde por emquanto estabelecer correlações entre ellas e por isso convem tratal-as separadamente.

Os arenitos de Baurú, assim denominados por Gonzaga de Campos, são as camadas mais novas do oeste de S. Paulo, onde sobrepũem-se 
as rochas eruptivas e fórmam os cumes das serras, chapadas, e morros.

A rucha é um arenito molle, calcareo, mui pouco resistente, de estratificaçã quasi horizontal, e tem a espessura de cem a 150 metros (1). Esta formação é a rocha superficial da maior parte do estado de S. Paulo a oeste de Lençóes, Beriry, e Monte-Alto. Fosseis de animaes vertebrados achados nesies arenitos parecem provar que elles pertencem á idade cretacea (2) ou mais exactamente ao Wealden de Inglaterra, que é a formação de passagem entre o jurassico e cretaceo. Camadas que parecem occupar a mesma posição geologica fóram notadas por Dr. Lisboa no sul de Matto Grosso.

As rochas das ilhas dos Abrolhos foram referidas ao cretaceo por llartt, mas esta determinação é muito duvidosa. Os unicos fosseis conhecidos daquellas ilhas são fragmentos indeterminaveis que " parecem escamas de peixes » (3).

As camades sedimentarias são ali sotopostas ás rochas eruptivas, e por isso parece possivel, ou até provavel, que as camadas sedimentarias sejam mais antigas que o cretaceo. Pelo menos não se conhece outro lugar no Brasil onde rochas eruptivas cortam ruchas mais novas que as jurassicas.

Ao longc do litoral as rochas de idade cretacea occupam bacias destacadas que penetram algumas dezenas de kilometros apcras no interior do continente e que, no geral, attingem alturas de poucas dezenas de metros apenas acima do nivel do mar. Partes destas bacias são occupadas por depositos de agua doce ou salobra, parte por depositos francamente maritimos. Em geral as camadas são ligeiramente perturbadas apresentando uma inclinação relativamente fraca para u mar que evidentemente tem invadido e destruido grande parte das bacias primitivas.

(1) Gonzaga de Campos. Reconhecumento da zona comprehendida entre Bauri eItapura. S. Paulo, 1905, pags. 11-12.

(2) Juviano A. d'Am. Pacheco. Geologia do valle do Rio Grande. Commissão Geowraphica e Geologica de S. Paulo. S. Paulo, 1913, pags. 33-38. 1870 .

(3) C. F. Hartt. Geology and physical geograpluy of Brazil, p. 176. Boston, 
Entre as bacias maritimas a melhor conhecida é a do estado de Sergipe, nas visinhanças das cidades de Maroim e Larangeiras, que se estende desde a Serra de Itabaiana até o mar, tendo porém as suas camadas

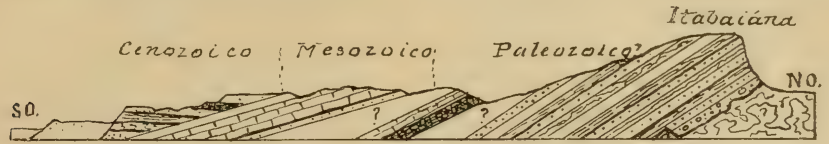

Fig. 152. - Secção mostrando a estructura geologica geral atravez da Serra da Itabaiana até o mar, no estado de Sergipe.

cobertas perto da costa por depositos mais recentes. (Vêde fig. 12̌2). Uma grande collecção de fosseis feita nesta bacia pela extincta
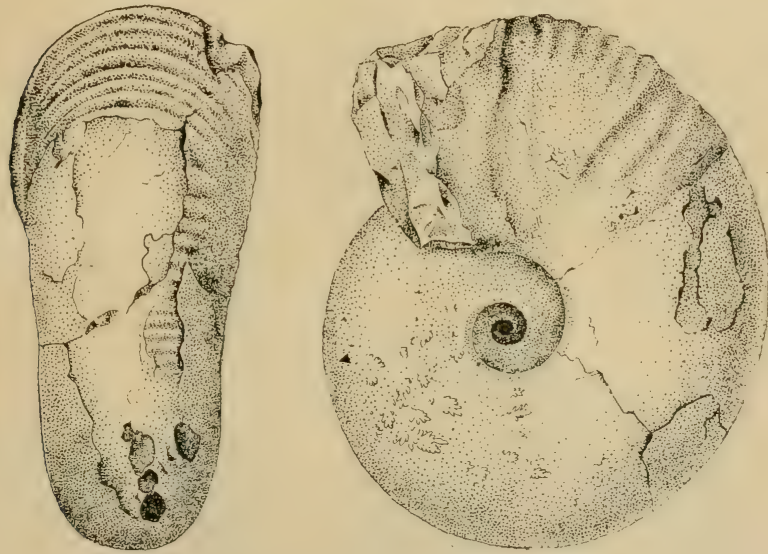

Fig. 153. - Ammonites (Pachydiscus) hopkinsi Forbes, das camadas cretaceas de Maroim, Sergipe. Metade do tamanho natural.

Commissão Geologica do Brasil foi descripta pelo Dr. C. A. White (1) que identificnu 48 especies de lamellibranchios, 17 de gasteropodes, 14 de cephalopodes e $\mathbf{1 1}$ de echinodermes.

(1) C.-A. White. Contribuiçōes á Paleontologia do Brasil. Archivos do Museu Nacional, vol. VII. Rio de Janeiro, 1887. 
Com refurencia a esta fauna o Dr. White observa: " $\Lambda$ s colleçees até agora feitas no Brasil indicam que existe naquelle paiz uma fauna rpetacea que não é excedida em interesse e importancia pela de qualquer outra parte do mundo. »
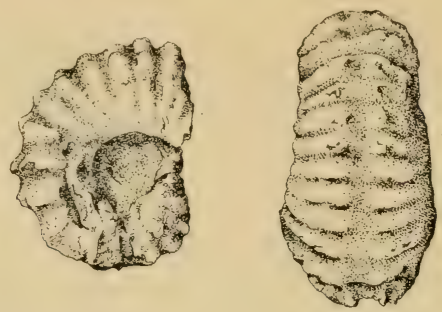

Fig. 154. - Ammonites (Hoplites) offarcinatus White, das camadas cretaceas de Maroim, Sergipe. Metade do tamanho nạtural.

Aguns dos mais caracteristicos destes fosseis são representados nas figs. 1333 a 156 . Entre elles os cephalopodes são especialmente interessantes por apresentareın, como já referido, certas affinidades com os fosseis correspondentes da idade jurassica.
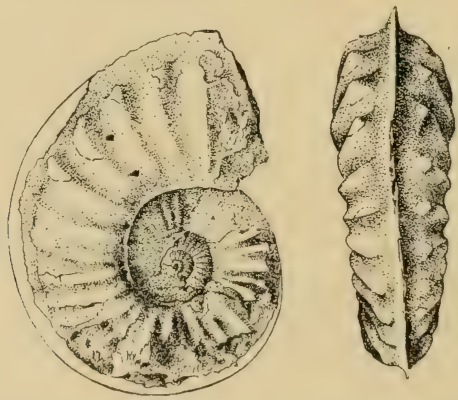

lig. 155. - Ammonites (Schloenbachict) sergipensis White, das camadas cretaceas de Maroim, Sercripe. Metade do tamanho natural.

\section{EXPLIGACG̃̃O DAS FIGURAS DE FOSSEIS CRETACEOS}

93 a. Ostra palmella Sowerby. Vista interna, tamanho natural. Lastro, Maroim, Sergipe. 


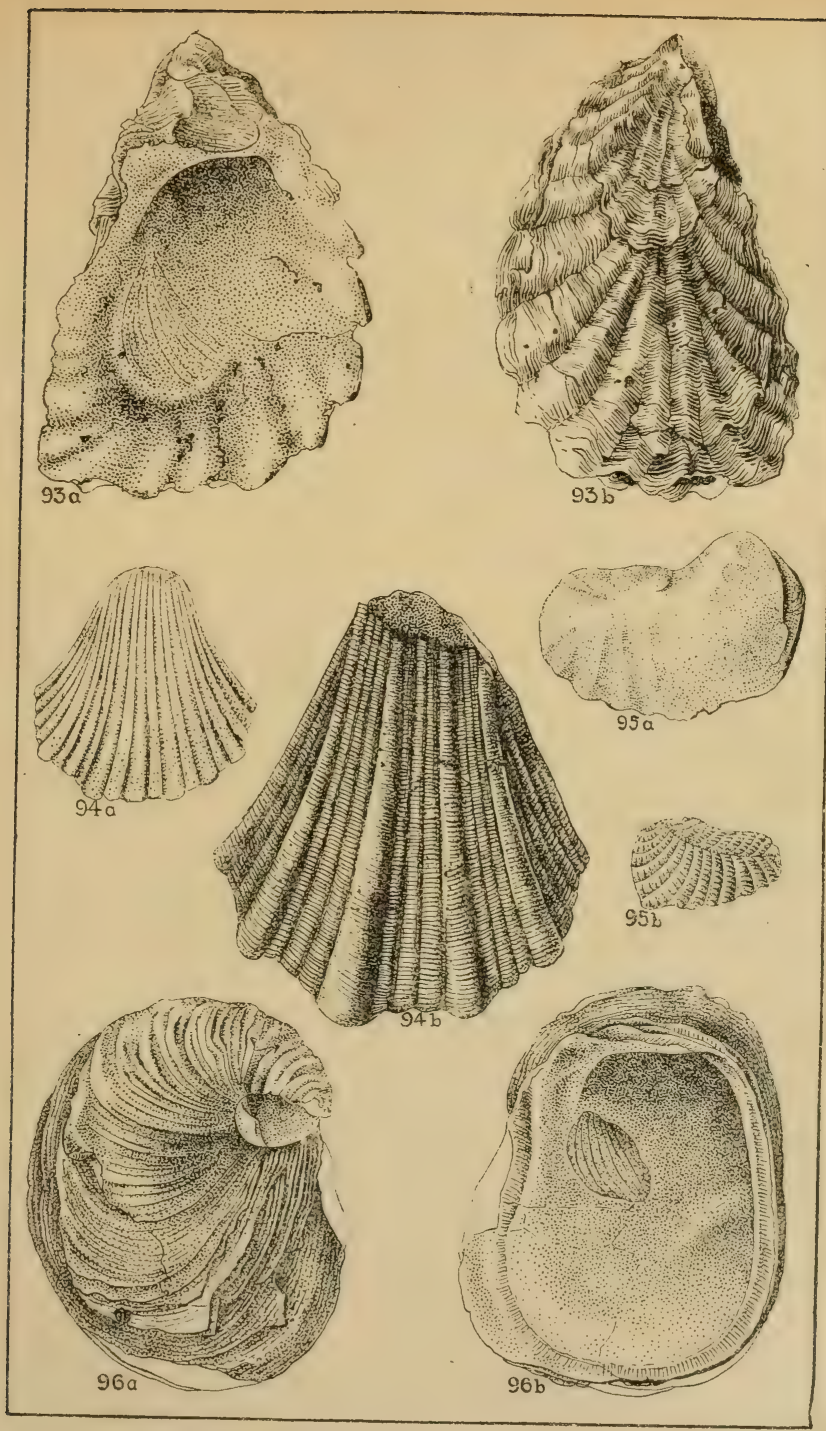

Fig. 156. - Fosseis caracteristicos das camadas cretaceas do estado de Sergipe. 
93 b. Ostra palmella Sowerby. Vista externa da valva inferior, tamanho nalural. Lastro, Maroim, Sergipe.

94. a. Neilhea quadricoslata Sowerby. Vista externa de uma prquena valva direita faltando a parte umbonal, tamanho natural. I astro, Maroim, Sergipe.

94 b. Neithea quadricostnta Sowerby. Vista semelhante de uma grante valva direita, tamanho natural. Lastio, Maroim, Sergipe.

95 a. Trigonia subcrenulala d'Orbigny. Molde natural do interior de uma valva direita, tamanho natural. Porto dos Barcos, Larangeiras, Sergipe.

$9 \ddot{\mathrm{b}}$ b. Trigonia subcrenulata d'Orbigny. Fragmento da superficie de uma valvat esquerda, mostrando o caracter das costellas transversaes, tamanho natural. Lastro, Maroim, Sergipe.

96 a e b. Exogyra ostracina Lamark? Vista externa e interna de uma valva interior; tamanho natural. Lastro, Maroim, Sergipe.

Na costa do estado da Bahia a unica localidade até agora conhecida que tem fornecido fosseis cretaceos maritimos é perto da barra do pequeno rio Marahú onde recentemente se tem reconhecido rochas muito semelhantes ás da bacia de Sergipe e contendo alguns dos mesmos fosseis entre estes o representado na figura $94^{\mathrm{b}}$ na pagina 3 彷 (1).

Uma importante collecção de peixes fosseis feita perto de Ilheos no estado da Bahia por Dr. Ennes de Souza tem contribuido muito para nosso conhecimento do cretaceo da costa do Brasil. Os fusseis são conservados num folhelho bituminoso muito parecido com os folhelhos de Marahú. Professor A. Smith-Woodward que descreveu a colleç̧io diz (2) que os fosseis são da idade cretacea inferior (Wealden) como os da propria Bahia, e que incluem tambem fórmas jurassicas. As fórmas descriptas por elle na lista de Ilheos são: Mawsonia minor S. W. Lepidotus Souzai S. W., e Scombroclupea scutata S. W.

Na figura junta mostrando a distribuiçào do terciario ao lorigo da costa norte do Brasil, o cretaceo daquella zona não está descriminado:

(1) Gonzaga de Campos. Reconhecimento geologico, e estudo de substancia bituminosa da bacia do rio Marahù, estado da Bahia. S. Paulo, 1902.

(2) A. Smith-Woodward. Quar. Journal, Geological Society London, vol. 61, 358-362, London, 1908. 
mas é provavel que se sobpoe ao terciario em muitos lugares, embori não em todos.

Os estudos de Gonzaga de Campos mostram yue na região visinha a Iarahú o cretaceo repousa directamente sobre as rochas crystallinas do complexo brasileiro, que os folhelhos bituminosos de Maralıú sào da idade terciaria e sobrepoem ao cretaceo, e que as duas series tèm uma inclinação suave (de dois para vinte graus), variavel, mas geralmente na direç̧ào do oceano .

Esta bacia cretacea, porém, é de pequenas dimensões, a largura nào passando de doze kilometros na latitude de Marahú.

Na chapada central do sul de Matto Grosso e nos picus de Serrinha, Dr. Lisboa achou certas camadas sedimentarias que elle refere á idarte cretacea, mas com duvidas (1).

Logo ao norte da hacia pernambucana relı a da Parahyba do Norte que tem sido reconhecida destle o morro sobre o qual se assenta a cidade até a estação do entroncamento na estrada de ferro que se dirige para o interior, não se sabendo a sua extensão ao longo da costa (vêde mappa na pag. 367). Os poucos fosseis aqui conhecidos são de typos ca-

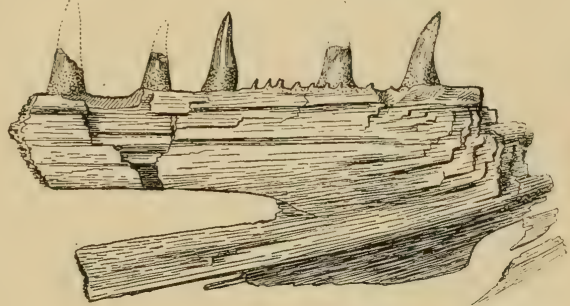

Fig. 157. - Parte da maxilla direita de uma especi. de peixe, Cimolichthys, sp., Williston. Parahyba do Norte. Tamanho natural.

racteristicamente cretaceos. Sào uma especie de cephalopode do generu Sphenodiscus, um carangueijo (Zanthopus cretacea Rathbun) e um peixe do genero Cimolichthys (2). A seguinte é uma lista completa dos fosseis até agora descriptos das camadas marinhas consideradas como cretaceas distribuidas pelas diversas bacias do Maroim e Estancia.

(1) M. A. R. Lisboa. Oeste de S. Paulo, Sul de Matto Grosso, pags 64-65. Rio de Janeiro, 1910.

(2) J. C. Branner. Geology of the northeast coast of Brazil. Bulletin of the Geological Society of America, XIII, 41-98. 1904. 


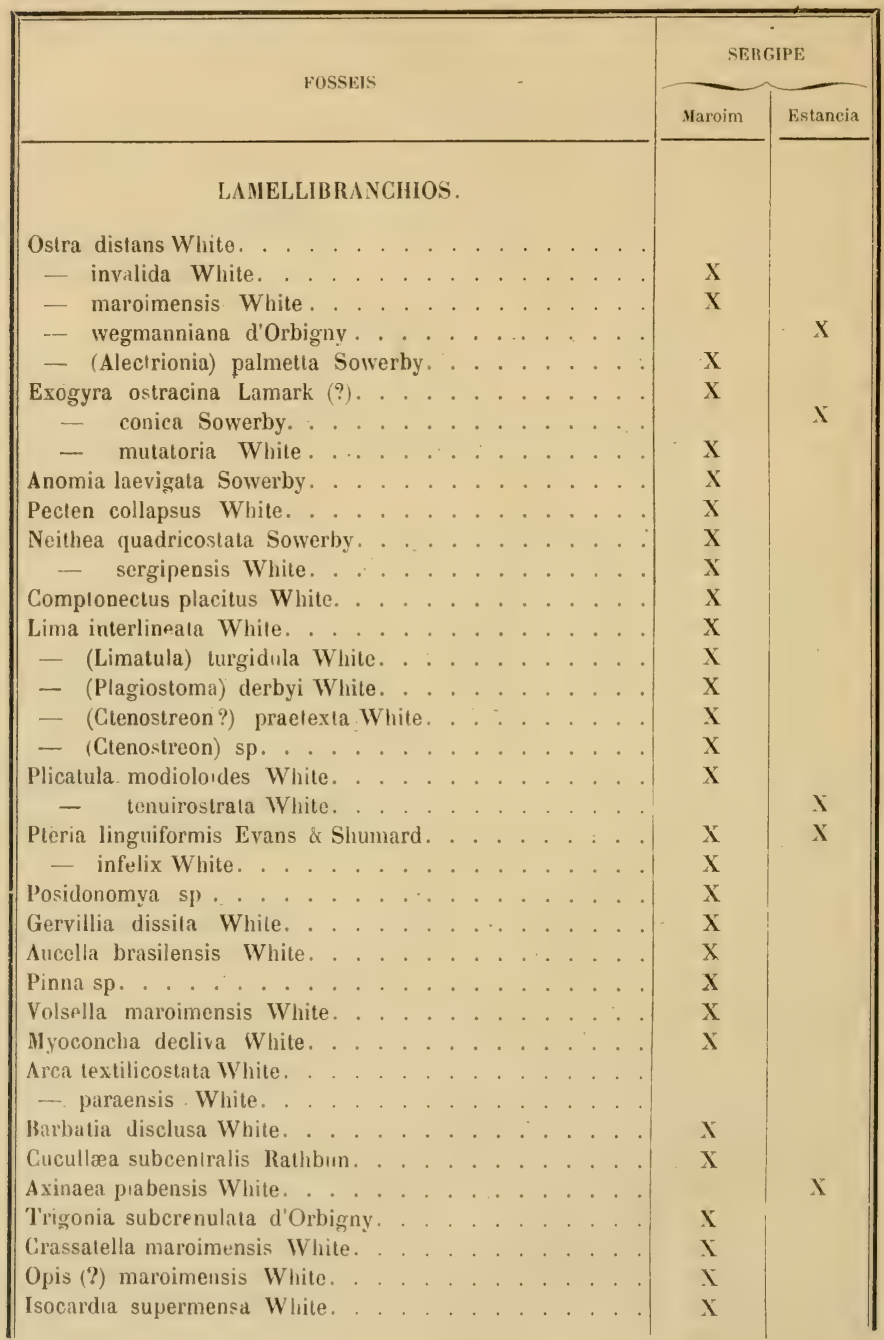




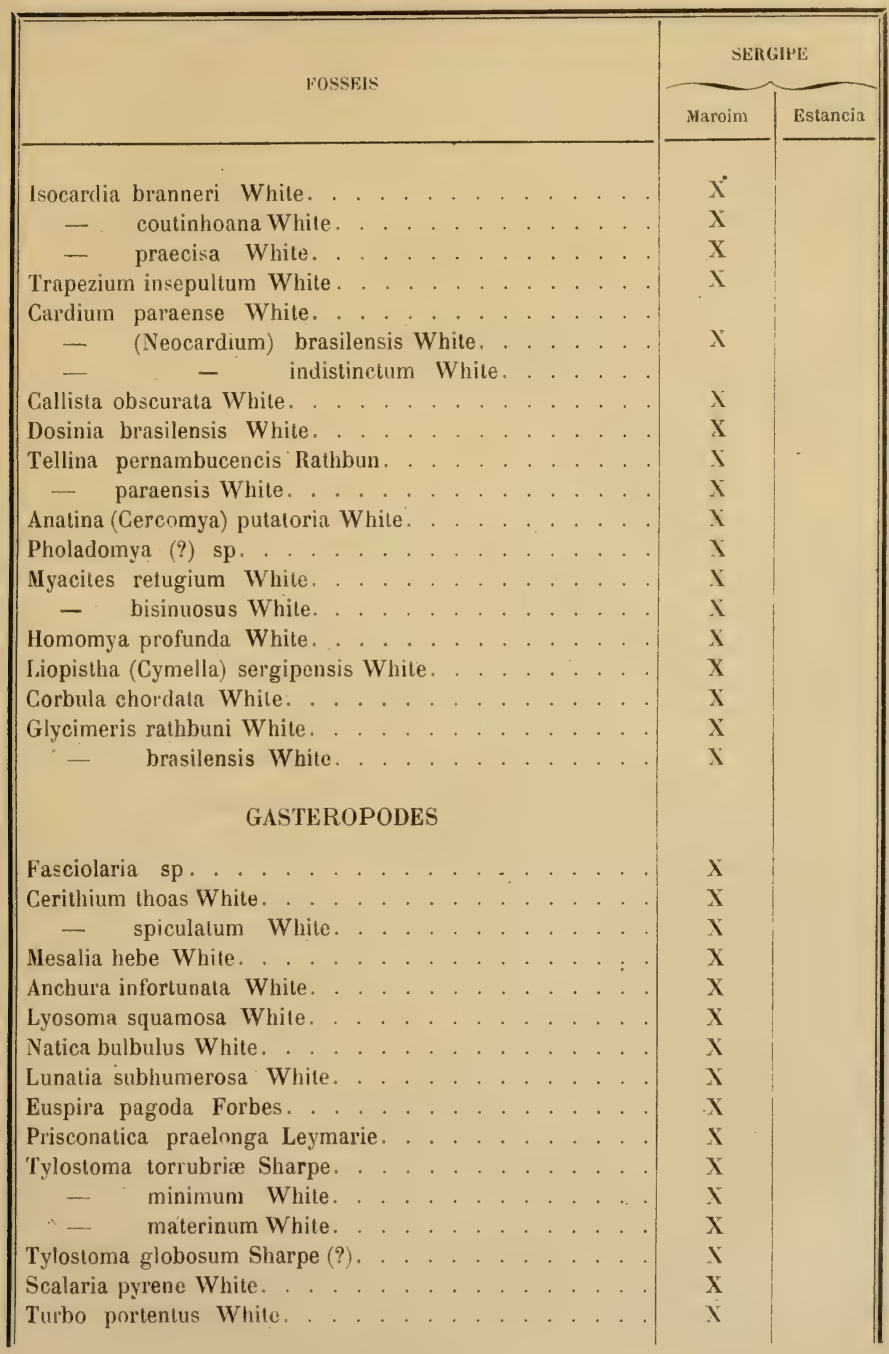




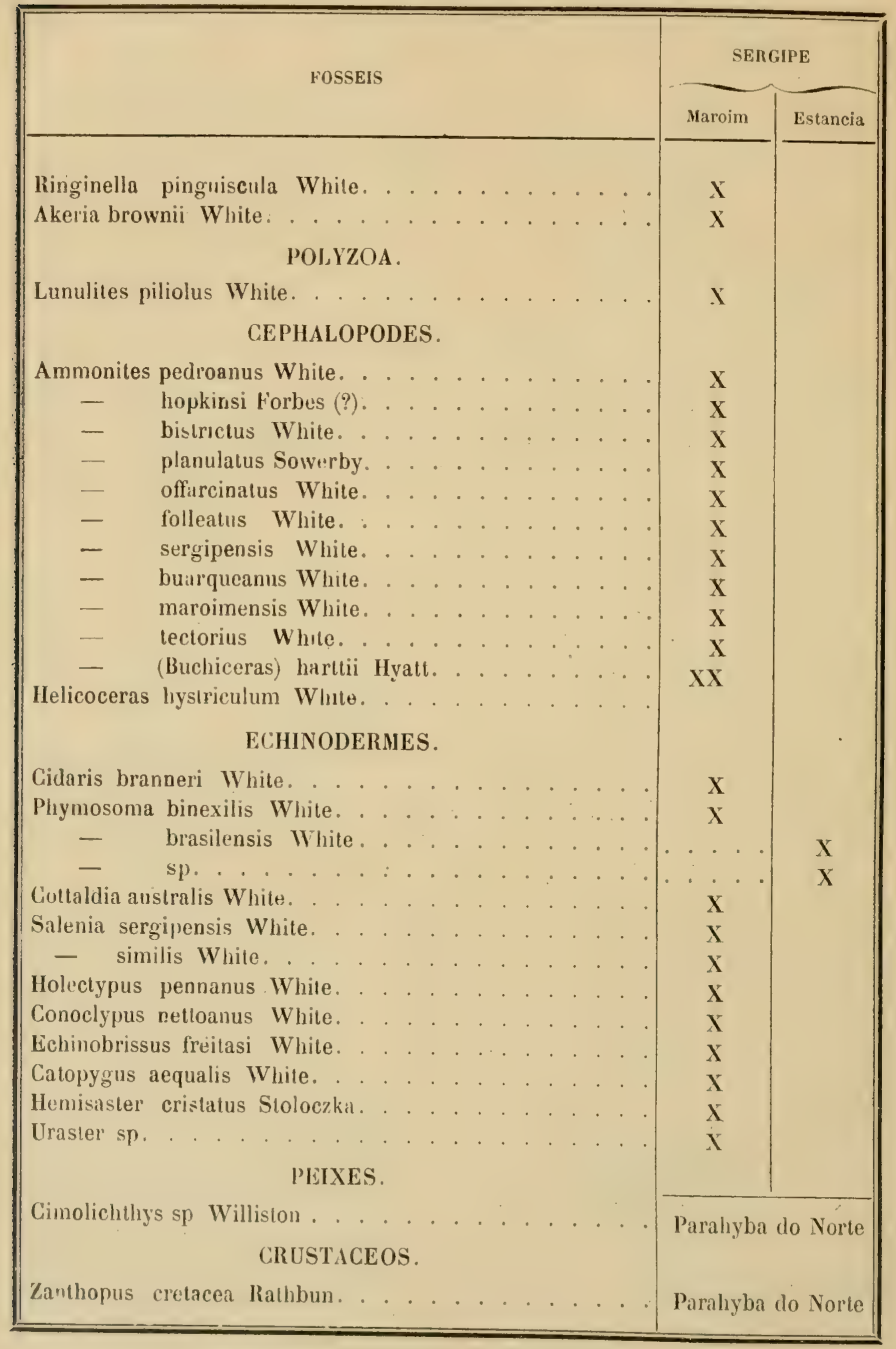


Nas ilhas e margens da bahia de Todos os Santos apresentam-se camadas de conglomerados, arenitos c folhelhos contendo restos de reptis e peixes associados com molluscos de agua doce, crustaceos bivalvos (Entomostracos) e fragmentos de madeira que indicam que os depositos se formaram numa bacia de agua doce. Esta bacia tem sido descripta com alguma minudencia por Allport(1), Hartt (2) e Raıbbun (3). Parece occupar uma depressão synclinal entre as lombadas de rochas

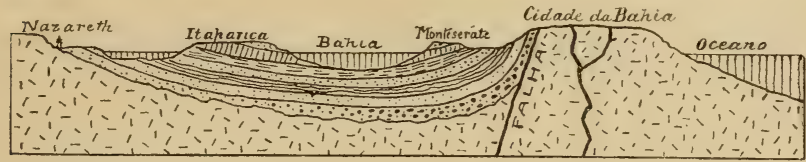

Fig. 158. - Seç̧ão hypothetica atravez da bacia da Bahia.

1rystallinas da Bahia e Nazareth, sendo deprimida abaixo da primeira ao longo de uma falha, conforme se vê na figura junta.

A existencia de madeiras carbonizadas nestas camadas tem dado lugar a diversas explorações em busca de carvão, especialmente na ilha de Itaparica, mas só se encontram ali pequenos fragmentos destacados que muitas vezes são transformados em azeviche.

Entre os restos de rejtis achados nesta bacia bahiana, Marsh (4) identificou uma especie de crocodilo (Goniophilis harttii Marsh) e de Dinosauro (Thoracosaurus bahiensis Marsh) e Woodward (̋) julgou reconhecer ossos de Plesiosauros e Pterosauros (reptis alados).

Estes, cumo os peixes ganoides (Lepidotus mawsoni Woodward e

(1) S. Allport. On the discovery of some fossil remains near Bahia in South America. Quarterly Journal of the Geological Society, vol XVI, pags 263-266. London, 1860.

(2) Ch. Fred. Hartt. Geology and phystcal geography of Brazil. Boston. 1870.

(3) Kicardo Rathbun. Obseroaşoes sobre a geologio. Aspecto da ilha de Itaparica na bahia de Torios os Santos. Archivos do Museu Nacional, vol. III, pags 159-183. Rio de Janeiro, 1878.

(4) O. C. Marsh. Notice of some new reptilian remains from the Cretaceous of Brazil. Americam Journal of Science. vol. XCVII, pp. 390-392. New Haven, 1869.

(5) A. Smith Woodward. Evidence of the occurrence of Pterosaurians and Plesiosaurians in the Cretnceous of Brasil discosered by Joseph Mauson. Annals and Magazine of Notural History. vol: VIII, pp. 314-317. London, 1891. 
Megulurus mawsoni Woodward typo jurassico (1), e tubarōes (Acrodus nitidus Woodward), representam typos que podiam ser de idade jurassica, mas os outros peixes (Diplomystus longicostatus Cope (2) Chiromystus mawsoni Cope) são considerados como caracteristicos da ilade. cretacea.

A fauna inteira indica o principio da idade cretacea (3).

Na memoria já citada o Dr. C. A. White descreveu e figurou as seguintes especies de molluscos de agua dnce provenientes desta bacia : Lioplacoides (Paludina) williamsi Hartt; Pleurocera (Melania) terebriformis Morris; Neritina prolabiata White ; Planorbis (Gyraulus) monserratensis Hartt; Sphaerum ativum White; Anadonta (?) (Unio) I0tium-sanctorum Hartt; $\boldsymbol{A}($ (?) harttii White ; $\boldsymbol{A}$, (?) mawsoni White, o 1. (?) allporti White. Com referencia a estes fosseis o Dr. White observa que todos os typos genericos são representados entre os molluscos ainda existentes. Esta circumstancia dá á fauna um aspecto relativamente moderno e se não fộssem os fosseis vertebrados, as camalas podiam com certa plausibilidade ser referidas á idade terciaria.

Os entomostracos da mesma região, descriptos pelo Sr. Rupert Iones (4), são os seguintes: Cypris (?) conculcala Jones; Ci, (?) monleserratensis Jones: C. (?) allporliana Jones; Candona randida Mul-

1) A. Smith Woodward. Note on some Vertebrate lossils from the Prooince of Bahia, Brazil, collected by Joseph Mawson. Annals and Magazine of Natural History, vol. V. pp. 132-136. London, 1888.

(2) Joseph Mawson and A. S. Woodward. On the eretacenus of Bahia. Q. J. G. S. LXIII, 128-139. London, 1907.

A. Smith Woodward. On an Amoid fish Megalurus mawsoni, sp. $n$. from the. Cretaceous of Bahia, Brazil. Annals and Magazine of Natural History, vol. IX, pp. 87-89. London, 1902.

(3) E. D. Cope. A contribution to the vertebrate palueontology of Brazil. Proredings of the Ameriun Philosophieal Society, vol XXIII, Philadelphia, 1866.

A. Smith Woodward. On two deep-bodied species of the Clupeoid genus Diplomystus. Annals and Magazine of Natural History, vol. XV, pp. 1-3. London 1895 .

(4) 'T. Rupert Jones. Note on the fossil Entomostraca from Monserrate. Bahia. Quarterly Journal of the Geological Society, vol. XVI; pp. 266-268. London, 1860.

T. Rupert Jones. On some fossil Entomostract from Hrosil. Geological Mugrtzine, vol. 1V, pp. 195-202 e 289-233. London, 1897. 
ler; Estheriina brasiliensis Jones; E. expansa Jones; E. asteroides Jones, e E. mawsoni Jones.

Ao sul da cidade da Bahia nas margens do rio Marahú, Gonzaga de Campos refere a occurrencia de camadas de arenito contendo madeiras carbonizadas que elle julga ser identicas ás rochas semelhantes da vizinhança da Bahia. Mais ao sul nas vizinhanças da lagôa da Itahype perto de Ilhéos existem folhelhos bituminosos com fragmentos de azeviche e peixes fosseis semelhantes aos da bacia da Bahia. An que parece estes depositos de agua doce da bacia de Marahú occupam um horizonte geologico superior ao das camadas com fosseis marinhos da mesma bacia.

Nas ilhas dos Abrolhos apresentam-se camadas de arenito (vède fig. 75 e 76 p. 223) e folhelhos contendo restos obscuros de plantas e peixes que são presumivelmente semelhantes ás das bacias de terra firme acima descriptas (1). Associado com estas camadas acha-se um lençol de rocha eruptiva de typo diabasico, um essexite ou olivenegabbro diabase.

No planalto central do Brasil as camadas cretaceas apresentam-se com a espessura de cerca de 300 metros formando chapadas que carac. terisam especialmente a região entre o rio São Francisco e os rios Jaguaribe, Parnayba e Tocantins. Entre estas chapadas a mais bem conhecida é a da Serra de Araripe no extremo sul do estado do Ceará em cuja base se uncontram concreções calcareas contendo peixes fosseis bellamente conservados (2). Uma ramificação para o sul desta chapada é cortada pelo rio São Francisco acima da cachoeira de Paulo Affonso $c$ ahi consiste de camadas de folhelhos marnosos e gypsiferos cobertas por possantes camadas de arenito (3).

Os peixes fosseis do Ceará vêm principalmente do districtu de

(1) Ch. Fred. Hartt. Geology and physical geography of Brazil, pp. 174-179. Boston, $18 \% 9$.

(2) George Gardner. Geological notes made during a journey from the coast into the interior of the prooince of Ceara in the north of Brazil embracing an account of a deposit of fossil fishes. Edinburgh New Philosophical Magarine, vol. $30 \mathrm{pp}$. 75-82. Edinburgh, 1841.

George Gardner. Tracels in the interior of Brazil. London, 1846.

(3. Orville A. Derby. Contribuição para o estudo da geologia do oalle do rio S. Francisco: Archivos do Museu Nacional, vol. 4 pp. 87-119. Rio de Janeiro, 1881. 
Jardim na base sul da serra de Araripe, mas tèm sido transportados, como objectos de curiosidade, para grande parte do norte do Brasil " assim vem referidos a um grande numero de localidades das quaes algumas são provavelmente verdadeiras, sendo, porém, uma parte evidentemente erroneas.

Esses peixes fosseis fòram encontrados pela primeira vez em 1840 por George Gardner, botanico inglez, que estava explorando o interior do Brasil, e descriptos originalmente por L. Agassiz (1) sob cinco generos e seis especies. Só no anno 1907 foi feita uma collecção mais completa por Francisco Dias de Rocha de Ceará, e descripta por Dr. D. S. Jordan (2). Um pouco mais tarde colleç̧ũes importantes forram feitas pelos geologos do serviço geologico e da Inspectoria de Obras contra as Seccas, e descriptas por Dr. D. S. Jordan cujo relatorio ainda não sahiu lo prelo, mas já está nas mãos do Serviȩo Geologico do Brasil. Os lugares onde os peixes fosseis foram encontrados são: Jardim, Riachão, Simões e Sant'Anna do Cariry. A seguinte é a lista completa de todos os peixes fosseis achados naquella região : Vinctifer comptoni, Lepidotus temnurus, Tharrias araripis, T. rochae, Brannerion vestitum, Calamopleurus brama, Rhacolepis buccalis, Emneles audax, Ennelichthys derbyi, Ciladocyclus gardneri, Anuedopogon tenuidens, Dastilbe crandalli.

Certas camadas desta serie contèm quantidades enormes de foraminiferos fosseis, mostrando claramente que estas formações são depositos marinhos.

Dr. H. L. Small, geologo da Inspectoria e Obras contra as Seceas disse, a respeito da geologia da Serra do Araripe, que aquella chapada é, por toda a parte, de arenitos e folhelhos em camadas approximadamente horizontaes, e sobrepostas an granito e gneiss. Na extremidade uccidental perto do S. Gonçalo, Simões, e Aldeia o granito está exposto Intma altitude de 600 metros, e mais perto ao alto da chapada do que

(1) L. Agassiz. On the fossil fishes found by Mr. Gardner. Edinburgh New Philosophical Journal, XXX, 83. 1811.

(2) D. S. Jordan e J. C. Branner. The Cretaceous fishes of Ceara Brazil. Smithsonian Miscellaneous Collection. Washington, 1908. 
no lado oriental na vizinhança de Crato que fica no arenito numa altitude de 400 metros.

As duas secçòes geologicas juntas, feitas por Dr. Small, dào uma boa idea da estructura geral da Serra do Araripe. No fundo a camada do arenito conglomeratico em certos lugares tem uma espessura de cin-
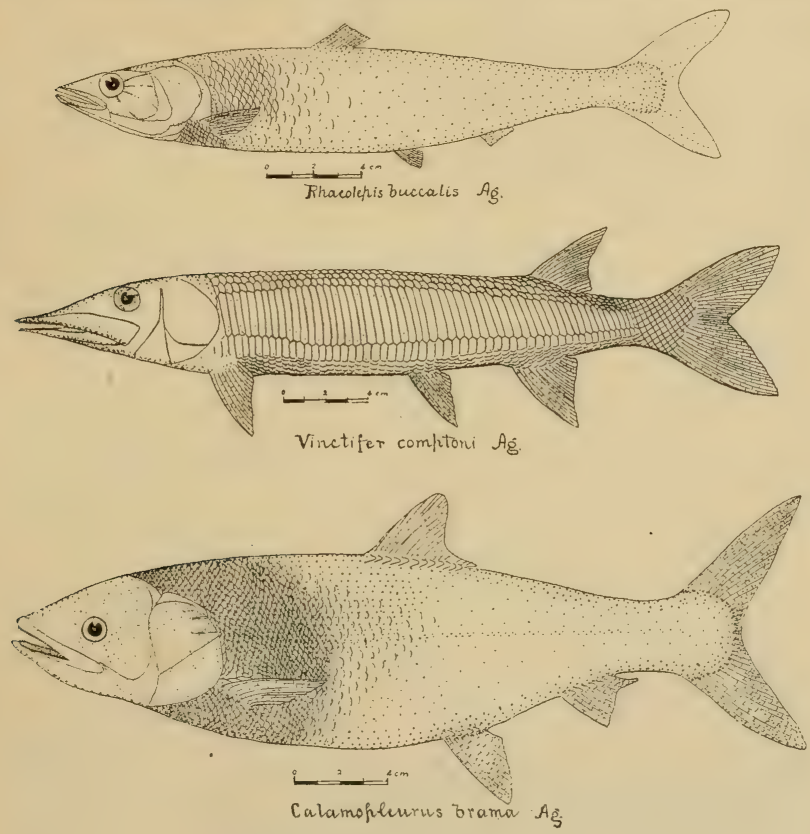

Fig. 159. - Rhacolepis, Vinctifer, e Calamopleurus, tres peixes cretaceos do Cearà restaurados. Figuras reduzidas da monographia do Serviço Geologico do Brasil.

coenta metros ; o arenito inferior que a sobrepoe tem uma espessura de cem metros, e o calcareo de Sant'Anna, que tem os peixos fosseis, tem a espessura de noventa metros. Em cima do calcareo umas camadas de arenito vermelho têm uma espessura total de trezentos metros ou mais e estas ultimas fórmam o cume da chapadá. 
Os fosseis conhecidos, mas ainda não descriptos, das camadas nas margens do São Franscisco são madeiras (inclusive grandes troncus de
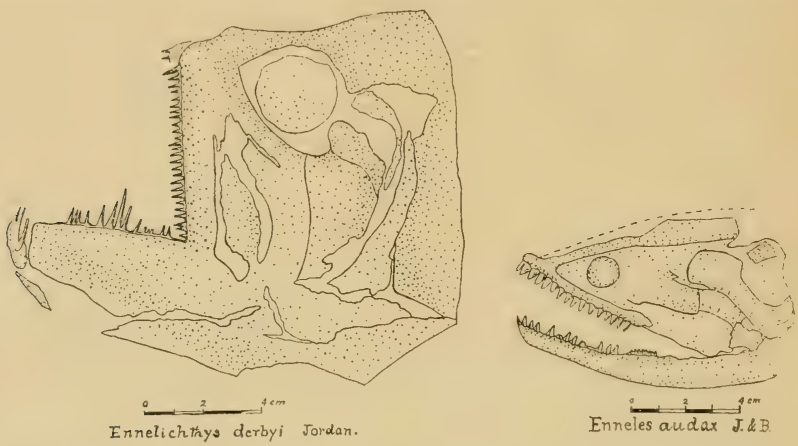

Fig. 160. - Cabeças de peixes cretaceos do Cearí. Figuras reduzidas do Serviço Geologico do Brasil.

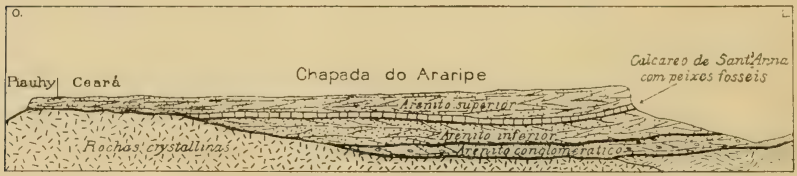

Seção sీeologica mostrando a estructrua da Chapada do Araripe. Conforme H.L.Small.

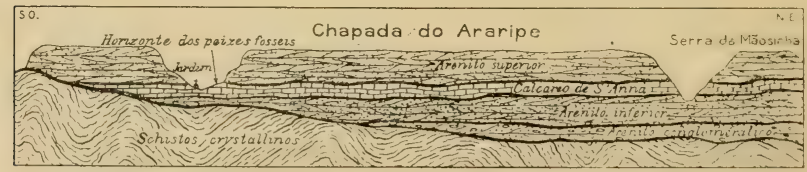

Secção geologíca da Chapada do Araripe entre Serrá da Mãosinha e Jardim. Conform. H.L.Small.

Fig. 161.

arvores), dentes de tubaróes, escamas de peixes (Lepidotus), crustarons bivalvos. Parecem representar depositos em agua doce ou salohir. Da regiào cretacea typica acima descripta estendem-se diver'sis tha. 
padas que pela scmelhança nos caracteres topographicos, parerem pertencer á mesma furmação; supposição esta que se acha de certo modo confirmada pela occurrencia de madeiras petrificadas de typos que não fódem ser mais antigos de que a cretacea na regiào de Therezina nı valle do Parnahyba e na de Indaia no do alto Sào Francisco (1). Uma destas chapadas com o nome de Serra de Apody estende-se na zona limitrophe entre os estados do Ceará e Rio Grande do Norte até o mar : outra com o nome de Serra de Ibiapaba estende-se do mesmo modo na zona limitrophe dos estados de Ceará e Piauhy e tambem alcança o mar, e ainda outra estende-se para o sul na região a oeste do rio São Francisco, apparecendo nas margens deste rio acima de São Romão e dahi acompanhando-as até perto das cabeceiras. Parece tambem provavel que parte das chapadas dos estados do Maranhão, Goyaz e Pará na bacia do Tocantins pertença á formação cretacea. Em diversos pontos as terras proximas ás chapadas são salinas devido presumivelmente á lixiviação de camadas saliferas existentes entre as das chapadas.

No valle do Amazonas Derby tem referido á cretacea as camadas de arenito de varios serrotes nas vizinhanças de Monte-Alegre e Obidos, baseando-se para isto na occurrencia de madeiras e folhas fosseis nos de Ereré e Paituna as quaes não pódem ser mais antigas do que esta idade (2).

Na parte şuperior do mesmo valle na região da fonteira com a Bolivia, Chandless achou nas margens do rio Aquiry (Acre) restos de uma especie de Mosasaurus que é um genero caracteristico da idade cretacea (3). Um grande crucodilo (Dinosuchus terror Gervais) (4) tem sido

(1) Orville A. Derby. Nota sobre a geologia e paleontologia de Matto-Grosso. Archivos do Museu Nacional, vol. IX, p. 68. Rio de Janeiro, 1895.

(2) Orville A. Derby. Contribuicōes para a geologia do baixo Amazonas. Achivos do Museu Nacional, vol II. Rio de Janeiro, 1879.

0 artigo citado diz que provavelmente as camadas em questão nāo poderiam ser mais recentes do que o cretaceo por serem perturbadas. Mas a perturbação das camadas não tem nada com a idade geologica das rochas no Brasil e nas outras partes do mundo tão pouco.

(3) W. Chandless. Notes on the river Aquiry, the principal affluent of the river Purus. Journal of the Royal Georgraphical Society, vol XXXVII, p. 119. London, 1866.

(4) M. Paul Gervais. Crocodile gigantesque fossil au Bresil. Journal de Zoologie, vol. V. pp. 232-236. Paris, 1876. 
descripto do estado do Amazonas, mas não se sabe bem da lucalidide exacta, nem se pertence á cretacea ou á terciaria. Parece provavel ques os terrenos cretaceos serão encontrados occupando areas extensas nas regiões brasileiras proximas dos Andes.

\section{Periodo Cenozoico.}

Terciario. - 0 terciario foi dividido pelo geologo inglez Lyell, em eoceno, mioceno e plioceno conforme a percentagem de especies que ainda tem representantes na actualidade entre os seus molluscus fosseis. As camadas contendo entre os fusseis 50 a $90^{\circ}$ " de especies viventes são chamadas pliocenas; as com $30 \%$ sio chamadas miocenas e as com รั a $10 \%$ apenas são chamadas eocenas.

0 nome oligoceno é uma modificaęào importante proposta um pouco mais tarde por Beyrich (1) para incluir certos estratos anteriormente incluidos no eoceno superior e no mioceno inferior. Esta divisão é bem notavel na França, na Belgica, e na America do Norte, mas ainda não foi reconhecida como tal no Brasil.

A era terciaria é conhecida como a dos mammiferos, mas os mammiferos daquelle periodo estão todos extinctos. Alguns delles eram gigantescos. Abundaram as aves, e insectos, e entre as plantas as coniferas e palmeiras.

No Brasil as rochas terciarias cobrem uma zona estreita ao longo la costa desde as vizinhanças da Victoria no estado do Espirito Santu para o norte até o valle do Amazonas. Em diver'sos lugares esta zona i muito estreitada, ou mesmo completamente destruida. Em Ilhéos, por exemplo, não existem rochas terciarias na costa.

Porém na vizinhanęa de Marahú camadas terciarias de arenitos molles e com plantas fosseis sobrepoem-se ao cretaceo dos follhelhos hituminosos que contèm os peixes fosseis deseriptos por Dr. Smith-Windward. Ao norte de llhéos a zona continua estreita e quasi sem interrupção até ao valle do rio Amazonas.

(1) Monatsbericht. Akad. Berlin, 1854, 640-666. 


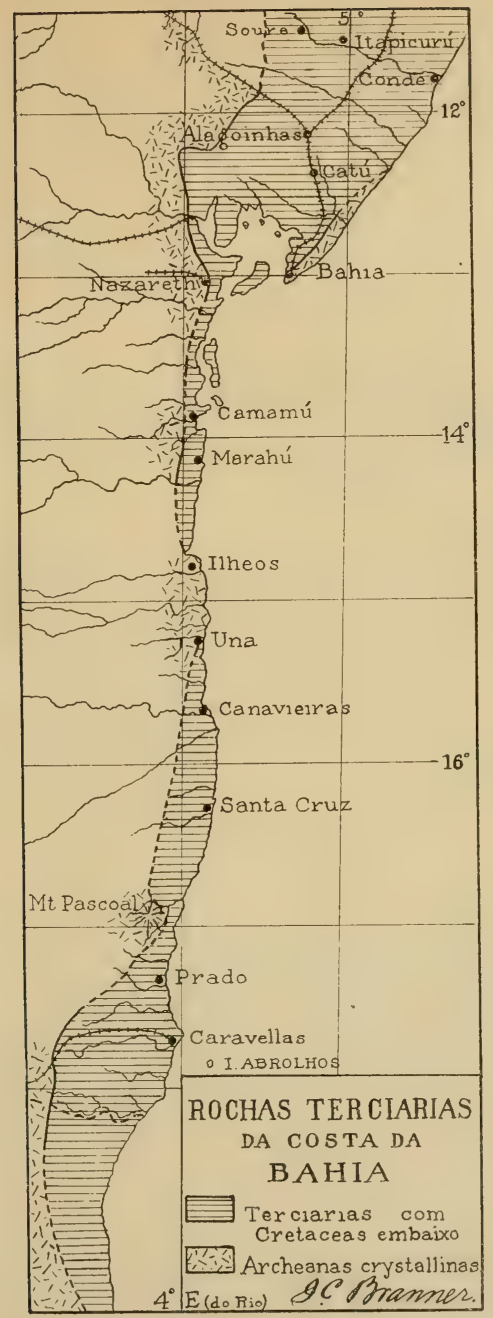

Fig. 16\%. - Mappa dos sedimentos terciarios da costa da Bahia e Espirito Santo. 
No Cabo Santo Agostinho e em Pedra do Porto logo ao sul de Tamandaré os sedimentos terciarios tèm sido removidos deixando expostas as rochas crystallinas subjacentes.

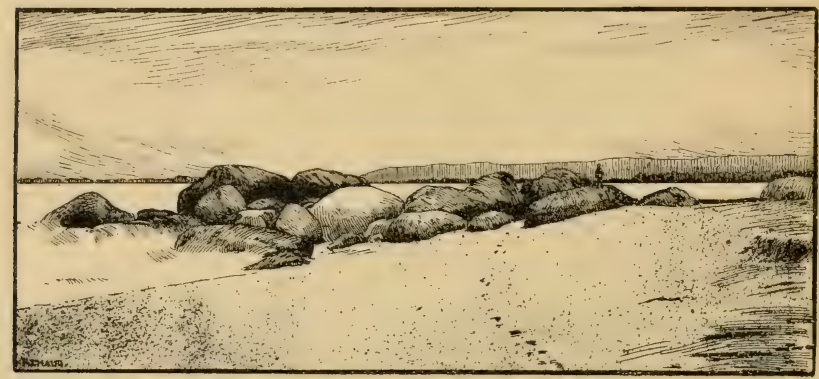

Fıg. 163. - Blocos de decomposição de granito na Pedra do Porto, de Pernambuco O granito acha-se exposto pela remoção dos sedimentos terciarios sobrejacentes

No sul do estado da Bahia esta zona fórma uma extensa chapada que elerando-se para o interior, penetra entre os picos de rochas crystallinas da Serra dos Aymorés e se estende até o kilometro 160 da eslrada de ferro Bahia e Minas como se vê na figura junta.

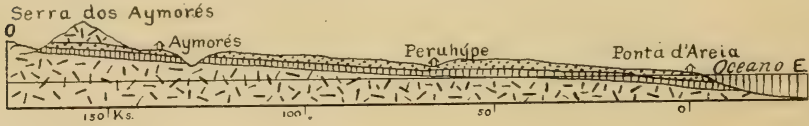

Fig. 164. - Seção atravez da parte meridional do estado da Bahia mostrando a extensão da chapada do littoral por uma garganta da Serra dos Aymorés.

$\Lambda$ distribuição desta zona sedimentaria sem descriminação da cretacea e terciaria e a sua relação com os terrenos crystallinos antigos em partes dos estados de Pernambuco, Parahyba e Rio Grande do Norte sĩo mostradas na figura 170, e as relações das suas camadas com as rochas subjacentes na vizinhanȩa da cidade de Maceió no Estado de Alagôas na figura junta á pagina 361 .

Em diversos lugares ao longo da costa de Alagôas, mas notavelmente num lugar chamado riacho Doce, uns doze para quinze kilome- 
tros au norte de Naceió, e em outros lugares mais ao norte chamados Garça Torta, morro do Camaragibe, porto de Pedras, barreira do Bo-

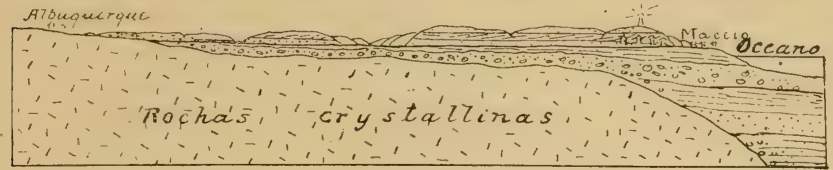

Fig. 165. - Secç̃o mostrando a relação dos sedimentos terciarios com as rochas crystallinas do interior em Maceió.

queirio, Pitingui e Japaratúba, as rochas èpostas nas praias e nos barrancos são follethos laminados e bituminosos e arenitos. Os folhe-
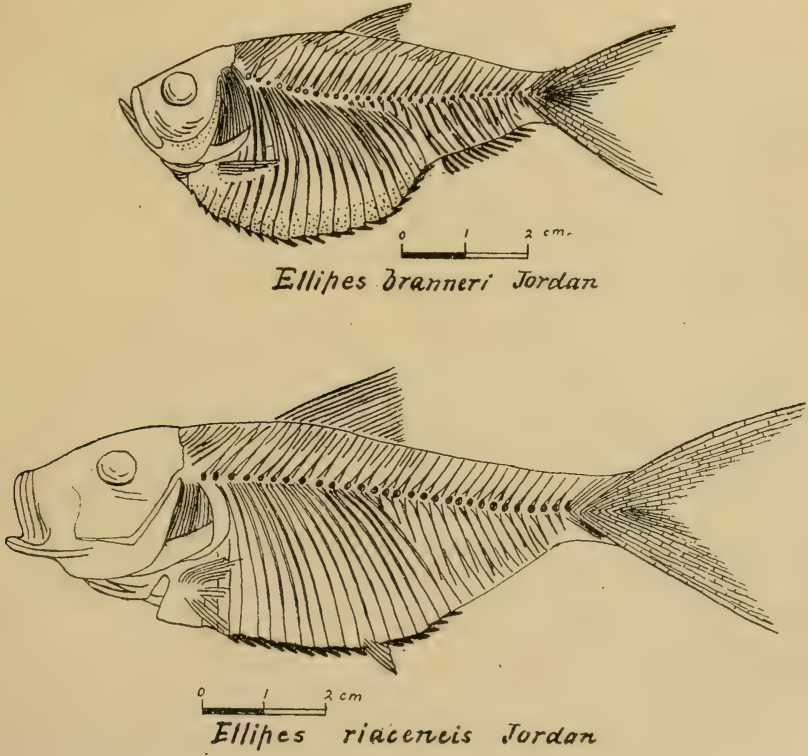

Fig. 166. - Peixes fosseis da idade eocena. Riacho Doce, Estado de Alagoas.

lhos contèm uma abundancia de peixes fosseis dos quatro generos seguintes : Ellipes (tres especies), Dastilbe (uma especie), Chiromystus 
(uma especie), e Arius ? (uma especie). Estas fórmas sà) caracteristi"as de estuarios ou de agua salobra. Esses fosseis mostram que as rochas são provavelmente eoceno terciario, mas que não é provavel que sejam cretaceo superior (1). Estes folhelhos tèn tambem ostracodas e plantas fossilisadas. Sô Estheria foi reconhecida, mas esta não adianta o que os peixes fosseis já ensinam. Os folhelhos bituminosos são bastante ricos em oleo mineral e parafina e tem-se feito diversas tentativas para exploral-os industrialmente (2).

Na primeira edição desta obra apparecem algumas duvidas a respeito da idade de certos depositos da costa oriental do Brasil. Estudos mais recentes resolveram essas duvidas, em parte pelo menos.

0 estudo de uma collecção de fosseis feita ultimamente da ilha de Trinidad ao norte de Venezuela (3) esclareceu as questões relativas á idade das camadas de Maria Farinha, Olinda, e ponta de Pedras. e de outras localidades no norte do Brasil, e indirectamente confirmou as conclusôes de Jordan a respeito dos depositos de Alagôas. Agora estí bem estabelecido que temos o eoceno nestes lugares e em muitos outros ao longo da costa do Brasil. Em alguns lugares as camadas eocenas jazem sobre as rochas crystallinas do interior, em outros sobre rochas sedimentarias da idade cretacea.

No estado de Pernambuco nas vizinhanças da ilha de Itamaracá e no rio Maria Farinha fronteiro a ella existe outra bacia maritima que se estende para o sul até a cidade de Olinda e au norte até Ponta de Pedras perto da fóz do rio Goyana e talvez mais longe (vède mappa na pag. 359). Entre as 76 especies de fosseis descriptas desta bacia pelo Dr. White súmente seis são identicas com as da bacia cretacea de Sergipe e o aspecto geral da fiuna se assemelha de tal maneira com o da idarle subsequente que diversos paleontologistas a tem referido á

(1) D. S. Jordan. Fossil fishes from the bituminous shales ut Riucho Doce, State of Alagôas, Brazil. Annals Carnergie Museum, VII, 1910, pp. 23-31.

(2) J. C. Branner. The oil bearing shales of the coast of Brazil. Transaction. Ameriean Institute Mining Engs, XXX, 537-55t. New York, 1900.

(3) Carlotta Joaquina Maury. A contribution to the paleontology of Trinidad. Journal Academy Natural. Science, Philadelphia, XV., pp. 32-33. Philadelphia, 1912. 
terciaria (1). A figura junta e as das paginas 364 e 36.5 representam alguns dos mais caracteristicos destes fosseis eocenos.

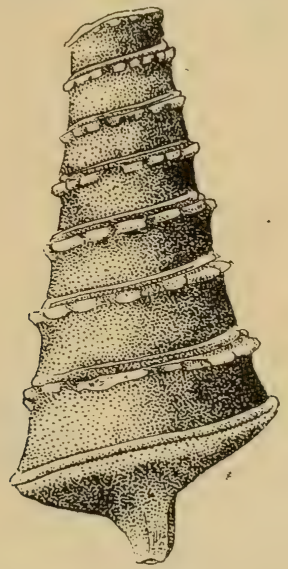

Fig. 167. - Nerined burrquiana, White. Vista lateral de um exemplar imperfeito, metade do tamanho natural. Maria Farinha, Pernambuco.

\section{EXPLIGACT̃O DAS FIGURAS DE FOSSEIS EOGENOS.}

97 a e b. Hercoglossa (Nautilus) sowerbyana D'Orbigny. Vista lateral e peripheral de um exemplar pequeno e imperfeito; tamanho natural. Maria Farinha, Pernambuco.

98 a e b. Volutilithes radula (Sowerby) Forbes. Duas vistas de um exemplar pequene; tamanho natural. Na figura $98 \mathrm{~b}$ o labio externo foi quebrado de modo a mostrar as duas dobras sobre a columella. Maria Farinha, Pernambuco.

98 c. Volutilithes radula (Sowerby) Forbes. Vista latéral de um outro exemplar imperfeito e parcialmente achatado; tamanho natural. Maria Farinha, Pernambuco.

99. Mazzalina (Fascioloria) acutispira White. Vista lateral de um exemplar cuja superficie natural foi um tanto corroida; tamanho natural. Maria Farinha, Pernambuco.

(1) John C. Branner. Geology of the northeast coast of Braxil. Bulletin of the Geological Society of America, vol. 13, 1902.

J. C. Branner. The oil-bearing shales of the coast of Brazil. Transactions the American Institute of Mining Engineers, vol. XXX, pags. 537.554. New York of 1900. 


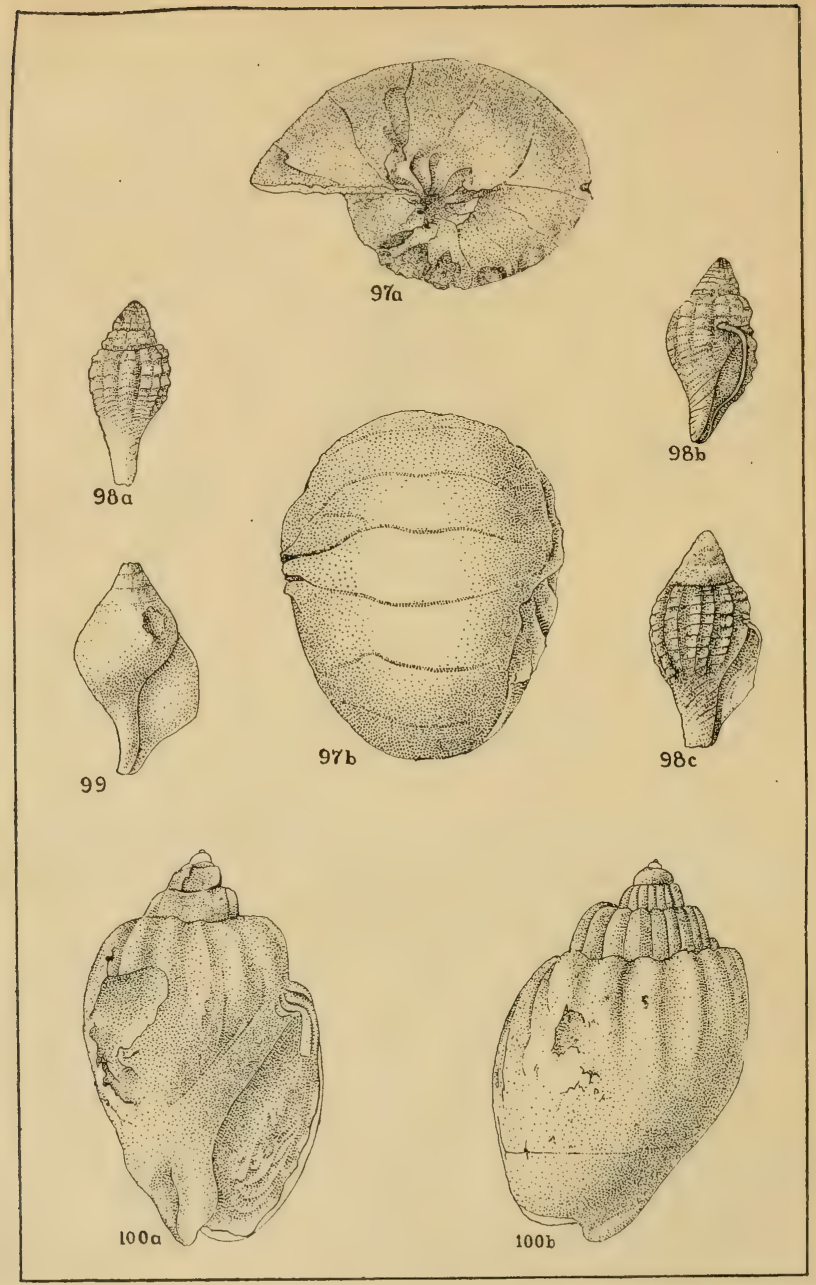

Fig. 168. - Fosseis caracteristicos das camadas eocenas de Maria Farinha, Pernambueo. 


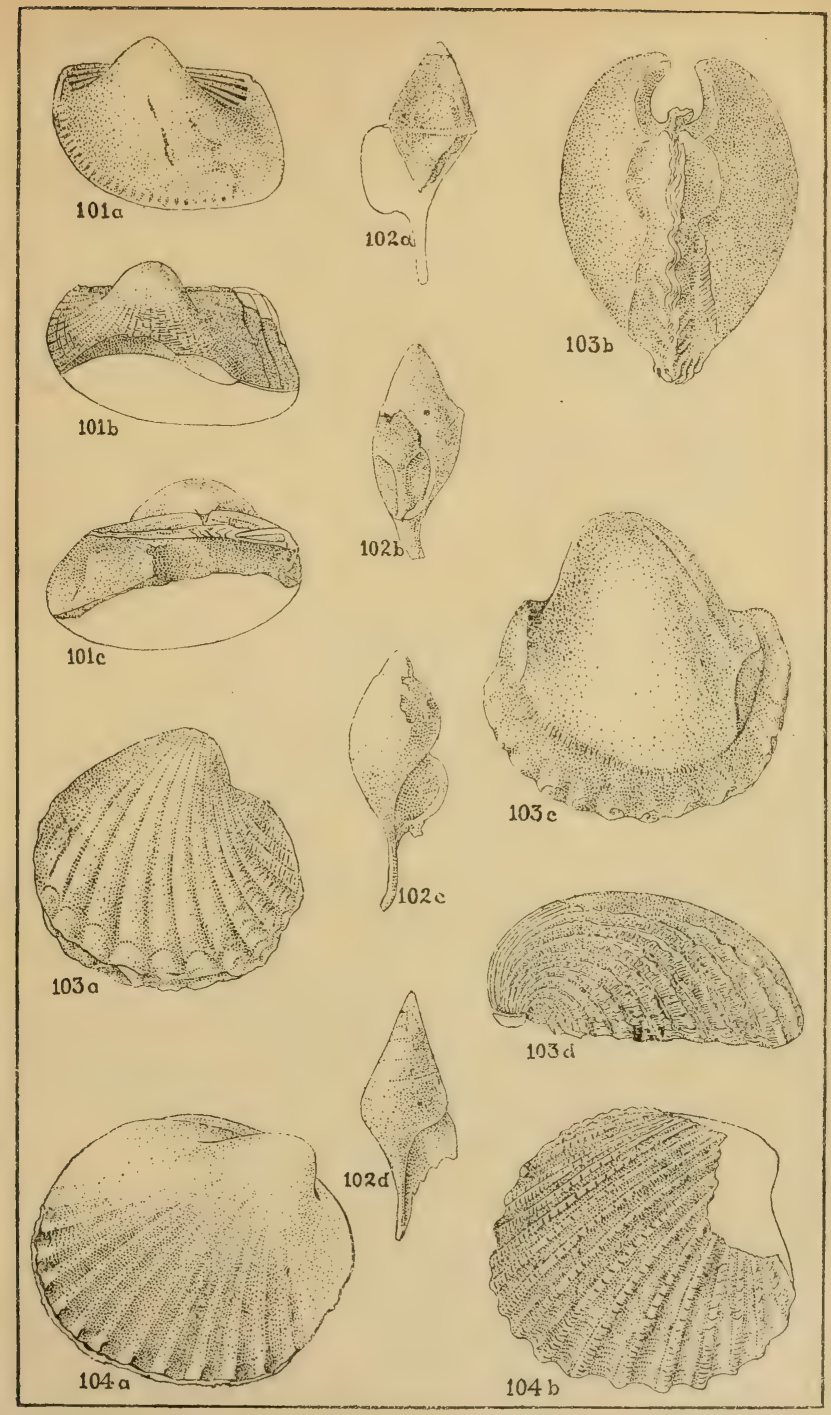

Fig. 169. - Fosseis caracteristicos das camadas eocenas de', Maria Farinha, Pernambuco. 
100 a e b. Pseudoliva (IIarpa) dechordata White. Visla lateral e de frente; tamanho natural. Maria Farinha, Pernambuco.

101 a. Culcullaxa harllii Rathbun. Molde natural do interior de uma valva esquerda; tamanho natural. Maria Farinha, Pernambuco.

101 b e c. Cucullaca harttii Rathbun. Duas vistas de uma impressão tirada de um molde natural em calcareo; tamanho natural. Maria Farinha, Pernambuco.

102 a. Calyptraphorus (?) chelonites White. Vista de um exemplar mostrando uma ruga annular de callosidade; tamanho natural. Maria Farinha, Pernambuco.

102 c. Calyptraphorus (?) chelonites White. Vista lateral de um exemplar mostrando o lado achatado da espira coberta com a callosidade; tamanho natural. Maria Farinha, Pernambuco.

102 d. Calyptraphorus (?) chelonites White. Vista lateral de uma concha que se suppunha pertencer a esta especie e representar um estado de crescimento anterior á deposição de uma callosidade sobre a superficie externa : tamanho natural. Maria Farinha, Pernambuco.

103 a. Venericardia (Cardita) morganiana Rathbun. Vista do lado direito de um exemplar de tamanho medio, cuja ornamentação tem sido casualmente removida da maior parte das costellas; tamanho natural. Naria Farinha, Pernambuco.

$103 \mathrm{~b}$ e c. Venericardia (Cardita) morganiana Rathbun. Vista de frente e do lado de um molde interno; tamanho natural. Maria Farinha, Pernambuco.

103 d. Venericardia (Cardita) mmganiana Rathbun. Vista de frente de uma impressão tirada de um molde natural de parte de uma valva esquerda mostrando as costellas e a sua ornamentação ; tamanho natural. Naria Farinha, Pernambuco.

104 a. Venericardia (Cardila) wilmotii Rathbum. Vista de uma impressão de uma valva direita: tamanho natural. Maria Farinha, Pernambuco.

104 b. Venericardia (Cardita) wilmotii Rathbun. Vista de uma impressão tirada de um molde natural da maior parte de uma valva direita mostrando as costellas e a sua ornamentação ; tamanho natural. Mlaria Farinha, Pernambuco.

Os vertebrados acham-se representados nas camadas de Maria Farinha e Itamaracá por um reptil, Hyposaurus derbianus Cope; por duas especies de tubarões, Galeocardo pristodontus Agassiz; e Apocopodon sericeus Cope, e uma do typo ordinario de peixes, Enchodus subaequilateris Cope (1).

No estado do Rio Grande do Norte calcareos fossiliferos se apre-

(1) E. D. Cope. Contribution to the vertebrate paleontology of Brazil. Procedings of the American Philosophical Society, vol. XXIII. Philadelphia, 1886. 
sentam em varios pontos ao longo da estrada de ferro que da capital se dirige para o sul a poucos kilometros da costa (vède mappa na

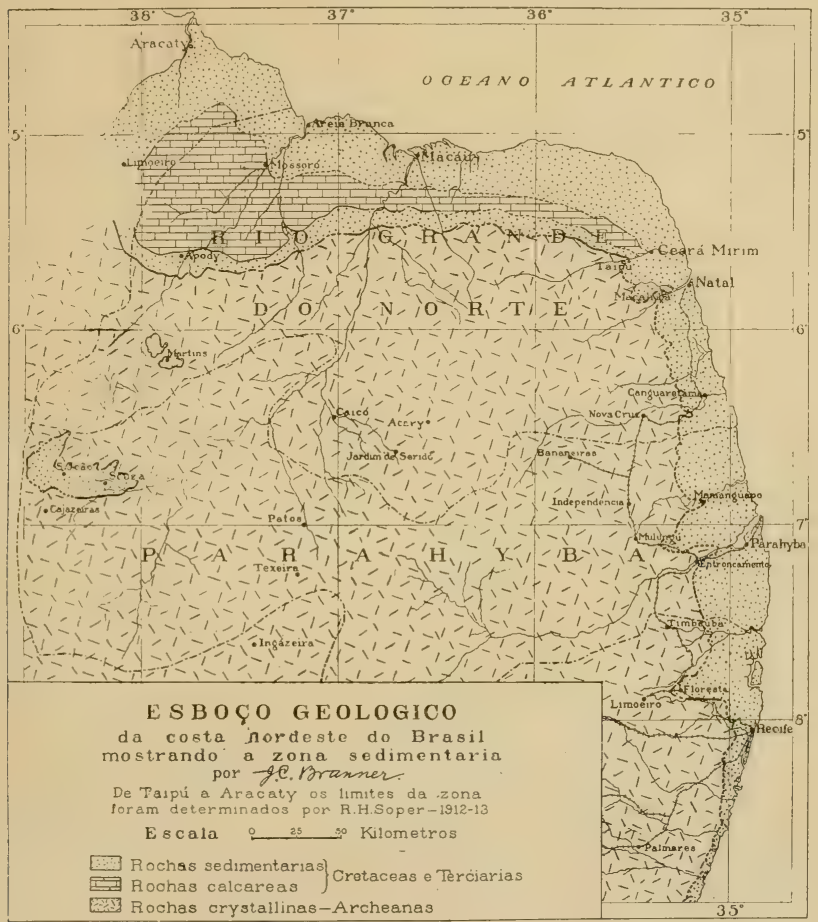

Fig. 170 .

pag. 367 ) e tambem no norte do Estado no valle do Rio Mossoró. A serra do Martins, um taboleiro alto no interior do estado de Rio Grande do Norte, com a altitude de mil metros, é de gneiss na

(1) John C. Branner. Geology of the northeast coast of Brazil. Bulletin of the Geological Society of America, vol. 13, pags. 41-98. Rochester, 1904. 
base, mas está sotoposta com quarenta e cinco metros de arenito que fórma o cume 'da montanha (1).

Em Nacau, estado do Rio Grande do Norte, poros furados pela Inspectoria de Obras contra as Seccas penetram as rochas sedimenta-

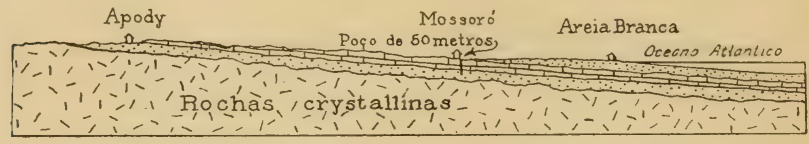

Fig. 171. - Secção mostrando a estructura geologica entre Apody e o ocemo. R. H. Soper.

rias mostrando camadas de arenito na flòr da terra com pedra calcarea em baixo e arenitos em baixo da pedra calcarea (Soper).

Ao nordoeste do Cabo S. Roque esta zona estreita de sedimentos terciarios se estende ao longo da costa do Ceará, Maranhão e Pará, e entrando pelo valle do Amazonas continua até e além da fronteira do Perú entre Tabatinga e Iquitos, estendendo-se tambem por alguma distancia ao sul no valle do rio Javary.

As rochas terciarias da costa consistem principalmente de arenitos e folhelhos de còres extremamente variegadas e geralmente tão molles que púdem antes ser chamadas de areias e argillas. Estas rochas jazem em camadas horizontaes que não têm sido muito perturbadas. Na região do alto Amazonas apresentam-se camadas de lignito intercaladas nas de argillas, e é possivel que uma parte dos folhelhos bituminosos e das rochas calcareas da costa do Atlantico que tèm sido referidas á cretacea pertençam á terciaria. Em Marahú no sul do estado da Bahia existe um deposito de uma substancia especial chamada " turfa " que contem cerca de oitenta por cento de materias bituminosas e que tem sido aproveitada para a extraç̧ão de oleos mineraes.

M. Eug. Bertrand, geologo francez, examinou amostras desta turfa e verificou que é composta de algas.

Em geral os depositos terciarios são polıres em fosseis sendo ter-

(1) Fé R. H. Soper. 


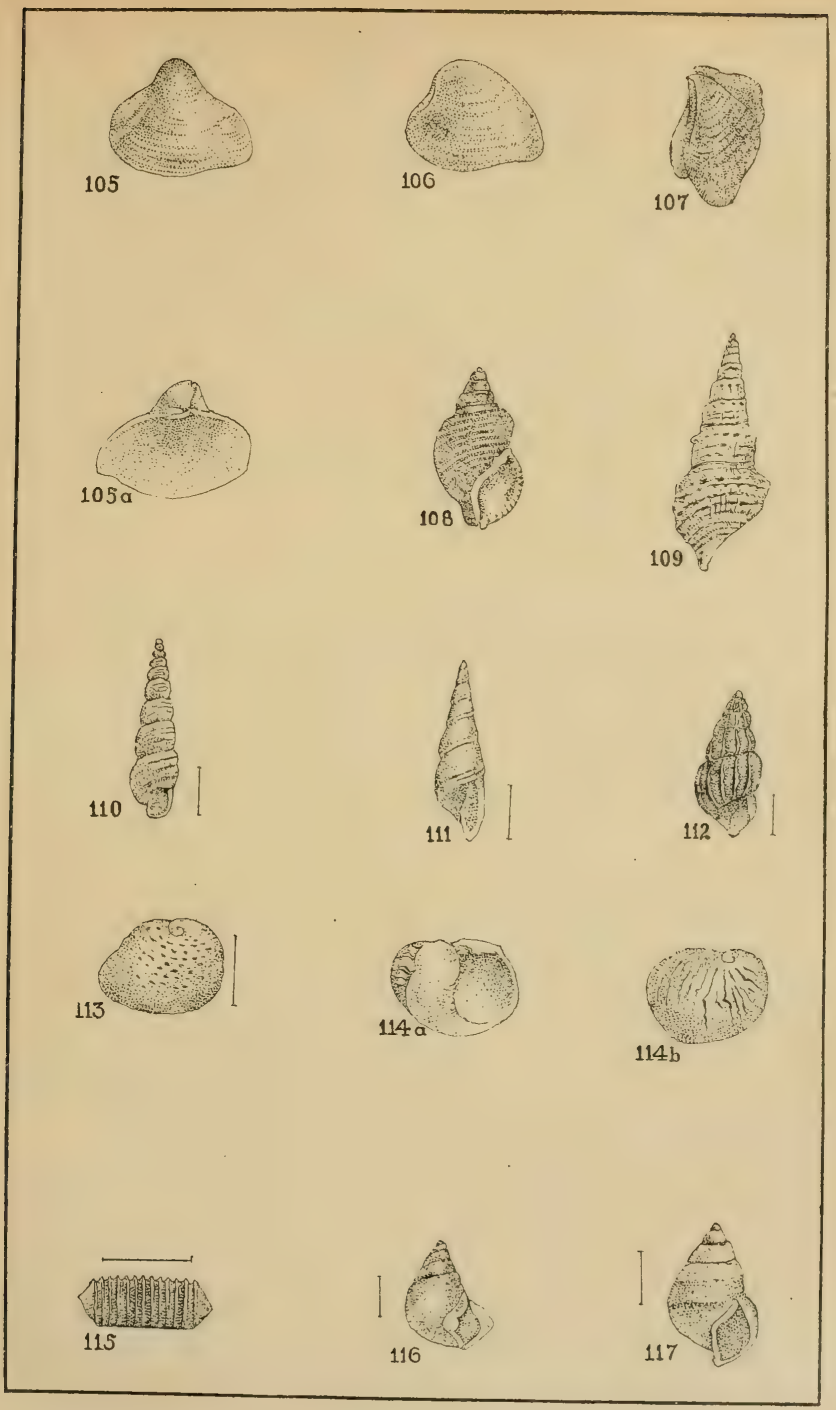

Fig. 172. - Fosseis caracteristicos das camadas terciarias do Alto-Amazonas. 
restres ou de agua doce, ou salobra, os poucos que se tem encontrado. A turfa de Marahú contem folhas de plantas dicotyledonias que tambem tèm sido encontradas em uma camada de argilla proxima á estação de Ouriçanguinhas na região de Alagoinhas no estado da Bahia (1).

As camadas que contèm as plantas fosseis perto de Ouriçanguinhas cobrem outra serie da camadas sedimentarias descordantemente. Parece provavel que a serie inferior pertença ao cretaceo da Bahia.

Na região do Alto Amazonas apresentam-se em diversas localidades depositos com molluscos de agua salobra indicativos de deposição em estuarios. Os de Canamá no rio Javary no estado do Amazonas são representados na pagina 369 (2).

\section{EXPLICACSTOO DAS FIGURAS DE FOSSEIS TERCIARIOS}

105 e 105 a. Corbula canamaensis Etheridge.

106. Anisothyris (Pachydon) tumida Etheridge.

107. Dreissena acuta Etheridge.

108. Melanopsis (?) brownii Etheridge.

109. Cerithium coronatum Etheridge.

110. Melania tricarinata Etheridge.

111. Melania bicarinata Etherídge.

112. Melania scalaroides Etheridge.

113. Neritina puncta Etheridge.

114. a e b. Neritina ziczac Etheridge.

115. Myliobatis sp. (placa de um dente palatal).

116. Pseudolacuna macroptera Bottg.

117. Hydrobia dubia Etheridge.

$\Lambda$ linha ao lado das figuras mostra o comprimento da amostra : as figuras sem linha são do tamanho naturai.

Sobre o rio Pauhinym, um affluente do rio Purus no alto Ama-

(1) Dr. F. Krasser. Konstantin von Ettingshausen's. Studien über die fossile flora oon Ouriçanga in Brasilien. Sitz. der K. Akad. d. Wiss. in Wien Math. Nat. Kl. Bd. CXII. Dez. 1903. (Abt. 1).

(2) R. Etheridge. Mollusca from the Tertiary deposits of Solimoses and Jaoary rivers, Braxil. Quarterly Journal of the Geological Society, vol. XXXV, pags. 82-88. London, 1879. 
zonas, (lescobriu-se um jacaré fossil (Gryposuchus jessei Gürich) que parece pertencer ao terciario ou mesmo ao quaternario.

Além dos depositos acina descriptos que fórmam uma especie de beirada da massa continental ao longo do littoral e da depressão amazonica, existem diversas bacias terciarias espalhadas sobre a superficie do planalto central. A mais bem conhecida e a mais extensa é a do valle do alto Parahyba no estado de S. Paulo que se estende desde Cachoeira até Jacarehy com o comprimento de cento e doze kilometros. Uma outra semelhante se apresenta no valle do Tieté em redor da cidade de S. Paulo estendendo-se desde Mogy das Cruzes até uns trinta kilometrus ao oeste da cidade de S. Paulo. Ha uma outra pequena tambem entre Rezende e Campo Bello no estado de Rio de Janeiro.

Os depositos mostram que estas areas fòram antigamente cobertas por' lagùas de agua doce. Na vizinhança da cidade de Taubaté na bacia do Parahyba existem folhelhos bituminosos terciarios que produzem cerca de cem litros de oleo por tonelada e que têm sido explorados para o fabrico de gaz e de oleos.

Os seguintes resultados de uma avaliação dos folhelhos de Taubaté forão obsequiosamente fornecidos pelo chimico, Dr. Guilherme Florence de S. Paulo.

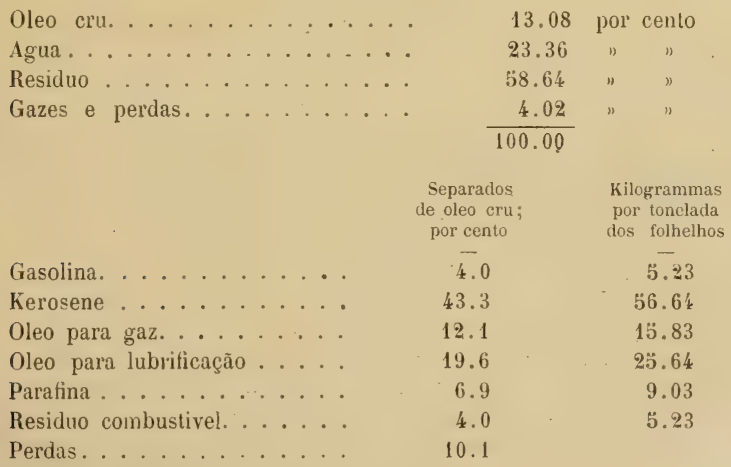

(1) G. Gurich. Griposuchus jessei... des oberen Amazonas-Gebietes. Jahrb. d. Hamburgischen Wiss. Anstalten XXIX, 1911, 59-71. Hamburg, 1912. 
Estes folhelhos contèm restos bem conservados de peixes de agua doce dos quaes se tem descripto as seguintes especies (1): Arius iheringi Woodward, Tetragonopterus avus Woodward, Tetragonopterus li!miticus Woodvard, e Percichthys antiquus Woodward.

No interior do estado de Minas Geraes existem outras bacias ter ciarias de agua doce contendo plantas fosseis e lignito. Uma destas acha-se em Gandarela a sessenta kilometros ao norte de Ouro Preto e ao pé da Serra do Caraça na elevação de mil e cem metros acima do nivel do mar. Uma outra acha-se perto do arraial de Fonseca cerca de quarenta kilometros distante da de Gandarela, estendendo-se desde a base da Serra da Caraça até o rio Piracicaba, aflluente do rio Doce. As plantas fosseis destas bacias mineiras mostram que a sua idade é pliocena ou miocena. As camadas incluem folhelhos bituminosos e lignitos que tèm sido aproveitados na Escola de Minas de Ouro Preto para o fabrico de gaz (2).

Segundo consta, existem outras bacias terciarias em outras partes do Brasil, mas por emquanto pouco se conhece a respeito do seu caracter e distribuição.

\section{Periodo psychozoico.}

\section{PLEISTOCENO OU QUATERNARIO}

Nas regióes temperadas do globo o pleistoceno foi caracterisado pela invasão do gelo que cobriu a maior parte da Europa septentrional e toda a parte septentrional da America do Norte. No Brasil não houve época glacial, se bem que se haja attrihuido á glaciaçào alguns dos phenomenos da decomposição das rochas (3).

(1) A. Smith Woodward. Considerạnes sobre alguns peixes terciarios dos schistos de Taubaté, estado de S. Paulo, Brasil. Reoista do Museu Paulista, vol. 3, pags. 63-75, S. Paulo, 1893.

(2) H. Gorceix. Bacias terciarias d'agua doce nos arredores de Ouro Preto. Annaes da Escola de Minas de Ouro Preto, vol. III, pags. 95-114. Rio de Janeiro, 1881.

(3) J. C. Branner. A supposta glaciaçäo do Brasil. Reoista Brasileira, vol. VI, pags. 106-113. Rio de Janeiro, 1896. 
Parece provavel que houvesse uma ligeira elevação do continente da America do Sul durante a idade pleistocena ou logo depois daquelle periodo. Esta theoria está sustentada pelos restos de animaes marinhos e pelas obras de animaes marinhos achadas fóra do alcance das marés actuaes.

Em roda da bahia de Todos os Santos existem muitos depositos de conchas marinhas com uma altitude de dois metros acima do mar. Ao longo do rio Itapicurú no estado da Bahia existem conchas marinhas em camadas de um metro de espessura entre Missão e Sipó, de cinco para oito metros acima do rio, e como o rio nesse lugar tem uma altitude de sessenta a cem metros acima do mar, é claro que houve ali uma elevação de sessenta a cem metros pelo menos. As conchas são todas de especies que ainda vivem na costa do Brasil, e por isso se conclue que a elevação teve lugar no periodo pleistoceno.

Durante o periodo pleistoceno o Brasil foi habitado por mammiferos gigantescos, taes como o Mastodonte, uma especie de elephante; Megiatherium, uma especie gigantesca de preguiça, e Glyptodonte, uma especie gigantesca de tatú, que são agora extinctos tanto no Brasil como nas outras partes do mundo. Os restos do Mastodonte tem sido encontrados em diversos lugares, notavelmente em redor de Aguas Bellas no estado de Pernambuco e no Ceará (1). Encontram-se geralmente em terrenos baixos ao fazer excavargòes para bebedouros de gado. Na bacia do Rio da Prata a formação que contem este fossil se chama Pampiana.

A figura 174 mostra a fórma de dois dos dentes molares do Mastodon (Dibilodon) humboldtii Cuvier, a especie que habitava o Brasil (2).

No Instituto Geographico e Historico da Bahia existem dois queixos com os dentes quebrados. Diz-se terem sido encontrados em Santa Luzia naquelle estado.

(1) J. C. Branner. The occurrence of fossil remains of mammals in the states of Pernambuco and Alagoas, Brazil. American Journal of Science, vol. XIII, pags. 133-137. New Haven, 1902.

(2) Paul Gervais. Recherches"sur les mammiféres fossiles de l'Amérique Méri. dionale, planche 5. Paris, 1855. 
Dr. Adolpho Diniz Gonçalves da Bahia tem dentes e ossos de mastodonte que vèm de Monte-Alto, comarca de Urubú, estado da Bahia, perto do rio S. Franciseo.

0 museu nacional do Rio de Janeiro tem restos de mastodontes do Ceará, e de Sergipe; um dente do de Sergipe tem o comprimento de um metro. A localidade onde forram achados estes fosseis no estado de Sergipe se chama lagôa dos Elephantes.

Ultimamente (1913), restos de mastodonte foram achados em Limoeiro no estado de Ceará.

0 museu nacional tambem tem o craneo e queixo inferior do

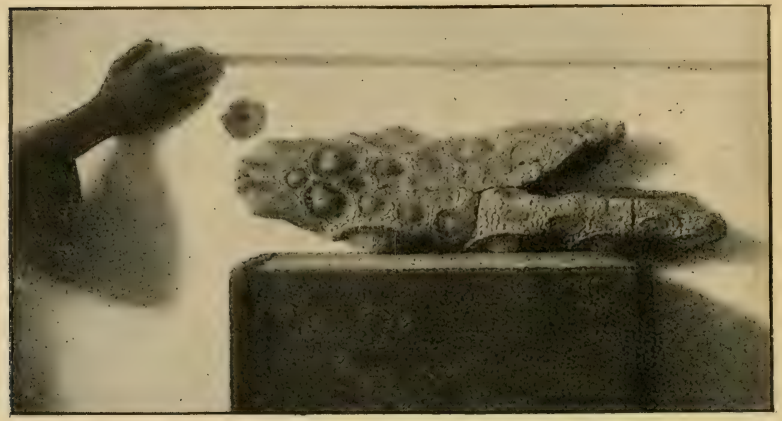

Fig. 173. - Parte do rabo de Panochtus, uma especie de Glyptodonte descoberto no Riacho do Sangue, estado de Ceará. A amostra está no museu Rocha, na cidade de Fortaleza, Ceará.

Megatherio achado por Sr. Carlos Schreiner na fazenda Catinga de Moura uns cincoenta kilometros ao oeste de Jacobina no estado da Bahia. Aquelle museu tambem tem montado uma amostra completa e bem conservada, do animal proveniente de Catinga de Moura .

Restos do Glyptodonte são conservados no museu nacional e nas collecções do Serviço Geologico no Rio de Janeiro. No museu Rocha no Ceará ha um exemplar de Glyptodonte descoberto no riacho do Singue naquelle mesmo estado; este ultimo parece ser um Panochtus de uma especie differente do tuberculatus. Outra amostra desta ultima especie 
vendo de Quixeramobim, Ceará, está nas collecções do Serviço Geologico no Rio de Janeiro.

Nas vizinhanças da Lagôa Santa na região do Rio das Velhas no estado de Minas Geraes o naturalista dinamarquez Lund achou em cavernas e poços grande numero de fosseis da idade pleistocena. Entre
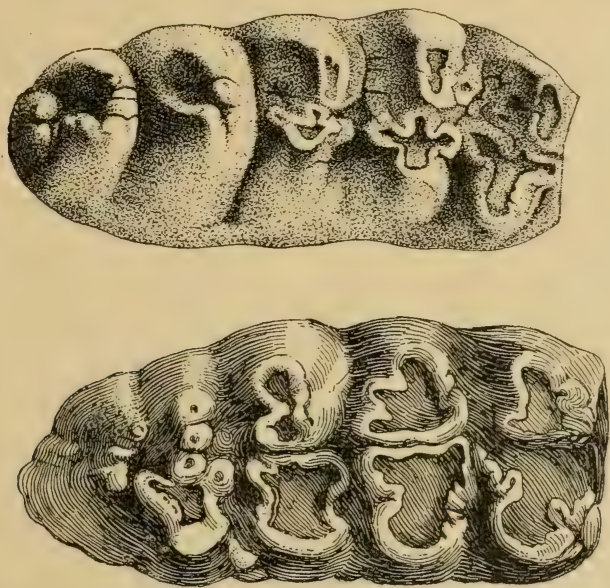

Fig. 17. - Sexto dente molar (superior e inferior) de Mastodon humboldtii, do Brasil. Reduzidos a um terço do tamanho natural. (Geroais.)

estes acham-se representados os seguintes generos extinctos: Tox'orlon, Macriuchenia, Glyptodon, Mylodon, Megatherium e Protopithecus. Misturados com estes restos encontram-se instrumentos de pedra e Lund chegou á conclusão que o homem era contemporaneo com estes animaes na America do Sul.

0 professor Reinhardt de Copenhague que tomou conta das colleç̧ões feitas por Lund dá o seguinte summario das conclusões que se derivam do seu trabalho (1).

1. No tempo pleistoceno o Brasil foi habitado por uma fauna mam-

(1) Reinhardt. Bone caves in Brazil and their animal remains. American Journal of Science, vol. XCVI, pags. 264-265. New Haven, 1868. 
mifera muito rica, da qual se póde dizer ser a fauna actual apenas um resto pequeno ou definhado, visto que muitos generos e até grandes grupos systematicos, taes como familias e ordens, tèm desapparecido e muito poucos apenas tèm continuado a existir até nossos dias.

2. A fauna mammifera brasileira durante o tempo pleistoceno apresentou a mesma feição especial que actualmente distingue a fauna sul-americana da do Velho Mundo, visto que os generos extinctos pertencem a familias e grupos que ainda hoje caracterisam particularmente a America do Sul. Sómente dois destes generos (um extincto, o Mastodonte, e o outro ainda vivo: o cavallo) pertencem a familias que sio hoje limitados ao hemispherio oriental, e assim fórmam excepção á regra.

3. As ordens mammiferas não eram, antigamente, em muito, mais ricas em generos de que agora. Os ruminantes, pachydermes, elephantes e carnivoros tèm soffrido a maior perda ; ao passo que algumas crdens, taes como os cheiropteros e macacos, contèm, talvez, mais generos hoje de que antigamente.

4. Na America do Sul a fauna mammifera pleistocena era mais distincta da actual, e era mais especialmente rica em generos peculiares e agora extinctos do que era o caso com a fauna correspondente do Velho Mundo.

ร. $\Lambda$ pobreza em grandes animaes (quasi se póde dizer o caracter anão da fauna mammifera sul-americana de nossos dias em comparação com os mammiferos do hemispherio oriental), era muito menos saliente, ou antes não existia de todo na fauna prehistorica. Os Mastodontes, Ilacrauchenias, Toxodontes, com os gigantescos tatús e preguiças bem podiam competir cum os Elephantes, Rhinocerontes e Hippopotamos que neste tempo habitavam a Europa.

Una especie de zebra, Esquus lundi Boas, habitava os campos de Minas Geraes durante os tempos pleistocenos. Esta zebra é uma fórma intermediaria entre o genero extincto Hipparion e o moderno Caballus (1).

(1) Dr. J. E. V. Boas. Om en fossil Zebra-form fra Brasilicus Campos. Copenhague, 1881 . 
Uma collecção de ossos de mammiferos feita por Ricardo Krone nas cavernas do rio Iporanga no estado de S. Paulo mostra que a fauna daquellas cavernas é mais recente que a parte superior da formação pampeana de Argentina. Dr. Ameghino quem descreveu a collecção conclue que no Brasil, como na Europa e na America do Norte, a fauna das cavernas é quaternaria (1).

O homem primitivo. Foi durante os tempos pleistocenos, ou talvez um tanto mais cedo, que o homem appareceu sobre a terra. Parece provavel que o seu primeiro apparecimento fosse n'um paiz tropical onde o clima era brando e onde se encontravam fructas durante todo 0 anno; e tambem parece provavel que viveu primeiro nas costas do mar onde os peixes, molluscos, crustaceos, etc., sempre se obtèm facilmente para a alimentação. Estes, porém, são assumptos hypotheticos. A evidencia geologica da existencia do homem consiste em :

I. - Obras conservadas.

II. - Restos de esqueletos conservados.

De vez em quando consta a descoberta de pegadas em rochas mais antigas do que as pleistocenas, porém até agora nenhuma dellas tem authenticidade provada.

Tèm apparecido artigos sobre o homem primitivo dizendo que ha provas da origem delle na America do Sul. Ultimamente essa questão foi estudada cuidadosamente com o resultado de que não se achou prova alguma da origem remota de homem primitivo na America do Sul (2).

OS restos humanos mais antigos descobertos no Brasil fòram achados nas cavernas de Lagòa-Santa no estado de Minas Geraes por P. W. Lund, o bem conhecido explorador dinemarquez, entre $183 \check{\text { e }}$ 1844. Mas infelizmente nảo foi possivel determinar com exactidão a idade geologica da formação em que esses restos fòram descobertos. Lund chegou á seguinte conclusão geral, depois de muitos annos de estudos dos restos das cavernas do Brasil :

(1) F. Ameghino. Reoista do Museu Paulista, VII, 59-124. S. Paulo, 1907.

(*) A. Hrdlicka. Early man in America. American Journ. Science, vol. 184, 534.554 ; Bul. 52 Bureau of American Ethnology. Washington, 1912. 
1. " $\Lambda$ occupação da America do Sul por homem extende-se, não somente além da epocha da descoberta desta parte do mundo, porém remotamente na epocha historica (isto é no tempo historico em geral) e, provavelmente dentro dos tempos geologicos. Certo numero de especies de animaes tèm desapparecido do mundo, depois do apparecimento do homem nesta hemispheria ».

2. "A raça que occupou esta parte do mundo na antiguidade remota era do mesmo typo que aquella que habitou o paiz na epocha do descobrimento pelos Europeos »(1).

Hrdlicka, depois de estudar os dados de Lund e de outros, conclue que « é claro que os restos humanos da Lagôa-Santa não podem ser acceitos, sem mais concludentes provas, como pertencentes a uma raça contemporanea com os animaes extinctos achados nas mesmas cavernas ».

Reliquias humanas. - As reliquias, ou obras humanas, que se encontram conservadas consistem de instrumentos de pedra, taes como pontas de flechas, pontas de lança, pedras lascadas, machados de pedra, mãos de pilão, almofarizes, gravuras sobre ossos e rochas, instrumentos de osso e concha, louça, estructuras de pedra, e ossos humanos. Estas reliquias se encontram de vez em quando:

I. - Em cavernas. A caveira de Enghis com os ossos correspon-. dentes foram encontrados n’uma caverna perto de Liége na Belgica, associados com restos de animaes extinctos. No sudoeste da França fòram encontradas n'uma caverna figuras gravadas do elephante gigantesco, ou Mamouth.

II. - Em turfeiras.

III. - Em depositos lacustres e fluviaes. Nas operaçōes da drena-

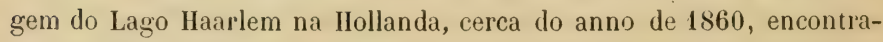
ram-se muitas reliquias humanas.

IV. - Nos depositos glaciaes.

V. - Em montes de conchas. 0 que no Brasil se chama samba-

(1) A. Hrdlicka. Early man in South Amertca. Bulletin 52, Bureau of American Ethnology. Washington, 1912, pags: 153-184. 
quis são montes de conchas accumulados perto das costas do mar pelos homens que empregaram os molluscos para alimentação, jogando fóra nestes montes as conchas. Encotram-se frequentemente instrumentos de pedras e ossos humanos enterrados nestes grandes montes de conchas (1).

VI. - Em montes funerarios ou cemiterios. Muitas raças primitivas enterraram os seus mortos em grandes potes ou urnas feitas de barro queimado ajuntando, muitas vezes instrumentos de pedra e osso. Na ilha de Marajó existem alguns dos mais notaveis montes funerarios conhecidos (2).

\section{A extensảo do tempo geologico.}

Não se póde dar com precisão em annos o comprimento do tempo geologico. Muitas estimativas baseadas em dados muito diversos tem sido feitas.

A marcha da recessĩo da cataracta de Niagara tem sido utilizada em tentativas para determinar a extensão de tempo depois da épocha glacial na America do Norte. Empregando no calculo a marcha actual, chega-se á conclusão que a excavação do cañon actual teria exigido cerca de 7.000 annos a datar da retirada do gelo daquella regiǎo. No estudo da recessão do salto de Santo Antonio no rio Mississippi chegouse a resultados proximamente eguaes.

A marcha da erosão e da deposição determinada por observaçùes sobre os grandes cursos d'agua, combinadas com as relações conhecidas entre terra e agua e a espessura dos sedimentos, dá cerca de cento e trinta milhões de annos para a idade da terra a datar do fim dos tempos archeanos (3).

Imaginando que a terra era originalmente uma massa fundida, e

(1) Alberto Löfgren. Os sambaguis de S. Paulo. Boletim da Commissão Geographica e Geologica de S. Paulo, n. 9. S. Paulo, 1893.

(2) Ch. F. Hartt. Contribuiçoes para a ethnologia do oalle do Amazonas. Archivos do Museu Nacional, vol. VI, pags. 1-174. Rio de Janeiro, 1885.

(3) Nature, vol. LI, pags. 533.507, London, 1895. 
calculando o tempo necessario para o resfriamento de um tal globo, chegou-se á conclusãu que a idade da terra é cerca de vinte e quatro milhões de annos.

Outras estimativas tim sido baseadas sobre a marcha de crescimento de coraes e calcareos; sobre a somma total de sodio nos oceanos do mundo; sobre a formação de mineraes radio-activos, etc., etc. Estas estimativas da idade geologica do mundo variam extraordinariamente entre si, desde o minino de tres milhões de annos até o maximo de dois mil e quatrocentos milhões. A unica conclusão satisfactoria é que " 0 tempo é tão comprido quanto o espaço é largo. " 


\section{INDICE ALPHABETICO}

A

Abrolhos........... 70

— variação das mares. . . . . 67

- recifes de coral. . . . . . . 188

- ilha de Santa Barbara. . . . 223

- rochas cretaceas. . . . . . 341

Abaixamento da costa do Brasil. 164

— da crosta da terra. . . . . . 164

Abreu (caverna). . . . . . . . 114

Acanaladuras. . . . . . . . 51

Acidos :

— carbonico ......... 104

- humico. . . . . ..... 171

- nitrico. . . . . . . . 105

- organicos. . . . 106, 171, 173

Actividade vulcanica. . . . . 134

Afloramentos . . . . 242, 246

Agassiz (Alexandre), 27, 157, 177, 200 Agatha, formação no Brasil. . . 238

- nas rochas triassicas. ... . 333

Agentes :

- aquosos mechanicos. 44, 63, 65

- chimicos. . . . . . 20, 103, 128

- constructivos. . . . . . 78, 179

- desnudadores. . . . . . . 145

- destructivos. . . . . . . 171

- geologicos. . . . . . . 20

- igneos. . . . . . . . 20, 128

- mechanicos.

20
Agentes :

- organicos. . . 20, 171, 179

- protectivos. ....... 176

Agnotozoico (periodo) . . . . . 287

Agua Quente. . . . 133, 217, 268

Agua Suja. . . . . . . . . . 336

Aguas :

- alcalinas. ......... 125

- carbonatadas. . . . . . . 117

- dos geysers. . . . . . . . 147

- meteoricas. . . . . . . . . 148

- mineraes. . . . . . . . . 276

- mortas. ......... . 67

- quentes. . . . 126, 129, 268

- sulphurosas. . . . . . . . 185

- subterraneas . . . 104, 269, 272

- vivas. . . . . . . . . . 67

Ajustamento da crosta da terra. 169 Alaska, geleiros em .... 91, 99

- terremotos em. ........ 151

Alagôas :

- costa das. . . . . . . . 200

- gneissem. . . . . . . . 290

- lagos de....... 84, 164

- rochas metamorphicas em. . 294

- seç̧ão geologica. . . . . 360

Alcali. . . . . . . . . . . . 37

Algas (accumulações de), 177,183, 186

- calcareas. . . . . . . . 187

- silicosas . . . . . . . 202 
Allemanha :

- geleiros antigos em. .....

- augumento de temperatura subterranea.

- depositos de sal.

Alluvióes auriferas .

Almeirim. 111,271

Altas temperaturas. $296, \quad 302$

Alteração das rochas. 126,

Alternação das camadas.

Altura das montanhas.

Amazonas (Estado).

Amazonas (rio) :

- terras cahidas.

49

- mares.

— sedimento. $80, \quad 107$

— vegetação marginal.

- turfa.

- rochas

- rochas silurianas. 295 ,

- rochas devonianas. 301 ,

- rochas carboniferas.

- rochas triassicas.

- rochas cretaceas.

- rochas terciarias.

$$
\text { . . . 341, }
$$$$
358 \text {, }
$$

America do Sul :

- geleiros. 91,97,

- volcũes.

- geysers. 141

- terremotos. 147

- animaes. 154

- rochas archeanas ... 289,

- fauna mammifera antiga. . .

- amphibios fosseis, 301, 313,

Andes:

- leques de alluvião. . . . . . .

- geleiros.

- cavernas de lava.

- picos.

- terrenos cretaceos.
Andesito.

221

Animaes :

- calcareos. . . . . . . . 201

- cavadores. . . . . . . . 173

- constructivos. . . . . 179, 18\%

- domesticados. . . . . . . . 20.

- distribuiçũo. . . . . . 21, 166

- fosseis ......... 16ti

- microscopicos. . . . . . 200

- radiados. . . . . . . . 202

- como agentes geologicos, 173,176

- marinhos. . . . . . 200, 202

Anthracite. . . . . . . 183

Antilhas. . . . . . . . 143, 169

Anticlinos. . . . . . 242, 217

Apatite. . . . . . . . 288, 293

Aquecimento, diario...... 131

- das rochas. . . . . . . . 169

Aquiry (rio). . . . . . . 357

Araguary (rio) . . . . . . . .

Araguaya $($ rio) . . . . . . 335

Archeano. . . . . . 286, 287

Arcos naturaes. . . . . . 116

Ardosia. . . . 208, 234, 258, 261

Areia. . . . . . . . . . 208

- transportada pelo vento... 21

- cortante ......... 26

- volante......... 26

- aeoleana. ......... 202

Arenito :

- salitroso. . . . . . . 38

- de Fernando de Noronha, 28, 217

— definição. . . . . . . . . 208

- transformação. . . . . . 258

- formação. ........ 283

Argilla. . . . . . . . . 208

- formação de. . . . . . . 28:3

- refractaria. ......... 31:3

Argentina :

358 - tempestades de areia. .... 21 
Argentina :

- efflorescencia de sal .... 38

- leques de alluvião. . . . . . . 63

— aguas salobras. . . . . . 123

- rochas jurassicas . . . . 338

Arkansas :

- espessura dosedimentos, 167, 313

- (rio).......... 56

Arrastamento. . . . . . . 243

Arroio dos Ratos. . . . 319, 322

Arvores fosseis. . . . 162, 182, 184

Asia :

- rochas da.

- volcões.

Atmosphera :

- trabalho directo...... 20

— acção directa. . . . . . . 20

- indirecta. . . . . . . . . 28

- retardamento. . . . . . 41

- como carregador. . . . . . 42

Atolls. . . . . . . . 195, 196

Atterrados naturaes . . . . . 60

Australia :

- glaciação antiga. . . . . . . 101

- recifes. . . . . . 164, 188, 191

- ligações continentaes. . . . 166

- plantas. ......... 204

- flora fossil. . . . . . . 328

Austria-Hungria :

- glaciação. . . . . . . . 9. 97, 99

Avalanches de lama...... 181

Aveiros ........... . 313

Aves fosseis. . . . . 337, 341, 358

Azeviche. . . . . . . . 351

Azoico.
B

Bacterias. . . . . . 185, 186

Bahia (cidade) :

- mares. . . . . . . . . 67

- acido carbonico. . . . . 105

— acido nitrico. . . . . . 105

—. synclino . . . . . . . 242

- fosseis. ....... . 351, 352

Bahia (Estado) :

- rios. . . . . . . . 55

- grutas. . . . . . . . . 114

- recifes...... 191, 192, $21 \%$

- rochas archeanas. . . . . 290

- região diamantifera. . . . . . 336

- rochas cretaceas . . . . . . 346

- rochas jurassicas. ..... 337

- turfa .......... 368

Bahia :

- de Fundy. . . . . . . . . 67, 162

— de Hudson. . . . . . . . . . . 99

- do Rio de Janeiro. . . . . . 161

- de Santos. . . . . . . . 161

- de Todos os Santos. . . . . 351

Bahias. . . . . . . . . 164

Bancos de areia...... 61, 84

- submarinhos. . . . . . . 84

Barbosa Rodrigues (J). . . . . 297

Barcélona. . . . . . . . 124

Baroneza. ........... 177

Barras. . . . . . . . 61, 83

Barreiras. . . . . . . . 40, 193

Barreto, Barros de. . 7, 62, 208, 218

Basalto. . . . . 221, 335, 336

Batrachio fossil. . . . . . . 327

Betas. . . . . . . . . 262

Bibliographia. ....... . . 6

287 Bioxido de carbono. . . . 104, 117 
Blocos.

50

- de decomposição, 29, 31, 32, 360

- erraticos. ..... .93, 100, 321

- glaciaes. . . . . . 95, 100

Bocca de Mississippi, 85, 167, 169

Bolsas de rocha fundida. . . . . 129

Bombas vulcanicas. . . . . . 138

Bom Jesus da Lapa. . . . 114, 297

Borax. . . . . . . 121, 125

Batucatú. . . . . . . . 143, 335

Boubee.

Brachiopodes fosseis, 282294 , 295, 300, 301, 303, 309, 312, 314.

331

Brejo das Freiras. . . . . . . . 149

Breccia. . . . . . . . . . 209

Bryozoarios fosseis, 295, 302,312, 316

\section{C}

Cabo :

- Frio. . . . . 68, 144, 336

- do Norte. . . . . . . . . 71

- São Roque, 41, 67, 122, 188, 368

- Santo Agostinho, 143, 159, 219.

360

Cachoeira, de Paulo Affonso. . 57

— de Vira Mundo. . . . . . . 296

Cal. . . . . . . . . . . . 201

Calcareo ...... 187, 208, 283

— derivado de coral. . . . . . . 199

- derivado de varios animaes 200.

- transformado em dolomite.

- archeano.

- de S. Francisco.

- hydraulico.

- carbonifero.

- no Amazonas. . . . . . . . . . 313

- permiano.....318, 319, 322

- triassico. . . . . . . . . 336

- cretaceo. . . . . 165, 347,
Calcedonia.

$120, \quad 333$

Caldeiröes.

5)

Caldas (serra de). . . . . . 141

Calor (producção de). . . . . . 258

Camadas :

- levantadas. . . . . . . . 134

- erodidas. . . . . . . . . 161

- de argilla. . . . . . . . 182

— de carvão. . . . . . . . 162, 182

— de lignito. . . . . . . . 182

- calcareas. .......... 199

— saliferas. . . . . . 357

- sedimentarias. . . . . . 167

- sobrepostas. . . . . . . . 134

- cretaceas. ......... 353

- devonianas. ......... 335

- triassicas. . . . . . . . 334

Camarões. . . . . . . . . . 175

Cambriano. . . . . . 286, 29.1

Campos (Gonzaga de), 159, 254, $323,342 \ldots \ldots \ldots \ldots$

Canaes subterraneos. . . 139, 148

— submergidos. . . . . . 165

Canga. . . . . . . . 216

Cañon do Rio Colorado. . . . 57

-- do rio S. Francisco. . . . . 5 5 r

Caracteres lithologicos. . . . . 283

Caranguejos. . . . . . 175, 347

Carbono. . . . . . . 104, 180, 184

Carbonato :

- de cal, 119, 123, 187, $189,216,236$

- de ferro......... 185

- de magnesia. . . . . . . . 189

Carbonatos. . . . . . . 106

Carbonifero. . . . . . 312, 318

Carnivoros fosseis. . . . . 276

Carvão, 162, 163, 183, 284, 312, 314

- abaixo do mar. . . . . . . . 163

- pardo.......... 181

- bituminoso. . . . . . . 182 
Carvão anthracito

183

- no sul do Brasil.

319

- cretaceo.

322

Cascalho. $208,2 \% 0, \quad 271$

('ascalhão 208

Cascatas de rocha. $11 \%$

Catinga de Moura. 114

Caucaso.

Cavallo fossil. $3 \approx 6$

Cavernas, 112, 115, 272, 282, 375, 378

- de S. Diego.

Caxoeiras

Cayambe

137

Ceará (cidade)

105

Ceará (Estado) :

...- dunas.

- correntes da costa

- rios.

- recifes 217

- rochas . 290, 293, 294, 353,

Cenozoico

Centopeias fosseis

Centro da terra.

Cephalopodes fosseis, 294, 301, $331,337,313,347$

368

358

295

130

Chapada (villa) . . . . 311, 335

Chapadas. . . 3 353, 356, 357 ,

Cheiropteros fosseis.

Chile :

- efflorescencia de sal.

- geleiros ......... 100

- nitro.......... 121

— mudanças de nivel. . . . . 169

Chumbo.......... 2. 295

Chuva.

45

- no Brasil 101

- de lama

- em S. Paulo

- de cinzas 138

- trabalho mechanico

45
Cinzas calvunicas, 25, 135, 318, $139,208,225$.

Clarke (J. M), 29, 296, 300, 302, 305,307

Clarke (F. W)

Clivagem 233

Clima . $88, \quad 129$

Coal Measures 286 ,

312

Coke. 259

Colombia :

- erosão . .

- geleiros 100

- geysers. $147, \quad 148$

Columna geologica. . . . 283, 286

Columnas basalticas... 141, 227

Complexo brasileiro . . . . . 289

Comprimento do tempo. . . . 379

Concentração da agua . . . . 122

Conchas em lava. . . . . . 139

Concepcion......... 99, 169

C'oncreções . . . . 236-238, 353

Conductibilidade das rochas, 132, 151

Cones:

- de alluvião ......... 63

- de lava........... 224

- vulcanicos ........ 140, 141

Conformidade......210, 211

Congelação . . . . . . . . 99 90

Conglomerados, 208, 215, 272, 283, 313 ............ 351

Coniferas fosseis, 313,319 , 322, 324.

358

Contracção, 169, 228. . . . . 261

Cope, (E. D.) . . . . . 35̌2, 366

Cor das rochas........ 283

Cores nos mappas . . . . . . 287

Coraes... 162, 164, 187-197, 281

- condições de crescimento, $157 \ldots \ldots . . \ldots 191$

- fosseis. . . 294, 301, 312, 316 
Coralinas . . . . . . 176, 187

Corcovado ........ 43, 64

Correlação. . . . . . . 283, 284

\section{Correntes :}

aereas............ 42

- dos mares. . . . . . (i7, 78

- oceanicas. . . 41, 66, 78, 80, 206

— fluviaes. . . . . . . . . 184

Correntezas do oceano ..... 66

Corridas de lava . . . . 137, 332

Corthell (E. L.) . . . . . . . 167

Costa do Brasil. . . . . 187, 205

- de Pernambuco........ 143

— do Japão. . . . . . . . . . 177

— da Sicilia ........... 141

- do Pacifico .......... 1(i)

Cotinguiba, rio. . . . . . 23, 62

Cotopaxi. . . . . . . . 137

Cracas. . . . . . . . . 1 17

Crandall (R.). . . . . 174, 290, 296

Creep . . . . . . . . . . . 243

Crescimento, dos coraes, 157, 380

— dos recifes. . . . . . . . 198

Cretaceo . . . . . . . . 338-358

Crevasses

93

Crinoides fosseis, 202, 264, 281, $295,312,319 \ldots \ldots \ldots \ldots$. 331

Crocodilos fosseis. . . 341, 351, 357

Croll (James). . . . . . . . 102

Crosta de terra. . 129-131, 150, 162

Crustaceos fosseis, 187, 201, 281,

351 .

356

Crystalização. . . 170, 258, 261, 265

Cubatão (serra). ........ 43

Cunhahú (recife). . . . . . 212

Cupim . . . . . . . . . 175

Cursos de agua, 48, 63, 107, 184.

Curuá (rio). . . . . 296, 302,

Cuspides... . . . 82, 212,

Cuscuzeiros

(1)

Dama do Lago . . . . . . . . . 17

Dana (J. D.). . . . . 188, 196 ;

Darwin (Charles), 169, 173, 188, 196

Daubrèe (A.). . . . 220, 230, 231

Decomposição das rochas, 34,

$44 \ldots \ldots \ldots \ldots \ldots 17$

Deltas. . . . 64, 81, 81-87, 206

1)eposição chimica. . . . . . 116

Deposição de sedimentos, 20, $59,95,116,176,212,215,280, \quad 379$

Depositos :

- auriferos. . . . . . . 20 20

- chimicos. . . . . 19, 203

- calcareos.... . 149, 179, 18 \%

- carbonaceos . . . . . 179, 180

- diamantiferos........ 111

- ferruginosos . . . . 179, 185

- lacustres. . . . . . . . 378

- maritimos........ . 281

- mechanicos ........ 81

- nitrogenosos. . . . . 179, 186

- phosphaticos... . . 179, 203

- salinos .......... 125

- sedimentarios. . . . . 20, 221

— silicosos. . 149, 179, 186, 202

- sulphurosos . . . . . 179, 185

- terrestres. . . . . . 208, 282

- de alluvião . . . . . . 270

- de cinzas ......... 138

- diatomaceas.......... 186

- de mineraes........ $25 \%$

- de turfa ........... 181

Derby (O. A.): 110, 144, 145, $185,296,302,311,313,337$, 353. . . . . . . . . 35

Depressão, 130, 155, 16², 166, 167. . . . . . . . . 169

Descordancia . . . ...... 211 
Desgastamento das rochas, 20, $26,51,89$.

Desintegração das rochas.

Deslocação das rochas, 130, $144,168,239,251,253 . \ldots$.

Desmoronamentos . . . 46-48, 181

Desnudaçĩo. . . . . . . . . 21t

Devoniano . . . . . 286, 301-312

Diabase, 36, 143, 223, 302, 320, $332,335$.

353

Diamantes, 52, 180, 183, 271, 336 Diatomaceas. . . . . 186, 202, 215

Diques, 129, 145, 146, 205, 222$225,259,269$.

320

Diques de arenito....... 233

Distribuição :

- de plantas e animaes, 24, 162,

- de vulcões.

166

- de mudanças de nivel. . . 168

Dobras das camadas, 134, 239,

$245-248,264 \ldots \ldots \ldots \ldots 284$

Dobramento. . . . . . 241, 249

Dolomia. . . . . . . . . 272

Dolomitação.

Drenagem subterranea . . . . 116

Dunas . . 21, 27, 81, 138, 177, 217

\section{E}

Echinodermes fosseis, $316,343,350$

Echinoides . . . . . . . . 294

Efflorescencia. . . . . . 37-40

Ejectamentos vulcanicos, 135, $137,138-140 \ldots \ldots \ldots . . .144$

Elephantes fosseis . 166, 376, 378

Elevações da superficie da terra,

$130,157 \ldots \ldots \ldots \ldots 280$

- das costas. . 157, 159, 168, 169

- das lavas. . . . . . . . . . 135

- causas de .......... 169

- differenças. . . . . . . . . . 284

Empuxo das rochas.
Enchimento de vieiros . . . . 266

Endurecimento das rochas, 216, 218.

258

Entomostracos fosseis. . . . . 351

Enxofre . . . . . . . . . 18

Eozoon . . . . . . . . . 290

Epicentro dos terremotos. . . 151

Epoca glacial. . . 95, 101, 372, 379

Erosão, 48, 57, 88, 161, 179, 281, 379

Erosão chimica. . . . . . . . . 108

Erupções : vulcanicas. . . . 72, 135

Escala Rossi-Forel. . . . . . . 153

Escorregamento das rochas,

$150,258 \ldots \ldots \ldots . .261$

Esfoliamento das rochas, 29, 30, 33

Esporos no lignito, 182; no carvão.

184

Esponjas fosseis. . . 202, 294, 312

Espessura :

... das camadas. . . . . . . . . 251

— dos sedimentos. . . . 162, 167

Espirito Santo :

— decomposição de rochas. . . 110

— provas de elevação. . . . . 159

- rochas archeanas. . . . . . . 289

- rochas terciarias ...... 358

Estratificação falsa . . . . . . 210

Estratos . . . . . 209, 214, 283

Estrias . . . . . . 94, 96, 256

Estreito de Magallıães . . 91, 160

Estrondos vulcanicos . . . . 135

Estuarios. . . . . 164, 205, 370

Estructura geologica . . . . 207

- concentrica ........ 238

- fluxional. . . . . . . . 221

- isoclinal . . . . . . . . 248

Evaporação. . . . . . 36, 120, 122

Exfoliaç̃̃o . . . . . . . . 29-35

Expansão das rochas, 34, 134, 169

Explosões ...... 135, 138, 139 


\section{F}

Falhas, 151-154, 162, 168, 170, 251-257.

284

Fauna mammifera . . . . 375-376

Feldspatho ... . . . . . 45, 109

Felsito. . . . . . . . . 296

Fendas . . . 135, 152, 154, 203-265

Fendas do solo. . . . . . . . 214

Fernando de Noronha :

- calcareo ........... 201

- corrosão. . . . . . . . . 70

- columnas basalticas. . . . 228

- mares ........... 70

- phosphatos ......... 203

- rochas ..... 28, 141, 143

- sulcos .........

Ferro :

- carbonato ......... 185

- ocidos .......... 321

- estructura. . . . . . . . 234

- minereos . . 288, 293, 295, 313

Fetos fosseis . . . . . 313, 319

Filões . . . . . . . . . . . 262

Fiordes. . . . . . . . 161, 164

Fixação das dunas. . . . . . . 179

Florence (G.) . . . . 144, 211, 338

Florestas. . . . . . . . . . 204

Floculação . . . . . . 8 80, 86

Foco de terremotos. ...... 151

Folhelhos :

- definição. . . . . . . . . 208

- laminação. . . . . . . 215

Fontes. . . . . . . . . 271

- emergencia. . . . . . . 257

- aguas. . . . . . . 129, 271

- quentes. . . . . . . . . 149 thermaes.
Foraminiferos.

$200, \quad 316$

Forma das costas. . . . . . . 76

Formigas. . . . . . 173-175

Fosseis, definição . . . . . . 214

— valores relativos. . . 282, 285

Fracturas. . . . . . . 230, 269

França . . . . 71, 97, 204, 358

Frequencia das erupções. . . . 148

Fulgaritos. . . . . . . . . 239

Fumaça vulcanica . . . . . . . 138

Funafuti . . . . . . . 191, 197

Fundo do mar . . . . . . . . 161

Furnas do Agassiz. . . . . . 33

Fusão das rochas . . . . . . 134

\section{G}

Gabbro. . . . . . . . . . 143

Gaz natural. . . . . . . . . . 301

Gazes ................ 139

- quentes .......... 128

— vulcanicos . . . . . . 135-139

Geleiros. . . . . . . . . . . 9 90

Gelo . . . . . . . . . . . . 89

Geologia estructural. . . . . . 207

- historica. . . . . . . . . 279

Geodes. . . . . . . . 238, 333

Gervais (Paul) . . . . . 357, 373

Gesso . . . . . . . . . . . 295

Geysers . . . . . . . 147-149

Giz . . . . 201, 208, 259, 338

Glaciação, no Brasil. . . . . . 100

- antiga .......... 95

— na America do.Sul . . . 99

Globo rigido, theoria . . 129, 130

Glyptodonte. . . . . . . . 373

Gneiss . . 31, 34, 110, 221, 292, 293

Gonzaga de Campos (L. F.),

$159,255,311,342 \ldots \ldots .346$

186 Gorceix (H.) . . . . . . . 372 
Goyaz:

- rochas archeanas. . . 290, 293

- rochas cambrianas. . . . . 294

- rochas devonianas ..... 311

- rochas triassicas . . . . . 334

- rochas cretaceas . . . . . 357

Granito . . . . . . 31-34, 289-293

Graphite, 46, 180, 184, 259, 288, 293

Greda. . . . . . 201, 218, 338

Grutas. . . . . . . . . 112

Guama (rio)..........

Guano . . . . . . . . 203, 205

Guimarães (G. A. J.) . . . . 208

\section{H}

Harris (G. D.) . . . . . . 125

Hartt (C. F.). . . 342, 351, 353, 379

Herculano . . . . . . 138, 206

Homem, primitivo . . . . . $37 \%$

- como agente geologico. . . 204

Hrdlicka . . . . . . . 377, 378

Hydro-carbonos. . . . . . . 180

Hydrozoarios . . . . . . . 294

\section{I}

Icebergs. . . . . . . . . 90, 102

Idade da terra. . . . . . . . . 379

Iguape. . . . . . . . . . 84

Ilha Rapta. . . . . . . . . . . 28

Ilha Raza . . . . . . . . . 76

Ilhas :

- formadas pelo mar . . . . . 86

- formadas por serpulas . . . 260

— vulcanicas ........ 141, 143

- dos Açores. ........ 13

- Aleucianas. ......... 141

- dos Abrolhos. . 67, 143, 188, 341
Ilhas

- Falklandas. . . . . . . . . 322

- Hawaiianas . . . . . . . 135

- Philippinas ......... 143

Ilheos . . . . . . . . . 353, 358

Impressões da chuva. . . . . . 213

- das plantas. . . . . . . . 180

Inclinação das rochas . . . . . . 943

Inclusões. . . . . . . . . . . . 138

Inconformabilidade . . . . 211

Infiltraçies. . . . . . . . . 266-26ir

Influencia do homem. . . . . . 201

Insectos fosseis . . . 295, 313, 358 Instrumentos, de pedra. . . 375, 378

- de osso . . . . . . . 378-379

Interior da terra . . . . . 128-131

Invasão do mar . . . . . . . 162-168

Ipanema . . . . . . . . 144, 336

Isoclino . . . . . . . . . . . 248

Isostasia. . . . . . . . . . . . . . 169

Itacolomite $\ldots \ldots \ldots .44,185$

Itatiaia. . . . . . . 5 51, 144, 336

\section{$\checkmark$}

Jones (T.), Rupert . . . . . . . 352

Jordan (D. S.). . . . . . . . . 362

Juntas . . . . . . . . 126, 229

Jurassico. . . . . . . . 337-338

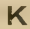

Kaolin . . . . . . . . . . . . 109

Krone (R.). . . . . . . . 113

Kyle . . . . . . . . . . 107

Laccolitos. . . . . 147, 222, 224

Lagarto fossil . . . . . 327, 330 
Lago :

- Brienz .......... . 65

- Genebra......... 75, 212 Haarlem . . . . . . . . 378

Lagôa :

Lagôas. 83

Lagos :

- alcalinos 125

- amargos 125

- crescentricos

- sedimentos. 63

- das praias ......... 8

- de Alagûas. 164

- de borax. 125

- salgados . . . . . . . . 121

— formados pon lavas . . . . . 137

- Jiquiá. . . . . . . . . . 164

- Mangueira. . . . . . . . . 83

- Mirim. . . . . . . . . . . 83 Manguaba . . . . . . . . 164

— do Norte... . . . . . . . . 164

- dos Patos. ........ 63, 83

- Poxim .......... 164

- Santa . . . . . . . 113, 378

— de Sinimbú. . . . . . . . . . . 84

Lamella de rocha. . . . . . . . 209

Laminação das rochas . . . 209, 215

Lapa, Nova de Maquiné . . . . . 117

— Vermelha .......... 113

Lapidas. . . . . . . . 249-250

Lapilli . . . . . . . . . . . 138

Larangeiras . . . . . . . . . . 343

Lava . . . 129, 137, 140, 222, 224

Lemos (Pedro S.) . . . . . 149, 277

Lençóes de lava. . . . 129, 135, $137,143,222-224$

Lepidotus. . . . . . . . . 351, 354

Leques de alluvião. . . . . . . 63

Leucite. . . . . . . . . . . 336
Lignito . . . 180-182, 208, 368, 372 Linhas de actividade vulcanica. 151 - de fraqueza ........ 151

- de terremotos. . . . . . . 151

Lirios do mar. . . . . . . . . 202

Lisboa (M. A. R.), 6, 7, 36, 72, $144,222,233,238,282,329 . \ldots 347$

Lithodomus . . . . . . . . 159

Loess . . . . . . . . . 28, 208

Löfgren (А.) . . . . . . . 379

Lombadas anticlinaes . . . . . 248

— isoclinaes. . . . . . . . . . 248

- monoclinaes. . . . . . . . 248

Lorimer (A. J.) . . . . . . . . 103

Lund (P. W.) . . . . 11\%, $3 \pi 8$

Lycopodiaceas fosseis. . . . 313, 322

\section{M}

Macacos fosseis. . . . . . . . 376

Madeira silicificada ... . . . 186

Maecurú (rio) . . . . 296, 302. 314

Mammiferos fosseis. . 331, 358, 373

Mangues. . . . . . . . 177, 205

Marahú . . . . . . . 358, 359, 368

Maranhão :

- dunas. ............ 23

- correntes........... 42

. pororoca......... 71

- rochas archeanas. . . . . . 290

- rochas permianas. . . . . . 329

- rochas cretaceas . . . . . . 35 z

- rochas terciarias. . . . . 368

Mares . . . . . . . . . . . 67

Marmore, 172, 258, 261, 288, 293, 295

Massape... . . . . . . 36

Mastodonte . . . . 373, $375 \quad 376$

Mastodon humboldtii . . . $373 \quad 375$

Matações. . . . . . . . . . . 30-33 
Matto Grosso :

— rochas archeanas. . . . . . 290

- rochas cambrianas ... . . . 294

- rochas devonianas. . . . 307, 311

- rochas permianas. . . . 328-329

- rochas triassicas . . . 331-331

Maury (C. J.) . . . . . . . . . . 362

Magatherium . . . . . . . 375

Merrill (G. P.) . . . . . . . . 109

Mesozoico . . . . . . . . . . 331

Metamorphismo. . . . . . 258-262

Mexilhões . . . . . . . . 169, 176

Mica . . . . . . . . . . . . 46

Mineralizacão. . . . . . . 257

Minereos. . . . . . . . 262-2\%0

Minhocas ... . . . . . . 173

\section{Minas Geraes :}

— decomposição das rochas . . 126

- cavernas ........... 113

- temperaturasubterranea, 126 , $132 \ldots \ldots \ldots \ldots . \ldots 133$

- terremotos . . . . . 155-156

- endurecimento das rochas. . 216

- ouro. ......... 270, 293

-- rochas archeanas. . . . 290-293

- rochas cambrianas . . . . . 294

- rochas triassicas. . . . . 335-336

- rochas terciarias . . . . . . 372

- rochas quaternarias .... . 375

Modificação das rochas . . . . . 207

Molluscos fosseis. 187, 201, 202, $281 \ldots \ldots \ldots \ldots . \ldots . \ldots 22$

Montes de conchas. . . . . . . 379

Montanhas :

- altura das 65

- vulcanicas . . . . . . 139-145

Monoclino . . . . . . . 243, 248

Morenas . . . . . . 93, 97, 99

Morize.
Morros, anticlinaes . . . . . 248

— synclinaes ......... 248

- de chapeu.... . . . . . 334

Movimentos da crosta da terra . 130

- de geleiros. . . . . . . . . 91-92

- de revolução. . . . . . . . 129

Mudanças :

- de corr.......... 258

— de nivel. . . . . . 155, 168, 169

- de temperatura....... 131

- no interior da terra. ..... 170

Museu Rocha. . . . . . . . . . 374

Musgo . . . . . . . . . . . . . 181

\section{N}

Nepheline. . . . . . . . . 336

Nivel, mudanças . . . . . . 168-169

Obliteração de fosseis . . . . . 258

Oceanos, profundidade ..... 65

- trabalho mechanico. . . . 65-75

Oleo mineral . . . . . 353, 362, 371

Oliveira (E. de) . . . . . . . . . 238

Oliveira (F. de P.), 227, 238, 261, $293 \ldots \ldots \ldots \ldots . \ldots . \ldots 33$

Olivine. . . . . . . . . . . 143

Ondas dos mares. . . . . . . . 68

Oolitos. . . . . . . . . . . 238

Ooze .............. 200

Ordoviciano....... 286, 294

Organismos marinhos . . . 157-160

Orientação das camadas . . 243, 245

Ortmann (A. E.) . . . . . . . 166

Ossos fosseis. . . . . . 281, 378

Ouriȩos. . . . . . 159, 175, 176 


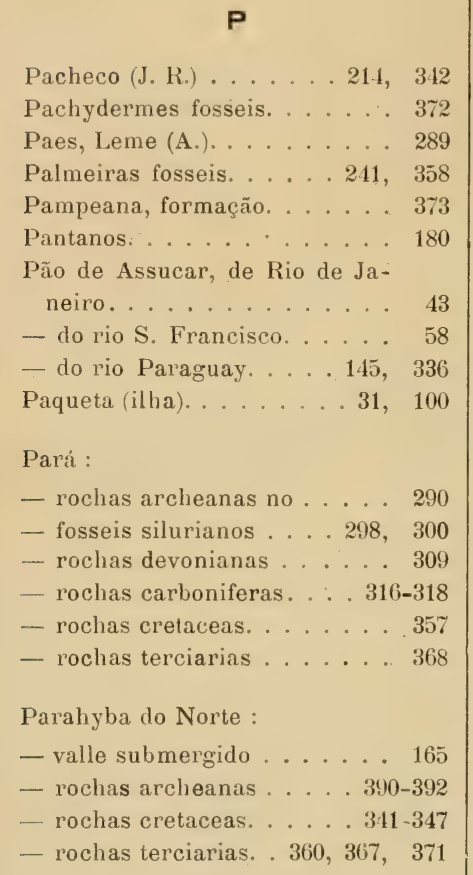

Paraná :

- lençóes de lava.... 144, 223

- pederneiras ........ 202

- agathas. . . . . . . . 2 238

— rochas archeanas. . . 290, 293

- rochas cambrianas . . . . . 294

- rochas devonianas . . . 308-312

- rochas permianas. . . . 319-328

- rochas triassicas ..... . 331

Paulo Affonso (cachoeira), 50,57, 233 Pederneiras, 186, 202, 215, 321, 333 Pedra-pomes ......... 137 Pedra-sabão.
Pedras de agua. . . . . . . . 333

- lascadas ......... 378

Pedras Pretas. . . . . . . . 143

Pegadas nas rochas ..... . 377

Peixes ............. 167

- fosseis, 281, 286, 295, 322, $337,341 \ldots \ldots . \ldots 347$

Pendor............ 2 213

Pendões de nuvens: . ..... 43

Permiano ....... 318-330

Pernambuco :

- fosseis quaternarios ... . 373

- mangues......... . 178

- salitre ......... . 38

- rochas eruptivas, $143,146,158,161$

- terremoto.......... 1 อ 6

- recife. . . 175-176, 217, 220

- rochas archeanas . . . 290, 293

- rochas cambrianas . . . . 294

- rochas cretaceas . . . ... 347

- rochas terciarias. . . . . 360-367

Persistencia dos estratos . . . 2 214

Petroleo. . . . . . 353, 362, 371

Phenomenos vulcanicos.... 135

Pholas .......... 160, 174

Phonolito........ 143, 336

Phosphatos. . . . 20. 203, 288, 301

Piauhy:

- rochas archeanas. . . . . 290

- rochas permianas. . . . . . 329

- rochas cretaceas. . . . . . 357

Piçarra. . . . . . . . . 208

Picos :

- submarinhos. ........ 141

—vulcanicos........ 139

Picu (serra) . . . . . . . 141

Pisolitos........... 2. 238

Placers ......... 2. 270

46 Planalto central. . . . . . 353 


\section{Plantas :}

- como agentes geologicos, 171

$-173,177-179$

- distribuidas pelo vento. ... 25

- constructivas ....... 17!

— distribuição . . . . . . . . 166

- fluctuantes. . . . . . . 17.

- influenciadas pelo homem. . 204 Pleistoceno ....... 372-379

Poços. 271-274

- artesianos 275

— em recifes de coral. . . . . 164

Poços de Caldas. . . . 126, 149, 277

Poeira vulcanica . . . 25, 138, 140

Polypos coraliferos. . 157, 188, 191

Pompea.......... 138, 206

Ponta da Areia . . . . . . . . . 23

Ponta Grossa . . . . . . . . . 312

Ponto de fusão . . . . . . . . . 134

Pontaes ............ 82

Pororóca. . . . . . . . . 71

Porosidade. . . . . . . 2:1-272

Portão . . . . . . . . . . 7

Porto Alegre. . . . . . . 144, 334

Portos ... . . . . . . . . . 164

Praias . . . . . . . . . . . 81

Preas. . . . . . . . . 17t

Preguiça tossil . . . . . . 3 373

Pressão . . . . . . . . . . . 134

- augmento ......... 100

Profundidade dos oceanos. . . . 65

Protozoarios. . . . . . . . . 282

Psaronius. . . . . . . 324, 32!)

Psrchozoico. . . . . . . . 3 372

Pteropodes. . . . . 295, 305, 312

Pudim . . . . . . . . . . . 208

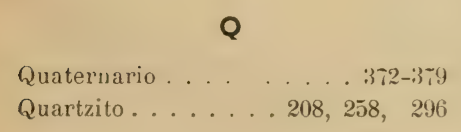

\section{$\mathbf{R}$}

Radiados .... 18\%, 188, 201, 2112 Ramiz Calvão. . . . . . . . 5

Rastos de animaes : ... . . . 214

Rathbun (R.) . . . . . . . . 35!

Reade (T. Mellard). . . . . 10 10

Reacções chimicas . . . . . . . 11!

Recifes :

- de arenito ......217, 220

- de coral. ....... 188, 19!

- de barreira. . . . . . . . . 19:3

- circulares ... . . . . . 195

- theorias das. . . . . . . . 196;

- crescimento . . . . . . . 198

- em franja. . . . . . . . 193

Reconcavo da Bahia..... . 212

Redomoinhos . . . . . . . . 50

Regelação.......... (92

Regiões aridas . . 20, 37, 110, 115

- vulcanicas . . . . 222, 320, 332

Registros humanos. . . . 161, 16i

- de um seismographo.... 152

Reinhardt. . . . . . . . . 3r;

Reliquias humanas. . . . . . . 378

Remoção da terra....... 88

Reptis fosseis. . 281, 319, 322, 3337

Represas. . . . . . . . 92

Resaca. . . . . . . . 78,80

Reslriamento :

- da crosta da terra. . . . . 288

— diario.......... 131

- das lavas. . . . . . . . 141

- das rochas . . . . . . 141, 169

Restingas ........... 8 83

Rhinocerontes fosseis . . . . . 3\%

Rio Grande do Norte :

- dunas. . . . . 22, 23, 
Rio Grande do Norte :

- recifes. . . . 77, 177, 212, 213

- sal.

- rochas cretaceas . . . . . 367

- rochas terciarias .... 367-368

Rio Grande do Sul :

- porto.......... 63

- restingas......... 83

- alteração das rochas . . . . 126

- rochas eruptivas. . . 144, 283

- pederneiras . . . . . . . . 202

- ogathas. . . . . . . . . 2 238

- rochas archeanas... . . . 290

- rochas devonianas . . . . . 311

- rochas permianas. . . 322, 323

- rochas triassicas. . . . 331, 334

- rochas jurassicas . . . . . . 337

Rio de Janeiro :

- restingas.

rochas

turlia

- rochas eruptivas . . . . . 336

- rochas archeanas. . . . 289-290

Rios tapados. . . . . . . . 81-82

Ripple-marks . . . . . . . . 212

Riscos na mineração. . . . . . 269

Rocas (ilha das). . . . 67, 188, 198

Rochas :

- acidas.

- archeanas 287

- basicas. 221

- carboniferas.

312

- calcareas. 200-201

- chimicas $116-127$

- coraliferas.

188

- cretaceas. 338

- crystallinas. . . . . . . 258-262

- devonianas.

301
Rochas :

- eolias.......... 27, 217

- eruptivas. .......... 220

- estratificadas. . . . . . 20 ${ }^{-}-215$

- igneas. . . . . . . . . . 221

- jurassicas ......... 337

- massiças. . . . . . . . 220

- metamorphicas ... . . . 337

- organicas. . . . . . . 179-203

- origem . . . . . . . . 203

— sedimentarias . . . . . . 207

- terciarias. . . . . . . . 358

- triassicas. . . . . . . . 331

- vulcanicas ....... 141, 221

Rossi-Forel, escala. ....... 153

Ruminantes fosseis. . . . . . 376

\section{S}

Sal : formação. . . . . . . . 121

- depositos. . . . . 37, 295, 357

— efflorescencia ........ 37

- nas rochas ...... . . 37-38

- origem........... 123

Salitre . . . . . 37-38, 186

Salmourão. . . . . . . . 36

Sambaquis. . . . . . . . . 378

Santa Cruz . . . . . . 78, 217

Santa Catharina :

- lagos........... 83

- rochas eruptivas ...... 144

- agathas. . . . . . . . 2 238

- rochas archeanas . . . . . . 289

- rochas devonianas . . . . . 301

_ rochas permianas. . . . . . 318

- rochas triassicas ....... 331

Santo Agostinho (cabo de), 143,

$159 \ldots \ldots \ldots . . \ldots 219$

Santo Aleixo . . . . . . . . 143

Schistosidade .......235, 258 
Sehistos erystallinos. . . . . 261

Schizodus . . . . . . . . 328

Seccões . . . . . . . . . . 240

Sedimentos:

- mechanicos . . . 87, 88, 207

- marinhos.

- espessura. 167

- deposição $59-88$

- classificação. 208

Segregações de mineraes. . . . 269

Seismographo. . . . . . . . 152

Seixos. . . . 50, 51, 52, 69, 78, 79

Sena $(\mathbf{N}$. de $) \ldots . . . . . .113$

Sergipe :

- solo.

36

- calcareo 201

- pederneira.

202

- rochas archeanas.

290

- rochas cambrianas. 294

- rochas carboniferas

314

- rochas permianas. 328

- rochas cretaceas.

Serpentina ....... 46, 261

Serpulas . . . . . . . 176, 200

Siluriano . . . . . . 294, 295-301

Sinter

186

Slickensides .

$154, \quad 256$

Small (H. L.) $354 \quad 356$

Smith-Woodward (A.), 331, 346 351. 372

Solo : formação

— massapé

- glacial .

- residuario

- salmourão $35, \quad 109$

- terra roxa $36,109, \quad 321$

Soluções.

Soper (R. H.) $367, \quad 368$

Souza (Ennes de). Spiculos de esponjas
Sphagnum. 180

Stalactites. 117

Stalagmites . . . . . . . . 117

Stevenson (J. J.) . . . . . . 183

Subsidencia de recifes. . . . . 196

Sulcos glaciaes .

- das vagas

$76,159-160$

Sulphato de magnesia . . . . . 123

Sumidouros 116

Superficies erodidas . . . . . . 161

Syenito. . . . . . . . . . 336

Synclino . 242,247

\section{T}

Tabella das formações . . . . . 2 286

Taboleiros. . . . . . . . . 222

Tatu fossil. . . . . . . . 378

Temperatura :

- augmento.

106,131

- diminuição. . . . . . . . . . 106

- mudanças. . . . . . . . 29

- dos oceanos ......... 66

- das fontes quentes ... 149-150

Tempestades de areia. . . 20, 21

Tempo geologico. . . . . . . 379

Terciario........... . . 358

Terra do Foga .... 99, 141, 165

Terra roxa. . . . . . 36, 109, 321

Terra Santa. . . . . . 123, 126

Terras cahidas ......... 49

T'erremotos . . . . . . . 150-156

Tidal waves'. . . . . . . 72

Topographia. ........ 88

Trabalhos humanos. . . . 205-206

Trachyte......... 143, 158

Transporte por cursos.... . 55

- por gelo. . . . . . . . 93-95

- pelo vento......... 20

Travertino. . . . . . . . . 117

Tremores de terra. . . . 150-156 
Triassico. . . . . . . . 331

Trindade (ilha da) . . . . . . 141 Trombetas (rio). . 295, 296, 302, 314 Tubarões fosseis . . . . . 295, 352 Tufos. ......... 20. 208, 225 Turfa . . . 180-182, 208, 368-370

\section{U}

Ubajarra. . . . . . . . . . 114

Unnas funerarias . . . . . . . 379

\section{V}

Vagas............. 40

- poder das. . . . . . . . 688-69

- catastrophicas ...... . 72-73

— trabalho constructivo. . . . 78

Valles anticlinaes ...... 247

- synclinaes........ 247

- submergidos. . . . . . 164

- suspensos ......... 58

Vapor . . . . . . . . . . 128

Varzeas . . . . . . . . . 35, 60

Verto :

- depositos pelo....... 26

- desgastamento........ 26

- effeito na agua........ 40

- sobre correntes....... 41

Vertebrados fosseis. . 187, 201, 295
Vermes. . . . . 171, 173, 294

Vieiros . . . . . . . . . 2622-267

- enchimento ....... 268

Vira-mundo. . . . . . . . . . 296

Von Jhering. . . . . . . . . 3332

Vulcões activos......... 135

- submarinhos........ 141

- brasileiros ...... . 141-143

- extinctos ......... 143

— idade dos. . . . . . . 147

- ejectamentos dos ...... 138

\section{w}

Wallace (Alfred) . . . 102, 166 Waring (G. A.), 76, 150, 273, 275,

$289 \ldots \ldots \ldots \ldots \ldots$

White (C. A.) . . 343, 348, 350, 352

White (David) . . . 182, 322, 328

White (I. C.), 147, 260, 324, 337. . . . . . . . . 343

Williams (H. E.), 143, 158, $161 \ldots \ldots \ldots \ldots \ldots$

Willis (Baily) . . . . . . . 287

Woodward (A. S.), 331, 332, 346,

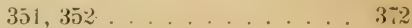

Woodworth (J. B.) . . . . 101, 321

Zebra fossil . . . . . . 376

Zeiller (R.) . . . . . . . . . 32. 





\section{Á VENDA NA LIVRARIA FRANCISCO ALVES}

\section{ALGEBRA}

Algebra Gymnasial, por Arthur Thiré, lente de Matematiea no Colejio Pedro II. I vol. in-8, com 3or pags., cart. . . . . . . . . . .

Elementos de Algebra, por João Bonges e Gomes, Cardim, professores da Escola Complementar anexa á Escola Normal da Capital de S. Paulo, adotada no Ginazio Diocezano, na Escola Normal e colejios particulares, $2{ }^{a}$ edição correta e aumentada. $\mathrm{r}$ vol. in- $8 \mathrm{fr}$. de $23 \mathrm{o}$ pags, , eart. . . . .

Algebra, por C. B. Otronı, 12. ${ }^{3}$ edição aumentada com muitas notas intercaladas no texto, por G. S. M. I vol. de $3-6$ pags. . . . . . . . . . .

Theoria dos Determinantes (Primeiros principios da), para uzo dos Liceus, por J. A. ALBuquerque, enjenheiro civil, lente de Mecanica raeional da Academia Politécnica do Porto e outr'ora professor de Matematica elementar no Liceu central da mesma eidade. I vol, in-8. . . . . . . . . . . .

$4 \$ 000$

$5 \$ 000$

$4 \$ 000$

$3 \$ 000$

\section{GEOMETRIA}

Elementos de Geometria, por F. Carrita, professor da Escola Politéeniea e Escola Normal desta capital. 2. ${ }^{a}$ edição melhorada; obra adotada na Escola Normal da Capital Federal. I vol. enc.

Elementos de Geometria e Trigonometria Rectilinea, compilados pelo Exm. Snr. Conselheiro C. B. Оттолı. II ${ }^{a}$ edição correta e aumentada com numerozas notas e figuras intercaladas no texto, impresso em tipo menor. I vol, in-8, enc. . . ....

Curso de Geometria, por Trмotheo $\mathrm{PE}_{-}$ REIRA, obra adotada no Ginazio Nacional. 5. ${ }^{a}$ edi§̧ão. I vol. in-8, enc. . . . . . . . . . . . . . Io\$ooo

\section{TRIGONOMETRIA}

Memento de Trigonometria Elementar, compendiado por Arthur Thrḱ: 2, edięão, I vol. cart.

Curso de Trigonometria Rectilinea e Espherica, por Trmotheo Pereira, obra adotada no Colejio Militar e no Ginazio Nacional, I vol, ene. 